\title{
Deli Eszter
}

A vizuális retorika triadikus koncepciója - Elméleti keret és esettanulmányok

Vizuális retorika a katasztrófa-hírközlésben 


\section{Magatartástudományi és Kommunikációelméleti Intézet}

\section{Prof. Dr. Aczél Petra Katalin Egyetemi Tanár}

\section{Copyright}




\section{Budapesti Corvinus Egyetem}

\section{Társadalmi Kommunikáció Doktori Iskola}

A vizuális retorika triadikus koncepciója - Elméleti keret és esettanulmányok

Vizuális retorika a katasztrófa-hírközlésben

Doktori értekezés

Deli Eszter

Budapest, 2018 
Édesanyámnak 


\section{Köszönetnyilvánítás}

Doktori értekezésem elkészülte több éves munka eredménye, amely nem csak az idáig vezető kutatói, hanem oktatói életpályámat is jelképezi. Egy disszertáció megszületése azonban sohasem a kezdő kutató egyedüli érdeme, így megragadom az alkalmat, hogy hálás köszönetemet fejezzem ki mindazoknak, akik e munka létrejöttét segítették.

Mindenekelőtt pedagógiai pályám legmeghatározóbb személyiségének, Dr. Aczél Petra Tanárnőnek tartozom hálával, akinek nem csak azt köszönhetem, hogy 2013-ban elindulhattam a tudományos élet szépségekkel, lehetőségekkel és inspiráló szakmai kihívásokkal teli útján a Budapesti Corvinus Egyetemen, hanem azt is, hogy tanáromként és mentoromként megismertetett a társadalomtudományos gondolkodásmód alapjaival, felébresztve bennem az alkotás iránti szeretetet, és a folyamatos fejlödés iránti elköteleződést. Munkám elkészítése során nélkülözhetetlen szakmai segítséget és iránymutatást kaptam Töle, a számtalan lélekmentő beszélgetésért és a szilárd alapot nyújtó gondoskodásért azonban még hálásabb vagyok.

Mély hálával és köszönettel tartozom Dr. Nyíri Kristóf Professzor úrnak, aki a Dr. Benedek András Professzor úrral közösen szervezett Visual Learning Nemzetközi Konferencián történő megismerkedésünk óta rendkívüli szakmai lehetőségeket biztosítva kísérte végig eddigi kutatói pályafutásom, és aki jelen értekezés témájának meghatározásában is közvetlen érdemekkel rendelkezik. Hatására egyre nagyobb kíváncsisággal kutattam a vizualitás tárgykörét, amely kíváncsiság mostanra e kutatási terület iránti teljes elköteleződéssé és odaadó szeretetté fejlődött, amiért nem tudok eléggé hálás lenni.

Köszönetemet fejezem ki Dr. Horányi Özséb Professzor úrnak, aki nem csak doktoranduszi éveimet segítette személyes konzultációinkkal és korábbi anyagaim véleményezésével, hanem az után is törődött életutam és disszertációm alakulásával. Szakmailag és emberileg is sokat köszönhetek Neki.

A generációmhoz tartozó pályatársaim közül hálás köszönettel tartozom Németh Gabriella kolléga- és barátnőmnek, aki a doktori programban való megismerésünk óta nem csak számos közös kutatás, konferenciaelőadás és publikáció elkészítésében, illetve disszertációnk 
párhuzamosan történő megírásában, hanem a mindennapi életben is segítőtársam. Ösztönző, kreatív kutatói magatartásával és őszinte barátságával felejthetetlenné tette az elmúlt éveket.

Édesanyám határtalan áldozatvállalása és mérhetetlen szeretete egész életemet végigkíséri. Általa kaptam lehetőséget egyetemi, majd később doktori tanulmányaim folytatására, általa sajátítottam el az angol nyelvet olyan mértékben, hogy most oktatói pályám legfontosabb eszközeként tekinthetek rá, és általa tanulhattam meg, hogy a tudás megszerzése sohasem lehet öncélú, azzal mindig hozzá kell járulnunk mások fejlődéséhez is. Szakmai kiválósága, odaadó tanári munkája és fáradhatatlan anyai támogatása minden nap inspirál.

Édesapám az intellektuális teljesítmény tiszteletére, a bölcsészettudományok szeretetére és az élet nehézségeinek humoros-ironikus tudomásul vételére tanított, az olasz és orosz nyelv iránti érdeklődés mellett. Köszönöm azt a könnyed mentalitást, igényes szakmai magatartást és pozitív életszemléletet, amit Tőle kaptam örökül.

Megkülönböztetett hálával tartozom Testvéremnek, akire születésem óta felnézhetek, akinek kimagasló szakmai tevékenysége motivált arra, hogy beadjam jelentkezésem a Társadalmi Kommunikáció Doktori Iskolába annak idején, és aki egész életemben igazi példaképként áll előttem. Szakmaszeretete, szorgalma és mindenre kiterjedő tudásvágya engem is folyamatos elmélyülésre és fejlődésre sarkall.

Szeretnék továbbá köszönetet mondani szerető Völegényemnek, aki a töretlen segítségnyújtás mellett kimeríthetetlen türelemmel viselte a munkával járó kellemetlenségeket és a legnagyobb kilátástalanság közepette is reménnyel és bizakodással töltött el.

Végezetül hálával tartozom egykori és jelenlegi Diákjaim véget nem érő szeretetéért és biztatásáért, általuk él bennem a remény hogy minden nap jobb oktatóvá, jobb kutatóvá válhatok. 


\section{Tartalom}

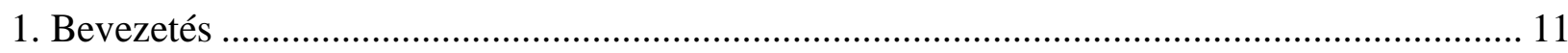

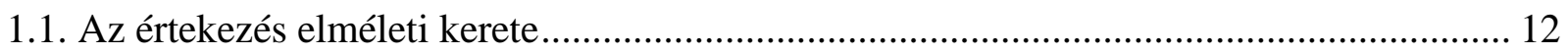

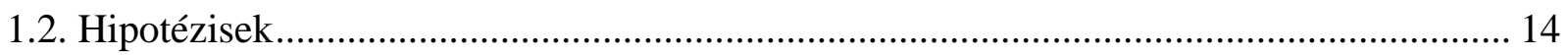

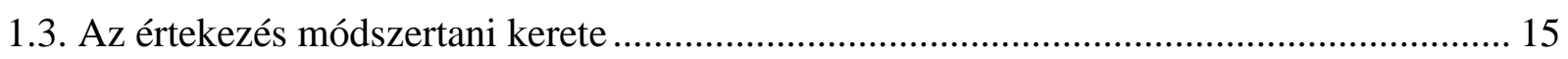

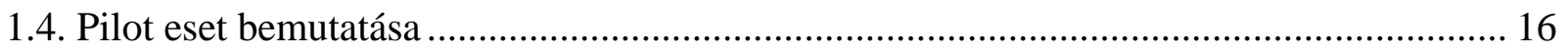

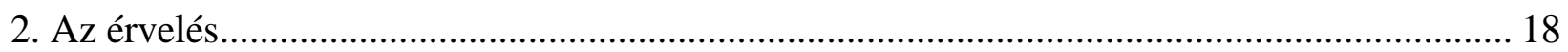

2.1. Az érveléselmélet történeti áttekintése........................................................................ 18

2.2. Az érvelés konceptualizációja...................................................................................... 20

2.3. A 3P: Produktum, Procedúra, Processzus …………………………………………....... 22

2.3.1. Az argumentáció mint eredmény (produktum) ………………………………........ 22

2.3.2. Az argumentáció mint eljárás (procedúra) ……………………………………....... 25

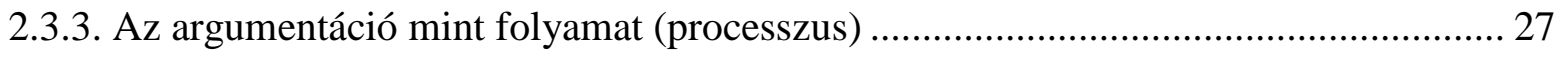

2.4. A hétköznapi érvelés és a formálisan szabályos bizonyítás különbségei........................... 28

2.5. Az érvelés dimenziói és megközelítései........................................................................ 29

2.5.1. Az érvelés logikai megközelítése ............................................................................... 32

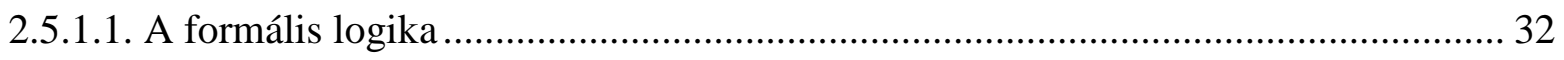

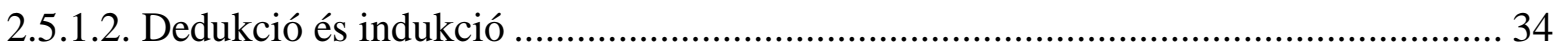

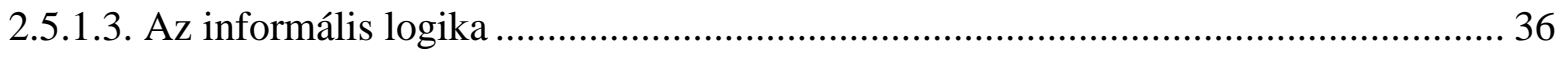

2.5.1.4. A logikai megközelítés problémái .......................................................................... 38

2.5.1.5. A rugalmasság ...................................................................................................... 38

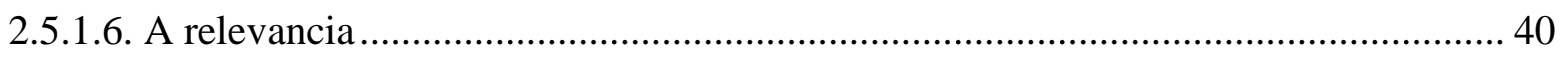

2.5.2. Az érvelés dialektikai megközelítése ………………………………………............. 41

2.5.2.1. A pragma-dialektikai megközelítés ........................................................................... 42

2.5.2.2. A pragma-dialektikai megközelítés problémái .......................................................... 43

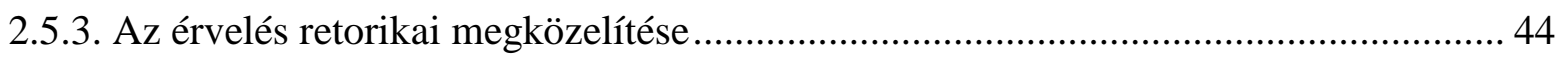

2.5.3.1. A retorika és annak kapcsolata más tudományterületekkel...................................... 45

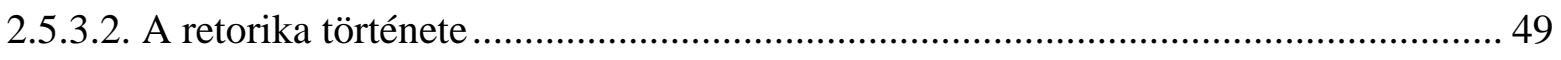

2.5.3.2.1. Retorika az ókorban.......................................................................................... 49

2.5.3.2.2. Retorika a középkorban .................................................................................... 52 


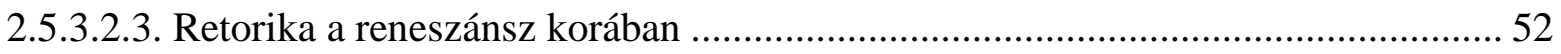

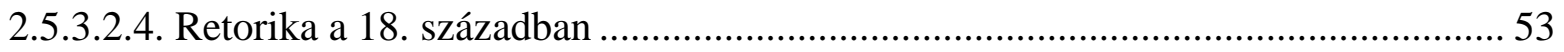

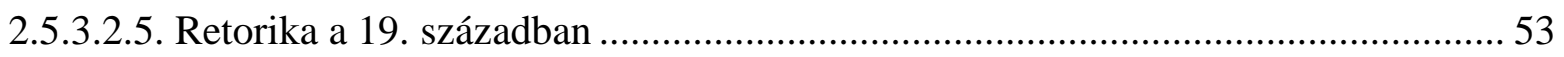

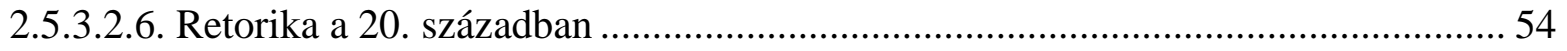

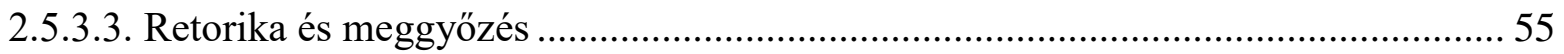

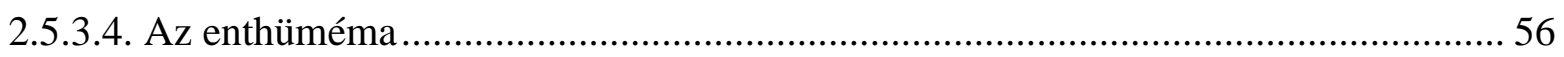

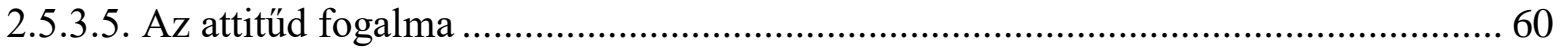

2.5.3.6. A hozzáállás (attitűd) megváltozásának elmélete..................................................... 62

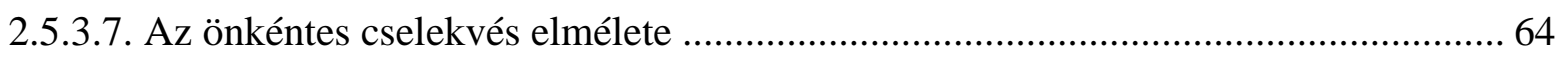

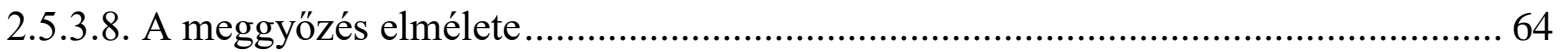

2.5.3.9. A kritikai retorika megközelítése: a dramatizálás .................................................... 66

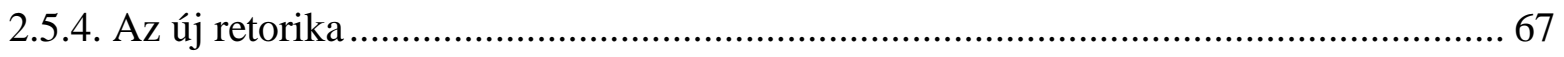

2.5.4.1. Az érzelmek és az érvelés .......................................................................................... 68

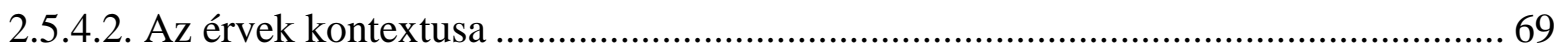

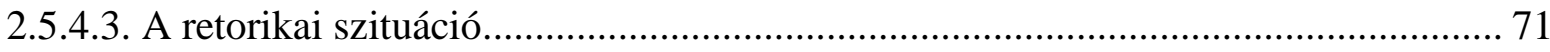

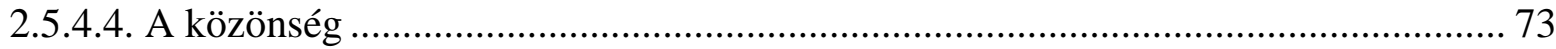

2.5.4.5. A partikuláris és univerzális közönség ………………………………………......... 75

2.6. A retorikai megközelítés problémái …………………………………………………..... 76

2.7. Miért a retorika a megfelelö keret? …………………………………………………..... 77

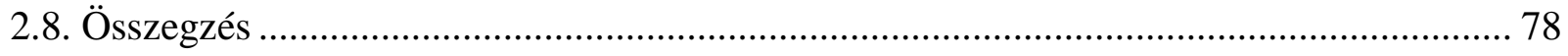

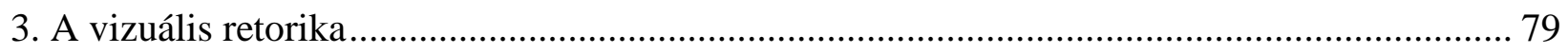

3.1. A vizuális retorika mint önálló diszciplína ………………….............................................. 81

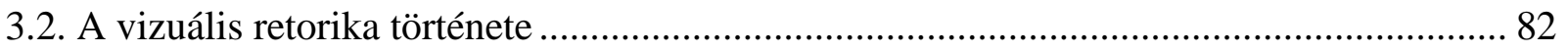

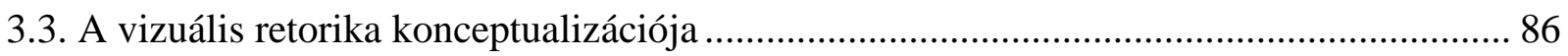

3.3.1. A vizuális retorika mint produktum/artefaktum ......................................................... 88

3.3.2. A vizuális retorika mint vizuális típusú adatok közlésfolyamata ................................ 90

3.3.3. A vizuális retorika mint nyilvános üzenet ................................................................... 91

3.3.4. A vizuális retorika mint hétköznapi valóság ................................................................. 93

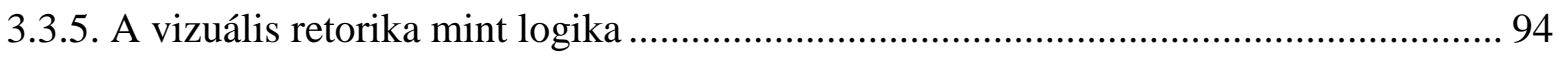

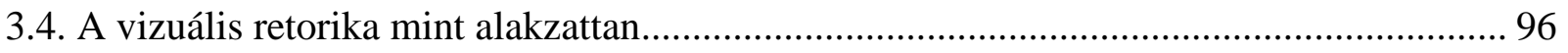

3.5. Vizuális retorika problematizálása ................................................................................... 100 
3.5.1. A vizuális retorika mint előadásmód/produktum: a vizuális retorika fogalmai ........ 102

3.5.1.1. A kép fogalmi megközelítése ........................................................................... 102

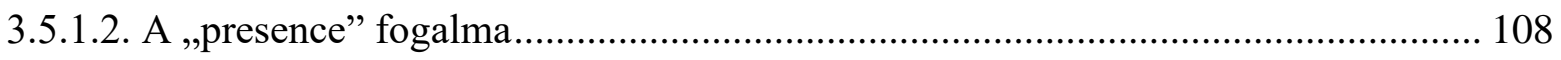

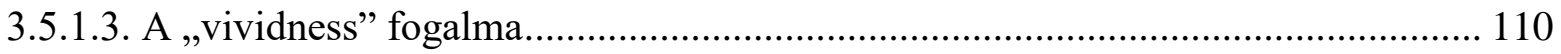

3.6. A vizuális retorika mint érvelés/procedúra ............................................................... 112

3.6.1. A vizuális retorika és az érvelés problémája .................................................... 113

3.6.2. A három legfontosabb ellenérv és cáfolatuk ...................................................... 118

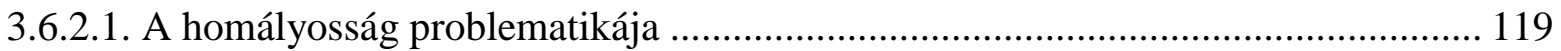

3.6.2.2. A propozicionalitás problematikája ............................................................. 121

3.6.2.3. A nyelvi transzláció problematikája ................................................................ 127

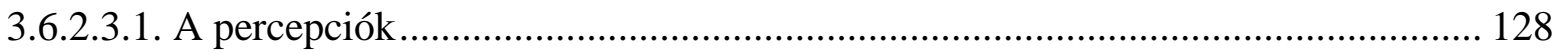

3.7. A vizuális retorika mint interpretáció/processzus ................................................. 132

3.7.1. A vizuális retorika és a média......................................................................... 132

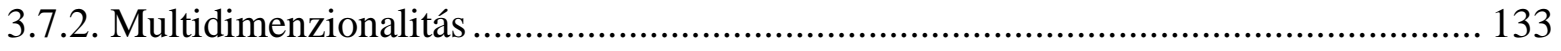

3.7.3. Ideológia, interpretáció, identifikáció és nyelv ................................................. 135

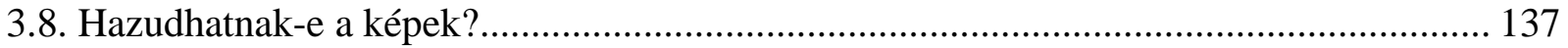

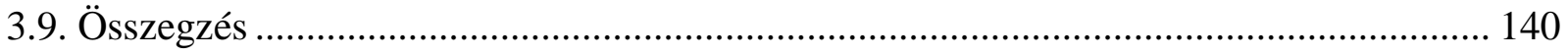

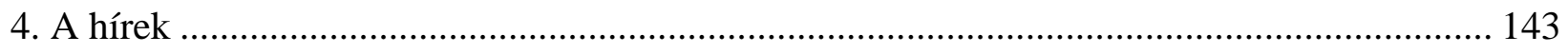

4.1. A hírek történeti elhelyezése ........................................................................... 143

4.2. A hírek konceptualizációja ............................................................................... 144

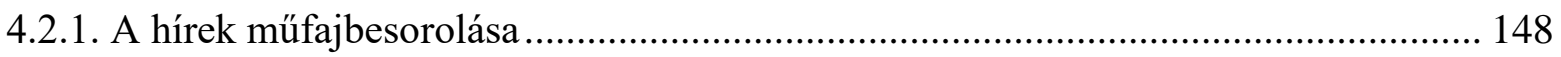

4.3. A hírek és a meggyőzés.......................................................................................... 151

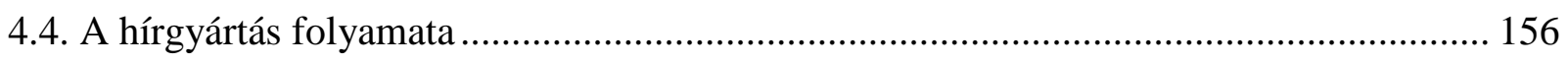

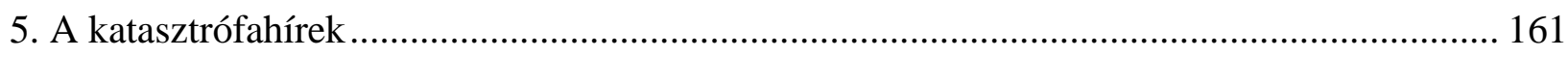

5.1. A katasztrófahírek konceptualizációja ..................................................................... 161

5.2. A katasztrófahírek médiareprezentációja ................................................................. 166

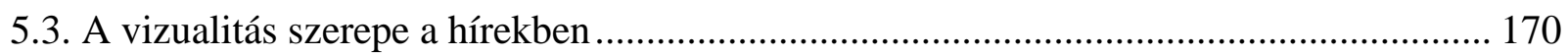

5.3.1. Az apokaliptikus vizuális ábrázolás ............................................................ 172

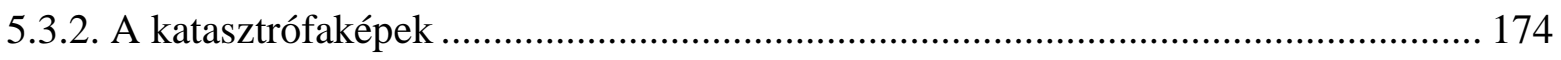

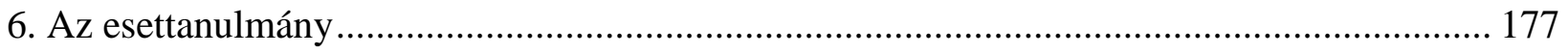

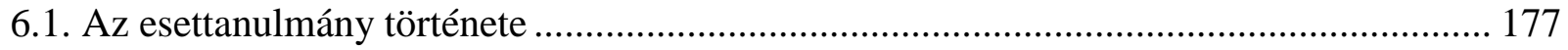


6.2. Az esettanulmány módszere a társadalomtudományokban........................................ 178

6.3. Az esetek típusai............................................................................................ 180

6.4.Az esettanulmány módszerének előnyei .................................................................... 181

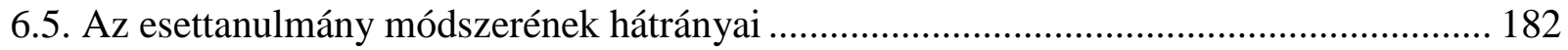

6.6. Integrált komplex módszertani keret: esettanulmány és tartalomelemzés ..................... 182

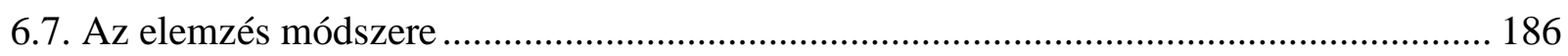

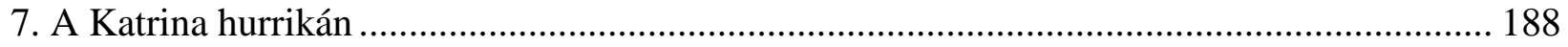

7.1. A Katrina hurrikán 3P alapú esetelemzése..................................................................... 190

8. A Bataclan színház elleni terrortámadás ........................................................................ 195

8.1. A Bataclan színház elleni terrortámadás 3P alapú esetelemzése .................................. 196

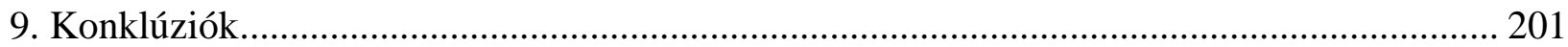

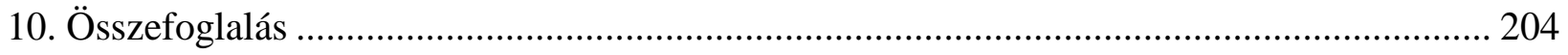

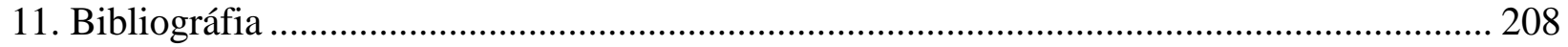

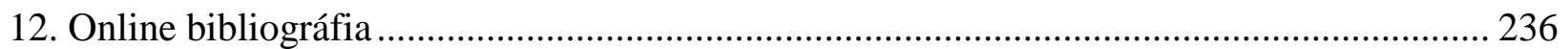

13. A témában megjelent publikációk …........................................................................... 237

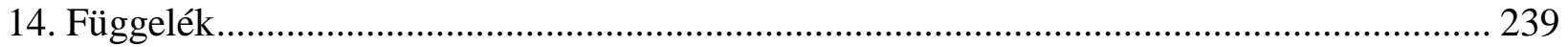




\section{Bevezetés}

„Bilder sind eindringlicher als Worte; sie brauchen nicht übersetzt zu werden und wirken unmittelbar. Ein Verfolgter klagt nicht seine Leiden; er zeigt seine Wunden vor."1

„Egy kép többet mond ezer szónál” - tartja a híres, meglehetősen sablonos mondás. De mint minden klisé, az említett idézet is elemi igazságot fogalmaz meg: „többet mond”; mond, és nem mutat, ábrázol, díszít; mond, tehát állít, közöl, érvel. Bárhogyan is tekintsünk rájuk, vitathatatlan, hogy a képek sok mindent jobban tudnak, mint a beszélt vagy az írott nyelv, ezáltal a vizuálisnak nagyobb hatalma van a verbálisnál. Gombrich aggodalma azonban nem alaptalan: egy-egy kép „helyes” megértése, értelmezése, dekódolása valóban rengeteg olyan tényezőtől függ, ami jóllehet hozzátartozik, mégis kívül esik rajta, nem jelenik meg explicit módon (Gombrich [2003] pp. 92-107.). A képekkel kapcsolatos számos ellentmondásnak és a vizuális retorikát övező dichotómiának köszönhető e tanulmány létrejötte. Témaválasztásomat nagyban motiválta, hogy - számos kutatóval egyetértve - úgy vélem, az érvelés és meggyözés vizuális komponensei nem kapnak elegendő figyelmet annak ellenére, hogy a jelen érát leggyakrabban a „modern képkorszak” (Tasnádi [2012]) vagy - Mitchell alapján a - „képi fordulat” (Mitchell [1995] pp. 12-13.) elnevezéssel illetjük, és azt mondhatjuk, hogy a képek soha nem látott mértékben tornyosulnak a szavak fölé. A vizuális retorika egy viszonylag új elméleti keret kialakulásával jött létre, amely leírja, hogy a vizuális imágók hogyan kommunikálnak a hangzásbeli, verbális és más üzenetekkel szemben. Komplexitása és interdiszciplináris természete miatt olyan különbözö tudományterületekhez kapcsolódik, mint a nyelvészet, szemiotika, müvészettörténet, a marketing és kommunikáció vagy éppen a klasszikus retorika (CTI Reviews [2016]).

Azt, hogy mai modern korunkat a képi fordulat korszakának tekintjük és a vizuális retorikának nagyobb jelentőséget tulajdonítunk, mint valaha - Foss alapján - három különböző szükségletünk alapján állíthatjuk (Foss [2008] p. 303.). Az első a vizuális érvelés mindent átható jelenléte és hatása kortárs kultúránkra. A vizuális artefaktumok fontos részét képezik a retorikai környezetnek, így figyelmen kívül hagyni őket és csak a verbális diskurzusokra fókuszálni annyit

\footnotetext{
${ }^{1}$, ,A képek eröszakosabbak, mint a szavak, nem szükséges öket leforditani és közvetlenül hatnak. Egy üldözött nem panaszolja el szenvedéseit, hanem megmutatja a sebeit." (Fordította: Veszelszki Ágnes)
} 
jelentene, hogy a bennünket nap mint nap érő ingerek és szimbólumok pusztán egy apró részét fogjuk fel. A vizuális szimbólumok retorikai perspektívájú megközelítését az a felismerés is motiválja, hogy ezek a szimbólumok egy sor olyan emberi tapasztalathoz engednek hozzáférést, amelyekhez diskurzusokon keresztül nem juthatnánk el, pl.: térbeli, nem lineáris, multidimenzionális vagy dinamikus tapasztalatok, amelyekhez a vizualitás elengedhetetlenül fontos. Végezetül, a vizuális érvelés vizsgálatának legfontosabb célkitüzése egy olyan retorikai elmélet kidolgozása, amely átfogóbb és megengedőbb. A hosszú múltra visszatekintő retorika abszolút ideológiai hegemóniát élvezett, pusztán nyelvi artefaktumokra fókuszálva, míg a vizuális szimbólumokat jelentéktelennek, másodlagosnak tüntette fel. E diskurzusalapú tradíció miatt pedig a retorikusok nem rendelkeznek azzal a szofisztikált megértéssel, amely a vizuális komponensek által történő jelentéslétrehozáshoz szükségeltetne. A vizuális retorika növekvő népszerüsége, a multidimenzionális emberi tapasztalatokhoz való hozzáférhetősége és egy átfogó retorikai elmélet megalkotása érdekében azonban a retorika nagy alakjai mára fotókat, rajzokat, festményeket, szobrokat, grafikonokat és táblázatokat, az építészet egyes elemeit, Internetes képeket és filmeket elemeznek, így törekedve egy egységes teória és definíció megalkotására (Foss [2008] p. 303.).

\subsection{Az értekezés elméleti kerete}

Campelo et al szerint a vizuális retorika elsősorban az üzenetek keretezésével és a hatékony meggyőzés módszerével és eljárásaival foglalkozik (Campelo et al [2010] p. 1.), amelynek szerepe a művészettörténet, a reklám és a marketing területén éppen olyan fontos és nyilvánvaló, mint a média- és kultúrakutatás vagy az esztétika gyakorlataiban (Mitchell [2008] p. 165.). Jelen disszertáció azonban, túlmutatva a retorika mint meggyőzés és keretezés felfogáson, újfajta paradigmát kínál. Dolgozatom komplex, összetett retorikát mutat be, amelynek sajátossága, hogy nem csak a dologról szól, hanem arról is, ahogyan elkészült, és ahogyan használják. Ehhez az érvelés produktum (az érvelés mint eredmény, termék vagy artefaktum), processzus (az érvelés mint kommunikatív folyamat), és procedúra (az érvelés mint eljárás) megközelítését érvényesnek tekinti a képek esetében is, utalva ezzel a címben szereplő vizuális retorikai triadikus koncepcióra. Az argumentáció mint eredmény - formális logikai kötődésének köszönhetően rendkívül szabad felfogást kínál: nem foglalkozik azzal, hogy az érvelést ki hozza létre, kinek és milyen célból, ezáltal létrejötte voltaképpen egy kontextuális elemeitől megfosztott szempont. 
Az érvelés eljárásalapú szemlélete arra utal, hogy az argumentáció müködését különböző dinamikák, eljárások, szabályos minták és müveletek biztosítják. Ezáltal a procedurális felfogás az érvelési folyamatokra, ezek szabályainak létrehozására, magyarázatára és megértésére vonatkozik, amelynek középpontjában nem a mi, hanem a hogyan található. Végül, az argumentáció mint folyamat típusú megközelítés pragmatikus, hatás és szándékalapú felfogást kínál. Az argumentáció imént bemutatott három vetülete természetesen szoros összefüggésben áll egymással: az argumentáció mint eredmény létrehozásának szabályos rendjén alapul és folyamatként realizálódik az interakcióban. (A jobb szemléltetés és könnyebb megértés céljából egy példával élve: olyan megközelítésnek fogható ez fel, mint az oktatás problematikája: mit oktatunk - ez adja a produktumot; hogyan oktatjuk - ez a procedúrát; és végül milyen kontextusban, szituációban oktatjuk - ez pedig a folyamatot jelöli.)

Jelen disszertáció amellett érvel, hogy a vizuális retorika, logikai eszközrendszerének és retorikai gondolkodásának, hatásosságának köszönhetően kielégíti az érvelés mindhárom fogalmát. A dolgozatnak nem célja a retorikai fogalmak alapos kronológiai bemutatása, ennek következtében a relevancia szempontjából használja a történeti kútföket; esetenként modern, posztmodern, máskor a klasszikus szerzőkre hivatkozva, szisztematikus időbeli követés nélkül.

Értekezésem a 3P vizuális retorikai vizsgálatának tárgyaként a híreket jelöli ki, amelyeknek közvélemény-formáló hatásait csak az 1960-as évek közepén kezdték el felismerni, miután a müsorszolgáltatók bebizonyították, hogy az új kommunikációs technológiák és a különböző híranyagok folyamatos áramlása bármely fontos esemény képeit elérhetővé tehetik órákon belül, a világ bármely országa számára. Az évek során a világ közönségének tagjai osztoztak a Kennedy gyilkosság, különböző diák zavargások, a Watergate-botrány, számos terrortámadás és háború képeiben, és a hírek szépen lassan kultúraformáló szerepet töltöttek be minden olyan társadalomban, amelynek része a televíziózás, újságírás (Yorke [2013] p. 3.). A hírek, azon belül a természeti és ember által okozott katasztrófák hírei rendkívüli hatékonysággal ragadták meg a közvélemény figyelmét az elmúlt pár évtizedben. Az olyan támadások és katasztrófák okozta halálesetek és pusztítás, mint szeptember 11-e, a Katrina hurrikán, a nagy Kelet-Japán földrengés, az indiai-óceáni szökőár vagy az elmúlt időszak terrortámadásai nem meglepö módon arra sarkallták az embereket, hogy tömegmédiához forduljanak információszerzés és bizonytalanságcsökkentés céljából. Egy katasztrófa megtörténtekor a 
tömegmédia szerepkörébe tartozik a polgárok figyelmeztetése, a történtek leírása, az információáramlás biztosítása az események alatt és után, sőt, az egyéni és közösségi felépülés és a rend helyreállítása is (Houston et al [2012] pp. 606-607.). Jelen tanulmány megközelítése szerint a katasztrófahírek szerkesztői különösen sok képi reprezentációt alkalmaznak, méghozzá a képek azon tulajdonságának köszönhetően, hogy nyelvi transzláció nélkül, könnyedén képesek eljuttatni mondanivalójukat a befogadókhoz.

Figyelembe véve azt, hogy a nyilvánosság milyen gyakorisággal fordul a médiához a katasztrófákkal kapcsolatos információk megszerzéséért, megállapítható, hogy milyen nagy szükség van a katasztrófahírek egyénekre és közösségekre gyakorolt potenciális hatásainak, valamint a tömegmédia normatív szerepének vizsgálatára, jelen tanulmány pedig ezek vizuális retorikai megközelítését mutatja be egy természeti, és egy ember által okozott katasztrófa esettanulmány típusú elemzésén keresztuil. A választott katasztrófák a 2005 augusztusában, az Egyesült Államok déli területein végigsöprő Katrina hurrikán, valamint a 2015. november. 13án, a párizsi Bataclan Színház ellen elkövetett terrorakció. A fentiek értelmében disszertációm a következö öt állítás bizonyítására vállalkozik.

\subsection{Hipotézisek}

1. A vizuális retorika önálló diszciplináris terület. Ugyan a vizuális retorika terminusát mintegy két évtizede használják, e kifejezés még mára sem vált egyértelmű diszciplínameghatározó fogalommá. Eddigi története azt mutatja, hogy a vizuális retorika a „létezik ilyen” és nem a „létezik” kategóriáját jeleníti meg.

2. A vizuális retorikai érvelés elkülöníthető és diszciplinárisan köthető logikaikommunikatív folyamat.

3. A vizuális retorika kielégíti az érvelés három minőségét: a produktum (a képi érvelés mint termék vagy artefaktum), a procedúra (a képi érvelés mint eljárás), és a processzus (a képi érvelés mint kommunikatív folyamat) megközelítését.

4. A vizuális retorikai érvelés nyelvi transzláció nélkül is elképzelhető, amely állítás szorgalmazza, hogy a vizuális retorikával, azon belül az érveléssel kapcsolatosan egy új paradigma alakuljon ki. 
5. A természeti és ember által okozott katasztrófák híreinek vizuális reprezentációja eltéréseket mutat mind a produktum, mind pedig a procedúra és processzus megközelítését tekintve.

\subsection{Az értekezés módszertani kerete}

Disszertációm két esemény elemzésén keresztül mutatja be a vizuális retorika mint önálló diszciplína és a produktum-, procedúra-, és processzus-orientált vizsgálati módszer érvényességét. Elemzésem a Katrina hurrikán mint természeti katasztrófa, illetve a Bataclan Színház elleni terrortámadás mint ember által okozott katasztrófa médiában megjelenő vizuális anyagainak vizsgálatára vállalkozik, összesen 150 kép elemzésével. A képek forrását tekintve olyan platformokra támaszkodtam, mint a CNN, a US News, a The New York Times, a The Huffington Post, a Daily Mail vagy a Nyugat, az Origó és a Blikk online oldalai. A képeket véletlenszerủ mintavételen alapuló adatgyüjtés (random sampling) módszerével választottam ki. Ugyan jelen elemzés adott esetekböl ragad ki képeket, így akár tartalomelemzésnek is minősülhetne, vizsgálatomra azonban elsősorban mégis esetelemzésként tekintek. A két katasztrófa képei gyakorlatilag eseteket kondenzálnak, történelmi, politikai és társadalmi kérdéseket sürítve. Az eset típusú megközelítés segítségével pedig nem csak a képek tartalma, hanem azok kontextusa is ugyanúgy a fókuszba kerülhet. Vizsgálatom ezáltal egyfajta hibrid módszerrel közelít, amelynek egyik bemenete a képek kódolásán keresztül történö tartalomelemzés, a másik, fö bemenete pedig az esetelemzés, amelyben vizsgálatom a képek kontextusát, szándékát, hatását, megjelenített toposzát és perspektíváit is képes tekintetbe venni.

Kutatásom célja annak feltérképezése, hogy milyen hasonlóságokat és eltéréseket mutat egy természeti és egy ember által okozott katasztrófa vizuális reprezentációja, feltételezve, hogy esetelemzésem számos különbségre mutat majd rá a két eset vizsgálata során. A választott két esemény 75-75 képének produktum, procedúra és processzus alapú elemzéséhez az alábbi kódrendszert alakítottam ki:

1. A kép produktum típusú megközelítését tekintve a következő aspektusokat vizsgáltam: előtér, nem, kor, feketék/fehérek, pozitúra/proxemika, öltözet, háttér, mise en scène, azaz a kép fókuszának, keretbe helyezésének vizsgálata. A 8 kód közül a pozitúra/proxemika kódot az összesítés során végül elvetettem, a fényképeken szereplö alakok/épületek 
pozitúrájának sokfélesége miatt. A kép eredmény típusú megközelítése tehát kontextusából kiragadva mutatja be a vizuális elemeket, eltekintve, vagy nem elsősorban figyelembe véve a közlésfolyamat egyéb kommunikatív szempontjait.

2. A kép mint procedúra megközelítésében az alábbi aspektusok vizsgálatára tértem ki: a kamera nézőpontja (alulról, felülről, szemböl vagy hátulról mutatja be), az alakok mozdulata, mimikája, a kamera proxemikája (közeli vagy távoli kép), speciális effektek (éles vagy homályos elemek a képen), és az időfaktor. Jelen perspektíva a kép készítőjének elemzési szempontrendszere. Azt írja le, ahogyan ő látja és láttatja a történteket. Ez az aspektus tehát már kontextusában vizsgálja a képet, nézőpontja pedig mindenképpen értéktelített, akaratvezérelt.

3. A kép processzus típusú megközelítését tekintve három kódot határoztam meg: a kép szándékát, hatását, harmadik aspektusként pedig a kép által bemutatott toposzt, vagy megtestesített cselekményelemet különítettem el (pl.: szenvedés, agresszió, veszteség, halál stb.). A képi elemzés esetlegességének és szubjektivitásának kiküszöbölése érdekében társkódoló segítségét vettem igénybe (a kódolásban Németh Gabriella, a Budapesti Corvinus Egyetem Társadalmi Kommunikáció Doktori Iskolájának doktorjelöltje volt segítségemre).

\subsection{Pilot eset bemutatása}

A fent megfogalmazott hipotézisek és a kialakított kódrendszer szemléltetése érdekében disszertációm egy mintapéldán, úgynevezett pilot eseten keresztül mutatja be a vizuális retorika produktum, procedúra és processzus típusú megközelítését, annak bizonyítására, hogy rendszerben tekintem e hármast. A választott eset a „Saigon Execution Photo”, azaz a saigoni kivégzésről készült felvétel, amelyet Eddie Adams készített, 1968.február 1-én. A vietnámi háború egyik legikonikusabb fotóján a dél-vietnámi Nemzeti Rendőrség dandártábornoka, Nguyon Ngoc Loan látható, amint éppen kivégzi Nguyen Van Lem, vietkong rabot. 


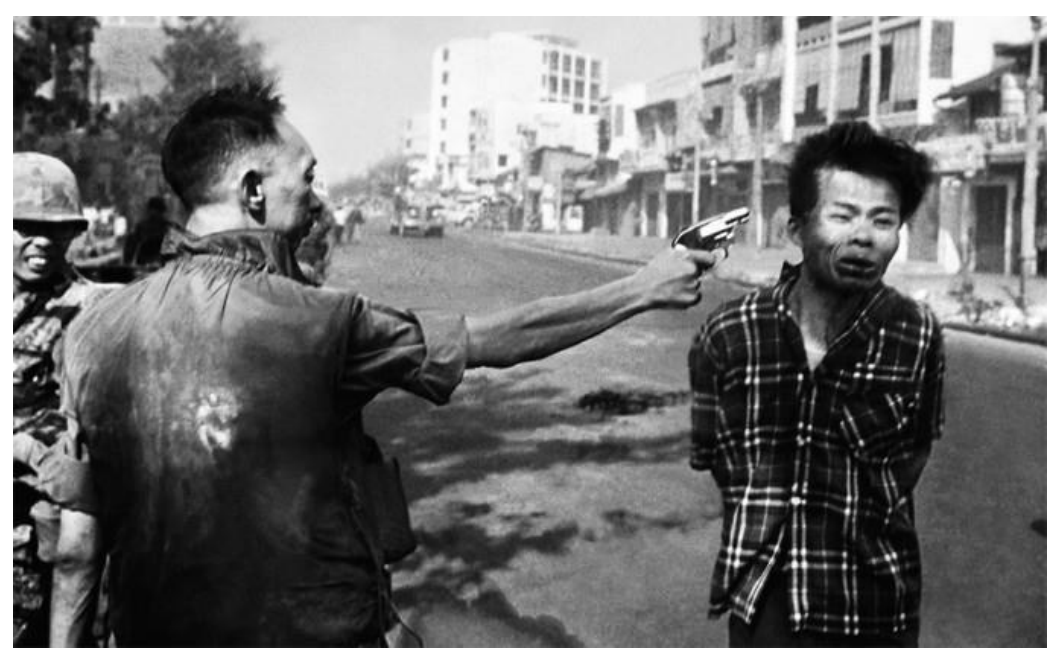

A kép forráshelye: http://www.newseum.org/2015/05/12/pulitzer-prize-photography-saigon-

\section{execution/}

Kontextusából kiragadva a képet egy hidegvérü, elszánt gyilkost látunk, aki kivételes kegyetlenséggel agyonlő egy ártatlan rabot, esetlegesen civilt. Amit azonban a kép nem mond el, hogy a lelött férfi, Nguyen Van Lem, egy vietkong bosszú-század parancsnoka volt, aki korábban fegyvertelen civilek tucatjait, és a Nemzeti Rendörség számos tagját családostul mészárolta le, így - háborús büntettei és gerilla tevékenysége miatt - kivégzése jogszerü volt. A kép azonnal a vietnámi háború könyörtelen barbarizmusának szimbólumává vált, a ravaszt meghúzó tisztet pedig ikonikus gazemberré tette (Magyar Fotográfusok Háza [2013]). A fénykép egész életében kísértette Nguyon Ngoc Loan dandártábornokot, akinek gyógykezelését a háború után több intézmény is megtagadta, így az Egyesült Államokban próbált új életet kezdeni, ahol emberjogi aktivisták tüntetései nyomására kishíján deportálták. A tábornok, hosszas hányódás után végül az USA-ban, 1998-ban, 67 éves korában hunyt el rákban (Magyar Fotográfusok Háza [2013]).

Eddie Adams fotográfus ezért a felvételéért 1969-ben - számos más díj mellett Pulitzer-díjat is kapott. A fotó kapcsán később így nyilatkozott: „1969-ben Pulitzer-díjat nyertem egy olyan fotóval, amelyen egy ember lelő egy másikat. Két ember halt meg a képen: az, aki a fejlövést kapta, és Nguyon Ngoc Loan tábornok. A tábornok megölte a vietkong-ot, én pedig megöltem a tábornokot a fényképezőgépemmel” (Time Magazine [1998]). 
Produktumként való megközelítését tekintve egy fekete-fehér képet látunk, amelynek előterében két középkorú férfialak látható, ábrázolásuk éles. A háttérben további emberek, házak, fák és járművek találhatók, ezek azonban elmosódottak, helyenként alig kivehetőek. A kameraállás szemből mutatja be az eseményeket, a két szereplő szinte teljesen kitölti a felvétel keretét. A fegyvert tartó férfialak katonai felszerelésben, kinyújtott karral, míg a másik férfialak hétköznapi, kockás ingben, hátrakötözött kézzel jelenik meg. A fegyvert tartó férfialak arca profilból látszik, míg a lövést fogadó személy arcát szemből mutatja a kamera.

Procedurális megközelítését tekintve a kamera logikája világos. A dandártábornok arcát nem mutatja egészében, hiszen ő pusztán a kegyetlen, hidegvérü gyilkos, a halálosztó szimbóluma, nem az ő érzései, indítékai vannak a középpontban, hanem a rab halálfélelme. A nézőpont tehát egy teljes mértékben sugalmazó nézőpont, amely a befogadót a rab történetébe, érzelmeibe helyezi bele. A hangsúly a tábornok kezében megcsillanó pisztolyon, illetve a rab szenvedéssel és félelemmel teli arcán van. A kép elötérbe helyezi a tábornok kinyújtott karját, amely proxemikailag méginkább eltolja magától a látszólag ártatlan rabot.

Végezetül, processzusként való megközelítését tekintve elmondható, hogy a felvétel egy szegény, ártatlan ember megölésének hatását kelti. Elsődleges szándéka a tábornok (és általa az egész vietnámi háború) brutalitásának bemutatása. A felvétel az együttérzés és sajnálat érzéseit váltja ki a befogadóból, hiszen az előbbi két aspektus (produktum: öltözet, nonverbális kommunikáció, proxemika; és procedúra: kameraállás, hangsúlyok, fókusz) mind egy ártatlan ember illúzióját alkotja meg. A kép megjelenített toposza egyértelmüen a szenvedés.

\section{Az érvelés}

\subsection{Az érveléselmélet történeti áttekintése}

Az érvelés történetét többnyire a retorika történetével együtt kezelik, hiszen mind a kettő része mindennapjainknak, mind a kettő a hétköznapi ügyekkel, komplexumokkal foglalkozik. Az eredetét körülvevő bizonytalanságra hívja fel a figyelmet Feyerabend osztrák filozófus is, aki úgy véli, az érvelés, csakúgy, mint a nyelv, a müvészet vagy a rituálék, univerzális; de csak úgy, mint a nyelvnek, a müvészetnek és a rituáléknak, az érvelésnek is számos formája van. Egy 
egyszerü mozdulat, vagy felmordulás is eldöntheti a vitát néhány résztvevő számára, míg másoknak terjedelmes és színes áriákra van szükségük ahhoz, hogy elfogadják a beszélő szándékait. Ezáltal az érvelés feltételezhetően jól megalapozott volt már a görög és római filozófusok elméletalkotása előtt is, mégis általuk nyerhette el mai formáját, megbecsültségét és gyakorlatait (Tindale [2004] p. 32.).

Történeti meghatározását tekintve tehát az érvelés hagyományosan a római és görög tanítások és gyakorlatok összességére vonatkozik, amely Hésziodosz és Homérosz korának epikusaitól kezdve magában foglalja a szofisták és római szónokok, drámaírók és filozófusok beszédeit, prédikációit, kézikönyveit és retorikai költészetét, a Római Birodalom idejével bezárólag. E tanítások és gyakorlatok a nem nyugati kultúrák, vagy a középkori, reneszánsz és modern nyugati kultúrák viszonylatában értelmezhetők leginkább, amelyek elszakadtak a klasszikus gyakorlatoktól (Kennedy [2006] p. 104.). Elméleti meghatározását tekintve a klasszikus érvelés a nyilvános beszéd oktatására irányuló szisztematikus és átfogó ismeretanyagként értelmezendő. Ezt a felfogást oktatják és gyakorolják a nyugati civilizációkban ma is, kiterjesztve a rendszer beszédközpontúságát az írásos diskurzusok és a költészet elemzésére, tanítására. A szofisták, Platón, Iszokrátész, Arisztotelész, a hellenisztikus korszak filozófusai és a Római Birodalom kritikusai mind hozzájárultak a fent említett elmélet kialakításához, de Cicero írásai (De inventione, De oratore, Partitiones oratoiae stb.) és Quintilianus szónoki ismérvekről szóló retorikai alkotása (Institutio Oratoria) a nyugati klasszikus hagyomány megalapozásának elsődleges forrásai voltak (Moss [2006] p. 129.). Az ókori görögök meghatározásait tekintve a retorika és az érvelés fogalma számos változáson ment keresztül. A Szirakúza bíróságaitól induló retorika többek között Arisztotelész által nyert kiterjesztést, aki egyértelmüen a meggyőzésre helyezi a hangsúlyt: „Fogadjuk el, hogy a retorika olyan képesség, amely minden egyes tárgyban feltárja a meggyőzés lehetőségeit (Arisztotelész [1355b]).” A retorika a későbbiekben már nem csak a bíróság előtti nyilvános beszédekre, hanem a fórumokon megtartott politikai és ünnepi felszólalásokra is vonatkozott. Később, Cicero bevezette a retorika tanító, gyönyörködtető és megindító funkcióit is, Burke pedig már egyenesen a nyelv, mint szimbolikus eszköz használatának nevezte, amely elősegíti az érvelők közötti kooperációt (Blair [2012] p. 310.). 
Mára a tágabb, jelen tanulmány szempontjából leginkább releváns megközelítések szerint az érvelés gyakorlatilag bármilyen emberi eredetü szimbólumot tartalmazhat, amelyből a közönség jelentést képes alkotni. A korai felfogásokhoz képest az érvelés fogalma tehát kibővült. Az érvelés mint társadalmi gyakorlat (sok egyéb mellett) az érvek felsorolására és ütköztetésére utal, értelmezése pedig rendkívül sokat változott a történelem folyamán. Arisztotelész úgy véli, a retorikában betöltött szerepe mellett, az érvelés a filozófiai elméletek konstruálásának és ellenőrzésének módszereként, valamint a szélesebb közönséget megcélzó beszédek eszközeként tekintendő. A kortárs elméletben többen tettek törekvést az érvelés hatáskörének korlátozására, a nézeteltérések feloldása érdekében (pl.: van Eemeren és Grootendorst), míg Willard az egyezkedés, egyetértés módjaként értelmezi azt. Goodnight a nyilvános színtéren történő tárgyalások, Meiland a vizsgálódás, Rieke és Sillarspedig a döntéshozatal eszközének nevezi az érvelést (Blair [2012] p. 310.).

\subsection{Az érvelés konceptualizációja}

Mielőtt az érvelés meghatározására térnék, szükségszerü magát az érvet is bemutatnom. Definíció szerint az érv vagy argumentum indoklást, megokolást vagy bizonyítékot jelent, amely a kétséges dolgokat azzal erősíti meg, amihez nem férhet kétség. Maga az „érv” magyar terminus az „ér”, „elér valamit” kifejezésekhez vezethető vissza, ezáltal válik a kétségbe nem vonható állítás elérésének célkitüzésévé (Adamik [2010] p. 352.). Quintilianus szerint az érv olyan indoklás, amely bizonyít, és általa egy dologra egy másik dologból következtethetünk, ami megerősíti azt, ami kétséges, azzal, ami nem kétséges. Ha nem lennének érvek, nem lenne semmi, amivel bizonyíthatnánk, és amivel a kétséges dolgok hitelt érdemlővé válhatnának (Quintilianus [2008]). Quintilianus felfogásában érvnek tekinthetünk mindent, amit érzékeinkkel felfogunk, valamint az általános meggyőződés tárgyát képező dolgokat, végezetül mindazt, amiről a két fél megegyezik, ami ellen a másik fél nem talál kifogást (Quintilianus [2008]).

Az érv kifejtésével szemben az érvelés meghatározása számos szempontból problematikus, kevesen tudják ugyanis, hogy mi is az érvelés, mivel foglalkozik e tudományág. Gyakran a bizonyítás szinonimájaként gondolunk rá, esetenként a vitával, meggyőzéssel vagy a manipulációval azonosítjuk, de számos kérdést vet fel az is, hogy sokan továbbra is az érvelés pusztán verbális kódhoz való kötődését támogatják. Aczél szerint az argumentáció „olyan 
okadatolás, amely egy gondolat vagy cselekvés megváltoztatására irányul és egy álláspont igazolására szolgál” (Aczél [2005] p. 326.), míg al-Musawi úgy fogalmaz, hogy az érvelés tudománya olyan érvekkel foglalkozik, amelyeket az emberek vélekedéseik és meggyőződéseik alátámasztása érdekében alkalmaznak azért, hogy befolyásolják mások gondolatait és cselekedeteit (al-Musawi [2006] p. 42.). Fókuszában a diskurzus során bevezetett állítások racionalitása, észszerüsége áll. Ezek az állítások pedig csak akkor válnak indokolttá, ha bizonyítékaik és következtetéseik maguk is megalapozottak, jó kiindulópontként szolgálva ezzel az érvelést felépítő kijelentésekhez. Az argumentáció erős normatív vagy értékelő komponenssel, valamint tág pedagógiai dimenzióval rendelkezik, bár sok leíró jellegű tudomány is foglalkozik azzal, hogy az emberek - kontextustól és szituációtól függően - mit fogadnak el jó érveknek egy állítás felépítéséhez (al-Musawi [2006] p. 42.).

A különböző megközelítések szerint az érvelés egyfelől tekinthető egy adott típusú diskurzusnak, másfelől perspektívának, amely bármely diskurzusra alkalmazható, az érvek dimenziójára fókuszálva. Az előző megközelítés megkülönbözteti az argumentációt olyan más zsánerektől, mint a leírás vagy elbeszélés, amelyeknek nem célja bizonyos állítások és érvek megfogalmazása; az utóbbi azonban értelmezheti az implicit érvelési struktúrákat a történetekben vagy a leírás egyes elemeiben, sőt, még a nem-verbális vagy nem-diszkurzív „szövegeket” is vizsgálhatja az állítások megfogalmazásának és védelmének tükrében. Hasonlóképpen, az érvelés elemzési egysége jelentheti egyetlen önálló érv komponenseit, vagy akár idővel kialakuló társadalmi vitákat is. A „mikroszintü” vizsgálatok az egyes kijelentéseket vizsgálják, és azt írják le, hogyan, milyen erővel müködnek. Az úgynevezett „középkategóriás” (midrange) vizsgálatok az állítások együttesét nagyobb egységekben - pl.: beszédek vagy értekezések - vizsgálják. Végezetül a „makroszintü” tudományok az olyan, többszereplős viták dinamikáját tárják fel, amelyek időben kiterjedhetnek (al-Musawi [2006] p. 42.).

Al-Musawi azonban arra hívja fel figyelmünket, hogy még a fenti leírás sem ragadja meg az érvelési tanulmányok sokféleségét, mivel számos különböző felfogás létezik az érvelés alapvető jellemzőivel, és azzal a perspektívával kapcsolatosan, amelyből vizsgálják. Daniel J. O'Keefe elkülöníti egymástól az argumentációt mint valamely érv létrehozását (,making an argument”) és az argumentációt mint valamely érvek ütköztetését (,having an argument”) kifejezést, ahol az előbbi egyfajta szöveget jelöl, az utóbbi pedig egy interakciót (O'Keefe [1982] 
pp. 3-23.). Ebből az elgondolásból született meg az érvelés mint eredmény (produktum) és az érvelés mint folyamat (processzus) megkülönböztetése. Joseph Wenzel Perspective on Argument címü munkájában azonban már az érvelés hármas megközelítését javasolja, az érvelés mint eljárás (procedúra) kiegészítéssel élve (Wenzel [1991] pp. 121-143.) A bizonyítás fent említett hármas szemléletét a kognitív értelmezés egészíti ki, amely szerint az érvelés a szöveg létrehozójában, a közlőben az interakció előtt játszódik le (L. Aczél [2013, 11-12]). Az eredmény/folyamat/eljárás triád azóta széles körben elfogadottá vált, a jelen disszertáció pedig arra vállalkozik, hogy bebizonyítsa, egy vizuális tartalom is kielégíti az érvelés mindhárom fogalmát, méghozzá a nyelvi transzláció szükségessége nélkül.

\subsection{A 3P: Produktum, Procedúra, Processzus}

\subsubsection{Az argumentáció mint eredmény (produktum)}

Az érvelő, argumentatív szöveg abban különbözik a leírástól vagy elbeszéléstől, hogy egy bizonyos álláspontot fogalmaz meg, ezt igyekszik igazolni, indokolni (Aczél [2005] p. 326.). A szövegtípus vizsgálata elsősorban a formális logika elveit veszi alapul, segítségével pedig a bizonyítás érvényességét és helyességét, helytállóságát, vagy ezek ellenkezőjét állapíthatjuk meg. A vizsgálat tehát a bizonyítás formájának értékelésében, az érvformák felismerésében és logikájuk formai tisztaságának detektálásában valósul meg (Aczél [2005] p. 326.). A bizonyítás alapvető szervező elve, s egyszersmind alkotóeleme a szillogizmus, azaz propozicionális állítások sorozata, elkülöníthető premisszákkal, amelyek maguk után vonják a konklúziót. Ha az érvelés formája nem helyes és a konklúzió nem bizonyított, maga a szillogizmus is érvénytelen. Az érvényesség tehát a formára vonatkozik és független az érv tartalmától (al-Musawi [2006] p. 43.). A szillogizmusokat Arisztotelész olyan diskurzusokként írja le, amelyekben „bizonyos állításokat teszünk és ezek létezéséből szükségszerűen olyasvalami következik, amelyet nem állítottunk eleinte. A mondat második fele arra utal, hogy ezek az állítások hozzák létre a konklúziót, ezáltal semmilyen további feltételnek nem kell teljesülnie a konklúzió szükséges létrejöttéhez" (Aristotle [2015]). Arisztotelész tehát azt nevezi tökéletes szillogizmusnak,

amelynek az eredeti tételeken kívül semmi más nem kell ahhoz, hogy kiderüljön: ami következik, az szükségszerüen következik. Nem-tökéletes szillogizmusnak ezzel szemben azt nevezi, amelyeknek ehhez még egy vagy akár több olyan tétel kell, amelyek ugyan 
szükségszerüen következnek a lefektetett fogalmakból, de mégsem nyertek tételszerü kifejezést (Arisztotelész [1961] p. 193.). A szillogizmus három fö típusa a kategorikus (amelyben az állítások kategóriákat viszonyítanak kategóriákhoz), a kondicionális vagy feltételes (amely a haakkor struktúrákban érvényesül) és a diszjunktív vagy választó szillogizmus (amely a vagy-vagy állításokra és konklúziókra utal, és egymást kölcsönösen kizáró fogalmakat tartalmaz) (Aczél [2005] pp. 284-302.).

Ahogyan az a fentiekböl is látszik, az argumentatív szöveg kritériumai tehát nem a retorikai, hanem a logikai, dialektikus megközelítést érvényesítik. A 20. század során azonban kutatók egy csoportja megkérdőjelezte a szillogizmus központi pozícióját az argumentatív szövegben. E kritikusok közé tartozik többek között a filozófus Stephen Toulmin és Chaïm Perelman, valamint a logikus C. L. Hamblin és Douglas Walton, akik úgy vélik, a szillogizmus nem a megfelelő keret az érvelés számára (al-Musawi [2006] p. 43.). Kritikájuk abban áll, hogy a szillogizmus az érvelés teljesen atipikus módját írja le, amely csak egy zárt rendszerben képzelhető el, és amely konklúziójában pusztán átrendezi azokat az információkat, amelyek amúgy is megjelennek a premisszákban implicit módon. Nyilvánvaló továbbá az is, hogy míg a szillogizmus a dedukció eszköze, ezáltal a formális logika alkotóeleme, addig a retorikai szituációkban létrejövő szövegek többsége induktív, azaz a már ismertről egy következtetett ugrással jutunk el konklúziónkig (Aczél [2005] pp. 326-327.). Stephen Toulmin a The Uses of Argument címü munkájában az érvelés olyan alternatív struktúráját kínálja, amely - az okadatolás formális és gyakorlati megközelítésén keresztül - helyettesítheti a szillogizmust (Toulmin [1958] pp. 87-131.). Míg az előbbi, formális eljárást a matematika, az asztronómia és a logika használja, addig az utóbbi, gyakorlati eljárásmód fókuszában az argumentáció, azaz az érvelés áll, amelynek nem az érvényesség/érvénytelenség vagy helyesség/helytelenség meghatározása a célja, hanem a relevanciára, erősségre és indokolhatóságra helyezi a hangsúlyt (Aczél [2005] p. 327.). Az adatokon (data), biztosítékokon (warrant) és az állításokon (claim) túl modelljében bevezeti az állítás erősségére utaló minősítőket (qualifiers), a támogatás (backing) és a megengedés (rebuttal) kifejezéseket. A fenti kiegészítések által az érvelés ereje annak eredményességében rejlik (al-Musawi [2006] p. 43.). Toulmin argumentációs modelljén kívül meg kell említenünk Chaïm Perelman argumentációs retorikáját is. A lengyel filozófus ugyanis a méltányosság vagy igazságosság szabályát vezeti be az érvényesség alapjaként, azt javasolva, hogy az alapvetően hasonló személyeket azonos módon kell kezelni (Perelman [1963] 
p. viii.). Az informális logika kiemelkedő képviselői, Hamblin és Walton az olyan érvelés mintákra koncentrálnak, amelyeket a formális logika érvelési hibáknak, falláciáknak tekintene. Az informális logikusok számára azonban a legtöbb ilyen érvelés tökéletesen észszerü. Az hogy hibásak-e vagy sem nem pusztán az érvek formájától függ, hanem magában foglalja azokat az összefüggéseket is, amelyek a kontextusban rejlenek. A puszta formán kívül a két említett kutató figyelembe veszi az emberi tapasztalatokat, a jelentésbeli különbségeket és a nyelvi konvenciókat is (al-Musawi [2006] p. 43.). De nem csak a filozófusok és informális logikusok kérdőjelezik meg a szillogizmus központi szerepét. A retorikusok úgy vélik, az érvelőnek nem az a szándéka, hogy megismételje a már ismert tudásokat, hanem, hogy elfogadtassa közönségével álláspontját, ezért a retorikusok nem a szillogizmusra, hanem annak közeli rokonára, a későbbiekben részletezett enthümémára hívják fel a figyelmet. Ez a megközelítés tehát abban áll, hogy a rétor a közönség bevonásával indokolja állításait, így nem képes érvényes érvelést alkotni, csakis a hallgatósággal közös együttmüködésben (al-Musawi [2006] p. 43.).

Az argumentáció mint eredmény tehát - formális logikai kötődésének köszönhetően meglehetősen szabad felfogást kínál: nem foglalkozik azzal, hogy az érvelést ki hozza létre, kinek és milyen célból, születése gyakorlatilag egy kontextuális elemeitől megfosztott szempont. A produktumorientált olyan struktúraközpontú nézet, amely eltekint, vagy nem elsősorban foglalkozik a közlésfolyamat egyéb szempontjaival. E megközelítés a tanulmányom fókuszában álló vizualitásra is mindenféleképpen érvényesnek tekinthető: a produktum a képek esetében azzal a logikával érvel, amivel a látás is. Ezzel a területtel pedig az úgynevezett spaciális logika foglalkozik, amely alatt definíció szerint olyan széles értelemben vett geometriai entitásokat és kapcsolatokat ábrázoló szerkezetek csoportját értjük, amelyek interpretációja egy formális nyelven keresztül zajlik. A szóban forgó formális nyelv bármilyen logikai szintaxist használhat: az elsőrendủ logika és magasabb rendü logika elemeit is. Azok a struktúrák, amelyeket e formális nyelv értelmez, bármely geometriai osztályhoz tartozhatnak: lehetnek topológiai terek, affin terek, metrikus terek, de lehet akár egyetlen tér is, mint a projektív sík, vagy az Euklideszi vektortér. A nem-logikai nyelv alapjai pedig a meghatározott releváns területek bármely geometriai tulajdonságaként vagy kapcsolataként értelmezhetők, pl.: a terek topológiai kapcsolódása, a vonalak párhuzamossága, vagy valamely két pont közötti távolság (Aiello et al [2007] p. 1.). A produktumorientált áttekintés mindenképpen fogalmi alapot ad a vizualitásnak is, de nem biztos, hogy a fent említett, toulmini vagy perelmani kategóriákban, így a jelen 
disszertáció a későbbiekben arra törekszik, hogy megmutassa, ez a logikai felfogás hogyan alkalmazható a vizuális vagy spaciális logika esetében.

\subsubsection{Az argumentáció mint eljárás (procedúra)}

Az argumentáció mint eljárás felfogásának alapvetése, hogy az argumentáció eltér a többi egyet nem értés kifejezésére szolgáló módtól azáltal, hogy tartalmaz bizonyos szabályokat, amelyek a diskurzust kontrollálják. Ez azt jelenti, hogy egy adott vélemény viszonyában létező ellenvélemény normaként vonatkoztatható az érvelésre (Aczél [2005] p. 348). Az, hogy az érvelő az ellenérvelő cáfolatára számíthat, minél erősebb, vitathatatlanabb érvek felállítására ösztönzi őt. A gyenge, vagy hibás érvelések kevésbé tudnak győzedelmeskedni az ellenérvelő érvei felett. Az érvelés kompetitív természetét gyakran kritizálják, mivel aláássa a két fél közötti tiszteletet és érzékenységet, hatására elsikkad az emberi tényező, a közlés etikája pedig háttérbe szorul. Ez kritikai a szemlélet azonban figyelmen kívül hagyja, hogy - amennyiben a vitázó felek felismerik pozícióik reciprocitását, azaz egyszerre érvelnek valami mellett és valami ellen szükségképpen szabályozzák a saját, illetve a másik támadásának erejét, ezzel hozzájárulva egy minőségi diskurzus kialakításához (al-Musawi [2006] p. 43.).

Bizonyos érvelésekben több explicit szabály és konvenció létezhet. A legismertebb eljárási szabályok a jogi, illetve a természettudományos érvelésekre vonatkoznak, azonban a legtöbb szakmának megvannak a sajátos módszerei, a közéleti és személyes érveléshez hasonlóan. Az eljárás rendjének szabályozása mindig ugyanazzal a céllal történik, mint amit az érvek érvényes felállításakor a formális logika érvényesít (Aczél [2005] p. 348). Az elmúlt években az argumentáció mint eljárás perspektívát az informálisabb érvelésekre is alkalmazták. A pragma-dialektikának nevezett megközelítést a University of Amsterdam szakemberei vezették be, Eemeren és Grootendorst irányításával. A két említett, érveléselmélettel foglalkozó kutató pragma-dialektikus megközelítése a beszédaktus-elméleten alapszik, amely a pragmatika egyik legátfogóbb nyelvfilozófiai indíttatású elméleti keretének tekinthető (Adamik [2010] pp. 136-137.).Jelen elméleti keret segítségével képesek vagyunk olyan sztenderdeket létrehozni, amelyek megmutatják, hogy a szöveg mennyiben felel meg a vitát, ellenvéleményeket feloldó ideális szövegnek. E megközelítés pedig egyszerre nyújtja az érveléshez szükséges elemzési módszert és az elkészítésre vonatkozó irányelveket. 
Douglas Walton érvelési hibákat vizsgáló elmélete szintén releváns az argumentáció mint eljárás szemléletét tekintve (Walton, [1995]). Munkájában a következőképpen különíti el a társalgás típusait: információszerző, párbeszéd és meggyőzőbeszéd. Véleménye szerint azt, hogy egy érvelést hibásnak tekintünk, az adott párbeszédek kontextusa fogja meghatározni. Ezért a párbeszéd típusának azonosítása, amelyben a vitázó felek részt vesznek, segíthet tisztázni az eljárási konvenciókat, amelyek az ilyen típusú párbeszédek során az érvelést szabályozzák (alMusawi [2006] p. 43.).

Végezetül Aczél arra hívja fel figyelmünket, hogy az érvelés eljárásként való megközelítése erősíti a szabályfelismerö képességeket, de elvonja a figyelmet a tartalomról, ezáltal nem a mi, hanem a hogyan kerül a középpontba (Aczél [2012] pp. 35-36.). Ugyan ez az érvelés szempontjából kockázatosnak tünhet, Aczél szerint azonban a szabályok és eljárások megismerése és megértése is tartalmas, következtetésekkel járó eljárásnak tekinthetö. Éppen ezért elmondható, hogy a proceduralitás az érvelési folyamatokra, ezek szabályainak létrehozására, magyarázatára és megértésére vonatkozik. Az érvelés procedurális megközelítésekor nem szavakat vagy képeket alkotunk, hanem: viselkedési szabályokat, dinamikus modellt, kódokat. Ez a fajta érvelés pedig azért válik meggyőzővé, mert a benne müködő szabályok (érvek) követése révén különböző felismerésekhez jutunk el. Fontos tehát újra kiemelnünk, hogy a képek vagy szövegek nem önmagukban, hanem abban az eljárásban válnak meggyőzőkké, amelyet a szabályrendszeren belül az érvelő elfogad (Aczél [2012] pp. 3536.).

Az érvelés eljárásalapú szemlélete tehát arra utal, hogy az argumentációt dinamikák, eljárások, szabályos minták és műveletek müködtetik. A vizualitásban ugyanúgy fellelhetők ezek a szabályozott eljárások, ahol egy bizonyos képi elemet egy másik elem viszonylatában értelmezünk, megvizsgálva öket összefüggéseikben, kölcsönhatásaikban, fejlödésükben és ellentmondásaikban egyaránt. A képi elemek vizsgálata tehát a hogyan kérdésre ad választ, bemutatva a képek esetleges hangsúlyait, nézőpontjait, a (jelen disszertáció esetében katasztrófa) képek készítőinek logikáját és eljárásmódját. 


\subsubsection{Az argumentáció mint folyamat (processzus)}

Az argumentáció mint folyamat szemléletének létrejötte az 1970-es évektől élénkülő interperszonális kommunikációs kutatásoknak köszönhető. Fókuszában a mindennapi kommunikációs helyzetekben létrejövő ellentétek, konfliktusok és azok megoldása, illetve az argumentáció mint ellentétek és ellentmondások leszükítésének, kiterjedésének vagy megszüntetésének folyamata áll. Ebben az értelemben az argumentáció az interakció egy típusaként értelmezhető. Az argumentatív folyamat forrásai az argumentáció mint eljárás és mint eredmény értelmező megközelítések, ez az elmélet azonban az argumentáció helyességét funkcionális fogalomnak, ezáltal a meggyőzést szándéknak, hatásnak tekinti.

Az argumentáció e pragmatikus, hatás és szándékalapú felfogása szintén érvényes a vizualitás esetében is. A képek, létrehozóik akaratát evokatív, sürített módon képesek közvetíteni, bevonva és interakcióra bírva ezzel a közönséget (Aczél [2012] p. 102.). Gondoljunk csak a hírek képeire, amelyek nem információt, hanem eseményeket, értékeket közvetítenek, az átélés, véleményformálás lehetőségét biztosítva ezzel. A képi érvelés folyamatalapú megközelítésének elsődleges célja bizonyos toposzok megjelenítése. A toposz fogalma olyan helyre vagy forrásra utal, ahonnan érveinket meríthetjük, ezért gyakran „közös helynek” vagy „érvelési közhelynek” is nevezik. Fontos elkülöníteni a toposz, illetve a közhely szó köznapi, irodalmi és retorikai jelentését. A toposz „érvelési közhely” vagy „érvforrás” retorikai terminus technicust el kell különítenünk a szó egyéb jelentéseitől: retorikai terminusként ugyanis nem a közfelfogás szerinti bölcsességeket, vagy az irodalmi művek közismert képeit, hanem érvforrásokat értünk alatta (Lanham [1991] p. 169.). A médiában megjelenő toposzokat tekintve egy kép hatására vélhetem az ábrázolt személyről, hogy áldozat és azt is, hogy gazember, mindez pedig az érvelés szemiotikájának köszönhető.

Az argumentáció fent bemutatott három vetülete természetesen szoros összefüggésben áll egymással: az argumentáció mint eredmény létrehozásának szabályos rendjén alapul és folyamatként realizálódik az interakcióban (Aczél [2005] p. 348.). Az argumentáció - elméleti

mindhárom keretét tekintve - különbözik ugyan a klasszikus retorikai hagyomány érvelésétől (az előbbi a jelrendszereken és csatornákon keresztül történő összes közlés leírására, az utóbbi a gyakorlatközpontú felhasználásra és alkotásra utal), a jelen disszertáció mégis amellett érvel, 
hogy a vizuális retorika, eszközrendszerének és retorikai gondolkodásának, hatásosságának köszönhetően kielégíti az érvelés fogalmát.

\subsection{A hétköznapi érvelés és a formálisan szabályos bizonyítás különbségei}

Ezúttal nincs lehetőség az érvelés valamennyi tényezőjének (pl.: stílus, szöveg szerkezet stb.) kifejtésére, így értekezésem jelen fejezetében az érvelés és bizonyítás különbségeinek tisztázására szorítkozom. Arra a kérdésre, hogy mi különbözteti meg a hétköznapi érvelést a formálisan szabályos bizonyítástól, Chaïm Perelman ([1982]; [2018]) azt feleli, hogy a bizonyításban használt jelekről feltételezhetjük, hogy nélkülöznek minden kétértelmüséget, szemben az érveléssel, ahol a kétértelmüségek nem zárhatók ki előre. A helyes érvelés továbbá szabályoknak felel meg, amelyek formális rendszerekben realizálódnak. Ez pedig arra utal, hogy az axiómák (azaz olyan elvek, amelyekből kiindulhatunk) helyzete eltérő a bizonyítás és az érvelés esetében. Egy matematikai bizonyításban az axiómák nem képezhetik vita tárgyát, tekintsük azt igaznak vagy evidensnek, esetleg egyszerü hipotézisnek, általában nem foglalkozunk azzal, hogy a hallgatóság elfogadja-e őket, vagy sem. Így azoknak, akik igazolni kívánják az axióma választását, az érveléshez kell folyamodniuk (Perelman [2018] p. 24.).

Mivel az érvelés célja nem a következmények levezetése adott premisszákból, hanem a hallgatóság véleményének, elköteleződésének elnyerése és megerősítése bizonyos tételekkel kapcsolatosan, amelyeket beleegyezésük megnyerése érdekében terjesztünk elö, az érvelés minden esetben feltételezi a lelkek összekapcsolódását a szónok és hallgatósága között. Egy beszédet meg kell hallgatni, egy könyvet el kell olvasni, így képesek csupán kiváltani a kívánt hatást. Elkerülhetetlen a lelkek összekapcsolódása akkor is, amikor önmeggyőzésről beszélünk. Ebben az esetben az, aki állít, és az, akinek az érvelés szól, egy és ugyanaz a személy. Bizonyos mondások is utalnak az önmeggyőzés lehetőségére: „Hallgass a lelkiismereted szavára!”, „Erről nem nyitok vitát.” (Perelman [2018] p. 24.).

Mivel az érvelés hatni akar a hallgatóságra - a beszéd által módosítva meggyőződésüket, mentalitásukat, amelynek ők a címzettjei, és amelynek kitüzött célja, hogy elérje a lelkek összekapcsolódását bármilyen kényszer vagy uszítás okozta manipuláció nélkül - nem elhanyagolható a szónok személye sem. Olyan személynek kell lennie, akinek a véleményének értéket tulajdonítunk, akinek bízunk a szavában. Ugyanígy fontos, hogy bizonyos körülmények 
között magunkhoz tudjuk ragadni a szót, hogy egy csoport, intézmény vagy egy állam szóvivőiként meghallgassanak bennünket. Ilyen célból szervezik meg (vagy teszik kötelezővé) az államok a szertartásokat, oktatási programokat, parlamenti gyüléseket, amelyek biztosítják a találkozás és a közönség meggyőzésének lehetőségét (Perelman [2018] pp. 24-25.).

Szent Ágoston A keresztény tanitásról címü müvében azonban arra hívja fel a figyelmet, hogy a hallgatóságot nem győztük meg igazán hallgatóságunkat, csak akkor, ha „szereti amit ígérünk, ha fél attól, amivel fenyegetjük, ha gyülöli azt, amit kárhoztatunk, rajong azért, amit kínálunk neki, ha fájlalja azt, amit ilyennek festünk le, örül annak, amit örömtelinek hirdetünk, ha megkönyörül azon, akiket szavainkkal könyörületre méltónak állítunk eléje, és kerüli azokat, akiktől ijesztő szavakkal óvjuk (Szent Ágoston [2012] p. 244.).”

\subsection{Az érvelés dimenziói és megközelítései}

A szakirodalomban számos, egymástól nagyban különböző érveléselméleti megközelítés vagy tradíció figyelhető meg. A fontosabbak közé sorolhatjuk a holland pragma-dialektikai érvelés modellt (van Eemeren és Grootendorst munkája alapján), a folyamatosan fejlődő informális logikai megközelítést (Johnson és Blair, Kahane, vagy Thomas, a modernebb elméletalkotók közül pedig Walton és Govier munkája releváns), a társadalmi interakció és a konstruktivista megközelítéseket (Jacobs és Jackson, és a már említett van Eemeren és Grootendorst írásaira támaszkodva), és végezetül egy kezdetlegesebb megközelítést, amely a gyakorlati filozófia (különösen retorika) hagyományait használja az elemzés alapjául (pl.: Goodnight vagy Tindale alapján) (Jasinski [2001] p. 50.).

Mivel jelen disszertáció ez utóbbi szemléletet javasolja az érveléselmélet helyes keretének, a következőkben az ókori (arisztotelészi) hagyomány szerint Christopher W. Tindale Acts of Arguing címü munkájából kiindulva mutatom berészletesen az érvelés hármas diszciplináris megközelítését:

1. Az érvelés logikai megközelítését

2. Az érvelés dialektikai megközelítését

3. Az érvelés retorikai megközelítését (Tindale [1999] p. 18.). 
Az érvelés leírása más szempontból történhet meg a három fent említett diszciplína esetében. A logika az állítások és a konklúzió szerkezetéből, viszonyából indul ki, annak eredményére kíváncsi. A dialektika ezzel szemben a dialógusok érvelésének váltásait vizsgálja, feltárva azokat a helyes eljárásokat, amelyek során az érvelés megvalósul. Végezetül, a retorika a szónok és hallgatósága között létrejövő argumentatív kommunikáció potenciális eszközeit vizsgálja, és az érvelésre folyamatként tekint (Aczél [2006] p. 79.). E hármas megközelítés nem választható szét élesen, hiszen a retorika érvelése a klasszikus logika tételeiben gyökerezik, a dialektika érvelö eljárásai pedig logikai szabályokból indulnak ki. Különbséget fedezhetünk fel azonban a három diszciplína vizsgálati szempontjai között: a logika az állításokat, a dialektika a normákat, szabályokat, a retorika a hatást tekinti meghatározó elemzési perspektívának. Azt is látnunk kell továbbá, hogy módszertanilag is más a háromféle érvelésfelfogás: míg a logika rendszerszemléletủ és az érvelés lehetséges helyes és érvényes struktúráit írja le, a dialektika dinamikus rendszerközpontúsága az érvelés mintázatait vizsgálja, a folyamatközpontú retorikai felfogás pedig az érvelés hatását méri a meggyőzéssel. Ez alapján Aczél úgy fogalmaz, hogy a logika a szerkezet, a dialektika az indokolhatóság, a retorika pedig a hatás normáját írja le (Aczél [2006] p. 79.).

Wenzel ([1992] p. 134.) a következő táblázatban foglalja össze a három szemléletmód jellemzőit: ${ }^{2}$

${ }^{2}$ Ld. még: Lózsi, Tamás; [2017] : A reklám mint érvelés. Doktori értekezés. p. 38. 


\begin{tabular}{|c|c|c|c|}
\hline & $\begin{array}{l}\text { Retorika: folyamat } \\
\text { (processzus) }\end{array}$ & $\begin{array}{l}\text { Dialektika: eljárás } \\
\text { (procedúra) }\end{array}$ & $\begin{array}{l}\text { Logika: eredmény } \\
\text { (produktum) }\end{array}$ \\
\hline Gyakorlati szándék & Meggyőzés & Bírálat & Ítélet \\
\hline Elméleti szándék & $\begin{array}{c}\text { A hatásos érvelés } \\
\text { feltételeinek } \\
\text { megértése }\end{array}$ & $\begin{array}{c}\text { Az öszinte és kritikai } \\
\text { érvelés feltételeinek } \\
\text { magyarázata }\end{array}$ & $\begin{array}{c}\text { A megbízható érvelés } \\
\text { szabványainak } \\
\text { megalapozása }\end{array}$ \\
\hline Szituáció & $\begin{array}{l}\text { Természetes retorikai } \\
\text { szituációk }\end{array}$ & $\begin{array}{l}\text { A diskurzus számára } \\
\text { létrehozott arénák }\end{array}$ & Érvelésmezők \\
\hline Szabályok & $\begin{array}{c}\text { Hallgatólagos } \\
\text { társadalmi szabályok }\end{array}$ & $\begin{array}{l}\text { Explicit eljárási } \\
\text { szabályok }\end{array}$ & $\begin{array}{c}\text { Explicit } \\
\text { következtetési } \\
\text { szabályok }\end{array}$ \\
\hline Mérték & Hatásosság & Őszinteség & Megbízhatóság \\
\hline Beszéló & $\begin{array}{l}\text { Naiv társadalmi } \\
\text { szereplő }\end{array}$ & Tudatos felszólaló & $\begin{array}{l}\text { Személytelen } \\
\text { magyarázó }\end{array}$ \\
\hline Hallgatók & $\begin{array}{l}\text { Partikuláris } \\
\text { hallgatóság } \\
\text { egyetemesen }\end{array}$ & $\begin{array}{l}\text { Partikuláris } \\
\text { hallgatóság }\end{array}$ & $\begin{array}{l}\text { Univerzális } \\
\text { hallgatóság }\end{array}$ \\
\hline
\end{tabular}

\section{TÁBLA Joseph Wenzel retorikai, dialektikai, logikai hármas felfogásáról}

(saját szerkesztésü tábla)

Az arisztotelészi logika - dialektika - retorika hármasa tehát eltérően ragadja meg az érvelést. A jelen disszertáció amellett érvel, hogy az argumentáció retorikai perspektívából történő megközelítése adja az érvelés helyes keretét, megragadva a másik két alternatív perspektíva erősségeit, de elkerülve azok problémáit. Ahhoz azonban, hogy ez a kijelentés bizonyítást nyerjen, az alábbiakban bemutatom a másik két szemlélet különböző aspektusait. Tanulmányom először a logikai perspektíva ismertetésére vállalkozik, kitérve a formális és informális logika 
viszonyrendszerére és bemutatva e megközelítés érösségeit és gyengeségit, ezután pedig a dialektikai, azon belül pedig a pragma-dialektikai perspektívát vetem alá hasonló vizsgálatnak azt konkludálva, hogy míg az argumentáció dialektikai felfogása egy üdvözlendő előrelépés a logikaihoz képest, ez sem maradéktalanul kielégító.

\subsubsection{Az érvelés logikai megközelítése}

Az argumentáció logikai megközelítésének számos variációja létezik, ezek közös gyökerének feltárása pedig elengedhetetlen az érvelés diszciplináris feltérképezése érdekében. Kapcsolódva az argumentáció korábbi hármas elkülönítéséhez (produktum, processzus, procedúra), Tindale úgy véli, a logikai perspektíva fókuszában az érvelés mint produktum, azaz eredmény áll, ugyanis a logika úgy tekint az érvekre mint állítások egy halmazára, és az egyes állítások között található absztrakt viszonyokat vizsgálja. Mindez azt jelenti, hogy e megközelítés fő célkitüzése az olyan állítások összegyüjtése, amelyek tartalmaznak egy konklúziót, és egy vagy több premisszát (PPC - premis, premis, conclusion) így érvnek tekinthetők, majd ezek

érvényességének és erősségének megítélése következik. Általában az argumentáció mint produktum szemlélet a formális logika keretében értelmezendő, de, mivel a későbbi informális logikák tartalmazhatnak formális elemeket, ezek együttes vizsgálata válik szükségessé (Tindale [1999] p. 21.).

\subsubsection{A formális logika}

Mivel is foglalkozik a logika, mi annak tárgyköre és milyen módon vizsgálja az érveléseket? A logika fejlődésének története kezdetektöl fogva fontos részét képezi az európai tudományos gondolkodás kialakulásának. A logikával leginkább a matematika és a filozófia állt szoros kölcsönhatásban, olyannyira, hogy egyrészt a logikát gyakran ma is a filozófia részének tekintik, másrészt a 20. század legdinamikusabban fejlődő területének a matematikai logika tekinthető, amelynek hatása a modern matematikai elméletekben is érezhető. A legkorábbi, állításait tisztán logikailag bizonyító szöveg filozófiai természetủ és Parmenidész nevéhez köthető. Az i.e. V. századi filozófus a szülőatyja a logikai gondolkodás egyik legmeghatározóbb elemének, az indirekt bizonyításnak. Módszerét tanítványa, Zénón fejlesztette tovább ismert paradoxonjaiban. A logikai bizonyítás igazi diadalt azonban nem a filozófia, hanem a matematika területén ért el. 
Parmenidész és Zénón gondolatainak hatására a matematika elnyerte úgynevezett „mai alakját” és olyan tudománnyá vált, amely szigorúan logikai úton, azaz minden megfigyelés és tapasztalat kizárásával, egyedül az értelemre támaszkodva bizonyít. Az i.e. 4. században Platón munkáiban már nem találunk matematikai utalásokat, a bizonyításon alapuló matematika egyszerủen az emberi gondolkodás részévé, mintapéldájává vált. Az első rendszeres logikai elmélet a görög filozófia másik prominens alakja, Arisztotelész nevéhez köthető. Platón tanítványa, majd későbbi filozófiai ellenfele a következtetési sémák széles körét vizsgálta, kiválasztva a helyes és cáfolva a hibás következtetéseket (Pólos - Rúzsa [1987] pp. 181-182.). Ahogyan azt az érvelés mint eredmény (produktum) szemlélet bemutatásakor már kifejtettem, a kortárs érveléselmélet legmeghatározóbb formális logikai modelljét annak kritikájaként Toulmin hozza létre, akinek újító teóriájában az argumentáció két fajtája (formális és gyakorlati) különválik. Az ismétlés elkerülése érdekében álláspontját nem részletezem újra, a szemléletek közötti átfedés azonban megköveteli, hogy Toulmin modellje itt is említést nyerjen.

Acsayt idézve Aczél Petra úgy fogalmaz, hogy a logika azon törvényeket tárgyalja, amelyek a helyes gondolkodást táplálják, míg a szónoklattan azzal foglalkozik, hogy hogyan találjuk meg, és hogyan alkalmazzuk a megfelelö érveket (Aczél [2005] p. 281.). Ezt kiegészítve Kutrovátz azt mondja, hogy a logika a következtetések érvényességének feltételeivel foglalkozó tudomány (Kutrovátz [2018]). E definíció mélyebb értelmezése érdekében indokolt magát a következtetés fogalmát is elemezni. A következtetések olyan, a világ tényállásának leírását szolgáló kijelentések közötti viszonyrendszert jelentik, amelyekre vonatkoznak bizonyos nyelvi megkötések. Nem lehetnek például ezek a kijelentések óhajtó, felszólító vagy kérdő mondatok, pusztán kijelentő módú frázisok kapcsolatát írhatják le. Itt azonban egy újabb megkötéssel kell élnünk, bizonyos kijelentő grammatikai kategóriájú mondatok ugyanis nem fejeznek ki tényt, nincsen leíró vagy ábrázoló funkciójuk. Ilyen például a „Köszönöm.” „,Gratulálok.” vagy „,Jó napot kívánok." kijelentő módú mondat, amely megnyilatkozásokat performatívumoknak nevezzük, mivel kimondásukkal bizonyos cselekvéseket hajtunk végre. Kívánunk, megköszönünk, elnevezünk, ígéretet teszünk. Mindezen mondatoknak azonban nincsen propozíciós értéke, nem értelmezhetők igaz-hamis dimenziók alapján, így elemzésük a logika fogalmi körén kívül esik. Kutrovátz szerint a propozíciós- vagy igazságérték a legtöbb logikai elméletben a kétértéküség szabályai szerint müködik, amely szerint minden kijelentésnek két értéke lehet, az igazság, vagy a hamisság valamelyike. Ezen szabályrendszert kiegészíti az 
ellentmondás-mentesség elve (vagyis egy kijelentésnek nem lehet egyszerre több igazságértéke), illetve a kizárt harmadik elve, amely elmélet tagadja, hogy az igaz és hamis igazságértéken kívül létezne több is.

A logika tehát az érvelést kontextusából kiragadva, elemeiben vizsgálja, ezt a rendszert az elemek alkotják (Aczél [2006] p. 79.). Kutrovátz szerint ezek az elemek két csoportra oszthatóak, a premisszákéra, amelyek számát tekintve a modern logika nem ismer kikötést, illetve a konklúzióéra, amelyből minden következtetésben egy lehet, így azok a szerkezetek, amelyekben bizonyos premisszákból több konklúzió is levonható, külön-külön következtetéseknek tekintendőek (Kutrovátz [2018]). A konklúzió, amely lényegében a kommunikátor véleményét vagy nézőpontját fejezi ki, a mondat bármely pontján elhelyezkedhet, vannak azonban bizonyos konklúziójelzők, amelyek megkönnyítik annak felismerését, például az így, tehát, összegezve, mindent összevetve stb., míg a premisszák összekapcsolódva, de egymástól függetlenül is alátámaszthatják a konklúziót, jelzőik pedig az egyfelöl, másfelöl, elöször is, annak fényében stb. (Johnson - Blair [1994] p. 13.).

\subsubsection{Dedukció és indukció}

A logikai érvelés vizsgálata során a filozófusok - a premisszák és konklúzió közötti kapcsolat természete alapján - az érveket két nagy kategóriába sorolták: a dedukció és az indukció csoportjába (Goel et al [1997]). Míg az előbbi általános igazságok alá rendel egyedi ismereteket, addig az utóbbi egyedi ismeretekböl következtet általánosabb tudásokra. A deduktív következtetések érvényességüket logikai formájuknak köszönhetik (Govier [2014] p. 178.), eszközük pedig a szillogizmus, amely a formális logika egy olyan érvformája, melynek struktúrája jellemzően hármas tagolású: két premisszából és egy konklúzióból áll. Az érvényesség és helytállóság problematikáját tekintve a szillogizmusok formai és tartalmi szempontok alapján vizsgálhatók. Tartalmilag akkor lesz helyes a szillogizmus, ha premisszái igazak, míg formai érvényessége attól függ, hogy a premisszák megfelelően igazolják-e a konklúziót (Aczél [2005] pp. 281-283.). Érvényes és helytálló szillogizmusok esetében tehát a premisszák szükségszerüen és relevánsan támasztják alá a konklúziót, vagyis lehetetlen, hogy a premisszák igazsága mellett hamis konklúziót kapjunk (Wilhelm - Engle [2004] p. 373.). Ezáltal a deduktív érvelések az elképzelhető legjobb és legerősebb következtetési struktúrák, 
ezek vizsgálatának fogalmi apparátusát pedig a formális logika biztosítja (Margitay [2007] p. 93.).

Aczél Retorika címü müvében a formális logika három deduktív érvtípusát különíti el, ezek pedig az Arisztotelésztől származó kategorikus, a korai peripatetikusokhoz és sztoikusokhoz köthető feltételes és végül a választó szillogizmusok (Aczél [2005] p. 284.). Míg az első, kategorikus szillogizmusban a kijelentések különböző kategóriákat vetnek össze, ezek viszonya pedig lehet univerzális, partikuláris, inkluzív vagy exkluzív, addig a hipotetikus vagy feltételes szillogizmusok ha-akkor érvrendszerbe szervezik az állításokat, és az előtag és az utótag igazságtartalmát vizsgálják. Kant alapján azt mondhatjuk, hogy minden hipotetikus szillogizmusnak kétféle alkalmazása van, nevezetesen a modus ponens, amelyben egy állításból, azaz az előtagból következtetünk a konklúzióra, illetve a modus tollens, amelynél az utótagból következtetünk az elötagra (Kant [2004] p. 285.). A végső, választó vagy diszjunktív szillogizmus, amely olyan állítás, melynek egyik tagjával automatikusan kizárjuk a másikat, illetve a másik tagadásával szükségszerüen elfogadjuk az egyiket.

Ahogyan azt már az előbbiekben bemutattam, a bölcseleti hagyományok a deduktív és induktív érvelés közötti fő különbségeket az egyedi és általános érvényű állítások lehetséges következtetéseinek természetében látták. William Minto úgy fogalmazza meg az indukcióval és dedukcióval kapcsolatos axiómákat, hogy míg az indukciónál, amit megjósolhatunk minden elemmel kapcsolatban, azt jósolhatjuk meg az egésszel kapcsolatban is, addig a dedukciónál a Dictum de Omni elv érvényes, tehát amit az egésszel kapcsolatban mondunk, az igaz lesz minden részével kapcsolatban is (Minto [2008] p. 236.). Kutrovátz azonban nem azt tartja a leglényegesebbnek, hogy milyen viszonyt teremtenek általános és sajátos kijelentések között, hanem azt, hogy a deduktív érvelés logikailag érvényes, míg az induktív nem az (Kutrovátz [2018]). Egy másik releváns különbség az lehet, hogy míg a dedukció az ismeretek értelmezésére és elemzésére törekszik, addig ,az indukció az ismeretek megszerzésének gondolati folyamata” (Aczél [2005] p. 304.). Govier megállapítása szerint az indukció a világgal kapcsolatos józan hiedelmeink alapja. Azt gondoljuk, hogy az északi féltekén decemberben hidegebb lesz, mint júliusban, hogy a brokkoli keményebb a paradicsomnál és hogy a tornádók veszélyesek. Előfordul, hogy ezeket a meglátásainkat saját múltbéli tapasztalataink bizonyítják, de gyakorta hagyatkozunk más emberek ismereteire is. Az induktív érvelés során úgy gondoljuk, hogy amire 
a múltban volt példa, arra a jövőben is lesz, így Govier szerint az induktív érvelés legáltalánosabb megfogalmazása az, hogy múltbéli tapasztalatokból extrapolálunk olyasmit, amit még nem tapasztaltunk meg (Govier [2014] p. 255.). Míg deduktív következtetésre jó példa lehet a Minden ember halandó, Lajos ember, tehát halandó érvelési struktúra, addig a Lajos ember és halandó, Károly ember és halandó stb., tehát minden ember halandó az induktív érvelés rendszerét mutatja be, nyilvánvalóan implikálva, hogy egy bizonyos számú egyén megfigyelése sok esetben nem jelenti a teljes populációra való érvényes következtetés lehetőségét, ettől függetlenül gyakran kiválóan müködik (Kutrovátz [2018]). Természetesen, egy érvényes dedukció hamis premisszák alapján is juthat igaz konklúzióra, de ez pusztán a szerencsén múlik, nem a helyes érvelésen. Az a tény azonban, hogy egy érvényes deduktív érvelés számára nem lehetséges igaz premisszák alapján hamis konklúziót állítani, igazi jellegzetesség és nagy erény. A deduktív érvek tehát korlátozottak, mivel nem képesek olyan konklúzióra jutni, amelyek legalább implicite nem szerepelnek az őket bizonyítandó premisszákban, ez a feladat ugyanis az indukcióra hárul (Cavender - Kahane [2010] p. 10.). Az induktív érvelések, a deduktívval szemben, olyan konklúziókkal rendelkeznek, amelyek túlmutatnak a premisszákban található állításokon, így ezek mögött a tapasztalati alapú tanulás vagy érzékelés áll. Cavender és Kahane az alábbi kismintás, tapasztalatokon nyugvó példát hozza indukcióra: „A Fogtündérröl kiderült, hogy nem valóságos. A Húsvéti Nyusziról is kiderült, hogy nem valóságos. Gyanakodni kezdtem a Télapóval kapcsolatban is" (Cavender - Kahane [2010] p. 11.). Az ilyen jellegü indukciók esetében mindig egyedi tartalmi megfontolásokra van szükségünk ahhoz, hogy erősségét meg tudjuk állapítani, ezekhez Margitay az R-E-I (relevánsak-e a premisszák, elegendőek-e a premisszák, igazak-e a premisszák) (Margitay [2007] p. 114.), míg Aczél az ehhez szorosan kapcsolódó, ám egy apró megfogalmazásból adódó eltérést mutató M-E-I módszert javasolja, ahol a másik két tényező állandósága mellett az M a megfelelőek-e a bizonyítékok a konklúzió bizonyításának érdekében kérdésre utal (Aczél [2005] p. 309.). Ha mind a három kérdésre igennel tudunk válaszolni, az indukció erősnek tekinthető.

\subsubsection{Az informális logika}

Sokkal könnyebb meghatározni a formális és informális logika különbségeit, mint átfogó definíciót adni arról, mi is az informális logika és mi tartozik annak tárgykörébe. Feltủnő ugyanis a szakirodalomban, hogy ismét megjelent egy új megközelítés, egy terminus technicus, amely - a 
retorikához és dialektikához hasonlóan - szintén egy dialektikai, pragmatikai megközelítést javasol, megnehezítve ezzel elkülönítését, értelmezését. 1980-ban az informális logika két pionírja, J. Anthony Blair és Ralph H. Johnson úgy fogalmaztak, hogy e terület túlságosan fejletlen ahhoz, hogy egyértelmű meghatározást lehessen róla alkotni. Egy évtizeddel később, az informális logika elméleteinek minőségi és mennyiségi fejlődése után az említett kutatók továbbra is úgy gondolták, hogy nincsen elkülöníthető módszertan, paradigma, vagy egy domináns elmélet az informális logikában (Tindale [1999] p. 25.). Ez a fajta inkonzisztencia az alábbi definíciókban is megfigyelhető.

Az informális logika elnevezés Margitay szerint kifejezetten félrevezető, hiszen azt a téves látszatot kelti, mintha az informális logika a formálistól eltérő területhez tartozna, holott az informális logika felhasználja a formális logika kínálta eredményeket, csak más szempontú értelmezését javasolja az érvelésnek (Margitay [2007] p. 18.). Aczél az informális logikát a formális logika elméleti alternatívájának tekinti, amely arra tesz kísérletet, hogy a kommunikáció különböző színterein és szintjein (pl.: interperszonális, tömeg-, közéleti, politikai, bírósági, kereskedelmi, mediatizált) megjelenő mindennapos érvelések logikáját kidolgozza, így a logika és dialektika összekapcsolásának eredményeként jön létre (Aczél [2006] p. 79.). Míg a neves filozófus, Gilbert Ryle Dilemmas című müvében, a logikai problémákkal kapcsolatos szinoptikus szemléletének köszönhetően olyan koncepciókat köt az informális logika fogalomköréhez, mint a látás, lehetőség, vagy élvezet (Ryle [2015]), addig Douglas Walton pragmatikai megközelítése által az érvelés kontextuális és retrospektív természetére, valamint az informális falláciák (érvelési hibák) fontos szerepére hívja fel a figyelmet (Walton [2007] p. 11.), az informális logikát a kritikai argumentációval azonosítva (Walton [1989] p. ix.). Akadnak azonban olyan kutatók is, akik informális logika alatt egyszerüen az elemi deduktív logika nem formális felfogását értik, ez azonban Anthony Blair szerint azt jelentené, hogy nem lehetséges az informális logika teoretikus megközelítése (Blair [2012] p. 47.). Emellett a szakirodalomban számos olyan feltevéssel is találkozhatunk, melyek szerint az informális logika gyakorlatilag nem is tekinthető logikának. Népszerü ellenérv például, hogy a logika definíció szerint formális intézmény, így az informális logika terminus fogalmi önellentmondásnak minősül. Blair és Tindale azonban úgy véli, hogy más szempontból is interpretálható a „formális” kifejezés, felfogásuk szerint ugyanis jelentéseinek egyike, hogy absztrakt mintázatok reprezentációit foglalja magában mindaz, ami formális, így az informális logikának - elnevezése ellenére - 
számos olyan manifesztációja van, melyek arra utalnak, hogy formális intézmény, hiszen a legtöbb teoretikus olyan érvelési mintákra vagy sémákra fókuszál, amelyek az érvek elemzése és értékelése szempontjából relevánsak (Blair [2012] p.121.). Az informális és formális logikát összevetve azonban azt látjuk, hogy mind a kettő állítások strukturált egységének tekinti az érveléseket és ezeknek szerkezetét, belső összefüggéseinek rendszerét vizsgálja (Margitay [2007] p. 19.). Az informális logika fókuszában az érvényesség és helytállóság helyett az érvek ereje és hatásossága áll, és az érveket olyan kritériumok alapján értelmezi, mint a relevancia, alkalmazhatóság és elfogadhatóság (esetleg, pár helyettesítő kritériumot is bevezetve: az igazság és a konzisztencia). Továbbá, ahogyan a formális logikában összekapcsolódik a forma és az értelmezés, az informális logikában is összefüggés figyelhető meg az értelmezés és az érvek struktúrája között. E nyomvonalon haladva az elmúlt évtizedekben az informális logika számottevő fejlődésnek indult, mára pedig teljesen kialakult diszciplínává érett, elismert tartalommal és módszertannal (Tindale [1999] p. 28.).

\subsubsection{A logikai megközelítés problémái}

A logikai vizsgálatok egy mesterséges nyelv segítségével a következtetések érvényességét analizálják normatív elöírások alapján, felhasználva a logika precizitását, es egyben egyre távolabb kerülve a természetes nyelvtől (Kutrovátz [2018]). A logikai megközelítés kapcsán felmerülő számos probléma orvosolható vagy enyhíthető az informális logika fejlődésének köszönhetően, kettő azonban továbbra is megválaszolatlan, ezek pedig a 1.) rugalmasság és a 2.) relevancia.

\subsubsection{A rugalmasság}

Ahogyan az a fentiekből is kiderül, a formális logika semmilyen rugalmasságot nem képes mutatni más tudományterületekkel szemben. E hiányosság komolyságát Toulmin fogalmazza meg, szerinte ugyanis a logikai kategóriák tudományterület-függése alapvető jellemzőjük, mivel feloldhatatlan különbségek vannak az olyan problémák típusai között, amelyeket az érvek képesek kezelni. Ha meghatározzuk a probléma megoldásának módját egy adott helyzetben, annak megfelelően kell kiválasztanunk a biztosítékokat (warrant), az állításokat (claim) és érveink támogatását (backing), ezek azonban nem alkalmazhatóak az érvelés más területein; ha 
mégis megpróbálnánk, az Toulmin szerint „,a filozófiai delírium állapotát idézné elő” (Toulmin [1958] p. 163.). Toulmin alapján tehát azt mondhatjuk, hogy a logika az egyes területek problémáinak megválaszolását nem képes holisztikusan kezelni, így pl.: a geometriai érvet olyan területnek tekinthetjük, amely geometriai problémákkal foglalkozik, a morális érvet pedig egy morális probléma hívja életre. Ezáltal, Toulmin szerint a formális érvek gyakorlati alkalmazása nem lehetséges, annak ellenére, hogy az érvelés elmélete ezt megkövetelné komponenseitől (Tindale [1999] p. 29.).

A fordítással kapcsolatos problémák is széles körben elterjedtek és, a formális logika kutatói számára, tapasztalhatóak. Még egy egyszerü modus ponens (ha p, akkor q, p/q) típusú érvelésnél is nehéz meghatározni, hogy az első premissza „p”-je és a második premissza „p”-je (vagy az első premissza „q”-ja és a konklúzió „q”-ja) pontosan ugyanazt a kifejezést vagy állítást szimbolizálja-e. A hétköznapi nyelvhasználat érvei - alapvető kétértelműségeivel és árnyalt jelentéseivel - ritkán keverednek ilyen egzakt fordítási szituációkba (Tindale [1999] p. 29.).

A jelentés egy következő olyan kontextuális probléma, amelyet a formális logika nem kezel helyesen, ha egyáltalán foglalkozik vele. Általánosan azt mondhatjuk, hogy az előterjesztett érv és a benne található kijelentések közötti kapcsolat vizsgálata ezek hátterére való utalás nélkül történik: figyelmen kívül hagyja a körülményeket, amik között létrejön az érvelés, a következményeket, az érvelőket és azok szándékait, amiért részt vesznek a vitában, valamint a közönség tagjait és azok hiteit, elvárásait. Toulmin úgy fogalmaz, hogy az érvek elfogadhatóságát a gyakorlatban mindig a kontextus tükrében kell vizsgálni, azaz figyelnünk kell az időre és térre, amelyben az érvelés végbe megy (Toulmin [1958] p. 170.).

Az informális logika jobban teljesít a fent említett nehézségek tekintetében. Míg a logika kritikusai egyszerre vetik ki hálójukat mind a formális, mind pedig az informális változatokra, az informális logika képes megválaszolni azokat a felmerülő ellenérveket, amelyeket formális párja nem. Az informális logika alapvető kritériumrendszere - pl.: relevancia, hatásosság, elfogadhatóság - átfogóbb értékelés enged, mint a formális logika által alkalmazott érvényesség és helyesség. Az el/befogadhatóság magában foglalja az érvek kontextusának megfontolását. Az informális logika ezen kívül különböző eljárásokat kínál az érvek standardizálásával létrejövő nyelvi problémákkal kapcsolatosan, valamint kontextus- és közönség-érzékeny megoldásokat 
javasol, ezáltal produktum-orientált modelljeinek értelmezhetősége és gyakorlati alkalmazhatósága gazdagabb (Tindale [1999] p. 31.).

\subsubsection{A relevancia}

A formális következtetések maguk után vonják, sőt garantálják az érvek elemeinek sorrendjét, érvényességét és helyességét. Egy premissza - annak igazsága esetén - implikálja a konklúzió igazságát is. Azonban ez a fajta következtetés nem kapcsolódik szorosan a relevancia fogalmához semmiféle hasznos módon. Míg az igazság e tekintetben az állítások tulajdonságát jelenti, a relevancia a köztük lévő kapcsolatra utal, egy következtetés pedig nem képes hasonló kapcsolatot kifejezni. Egy átlagos tankönyvben (Tindale példájával élve) találhatunk ilyen illusztrációnak szánt következtetést: „New York New York-ban van. Tehát New York New Yorkban van. (Tindale [1999] p. 31.)" De ahhoz, hogy egy premissza releváns és hasznos legyen a konklúzió számára, olyan okként kell fellépnie, amely növeli az elfogadásunkat, vagy amely egyenesen meggyőz bennünket, hogy elfogadjuk a konklúziót. A klasszikus retorikában az olyan konnektívumok, mint a „\&” és a „V” lehetőséget adnak komplex propozíciók létrehozására. A konnektívumok és az általuk összekötött propozíciók igazságát igazságtáblák segítségével tudjuk megadni, amely lehetővé teszi az érvek érvényességének felismerését - így tehát amikor a konklúzió igaz, a premisszák is szükségszerüen igazak. Ami viszont kifejezetten érdekessé teszi a propozicionális logikát az az, hogy érvényes következtetései (a relevancia szempontjából) gyakran meghökkentő, sőt, sokkoló eredményeket mutatnak. Egy olyan következtetésben, mint a „B/A>B”, A és B helyettesítésekor sok esetben érdekes megoldásokat kapunk. Pl.: „Havazik. Ezért, ha a szendvicsek halkrém ízüek, akkor havazik.” A felszínen természetesen semmiféle kapcsolatot nem látunk a hóesés és a szendvicsek halas íze közt. Azonban, a feltételes állítások tekintetében ez a következtetés érvényes. Ha a B igaz, akkor „A\&-B” mindenképpen hamis, ezáltal az „A>B” a B igazságából következik (Tindale [1999] p. 34.).

A feltételes állítások okozta problémák arra sarkalltak számos kutatót - többek között Alan R. Anderson-t és Noel D. Belnap-ot - hogy bevezessék a relevancia fogalmát a logika tárgykörébe (Anderson - Belnap [1992] pp. 142-267.). A releváns logika terminus használata egy következtetéses kapcsolatot jelöl és arra törekszik, hogy összeegyeztesse a következtetés fogalmát intuícióinkkal. Egy igaz következtetés szükségszerủen igaz; a problémás esetek azok, 
amikor a következtetések szimplán nem igazak. Ezért, Anderson és Belnap ugyan elismeri, hogy az érvényes következtetések szükségszerüen érvényesek, mégis megkötik, hogy az érvényes állítás premisszája releváns kell, hogy legyen konklúziója számára. Ezt az elméletet más kutatók számos kiegészítéssel és kritikával illették, legyenek azok logikusok (pl.: Read) vagy informális logikusok (pl.: Walton) (Tindale [1999] pp. 33-34.).

$\mathrm{Az}$ érvelés logikai megközelítéséröl összességében elmondható, hogy a logika argumentációban betöltött szerepe jelenleg az egyik legfontosabb megoldatlan probléma. Számos kutató éppen ezért az érveléselmélet retorikai megközelítését preferálja a logikaival szemben, azaz - Perelman alapján - az észszerüt (reasonable) a racionálissal szemben (rational) (Perelman [1979] p. 117.). Mielőtt azonban rátérnék a retorikai perspektíva kifejtésére, tanulmányomban az érvelés dialektikai megközelítését veszem górcső alá.

\subsubsection{Az érvelés dialektikai megközelítése}

A dialektikának számos megközelítése létezik, ezek közös jellemzője azonban, hogy a dialektikát egy dialóguson belül történő, szabályok által irányított eszmecserének tekintik, amely egy nézeteltérés feloldását célozza meg. A dialektikai érvelés az informális logika kutatói számára is iránymutató (Tindale [1999] p. 43.). Anthony Blair szerint az érvelés logikai megközelítése episztemikus és igazoló jellegü. A retorikai perspektíva ezzel szemben azon normák tanulmányozására irányul, amelyek egy adott szituációban az érvelő diskurzus célkitüzéseit a leghatékonyabban képesek elérni. Végezetül, a dialektikai szemlélet - Blair nyomán - az érvelés konfliktus-feloldó funkciójára fókuszál (Blair [2012] pp. x-xi.), és procedúrának, azaz eljárásnak tekinti azt (Aczél [2006] p. 79.). Ralph Johnsonnal közös munkájában pedig úgy fogalmaz, hogy amikor egy érvelést dialektikusnak tekintünk, akkor olyan emberi gyakorlatként értelmezzük, amelyben két vagy több személy közötti eszmecsere figyelhető meg úgy, hogy az interakció folyamata hatással van annak eredményére (Blair Johnson [1987] p. 46.). Finocchiaro az érvelést a következőképpen határozza meg: meglátása szerint egy érv a konklúzió védelmében jön létre tényleges vagy potenciális ellenérvek hatására (Finocchiaro [1995]). Ebből a definícióból pedig jól látszik, hogy az érvelés középpontjában a dialógus áll. 


\subsubsection{A pragma-dialektikai megközelítés}

A dialektikai megközelítés egy érdekes és széles körben elfogadott típusa az 1970-es évek elején, az Amsterdami Egyetemen körvonalazódó pragma-dialektikai elmélet. E szemlélet célja, hogy az argumentáció és a kritikai észszerüség olyan elméletét dolgozza ki, amely észszerü kombinációját kínálja a pragmatikának, a nyelvi cselekvések elvének és a kritikai párbeszéd elméletének, azaz a dialektikának (Forgács [2015] p. 1095.). A megközelítés J. L. Austin és John Searle beszédaktus-elméletében és a gricei konverzációs implikatúrákban gyökerezik, amely arra utal, hogy az érvelést olyan nyelvhasználati jelenségnek tekinti, amelynek fókuszában az argumentatív nyelvi események állnak. Ez alapján az argumentáció egy explicit vagy implicit diszkusszió nyelvhasználati formája, amely a két vagy több nyelvhasználó közötti véleménykülönbség feloldására irányul, azaz lényegében egy szabályozott kritikai vita (Tindale [1999] pp. 44-45.). A pragma-dialektika meghatározása szerint az érvelés verbális, szociális és racionális cselekvések együttese, amelynek célja a kritikus meggyőzése egy álláspont elfogadhatóságáról. A vitapartnerek olyan állításokat mutatnak be, amelyek a védendő álláspontot kifejező állításhalmaz igazolására vagy cáfolására vonatkoznak, ezek érvényességéről (és ebből következően a vita kimeneteléről) pedig az észszerű kritikus dönt. A vita célja, hogy végül olyan racionális álláspontra jussanak, amely a véleménykülönbség feloldására alkalmas és mindkét fél számára elfogadható.

Amint az a fenti definícióból is látható, hogy a pragma-dialektikai megközelítés az érveléskutatás több szempontját igyekszik összekapcsolni. Egyfelől ötvözi az érvelések eredményként (produktum) és folyamatként (processzus) való felfogását (Forgács [2015] p. 1096.). Az érvelési folyamat során az érvelők állításokat, és az ezek között létrejövő logikai kapcsolatokat mutatják be. Ez alapján az argumentáció az érvelö felek között végbemenő érvelési folyamatban létrejövő argumentumok, mint termékek kölcsönhatásaként értelmezendő. Az argumentáció során az egyik vitapartner állítások sorozatát mutatja be, amire a másik vitapartner valamilyen válaszlépéssel válaszol. Forgács e megközelítést a sakkjátékhoz hasonlítja, azzal a különbséggel, hogy a lépések nem a sakktáblán, hanem a való élet interakcióiban mennek végbe, nyelvi eszközök segítségével. Az elmélet hasonlóképpen kapcsolja össze a geometriai és antropológiai racionalitásfogalmakat is. A geometriai racionalitással szemben az interszubjektív érvényességet preferálja, amely arra utal, hogy egy 
érvelés érvényessége egy bizonyos időpontban, emberek egy bizonyos csoportjára vonatkozik, következésképpen az emberi ítéletek által meghatározott. Az érvek érvényességét ugyanakkor egy racionális döntőbíró végzi, a közösségi észszerüséget reprezentálva. Az elmélet továbbá egyesíti a normatív és deskriptív dimenziókat is, amely arra utal, hogy miután rekonstruálja az érvelési helyzetet, a rekonstruált érvelési helyzetet a dialektikai normák alapján értékeli ki, amely jó módszer az érvelési hibák detektálására és egyúttal a vita minőségének meghatározására (Forgács [2015] p. 1096.).

\subsubsection{A pragma-dialektikai megközelítés problémái}

Nehézsége e megközelítésnek, hogy a vitapartnerek úgy győzzék le egymást a vitaszituációban, hogy közben nem sértik meg a pragma-dialektika normáit. Azt a folyamatos erőfeszítést pedig, amelyet a vitapartnerek tesznek annak érdekében, hogy megtartsák az egyensúlyt a dialektikai racionalitás és a retorikai hatékonyság közt, stratégiai manőverezésnek nevezzük. A retorika és a dialektika dimenzióinak feszültségét a pragma-dialektika stratégiai manőverezés során oldja fel úgy, hogy a dialektikai célokat elsődlegesnek tekinti a retorikai célokkal szemben. Amennyiben a retorikai célok meghaladják a dialektikai célokat, a pragma-dialektika a vitát nem tekinti érvényesnek. Forgács azonban nem a vita folyamatában, hanem keretfeltételeinek meghatározásában látja a fő problémát. A vitázó feleknek előzetesen meg kell egyezniük abban, hogy mit tekintenek észszerünek a vita lefolytatásakor. Felmerül azonban a kérdés, hogy a vitázó felek vajon képesek-e a kritikai diszkusszió eljárási szabályainak megfelelően megnyilvánulni (azoknak a szabályoknak, amelyek biztosítják a résztvevők racionalitását) (Tindale [1999] p. 55.). Kétségtelen, hogy egyetlen fél sem kíván stratégiai hátrányból indulni a vitában, így amikor bármelyik partner veszélyeztetve érzi álláspontját, előfordul, hogy nem vesz részt a pragmadialektikai normák által szabályozott vita kialakításában, ellehetetlenítve ezzel a tényleges vita létrejöttét (Forgács [2015] p. 1096.). További problémák léphetnek fel a bizonyítás terhének kiosztásakor, az előzetesen elfogadott kiindulófogalmak és állítások megállapításakor, illetve a vita kimeneteléről döntő észszerü kritikus elfogadásakor. A kritikus szakértő elfogadását tekintve Grootendorst az interszubjektivitás problémájára hívja fel a figyelmet. Míg a szakértők más irányú megközelítésekor a szakértőiség egy objektív, igazolható tény, a pragma-dialektika tükrében ez a vitapartnerek interszubjektív megegyezésén múlik. A vitázó felek fogják eldönteni, hogy ki elfogadható, megfelelő szakértő a vita kimenetelének elbírálására. Grootendorst szerint 
ez az attitüd mindenképpen hibás, mivel a szakértő megválasztása is az érvelés kontextusától függ (Grootendorst [1987] p. 339.). Erre a problémára többen is felhívták a figyelmet. Walton munkájára reflektálva Hajek pl. azt mondja, hogy még egy egyszerủ modus ponens is lehet hibás egy csúszkaérven keresztül, és fordítva, egy érvelés lehet hibás a hagyományos értelemben, pl.: az előtag állitása, mégis előfordulhat, hogy a vita valamely résztvevője őszintén úgy gondolja, hogy érvelése érvényes, és nem akarja partnerét csőbe húzni (Hajek [1992] p. 23.).

Ahhoz, hogy a jelen modell alkalmazható legyen az érvelés esetében, Forgács szerint egyfelöl be kell látni, hogy a pragma-dialektikai megközelítés alárendeli az érvelés retorikai aspektusát a dialektikainak, mindamellett, hogy az elméleten belül nincs megfelelö magyarázat arra, hogy az érvelések gyakorlatilag egy nyelvi-retorikai térben jönnek létre, melyben egy szónok bemutatja érveit közönsége (vitapartnere és az észszerü döntőbíró) számára. Másfelől azt sem szabad figyelmen kívül hagyni, hogy a vita keretének meghatározása nem bízható egyszerủen az észszerüségre, hiszen a vitapartnerek bármikor dönthetnek úgy, hogy - a vereség elkerülése érdekében - nem müködik együtt a vitában, így nem alakul ki vitahelyzet (Forgács [2015] p. 1096.). A fent említett hiányosságok miatt dolgozatom a dialektikai megközelítést sem tekinti megfelelő keretnek az argumentáció leírásához, így a következőkben a tanulmány által preferált retorikai megközelítés kerül bemutatásra.

\subsubsection{Az érvelés retorikai megközelítése}

Arisztotelész vélekedése szerint a retorika a dialektika hasonmása. Mind a kettő olyan ügyekkel foglalkozik, amelyek minden ember az általános ismeretkörének részei, és egyik sem tartozik teljes mértékben elhatárolható tudományterületekhez. Ennek megfelelően minden ember használja mind a két megközelítést, saját vélekedésének megvédése, vagy a másik vélekedésének megtámadása érdekében; a hétköznapi emberek ezt vagy véletlenszerüen, vagy a gyakorlatban szerzett szokásokon keresztül teszik (Aristotle [1354a] p. 593.). Az azonban fontos megállapítás, hogy az érvelés retorikai megközelítése maga a meggyözés. Az érvelés retorikai perspektívája megtalálható Arisztotelész Rétorikájában is, az érvelés és a retorika kapcsolatát és közös gyökerét tekintve azonban különböző tradíciók léteznek. Arisztotelész retorikai érvelését az éthosz és pathosz, valamint az enthüméma paradigmáját tartalmazó retorikai érvek iránti érdeklődés jellemezi. A későbbiekben külön alfejezetként tárgyalt enthümémát Arisztotelész 
Rétorikájában egy lehetséges, mindennapos érvként írja le, amely mentes a komplex következtetési láncoktól és megköveteli a közönség aktív részvételét (Aristotle [1354a]). Ebből a szempontból a retorikai érvelés egy kooperatív vállalkozás, amely folyamatában és eredményében is tartalmazza az érvelő és közönsége együttesét (Tindale [1999] p. 69.).

Ez az argumentációs perspektíva tehát nagyban eltér a fentiekben bemutatott pragmadialektikai modelltől. A Walton által leírt meggyőző dialógusban mind a két félnek kötelessége igazolni állítását a másik számára, míg a retorikai megközelítés elsődleges fókuszában az a törekvés áll, hogy az érvelő növelje közönsége elfogadását, odaadását a téma iránt. Ahogy láthatjuk, a közönség nem játszik passzív szerepet ebben a modellben sem, de nem is tekinthető aktív félnek, aki bemutatja saját érvelését a meggyőző dialógus során. A közönség tehát elsősorban nem a meggyőzésre törekszik, hanem a megragadásra, megfontolásra és az értékelésre. Ezzel egy időben a közönség mégis meggyőz, méghozzá saját magát: az érvelés legitimitásáról, igazságáról a hallgatóság sokkal inkább győzi meg önmagát, mint amennyire a rétor teszi ezt beszédével. A Rétorikában olvasható eredetén túl a retorikai érvelésnek Chaïm Perelman és Lucie Olbrechts-Tyteca óta van egy kortárs felfogása is, az úgynevezett új retorika, e szemlélet bemutatására pedig a következőkben kerül sor, előtte azonban dolgozatom a retorika fogalomkörének részletesebb ismertetésére vállalkozik.

\subsubsection{A retorika és annak kapcsolata más tudományterületekkel}

Az érvelést a logika eredményként, a dialektika eljárásként, a retorika pedig folyamatként ragadja meg (Aczél [2006] p. 79.). Ez utóbbi, görög eredetű szó tulajdonképpen egy jelző főnévként való önállósulása: hé rhétoriké tekhné ugyanis annyit jelent, mint szónoki művészet, mesterség. Latin megfelelöi a rhetorice vagy rhetorica (Szabó - Szörényi [1997] p. 15.). Az antikvitáshoz visszanyúlva Arisztotelész a meggyőzés eszközének tekintette a retorikát, míg Ciceró definíciója szerint a szónok célja, hogy megmozdítson, tanítson és gyönyörködtessen. Quintilianus egyszerüen a jó beszéd müvészeteként (ars bene dicendi) összegzi a retorika elméletét, egyszerre utalva a beszéd hatékonyságára, erkölcsösségére vagy szépségére, amely kétértelmüség a retorika későbbi konceptualizációiban is felfedezhető (Perelman [1979] p. 1.).

A mai gondolkodók retorikai megközelítése számos ponton egyezik az ókori tudósok

szemléletével. Renato Barilli Rhetoric címü munkájában úgy fogalmaz, hogy a retorika a 
diskurzusalkotás átfogó, teljes módja (Barilli [1989] p.vii.). Gáspári László szerint ugyanakkor a retorika a beszéd, azon belül is a nyilvános megszólalás gyakorlati diszciplínája (Gáspári [1991] p. 7.). Gáspári megközelítéséhez csatlakozva Margitay úgy véli, a retorikaimegközelítés számára az érvelések mindenekelőtt a nyilvános meggyőzés eszközeként jelennek meg, jóságuk pedig attól függ, hogy a közlő eredményesen tudta-e befolyásolni közönségét (Margitay [2007] p. 17.). Éppen ebből kifolyólag a retorika megítélése nem minden szempontból pozitív, esetenként úgy gondolunk rá, mint tartalom nélküli üres szavak halmazára, a gonosz mesterkedésre, a tettek elodázásának és a másik fél gátlástalan befolyásolásának eszközére (Connor [1996] p. 63.). A retorika azonban korántsem pusztán negatív konnotációval kecsegtet. Esetében olyan különböző diszciplínákon átívelő gondolkodásmódról, szövegtanról, vagy akár müvészetről beszélhetünk, amely ugyanúgy otthont ad a matematika, logika vagy filozófia fogalmainak, mint a költészet vagy etika gyakorlatainak. Gondolkodásmód, amely egyszerre ad hitelt és lehetetlenít el, szövegtan, amely a nyelvünkön élő másik nyelv, vagy mủvészet, amely életre kelti a szépséget, hatalmat, igazságot (Aczél [2005] p. 253.). Talán nincs még egy ilyen tudományág, amelynek ennyiféle megközelítését tartja számon a szakirodalom. A retorikát - mủvészet- és szövegalapú megközelítésén kívül - Aczél Médiaretorika címü müvében kódként írja le, amely a reprezentálás rendszerét kínálja; mesterségnek tekinti, amely alatt a szöveg segítségével történő eljárásokat, szóval, képpel és hanggal való cselekvést érti; gyakorlatként mutatja be, hiszen szimbolikus világunk is retorikai jelenségeken nyugszik; végül pedig médiumnak nevezi, amely dramatizál, ritualizál, alkot és közvetít (Aczél [2012] p. 9.).

A retorika más tudományágakhoz köthető viszonyait vizsgálva Aczél öt területet különít el. A retorikát mint kommunikációt, szövegtant, nyelvtant vagy nyelvmüvelést, a stílus tanát és végezetül mint szemantikát.

1. A retorika és a kommunikáció kapcsolata megkérdőjelezhetetlen. Míg az előbbinek müveletei vannak, az utóbbi funkciókkal bír. A kommunikáció gyakorlati szempontú megközelítésének hátterében a klasszikus retorika áll, ugyanakkor a meggyőző kommunikáció is jó kiegészítője lehet a retorika rendszerének. A retorika tehát azt írja elő, hogy milyen legyen, a kommunikáció azt modellálja, milyen lett a beszéd. 
2. Minden szöveg, amely eleget tesz a szövegszerüség ismérveinek kommunikatívnak tekinthető, ezáltal a retorika perspektívájából értelmezhető. Szövegnek tekinthető mindaz, amely koherens, szándékolt, releváns, elfogadható és együttmüködésre sarkall.

3. A kommunikáción és szövegtanon kívül a retorika a grammatikához ugyancsak kapcsolódik. Kétségtelen, hogy az antikvitásban a retorika látta el azokat a feladatokat is, amelyekért ma a grammatika felel, pl.: a kötőszavak, a nemek, vagy az egyes és többes szám helyes használata stb.

4. A stilisztika több szempontból is a retorika résztudományának tekinthető. Hagyományosan elfogadott az a nézet, amely szerint a stilisztika elengedhetetlen a szónoki beszéd elkészítéséhez és a szöveg elocutio-s, szóékítményeket, figurákat kifejező részéhez.

5. A retorikusok trópusokra és figurákra vonatkozó gondolatai szemantikai természetüek voltak, amelyet a retorika sajátos jelei, jelvonatkoztatásai is egyértelmüsítenek (Aczél [2005] p. 258.).

Az ókoriakhoz visszanyúlva azonban észrevehető, hogy a retorikát sürün hozták kapcsolatba olyan tudományágakkal is, mint az építészet, a müvészettörténet, vagy a zene.

1. A retorika mint építészet: A klasszikus retorika és a klasszikus építészet közötti analógiára Vitruvius hívta fel a figyelmet a Krisztus előtti első század végén, azt állítva, hogy mind a retorika, mind pedig az építészet saját igényeinek megfelelő, saját maga által létrehozott építőelemekkel dolgozik. A klasszikus építészet, csakúgy, mint a klasszikus retorika, tradicionális formákat, stílusokat és díszítőelemeket hozott létre, szerkezete pedig a retorika három nagy stílusával tehető egyenlővé: a dór oszloprend az egyszerü, kissé nehézkes stílusnak, a karcsúbb, finomabb részletekkel bíró ión oszloprend a közepes stílusnak, míg a legdíszesebb és legnyúlánkabb korinthoszi oszloprend a legmagasabb retorikai stílusnak felel meg. Az építészet és a retorika is sürün használja az olyan, hagyományos díszítő elemeket, amelyeket trópusoknak vagy alakzatoknak nevezhetünk, és mind a két tudományterület az egység, ritmus és dinamika kifejezésére törekszik. A klasszikus építészetben és retorikában fellelhető struktúrák, motívumok és 
stílusok az egész nyugati történelem során meghatározóak voltak, sokoldalú és kreatív, új adaptációk és változatok formájában (Kennedy [2006] p. 123.).

2. A retorika mint müvészet: A vizuális müvészet és a müvészien megfogalmazott szavak kapcsolata a görög világban kezdődő írás óta foglalkoztatja az elméletalkotókat. Homérosz 130 versből álló leírása Akhilleusz pajzsáról nem csak egy metatextust kínál Iliász történetéhez, de feltárja a verbális és vizuális narratívákban rejlő lehetőségeket is. Homérosz ekphraszisza, azaz képi elbeszélése későbbi szerzők sokaságának adott ihletet, mint pl.: Vergilius trójai háborújához Aeneis címü eposzában, Hésziodosz teremtéstörténetéhez és a római regények különböző képeihez (Borg [2014] p. 235.). A korai és modern írók mind egyetértenek abban, hogy az ekphraszisz fö mozgatórugója a benne rejlő energeia, azaz élénkség, hiszen magában foglalja a szerzők azon képességét, amellyel érzelmileg bevonják, sőt, elcsábítják közönségüket, és amellyel arra ösztönzik olvasóik vagy hallgatóságuk képzeletét (phantasia), hogy az elbeszélést úgy lássák belső szemük előtt, mintha az valóban, fizikálisan is jelen lenne (Borg [2014] p. 235.). Ugyanezen terminusoktermészetesen érvényesek a (fal)festészet, szobrászat és építészet esetében is, ahogyan ez utóbbira már fentebb kitértem.

3. A retorika mint zene: Habár a nyelvi mủvészet eszközeként jöttek létre, az alakzatok nem korlátozódnak kizárólagosan a nyelvi diskurzusokra, a képi és müvészeti elemek létrehozásában és vizsgálatában ugyanolyan fontos szerepet játszanak. Ciceró Arisztotelészhez hasonlóan - a beszédet az érzelmek továbbításával kapcsolja össze, azt állítva, hogy minden érzelem egyedülálló megjelenést, hangnemet és gesztust hordoz magában, csakúgy, mint a zenei akkordok (Welch [2006] p. 230.). Bonds Wordless Rhetoric című munkájában arra hívja fel a figyelmet, hogy a 19. század előtti időszakban az instrumentális zenét esztétikailag széles körben értéktelenebbnek tartották a vokális zenénél (Bonds [1991] p. 162.). Johann Georg Sulzer úgy vélte, a hangszerekkel játszott zene kellemes és időnként megindító, de ,jelentése” viszonylag homályos. Szerinte, a szöveg nélküli zene nem képes megadni a hallgatóság számára a zenében létrejövő érzelmek pontos jellegét és jelentését, míg az énekhangra írt és előadott zene érzelmi motivációit sokkal könnyebben teszi explicitté a szöveg segítségével (Sulzer [1995] pp. 95-96.). Éppen ezért, az 1800-as évek paradigmája szerint a zene csak akkor képes ellátni feladatát és beteljesíteni a tőle várt katarzist, ha szöveggel, költészettel kombináltan 
jelenik meg. Csak a 19. század második felében terjedt el az a nézet, amely szerint az instrumentális zene mind esztétikailag, mind pedig jelentésében legalább ugyanolyan, vagy még inkább eredményes, mint vokális társa (Bonds [1991] p. 162.). Érdekes megfigyelni a zene és a vizualitás történetében fellelhető analógiát: a vizuális imágókat pontosan ugyanezen vádakkal illetik a szakirodalomban, retorikai, érveléses kötődését

számos kutató nem, vagy csak a nyelv kontextusában fogadja el. A jelen disszertáció azonban - a verbális közlésen túlmutatva - a retorika vizuális elemek kodifikálására és szabályozására való alkalmassága mellett is érvel.

\subsubsection{A retorika története}

\subsection{Retorika az ókorban}

Akár a görög rhétor, a latin orator vagy eloquens, akár a magyar szónok kifejezést tekintjük, láthatjuk, hogy a retorika a szólni, kimondani vagy beszélni igére vezethető vissza; elemei, legáltalánosabban elfogadott meghatározásai is mind a beszédre utalnak (Adamik [2005] p. 17.). A rhétor elsőként Arisztophanésznál fordul elő szakszóként, a rhétoriké pedig Platónnál jelenik meg mint szakkifejezés, aki a retorikát a lelkek irányításának tekinti, beszédeken keresztül ahogyan azt az érvelés és formális bizonyítás elválasztásánál már láthattuk (Adamik [2005] p. 17.). Hasonlóképpen Tisziasz is a rábeszélés mesterségeként gondolt a retorikára, Gorgiasz, az előbbiek tanítványa pedig - ugyan bővebb meghatározást kínál, magvában azonban ugyanazt állítja - úgy véli, „a retorika a meggyőzés müvészete, oly beszédek segítségével, amelyekben rábeszélö, és nem oktató erő van" (Szabó - Szörényi [1997] p. 15.).

Az évszázadok során a történelmi változásokkal párhuzamosan azonban retorika funkciói is módosultak, így hát nem véletlen, hogy retorika fogalmának megjelenése óta mindvégig nélkülözte az egységes definíciót. Eleinte a stílus művészeteként említették, majd a prédikációval, oktatással és az írás mesterségével tették egyenlővé, a középkorban pedig a logika és grammatika mellett a három szabad művészet egyikeként hivatkoztak rá (Foss et al [1985] pp. 4-7.).

A retorika sokszínűsége történelmi hagyományaiban is megmutatkozik: e gyakorlati tudomány - vagy idegen elnevezéssel techné - Szirakúzából indult hódító útjára a Krisztus elötti 
5. században és meg sem állt Athénig, ahol a demokrácia megteremtésének és megszilárdulásának elsőszámú alapkövei, a népgyülés és a bíróság segítőtársa lett a politikai és törvényszéki beszédek eszközeként (Gáspári [1991] p. 11.). A zsarnokok uralkodását felváltó demokrácia számos egymással konfliktusban álló tulajdoni igény összecsapását eredményezte, a földbirtokosok ugyanis nem tudtak dülőre jutni abban, hogy azt illeti-e meg a föld, akié eredetileg volt, vagy azé legyen, akihez a zsarnok uralkodása alatt került (Foss et al [1985] p. 2.). Mivel a város polgárainak önmagukat kellett képviselniük a bíróság előtt - a görögöknél ugyanis nem volt ügyvéd - ezért ki-ki magának intézte saját peres ügyeit, ehhez pedig az ékes beszéd és stratégiai érvelés elsajátítása elengedhetetlen volt. Ebből is tisztán látszik, hogy a korai görög társadalmi élet a szóbeli közlésen alapult: a politikai, törvényszéki és társadalmi érintkezés eszköze hosszú évszázadokon keresztül az élőszó volt, tehát a jogé, irodalomé, filozófiáé stb. Az élőszó fontosságának ez a felismerése késztette arra a görögöket kezdettől fogva, hogy a beszédet tanítsák, értelmezzék, elemezzék (Adamik [2010] p. 450.). A görög filozófus, Korax elsőként járult hozzá a beszédek elemeinek rendszerezéséhez, a ma is érvényes hármas tagolást bevezetés, érvelés vagy bizonyítás és konklúzió - javasolva. A retorikaoktatás megérkeztével az ékesszólás mint művészet értéke is megnövekedett, így megjelentek az érvelést, filozófiát és általános bölcsességet tanító szofisták, a bölcsesség oktatói (Gáspári [1991] p. 11.). Munkásságukat több szempontból is bírálták: idegenek voltak Athénban, bölcsességet és kiválóságot oktattak, amely értékek a görögök szerint nem taníthatók és nem mellesleg díjat számítottak fel szolgáltatásaikért. A Kr. e. 4. század elejétől már egyre nagyobb ellenszenvvel figyelték a szofisták tevékenységét, a velük folytatott vita során alakult ki a tekhné rhétoriké, azaz tudományos retorika fogalma is, amelynek megalkotói közül hárman emelkednek ki: Arisztotelész, Iszokratész és Platón (Adamik [2010] p. 452.). Iszokratész 393 táján nyitotta meg Athénban iskoláját, amely kiemelkedő jelentőséggel bír az európai müvelődéstörténetben, vele kezdődik ugyanis a felsőfokú oktatás és alakul ki a ma is érvényes, hármas alap, közép és felsőfokú oktatási forma. A szofisták ellen címü értekezésében Iszokratész nyilvánvalóvá teszi, hogy a fizetség reményében több tudást kínáló, de azt teljesíteni nem tudó szofisták retorikája helyett az erkölcsi alapokon nyugvó retorikát részesíti előnyben. Platón Gorgiász címü müvében elítéli a korabeli retorikát, mivel az nem az igazságra fókuszál, és felvázolja egy tudományos retorika lehetséges körvonalait. Mivel azonban a rosszra is rá lehet beszélni, Platón nem vállalkozott egy holisztikus, tudományos retorikai álláspont megalkotására. Ezt a feladatot végül 
Arisztotelész végzi el, Rhétorika címü, háromkötetes munkájában, amelyben a retorikát önálló módszertannal bíró tekhnének (mesterségnek) nevezi, legfőbb feladataként pedig a meggyőzés lehetséges módjainak feltárását jelöli ki (Adamik [2010] p. 452.). A fenti kritikák ellenére a szofisták ugyanolyan fontos szerepet játszottak a retorika történetében, mint hajthatatlan ellenfelük, Platón, tanítványa, Arisztotelész, vagy a római retorika megtestesítői, Cicero és Quintilianus. E filozófusok és szónokok nagysága nem, a retorikával kapcsolatos általános megközelítésük azonban nagyban különbözött egymástól, mint ahogyan a görög és római retorika is számos eltérést mutatott. A demokrácia bölcsőjében létrejövő, főként érvelő típusú, görög retorikaannak a szükségletnek hatására jött létre, hogy a rétor - politikai vagy bírósági vitákban - szándéka szerint tudja meggyőzni közönségét. Ebben az összefüggésben e retorika racionális, vagy legalábbis következtető jellegü. Célja, hogy megoldást nyújtson akkor, amikor analitikusan meggyőző érvek nem álltak rendelkezésre.

A római ezzel szemben kevésbé érvelö, sokkal inkább narratív jellegü retorika volt. Következésképpen sokkal inkább a beszélő személyiségére, identitására, társadalmi státuszára fókuszált, annak érdekében, hogy az orátor és közönsége közötti kapcsolatot megerősítse, értékközösséget teremtve ezáltal. A közösségi érzés kialakítása mellett a római retorika természetesen a szónok pozíciójának megerősítésében is kiemelkedő szerepet játszott (Meyer [2014] p. 419.). A rómaiak természettől szerettek beszélni, gondolataikat pontosan és egyértelmủen tudatták másokkal, arra is odafigyeltek azonban, hogy mondanivalójuknak társadalmi hasznossága is legyen, amelyröl föként bölcs mondásaik, a sententiák tanúskodnak. A rómaiak korán, már az 1. és 2. pun háború idején (Kr.e. 3. sz.) megismerkedtek a görög retorika tanításaival, mivel sok művelt görög került hadifogolyként, rabszolgaként Rómába. Ők többnyire tanítói feladatokat láttak el, grammatikára és retorikára oktatva az előkelő római családok fiait (Adamik [2010] pp. 1046-1047.). A retorika gyakorlata és elmélete hamar felkeltette a rómaiak érdeklődését: az elsőként egészében ránk maradt szónoklattan Conificius nevéhez köthető (Rhetorica ad Herennium címen), de Cicero retorikai müvei is korszakalkotó munkáknak minősültek. Cicero műveiben a görög retorikát római hagyományokkal ötvözte, és megteremtette a sokoldalúan képzett, tökéletes szónok alakját (perfectus orator) (Adamik [2010] pp. 10461047.). Ez a fajta személyiség, identitás és hatás központú megközelítés Cicero következő tanításában is megnyilvánul: „Az a legjobb szónok, aki beszédével a hallgatók lelkét tanítja is, 
gyönyörködteti is, meg is indítja: tanítania kötelesség, gyönyörködtetnie becsület dolga, megindítania végül szükséges” (Szabó - Szörényi [1997] p. 24.).

\subsection{Retorika a középkorban}

Ahogyan azt a fentiek is alátámasztják, a középkor (kb. 500-1400) tökéletesen kidolgozott retorikai struktúrát kapott örökül, amely négy hagyományt ötvözött:

1. a retorikát a dialektika párjának tekintő arisztotelészi tradíciót;

2. a gyakorlatibb, szabályokon alapuló iszokratészi (cicerói) látásmódot;

3. a Horatius Ars poeticáját is magában foglaló grammatikai felfogást, mivel az antik felfogás szerint a grammatika feladata volt a helyes beszéden és íráson kívül a költők magyarázata is;

4. végül a második szofisztika hagyományát, amely az iskolai gyakorlatokra helyezte a hangsúlyt (Adamik [2010] p. 669.).

Míg az ókorban a felsőfokú oktatás tananyagát a retorika oktatta, a középkorban kiszorította pozíciójából a teológia, jog és orvostudomány. A kolostori iskolákban is áthelyeződött a hangsúly az igehirdetésről a szemlélődésre, Isten dicsőségének megismerésére. Később a feudális állami berendezkedés sem engedett teret a retorikának, mivel nem teremtették meg azt a politikai és társadalmi színteret, amelyben a retorika virágozhatott volna. A beszédben kardinális szerepet játszó retorika feladatköre ekkora csupán a levelek, okiratok és törvények megszövegezésére és értelmezésére korlátozódott. Az ókori retorikai hagyományokat felhasználva a középkori feudális társadalmak igényei szerint a költészet, a levélírás és a prédikálás szolgálatába állt a retorika. A későbbi középkori filozófusok az invenciót és diszpozíciót a dialektika területéhez kapcsolták, így a retorika végül csupán a stílusra (kifejezésmód) korlátozódott (Adamik [2010] pp. 669-672.).

\subsection{Retorika a reneszánsz korában}

A reneszánsz retorika (kb. 1400-1600) továbbra is betölti azokat a szerepeket, amelyeket a középkorban betöltött, ebben a korban azonban egy jóval elmélyültebb, kidolgozottabb formát mutat azáltal, hogy felfedezik a klasszikus retorika középkorban nem ismert nagy müveit is. A 
retorika újjáéledését segítette az is, hogy az újonnan felfedezett latin és görög szövegeket kinyomtatták, ezzel elősegítve terjedésüket egész Európában. A középkorral szemben a reneszánszban a retorika a társadalmi élet minden területén érezteti a hatását. Míg az előző korszakban a retorika bizonyos részeit kiszakították, a reneszánszban a retorika holisztikus látásmódja valósul meg azáltal, hogy egyrészt nagyobb teret kap a nyilvános beszéd, másrészt integrált jellegü, esztétikai orientációjú tudományággá válik, amely nem csak a társadalmilag igényelt írásmódot, hanem az elfogadott beszéd- és viselkedésmódot is oktatja. Később a retorika áthatotta a zenét és a költészetet is, amely szintén bizonyítéka annak, hogy a reneszánsz szerzők az ókori retorika egész rendszerét tárgyalták és vizsgálták. Ebben a korszakban a retorikai alakzatok is kitüntetett figyelmet kaptak. A retorika klasszikusokkal történő bővítése mellett a későbbi, humanista korban annak szükítésére is történtek lépések, amelyek aztán a retorikával kapcsolatos későbbi meghatározásokat jelentősen befolyásolták (Adamik [2010] pp. 10181021.).

\subsection{Retorika a 18. században}

A felvilágosodás korában ismét felfigyeltek a retorika és a filozófia közös kapcsolódási pontjaira. E korszak igazi fordulópontnak tekinthető a retorika történetében. A korszak prominens gondolkodói, Francis Bacon, René Descartes, John Locke, és David Hume megközelítései mind arról árulkodnak, hogy a felvilágosodással a retorika klasszikus, egyházi kötődését felváltja egyfajta modern szemlélet. A 18. században megkezdődik az üzleti és kereskedelmi oktatás, amellyel a görög és latin nyelv teljhatalmát az angol veszi át. A könyvek sokszorosításával az írástudás is megnövekedett, így a retorika ismét az irásbeliségre fókuszált (Horner [2010] pp. 205-207.).

\subsection{Retorika a 19. században}

A 19. századi retorika jelentette az átmenetet a 18. századi és a modern retorika között. E korszak különlegessége, hogy a retorika korábbi feladatait más tudományágak tárgykörébe sorolta, ezzel átrendezve és destabilizálva a retorika diszciplináris határait. A század első évtizedeit követően a kor nagy gondolkodói (pl.: Thomas Huxley, Jeremy Bentham, Charles Sanders Peirce, William James, vagy John Stuart Mill) már egyáltalán nem a klasszikus 
retorikából indultak ki, a retorika oktatása pedig Amerikában és Skóciában áthelyeződött a nyelvtan, mondattan, kompozíció, elokúció és logika területére. Ez hangsúly áthelyezés szónok személye felől az író személye felé, illetve a meggyőzés felől a kommunikáció felé történő elmozdulásban is megmutatkozott. A 19. században a filozófián kívül olyan diszciplínák is jelentős hatással voltak a retorika tudományára mint a társadalom- vagy a politikatudomány (Ferreira-Buckley [2010] pp. 468-473.).

\subsection{Retorika a 20. században}

A 20. század elején a nyelvészek és nyelvfilozófusok föként a nyelvrendszerek müködésének szabályait vizsgálták úgy, hogy a nyelvet zárt rendszernek tekintették. A kor egyik kiemelkedő gondolkodója, Ferdinand, de Saussure szemiotikai megközelítésével lefektette a strukturalizmus alapjait, amelyben a retorika ugyan nem játszott centrális szerepet, a szemiotika és a strukturalizmus jelentéstanhoz való kapcsolódása mégis nagy hatással volt a retorika elméletére. A korábbi korszakokhoz hasonlóan a filozófia és a retorika kapcsolata a 20. században is vitatott volt, a filozófia nyelvi kapcsolódása azonban megkérdőjelezhetetlenül megerősítette a retorikához füződő viszonyát. A 20. század közepétől ismét vizsgálni kezdték a retorika és érvelés, valamint a retorika és meggyőzés kapcsolatát, a retorika területének tágabb értelmezését szorgalmazva (Casaregola és Farrar [2010] pp. 732-739.).

Korunk retorikai megközelítése is ezt a tágabb értelmezést támogatja, önálló tudományként tekint a retorikára. A retorika kompetenciái címü munkájában Wacha Imre a következő megállapítást teszi: ,a retorika egyrészt a.) müfajismeret, s ezen belül a prózai és verses (elbeszélő és leíró) müfajok ismeretének tudománya, másrészt b.) a meggyőző nyilvános (szónoki) beszédnek, harmadrészt c.) a prózai ékesszólásnak, az elegáns, választékos szónoki stílusnak a tana, negyedrészt d.) szerkesztéstan. Mindezeken belül egyrészt deskriptív, rendszerező tudomány, másrészt preskriptív és gyakorlati célokat szolgáló tudomány. Hogy az említettek közül melyik dominált az egyes retorikákban, az mindig az adott kor szólásszabadságának és gyakorlati vagy tudományos céljainak volt a függvénye” (Wacha [1994] pp. 53-88.).

A retorika kortárs megközelítését tiszteletben tartva Sonja K. Foss és társai úgy gondolják, hogy a retorika ma alapjait tekintve pontosan ugyan olyan, mint amilyen Korax 
korában volt (Foss et al [1985] p. 13.). Természetesen figyelembe veszik, hogy Korax idejében a retorika ereje főleg nyilvános beszédekben manifesztálódott, míg a mai tömegkommunikációs eszközök használata drasztikusan megváltoztatta a retorika folyamatait. Emellett az ókori szónokoknak nem kellett megküzdenie a személyközi vagy szervezeti kommunikáció nehézségeivel, ez is egy új aspektusa a retorikának. Az említett kutatók mégis úgy gondolják, hogy a retorika ma is ugyanazt jelöli, mint hajdan: a szimbólumhasználat egyedülállóan emberi képességét, amely meghatározás egyszersmind magában foglalja az összes formát és kontextust. Aczél ezzel szemben úgy vélekedik, hogy a harmadik évezredhez érve a retorika alapvető változásokon ment keresztül. Többé már nem csak a beszédre, hanem - többek között - az írásra és írott beszédre, sőt, a vizuális elemekre is vonatkozik, miközben a jelrendszer, amely az alapját adja továbbra is a meggyőzés nyelve. A meggyőzés nem csupán a szociálpszichológia szempontjából vizsgálható, hiszen gyökerei a logikában találhatók, kifejeződése pedig a pragmatikán keresztül érvényesül. A formális logika dedukciójától való távolodása is azt bizonyítja, hogy a retorika önálló szisztéma, amelynek célja az akarat befolyásolása, a meggyőző hatás indukálása (Aczél [2005] pp. 260-261.). Szerinte a retorika egyszerre forrása és eszköze a meggyőzésnek, miközben a meggyőzés nem a szövegformákra, hanem annak hatásaira koncentrál. A retorika egyszerre képes érvelni és meggyőzni, ez pedig Aczél szerint abban is megnyilvánul, hogy „a meggyőzés szociálpszichológiai jelenségeihez a klasszikus elmélet eszközeit és terminológiáit kapcsolja” (Aczél Szóerő).

\subsubsection{Retorika és meggyőzés}

Aczél előbbi gondolatát erősítve a retorika meggyőző típusú megközelítését javasolja Kenneth Burke, aki szerint e diszciplína fő funkciója, hogy humán ágensek úgy használják a szavakat, hogy ezáltal más humán ágensek attitüdjeit formálják, és őket cselekvésre késztessék (Burke [1969] p. 41.). Arisztotelész számára a meggyőzés célja egy bizonyos nézet kifejtése, míg a már említett szofisták úgy gondoltak a meggyőzésre, mint a fontos tényekre való rátalálás egyik eszközére. Ennek ellentmondva Arisztotelész kijelentette, hogy a tudás csakis logika és következtetések útján szerezhető meg, azonban sajnálatos módon nem mindenki alkalmas arra, hogy világos következtetésre jusson minden kérdéskörben, így e személyek számára a meggyőzés müvészetével lehet megmutatni az igazságot, a helyes végkövetkeztetés reményében (Pratkanis - Aronson [1992] p. 19.). A retorika perspektívájából nézve Zarefsky szerint az 
érvelés feladata, hogy olyan állításokat tegyen, amelyek relevánsak a szónok közönségének meggyőzése szempontjából, azt sugallva, hogy hogyan kellene vélekedni, esetleg eljárni egy adott ügyben (Zarefsky [2014] p. 3.). Az ilyen, attitüdváltozásra irányuló meggyőzés alapvető szerkezete Walton véleménye szerint nagyon könnyen megállapítható. A központi elképzelés az, hogy két résztvevő fél van, és az egyik megpróbálja meggyőzni a másikat az általa kiindulópontnak tekintett állítás igazságáról (Walton [2007] p. 53.). De hogyan is győzünk meg másokat arról, hogy elfogadják nézeteinket? Hogyan vesszük rá őket, hogy azonosuljanak látásmódunkkal?

Ahogyan arra a retorikai érvelés bevezetésében is utaltam, Arisztotelész, a meggyőzés első teljes elméletének kidolgozója, a hallgatóság meggyőzését illetően három elengedhetetlenül fontos tényezőt különít el egymástól: az értelmükre való apellálást (logos), az érzelmeikre való apellálást (pathos) és végezetül a saját személyiségünkre, karakterünkre való apellálást (éthos) Corbett [1965] pp. 271-279.).Az argumentáció első alappillére, a logosz valójában maga a szó, illetve mindaz, amit a szóval elérhetünk. Ez tekinthető az érvelések szerkezetének, illetve a nyelv racionalitásának és hatásának leíró jelenségének is. Míg a következő alapkőnek, az éthosznak a beszélő megbízhatóságának demonstrálása a célja az arisztotelészi hármas tagolás alapján (bölcsesség, erény és jóakarat) addig a pathosz arra ügyel, hogy a szónok szenvedélyeket célzó emóciós szándéka a kívánt hatást legyen képes elérni közönségében (Aczél [2005] pp. 271-279.).

\subsubsection{Az enthüméma}

Arisztotelész retorikai elemzésének középpontjában az enthüméma áll. A görög tudós Rétorika címủ munkájának egy ismert szakaszában az enthümémát a retorikai meggyőzés esszenciájának, lényegének nevezi (Arisztotelész [1354al5]). De mi is az az enthüméma? Ez a kérdés számos akadémiai terület kutatóját foglalkoztatja, különös tekintettel a retorika tudósaira. A Stanford Online Encyclopedia of Philosophy meghatározásában az enthüméma görög fönév az enthumeisthai igéből származik, amelynek jelentése „megfontolni” vagy „tekintetbe venni”. ${ }^{3} \mathrm{Az}$ enthumeisthai ige azonban a „valamire emlékezni” vagy „,az elmében meglévő” jelentéssel is bír, míg, ha elemeire bontjuk e kifejezést, és megvizsgáljuk összetevőinek etimológiai gyökereit, azt

${ }^{3}$ https://plato.stanford.edu/search/searcher.py?query=enthymeme 
találjuk, hogy az en a -ban -ben ragot, míg a thymos a szenvedély fönevet jelöli. Az enthüméma etimológiai struktúrája tehát a szenvedély fogalmában gyökerezik.

Arisztotelész retorikájában az enthüméma, azaz a retorikai szillogizmus központi szereppel bír, mivel a közönség vélt hitvilágát, tudásait, ismereteit a feltalált érveken keresztül összekapcsolja a rétor szándékolt következtetéseivel (Enos [2010] p. 223.). Ugyan az enthümémát gyakran szembeállítják az éthosszal (jellem) és a pathosszal (érzelem), pedig Arisztotelész meghatározásából is tisztán látszik, hogy érzelmileg terhelt állítások is lehetnek az enthümémák premisszái, mivel ezek a hallgatóság meggyőződésén és hitén alapulnak (Adamik [2002] p. 21). A görög tudós a retorika logikai bizonyítékainak két módját különbözteti meg: a deduktív enthümémát és az induktív példát; vélekedése szerint mindenki bizonyítással érvel úgy, hogy vagy példát alkalmaz, vagy pedig enthümémát, e kettőn kívül nincsen más lehetőség. Arisztotelész úgy véli, a szillogizmussal ellentétben az enthümémának szükségszerüen „több propozícióból kell állnia”, ,az érvelésben pedig nem léphet vissza túlságosan”, mivel egy érvelés minden egyes elemének alkalmazása túlzottan egyértelmüvé, vagy homályossá tenné azt (Enos [2010] p. 223.).

Az enthüméma fogalmát az ókori retorikától napjainkig számos kutató, számos módon újragondolta. Míg Arisztotelész a legfőbb bizonyítási eljárásnak, Cornificius ellentétnek, Quintilianus megfontolásnak nevezte (Aczél-Adamik [2010] pp. 331-333.), addig Minoukianos szükített indukcióként (compressed induction), Rufus cáfoló állításként, Hermogenes díszítő záró kijelentésként (ornamental concluding statement) írta le (Enos [2010] p. 224.). Mások, mint pl. Barthes csonka szillogizmusként vagy retorikai szillogizmusként definiálták. Barthes úgy véli, „,valamelyik a két premissza közül, vagy a következtetés törölhető, ekként áll elő valamely állításból - amelynek igazságértéke az emberek szemében megingathatatlannak tűnik, s amely épp ezért egyszerủen az elmében lévő (en thümó) - (magában a jelentésben) elhagyás révén egy csonka szillogizmus" (Barthes [1997] p. 126). A retorika korai szakaszában tehát az enthüméma a logikai alapoktól a stilisztikáig többféle definícióval bírt.

A klasszikusoktól kissé eltérő, kortárs felfogást erősítve Thomas M. Conley úgy fogalmaz, hogy az enthüméma a szillogizmushoz hasonlóan szintén két premisszát és egy konklúziót tartalmaz, ezek közül valamennyi azonban nem feltétlenül jut kifejezésre. Az egyik állítás esetlegesen eltűnhet, és a másik állítás számíthat arra, hogy a hallgatóság tisztában van 
egy adott dologgal. Conley értelmezése szerint ezért az enthüméma mindig a hallgató és a szónok között létrejövő interakcióra épít (Conley [1984] pp. 168-187.).

Lloyd F. Bitzer felfogásában az enthüméma és a szillogizmus közötti különbség abban áll, hogy míg a szillogizmus esetében lefektetünk premisszákat a konklúzió elérése érdekében, az enthüméma esetében keressük az állításokat (Bitzer [1959] p. 399-408.).

Aczél szerint az enthüméma olyan retorikai alakzat, amely összeköti a logikus gondolkodást a retorikus hatással, és amely a verbális szinten kívül ugyanúgy megjelenhet a vizualitásban is (Aczél [2005] p. 320.). Felhívja továbbá a figyelmet, hogy „az enthüméma csonka szillogizmusként az érvek felhasználásával és a közhelyek odaértésével, a kikövetkeztetett rejtett érv megtalálásával a metafora alakító eljárását idézi. Aki az enthümémát értelmezi, az nem csupán dekódolja a hallott állításokat, hanem kódolja, előállítja a hiányzó érvet, amelyet a valószínűség és a közös helyek ismeretében tesz” (Aczél [2005] p. 322.).

Walton definíciója szerint az enthüméma olyan hiányos érvelés, amelynek néhány komponense explicit premissza vagy konklúzióként jelenik meg, azonban a harmadik premisszát a hallgatóságnak önállóan kell megtalálnia és beillesztenie az érvelésbe ahhoz, hogy az értelmet nyerjen (Walton [2008] p. 361.). A teljes érveléstől, azaz szillogizmustól eltérően az enthüméma megszólítja, bevonja és felhatalmazza közönségét, mégis a szónok szándéka szerint kontrollálja és irányítja azt.

Freeley és Steinberg úgy véli, a szillogizmus szigorú szabályai kiváló értékes eszközként szolgálnak az érvek elemzésekor, ugyanakkor, e szabályok korlátozzák azokat a szituációkat, amelyben előfordulhatnak. Ritkán beszélünk szillogizmusokban: sokkal gyakoribb, hogy kevésbé teljes következtetéseket alkalmazunk. Illetve sokkal több olyan helyzet van, amelyben valószínüségekkel találkozunk és nem bizonyosságokkal. Ezekben a szituációkban lehet hasznunkra az enthüméma. Freeley és Steinberg két definíciót kínál az enthüméma fogalmának tisztázására:

1. Az első definíció szerint az enthüméma, amelyben valamely premissza, vagy a konklúzió nincs megadva. Ahogyan említettem, számos érvet enthüméma formájában fejezünk ki, így, ha pl.: a felsőoktatás szövetségi támogatásáról hallunk egy vitát, ezzel az érvvel 
találkozhatunk: „Ez a terv szövetségi ellenörzéshez vezet, ezáltal nem kivánatos.” Enthüméma formájában kifejezve ez az érv így nézne ki:

- Fö premissza: Ez a terv szövetségi ellenörzést eredményez.

- Következtetés: Ezért ez a terv nem kívánatos.

2. A második definíció azt állítja, hogy az enthüméma olyan szillogizmus, amely valószínüségeken, jeleken és példákon alapszik, funkciója pedig a retorikai meggyőzés. Sikeres kivitelezése a beszélő és közönsége közös erőfeszítésein keresztül valósul meg, ez adja lényegi jellemzöjét. E megközelítés szerint tehát az enthüméma mindig valamilyen valószínüségből indul ki, amelynek bemutatására a következő példa szolgálhat alapjául:

- Fö premissza: Az inflációt okozó összes tervet el kell utasítani.

- Alpremissza: Ez a terv inflációt okozhat.

- Következtetés: Ezért ezt a tervet el kell utasítani.

Egy ilyen érv szillogisztikusan semmit sem bizonyít. A formális érvényessége nulla. Mégis hatásos lehet a közönség retorikai meggyőzésében, amennyiben észszerủ valószínüséget képes létrehozni (Freeley - Steinberg (2009) pp. 159-160.).

Végezetül Jasinski - Conley nyomán - az enthüméma úgynevezett domináns megközelítését mutatja be, amely különösen a retorikakutatók körében terjedt el, és amely más fénybe helyezi az enthüméma fogalmát a korábbi definíciókkal szemben. Ugyan nincsen abszolút megegyezés a domináns perspektívát illetően, hat pontban mégis konszenzusra jutottak e terület tudósai:

1. Először is, az enthüméma egy deduktív típusú érvelés, egy retorikai szillogizmus, amely az általánostól halad a konkrét felé, szemben a retorikai példával, amely egy induktív mozgást testesít meg a specifikustól az általánosig. Egy enthümematikus érv, csakúgy, mint logikai unokatestvére, a szillogizmus, három részből áll: kettő premissza és egy konklúzió. 
2. Másodszor, az enthüméma csonkított szerkezet, egy hiányos vagy csonka szillogizmus. E megközelítés gyakran ellenvéleményekbe ütközik, amely elvezet bennünket a konszenzus harmadik pontjához.

3. Számos kutató szerint mégsem érdemes csonka szillogizmusnak tekinteni az enthümémát, ha mégis megtörténik, annak pusztán gyakorlati okai vannak, nem formai. Általánosan elmondható, hogy egy jó rétornak mindig ki kéne hagynia a közönség számára nyilvánvaló premisszát, nehogy megsértse hallgatósága intellektusát. Amikor egy premissza kimarad, a közönség feladata azt behelyettesíteni.

4. A harmadik ponthoz szorosan kapcsolódó negyedik azt mondja ki, hogy az enthümematikus érvelés kooperatív interakció függvénye a beszélő és hallgatósága között.

5. Az enthüméma premisszái lehetséges állításokat takarnak, nem bizonyosakat.

6. E szemlélethez csatlakozva az utolsó pont kimondja, hogy egy enthüméma premisszái nem pusztán valószínü tényeket, hanem értékeket, attitüdöket is jelölnek. Ezáltal, retorikai kontextusukban nem csak logosz-ként funkcionálnak, hanem az éthoszt és pathoszt is segítségül hívják müködésükkor (Jasinski [2001] pp. 206-207.).

A retorika és meggyőzés kapcsolatát bemutató fenti alapelvek kifejezetten jól illusztrálják, hogy a meggyőzés milyen fontos szerepet játszik mindennapi életünkben, ezáltal korunk valódi kulcsszavának tekinthető. A meggyőzésnek számos elméletét tartja számon a szakirodalom, ezek közül a jelen disszertáció Aczél alapján a hozzáállás (attitüd) megváltozásának elméletét, az önkéntes cselekvés elméletét, a meggyőzés elméletét illetve a kritikai retorika megközelítésének elméletét tárgyalja. Először azonban az attitüd fogalmi meghatározása következik.

\subsubsection{Az attitüd fogalma}

Az attitüd szociálpszichológia által használt fogalom a viselkedésben vagy viselkedési szándékban kifejeződő meggyőződésre (Adamik [2010] p. 101.). Síklaki szerint az attitüd a meggyőzésre vonatkozó elméletek nélkülözhetetlen eleme, hiszen a meggyőzés azáltal képes befolyásolni a meggyőzendő személyt, hogy hatást gyakorol bizonyos vonatkozásban a vélekedéseire, attitűdjeire (Síklaki [1994] p. 17.). Petty és Cacioppo úgy írja le az attitüdöket, 
mint egy általános pozitív, negatív vagy semleges értékelése egy személynek, tárgynak, vagy bármilyen problémának (Petty - Cacioppo [1986] p. 25.). Ez utóbbi tényezőket összefoglalóan attitüdtárgyaknak nevezzük, amelyekkel kapcsolatban kognitív, affektív és konatív elköteleződéseink lehetnek. A kognitív dimenzió az attitüdtárggyal kapcsolatos értékeléseinkre, vélekedéseinkre és tudásunkra utal, míg az affektív a hozzá köthető érzelmeinket, a konatív pedig a kapcsolódó szándékainkat, cselekvési tendenciáinkat jelzi (Síklaki [1994] p. 17.). Az attitüdöknek olyan dimenzióit különíthetjük el, amelyek a mérés problematikájának szempontjából mindenképpen relevánsak, ezek hatos tagolása Singh alapján a következő:

1. Irány: az attitűdök iránya a befogadó egy bizonyos tárggyal, személlyel vagy eseménnyel kapcsolatos pozitív vagy negatív értékelését, pro vagy kontra hozzáállását jelöli. Pl.: Lehetnek pozitív vagy negatív attitüdjeink a házasság előtti szexszel kapcsolatosan.

2. Mérték/Kiterjedés: ez a dimenzió egy attitüd kedvezőségének vagy kedvezőtlenségének fokára, mértékére utal. P1.: Általánosan támogatjuk-e a női egyenjogúságot, vagy csak az élet bizonyos területein.

3. Intenzitás: az attitüdöket kísérő potenciális érzések erősségének intenzitására utal. Arra, hogy a személy erős érzelmeket táplál az attitüdtárggyal kapcsolatban, vagy gyengéket.

4. Centralitás: arra utal, hogy az adott attitüdtárgy mennyire áll közel a személy attitüdrendszeréhez, értékrendjéhez, azaz, hogy mennyire szignifikáns számára a személy, tárgy vagy esemény.

5. Relevancia/szaliencia: Arra a mértékre utal, amennyire az adott személy az attitüdtárgynak fontosságot tulajdonít.

6. Következetesség: ez a dimenzió az attitüdök integrációját foglalja magában. Ha egy személynek például pozitív értékelései vannak a nőkkel kapcsolatban, felmerül a kérdés, hogy hasonló érzései vannak minden nő iránt, osztálytól és pozíciótól függetlenül (Singh [2015] p. 244.).

Az attitüdök értékelésekor e hat dimenzió számbavétele mindenképpen szükséges. A meggyőzés és az attitüdök kapcsolatának vizsgálatát Perloff a következőképpen fogalmazza meg: a meggyőzés nem más, mint az attitüdök és azok megváltoztatásának tudománya. Véleménye 
szerint a meggyőzés vizsgálata és gyakorlata koránt sem számít újdonságnak. Már az Újtestamentumban is találhatunk példát a szóbeli befolyásolás folyamataira, amikor Keresztelő Szent János buzdításait olvassuk Krisztus közelgő eljöveteléről. Ugyanígy Niccolo Macchiavelli, a 16. század egyik legnagyobb gondolkodója legismertebb, A fejedelem címü munkájában szintén a meggyőzés eszközeit alkalmazva ad iránymutatást az állam igazgatására (Perloff [2010] p. 4.). Mára pedig az elektronikával, reklámkampányokkal és folyamatos információáramlással teli világunkban a még több csatornán, platformon keresztül történő meggyőzés teljesen új nagyságrendeket öltött. De milyen módokon is tudjuk megváltoztatni mások attitüdjeit, amikor saját vélekedésünk helyességéről kívánjuk őket meggyőzni?

\subsubsection{A hozzáállás (attitűd) megváltozásának elmélete}

a.) A hozzáállás teóriája alapján a meggyőző folyamat során az attitüd megváltoztatását tüzzük ki célul. Egy attitüd megváltozása úgy tekintendő, mint bármilyen megfigyelhető változás hátterében meghúzódó konceptualizáció, amelyet Aczél szerint háromféleképpen érhetünk el:

- Megváltoztathatjuk meglévő attitüdjeinek irányát (pozitívról negatívra és fordítva);

- Megváltoztathatjuk meglévő attitüdjeinek intenzitását (meggyőződésének erejét növelhetjük vagy csökkentjük);

- Új attitüdöket alakíthatunk ki benne (Aczél [2005] p. 397.).

b.) Az elmélet második változata a hozzáállás funkcionális megközelítése. A hozzáállás-vizsgálat során kétféle funkciót különíthetünk el: a szimbolikus és instrumentális funkciót. A tárggyal kapcsolatos szimbolikus képzettársításokon alapuló hozzáállás szimbolikus funkciókat szolgál, míg a tárgy vagy téma belső attribútumaival kapcsolatos hozzáállás az instrumentális funkciókban manifesztálódik. Aczél példájával élve egy adott óramárkával kapcsolatos szimbolikus viszonyulásaink lehetnek az olyan morális asszociált tartalmak, mint a márkanév elismertsége, megkülönböztetett stílusa, míg hozzáállásunk instrumentális funkciói vonatkozhatnak a termék szerkezeti kidolgozottságára, energiatakarékos müködésére.

Az attitüd, vagy hozzáállás átalakulásának Aczél négy dimenzióját különíti el: az észlelés, érzelmi viszonyulás, a vélemény és végül a cselekvés megváltozása, amely tényezők véleménye szerint összevethetők a klasszikus retorika szövegrészeivel, nevezetesen a 
bevezetéssel, elbeszéléssel, kitéréssel, bizonyítással, cáfolással és végezetül a befejezéssel (Aczél [2005] pp. 398-402.).

- Az észlelés megváltozása

Az észlelés megváltoztatásának retorikai alapegysége a bevezetés és az azt követő elbeszélés, amelyek a szerénység eszközével, a jóindulat elnyerésével, valamint kérdések és válaszok segítségével keltik fel a közönség figyelmét, bemutatva az ügy szereplöit, körülményeit, ezzel irányítva a hallgatóság percepcióit és valóságképét.

- Az affiliáció megváltozása

Az érzelmi viszonyulás megváltoztatására a kitérés szövegrészében nyílik lehetőség a szónok számára, ez ugyanis egy olyan - látszólag a szöveghez nem, vagy csak minimálisan kapcsolódó - elem, amely saját történetet, anekdotát mesél el, növelve ezzel az elbeszélés hitelességét, személyességét és a tapasztalati alapokon nyugvó induktív érvelés erősségét.

- A vélemény megváltozása

A bizonyitás és cáfolás szövegrész bizonyítás eleme racionalizáció útján, logikai érvelés segítségével képes a vélemény megváltoztatására, legfőbb eszköze pedig a már említett enthüméma. A cáfolás szövegrész pedig az enthüméma egy sajátos típusát, a retorikai kérdést alkalmazza, amely azáltal fogadtat el kijelentéseket vagy felszólításokat, hogy választalan kérdéseket tesz fel, így esetében valójában egy kérdő mondat köntösébe bújtatott állításról, kinyilatkoztatásról beszélhetünk.

- A cselekvés megváltozása

Az észlelések, érzelmek és vélemények befolyásolása után nem marad más hátra, mint a közönség cselekvésre buzdítása. A cselekvések megváltoztatására a befejezés retorikai szövegrész tesz kísérletet, amely a tartalom rögzítésének és az ismétlés logikai szerkezetének segítségével törekszik a hallgatóságot új attitüdökkel útjára bocsátani (Aczél [2005] pp. 398-402.). 


\subsubsection{Az önkéntes cselekvés elmélete}

A második elmélet, az önkéntes cselekvés elmélete, nem közvetlenül a meggyőzésre, hanem az önkéntes cselekvést befolyásoló tényezőkre irányul. E tényezők vizsgálata fontos szempontokkal szolgálhat a meggyőző szándék érvényesítéséhez. A megközelítés fókuszában a megokolt cselekvés és a tervezett viselkedés kiváltásának befolyásoló faktorai állnak, amely alapján egy személy viselkedését egyfelől a hozzáállás (hogyan viszonyul egy bizonyos cselekvéshez) másfelől a szubjektív norma determinálja, amelyet egy számára releváns személy vagy csoport vélekedése határoz meg (hogy szerintük helyes-e az adott cselekvés).

\subsubsection{A meggyőzés elmélete}

A harmadik jelentős elmélet középpondjában maga a meggyőzés áll. A legnépszerübb elmélet a szakirodalomban Petty és Cacioppo „kettős folyamat” modellje, amely a meggyőzés két útját választja el egymástól. Az úgynevezett fơút (lásd még: centrális vagy szisztematikus út) egy adott személy figyelmes és gondos megfontolásai alapján történő döntéshozatalt feltételez, amelynek során a befogadó megalapozott információk és érvek/ellenérvek felsorakoztatásának segítségével tájékozódik, majd hozza meg döntését. A másik, úgynevezett mellékút (lásd még: perifériális vagy heurisztikus út) egyszerü tényezők hatására valósul meg - mint pl.: a kommunikátor vonzósága, vagy a tény, hogy a minket körülvevő személyek egyetértenek-e egy adott üzenettel - amelyek az információ megbízhatóságának és relevanciájának szükségszerü ellenőrzése nélkül indukálnak hatást (Petty - Cacioppo [1986] p. 3.). De mitől is függ az, hogy a meggyőzésnek melyik útján járunk? Amikor a meggyőzés főútját választjuk, a befogadó tüzetes vizsgálatnak veti alá kijelentésünket, ilyenkor sem a puha érvek, sem pedig a forrás minősége nem lesz meghatározó. Amikor azonban a mellékúton haladunk, a befogadónak nincsen ideje, motivációja vagy eszköze átgondolni az üzenetet, így perdöntő lehet egy nagytekintélyü forrás megjelölése is (Pratkanis - Aronson) [1992] p. 34.). A szerzőpár különböző kísérletek alapján úgy találta, hogy a meggyőzés első, főutas típusát rendszerint akkor alkalmazza a befogadó, ha személyes érintettsége, felelössége van az adott tárggyal kapcsolatban. A mindennapi élet tapasztalatai alapján azonban azt látjuk, hogy sok esetben hajlamosak vagyunk a kisebb energia befektetést igénylő perifériális utat választani közhelyszerü úgynevezett ökölszabályokra, heurisztikákra támaszkodva. Síklaki szerint a leggyakrabban használt heurisztikák többek között 
az „ami drága az jó is”, „a szakértő mindig jobban tudja”, esetleg „a társas forgatókönyv” heurisztikája, amely a társas helyzetek rutineljárásaira utal (Síklaki [1994] pp. 44-48.).

A meggyőzés bármelyik útját választjuk is, az alábbi hét kognitív eljárásmódot érdemes figyelembe vennünk a társadalmi befolyásolás és meggyözés tükrében:

- Először is a kontrasztot, amely arra a sorrendre vonatkozik, amelyben a meggyőző üzenetek prezentálásra kerülnek. Ha például egy drága terméket kívánunk eladni, célszerü egy még annál is drágábbat bemutatni a vásárlónak elsőként, így összehasonlítva, a másodjára kínált termék ára többé nem tünik irreálisnak.

- Az úgynevezett reciprocitás, azaz kölcsönösség elve a következő, amely arra utal, hogy a feladó azáltal kívánja meggyőzni a befogadót, hogy az érvelés megkezdése előtt lekenyerezi őt valamilyen módon.

- A konzisztencia technikája arra utal, hogy a befogadóval olyan előfeltevéseket fogadtatunk el, amelyek a későbbiekben azt a konklúziót támasztják alá, amelyet el szeretnénk vele ismertetni.

- A társas bizonyitás elve arra mutat rá, hogy más emberek véleménye befolyással lehet egy adott állítás elfogadására, esetleg javasolt cselekvések végrehajtására.

- Cialdini szerint a beszélő iránti szimpátia ugyanúgy hatással lehet az üzenetek befogadására. Magától értetődő módon minél szimpatikusabb a szónok, annál könnyedébben fogadjuk el állításait.

- Az autoritás elve a szaktekintély vagy annak elfogadott személy meggyőzőerejére utal.

- Végezetül a hiány vagy hiányérzet technikája kerül bemutatásra, amely arra apellál, hogy ha a befogadó által keresett terméket hiánycikknek állítjuk be, amelyért nagy verseny van, jóval nagyobb vásárlási hajlandóságot tudunk kiváltani a befogadóból (Walton [2007] pp. 24-25.). 


\subsubsection{A kritikai retorika megközelítése: a dramatizálás}

A kritikai retorika Kenneth Burke munkásságán alapszik, aki a nyelvészet, pszichológia, a szociológia és az ideológiakritika diszciplínából merítve különböztette meg ezt az irányzatot. A Burke elméleti keretében kialakult gyakorlatnak nyolc alapelvét különíthetjük el:

- A kritikai megközelítés gyakorlat, nem módszer.

- A létező, vagy lehetséges társadalmi viszonyokat maga a közlés alakítja.

- A retorika középpontjában nem a tudás (episztemé), hanem a vélemény (doxa) áll.

- Véleményorientáltságának köszönhetően a retorika legfőbb célja valami létezésének észleléséből fakadó interpretáció, jelenlévővé tétel.

- A közlést létrehozó, célközpontú és jelenlévő erők nem vezethetők vissza oksági kapcsolatok állításaira.

- A ki nem mondott, hiányzó állításoknak éppen olyan valóságalakító hatása van, mint az explicit kijelentéseknek.

- A többértelmü interpretációnak kiemelkedő szerepe van az állítások viszonylagos, lehetséges természetének megértésében.

- Amennyiben a retorikai tetteket performanciának (előadásnak) tekintjük, úgy az azokat kísérő elemzéseket is szükségszerüen előadásként kell értelmeznünk (Aczél [2005] p. 405.).

Jellemző vonulata e megközelítésnek a dramatizált valóság, a dramatizáló beszéd, amely létre hozta a kritikai gyakorlat új, azonosuláson alapuló meggyőzési szemléletét. A Burke-féle definíciót alapul véve úgy tekinthetünk a meggyőzésre, mint a kommunikátor arra irányuló igyekezetére, hogy a valóságról alkotott véleményét mint igazságot fogadtassa el közönségével (Burke [1962] p. 79.). A meggyőzés folyamatának elemzéséhez a dramatizálás öt szabályát alkalmazhatjuk, felhívva a kritikus elemző figyelmét a színjáték öt legfontosabb elemére: a cselekvésre, cselekvőre, helyszínre, előadásmódra, illetve a célra, amely fogalmakat Burke a válasz, alany, helyzet, inger és célpont terminusokkal látja el. A retorikus üzenet dramatizált felépítése az ügy szerkezetét is leírja: mi történt, hol, ki tette, hogyan és miért. Aczél azonban úgy véli, hogy a meggyőző folyamat Burke-féle elmélete nem ennyire pragmatikus, mivel cselekményét a büntudat és megváltás váltakozásának metaforája adja (Aczél [2005] p. 406.). 
Végezetül szükségesnek tartom az egymáshoz közelálló, mégis sokban különböző meggyőzés és manipuláció fogalmának elkülönítését. Nagyon fontos eltérés, hogy a meggyőzés esetében mind a meggyőző, mind pedig a meggyőzendő fél tudatában van a meggyőzés szándékának és folyamatának, így a befolyásolt saját döntése alapján képes változtatni magatartásán. Ez alapján a meggyőzést Síklaki úgy definiálja, mint a másik fél vagy felek viselkedésének szimbolikus interakció útján történő megváltoztatása. Ez természetesen meglehetősen körülményes folyamat, hiszen azt sugalmazza, hogy a meggyőzendő fél addigi hiedelmei, attitüdjei vagy cselekedetei hibásak voltak (Síklaki [1994] pp. 6-7.). A manipuláció esetében ezzel szemben a beszélő szándéka mindig rejtett. A Saussure és Schulz által idézett Rigotti szerint a manipuláció sikere abban rejlik, ha a manipulált fél nincsen tudatában a manipulációs stratégia folyamatainak. E rejtett szándék szükségessége más kapcsolódó jellemzőket is eszünkbe juttathat, pl.: azt, hogy a manipulációs eljárás valamilyen módon a

befogadó átverésére irányul. Éppen ezért számos kutató, talán kissé elhamarkodottan arra a konklúzióra jutott, hogy a manipulátor mindig szükségszerüen őszintétlen (Saussure - Schulz [2005] p. xi.). A szakirodalom szerint azonban a manipuláció nem minden esetben jelenti az ördög mesterkedését, alkalmanként pozitív, esetleg nevelő szándékkal élünk ezzel az eljárással, mivel a befogadó (még vagy már) nem képes a meggyőzés érveinek értelmezésére, elfogadására. A meggyőzés és manipuláció fogalmi definíciói után felmerülhet a kényszerítés koncepciója, amely abban áll, hogy a befogadó tudatában van a kibocsátó kényszerítő szándékának, mégis bizonyos javak elnyerése vagy büntetés elkerülése érdekében - a szerint cselekszik. Faden és Beauchamp úgy fogalmaz, hogy a kényszerítés eredményeképpen valaki nem tehet meg valamit, amit szeretne, vagy olyasvalamit tesz, amit nem szeretne (Faden - Beauchamp [1986] p. 339.).

\subsubsection{Az új retorika}

Az érvelés kulcsfontosságú eleme az „elmék találkozása” (meeting of minds), a rétor ugyanis nem kényszeríteni, vagy parancsolni akar, hanem meggyőzni, a közönség pedig azt értékelni, feldolgozni, esetlegesen elfogadni. E megközelítés hangsúlyozására jött létre a modern retorikaelmélet egyik legjelentősebb szemléleti irányvonala, az új retorika, amelynek elméletét Chaïm Perelman és Lucie Olbrechts-Tyteca dolgozta ki. Az új retorika olyan modell, amely megdönti Arisztotelész retorika és dialektika közötti éles elválasztásának elméletét, és előtérbe helyezi a logika folyamatait. Létrejöttét a retorikával kapcsolatos egyértelmüség hiánya 
motiválta, a korábbi megközelítésekben ugyanis - ahogyan azt a fentiekben részletezem müvészi nyelvhasználatként, az ékesszólás artisztikájaként vagy a nyilvános beszéd alapjaként említették. Majd, a 18-19. században, Dumarsais és Fontanier, két nagyhatású francia író munkái alapján létrejött a retorika stilisztikai megközelítése, amely gyakorlatilag szakít az Arisztotelész, Ciceró, Quintilianus és St. Augustine nevéhez köthető retorika húsz évszázadon át fejlődő ősi hagyományaival (Perelman [1979] p. 1.).

Ilyen előzményekkel jött létre Perelman a The New Rhetoric and The Humanities címü munkája, amely szerint az érvelő (aki egyszerre aktor és reaktor) beszédében értékeket állít a középpontba, melyek kapcsán konszenzust alakít ki közönségével, ezáltal a retorikai értékközösítést mint argumentatív eszközt értelmezi (Perelman [1979] p. 1.). Az új retorika megközelítésének alapkoncepciói a közönség, a kontextus, az érv és a „találkozás” (adherence); olyan koncepciók, amelyeket az érvelő közösség gyakorlatai és igényei folyamatosan formálnak, alakítanak. Az érveknek most már nem pusztán a konklúziók levezetése a célja, hanem, hogy megszüntesse vagy megerősítse a közönség tagjainak a tárgyhoz való viszonyulását, amely csakis a beszélő és hallgatósága közt kialakuló erős kapcsolat létrejöttével lehetséges (Perelman [1982] p. 9.). Az érvelésnek tehát nem pusztán az intellektuális kapcsolatteremtés a célja. Magában foglalja a cselekvésre való buzdítást, amely nem csak a hallgató intellektusára, érzelmeire és akaratára van hatással, hanem magára az emberre is. A különböző hatások elérése érdekében az érvelők olyan módszereket alkalmaznak, amelyek megfelelnek az adott szituációnak, a diskurzus céljának és a meggyőzendő közönségnek is (Tindale [1999] p. 70.). Ebből is látszik, hogy az új retorika megközelítésében a retorika a logika észszerüségével (rational) szemben inkább az elfogadhatóságra (reasonable) épít, ezért következtetése sem lehet abszolút, csak valószínü.

\subsubsection{Az érzelmek és az érvelés}

A retorikai érvelést motiváló humán gyakorlatok és az emberre mint értelmes, érzelmes, akarattal rendelkező lényre ható érvelés felvetik a filozófiai hagyomány értelmet és érzelmet elválasztó problematikáját. A domináns racionális nézőpont szerint ugyanis az érzelmi megfontolások irracionális és szubjektív mivoltuk miatt - gyanúsak, hacsaknem egyenesen hibásak és kizárandóak. Arisztotelészhez visszanyúlva azonban azt láthatjuk, hogy, miután Rétorika címü 
müvében óva inti olvasóját az érzelmekre való apellálástól (Tindale [1999] p. 72.), annak egy későbbi fejezetében a pathoszt ugyanolyan fontosságúnak titulálja, mint a logoszt és az éthoszt, azt állítva, hogy „az érzelmek azok a tényezők, amelyek megváltoztatják az emberek ítéleteit” (Arisztotelész [1378a]). Walton hasonlóképpen az érvelés érzelmi aspektusának számos legitim kontextusát sorolja fel, az érvényes érvek deduktív paradigmájának bemutatása után. Az utóbbi időben tehát nagy hangsúlyt kapott az értelem és az érzések viszonya, vitatva azt az elképzelést, hogy az értelem igazsághoz való kapcsolata a pártatlanságon és objektivitáson alapszik (Tindale [1999] p. 72.). Alan Brinton Appeal to the Angry Emotions címü munkájában azonban felhívja figyelmünket arra, hogy az érzelmek érvelésben betöltött szerepének strukturáltnak és önkényességektől mentesnek kell mennie. Ennek érdekében az érveknek tekinthető érzelmeket a pathetic argument elnevezésű keretben értelmezi, és azt állítja, hogy bizonyos érzelmi érvek igenis logikailag elfogadható argumentumoknak minősülnek (Brinton [1988a] p. 77.). Ha tehát tudjuk, mi számít észszerü érzelmi alapnak, akkor tudunk azoknak az érvtípusoknak a terminusaiban is gondolkodni, amelyek konklúziói érzelmeken alapulnak.

\subsubsection{Az érvek kontextusa}

A Perelman-féle új retorikai perspektíva szívében egyértelmüen a közönség áll, amely nem csak a modell fő érdeme, hanem annak legnagyobb kritikája is. Mielőtt azonban megvizsgálnánk a közönség centralitásának fontosságát, az érvek kontextusának bemutatása következik. A retorikai érvelés első jelentős modellje Arisztotelésztől származik, aki az érvek kontextusát a logosz, éthosz és pathosz közötti kapcsolatokban kereste (Tindale [1999] p. 75.). Azóta azonban más aspektusok is felmerültek, például az üzenet, a közös kód, vagy a társadalmi kontextus problematikája. Ezek alapján Tindale az érvek négyféle kontextusát különíti el: a lokalitás, a háttér, az érvelő és a kifejezés összefüggéseit.

1. A lokalitás: fogalma arra az időre és térre utal, amelyben az érv elhelyezkedik. A témától függően e megfontolások lehetnek periferikusak, de játszhatnak centrális szerepet is az érvek felismerésében és értékelésében. Az, hogy az emberek hol és milyen korban élnek meghatározza gondolkodásuk, és ezáltal érvelésük természetét. Az érvelés mindig olyan miliőben manifesztálódik, amely az érvelő számára ismerős. A kihívás pedig az, hogy az esetleges helyi vagy időbeli különbségek ellenére - a rétor szemszögéből lássuk a 
problémát. Elképzelni, hogy milyen volt a világ Platón korában, és azon értelmezések és hagyományok kereteiben gondolkodni, amelyek bizonyos szinten korlátozták gondolkodását. Az interkulturális érvelés szintén elvárásokat támaszt értelmezési készségeinkkel szemben. Itt azonban legalább ugyanabban az időn és világon osztozunk, csak abban nincsen egyetértés, hogy hogyan tesszük mindezt.

2. A háttér: Az előzőkhöz kapcsolódva a következő kontextus a háttér, amelyet számos kutató magával a kontextussal tesz egyenértékủvé. Háttér alatt az olyan eseményeket értjük, amelyek meghatározzák a szóban forgó érvelést és annak értelmezését, pl.: az esemény, amelyen a diskurzus megvalósul, az érvelő és közönsége között megfogalmazott előzetes érvek a témában, aktuális társadalmi/politikai kérdések, amelyek hatással lehetnek az érvre, a felsorakoztatott érvekkel kapcsolatos irónia, vagy az érvek hatására létrejövő következmények az érvelőre és közönségére.

3. Az érvelö: Az érvelés nélkülözhetetlen komponense annak forrása: a jelentés intelligens kezdeményezője. Míg a lokalitás és háttér a forráshoz járul hozzá, az érvelő annak fő alkotóeleme. Az érvelö lehet egyetlen individuum, de lehet csoport is, mint a reklámok, érdekképviseleti nyilatkozatok vagy politikai beszédek forrása esetében. Ugyan az érvelés legföbb komponense maga az érvelö, akárcsak a közönségről, a rétorról is gyakran megfeledkezünk, cselekedeteit pedig magára a produktumra vetítjük ki és hajlamosak vagyunk úgy fogalmazni, hogy „,ahogyan az érvek is mutatják”, vagy „,ahogy a konklúzió is alátámasztja”, esetleg „ahogyan a bizonyítékok is igazolják” stb. Ezekben az esetekben a kontextus helyreállítása megköveteli, hogy alaposan megnézzük az érvelés valós ágenseit.

4. A kifejezés: Az érvek felépítése, identifikálása, rekonstruálása és értelmezése szempontjából elengedhetetlenül fontos azok kifejezésének vizsgálata: az érvek kiejtése és kifejező módjuk erőssége, hogy mit mondanak, és mit nem mondanak ki, az érvelő modorossága és a médium, amin keresztül az érvelés megvalósul (Tindale [1999] pp. 7580.).

Tátrai Szilárd felfogásában a kontextus nem eleve adott realitás, hanem olyan dinamikus viszonyrendszer, amely a kommunikáció résztvevőit és az ő ismereteiket foglalja magába (Tátrai [2004] p. 479). Véleménye szerint a résztvevők nem belépnek egy már eleve létező kontextusba, hanem maguk konstruálják azt. A megnyilatkozás értelmezésekor azon tudásainkat mozgósítjuk, 
amelyhez a hasonló megnyilatkozások értelmezésével jutottunk, ezt pedig az analógiás értelmezés alapelvének nevezi. Tátrai meghatározása szerint tehát a kontextus a megnyilatkozás kommunikációs környezetére vonatkozó tudás, illetve annak alkalmazása. E felfogás alapján háromféle kontextusról beszélhetünk:

1. Szituációs kontextus, vagy beszédhelyzet: amelynek fókuszában egyfelől személyközi, másfelől tér- és időbeli viszonyok állnak (ki, kinek, mikor és hol nyilatkozik meg);

2. A cselekvés kontextusa: amely a megnyilatkozó szándékára vonatkozik (arra, hogy milyen cselekvést kíván a megnyilatkozással végrehajtani);

3. Tematikus kontextus: azokra a háttérismeretekre koncentrál, amelyek szükségesek annak a megértéséhez, hogy a megnyilatkozás miről szól, mire vonatkozik (Tátrai [2004] pp. 479-481.).

\subsubsection{A retorikai szituáció}

Az érvek kapcsán felmerülö kontextus mellett a retorikai szituáció kifejtése is üdvözlendő. Retorikai szituációnak általában személyek, események, viszonyok és dolgok természetes kontextusát tekintjük, valamint azt a szükségletet, amely határozottan megnyilatkozásra szólít fel. Ez az igényelt megnyilatkozás része a szituációnak, sőt, nélkülözhetetlen a szituációs tevékenység létrejöttéhez, és a szituációban való részvétele által nyeri el jelentését és retorikai jellegét (Adamik [2010] p. 1031.). Bitzer felfogásában a retorikai szituáció „személyek, események, tárgyak és viszonyok együttese, amelyben egy tényleges vagy lehetséges szükséglet merül fel, s ezt a szükségletet akkor lehet részben vagy egészben kielégíteni, ha a szöveg, beszéd, amely a szituációban létrejön, az emberi döntést és tevékenységet úgy tudja korlátozni és kényszeríteni, hogy az a szükséglet lényegi módosításához vezessen” (Bitzer [1968] p. 6.). Ez alapján a retorikai szituáció a következő állításokkal írható le:

1. A retorikai beszéd egy szituációra adott válaszként jön létre.

2. A beszéd a szituációtól nyeri retorikai jellegét: mint válasz egy kérdésre, vagy mint megoldás egy problémára.

3. A retorikai szituáció a retorikai beszéd szükségszerü feltételeként létezik. 
4. Ahogyan sok kérdés és probléma megválaszolatlan marad, úgy a retorikai szituációk egy része is anélkül keletkezik és múlik el, hogy megnyilatkozásra késztetne.

5. Egy szituáció akkor retorikai, ha beszédre invitál, amely képes részt venni a szituációban, megváltoztatva annak jellegét.

6. A beszéd akkor retorikai, ha illő válaszként funkcionál arra a szituációra, amelyben létre jön.

7. A szituáció oly módon kontrollálja a retorikai választ, ahogyan a kérdés kontrollálja a választ.

Bitzer ezután a retorikai szituáció három alkotóelemét mutatja be, amely a beszéd elkészítése előtt realizálódik:

1. Szükséglet (exigence): a szükséglet valamilyen tökéletlenség, amely azonnali megoldást igényel. A retorikai szituáció szervező elve és egyben az egyén igénye, hogy valamilyen problémát a beszéd segítségével oldjon meg. A szükséglet retorikai, ha képes megváltozni, ehhez a változáshoz pedig diszkurzív tevékenység szükségeltetik. A szükségletnek vannak tényszerü, valóságos és érdek-függő összetevői.

2. Hallgatóság (audience): a hallgatóság szerves része a retorikai szituációnak, hiszen a retorikai megnyilatkozás úgy idézi elő a változást, hogy befolyásolja olyan személyek döntését, akik befolyásolhatók a beszéddel, képesek döntést hozni az ügyben, vagy közvetíteni az üzenetet a döntéshozóknak.

3. Kényszerek (constraint): minden retorikai helyzet tartalmaz bizonyos korlátokat, amelyek eseményekből, személyekből, tárgyakból és olyan viszonyokból állnak, amelyek részei a szituációnak, mivel hatalmukban áll döntést vagy cselekvést kikényszeríteni a szükséglet pozitív megváltoztatása érdekében. A kényszer általános forrásai közé a hiedelmek, az attitüdök, a dokumentumok, a tények, a hagyományok, a képek, az érdekek, a motívumok és egyéb hasonló jelenségek tartoznak. Amikor a szónok belép egy retorikai szituációba, megnyilatkozása során nem csak felhasználja a helyzet által adott korlátokat, hanem maga is további fontos korlátokat ad hozzá a szituációhoz (a jellemét, a logikáját, a stílusát). A korlátokat Bitzer két csoportra osztja, amelyek megegyeznek a 
bizonyítékok két fö típusával: az első csoportba azok tartoznak, amelyek a megnyilatkozótól, illetve az ö módszereitöl függnek (ezek az Arisztotelész által művészeten belülinek hívott bizonyítékok), a második csoportot pedig azok alkotják, amelyeket a szónok csak felhasználhat (ezek a müvészeten kívüli bizonyítékok) (Bitzer [1968] pp. 6-8.).

Bitzer elmélete jelentős hozzájárulás a retorika elmélethez, annak ellenére, hogy megjelenése óta többen is kritizálták. Alan Brinton ([1981] pp. 234-247.) például megkérőjelezi Bitzer azon állítását, hogy korábban nem foglalkoztak a retorikai szituációval. Az ókorban valóban nem így nevezték (és nem is definiálták ilyen precizitással), de az illőség és tárgyszerüség elve (gör. kairosz és preopon, ill. lat. aptum és decorum) arra utal, hogy a szituáció szabta meg a beszéd tárgyát és stílusát. Brinton a kényszer esetében inkább az „érdek” kifejezést javasolja.

\subsubsection{A közönség}

A retorikai perspektíva középpontjában a közönség áll, amely Fisher szerint Perelman új retorikai megközelítésének legfontosabb, döntő koncepciója (Fisher [1986] p. 86.). A szónok közönségről általánosan elmondható, hogy mindig egy bizonyos módon rendszerezett konstrukciónak tekinthetö, amely vizsgálatának pszichológiai és szociológiai hagyományai is vannak. Pszichológiai, hiszen, ahogyan arra Cicero is felhívja figyelmünket, máshogyan kell érvelni női és férfi közönségnek, vagy éppen szociológiai, mivel - utalva az érvek kontextusának lokalitására - egy ember véleménye nem annyira függ saját személyiségétől, mint társadalmi környezetétől és az emberektől, akikkel együtt él és azonosulni tud (Perelman - Tyteca [1971] p. 20.).

A közönség fogalmának azonban már Arisztotelész is rendkívüli figyelmet szentelt: mivel a hallgatóság jellege alapján lehet vizsgálni a szónok beszéde által felszított szenvedélyeket és érzelmeket, Rétorikáját is a hallgatóság fogalma köré szervezi. „A hallgató szükségszerủen közönség vagy ítélő, mégpedig vagy az elmúlt események megítélöje, vagy az eljövendőké. Az eljövendő események megítélöje például a népgyülés tagja, az elmúltaké például a bíró, a szónoki képességé az egyszerü közönség” (Arisztotelész [1982] 1358b. p. 38.). 
Annak a szónoknak, aki arra vállalkozik, hogy konkrét individuumokat győzzön meg igazáról különböző alapvető tényezőkre kell ügyelnie. Ezek közül mutatom be a leglényegesebbeket az alábbiakban, Perelman meghatározása alapján:

1. A meggyőzendő közönség rendszerezett konstrukciónak tekinthetö. Éppen ezért, annak a szónoknak, aki konkrét egyének meggyőzésére vállalkozik elsődleges feladata, hogy beszéde alkalomhoz illö legyen, ehhez pedig szükséges, hogy olyan koncepciói legyenek közönségéről, amelyek a lehető legközelebb állnak a valósághoz. Az akadémiai gyakorlattá váló retorika a hagyományos közönségnek szól, az ilyen retorika pedig megengedheti magának, hogy sztereotípiás elképzelésekkel rendelkezzen. Azonban, a közönség e korlátolt vizsgálata Perelman szerint a retorika degenerációjához vezetett. Éppen ezért, egy valós érvelési szituációban gondoskodni kell potenciális közönségünk ismeretéről, hiszen, ha inadekvát képet alkotunk hallgatóságunkról - lustaságból, tudatlanságból vagy előre nem meghatározható okokból - gyakran sajnálatos következményekhez vezethet (Perelman - Tyteca [1971] p. 20.).

2. Másrészt, minden közönség komplex természetü, a jó szónok ismérve pedig, hogy a komplexitásnak megfelelően érvek sokaságával készül, a különbözö tagok meggyőzésére. A közönség komplexitása annak felépítésében rejlik. Perelman számára a közönség a beszélő személyes reflexióitól a kompetens és racionális emberekből álló úgynevezett „univerzális közönségig” tart. Ez a kompetencia pedig utalhat a teljesen átlagos természetü felvetések ismeretétől (amelyet Perelman loci-nak nevez) egészen a szaktudásokig. A hallgatóság azon tagjai a leginkább zavarbaejtőek, akikről elözetesen tudjuk, hogy nem értenek velünk egyet. A közönség vélekedésének előzetes ismerete tehát olyan kondíció, amely szorgalmazza a hatásos érvelés létrejöttét. Számításba kell venni, hogy bizonyos érvelések, amelyeket a szónok meggyőzőnek gondol, lehetséges, hogy éppen ellenkező hatást váltanak ki a közönségböl és, a beszélő akarata ellenére, nem saját igaza mellett, hanem éppen az ellen fog érvelni. Ezekben az esetekben az univerzális közönség modellje különösen hasznos (Tindale [1999] p. 85.).

3. Egy Arisztotelésztöl származó fogalommal, a közönség változékony természetének bemutatásával folytatódik a jelen felsorolás. A retorikai közönség 
nem érvek passzív befogadója, mint ahogyan azt néhány logikus gondolja. Az érvelésben aktív szerepet játszó közönség minden esetben meghatározza azon feltevések feltételeit, amelyeket a beszélő a közönség tudásainak, elköteleződéseinek ismeretében bevezethet. A hallgatóság saját feltételezéseivel is hozzájárul az érveléshez, gondoljunk csak az enthüméma alakzatára, amelynek hiányzó elemét a közönség adja meg.

4. A közönség fent említett három aspektusa elvezet bennünket negyedik, leginkább meghatározó pontunkhoz, amely kimondja, hogy az érveket nem belső logikai szerkezetük révén értékeljük sikeresnek vagy sikertelennek, hanem közönségre gyakorolt hatásuk tükrében. Az érvelő legfontosabb célja tehát állításának és közönségének összeegyeztetése, és ennek mértéke befolyásolja majd, hogy az érvelést erősnek vagy gyengének értékeljük. Ez azonban két kritikát is felvet: egyfelől, ha az érvelés sikeressége pusztán azon múlik, hogy a közönség elfogadja-e azt, úgy tủnhet, hogy az új retorika modelljében minden elfogadható vagy angol kifejezéssel élve ,, anything goes”, másrészt pedig, ehhez kapcsolódva, minden relativisztikus (Tindale [1999] p. 86.).

\subsubsection{A partikuláris és univerzális közönség}

E két kritikára Perelman a partikuláris és univerzális közönség elválasztásával reagált, ahogyan arra a közönség komplex természetének kifejtésekor már utaltam. A Perelman által javasolt distinkció ugyan nem olyan éles, mint amennyire szeretnénk, a definíciós kísérletek pedig paradox módon - még inkább elhomályosítják azt. Partikuláris típusú közönséget emberek bármilyen összetételủ csoportja alkothat, függetlenül attól, hogy kompetensek-e az adott témában. Gyakran „szituációs” közönségként is említik, amelynek tagjai a beszéd pillanatában közönségként értelmezhetők. Lényeges továbbá, hogy a partikuláris vagy egyedi típusú közönség olyan befogadók csoportja, akik osztoznak bizonyos közös jellemzőkön: egy „,szegmens”, egy szakértői fórum, egy politikai párt, fiatalok egy csoportja, vagy nők gyülekezete stb. (Jørgensen [2007] p. 80.). Az univerzális közönség ezzel szemben a téma szempontjából kompetens, racionális hallgatókra utal. A filozófusok gyakran szólítják meg az univerzális hallgatóság tagjait, nem azért, mert minden ember hatékony hozzájárulására számítanak - Perelman szerint a filozófusok pontosan tudják, hogy csak egy szük réteg olvassa munkájukat -hanem azért, mert 
úgy vélik, hogy mindazok, akik megértik az általuk bemutatott érveket, el is fogják fogadni konklúzióikat. Ezáltal az univerzális közönség egyetértése nem tényszerü, hanem egyenesen törvényszerü (Perelman - Tyteca [1971] p. 31.). Az univerzális vagy egyetemes közönség tehát olyan érvelést feltételez, amely alkalmas minden racionális lény összekapcsolására. Perelman azon szemlélete, hogy az univerzális közönséget a beszélő elméje hozza létre, állandó vita tárgyát képezi. Le kell azonban szögeznünk, hogy az univerzális közönség nem szubjektív konstrukció, az interszubjektív racionalitás része, úgy, hogy fogalma alatt a szónok mentális képét értjük, egy elképzelt közönséget, amely a témában kompetens, racionális hallgatókból áll. Szerepe, hogy egyfajta belső normaként segítse a jó és a rossz érvek szétválasztását (Aczél [2009] pp. 58-63.).

\subsection{A retorikai megközelítés problémái}

Ahogyan az a fentiekből is látszik, a retorika fogalma meglehetősen komplex elméleti és gyakorlati tartalmakra utal. Összetettsége révén tekinthető az ékesszólás és a hatékony érvelés útján történő meggyőzés müvészeteként, az elhihető diskurzus feltételeinek, szabályainak és módszereinek tudományaként, valamint egy átfogó, az előző két megállapításra egyaránt vonatkozó elméleti reflexióként is (ez utóbbi a retorika és fillozófia, illetve a retorika és a paideia, azaz müveltség kölcsönviszonyára utal) (Tóth [2004/1] p. 13.). Aczél Petra a világ megragadásának három közlésmódját különíti el: a dialektikus, a narratív és a retorikus közlésmódot (Aczél [2012] p. 18.). Míg a dialektikus ellentétekben a gondolkodás elemző mintái jelennek meg, a narratív közlésmódban pedig a gondolkodás kultúrát megtartó ereje - egyúttal pedig mindkettőben van valami állandóságra és folytonosságra való irányulás - addig a retorikus közlésmód a változás mozgatórugójaként, a bizonytalanság előidézője és csökkentőjeként értelmezhető. A retorikus közlésmód a társas-emberi dimenzióra vonatkozik, amely egyszerre lehet erőssége és gyengéje e megközelítésnek. A retorikus szemlélet ellenzői szerint a retorika nem eléggé kritikus, szabályai relatívak, megfoghatatlanok. Valóban, a retorikai érvelés alapját a valószínűség adja, mértéke pedig az ember, ezáltal közössége nem az elvont igazság, hanem maga a társadalom. Szabályszerüségeinek és abszolút kritériumainak metszetében a közösség igazsága és bölcsessége helyezkedik el, létrehozva ezzel a bizonytalanság és folyamatos változás lehetőségét (Aczél [2012] p. 18.). Ezáltal a retorika a vélekedések és észlelések illően, helyes időben és mértékben történő közössé tételeként értelmezhető, amely nem univerzálisan, hanem 
szituációsan kötött. Így tehát szabályai helyzetről helyzetre váltakozhatnak, dialogikus, interaktív természetének köszönhetően (Aczél [2012] p. 18.). Számos kritikus univerzális természetében látja egy diszciplína gyökereit, így a retorika egyén- és közösségformáló hatásai és radikális alkalomhoz illősége problematikus a számukra.

\subsection{Miért a retorika a megfelelő keret?}

E fejezet rendszerezése alapján az érvelés diszciplináris megközelítése a logika, a dialektika, illetve a retorika irányából történhet. Az érvelést mint produktumot tekintő logikai perspektíva középpontjában a helyes gondolkodást tápláló logikai törvények állnak, tudományával pedig leginkább a matematika és a filozófia áll mély kölcsönhatásban. E szemlélet hiányossága, hogy az érvelés következtetéseinek érvényességét kontextusából kiragadva, egy mesterséges nyelv segítségével analizálja normatív előírások alapján, ezáltal rugalmassága és relevanciája megkérdőjelezhető.

Az érvelést procedúraként értelmező dialektikai megközelítés alapján az érvelés olyan dialóguson belül történő, szabályok által irányított eszmecserének tekinthető, amelynek célja az esetleges nézeteltérések feloldása. A tárgykörén belül tárgyalt pragma-dialektikai modell azonban több szempontból is problémás. A felek számára kihívást jelenthet a vita keretfeltételeinek meghatározása, illetve a kritikai diszkusszió eljárási szabályainak megtartása. Továbbá problémát jelenthet a bizonyítás terhének kiosztása, az előzetesen elfogadott kiinduló fogalmak megállapítása, illetve a vita kimeneteléről döntő észszerü kritikus elfogadása, ezért a jelen disszertáció ezt az álláspontot sem tekinti kiindulópontnak.

Végezetül a jelen disszertáció preferált nézőpontját, az érvelést folyamatként értelmező retorikai perspektívát mutattam be. Aczél Petra $A$ szó ereje címü írásában a retorikára mint nyelvről szóló nyelvre tekint, amely a szavakból szőtt, gondolkodásra indító szövegtudomány eszköztárát kínálja. Eszközei és eljárásai segítségével képes meggyőződéseket megváltoztatni,

benyomásokat létrehozni. Építőelemeinek, az érveknek létrehozásakor és a meggyőzést célzó szöveg létrehozásakor egyszerre támaszkodik a logika és a pragmatika folyamataira (L. Aczél [2002] p. 45.). A Perelman és Olbrechts-Tyteca nevéhez füződő új retorikai perspektíva középpontjában a beszéd értékeit befogadó és értékelő aktív közönség áll, ezáltal e szemlélet a retorikai értékközösítést mint argumentatív eszközt értelmezi. Ezen argumentációs megközelítés 
újszerüsége abban rejlik, hogy a) elválasztja a formális logikát a retorikustól, ezzel kivonva a beszéd meggyőző erejét a logika szigorú szabályai alól, b) a racionális helyébe az elfogadhatót, az érthető helyett az kommunikálhatót állítja, c) eltörli a stílus és az érvelés közötti éles határt és megszünteti azok különállását, d) létrehozza az univerzális közönség fogalmát, amely tulajdonképpen egy belső, mentális konstrukció dialógus-viszonyában jön létre, e) végezetül meghatározza a és az érveléshez kapcsolja a közös fókusz által való jelenlétét (Aczél [2009] pp. 63-64.). Az új retorikai megközelítés olyan értelemben modern, hogy feltárja a klasszikus retorika elfeledett, kommunikatív aspektusait, rávilágítva ezzel a logikánál tágasabb és alapjaiban szociálisabb jellemzőire, mégis klasszikus marad abban az értelemben, hogy az érvelést, mint rendszert mutatja be (Aczél [2009] pp. 63-64.). A valós és nem mesterséges nyelvi környezet, az érvelés érzelmi aspektusa, kontextusa, a közönség kulcsfontosságú szerepe, illetve a retorika szocializáló, aktualizáló, szimbolizáló, ritualizáló és dramatizáló természete miatt (Aczél [2012] p. 19.) a jelen disszertáció azt az álláspontot erősíti, hogy az érvelés retorikai megközelítése tekinthető annak leginkább megfelelő keretének.

\section{8. Összegzés}

Disszertációm jelen fejezetében először az érvelés konceptualizációjára vállalkoztam, bemutatva az érvelés különböző megközelítéseit, az azzal foglalkozó tudományok széles spektrumát, illetve makro- és mikroszintü vizsgálatait. Ezt követően kitértem az érvelés hármas megközelítésére: az eredmény, folyamat, eljárás triád értelmezésére, olyan megkerülhetetlen kutatókra hivatkozva,

mint Perelman, Walton, Toulmin, Eemeren és Grootendorst vagy Aczél. Disszertációm egyik hipotézise, hogy a vizuális retorika az érvelés mindhárom perspektíváját maradéktalanul kielégíti, erre azonban a vizualitás elemzésekor térek majd ki részletesen.

Dolgozatom következő alfejezetében az érvelés három diszciplináris megközelítésének elkülönítésére tettem kísérletet, az érvelés logikai, dialektikai és retorikai szemléletének részletezésén keresztül, kapcsolódva a korábban kifejtett produktum, procedúra és processzus hármasához. A logikai perspektíva bemutatásakor kitértem a formális logika deduktív és induktív érveléseinek különbségére, illetve annak hármas tagolású érvformájára, a szillogizmusra is, majd az informális logika lehetőségeit ismertettem. Ezt a dialektikai modell áttekintése követte, kitérve a pragma-dialektikai viszonyulás lényegi elemeire, hiányosságaira. Végezetuil a 
disszertációm szempontjából leginkább releváns retorika - mint a nyilvános meggyőzés eszköze - történeti és fogalmi elhelyezésére törekedtem, kiemelve azon tulajdonságait, amelyek alapján tekinthető többek között müvészetnek, mesterségnek, vagy éppen gondolkodásmódnak. A retorika más tudományágakhoz füződő kapcsolatának ismertetése után e tudományterületet mint gyakorlatot olyan koncepciók mentén tárgyaltam, mint a meggyőzés vagy az attitűdelmélet. A retorika meggyőzéses aspektusát tekintve Arisztotelész meggyőzéselméletének alapjait, a logosz, éthosz, pathosz hármasát hívtam segítségül, ezt követően pedig az attitüdváltozások dimenzióit Aczél alapján - a klasszikus retorika szövegrészeivel vetettem össze azt implikálva ezzel, hogy a retorika szükségszerüen valahol az érvelés és meggyőzés gyakorlatainak határmezsgyéjén fekszik, hiszen a meggyőzés szociálpszichológiai jelenségeit a klasszikus elméletek segítségével magyarázza. Végezetül a retorika új, perelmani modelljének szemléltetése következett, olyan alapfogalmakra koncentrálva, mint az érvelés érzelmi aspektusa, kontextusa és a beszéd értékeit befogadó és méltató aktív közönsége.

A különböző teóriák definiálása mellett fő célkitüzésem a retorika fogalmának részletes, több szempontú bevezetése volt, amely alapok lefektetésének segítségével a továbbiakban rátérhetek a vizuális retorika elméletének és gyakorlatának fejtegetésére, a képi érvelés mibenlétére, valamint az azt erősítő és támadó megközelítések bemutatására.

\section{A vizuális retorika}

A vizuális retorika azonosítása történetileg hagyományosan a nyelvhez kötődik, hiszen megalapozó elméletalkotói, Arisztotelésztől Perelmanig azt a nézetet támogatták, hogy a retorika a szavak, a beszéd és a szónoklat mestersége, amely a nyelvi kifejezésre, a stílusra és annak eszközeire vonatkozik (Aczél [2012] pp. 39-40.). Ugyan a retorika kezdetektől fogva a nyelv meggyőző erejének vizsgálatára összpontosít, észre kell vennünk, hogy a verbális kód exkluzivitása soha sem zárta ki a vizuális és verbális összekapcsolódásának, illetve magának a vizuálisnak lehetőségét sem. Médiaretorika címü munkájában Aczél úgy fogalmaz, hogy a szóképek értelmezése szükségszerüen a vizualitás bevonásával jár. Giambattista Vico is ezt az álláspontot erősíti: úgy véli, hogy a világ elgondolása nem az intellektusunk által, hanem az érzékeink és érzéseink segítségével valósul meg, azaz a világra adott válaszainkat imaginatív 
univerzálék adják. Ebből pedig az következik, hogy a világgal kapcsolatos tudásainkat élénk képzelettel, képekkel és közvetlen megismerés útján szerezzük meg, nem pedig racionális okok és következtetések által. E megismerés a metaforában, a metafora pedig a retorikában keresendő, értelmezendő (Vico [1982] pp. 159-267.). Vicohoz hasonlóan George Campbell szintén diskurzus alapú megközelítést javasol, amelyben a vizualitás is helyet kap. Definíciója szerint a retorika, vagy ékesszólás a kommunikáció minden tartalmát és formáját magában foglaló egyetemes müvészetnek tekinthető. Egy másik meghatározásában úgy ír a retorikáról, mint a kommunikáció legmagasabb fokú müvészetéröl, amely nem csak ötleteken, hanem érzelmeken, szenvedélyeken, diszpozíciókon és célokon alapszik (Campbell [1963] p. xix.). A fenti definíciók minden olyan esetet, amelynek célja, hogy tájékoztassa, meggyőzze, vagy gyönyörködtesse közönségét, és amely cselekvésre buzdít, érzelmeket kelt, és kommunikációs tartalmával szenvedélyt, ötleteket és célokat generál, retorikusnak tekintenek. Ebből pedig nyilvánvalóan az következik, hogy semmilyen emberi kommunikáció, semmilyen tartalom nem kizárható: legyen az nyilvános vagy magán, költői, tudományos, vallásos, filozofikus, történelmi vagy politikai, minden kommunikációs müfaj - így a vizualitás is - retorikusnak tekinthető (Campbell [1963] p. xix.). Hasonlóképpen Kenneth Burke sem köti a retorikát egyértelműen a nyelvhez, Rhetoric of Motives címü munkájában pl. a retorikát, mint humán szimbólumrendszert a költészet és a dráma irányából vizsgálja, kitérve a meggyőzés képi és képzeletbeli aspektusaira is (Burke [1969]).

A különböző diszciplináris perspektívákból közelítő retorikusok jelentős figyelmet kezdenek tehát fordítani a vizuális retorikában rejlő lehetőségekre. Az elméletalkotók fotográfiák, rajzok, grafikonok és táblázatok, valamint mozgóképek elemzése révén azoknak a módoknak a feltárására törekszenek, amelyek alkalmasak az emberek attitüdjeinek, véleményének és hitének befolyásolására. E törekvések elég nagy diverzitást mutatnak, amely sok szempontból izgalmas és inspiráló lehet, ugyanakkor nehézséget okozhat azoknak, akik próbálják feltárni a vizualitás szerepét a retorika elméletében és gyakorlatában. Néhányan pusztán a kvantitatív kapcsolatok kifejeződését bemutató ábrák és grafikonok tekintetében gondolnak a vizuális elemekre, míg más elméletalkotók egyedül az Interneten megjelenő vizuális egységekre fókuszálnak (Hill - Helmers [2008] p. 2.). A kulturálisan orientált munkák többsége a müvészettörténeten és múvészetelméleten alapszik, azt a benyomást keltve, hogy amikor a „vizuálisról” vagy a „képekről” beszélünk, kizárólagosan művészi artefaktumokat említünk. 
Ennek megfelelően Mitchell arra buzdítja a multidiszciplináris retorikusokat és a kulturális kritikusokat, hogy fejlesszenek ki egy „szisztematikus” módot a szavak és müvészetek közötti kapcsolat feltárására, amellyel elkerülhetővé válik a képek „impresszionista”, azaz hangulati hatású megbélyegzése. Ez a szisztematikus megközelítés pedig olyan stabil elméleti alapot követel meg, amely a vizuális retorika területét diszciplinárisan képes elkülöníteni más tudományágaktól (Hill - Helmers [2008] p. 2.). A jelen disszertáció pedig, a vizuális retorika mint önálló diszciplína alapjául a retorika produktum, processzus és procedúra hármasára épülő megközelítését javasolja.

\subsection{A vizuális retorika mint önálló diszciplína}

Miért tekinthető a vizuális retorika önálló tudományterületnek? Egyáltalán mitől válik valami diszciplínává? A széles körben elterjedt alapfogalmak esetében gyakorta előfordul, hogy történeti gyökerei a múlt homályába vesznek. Nincs ez másként a „diszciplína” kifejezéssel sem. A Webster's New World Dictionary a kifejezés alábbi jelentéseit különbözteti meg: 1. az önkontrollt és hatékonyságot javító tréning; 2. az engedelmességet kierőszakoló szigorú ellenőrzés; 3. Helyes viselkedés; 4. szabályrendszer például szerzetesrendben; 5. javító vagy büntető eljárás (Palló [2005/9] p. 20.). A fenti értelmezések egyáltalán nem utalnak tudományterületekre, vagy a természet egymástól elhatárolódó részeire, inkább egyfajta szigorúságra, fegyelmezésre vagy rendezettségre, amely természetesen a tudományágak esetében is szükségszerüek. Palló szerint a tudományterületként értelmezett diszciplínák magva az enciklopédikus gondolkodás ellentéteként határozható meg, hiszen az enciklopédizmus máig az univerzális és teljes tudás szimbóluma. A tradicionális, premodern enciklopédiák, (pl.: a Gregor Reisch Margarita Philosophicája a reneszánsz korból, vagy Johannes Alsted professzor 17. század eleji gigantikus enciklopédiája) a tudás teljességének megőrzése és demonstrálása érdekében tartalmait nem alfabetikus sorrendben, hanem egyfajta elvi alapú elrendezésben jelenítette meg, amelyet a tudás természetesnek vélt osztályai vagy csoportjai alkottak (Palló [2005/9] p. 21.). A különböző címszavakat oszlopokba rendezték, azok fölé pedig közös elnevezéseket írtak. Ilyenek voltak például az oktatott szabad müvészetek, a retorika és a logika, a természetfilozófia területei, az optika, vagy az elméleti és gyakorlati mechanika stb. Az ilyen alcsoportokat tartalmazó osztályok egyfelől rendkívül jól szemléltették a tudás komplex, egységes természetét, másfelől kiválóan elkülönítették a tudás összefüggő, de egymástól eltérő 
területeit (és az oktatás tárgyköreit is, hiszen az enciklopédiákat a tudás átadására is alkalmazták). Az enciklopédikus hagyomány tehát a tudás körkörös megközelítését javasolja, amelyben a körív egy-egy részét képező tárgykörök egymással összeérve, mégis külön egységet alkotva hozzák létre a tudás egészét (Palló [2005/9] p. 22.).

A fentiekből kiindulva a vizuális retorika elnevezés több szempontból is megtévesztő. Először is egyfajta szubdiszciplináris pozícióba kényszerül elnevezése által, amely alsóbbrendüségén kívül azt is sugallja, mintha létezne a retorikának nem vizuális típusa is, mintha a pusztán nyelvi kódra kiépített szabály- és értelmezőrendszer most a vizualitás segítségére sietne, annak nyelven keresztüli megértését segítve (Aczél [2012] p. 39.). Jelen tanulmány azonban azt az álláspontot támogatja, hogy a retorika nem pusztán nyelvi szimbólumok összessége, ennek megfelelően a retorikai folyamatok dimenziói nem csak a diskurzusokban lelhetők fel. Azok az emberi tapasztalatok, amelyek térben orientáltak, nemlineárisak, többdimenziósak és dinamikusak gyakran csak nem-diskurzív szimbólumokkal, vagyis a vizualitás segítségével értelmezhetők (Foss [2005] p. 141.). A vizuális retorika ezen tulajdonsága pedig jól elkülöníti azt verbális társától, önálló szabályrendszerrel és értelmezési dimenzióval rendelkező tudományterületté téve azt, mégis elválaszthatatlanul összekapcsolva e két tudományágat.

\subsection{A vizuális retorika története}

Once again a complexly related transformation is occurring in [the] disciplines of the human sciences and the sphere of public culture. I want to call this shift "the pictorial turn."4

Mitchell ([1994] p. 11)

Az előző fejezetek fejtegetéseit figyelembe véve elmondható, hogy a retorika olyan ősi diszciplína, amely több, mint 2000 éven át alapvető fontosságú volt a nyugati gondolkodás szempontjából. Ám e tudományterület hirtelen hervadásnak indult a tudományos forradalom 1718. századi bekövetkeztével, 1900-ra pedig szinte teljesen eltünt a kánonból (McQuarrie Philips [2008] p. 3.). Mára azonban - egyelőre kevésbé értett okok miatt - a retorika újra

\footnotetext{
${ }^{4}$ Ismét egy összetetten kapcsolódó változás zajlik a humán tudományok diszciplínái és a közkultúra szférája között. Ezt az átalakulást „képi fordulatnak” nevezem.
} 
virágzik, amely, a jelen tanulmány szerzője szerint nagyban köszönhető a vizualitás iránti egyre növekvő érdeklődésnek és a képi retorika térnyerésének. E paradigmaváltás kialakulása azonban nem volt könnyü folyamat, hiszen - utalva az előző fejezetekben felsorakoztatott retorikai definíciókra - a kutatók többsége pusztán a retorika verbális megközelítését fogadta el érvényes keretként. Néhány, eddig még nem említett kutató színtisztán nyelv-centrikus meghatározásából is ez az elköteleződés látszik:

Scott alapján a klasszikus görögökhöz visszanyúló tradicionális (beszédközpontú) megközelítés szerint a retorikát olyan értelmező elvnek tekinthetjük, amely a kibocsátó fél érdekei szerint keretezi az üzenetet, egy bizonyos közönség befolyásolása érdekében. A feladó szándékai verbális érvekben manifesztálódnak: a bizonyítékokban, az érvelés sorrendjében és a kivitelezés stílusában. Az érvelés formai elemeit a kibocsátó a közönség beszélővel és témával kapcsolatos potenciális elköteleződései szerint választja meg, ezért a közönség lehetséges válaszait figyelembe véve alkotja meg üzenetét, a különböző konvenciók és közös tapasztalatok kínálta megosztott tudásra apellálva (Scott [1994] pp. 252-253.). Rivkin és Ryan Literary Theory című művében úgy nevezi a retorikát, mint a nyelvi aktusok előállítását szolgáló eszköz (Rivkin - Ryan [2004] p. 127.) míg Patton a nyelv retorikai elméletben betöltött központi szerepét hangsúlyozza (Patton [1979] p. 143.).

$\mathrm{Az}$ úgynevezett ikonikus vagy képi fordulat beköszöntével azonban a retorika veszélytelen, történeti megalapozottságú verbális kötődése rövidesen felülvizsgálatra került (Aczél [2012] p. 39.). De mit is jelent a képi fordulat kifejezés és milyen változásokat eredményezett társas világunkban? Richard Rorty a filozófia történetét nemes egyszerüséggel fordulatok sorozataként írja le, amely új problémákat helyez előtérbe és elhalványítja a régieket. Véleménye szerint a középkori filozófia dolgokkal, a 17-18. századi filozófia ideákkal, míg a felvilágosult, kortárs filozófia szavakkal foglalkozik. E felfogás pedig azt a nézetet támogatja, hogy a társadalmat mint szöveget, tudományos reprezentációit pedig mint diskurzust érdemes vizsgálnunk (Mitchell [1995] p. 11.). E nyelvi fordulatot követően azonban tagadhatatlanul egy új érába léptünk, amely mind a társadalomtudományok, mind pedig a közkultúra kutatóinak figyelmét felkeltette; ezt az új periódust nevezi Mitchell a képi fordulat korszakának, amely bekövetkeztével a retorika mára a vizuális érvelés fogalmi elemzésének alappilléreként tekintendő. 
A jelen ikonikus korszak létrejöttét olyan nagy gondolkodók elméletei támogatták, mint Peirce vagy Goodman, Derrida vagy Foucault, akik mind hozzájárultak a nyelvi és képi szimbólumok kapcsolatának feltérképezéséhez. Ezen kívül Wittgenstein ikonofóbiája és a nyelvfilozófia képi reprezentációkkal kapcsolatos általános aggodalma, valamint a szükség arra, hogy megvédjék a beszédet a vizuálissal szemben is biztos jele annak, hogy a képi fordulat korszaka valóban beköszöntött. Innentől kezdve a képek vizsgálata önálló területté és a társadalomtudományok központi beszédtémájává vált, valahogy úgy, mint a nyelv egykoron (Mitchell [1995] pp. 12-13.).

A retorika, vagy szónoklattan mint több évszázadon átívelő diszciplína új területeként jelent tehát mega vizuális retorika az 1970-es évek elején, addig ugyanis kizárólag a verbális diskurzusok képezték a retorika elemzésének tárgyát. A vizuális érvelés kutatása az Egyesült Államokban már a 20. század derekától kezdve virágzott ugyan, áttörő sikert azonban mégis húsz évvel később értek el a kutatók, amikor is a Speech Communication Association által összehívott Nemzetközi Retorika Konferencia résztvevői azt javasolták, hogy a retorikai perspektíva minden olyan emberi cselekvésre, folyamatra, termékre, vagy tárgyra kiterjesztést nyerjen, amely a figyelmet, felfogást, hozzáállást vagy viselkedést formálhatja, fenntarthatja vagy módosíthatja (Foss [2005] p. 141.). E tudományterület kiszélesedését mutatja az is, hogy az 1990-es évek közepétöl folyóiratok és különszámok jelentek meg a témában, míg ezzel párhuzamosan a kommunikációs szakok szemináriumaiban is tananyaggá vált és szakmai konferenciák témájaként szolgált, illetve szolgál mind a mai napig (Charlton [2008] pp. 8586.).A vizuális retorika fejlődésével és virágzásával kapcsolatos érdeklődés annak történeti hagyományaiban gyökerezik, amelyet az intellektuális, technológiai és társadalmi folyamatok ugyanúgy befolyásoltak, mint a politikai vagy gazdasági változások (Olson [2007] pp. 1-2.).E tudományterület intellektuális gyökereihez nagyban hozzájárult Kenneth Burke, aki - a már említett - Rhetoric of Motives címü müvében elsőként definiálta úgy a retorikát, mint szimbolikus cselekvés, amely rengeteg lehetőséget tartogatott a vizuális érvelés számára, nagy hatást gyakorolva ezzel az értelmiségi réteg számos generációjára. Sloane, 1971-ben például az alábbi javaslatot tette a retorikai gondolkodásmód bővítése érdekében: „A retorikai megközelítés perspektíváit ki kell szélesíteni a retorikai müveletek teljes körü vizsgálata érdekében: amelyek lehetnek informális beszélgetések, csoporton belüli vagy publikus megnyilvánulások, tömegmédia üzenetek, sztrájkok, szlogenek, kántálás, éneklés, menetelés, rituális, intézményi és 
kulturális szimbólumok, kultúraközi aktusok stb." (Sloane [1971] pp. 1-2.) $)^{5}$. A későbbi politikai, gazdasági és főként technológiai változások - pl.: fotográfia, film, televízió, a World Wide Web és a digitális technológia általában - szintén hozzájárultak a vizuális érvelés területének népszerüsítéséhez, hiszen alapjaiban változtatták meg annak módját, ahogyan a beszédeket vagy egyéb üzeneteket prezentálták a közönségnek.

A retorika meghatározásait olvasva mára már jóval szélesebb, tágabb perspektívát bemutató definíciókkal találkozhatunk. Aczél Petra Médiaretorika címü múvében úgy ír a retorikai kommunikációról, mint a társas cselekvés koordinátoráról, amely implicit vagy explicit módon irányítja a kollektív folyamatokat verbális vagy vizuális, beszélt vagy írott szimbólumok használatával. A szerző szerint a retorika a kommunikáció instrumentális formája, amely pragmatikus természetének köszönhetően - értelmezhető eszközként, amelyet egy bizonyos cél elérése érdekében alkalmazunk (Aczél [2012] pp. 14-15.). Aczélhoz hasonlóan Sonja K. Foss is úgy gondol a retorikára, mint egy (verbális vagy vizuális) szimbólumok sokaságával kommunikáló tudományágra, ezáltal a szerző szerint a retorika - legalapvetőbb értelemben - egy ősi kifejezés arra, amit ma kommunikációnak nevezünk.

A retorika jelenlegi meghatározásai továbbra is támogatják e tudományterület verbális szövegeken túlmutató bővítését, az idők során megjelenő számos kritika és támadás ellenére. Először is úgy jelent meg a vizuális retorika, mint egyfajta szubdiszciplináris terület - azaz annak a 2500 éves tudományágnak a kishúga, amely kizárólag nyelvi kódokkal, a beszéd segítségével törekszik a meggyőző kifejezésre, rábeszélésre - és nem úgy, mint egy önálló, a retorika belső gazdagságát demonstráló diszciplína (Aczél [2012] pp. 40-41.). Emellett olyan ellenérvek jelentek meg a vizuális szimbólumok és a retorika kapcsolatát illetően, mint pl.:

- A retorikai tudás nem foglalja magában a vizualitással kapcsolatos kompetenciákat, így a kutatók nem képesek érdemben vizsgálni e területet;

- A retorika elmélete a nyelvi központúságon alapszik, így a vizualitás nem kaphat föszerepet benne;

\footnotetext{
${ }^{5}$, , Rhetorical criticism must broaden its scope to examine the full range of rhetorical transactions: that is, informal conversations, group settings, public settings, mass media messages, picketing, sloganeering, chanting, singing, marching, gesturing, ritual, institutional and cultural symbols cross cultural transactions, and so forth."
} 
- A televízió vizuális ismeretelmélete beszennyezi a nyilvános kommunikációs formákat, valamint hozzájárul a közbeszéd komolyságának, egyértelmüségének és legfőképpen értékének hanyatlásához.

Michael Charlton ezzel szemben azt mondja, hogy a klasszikus retorika, bizonyos értelemben mindig is vizuális volt, így a kettő elválasztása még akkor sem lehetséges, ha más típusú szakértelem szükséges hozzájuk. Hogyan is lehetne képes a fizikálisan jelenlévő közönség figyelmen kívül hagyni a szóbeli meggyőzés orátorának vizuális jellemzőit (Charlton [2008] p. 78.)? Egy másik példa, amely a verbális és vizuális összefonódásának nézetét erősíti a retorikai memória, amely a belső látáson, képek elrendezésén alapszik, a beszédet pedig ezáltal nem kiegészíti, hanem egyenrangú társaként segíti (Wright [2005] p. 55.). A vizuális elemek vizsgálata így lassacskán nemcsak elfogadott és kutatott, hanem egyenesen virágzó területté vált az elmúlt évtizedekben, ez pedig az alábbi tényezőknek volt köszönhetö. Elöször is a vizualitás vitathatatlan hatást gyakorol mindennapjainkra hirdetések, televíziós müsorok, filmek, építészet, belsőépítészet, vagy a divat formájában, oly’ módon hozzájárulva ezzel a retorikai környezethez, mint ahogyan azt a beszéd tette egykor. Másodszor - ahogyan ezt a későbbiekben részletesebben is kifejtem - a vizuális ábrázolás retorikai megközelítése nagyban kiszélesedett a kutatók azon felismerésének köszönhetően, hogy a vizuális komponensek által olyan ismeretekhez van hozzáférésünk, amelyek a diskurzus vizsgálatával nem mindig elérhetőek számunkra (Foss [2005] pp. 142-143.).

\subsection{A vizuális retorika konceptualizációja}

A vizuális retorika konceptualizációja történetileg és szinkronikusan sem egységes. Egyesek diszciplínaként, mások pusztán paradigmaként tekintenek rá. Bizonyos elméletalkotók módszerként, megint mások konceptuális keretként értelmezik. A jelen tanulmány azt az álláspontot erősíti, amely szerint a vizuális retorika a retorika diszciplínán belüli adottsága, akárcsak verbális párja.

Nyíri Kristóf Elfelejtett képelméletek címü munkájában úgy fogalmaz, hogy „a vizuális retorika az a megközelítés a retorikáról szóló tudományon belül, amely a szónoklat vizuális elemeire -tehát pl. a mentális képeket ébresztő szófordulatokra, vagy éppen az arcjátékra és taglejtésekre - összpontosít. A beszéd őseredetien támaszkodik vizuális elemekre, és ezt kell 
tennie a sikerre számottartó nyilvános beszédnek is. Az írott szó uralmának századai után, a képiség és látás új világában, a vizuális retorika újjászületésének vagyunk tanúi” (Nyíri [2016/3] p.44.). Nyírihez hasonlóan Aczél is úgy véli, hogy a nyelvi szóképek jelentősége mindenképpen a vizualitás bevonásával jár, a retorikus nyelv azonosítható az imagisztikus kifejezéssel (Aczél [2012] p. 40.). A látszat ellenére azonban, a szakirodalmat feltérképezve kijelenthető, hogy csekély konszenzusalakult ki a kutatók között azzal kapcsolatban, hogy mi a vizuális retorika, illetve, hogy mit csinál. Éppen ezért érdemes azoknak az alapelveknek a bemutatásával kezdenünk, amelyeket illetően egyetértés van a szakirodalomban.

1. A vizuális retorika vizuális jelek jelentéssel bíró halmaza, ezáltal a kommunikáció egy módja. Azonban, csakúgy, mint a kommunikáció egyéb típusainál, a vizuális képalkotás nem kell, hogy mindenki számára értelmezhető legyen ahhoz, hogy retorikaként funkcionáljon. Egyes vizuális jelek bizonyos kultúrákban különös relevanciával bírnak, másokban pedig teljességgel jelentéktelenek.

2. A vizuális retorika a látásban, nézésben, vizualizációban gyökerezik. Elsősorban optikai folyamat, szemünkön kívül azonban testünk és szellemünk is részt vesz e folyamat értelmezésében.

3. Bár a vizuális retorika formái nagy változatosságot mutatnak - a képektől a fotókon, szobrokon és épületeken át a filmekig és a televízióig - mégis egységesen elmondható róluk, hogy emberi konstrukciók, sok esetben gyönyörködtető funkcióval. Így, miközben a tájak és a távoli csillagok is láthatók, nem értelmezhetők az emberi felfogás kereteink kívül.

A jelentéslétrehozás által válnak tehát a vizuális imágók hasonlóvá a retorika olyan más módjaihoz, mint a beszéd vagy az írás. A nehézség természetesen az, hogy a retorikai hagyomány előnyben részesíti a szót azáltal, hogy a beszélt és írott nyelv meggyőzőképességét veszi alapul. Ott és Dickinson azonban úgy véli, a festmények, fényképek, épületek, a televízió és a filmek nagyrészt szavak nélkül közvetítenek jelentést. Sőt, az említett szerzőpáros szerint ezeknek az üzeneteknek az erőssége nem a nyelv hiánya ellenére, hanem éppen a nyelv hiánya miatt mutatkozhat meg, hiszen ezek a tartalmak különböző kognitív struktúrákra hatnak, különböző megértéseket és érzelmi lehetőséget tartogatva. Ez pedig azt bizonyítja, hogy a vizuális retorika - ami nyilvánvalóan retorikus abban az értelemben, hogy üzenetei hitekkel, 
értékekkel és cselekedetekkel kapcsolatos véleményformálásra hívnak meg bennünket - nem úgy retorikus, ahogyan e tudományt leírták és oktatták 2000 éven keresztül, retorikus természete ettől függetlenül azonban megkérdőjelezhetetlen (Ott - Dickinson [2009] pp. 392-393.).

George Roque szerint a televíziós müsoroktól eltérően a rögzített vizuális elemek nem képesek interaktív dialógust kialakítani abban az értelemben, ahogyan Walton gondolja: „,véleménycsere két olyan beszédpartner között, akik egymást felváltó mondatszekvenciákkal érvelnek egy közös cél elérése érdekében” (Roque [2008] p. 185.). A képeket általában meggyőzőnek szokták tekinteni, de nem a kibocsátó és befogadó közötti meggyőző dialógus értelmében. Roque azonban azt mondja, hogy nem minden meggyőzési folyamat zajlik a waltoni értelemben vett interaktív párbeszéden keresztül. Az effektív képhasználat szerinte ugyanis képes megragadni a nézők figyelmét, ezáltal - a vizuális retorika újragondolásával - azt állítja, hogy a képek lehetnek dialogikusak, nem pusztán monologikusak, legalább is abban az esetben, ha figyelembe vesszük a közönséget és a kép által közvetített figyelemfelkeltő szándékot. A jelen tanulmány is ezt az álláspontot szándékozik alátámasztani, nagy hangsúlyt fektetve arra, hogy a képek - bizonyos állításokat téve - érvelő szándékot fejeznek ki, arra biztatva közönségüket, hogy valamit így gondoljanak és ne másként.

Foss a vizuális jelenségkör retorikai megközelítésének kétféle értelmezését kínálja: szerinte a vizuális retorikát tekinthetjük produktumnak vagy artefaktumként, illetve a vizuális adatok tudományának, tehát processzusnak. Az első arra a termékre utal, amelyet az egyének kommunikáció céljából alakítanak ki és használnak; a második pedig egy kutatók által használt perspektívát jelöl, amely a képek kommunikációjának szimbolikus folyamatait helyezi a fókuszba (Foss [2005] p. 143.).

\subsubsection{A vizuális retorika mint produktum/artefaktum}

Artefaktumként való megközelítése szerint a vizuális retorika nem más, mint egy tényleges kép, amelyet a rétorok alkotnak meg akkor, amikor kommunikáció céljából vizuális szimbólumokat használnak. Olyan kreatív tevékenységek kézzelfogható bizonyítékaként tekinthetünk rá, mint a festmények, hirdetések vagy épületek. Az artefaktumorientált megközelítés tehát ugyanazt a felfogást erősíti, amelyet a produktum típusú szemlélet kínál: egy kontextualitástól független, eredményközpontú megközelítést, amelynek fókuszában egy termék, mủalkotás, vagy tárgy, 
tehát egy artefaktum áll. Foss azonban úgy véli, hogy nem minden vizuális tárgy tekinthető vizuális retorikának. Szerinte három jellemző alapján válik egy vizuális tárgy kommunikációs artefaktummá, azaz olyan szimbólummá, amely képes kommunikálni, és amely retorikai szempontok alapján vizsgálhatók, ezek pedig az alábbi tulajdonságok:

a. A képnek szimbolikusnak kell lennie,

b. Emberi beavatkozás eredményeként (produktumaként) kell létrejönnie

c. A közönséggel való kommunikáció céljával kell funkcionálnia

a. A vizuális retorika szimbolikus aspektusa arra utal, hogy - más kommunikációs folyamatokhoz hasonlóan - jelek rendszereként fogható fel, amely alatt azt értjük, hogy egy jel azáltal kommunikál, hogy tárgyára referál. Ahhoz azonban, hogy vizuális retorikának tekinthessük ezt a jelölö-jelölt viszonyt, fontos, hogy a jelölö pusztán indirekt módon, szimbolikusan jelölje tárgyát. A stop tábla alakjának és színének például nincsen természetes kapcsolata az autó megállításával, e jel ezen dimenzióját ugyanis önkényesen alkották meg és indirekt, közvetett módon kapcsolódik jelölőjéhez. Ezáltal a stop tábla vizuális érvelésként értelmezhető, mivel önkényes szimbólumokat használ a kommunikációs aktusok elvégzéséhez. Fontos azt is hozzátennünk, hogy a stop tábla értelmezése múltbéli tapasztalataink függvénye, ezen tapasztalataink pedig előrébbvalók azoknál a szavaknál, amelyekkel leírhatnánk őket. E vizuális jel értelmezése tehát konvención alapszik és mellőzi a szóhasználatot (Murphy et al [2013] p. 46.).

b. A vizuális retorika produktumként/artefaktumként való megközelítésének második feltétele, hogy valamilyen emberi tevékenységet foglaljon magában. Az olyan művészi tevékenységeknél, mint a festés, rajzolás vagy fotózás, a kommunikáció, mint egy tudatos emberi döntéshozatal, illetve érvelési stratégia jelenik meg. Említésre méltóak ezen kívül azok az eredendően nem retorikai vizuális imágók, amelyeket az emberi beavatkozás tesz érveléssé. Egy fa például önmagában véve nem retorikus, ha azonban az emberek az otthonukban állítják fel öket a Karácsony szimbólumaként, vagy szórólapokon jelenítik meg őket a környezetvédelem előremozdításának érdekében, máris retorikussá válnak. Ebből pedig levonható, hogy a vizuális retorika emberi beavatkozásos aspektusa nem pusztán az alkotásra és teremtésre, hanem az interpretációs folyamatok eredményeire is egyaránt utal. 
c. Végezetül pedig a közönség jelenlétének fontosságára hívom fel a figyelmet. Kenneth Burke szerint a klasszikus retorika egy úgynevezett külső közönséget feltételez, ahol a rétor célja, hogy saját ügyét előnyös, ellenfeléét pedig hátrányos színben tüntesse fel. Ezt a logoszéthosz-pathosz és üzenet-beszélö-közönség hármasán alapuló klasszikus megközelítést Burke szerint azonban felváltja a modern retorika jelensége, amely a beszélő személyt éppen úgy az üzenet befogadójának tekinti, mint közönségét, mivel az általa alkalmazott stilisztikai kibúvók pszichológiailag ugyanúgy képesek önmaga meggyőzésére, mint másokéra (Walters [2014]). A modern retorikához hasonlóan a vizuális retorika is feltételez egyfajta valós vagy absztrakt közönséget, amely abban nyilvánul meg első sorban, hogy a rétor nem pusztán önkifejezése céljából rendezi vagy módosítja a vizuális elemeket, hanem a közönséggel való zavartalan, effektív kommunikáció érdekében. A rétor maga is felfogható közönségnek, nem kell, hogy

externális tényezőként tekintsünk rá. Összegezve, a vizuális retorikát, mint artefaktumot a színek, formák és egyéb produktumok tudatos elrendezéseként értelmezhetjük, amely annak érdekében jön létre, hogy egy adott - külső vagy belső - közönséggel kommunikáljon szimbólumok rendszerén keresztül és emberi beavatkozás segítségével (Foss [2005] p. 145.).

\subsubsection{A vizuális retorika mint vizuális típusú adatok közlésfolyamata}

A vizuális retorika kommunikációs artefaktumként való megközelítésén kívül fontos megemlítenünk a másik elméleti perspektívát, amely a vizuális imágók, adatok elemzésérének folyamatára vonatkozik. Míg az előbbi funkcionális, utóbbi értelmező megközelítést javasol (Aczél [2012] p. 41.).A vizuális retorika mint teoretikus szemlélet a vizuális adatok kritikai elemzését szorgalmazza, amely a képek kommunikatív dimenzióit hangsúlyozza. Ez a fajta meglátás különleges módon vizsgálja a képeket; olyan konceptuális lencsén keresztül, amely a képeket kommunikatív vagy retorikai jelenségként értelmezi. Ez a retorikai szemlélet túlmutat az esztétikai megközelítéseken, így egy képet nem a színe, formái, azaz érzékszervi aspektusai alapján elemez, hanem annak retorikai üzenetét vizsgálja, a jelentéstulajdonítás eszközével, ezáltal teljességgel megegyezik az érvelés processzus típusú, pragmatikus, hatás és szándékalapú felfogásával. Ehhez a megközelítéshez pedig elengedhetetlenül fontos a képek természetének, funkcióinak és értékelési folyamatainak vizsgálata. A képek természete arra a kettősségre utal, hogy vannak a képen fizikálisan jelenlévő elemek, és vannak olyan hiányzó szegmensek, amelyekhez a retorikai következtetés eszközével juthatunk el. A képek funkciója így az általuk 
kiváltott hatásra, a közönség mozgósítására vonatkozik, értékelésük pedig retorikai környezetük vizsgálatán keresztül történik, mindez pedig egy vagy több folyamat során valósul meg.

A Foss-féle kétdimenziós retorikai paradigma helyére Ott és Dickinson egy érzékenyebb és rendszerezőbb hármas megközelítést javasol, amely a vizuális retorika tárgyalásának az alábbi három módját különíti el:

1. A vizuális retorika mint nyilvános üzenet,

2. A vizuális retorika mint a hétköznapi valóság megalapozója,

3. A vizuális retorika mint logika (Ott - Dickinson [2009] p. 393.).

Ez a hármas rendszer - Foss kettes felosztásához hasonlóan - szintén jól reflektál a retorika hármas értelmezésére: a retorikára mint produktumra (eredményre), processzusra (folyamatra) és procedúrára (eljárásra) (Aczél [2012] p. 42.).

\subsubsection{A vizuális retorika mint nyilvános üzenet}

A vizuális retorika első felfogása a hagyományos, nyilvános funkcióból merít ihletet, amelyben a vizuális üzenetet stratégiai céllal állítják elő egy adott közönség meggyőzése érdekében. E perspektíva gyökerei Arisztotelészhez vezethetők vissza, aki a retorikát a rendelkezésre álló eszközökkel történő meggyőzés képességeként definiálta. Itt valójában a beszédet helyettesítjük be a vizuálissal, tehát gyakorlatilag kódváltás történik: a kép válik a stratégiailag létrehozott nyilvános üzenetté, amellyel a közönséget igyekszünk meggyőzni. A retorika mint nyilvános üzenet megközelítését összekapcsolva az érvelés 3P típusú szemléletével tisztán kirajzolódik, hogy a kép e tekintetben produktumnak minősül, egy termék, amely a szöveget felválta a meggyőzés eredményeként jelenik meg. Aczél szerint a képi üzenet mint meggyőző „szöveg” vagy „beszéd” vizsgálható a hatást kiváltó szervezés, szerkesztés és a kiváltott reakció szempontjából, ezáltal válva a legkézenfekvőbb vizuális retorikai megközelítéssé, amelyben nem esztétikai, hanem retorikai fogalmakat alkalmazunk (pl.: érvelés, alakzatok stb.) (Aczél [2012] p. 43.). A vizuális retorika mint nyilvános üzenet modellje tehát strukturalista alapelvekre és a képek szimbolikus vagy reprezentatív megértésének eredményére épül (Ott - Dickinson [2009] p. 394.). E módszer nyilvánvaló nehézsége ugyanakkor, hogy a vizuális retorika leíró kategóriái nyelvi kódokra szocializáltak, a beszédhez kapcsolódnak, ezért a képekre való mechanikus 
vonatkoztatásuk számos kérdést vet fel, pl.: létezik-e vizuális ,állítás”, ,érvelés”. Ahogyan arra a későbbiekben részletesen kitérek, az érvelések egyik legfontosabb jellemzője, hogy propozicionálisak, azaz rendelkeznek elfogadható vagy elutasítható igazságértékkel. Aczélhoz csatlakozva a jelen tanulmány is azt az álláspontot erősíti, hogy az igazságérték problematikája elfogadható a feltételezett vizuális érvelésre is, hiszen az, hogy valami nyelvileg kifejezhető nem azt jelenti, hogy feltétlenül azon is fejeződik ki, pusztán annyit jelöl, hogy nyelvileg is állíthatónak kell lennie (Aczél [2012] p. 48.). A verbális kommunikáció közvetíthető vizuálisan, ahogyan a vizuális kommunikáció kódjai is átfordíthatók a verbálisra, ez a fordítás azonban nem a vizuális verbálisra történő „,redukciója” (Aczél [2012] p. 48.). A képi kommunikáció - ahogyan azt a gazdag vizuális szimbolizmus is bizonyítja - jellemzően konvencionális, de konvenciói nem nyelviek. Így a vizuális érvelések olyan propozíciós állításoknak tekinthetők, amelyekben a propozíciók, az érvelő funkciók, és szerepek vizuálisan fejeződnek ki, de esetenként - és a jelen disszertáció állítása szerint nem szükségszerüen - lefordíthatók nyelvi kódokra is. Ezáltal a vizuális érvelésben a vizualitás inkább retorikus (vagyis állításon alapuló), mint dialektikus: nem az általános igazság kifejtett keresését szorgalmazza, hanem a közös kulturális értékek szituációs aktiválását segíti elő (Aczél [2012] p. 48.).

A vizuális retorika mint meggyőző, nyilvános üzenet a képi megjelenés leírásában a klasszikus retorika alakzattanát is alkalmazza, összekapcsolva ezzel az esztétikai szervezést és jelentéstételezést a hatás folyamataival, ezáltal éppen úgy beszélhetünk vizuális retorikai alakzati kategóriáról, mint a verbális megnyilatkozások esetében (Aczél [2012] p. 50.). Linda M. Scott szerint a vizuális komponensek számára szükséges, hogy képesek legyenek fogalmakat, absztrakciókat, akciókat vagy metaforákat reprezentálni, amelyek egy komplex érv megalkotásában használatosak. Ezen kívül a módszerek kiválasztásában is nagy szerepük van, így például a stílus kijelölésével sugalmazhatják az érvek szándékuk szerinti értékelését. Végezetuil irányítaniuk kell az érvelés sorrendjét a vizuális elemek elrendezésének segítségével (Scott [1994] pp. 252-253.). A vizuális retorika mint nyilvános üzenet területének ugyan értelemszerüen operacionalizáló eszközei az alakzatok, disszertációm azonban alább külön fejezetet szentel a retorikai trópusok vizuális megközelítésének, amelyben a metafora, metonímia, szinekdoché és irónia eszközei mind bemutatásra kerülnek. 


\subsubsection{A vizuális retorika mint hétköznapi valóság}

Ha a vizuális retorika mint nyilvános, meggyőző üzenet a tradicionális retorikai hagyományból és a strukturalista szemiotikából nyeri inspirációját, akkor a vizuális retorika mint a hétköznapi valóság a kritikai kultúrakutatásra és a poszt-strukturalista elméletekre támaszkodik (Ott Dickinson [2009] p. 396.). A kultúra és a szubjektív valóság kapcsolatát vizsgálva e megközelítést pártoló kutatók úgy vélik, hogy a vizualitás nem egy kifejezésmód, amely az egyes, létező és konstituált közönségre vonatkozik, hanem magára a mindennapi élet produktív befogadására utal. Burgin úgy fogalmaz, hogy a vizuális reprezentációkat nem lehet egyszerúen a valósággal szemben tesztelni, mivel a valóság maga is a reprezentációk közvetítése által jön létre (Burgin [1996] p. 238.). Nézetei szerint a vizuális retorika tehát a valóság elsőszámú megalapozója, nem egyszerüen annak mimetikus ábrázolása. Michel de Certeau a kulturális reprezentációk aktív befogadását javasolja, a reprezentációelemzés és a viselkedéselemzés összekapcsolásán keresztül (Aczél [2012] p. 55.). Úgy véli, a televízióban fellelhető vizuális elemek (reprezentációk) elemzése és a televízió-nézéssel töltött idő (viselkedés) kapcsolódjon össze annak tanulmányozásával, hogy mindeközben a befogadó mit „csinál” (,,makes” or „does”) ezekkel a képekkel (De Certeau [1988] p. xii.). Ez a „csinálás” (poiesis) pedig egy láthatatlan alkotás, mivel a „termelés” rendszerei által meghatározott és uralt területeken érvényesül (pl.: televízió, városfejlesztés, kereskedelem stb.). Ugyanez vonatkozik a szupermarketban való vásárlásra, az újságok által terjesztett történetekre és legendákra, vagy a városi tér használatára (De Certeau [1988] p. xii.), így - ez utóbbi gondolathoz csatlakozva amikor a certeaui sétálás retorikájával „látjuk” a várost, a térben történő mozgásaink, sétánk által sajátos urbanisztikai „szöveget” írunk, alkotunk. Ilyenkor a vizuális retorika nem a meggyőző nyilvános üzenet eszközeként, hanem a mindennapi élet valóságteremtő folyamataként, a szubjektivitás kontextuális és konstitutív megalapozójaként jelenik meg (Aczél [2012] p. 56.). Éppen ezért vitathatatlan, hogy a hétköznapi valóságot meg- és újraalkotó retorika folyamatként értelmezendő, hiszen egy processzuson keresztül képes a vizuális elemek és a közönség közötti interakciót megteremteni, illetve a vizuális elemeket azonosítani, értelmezni és ezáltal a közönség világképét formálni. 


\subsubsection{A vizuális retorika mint logika}

Míg az első perspektíva úgy közelítette meg a vizuális retorikát mint eredményt, a második pedig úgy viszonyult hozzá, mint a létezés vagy létrejövés folyamatának lehetőségéhez, azaz ideológiai tárgyak létrehozásához, addig a jelen aspektus úgy kezeli a vizuális retorikát, mint tudásmódot. Ez a megközelítés azt állítja, hogy a vizuális retorika nem pusztán a meggyőzés eszköze, hanem a gondolat létrejöttének alapvető feltétele. A vizuális retorika mint logika perspektívája azon az elképzelésen alapul, hogy a képek a saját egyedi kódjaik, szintaxisuk és nyelvtanuk szerint müködnek, ezáltal nem azt határozzák meg, hogy mit látunk, hanem azt, ahogyan nézünk, látunk (Ott - Dickinson [2009] p. 398.). A vizuális elemek logikájának feltérképezői tehát az észlelésből és a kognícióból indulnak ki, ezáltal e harmadik perspektíva a tudás megszerzésének eljárásaira vonatkozik, azaz procedúraként értelmezendő. Az észlelés és a kogníció fogalmait Ott és Dickinson a következő négy alapvető jellemzőben foglalja össze:

1. A látás kreatív: A látással tehát nem csak rögzítünk, hanem létre is hozunk. A látás gyakorlata nem pusztán stimulusokat és reakciókat tartalmazó fiziológiai folyamat, sokkal inkább egy olyan pszichológiai eljárás, amely magában foglalja a vágyat és a tudatalattit - ezáltal válik az elrendezés, átalakítás és végül a kialakítás szubjektív módjává. Azt, ahogyan a dolgokat látjuk, meghatározza, hogy mit tudunk, és miben hiszünk, és, mivel minden megfigyelö különbözőértékeket, meggyőződéseket és tapasztalatokat hordoz, két ember nem képes pontosan ugyanúgy tekinteni egy bizonyos tárgyra. Ezáltal válik a látás az aktív termelés, semmint a passzív befogadás eljárásává (Ott - Dickinson [2009] p. 399.). Aczél hozzáteszi, hogy a kreatív látást és a tudat szervező tevékenységét nagyban meghatározzák, sőt korlátozzák a képek által felkínált minőségek, pl.: szín, forma, vagy fény. Többek között ennek a kreativitásnak az eredménye a vizuális retorika mint a hétköznapi élet megalapozója (Aczél [2012] p. 57.).

2. A látás szelektív: Gyakran ugyanolyan fontos az, amit a képek segítségével látunk a világból, mint az, amit nem látunk, automatikusan kiszürünk. Vannak olyan dolgok, amelyeket nem látunk még akkor sem, amikor egyenesen rájuk nézünk, azaz vakon vagyunk bizonyos dolgokkal, és vakok vagyunk saját a vakságunkkal kapcsolatosan is. Az észlelés szelektivitása az ember önfenntartó ösztöne miatt 
jött létre. Mivel nem minden, amit látunk egyenlő fontosságú, a képesség, hogy kiszürjük a kevésbé fontos vizuális tartalmakat gyakran szó szerint életmentő lehet. Amikor valakit éppen elütne egy autó, sokkal fontosabb, hogy képes legyen azonnal meghatározni a jármü irányát és sebességét, mint detektálni egy másik járókelö öltözékét (Ott - Dickinson [2009] p. 399.). Aczél kevésbé radikális példájával élve a percepció érzékenyebb a mozgásra, mint a mozdulatlanságra, lassú változásra, gondoljunk csak a fény intenzitásának alakulására a nap folyamán. Ennek köszönhetően az élet konstans, operatív tényezőire kevésbé vagyunk figyelemmel, mint a nyilvánvaló, mozgásos tevékenységekre, így a látás tehát részleges. Ez a szelektivitás a vizuális retorika mint meggyőző, nyilvános üzenet hajtómotorja: az erősebb megjelenítéssel, alakzatokkal, különbségtételekkel nagyobb hatás érhető el a befogadóban (Aczél [2012] p. 57.).

3. A látás kontextuális: Az, hogy mikor és hol látunk valamit, nagyban meghatározza, hogy mit látunk. A látás szorosan kapcsolódik az időhöz és időzítéshez, a megfigyelés kulturális és történelmi pillanatához. Mivel a kulturális értékek, hiedelmek és gyakorlatok idővel megváltoznak, az is módosul, ahogy a befogadók látják és értelmezik a képeket. Emellett a látás a hely és elhelyezkedés függvénye is, értelmezésük nem különíthető el a társadalmi és anyagi terektöl, amelyekben látjuk őket (Ott - Dickinson [2009] p. 399.).

4. A látás térbeli, spaciális: A vizuális jelek legalább két alapvető dologban különböznek a verbálisoktól. Először is, míg a nyelvi jelek - legyenek azok szóbeli vagy írásbeli jelek - temporálisak, azaz időben elrendezettek, ezáltal feldolgozásuk szekvenciális, addig a vizuális jelek térbeli rendszerezést mutatnak, így feldolgozásuk egyidejüleg is lehetséges. Ez a kijelentés pedig arra utal, hogy ugyan két különböző szót egyszerre kiejteni lehetetlenség, kettő vagy több kép egyidejű megtekintése nem okoz problémát. A látás egyedülálló spaciális természetére reflektálva Arnheim úgy fogalmaz, hogy „Egyetlen tárgy sem tekinthető egyedinek vagy elszigeteltnek. Valaminek a látása megköveteli egy hely hozzárendelését is: egy helyet a térben, egy pontszámot a méret, fényerő vagy távolság skáláján" (Arnheim [1954] p. 11.). Másrészt, míg a nyelvi jelek teljesen önkényesek, a vizuális jelek jellemzően analógok. A képek azért 
értelmezhetőek, mert azokra a dolgokra hasonlítanak, amelyeket jelölnek, míg a nyelv pusztán amiatt érthető, mert egy adott társadalmi megegyezés, konvenció biztosítja azt (Ott - Dickinson [2009] p. 399.).

\subsection{A vizuális retorika mint alakzattan}

Az alakzat, ahogyan azt elnevezése is tükrözi, a beszédnek olyan alakjára utal, amely eltér a közönséges, vagy elsőként adódó beszédmódtól (Quintilianus [2008]). Quintilianus Institutio oratoria (Szónoklattan) címü munkája korszakalkotó az alakzatok értelmezésében és osztályozásában. Szintén Quintilianus alkalmazza elsőként a figura (alak, alakulat, külső) kifejezést terminus technicus értelemben, és az ő hatására terjedt el e formula ilyen jelentéssel az európai nyelvekben (Adamik [2010] p. 35.). Az alakzatok kifejezőerejére Gorgiasz figyelt fel először, később azonban Diodórosz Szikeliótész is említést tesz róluk, a következő típusokat sorolva: antitheszisz (ellentét), iszokólon (tagmondat-egyenlőség), pariszon (szóegybecsengés), illetve homoioteleuton (hasonló végződés) (Adamik [2010] p. 33.). Arisztotelész a stílus erényével, az illő világossággal kapcsolatban úgy fogalmaz: „A megszokottól való eltérés az ünnepélyesség látszatát kelti. Ahogy másképpen hat ránk az idegen, mint a hazánkfia, úgy van ez a stílussal is" (Arisztotelész [1404b]). Arisztotelész felismerte tehát a szóképek és alakzatok jelentőségét, főként azonban a későbbiekben részletezett metaforára (és a hozzá szorosan kapcsolódó hasonlatra) koncentrált. Cornificius retorikájában is megjelenik az alakzatok rendszere, aki az ékességet a dignitas (ékesség, dísz, fenség) szóval illeti, és ennek keretében tárgyalja az alakzatokat, szóalakzatra (verborum exornatio) és gondolatalakzatra (sententiarum exornatio), ahol a szóalakzat a beszéd finom csiszoltságában, a gondolatalakzat fensége pedig nem szavakban, hanem gondolatokban jelenik meg (Adamik [2010] p. 34.).

A szóbeli kódra kidolgozott alakzattan rendszerét a vizuális retorika produktumként való megközelítése szerint szokás értelmezni, hiszen olyan logikának tekinthető, amely jelentést hoz létre. Mégis fontos kiemelnünk, hogy a vizuális retorika procedurális és processzuális szemlélete az alakzatok tekintetében ugyanúgy üdvözlendő, hiszen szabályos mintázatait és a képi elemek egymáshoz képesti viszonylagosságát (eljárás) az imágók hatás- és szándékalapú közlése (folyamat) egészíti ki. 
A klasszikus retorikán nyugvó vizuális retorikát vizsgáló kutatók szerint a képelemzés célja az, hogy a retorikai szerkezeteket illusztrálja, a meglévő retorikai fogalmak, elsősorban a retorikai alakzatok képi megfelelőit keresve (Margitházi [2010] p. 57). A képek belső rendszerének fontosságát Phillips és McQuarrie a reklámok szempontjából mutatja be Beyond visual metaphor: A new typology of visual rhetoric in advertising címü munkájában, amelyben a vizuális elemek elrendezését retorikai szempontok alapján vizsgálják (Phillips - McQuarrie [2004].). Feltételezésük szerint minden képi elem rendelkezik egyfajta belső struktúrával, amelyben a képek különböző elrendeződést mutathatnak, más-más hatást gyakorolva ezzel. A szerzőpár a kép szerkezetét érintő valamennyi müveletet a metaforából vezet le. Chandler definíciója szerint metafora egy új jel, amely egy jel jelölőjéből és a másik jel jelöltjéből jön létre (Chandler [2007] p. 125.), míg Lakoff és Johnson szerint a metafora lényege egy dolog megértése és megtapasztalása egy másik tükrében (Lakoff - Johnson [1980] p. 5). A szerzőpár úgy véli, gondolkodásunk domináns módjai, valamint valóságunk is metaforákra épül. Metaphors We Live By címü munkájukban számos verbális metaforára hoznak példát, azonban Phillips és McQuarrie óta tudjuk, hogy a metafora vizuálisan is kifejezhető (Deli - Németh [2017]). Alátámasztva e nézetet, Pictorial Truth címú munkájában Nyíri úgy fogalmaz, hogy a verbális metaforák szükségszerüen a mentális képekre támaszkodnak (Nyíri [2017] p. 55.). Aczél szerint a metafora mint kiindulópont a gondolati mủvelet minőségileg megkülönböztethető két típusát kínálja: az összekapcsolást és az összevetést (Aczél [2012] p. 51.). Míg az előbbinél a kép még nem hasonlításra, pusztán asszociációra hívja a befogadót (pl.: A kapcsolatba hozható B elemmel, mivel...) így nem tekinthető metaforának, addig az utóbbi (amelynek alapja a hasonlóság és különbségtétel) már metaforikus gondolati müvelet (Aczél [2012] p. 51.). Ezen jelentésképző eljárások elkülönítése után a képi ábrázolás által alkalmazott klasszikus retorikai rendszer három eljárását mutatom be. Phillips és McQuarrie tipológiája alapján azt mondhatjuk a vizuális struktúrát illetően, hogy az elemek, amelyek a képen fizikálisan jelenlévő vizuális retorikai alakzatot alkotják, háromféle módon kapcsolódhatnak egymáshoz: juxtapozícióval, azaz mellérendeléssel, fúzióval vagy transzmutációval, illetve helyettesítéssel vagy immutációval; (McQuarrie - Philips [2004] p. 116.) amelyet Aczél (Quintilianus müveleti és gondolatalakzati kategóriáját átvéve) egy negyedik, úgynevezett elhagyás vagy detrakció kapcsolódási móddal egészít ki (Aczél [2012] p. 53.). 


\begin{tabular}{|c|c|c|c|c|}
\hline & & \multicolumn{3}{|c|}{ RICHNESS } \\
\hline & & \multicolumn{3}{|c|}{ Meaning Operation } \\
\hline & & \multirow[b]{2}{*}{$\begin{array}{c}\text { Connection } \\
\text { ('A is associated } \\
\text { with B') }\end{array}$} & \multicolumn{2}{|c|}{ Comparison } \\
\hline & $\begin{array}{c}\text { Visual } \\
\text { Structure }\end{array}$ & & $\begin{array}{l}\text { Similarity } \\
\text { ('A is like B') }\end{array}$ & $\begin{array}{l}\text { Opposition } \\
\text { ('A is not like B') }\end{array}$ \\
\hline $\begin{array}{l}\mathrm{C} \\
\mathrm{O} \\
\mathrm{M} \\
\mathrm{P}\end{array}$ & $\begin{array}{c}\text { Juxtaposition } \\
\text { (Two side-by-side } \\
\text { images) }\end{array}$ & Equal sweetener & Dexter shoes & $\begin{array}{l}\text { Comfort fabric } \\
\text { softener }\end{array}$ \\
\hline $\begin{array}{l}E \\
X \\
I \\
T\end{array}$ & $\begin{array}{c}\text { Fusion } \\
\text { (Two combined } \\
\text { images) }\end{array}$ & Discover card & $\begin{array}{c}\text { Tide } \\
\text { Reflex racquet }\end{array}$ & Kudos granola bar \\
\hline$v$ & $\begin{array}{l}\text { Replacement } \\
\text { (Image present } \\
\text { points to an } \\
\text { absent image) }\end{array}$ & Silk soy milk & Welch's juice & $\begin{array}{c}\text { Canadian magazine } \\
\text { industry } \\
\text { Sunny Delight }\end{array}$ \\
\hline
\end{tabular}

2. TÁBLA. A kép forráshelye: https://courses.helsinki.fi/sites/default/files/coursematerial/4482592/22.3_MT2004\%20Phillips.pdf

A vizuális ábrák, mint minden retorikai alakzat általában, alapvetően az elemek egymáshoz füződő kapcsolatát írják le. A fent említett kapcsolódási módok legegyszerübb fajtája a juxtapozíció, amely két egymás mellé helyezett vizuális elemet mutat be. Bonyolultabb szerkezetü elrendezési mód a fúzió, ahol két egymással összekevert, egybeolvasztott képet figyelhetünk meg, míg a legkomplexebb jelenség a helyettesítés, ahol a jelenlévő képi elem eszünkbe juttatja a hiányzó másikat. A szerzők szerint a juxtapozíció, fúzió és helyettesítés leírja egy kétdimenziós reprezentáció két képi elemének összes lehetséges kombinációját, ez a tipológia ugyanis azt állítja, hogy semmilyen más lehetőség nem vehető számba, illetve pontosabban azt, hogy minden más vizuális struktúra vagy az említett típusok alkategóriájaként, vagy pedig ezek ötvözeteként jelenik meg. Aczél azonban az elhagyás, vagy detrakció fogalmának bevezetésével arra a kapcsolódási módra is felívja a figyelmet, amikor egy kép részlete hiányzik, és ez a hiány lesz jelentéstelített (Aczél [2012] p. 53.). Phillips és McQuarrie úgy véli, hogy a különböző rendeződési módok közötti komplexitás lehet a fogyasztói reakciókban megfigyelhető eltérések alapja. A képek összetettsége tehát olyan tényező, amely 
szorgalmazza a fogyasztói feldolgozást, ezáltal, a jelen disszertáció értelmezési kerete szerint, ugyanúgy bevonja közönségét az értelmezés folyamataiba, mint a nyelvi rendszer belső összefüggései.

A vizuális megjelenítésben a metaforán kívül természetesen több alakzat is megjelenhet. Ilyen például a metonímia, amely a jelöltek közötti különböző indexikus kapcsolatokon alapszik, nevezetesen az ok hatással történő helyettesítésén, ezáltal a metonímia az egész előhívása egy bizonyos kapcsolaton keresztül (Chandler [2007] p. 129.). Chandler úgy fogalmaz, hogy úgy gondolhatunk a figuratív nyelvre, mint a költészet egyik legnyilvánvalóbb jellegzetességére, vagy általánosabban az irodalmi nyelv sajátosságára, mégis több metafora van az utcán, mint Shakespeare-ben (Chandler [2007] pp. 124-125.). Ha közelebbröl megvizsgáljuk az előbbi kijelentést, észrevehetjük, hogy Chandler szavai is metonimikusak: Shakespeare müveit és írásait a Shakespeare szóval helyettesíti, amely még inkább azt bizonyítja, hogy milyen gyakran és milyen öntudatlanul használjuk a trópusokat. A metonímiáknál azonban nem csak az ok hatással való helyettesítése figyelhető meg: tárgy a használója helyett, anyag a formája helyett, hely az intézmény helyett, intézmény a személyek helyett stb. A metonímia egyik legfontosabb szempontja tehát, hogy közvetlenül kapcsolódik a valósághoz, a metaforák puszta ikonicitásával és szimbolizmusával ellentétben (Deli - Németh [2017] p.5.).

A szinekdoché meghatározása gyakran jelentős eltéréseket mutat a teoretikusok körében. Az egyik széles körben elfogadott definíció Richard Lanham-től származik, aki úgy fogalmaz, hogy a szinekdoché a rész és egész helyettesítésére utal, csakúgy, mint a fajok és nemzetségek felcserélése, és vica versa (Lanham [1991] p. 97.). Ezáltal az egyik kifejezés átfogóbb, mint a másik. Egyes teoretikusok korlátozzák az alkalmazás irányát (pl.: rész az egész helyett lehetséges, de egész a rész helyett nem), néhányan pedig még tovább szúkítik a szinekdoché kereteit olyan esetekre, amikor az egyik elem fizikálisan része a másiknak (Chandler [2007] p. 132.).

Az irónia a legradikálisabb a négy alapvető trópus közül. Csakúgy, mint a metaforánál, az ironikus jel jelölője úgy tünik, mintha egy bizonyos dologra referálna, de egy másik jelölő által tudjuk, hogy valójában valami egész mást jelöl. Amikor valami az ellenkezőjét jelenti annak, amit jelöl, bináris ellentétről beszélhetünk, pl.: tükrözheti a beszélő érzelmeinek, gondolatainak ellentétét - azt mondani, hogy imádom, amikor valójában utálom, de vonatkozhat 
a külső valóság igazságára is - azt mondani, hogy micsoda tömeg van, amikor valójában kihalt a hely (Chandler [2007] p. 134.). Egy ironikus kijelentés természetesen nem ugyanaz, mint hazugság, mivel eleve nem szánták ,igaznak”. Az irónia alakzatát gyakran használják az internetes mémek, gifek, kritikus üzenetek, blogok stb. (Deli - Németh [2017] p.6.).

\subsection{Vizuális retorika problematizálása}

Disszertációm jelen fejezetében a képi érvelés és annak propozíciókhoz füződő kapcsolatával foglalkozom. Azért esett a választásom e tudományosan erősen vitatott kérdés kifejtésére is, mert számos kutatóval egyetértve magam is úgy vélem, hogy a 21. század mint új képkorszak létrejötte és a képek folyamatos jelenléte, sőt, dominanciája ellenére az érvelés és meggyőzés vizuális komponensei nem kapnak elegendő figyelmet. Az említett komponensek értelmezése elengedhetetlenül fontos, ha az életünkben kulcsszerepet játszó reklám, film, televízió, videó, multimédia vagy korunk nélkülözhetetlen kelléke, az internet megértésére törekszünk. A közelmúltban számos elemző tett arra kísérletet, hogy kifejlesszen egyfajta módot a képek elemzésére, értelmezésére. Annak oka, hogy a vizuális érvelés rendszerének vizsgálati módjait többen is igyekeztek feltérképezni az, hogy a vizuális jelek ugyanolyan döntő szerepet játszanak a bizonyításban, befolyásolásban vagy meggyőzésben, mint mindennapjainkban. Gombrich úgy fogalmaz, vizuális korban élünk. Reggeltől estig folyamatosan képek bombáznak bennünket. Amint felébredünk, a hírek között férfiak és nök fényképét látjuk a különbözö televíziós csatornákon és a közösségi média oldalain, aztán reggelinél a müzlis doboz hátulján lévő képen akad meg a szemünk. A postaládánkban színes prospektusok csábítanak bennünket vásárlásra, fogyasztásra. Otthonunkat elhagyva hatalmas óriásplakát keresztezi utunkat, munkahelyünkön pedig vázlatokkal, katalógusokkal, tervrajzokkal, térképekkel, vagy grafikonokkal babrálunk, mígnem az esti híradóban kéjek és horrorok képeivel végéhez ér napunk (Gombrich [2003] pp. 92-107.). E modern képkorszakban Gombrich azt feltételezi, hogy a képek szépen lassan átveszik a hatalmat az írott szó felett, éppen ezért szükséges tisztázni, hogy mit tudnak a képek az beszédhez vagy írott nyelvhez képest, illetve milyen lehetőségei vannak a képeknek a kommunikációban. Jelentőségükhöz képest elkeserítően kevés figyelmet szentelnek ezeknek a kérdéseknek (Gombrich [2003] pp. 92-107.). Gombrich-hal egyetértve Eisner is azt állítja, hogy az emberek a vizuális érvelés és a vizuális történetmesélés (visual storytelling) módszerét gyakran alacsonyabb státuszúnak tekintették, mint az epikát, a költészetet, vagy a történelmi 
prózát, annak ellenére, hogy a vizuális müvek mindig is létfontosságúak voltak ahhoz, hogy komplex narratívákat építsenek fel (Eisner [1985] p. 5.).

A vizuális érvek ereje abban rejlik, hogy a képek egyszerre tekinthetők a nyilvános vita, a verbális fölött aratott győzelem, és a meggyőzés hatékony eszközének (Groarke [1996] p. 105.). Elfogadjuk-e vagy sem, rengeteg példa támasztja alá azt a nézetet, hogy a közvéleményt egyre inkább a vizuális elemek irányítják, a politikai kampányoktól kezdve a reklámokon át a hírekig. Freedberg úgy véli, hogy az emberekre többféleképpen is hatást gyakorolnak a képek. Nem pusztán szomorúságot, zaklatottságot, boldogságot vagy felháborodást idéznek elő, hanem kiválthatnak szexuális izgalmat, empátiát és félelmet is, mindezt a primitív kultúrákban ugyanúgy, mint a modern társadalmakban, nemtől, kortól és kontinenstől függetlenül (Groarke [1996] p. 105.). Egy másik igazi előnye a vizuális érvelésnek a nyomtatott, vagy szóbeli argumentációval szemben, hogy jóval felidézhetőbb társainál. Ez részint komplexitásának köszönhetö, részint pedig annak, hogy rövid időn belül óriási számú vizuális komponens közvetítésére képes, pl.: a televíziós reklámok, ahol 30 másodpercben számos állítás tehető vizuálisan, míg, ha ugyanezt verbálisan próbálnánk megtenni, a közölt információ hatalmas mennyisége jóval meghaladná a normál emberi feldolgozási kapacitást. A vizuális elemek ilyen módon felhasználhatóak a narratíva közvetítésére, szükös időkereten belül is. A képi érvelés harmadik privilégiuma valósághủ természetében rejlik. A laikus álláspont általában ugyanis az, hogy a vizuális médiatartalmak jobbak, mint a verbálisak a tekintetben, hogy az elöbbi esetében saját szemünkkel láthatjuk az eseményeket, míg az utóbbi egy másik ember szemüvegén keresztül mutatja be az eseményt, így csupán másodkézből való hozzáférést biztosít a közönség számára. Hill-el és Helmers-szel egyetértve a jelen disszertáció is azt az álláspontot erősíti, hogy ez a nézet meglehetösen téves, hiszen amellett, hogy az adott esemény korlátozott számú kameraállásból, hangalámondással és rengeteg vágással kerül bemutatásra, számba kell vennünk azt is, hogy minden médiatartalom egy gondosan kidolgozott történetet mond el, amelynek van eleje (problémafelvetés), közepe (információk, vélemények) és vége (a válaszok megadása, a probléma feloldása) (Hill [2008] p. 51.). Hiába kapunk a végén egy erősen szürt, kevés perspektívát bemutató, lényegesen szerkesztett „valóságot”, a nézők számára mégis úgy jelennek meg a vizuális tartalmak, mint a realitás hiteles vizuális leképezései, amelyre a verbális híralkotás, vagy távolabbról tekintve a verbális érvelés nem képes. 
A vizuális retorika problematizálását tekintve a jelen tanulmány hármas megközelítést kínál, amelyeket szintén összekapcsol a produktum, procedúra, processzus triáddal. Disszertációm a vizuális retorikát komplex, összetett retorikának tekinti: egyfelől elöadásmódnak, azaz produktumnak tekinti, amely magában foglalja a vizuális retorika fogalmait; másfelől érvelésnek, tehát procedúrának tekinti, amely a már említett képi propozicionalitás problémájával foglalkozik; végezetül interpretációnak, azaz processzusnak tekinti, amely a vizuális retorika és a média kapcsolatát írja le.

\subsubsection{A vizuális retorika mint előadásmód/produktum: a vizuális retorika fogalmai}

\subsubsection{A kép fogalmi megközelítése}

Korunkban a képek jelentősége vitathatatlan; Tasnádi szerint a képek hiánya minden bizonnyal hamarabb feltünik a szemlélőnek, mint mindennapi jelenlétük, mivel mára életünk szerves részeivé, a hírmédia fő tartalmi elemeivé váltak. Történetét tekintve aligha ismerünk olyan kort, vagy kultúrát, amelyben a képeknek ne lett volna valamilyen társadalmi szerepük, használati formájuk, akár vallási, művészeti, ideológiai eszközökként, akár - mint napjainkban fogyasztási cikként (Tasnádi [2012]). Szintén érdekes megállapítás, hogy az emberi kommunikáció három jellegzetes formája (beszéd, írás, kép) közül a képről mondható el egyedül, hogy minden kultúrtörténeti korban jelen volt. Ugyan megjelenése tipikusan az ősi korszakra tehető, hosszú idő után a mai, posztmodern korban újra hétköznapi kommunikációs médiummá vált (Tasnádi [2012]).

Nyíri Kristóf $A$ gondolkodás képelmélete címü munkájában úgy fogalmaz, hogy az emberek elsősorban képekben gondolkodnak, és csak azt követően szavakban. Ez az elképzelés végigkísérte ugyan a Nyugat filozófiájának történetét, büszkén mutatkozott meg a brit empirizmusban, majd fejleszegve a 20. század első felében, világos megfogalmazást azonban sohasem nyert. Nem is nyerhetett mindaddig, amíg az érvelés, kifejtés és magyarázat nyelvének csakis a szónyelvet tekintették (Nyíri [2000]). Barthes hasonló problémát fejteget Image, Music, Text címümunkájában. A szó ősi etimológiája szerint az imágó szó az imitare (utánozni) kifejezésben gyökerezik (Barthes [1977] p. 32.). Ez pedig azonnal a kép szemiológiájával kapcsolatos legfontosabb problémához vezet bennünket: az analóg reprezentáció (a másolat) képes valódi jelrendszert előállítani, és nem egyszerủen csak szimbólumok agglutinációjaként 
tekinthetünk ráj? Tudjuk, hogy a nyelvészek elutasítják a nyelv jelenlétét minden más típusú kommunikációban, pl. a méhek „nyelve” vagy a gesztus „nyelv” olyan kommunikációs momentumok, amelyek nem kétszeresen artikuláltak, így nem digitális egységek kombinatorikus rendszereként értelmezzük, mint pl. a fonémákat. De nem a nyelvészek az egyetlenek, akik gyanakvóak a kép nyelvi természetét illetően; az általános vélekedés szerint is homályos a kép koncepciója, legalább is a nyelv és jelentés tükrében (Barthes [1977] p. 32.).

A következökben a képteóriákhoz, esztétikához, ikonográfiához, reprezentációelmélethez, filmelmélethez stb. kötődő megközelítések sokaságával nem áll módomban foglalkozni, értekezésemben a képek koncepciójának megragadására törekszem, bemutatva, hogy milyen jellemzö ismérvei vannak a képeknek, hogyan vethetök össze különböző fajta mondatokkal, illetve, hogy összességében, mitől kép egy kép.

Annak érdekében, hogy a képek koncepciójának megértéséhez közelebb kerülhessünk, disszertációm a továbbiakban John R. Searle A képi reprezentáció címü munkája alapján mutatja be a képek speciális jegyeit. Searle a képek következő tulajdonságait sorolja:

1. Intenzionalitás: Ahogyan a megnyilatkozásoknak és a mentális állapotoknak, úgy a képeknek is van intenzionalitás jegyük. Az állítások, vagy gondolatok kapcsolatban lehetnek egy tárggyal. Hasonlóképpen egy kép is lehet egy tárgynak a képe, vagy reprezentálhatja azt. És, ahogyan az egzisztenciális következmény és az ugyanazon tárgyra referáló kifejezések helyettesítése problematikus az egyik esetben, úgy a másikban is az.

2. A képek mint fizikai tárgyak és mint reprezentációk: A képek intenzionalitásának értelmezésekor fontos különbséget tennünk a fizikai tárgyként és a reprezentációként értelmezett kép között, intenzionális jegyük ugyanis csak az utóbbiaknak van. Így a következő a és b állítás nem vonja maga után $\mathrm{c}-\mathrm{t}$, hiszen az egyik esetben egy fizikai tárgy, a másikban pedig egy reprezentáció koncepciójaként értelmezzük azt.

a. Ezen a képen Napóleon lovagol.

b. Ez a kép azonos azzal a vászonnal, amelyre festéket kentek.

c. Ezen a festékkel bevont vászondarabon Naplóleon éppen lovagol.

E distinkció alapján beszélhetünk tehát a képek fizikai tárgyként való predikátumairól, és a képek reprezentációs predikátumairól 
3. Képi hasonlóság: Vannak olyan képek, amelyek hasonlítanak, tehát ténylegesen úgy néznek ki, mint azok a dolgok, amelyeknek képei. Searle felfogásában a sikeres képi reprezentáció szükséges feltétele, hogy a kép hasonlítson ábrázolt tárgyára. Ez tehát a fizikai tárgyként értelmezett kép és a reprezentált vagy ábrázolt tárgy között létrejövő fizikai viszony. Ha meg akarjuk határozni a köztük lévő intenzionális viszonyt, akkor arra kell rávilágítanunk, hogy miként foglalja magába a fizikai tárgyként értelmezett kép, valamint a reprezentációként értelmezett kép tárgya közötti természetes hasonlósági relációt. Fontos kiemelnünk azonban, hogy a hasonlóság nem elégséges feltétele a kép reprezentációnak, hiszen az természetes módon is létrejöhet, mint pl.: az árnyék vagy a lábnyom, amelyek közül egyik sem tekinthető reprezentációnak. A sikeresen reprezentáló képek valóban olyanok, mint a tárgy, amelyeknek képei. Ennek legkézenfekvőbb bizonyítéka, hogy pusztán képek alapján is felismerhetők olyan tárgyak, amelyeket korábban még soha nem láttunk. Searle azonban felhívja a figyelmet, hogy a hasonlóság felismerése nagyban függ a kifinomult gyakorlattól, a stílustól, a szokásoktól, a valamit valamiként látástól, és a néző részvételétől is.

4. A képi reprezentáció gyakorlata és egyes bele tartozó esetek közti megkülönböztetés: Searle különbséget tesz a képi reprezentáció gyakorlatával, valamint az ennek egyes eseteivel kapcsolatos kérdések között, amely distinkció a témával foglalkozó irodalomban gyakran elmarad. Azt mondhatjuk tehát, hogy a "hogyan reprezentálnak a képek?" kérdés kétértelműnek tekinthető:

a. Melyek a reprezentáció azon elemei, amelyek lehetövé teszik, hogy ez a tárgy kép legyen?

b. Melyek a tárgynak azon jegyei, adott gyakorlat esetén, amelyek döntőek abban, hogy képnek számít-e? (Searle [2003] pp. 205-208.).

A képi reprezentáció általános jegyeinek megadása után Searle a képi reprezentáció különböző speciális formáinak elemzésére tér rá. E formákat különböző fajta képek különböző fajta mondatokkal való összevetésen keresztül mutatja be. Az eddigiekhez hasonlóan Searle itt is a gyakorlat általános jegyeivel foglalkozik:

1. Típus: Képek, amelyeket olyan mondatokhoz hasonlóan használnak, amelyek sajátos tárgyakat vagy helyzeteket írnak le. 
Az ábrázolás legegyszerübb eseteinek azok tekinthetők, ahol az ábrázolt tárgy egy bizonyos tárgy vagy helyzet (pl.: egy jelenet fényképe, egy ember portréja, egy fötengely rajza). Az ilyen képekről mondhatjuk általában, hogy pontosak vagy pontatlanok, jó vagy gyatra hasonmások, élethűek vagy mesterkéltek stb. A kép használójának intenciója ezekben az esetekben hasonló ahhoz, amikor egy beszélő egy állító beszédaktust hajt végre.

2. Típus: Képek, amelyeket olyan mondatokhoz hasonlóan használnak, amelyek univerzális kvantort tartalmaznak.

Bizonyos képek nem sajátos tárgyat, inkább a tárgyak egy fajtáját ábrázolják. Audubon képe a szuláról (Sula bassana) nem egy sajátos madár ábrázolásának szándékával jött létre, hanem azért, hogy a (hím) szulák fajtáját reprezentálja. Így ez a kép - Ahogyan Audubon használta - azonos módon funkcionál egy univerzális kvantort tartalmazó állítással.

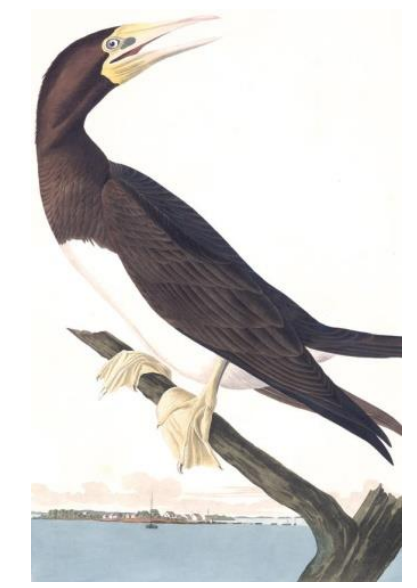

1. ÁBRA. A kép forráshelye: https://www.audubon.org/birds-of-america/boobygannet

3. Típus: Képek, amelyeket fiktív mondatokhoz és narrációhoz hasonlóan használnak.

Közismert, hogy nem minden kép készül olyan szándékkal, hogy valóságos tárgyakat vagy helyzeteket reprezentáljon. Egyes képek - bizonyos mondatokhoz vagy mondatsorokhoz hasonlóan - fiktív módon vannak prezentálva, azaz „olyan, mintha” reprezentációk. Az alkotó nincs elkötelezve az iránt, hogy az általa ábrázolt jelenet valóban megtörtént. A fiktív képek ugyanúgy a nem fiktív képeken „élősködnek”, mint 
ahogy a fiktív próza is parazitikusnak tekinthető a nem fiktív tükrében. A fiktív eset a nem fiktív „mintha” - példája.

4. Típus: Képek, amelyeket a felszólító mondatokhoz hasonlóan használnak.

Egyes képek az utasítás illokúciójával vannak prezentálva. A ház építészeti terve instrukcióhalmaz. Ahogyan az építész vagy vállalkozó használja, nem állításként, hanem utasításként funkcionál. A tankönyvi illusztrációk többsége is ilyennek tekinthető.

5. Típus: Képek, amelyeket tagadó mondatokhoz hasonlóan használnak.

A sítankönyvek gyakran nem csak arról tartalmaznak képeket, hogy mi a helyes testtartás kanyarodásnál, hanem azoknak a szokásos hibáknak az ellenképeit is tartalmazzák, bemutatva a kerülendő technikákat. Ezek egyszerre negatívak és felszólítók. Ezáltal a negatív felszólító mondatokhoz hasonlóan funkcionálnak.

6. Típus. Egyéb esetek.

Ugyan a reprezentáló képek leggyakoribb típusait a fentiekben már bemutattuk, ezzel nem meríettük ki a képek és mondatok lehetséges analógiájának teljes körét. Beszélhetünk még expresszív képekröl, amelyek az expresszív beszédaktusoknak felelnek meg. Léteznek bizonyos elkötelező mondatokhoz hasonlóként funkcionáló képek, pl.: a borbélynál látható frizura fotók. Lehetségesek továbbá hipotetikus mondatokhoz hasonlóan funkcionáló képek (háborús plakátok: mi lenne, ha...), vagy konjunkciókat tartalmazó mondatokhoz hasonlóan használt képek (elöször ez történik, később pedig az stb.) (Searle [2003] pp. 214-219.).

E fejezet utolsó elemeként a disszertációm empirikus hányadának szempontjából leginkább releváns fénykép fogalmát fejtem ki. A többi képtől eltérően a fénykép esetében döntő szerepet játszik a kauzalitás, hiszen a fénykép maga után vonja az ok-okazati összefüggést. A tárgy feltétele tehát a fényképnek. A „P egy képe $O$-nak” formájú állításoknak általában nem szükséges feltétele az, hogy $O$-nak okozati szerepe legyen $P$ létrehozásában. A „P egy fényképe $O$-nak” típusú állítások azonban logikailag maguk után vonják azt, hogy „O okozati szerepet játszott $P$ létrehozásában”. Ez az oka annak, hogy Sherlock Holmes-ról nincs fénykép, bár sok kép van róla. Ha valaki Sherlock Holmes-nak öltözik, az Holmes képe lesz, de semmiképpen nem fénykép. A fényképek és a kauzalitás viszonyának további implikálására Searle a következő példát hozza: képzeljük el, hogy egy kíváncsi férj és feleség kíváncsiságból saját genetikai struktúrájukra vonatkozó információkat táplálnak be egy kompjúterbe azért, hogy megnézhessék, 
milyen is volna elsőszülött gyermekük megszületésekor. Majd tegyük fel azt is, hogy a gyermek megszületésekor valóban hasonlít erre a képre. „Fényképe” ez a gyermeknek? A jelen kánon szerint nem, mivel a fénykép jelenlegi fogalma mellett a logikailag maga után von típusú viszony az érvényes - legalább is objektumok esetében. Searle felfogásában tehát a kauzalitás és a hasonlóság együttesen feltétele a fényképi reprezentációnak (Searle [2003] pp. 222-224.).

Susan Sontag szerint a fényképek gyüjtése olyan, mintha az egész világot gyüjtenénk össze. A fénykép készítőjét különös kapcsolatba helyezi a világgal, amely a tudás - és ezáltal - a hatalom érzését kínálja. A szokásos papíralapú tárgyak betegségei sújtják őket is: eltủnnek, és újra felbukkannak, megvásárolhatókká és eladhatókká válnak. A fényképeket gyakran kinagyítják vagy lekicsinyítik, megvágják és átdolgozzák, vizuális retorikai hatás esetében azonban semmi nem fontosabb, mint a pillanat ereje (a tudatos szerkesztéssel szemben). A Searle alapján fentebb kifejtett kauzalitás okán a fényképek bizonyítékokat szolgáltatnak. Ha olyasmit hallunk, amit kétségesnek találunk, bizonyítottnak tủnik, amint fényképet mutatnak be róla. Éppen ezért úgy tűnik, a fényképnek ártatlanabb, ezáltal pontosabb kapcsolata van a látható valósággal, mint a többi mimetikus tárgynak. Sontag szerint a közelmúltban a fotózás gyakorlatilag annyira széles körben gyakorolt szórakozássá vált, mint szex és tánc. Ez pedig azt jelenti, hogy - mint minden tömeges müvészeti formát -a fotózást sem múvészetként gyakorolja a legtöbb ember, melynek következtében a fotózás mára elsősorban társadalmi rítussá, a szorongás elleni védelemmé és a hatalom eszközévé vált (Sontag [1973] pp. 1-6.).

A fénykép (legyen professzionális vagy amatőr) leképezi a valóságot, bizonyít, megvéd és hatalmat ad, az állókép legfontosabb tulajdonsága azonban mégsem ez. Az állókép a jelenben szemlélődőt visszarepíti a megörökített múltba; ezáltal egyszerre szakít ki a valóságból és absztrahál. A mozgókép ezzel szemben mindig jelen idejüvé teszi a múltat (vagy jövőt) a mozgás illúziójának segítségével. Barthes a fényképek és a filmek közti különbséget a having been there és a being there kifejezés segítségével magyarázza. Minden fényképben van ugyanis valamilyen bódító bizonyíték arra, hogy hogyan voltak a dolgok, a filmekben pedig arra, hogy most hogyan vannak (Barthes [1977] p. 45.).

A fényképeket az idővel való viszonyuk teszi emlékezetesebbé a mozgóképeknél; hiszen az idő egy szeletét mutatják be, nem pedig annak áramlását. Minden egyes fénykép egy adott pillanatba repít minket vissza, vékonyka kis tárgy formájában megörökítve, amit újra és újra 
elővehetünk, megnézhetünk. Az olyan fotók, mint az 1972-ben leggyakrabban a címlapon látható, meztelen dél-vietnámi gyermeket ábrázoló kép, amelyen a kislány kitárt karokkal, sírva szalad a kamera felé, miközben az amerikaiak napalmmal bombázzák, valószínüleg többet tett a háború elleni nyilvános felszólalás növeléseért, mint százórányi televíziós filmanyag (Sontag [1973] p.13).

\subsubsection{A ,presence" fogalma}

Miben áll hát a képek hatalma, honnan veszik meggyőző erejüket a vizuális elemek? A képek jelentés- és valóságalkotása egyedülállónak tekinthető. Ahhoz azonban, hogy felfedjük, hogyan is érvelnek a képek, milyen módon alakítanak ki bennünk realitásokat, fontos definiálnunk a valóság fogalmát. Vitéz Ferenc szerint minden olyan tárgyat, eseményt vagy jelenséget valóságnak tekinthetünk, amely úgymond „tanúk” nélkül is létezik, megtörténik, valamint amelyet a nézés segítségével válogató szubjektum még nem formál át egy fotózandó tárgy jelévé (Vitéz [2012]). Jól teszik-e vagy sem, az emberek általában hisznek a média képeinek, valósághü természetük miatt. Charles A. Hill The Psychology of Rhetorical Images címü tanulmányában olyan koncepciókat keres, amelyek jól alkalmazhatók a képek és a képi retorika erejének, belső szerkezetének bemutatására (Hill [2008] pp. 27-29.). Egy ilyen lehetséges koncepció a Perelman és Tyteca által bevezetett jelenlét (presence) fogalma, amelyet a szerzőpáros az alábbi módon magyaráz (Perelman [1979] p. 17.). A Retorika Birodalma címü müvében Perelman úgy fogalmaz, hogy amikor egy bizonyos elemet kiválasztunk, megjegyzünk és előadunk a beszédben, akkor azok a tudat előterébe kerülnek, ezáltal jelenlétet adunk nekik, amely megakadályozza, hogy ezeket az elemeket figyelmen kívül hagyjuk. A jelentés bizonyos módon közvetlenül hat az érzékeinkre: egy tárgy bemutatása, pl.: Julius Caesar véres tógája, amelyet Antonius a magasba emelt, azonnali hatást ér el. Az tehát, ami jelen van, tudatunk előterébe kerül és fontossá válik, míg az, aminek nem kölcsönzünk jelenlétet, veszít fontosságából, absztrakttá, szinte nem létezővé válik. A kapcsolat pedig, amely bizonyos elemek tudatban való jelenléte és a nekik tulajdonított jelentőség között alakul ki, lehetővé teszi, hogy a retorikában ne lássunk mást, mint az előadásmód technikáinak köszönhetően létrejövő jelenlét megteremtésének mủvészetét, magunkhoz ragadva ezzel a közönség figyelmét és irányítva érzelmeit. Már pedig csak akkor vagyunk képesek megteremteni a kívánt érzéseket, ha egy tárgyra irányítjuk őket (Perelman [2018] p. 52.). 
Perelman és Tyteca szerint a legtöbb retorikai szituáció meglehetősen komplex, mivel két vagy több fél igyekszik elnyerni a közönség bizalmát és jóindulatát, miközben a hallgatóság arra törekszik, hogy eldöntse, mi lehet az igazság, melyik álláspontot célszerü támogatni a szóban forgó ügyben. Ezekben a helyzetekben a befogadóknak tényezők sorát kell megítélni olyanokét, mint például statisztikák, táblázatok és grafikonok, anekdoták és más elbeszélések, fizikai bizonyítékok, vagy éppen elvont etikai és filozófiai érvek. Ezek az elemek mind fontosak lehetnek a közönség meggyőzését illetően, azonban a kommunikátornak elővigyázatosnak kell lennie, nehogy az információk tengerében bizonyos érvek, befolyásoló tényezők feledésbe merüljenek. E veszély elkerülése érdekében egy jó rétor azon tényezőkre irányítja a közönség figyelmét, amelyekből a legnagyobb haszna lesz az érvelés befejeztével. Több okból is rendkívül nehéz lehet meggyőzni az embereket arról, hogy foglaljanak állást, mi több, gondolják meg magukat bizonyos dolgokkal kapcsolatban. Olyan kérdéseket illetően, amelyekkel kapcsolatosan a közönség nem rendelkezik kellő tudással vagy tapasztalattal, előfordulhat, hogy elutasítják a döntéshozatal lehetőségét, de vannak olyan külső hatások is, amelyek nagyban befolyásolják a hallgatóság véleményét, például a kommunikátor hanglejtése, megjelenése és egyéb faktorok, amelyek a hitelességet és megbízhatóságot befolyásolhatják. Ezen kívül fontos számításba venni a befogadók eredendő hiedelmeit, vagy véleményét, hiszen ezek is döntően meghatározzák jövőbeni attitűdjeiket.

Számos pszichológiai teszt támasztja alá, hogy az emberek hajlamosak azon nézeteket támogatni, amelyekkel eredendően egyetértettek, míg a felhívás azon vélemények újragondolására, vagy egy esetleges új attitüd kialakítására rendkívüli erőfeszítést igényel, és gyakran kudarcba fullad (Andsager - White [2007] pp. 64-65.). Így tehát mindegy, hogy egy adott érv/érvrendszer mennyire logikus vagy érvényes, nem biztos, hogy releváns vagy elegendő a cél elérése érdekében. A legnagyobb kihívás a rétor számára tehát, hogy azokat a tényezőket, amelyek leginkább alátámasztják pozícióját, relevánssá, emlékezetessé és feltünővé tegye. Ezek fényében a Perelman és Tyteca által használt jelenlét kifejezés arra a mértékre utal, amennyire egy tárgy vagy fogalom mindenekelött megragad a közönség tagjainak tudatában. Ahogyan a szóbeliségben az ismétlés, metabola, anafora vagy az amplifikáció képezi a jelenlét erősítésének eszközét (Perelman [1979] p. 18.), úgy Roland Barthes szerint a képek természetüktől fogva magas jelenléttel bírnak. A nyelvészprofesszor ugyanis úgy véli, hogy a fénykép - definíció szerint - egy tárgy vagy személy elkapott reflexiója, amely valóban létezik vagy létezett adott 
időben, tehát a fotó valamilyen módon bizonyíték a tárgy vagy személy létezésére, e létezés körülményeit körülölelő manipulációs technikák ellenére, amelyek a sötétkamrában mennek végbe (Hill - Helmers [2008] p. 29.). (A kijelentés az új digitális képmanipulációs technikák figyelmen kívül hagyásával értendő.) A jelenlét tehát nagyon fontos szerepet játszhat bizonyos nézetek elfogadásában vagy elutasításában (Gross - Dearin [2003] p. 136.). Így a rétor arra törekszik, hogy a retorikai szituáció meggyőzés szempontjából lényeges elemeinek jelenlétét minél inkább növelje, ennek érdekében pedig számos eljárás alkalmazható.

\subsubsection{A ,vividness" fogalma}

A leghatékonyabb módja annak, hogy növeljük egy adott tárgy retorikai jelenlétét, hogy fizikálisan megjelenítjük azt, erre azonban gyakran nincsen lehetőség. Ezáltal a jelenlét jelensége elválaszthatatlanul kapcsolódik a vizuális percepciókhoz. Kiváló példa lehet, hogy egy éhező gyermeket ábrázoló kép vagy fotó jóval nagyobb meggyőzőerővel bírhat, mint több millió ember éhezését bemutató statisztikák (Hill [2008] p. 29.). Vagy, hogy a Perelman és Tyteka által idézett kínai történet példáját említsem: „Egyszer a király megpillantott egy ökröt, amelyet éppen feláldozni készültek. Megrendültségében azt parancsolta, hogy inkább egy báránnyal helyettesitsék azt. Késöbb bevallotta, hogy azért tett igy, mert az ökröt saját szemével látta, a bárányt azonban nem” (Perelman -Tyteca [1971] p. 116.). ${ }^{6}$ A jelenlét tehát közvetlenül hat érzékeinkre, érzéseinkre. Ahogyan Bacon is mondja, a retorika legföbb kötelessége, hogy az akarat könnyebb irányítása érdekében hozzárendelje az észérveket képzeletünkhöz (Bacon [1994] p. 120), amellyel arra utal, hogy a jelenlét eleinte pusztán pszichológiai jelenség, majd az érvelés elengedhetetlen elemévé válik. Ha tehát a király a saját szemével látja a kivégzendő ökröt, sokkal ,jelenlévőbbé” válik számára, mintha csak tudtára hozzák, hogy rövidesen kivégzik az állatot. Habár saját tapasztalataink alapján mindannyian felismerjük e jelenséget, mégis nehezünkre esik megmagyarázni, miért is van ez így. Ha feltételezzük, hogy az éhező gyermeket ábrázoló kép egy fénykép, úgy gondolhatjuk, hogy az több episztemikus erővel bír a szónál, mivel a fotó létezése feltételezhetően bizonyítja tárgyának létezését is (szintén az új digitális képmanipulációs technikák figyelembevétele nélkül). Ennek alátámasztására Hill Charles Sanders Peirce jelelméletére hivatkozik, az amerikai származású filozófus/logikus ugyanis a

\footnotetext{
${ }^{6}$, , A king sees an ox on its way to sacrifice. He is moved to pity for it and orders that a sheep be used in its place. He confesses he did so because he could see the ox, but not the sheep."
} 
jeleket három kategóriába sorolja: az ikon, index és szimbólum osztályába. Amennyiben a jel és a jelölt dolog között hasonlóságon alapuló kapcsolat áll fenn, és tárgya nem létező, ikonról beszélhetünk. Peirce szerint egy grafitceruzával húzott csík jelölhet egy geometriai egyenest, kapcsolatuk pedig ikonikus (Hoopes [1991] p. 239.). Az index esetében a jel és a jeltárgy között valamilyen valós, fizikai kapcsolat van (pl.: golyó ütötte lyuk a falon, vagy lábnyomok a homokban), míg a szimbólum önkényes jel, ahol a jeltárgy és a jel kapcsolata valamilyen agyi asszociációra, szabályra vagy konvencióra vezethető vissza (Pietarinen [2006] p. 27.). A peirce-i értelemben a fénykép indexnek minősül, hiszen a jel és tárgya között valós kapcsolat van, tehát a fénykép létezése egyértelmüen bizonyítja tárgya létezését. Így jogosan gondolkodunk úgy, hogy a fotón szereplő, éhező kisgyereknek valósnak kell lennie, míg a statisztikák lehetnek pontatlanok, félrevezetők, sőt hamisak is. Ezért racionálisan járunk el, ha inkább a „létező” gyermekre fektetjük a hangsúlyt.

A vizualitás érzelmi válaszokkal, a verbalitás racionális válaszokkal való azonosítása gyakorta megtörténik, Hill szerint azonban mégsem üdvözlendő. Néhány vizuális jel ugyanis rendkívül racionális (pl.: oszlopdiagramok, vonaldiagramok és egyéb, statisztikai összefüggéseket ábrázoló komponens), számos pszichológiai kutatás pedig azt bizonyítja, hogy szavakkal is könnyedén ki lehet váltani érzelmi válaszokat. Az az általános felfogás, hogy egy narratív vagy deskriptív szöveg olvasásakor úgynevezett „mentális képek” alakulnak ki az olvasóban, a neurológiai vizsgálatok pedig azt bizonyítják, hogy ez szó szerint értelmezendö, mivel az agynak olyan területei aktiválódnak ilyenkor, amelyek a vizuális elemek feldolgozásáért felelősek. Ezek a mentális képek pedig hasonló érzelmi reakciókat képesek kiváltani, mint amikor egy tényleges képet néz a befogadó. A mentális képek szöveg olvasásán keresztül történő kialakulása és a célszemély attitüdjeinek és hiedelmeinek felülbírálása közötti kapcsolatot a pszichológusok az élénkség (vividness) koncepciója alapján magyarázzák. A pszichológiai kutatások úgy definiálják az élénkséget, mint érzelmileg érdekes és konkrét információk halmazát (Hill [2008] p. 31.), míg Spence és Deroy szerint az élénkség nem más, mint a kép gazdagságát és részletességét leíró tényező Spence - Deroy [2013] p. 162.). Cornoldi et al szerint az élénkség a mentális képek két tulajdonságára utalnak: a.) A mértékre, amennyire a képek megközelítik a valós vizuális tapasztalatokat b.) A kép érthetőségére, egyértelműségére (Cornoldi et al [1991] p. 105.) Az élénk információk konkrét, képi nyelv formáját öltik, személyes narratívákat, képeket, első kézből jövő élményeket, tapasztalatokat bemutatva. Az 
élénkség fokának meghatározása meglehetősen komplikált folyamat, általánosságban azonban azt mondhatjuk, hogy a tényleges tapasztalatok nagyobb élénkséggel, intenzitással bírnak (pl.: ha megtámadnak, vagy baleset ér bennünket, ide tartoznak továbbá a hanggal ellátott mozgóképek, statikus fényképek, realisztikus festmények stb., amelyek szintén magas élénkségü tényezők), a legkevésbé élénk információknak pedig az elvont, személytelen nyelvezetet és a statisztikákat tekinthetjük (Hill [2008] p. 31.).

A kép értékelési dimenzióin túl, amelyek felfoghatók intenzionalitásként, reprezentációként, hasonlóságként, mondatként stb., értekezésem a kép további jellemzőinek, a jelenlét és élénkség fogalmainak bemutatására vállalkozott. Ugyanakkor fontos kiemelnünk, hogy a képet nem tekinthetjük valamely egységes, monolit jelenségnek - amellett, hogy van egy érzékelhető valósága - hiszen befogadója, intenzitása, kontextusa stb. jelentősen befolyásolja azt, ami.

\subsection{A vizuális retorika mint érvelés/procedúra}

Ahogyan azt az előbbiekben említettem, számos kutató, élükön Leo Groarke-kal a vizuális érvelés újfajta elméletének kidolgozását szorgalmazza, az informális logika újraértelmezésével. Olyan teoretikusok támogatják e nézetet, mint Blair, Birdsell, Shelley, Gilbert vagy Slade (Johnson). Birdsell és Groarke szerint a vizuális érvelés komolyan vétele az argumentációelmélet minden aspektusára nézve fontos következményekkel bír, hiszen ezek többsége egyfajta verbális paradigmát hangsúlyoz, amely az érvelést szükségszerüen úgy látja, mint szavak összességét (Birdsell -Groarke [1996] p. 1.). Éppen ezért a legtöbb olyan kutató, aki argumentáció elmélettel foglalkozik, olyan érvek elemzését szorgalmazza - az említett szerzőpár egyet nem értését kiváltva ezzel - amelyek az érvelés verbális elemeit hangsúlyozzák és csekély, vagy egyáltalán semmilyen jelentőséget nem tulajdonítanak olyan más lehetőségeknek, amelyek a verbális egyéb szimbolikus formákkal való kapcsolatát indikálnák. A jelen disszertáció éppen ezért törekszik átfogó képet nyújtani a vizuális érvelés érvényben lévő, gyakran egymásnak ellentmondó elméleteiről, azt az álláspontot erősítve, hogy a vizuális érvelés - a képek propozicionális természetéből adódóan- értelmezhető úgy, mint önálló fogalmi entitás. 


\subsubsection{A vizuális retorika és az érvelés problémája}

A rendelkezésre álló szakirodalmat feltérképezve észrevehető, hogy számos kutató, számos indokból cáfolja a nem nyelvi érvelés létezését. Perelman és Tyteca New Rhetoric címü müvében például úgy fogalmaz, hogy az a legcélravezetőbb, ha a gondolatok összekapcsolódásának (adherence of minds) diszkurzív eszközeit vizsgálják, vagyis csupán azt a technikát, amely a nyelv segítségével törekszik meggyőzni, befolyásolni (Perelman - Tyteca [1971] p. 8.). Az említett szerzőpáros mellett Eemeren, Grootendorst és Kruiger is úgy gondolja, hogy az érvelés elkerülhetetlenül verbális, mivel mindenképpen szüksége van a nyelvhasználatra. A szerzők szerint az érvelés folyamatában részt vevő személy tesz egy állítást, kinyilatkoztat, feltételez, kétell vagy tagad valamit, és ezen tevékenységek végrehajtásához (szóban elhangzó, vagy írott) szavakat, esetleg mondatokat használ. E verbális eszközök mellett természetesen alkalmazhat nem verbális konstrukciókat is, pl.: különböző arckifejezések vagy gesztusok. A szerzők véleménye szerint ezeket a nonverbális funkciókat verbális eszközök segítségével explicitté lehet ugyan tenni, de sohasem helyettesíthetik azokat, mivel az érvelés nyelvhasználat nélkül lehetetlenség (Fleming [2005] p. 2.). Thinking Without Words címü müvében Bermúdez amellett érvel, hogy a nem nyelvi gondolkodáshoz a propozíciók nem nem-propozicionális alternatívájának kidolgozására van szükség, mivel a nem nyelvi gondolkodás aligha összevethető a propozicionális tudással (Bermúdez [2003] p. 38.). Az említett kutatókhoz hasonlóan Toulmin, Rieke és Janik is úgy gondolja, hogy nyelvhasználat hiányában az érvelés nem létezhetne. An Introduction to Reasoning címü könyvükben úgy fogalmaznak a szerzők, hogy mind az állítások, mind pedig az azokat alátámasztó megfontolások egyfajta nyelvi szimbólumrendszer által kerülnek kifejezésre, ezáltal a nyelv és érvelés mélyen, sőt, elválaszthatatlanul egybefonódik (Toulmin et at [1984] p. 201.). Kneupper szerint a nonverbális eszközök használhatóak ugyan az érvelés során, mégsem funkcionálnak érvként, ameddig nincsenek nyelvileg lefordítva, míg Balthrop úgy fogalmaz, hogy az érvelés eredendően diszkurzív és nyelvi (Fleming [2005] p. 2.).

Blair és Johnson úgy gondol az érvelésre, mint egy kijelentésre, amelyet az érvelő egy vagy több érv segítségével igyekszik alátámasztani (Blair - Johnson [1994] p. 10.). Fleming ezt a definíciót azzal egészíti ki, hogy az érvelés egyfajta kétoldali relációt tartalmaz, amelynek egyik részét az adatok, érvek, alátámasztó bizonyítékok képezik, míg a másik az álláspontra, állításra, tézisre vagy konklúzióra utal. Emellett kiemeli, hogy egy érvelés mindig korrigálható, kétségbe 
vagy felelősségre vonható, ezáltal olyan aktus, amely mások által szabadon megkérdőjelezhető, kritizálható és továbbgondolható. Így az érvelés a vita egy specifikus kontextusában létezik, ellentmondások, kételyek és ellenérvek között, álláspontja ezért szükségszerüen támadható (Fleming [2005] p. 2.). Ezek alapján Fleming úgy gondolja, hogy a képek sok mindenre képesek ugyan, de ezen kritériumok kielégítésére semmiféleképpen sem. Véleménye szerint egyrészt hiányzik a képekben a szükséges belső különbségtétel, azaz egy kép esetében lehetetlen megbízhatóan elkülöníteni az álláspontot és az azt alátámasztó bizonyítékokat. Másrészt a szerző úgy véli, hogy egy képet nem lehet biztonsággal cáfolni vagy tagadni. Ellent lehet neki mondani ugyan, ez azonban Fleming szerint csak szavak használatának segítségével történhet, a kép maga ugyanis nem tesz állítást, amelyek vitathatóak vagy kétségbe vonhatóak lehetnének. Így, ha valaki cáfolja képünk általunk megfogalmazott mondanivalóját, egyszerüen letagadhatjuk, hogy képünk valaha is azt állította volna, ennél fogva Fleming úgy véli, hogy egy kép álláspontja csak akkor megdönthető, ha először lefordítjuk azt beszélt vagy írott nyelvre, ezzel azonban teljes mértékben elhagyjuk a képek birodalmát.

Ralph Johnson Why „Visual Arguments” aren't Arguments címü írásában olyan, a vizuális érvelésre nézve meglehetősen provokatív kérdéseket tesz fel, hogy miért szükséges megalkotni a vizuális érvelés elméletét, milyen lenne ez az elmélet és mi hasznunk lenne abból, ha sikerülne egy egységes fogalmi meghatározást megteremteni, amikor az szükségszerüen kezdetleges, gyenge és törékeny lenne (Johnson). Ez a kijelentés, ami nyilvánvalóan azt implikálja, hogy nem kell figyelembe vennünk, mi is maga a vizuális a vizuális érvelésben, jellemző arra a gondolkodásmódra, amelyet a szakirodalom nyelvi imperializmusként tart számon (Roque [2009]). Ugyancsak ebben a munkájában Johnson Leo Groarke Logic, Art and Argument címü tanulmányában megfogalmazott nézeteit kritizálja, különböző szempontok alapján. Johnson véleménye szerint ugyanis Groarke-nak igaza van ugyan a vizualitás prominens voltát tekintve kortárs kultúránkban, az új elmélet kidolgozásának alapját azonban nem az informális logika újragondolásában látja. Szerinte ugyanis más elemzési és értelmezési módszerek sokkal hasznosabbak lehetnének a vizuális tudatosság új teóriájának megalkotásában, különös tekintettel a szemiotikai vagy üzenet/kommunikációtervezési elméletekre (Johnson). A szavak és képek összefonódását tekintve Johnson szintén egy másfajta megfogalmazást javasol: véleménye szerint ugyanis a szavak és képek közötti szimmetria abban rejlik, hogy a vizuális érvelés alapja a kép, a verbális érvelés alapja pedig az állítások és következtetések rendszere, 
azonban a képek által közvetített propozíciók nem pontosan meghatározhatók és érthetők. Ezért Johnson, a már fentiekben említett kutatókhoz csatlakozva úgy gondolja, hogy a vizuális érvelés erősen függ a verbális megnyilvánulásoktól, ezáltal illusztrálva, hogy a képek, mint érvek rekonstrukciójának folyamata azon múlik, hogy képesek vagyunk-e azokat szavakra „lefordítani”, a verbális érvelés során elsajátított tapasztalataink alapján. Szerinte tehát a képi érvelés folyamatát tekintve a befogadónak először észre kell vennie, hogy a képek érveket tartalmaznak, ezt követően pedig le kell fordítania, át kell konvertálnia a képeket propozíciókká. Tanulmányában Johnson úgy fogalmaz, hogy ,a folyamat, amellyel a kép átalakul az általa közvetített propozícióvá nem egyértelműen meghatározható, vagy egyelőre nem jól ismert, de ahogyan jelenleg értelmezni tudjuk, számomra úgy tünik, hogy a müvelet erősen függ a verbális érveléstől és annak megnyilvánulásaitól" (Johnson). ${ }^{7}$

Karl Bühler az emberi kommunikáció legfontosabb eszközének a nyelvet tekinti, amelynek három funkcióját különíti el, ezek pedig: a kifejezés, a felhívás és a leírás funkciója (ezek nevezhetők szimptómának, jelzésnek és szimbólumnak is) (Gombrich [2003] pp. 92-107.). Akkor beszélhetünk kifejező beszédaktusról, ha az a beszélő lelkiállapotáról informál, pl.: boldog, mérges, szomorú, míg a felhívás funkciónak az a célja, hogy egy bizonyos lelkiállapotot váltson ki a címzett személyben, pl.: felvidítson, elkeserítsen, feldühítsen stb. Ez a két kommunikációs funkció más - nem emberi - lényeknél is megtalálható, az utolsó, leíró funkció megléte azonban arra enged következtetni, hogy az emberi nyelv ennél többre képes. A leíró beszédaktus során a beszélő képes informálni beszédpartnerét múltbéli, jelenlegi vagy jövőbeli tényállásokról, megfigyelhető vagy távoli, tényleges vagy esetleges eseményekről. Gombrich példájával élve a beszélő mondhatja azt, hogy „,esik”, „esett” vagy „esni fog”, illetve „ha esik az eső, maradok”. A nyelv segítségével szintén lehetséges elkülöníteni az olyan apró partikulákat, mint a „ha”, ,amikor”, „nem”, „mert”, „mint” vagy „némely”, amelyek a nyelv logikai felépítését teszik lehetővé. Ugyanakkor Gombrich úgy véli, a vizuális imágó esetében nem minden említett funkció alkalmazható. Szerinte a vizuális imágó kitünő felhívó szerepben, meglehetősen problémás kifejező szerepben, és kiegészítő támpontok nélkül pedig teljességgel képtelen arra, hogy a nyelv leíró funkcióját ellássa (Gombrich [2003] pp. 92-107.).

\footnotetext{
${ }^{7}$, ,The process of going from the image to the propositions they convey is not clearly defined or nor yet well understood, but to the degree that we can understand it, it seems to me that process will be heavily dependent on verbal reasoning and verbal expressions of reasoning..."
} 
Általánosan azt mondhatjuk, hogy a verbális nyelv par excellence nyelvnek tekintendő. A 20. századi francia nyelvész, Benveniste azzal támasztotta alá e koncepciót, hogy - meglátása szerint - sok különböző szemiotikai nyelv létezik, a nyelvnek azonban van egy olyan kiváltsága, amely által meta-szemiotikainak tekinthető, ezáltal válik minden szemiotikai rendszer elemzőjévé, leírójává (Benveniste [1974] p. 58.). Ezen elmélet is azt a felfogást erősíti, hogy a verbális érvelés az érvelés alapkategóriája, ezáltal egyértelművé téve, hogy a verbális érvelés szinte minden definíciója a nyelvhasználat szükségességét támogatja, elutasítva ezzel a vizuális érvelés lehetőségét. Nem nehéz tehát a szakirodalomban olyan korlátozó definíciót találni, amely kizárja a vizuálist az érvelés birodalmából. Fontos azt is észrevennünk, hogy az érvelés ilyen jellegủ meghatározásában a „nyelv” szó puszta jelenléte képes megtagadni a vizuális érvelés esélyét, számos szerző ugyanis azt állítja, hogy az egyetlen nyelv a verbális nyelv, ezáltal indikálva, hogy a vizuális semmiképpen nem lehet az. Ez azonban, Roque véleménye szerint, pusztán annak függvénye, hogy hogyan definiáljuk a nyelv szót. A nyelv általános meghatározásakor a kettős artikuláció jelenségét szokás kiemelni, amely azt jelenti, hogy a nyelv szerkezete két egységtípusra osztható: az első artikuláció szintjén az üzenetet jelentéssel bíró egységekbe szerkesztjük, ezek az egységek pedig olyan nyelvi jelek, amelyek a jelölőből és a jelöltből állnak. Az első artikulációs szint legminimálisabb egységét monémának nevezzük (aminek az amerikai lingvisztikai terminológiában a morféma felel meg). A második artikuláció szintjén a monémákat alkotó fonetikai jelölők jelentéssel nem bíró, de megkülönböztethető egységekre, úgynevezett fonémákra bonthatók (írott nyelvi megfelelöik a grafémák). Ezek egyetlen funkciója, hogy a monémákat megkülönböztethessük (Chandler [2007] p. 244.). Mivel a vizuális nem képes megfelelni ezen követelményeknek, ezért számos kutató szerint nem lehetséges azt nyelvnek tekinteni. Eemeren-nel és Grootendorst-tal egyetértve azonban kijelenthető, hogy, ugyan az érvelést leggyakrabban verbális cselekvésnek írják le, amely a nyelvhasználat által válik szociális és racionális tevékenységgé, a gyakorlatban az érvelés folyamata számos esetben részben, vagy egészében nonverbális (Eemeren - Grootendorst [2004] p. 2.).

Words and Images in Argumentation címü tanulmányában Aspeitia a vizuális érveléssel kapcsolatos fent említett kritikáknak gyökeresen ellentmondva arra tesz kísérletet, hogy bemutassa, milyen nélkülözhetetlen szerepet játszanak a képek az érvelésben, mivel közvetlenül és jelentős mértékben járulnak hozzá a premisszák és konklúzió szerepét játszó propozíciók 
kommunikálásához (Aspeitia [2011] p. 123.). Arra a kérdésre, hogy a képek vajon pusztán illusztrálják, díszítik, illetve kísérik a verbális érveléseket, vagy a nyelvi megnyilatkozásokhoz hasonlóan felfoghatók a beszéd vagy kommunikáció aktusaiként úgy válaszol, hogy a képeknek semmiképpen sem pusztán illusztratív vagy díszítő funkciói vannak egy érvelés során. Aspeitiaval, és számos más kutatóval egyetértve magam is úgy gondolom, hogy a képek sok esetben tölthetnek be díszítő, illusztratív funkciót, legfőbb rendeltetésük mégis az, hogy közvetlenül járuljanak hozzá az érvelés egyik kulcskomponensének, a premisszák és konklúzió kifejezését szolgáló propozíció közléséhez. Tanulmányában Aspeitia úgynevezett heterogén érvekkel foglalkozik, amelyek nem egyetlen médiumon keresztül közvetített érvek, hanem a verbális és vizuális forrásokat párhuzamosan felhasználó argumentumok. Véleménye szerint ugyanis gyakran elöfordul, hogy az érvelök zökkenőmentesen és sikeresen kombinálják a verbális és vizuális eszközöket érveik vagy álláspontjaik ismertetése érdekében. A képek ebben az esetben szintén nem pusztán azt a célt szolgálják, hogy a szavaknak nagyobb erőt vagy díszesebb körítést adjanak, hanem nélkülözhetetlen elemei a premisszák és konklúziók kifejezésének. Ha a képeket eltávolítjuk az ilyen heterogén érvelésekböl, egy hiányos üzenetet kapunk, amelyet nem tudunk teljessé tenni implicit vagy kontextuális információk alapján (Aspeitia [2011] p. 123.). Az Aspeitia által heterogén érv kifejezést Hocks és Kendrick hibridizációnak hívja, szintén utalva ezzel a textuális és vizuális kultúrák egybeolvadására (Richards [2009] p. 8.). Tanulmányában Roque úgy fogalmaz, hogy az az elképzelés, amely szerint a vizuális érvelésnek a nyelvre van szüksége ahhoz, hogy verbalizáljuk, a szemiotikusok arroganciájából fakad, hiszen ezáltal teljes mértékben elveszítenék vizuális természetüket. Az ilyen érvelés, a szerző véleménye szerint feltehetőleg a szavak és képek szigorú és abszolút elválasztásában gyökerezik, pedig a képek és a szavak erős átfedést mutatnak, így lehetetlen volna elképzelnünk a képek univerzumát szavak nélkül, vagy a szavak univerzumát képek nélkül (Roque [2009]).

Még ha el is fogadjuk a vizuális és verbális érvelés közötti potenciális különbségeket, számos oka van annak, hogy miért nem szabad mégsem éket vernünk a két terület közé. Groarke szerint ezek közül négyet feltétlenül érdemes megemlítenünk. Először is, a meggyőzés és a nemlogikai kifejezésmód, amelyet feltételez, ugyanúgy a verbális érvelés fontos jellemzői, mint a vizuálisé. A meggyőzés ennek fényében tehát se nem kizárólag verbális, se nem kizárólag vizuális fogalom, szerves részét alkotja mind a két érveléstípusnak. Másodszor, a képekkel kapcsolatos olyan negatív konnotációk, amelyek azok emocionális és félreérthető voltára utalnak 
(lásd részletesen alább) eltúlzottak és megalapozatlanok. Számos vizuális elem jelentése - pl.: térképek, rajzfilmek, festmények, statisztikák - lehet pontos, precíz és érzelemmentes. Harmadszor, az érvek rejtettségét gyakran egyedül a vizuális érvelés sajátosságának tekintjük, pedig számos elmélet azt támasztja alá, hogy legszignifikánsabb verbális érvek implicite jelennek meg. Végezetül, Groarke szerint a vizuális érvelés tartalmazhat premissza-konklúzió szerkezeteket, ezáltal értelmezhető az érvelő meggyőzés fogalomkörén belül, túlmutatva ezzel a puszta meggyőzés határain (Groarke [1996] p. 107.). From Texts to Pictures: The New Unity of Science címü tanulmányában Nyíri Kristóf a következő állításokat fogalmazza meg a képekkel, képi érveléssel kapcsolatosan. Elöször is, véleménye szerint van, hogy a képek akkor is eljuttatják a kívánt üzenetet, amikor a szavak nem elegendők. Másodszor pedig a képek, különösen az animált képek (önmagukban, vagy szavakkal kombinálva) elég hatékonyan képesek gyakorlati tudást közvetíteni. Ennek demonstrálására Nyíri Einsteint idézi, aki számára a vizuális mellett a verbális folyamatok csupán másodlagos szerepet töltenek be. A 20. század legnagyobb elméleti fizikusa szerint ugyanis a szavak, vagy maga a nyelv - legyen az szóbeli vagy írott - nem játszanak semmilyen szerepet a gondolati mechanizmusainkban. Azok a fizikai entitások, amelyek gondolataink elemeiként szolgálnak valójában bizonyos jelek, vagy többékevésbé tiszta képek, amelyeket önkényesen reprodukálhatunk és kombinálhatunk (Nyíri [2003]). Az előzőekhez csatlakozva Pessi Lyyra tanulmányában José Luis Bermúdez Thinking without Words című munkáját elemzi, szintén azt állítva, hogy gondolataink, koncepcióink teljes mértékben függetlenek a nyelvhasználattól (Lyyra [2005] p. 9.).

\subsubsection{A három legfontosabb ellenérv és cáfolatuk}

A korábbiakban kifejtett kritikák mellett a szakirodalom három releváns ellenérvet tart számon a vizuális érvelés lehetőségét illetően. A jelen disszertáció fő célkitűzése ezek ismertetése és cáfolása.

1. Az egyik legelterjedtebb elöítélet a képi érveléssel kapcsolatosan, hogy a képek általánosan homályosak és kétértelmüek, így nem képesek érvelői tevékenységet ellátni.

2. A másik lényeges, és talán a legfontosabb kifogás a vizuális érvelés lehetőségével szemben, hogy a vizuális kommunikáció nem tartalmaz igazságértéket, ezért nem 
képes propozíciókat közvetíteni, pedig az érvelés megköveteli bizonyos propozíciók jelenlétét ahhoz, hogy ellássa feladatát.

3. Az utolsó kritika a vizuális érvelést illetően pedig az, hogy bár lehetséges nemverbális eszközöket alkalmazni az érvelési folyamatban, azok mégsem minősülnek érvnek egészen addig, amíg nyelvileg le nem fordítják őket.

\subsubsection{A homályosság problematikája}

Az első feltételezés, azaz, hogy a képek általánosan homályosak, önkényesek és kétértelmủek, azt a nézetet erősíti, hogy a képek kevésbé precízek, mint a szavak, különösen az írott szavak (Birdsell - Groarke [1996] p. 2.). Ennek prezentálására Gombrich a következő példát hozza: „A macska a szőnyegen van.” Véleménye szerint a probléma nem csupán abból adódik, hogy a nyelv absztrakciójának mértéke nem áll rendelkezésre a vizuális közegben. Általános iskolai példája nyilvánvalóan nem absztrakt mondat, mégis, ha megpróbáljuk vizuális elemekkel ábrázolni, be kell vallanunk, hogy a kép nem lesz ekvivalens az állítással. A képen nem tudjuk érzékeltetni azt, hogy „a” macskáról vagy „,egy macskáról” van szó, illetve, hogy ott ült, vagy még mindig ott ül-e, stb. (Gombrich [2003] pp. 92-107.). Számos kutatóval egyetértve azonban (a korábbiakban idézett Birdsell és Groarke, Blair ([2008] p. 46.) vagy Noth ([1995] pp. 10-12.)) a jelen disszertáció is azt az álláspontot támogatja, hogy mindenképpen érdemes tekintetbe venni a vizuális jelentés lehetőségeit és a verbális jelentés korlátait. A képek természetesen lehetnek kétértelmüek és homályosak, de pusztán ez a tulajdonságuk nem különíti el őket a szavaktól és mondatoktól, amik szintén lehetnek félreérthetőek, pontatlanok. Amellett pedig, hogy mind a vizuális, mind a verbális érvelést (csaknem ugyanolyan mértékben) érintő problémáról van szó, fontos megjegyeznem, hogy a homályosság és kétértelmüség nem minden esetben tekinthető hibának az érvelésben, vagy a kommunikációs folyamatokban általánosan. Blair kiváló példáival élve: ha valaki Kanada lakosságát össze kívánja hasonlítani Hollandiáéval, a legközelebbi millióra való kerekítés tökéletesen megfelel a viszonyítás céljának, míg ez a fajta pontatlanság elfogadhatatlan lenne, ha egy népszámlálási adatbázisban kéne rögzítenünk a populációk méretét. Ugyanígy, amikor a korunkról kérdeznek bennünket, nem kell percre, órára, napra vagy hétre pontosan megmondanunk, mikor születtünk, elegendő az évet elárulnunk, ami szintén elég homályos, a legtöbb társas helyzetben azonban tökéletesen elfogadható. Érdekes megfigyelni, hogy a gyerekek a korukat gyakran félévre pontosan határozzák meg, mivel az idő 
elörehaladtával több előnyre, szabadságra tehetnek szert, így van egyfajta (vélt) indoka a pontosságnak (Blair [2008] pp. 46-47.). Emellett a vizuális jelzések segítségével számos esetben csökkenthetjük a verbalitás okozta bizonytalanságokat, például azáltal, hogy mondandónkat egy mosollyal vagy kacsintással kísérjük (Birdsell - Groarke [1996] p. 2.). Így sokkal könnyebben felismerhetők a beszélő szándékai, illetve az olyan klasszikus retorikai gondolatalakzatok, mint a magasabb fokú múvészi kifejezés többféle eszközét mozgósító irónia vagy a hozzá szorosan kapcsolódó epés, maró, keserủ gúnyt megtestesítő szarkazmus (Szathmári [2003] p. 145.). Kijelenthetjük tehát, hogy a vizuális jelentés nem feltétlenül önkényes és homályos.

Emellett mind a vizuális, mind a verbális érvelés szempontjából lényeges kiemelnünk a kontextus fontosságát, mivel az nem csak kulturális feltevéseket, hanem szituációs jelzéseket, időérzékeny információkat és a verbális és vizuális különböző aspektusait is magában foglalja. A szavakkal kapcsolatosan nyilvánvalóan nem várhatjuk el, hogy egyetlen, vitathatatlan jelentéssel bírjanak. Ehelyett inkább megvizsgáljuk az őket kísérö másik szavakat, mondatokat, hogy megállapítsuk kontextuális jelentésüket, amelyet vagy alátámaszt a szó eredeti szótári definíciója, vagy sem. A magyar „ír” szó például vonatkozhat egy cselekvésre, egy nemzetiségre vagy a gyógyír fönévre, de ha azt mondjuk, hogy „Levente házi feladatot ír”, a szó kontextusából máris tudni fogjuk, melyik jelentés érvényesül. Ahogyan a verbális, úgy a vizuális érvelés esetében is érdemes megvizsgálni a kontextus fontosságát. Birdsell és Groarke szerint a képi érvelés legalább három kontextusa elkülönítendő, ezek pedig: a közvetlen vizuális kontextus, a közvetlen verbális kontextus, illetve a vizuális kultúra (Birdsell - Groarke [1996] p. 6.).

1. A közvetlen vizuális kontextus leginkább a filmek esetében releváns, mivel magában foglalja a képek folyamatos progresszióját, ezáltal az egyes elemeket egy átfogó érvelés alkotórészeiként leszünk képesek értelmezni. A képek sorozatának fejlödése által tudjuk majd megállapítani, hogy a kést tartó férfi vajon eladni, fözni, vagy ölni készül-e.

2. A közvetlen verbális kontextus szintén a vizuális jelek interpretációját segíti elő. Ez az aspektus arra a már Aspeitia által említett jelenségre utal, hogy a kép és a szöveg, sok esetben egyenrangú felekként, unióban egymással alkotják a premisszák és konklúziók kifejezésének elengedhetetlen eszközeit. 
3. Végezetül a kontextus harmadik fajtája, a vizuális kultúra alapjaiban különbözik az első két kategóriától, mivel olyan folyamatosan változó tényezők alakítják, mint a müvészet, tudomány, technológia stb. Magában foglalja továbbá a látással kapcsolatos konvenciókat, tehát azt, hogy mit jelent látni, reprezentálni, illetve utal a vizuális szókincs adott elemeinek folyamatos átalakulásaira is (Birdsell Groarke [1996] pp. 6-7.).

\subsubsection{A propozicionalitás problematikája}

A második alapvető kifogás a vizuális érvelés lehetőségével szemben az, hogy a vizuális kommunikáció nem tartalmaz igazságértéket, így nem képes propozíciókat közvetíteni, pedig az érvelés megköveteli bizonyos propozíciók jelenlétét ahhoz, hogy ellássa feladatát (Blair [2008] p. 47.). Annak érdekében, hogy ez az ellenérv is megválaszolásra kerülhessen, először a propozíció fogalmi meghatározására teszek kísérletet. King, Soames és Speaks a propozíciókat a kontextus tükrében - a kijelentő mondatok információs tartalmának felelteti meg, ezek a mondatok pedig, az általuk kódolt információk igazságértéke alapján lehetnek igazak vagy hamisak. Ezáltal, a szerzők véleménye szerint, a propozíciók az igazság és hamisság elsőszámú hordozói, mivel a mondatok igazsága szükségszerüen függ az általuk kifejezett propozíciók igazságától (King et al [2014] p. 5.). Az előbbi definíciót kiegészítve Groarke és Tindale úgy véli, hogy ugyan a filozófusok körében rengeteg vita alapjául szolgál a propozíciók természetének leírása, egy egységes meghatározása lehet a fogalomnak az, hogy a propozíció minden esetben megerősíti egy bizonyos helyzet fennállását. A következő példamondatok alátámaszthatják a szerzőpár állítását: A nukleáris háború a legnagyobb elképzelhető csapás. A következő 24 órában folytatódik a havazás. A postás meghozta a leveleket. Zeusz és Héra az olümposzi istenek családjának feje (Groarke -Tindale [2004] p. 196.). Kosslyn és Pomerantz úgy vélik, hogy a propozíciók absztrakt szerkezetek, amelyek a bizonyos entitások között fennálló pontos kapcsolatot írják le. Nem feltétlenül nyelvi struktúrák, mivel olyan koncepciókat is magukban foglalhatnak, amelyekből teljesen hiányoznak a verbális megnyilatkozások, bár gyakran egyszerü mondatok felöl közelítjük meg öket (Kosslyn -Pomerantz [1977] p. 55.). Végezetül Rudolf Arnheim definícióját mutatom be, amely már egyenesen azt állítja, hogy bármely absztrakt propozíció lefordítható valamilyen vizuális formára, ezáltal válva a vizuális gondolkodás egyik alapkövévé (Arnheim [2004] p. 159.). 
Tanulmányában Georges Roque a propozíciók pontos fogalmi meghatározásának érdekében fontosnak találja bemutatni azok mondatokhoz füződő kapcsolatát. Először is úgy gondol a propozíciókra a beszélt nyelvben is, mint konstrukciós és interpretációs folyamatok eredményeire, ebből kifolyólag a képi érvelés sem számít különleges esetnek. Három lényeges pontot fogalmaz meg a propozíciókkal kapcsolatosan:

1. Nem minden mondat fogalmaz meg propozíciókat, ezért az elsőszámú teendőnk az, hogy elkülönítsük a propozíciókat a mondatoktól. Csak különleges esetekben esik egybe a propozíció azzal a mondattal, amely kifejezi azt, pl.: Kettő meg kettő az négy.

2. Nem minden propozíció alkalmas arra, hogy létrehozzon egy érvelést. Néhány deklaratív propozíció lehet állítás, de az állítás nem feltétlenül érvelés.

3. Ezért célszerü megvizsgálni, hogy melyik propozíció szolgál premisszaként és melyik konklúzióként (Roque [2014] p. 181.).

Ahhoz, hogy megértsük a propozíciók mondatokhoz füződő viszonyát a szerző Copi, Cohen és McMahon Introduction to Logic címü müvére hivatkozik, amelyben a szerzők a következőképpen közelítik meg a problémát. Véleményük szerint, amikor egy propozíciót állítunk, azáltal tesszük azt, hogy valamely nyelv mondatába foglaljuk. Azonban a propozíció, amit állítunk, nem feltétlenül azonos a mondattal, amely kifejezi azt. Ez nyilvánvaló, hiszen két különböző mondat, amely szavak eltérő sorrendjét tartalmazza, hordozhatja ugyanazt a jelentést, és használható ugyanazon propozíció érvényesítésére. P1.: „Péter kidolgozott egy új elméletet” és „Az új elmélet Péter által került kidolgozásra” egyértelmüen két különböző mondat, amely ugyanazt az állítást teszi. A mondatok tehát mindig részei valamilyen nyelvnek, de a propozíciók nem függnek ezektől a nyelvektől. A szerzők az alábbi négy mondatot hozzák további példának: It is raining. (English) Está lloviendo. (Spanish) Il pleut. (French) Es regnet. (German) A fenti mondatok különböző nyelveken, különböző szavak használatával teszik ugyanazt az állítást, ezzel is azt bizonyítva, hogy a propozíció nem feltétlenül esik egybe magával a mondattal. Ezek tükrében a propozíció kifejezés a kijelentő mondatok által érvényesített állításokra utal és az érvelés építőkövének tekinthető (Copi et al [2014] pp. 4-5.).

Eemeren az érvelést úgy határozza meg, mint verbális, szociális és racionális tevékenységet, amelynek célja, hogy egy észszerü álláspontot vagy annak kritikáját 
elfogadtasson különböző propozíciók konstellációjának felsorakoztatásával, megerősítve vagy cáfolva ezzel az álláspontban kifejezett propozíciókat (Ott - Dickinson [2009] p. 109.). Amellett, hogy ez a definíció az érvelést prototipikusan verbális aktusnak írja le, jól kifejezi azt, hogy az érvelésnek szükséges feltétele, hogy legyen igazságértéke, azaz tartalmazzon propozíciókat. Az érveléseknek tehát elsődleges célja az, hogy az emberek hiedelmeit, attitüdjeit vagy viselkedését megváltoztassa, azáltal, hogy az érvelő a közönség már meglévő elköteleződéseit hangsúlyozza, majd kiegészíti azokat egy módosított, vagy új hiedelemmel. Az elköteleződések, hiedelmek tárgya mindig egy állítás vagy propozíció lesz, amely igaz vagy hamis, esetleg igazzá vagy hamissá tehető. Ahhoz, hogy a vizuális érvelés megvalósulhasson, szükségszerü, hogy a vizuális elemek igazak vagy hamisak legyenek, vagyis legyen igazságértékük. Egy fénykép, egy filmrészlet, egy sor képi elem (pl.: televíziós reklám), egy festmény vagy szobor nem „igaz” vagy „hamis”, így közvetített jelentésük sem propozícionális (Blair [2008] p. 47.). Éppen ezért éri sorozatosan az a támadás a vizuális érvelést, hogy bármilyen módon fejti is ki retorikai hatását, semmiképpen sem vizuális érvek használatával teszi azt, mivel az érvelés alapvető komponenseit, a propozíciókat nem lehetséges vizuálisan kifejezni.

A propozíciókkal kapcsolatos problémát Blair The Rhetoric of Visual Arguments címü tanulmányában kétféleképpen válaszolja meg. Elöször is egy David Low brit karikaturista által készített második világháború előtti helyzetet ábrázoló képet mutat be, amelyen egy meglehetősen önelégült, angol fiatalember kerti székében ülve újságot olvas, míg egy halom bizonytalanul egymáson egyensúlyozó szikladarab tornyosul fölé. A legalsó, kissé kiálló szikladarabra, amely az összes többinek alátámasztást nyújt, az van írva, hogy „Csehszlovákia”. Közvetlenül rajta található a „Románia” és „Lengyelország” feliratú kődarab, amelyek együtt tartják a „Francia szövetségesek” elnevezésű sziklát. Ezek tetején pedig az „Angol-francia biztonsági szolgálatának” szikladarabja található, amely bizonytalanul egyensúlyoz tartópillérein. A „Csehszlovákia” feliratú szikla kiálló végéhez egy vastag kötél van erősítve, amelynek másik vége a kép tetejébe veszik. Evidens, hogy egy erős rántással kimozdíthatnánk a Csehszlovákia címkével ellátott sziklát, amelynek következményeképpen az összes szikla az angol fiatalember fejére borulna, maga alá temetve őt ezzel. A karikatúra felirata pedig így szól: „What's Czechoslovakia to me, anyway?” (Mit nekem Csehszlovákia?) (Blair [2008] p. 48.). 


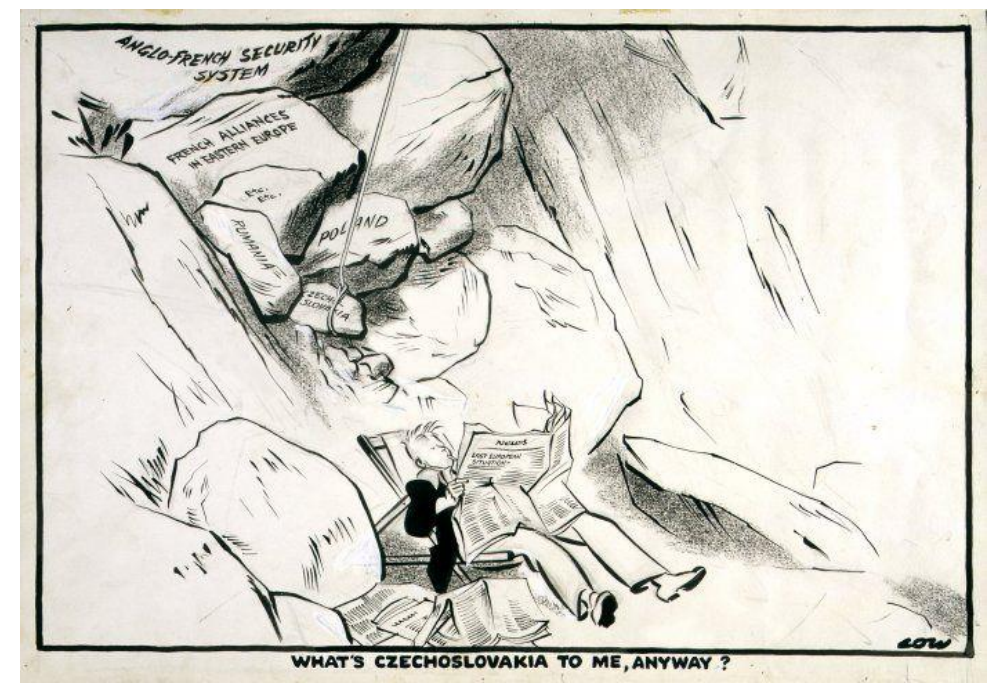

\section{2. ÁBRA. A kép forráshelye: http://mp.natlib.govt.nz/detail/?id=16137\&l=en}

Ezzel a karikatúrával Low nyilvánvalóan azt szándékozta kifejezni, hogy a meglátás, amely szerint Csehszlovákia sorsának alakulása semmilyen következménnyel nem lesz Angliára, hibás. Low azt a feltételes állítást teszi képe segítségével, hogy Csehszlovákia elesése Németországgal szemben események láncolatát indítaná be (pl.: Lengyelország és Románia elbukását), amely a francia szövetségesek és végezetül az angol-francia biztonsági szolgálat bukásához vezetne, amelynek katasztrofális következményei lennének Angliára nézve. Blair ezzel ki is fejezte Low vizuális érvelését és annak komponenseit, a karikatúra premisszáját és konklúzióját. Ez az érvelés pedig, a maga idejében, vagy igaz volt vagy hamis. Tehát vagy igaz volt, hogy hibás gondolat Csehszlovákia sorsát semlegesnek tekinteni Angliára nézve, illetve, hogy Csehszlovákia bukása események sorozatát indítaná be, vagy sem. Ez pedig nyilvánvalóan cáfolja azt a nézetet, hogy nem lehetséges vizuálisan propozíciókat kifejezni, hiszen éppen most tettük meg Low karikatúrájának segítségével (Blair [2008] p. 48.).

Egy újabb példa a vizuális érvelés lehetőségének alátámasztására a Birdsell és Groarke által bemutatott dohányzásellenes poszter, amelyet az USA Egészségügyi, Oktatási és Jóléti Minisztériuma készített. Az előzőhöz hasonlóan a jelen kép is a verbális és vizuális ötvözeteként értelmezhetö. A képen egy dohányzó halat láthatunk, amelynek szájából kilógó cigarettája horogra van akadva, a sárguló, unott arcú, egészségtelen állat felett pedig a „Don't you get hooked!” (Nehogy rászokj!) angol felirat látható. (A magyar fordításban sajnos elveszíti a 
szóvicc az élét, a hook angol kifejezés ugyanis kampót is jelent, igei alakban pedig a to be/get hooked a valamitől való függésre utal.)

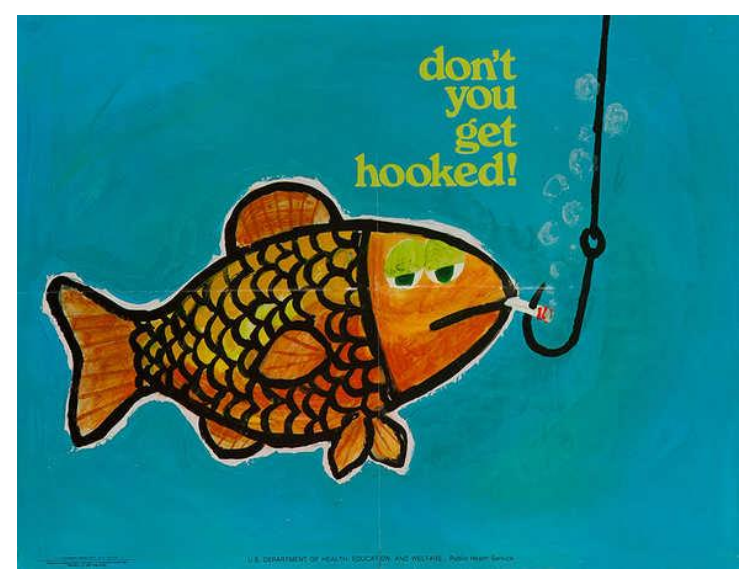

3. ÁBRA. A kép forráshelye: https://ladonnapigra.wordpress.com/2013/01/24/birdsell-and-theeverlasting-visual-argument/

Nyilvánvaló, hogy a kép nélkül nem tudnánk értelmezni a poszter üzenetét, hiszen a Nehogy rászokj! verbális figyelmeztetés homályos és kétértelmü. Nem referál explicite a cigarettára vagy dohányzásra, így könnyen utalhatna drogokra, alkoholra, vagy bármi másra, ami potenciálisan függőséget okozhat. Csak onnan tudjuk, hogy a poszter egy dohányzásellenes kampány része, hogy a képen egy cigarettájánál fogva horogra akadt halat láthatunk, a közvetített érvelés pedig a következő: „Óvakodnia kell a dohányzástól, mert rászokhat, és ezzel veszélyeztetheti egészségét!" Ez a kijelentés pedig egyértelmüen propozicionális, hiszen hordoz egyfajta igazságértéket (Birdsell - Groarke [1996] p. 3.).

Egy következő olyan példa, amelyben szintén a vizuális és verbális interakciójából jön létre az érvelés, vizuális enthüméma segítségével, a Tseronis által bemutatott WWF (World Wildlife Fund) nemzetközi civilszervezet 2009-es kampányának posztere. Az enthüméma fogalmát a korábbiakban már részletesen bemutattam, a retorikai trópusokhoz hasonlóan azonban a csonka szillogizmus is értelmezhető vizuális színtéren. Jens E. Kjeldsen vélekedése szerint a vizuális enthümémák 1.) magukban foglalják a lehetséges premisszákat és konklúziókat, 2.) és az érvelés etikai (cf. éthosz) és érzelmi dimenzióit 3.) az üzenet feladója és a közönség közötti megállapodás függvényében. Az utolsó pont különösen érvényes a vizuális retorika esetében, mivel a képi érvelés - speciális kódjainak köszönhetően - még inkább megköveteli a közönség aktív részvételét az érvek rekonstrukcióban (amelyet a közönségkutatás 
és az olvasói válasz elméletek is alátámasztanak). Ezért a vizuális érvelés egyik legfontosabb és leglényegibb jellemzője annak enthümematikus természete (Kjeldsen [2015] pp. 117-118.). A következő imágó kiválóan példázza, hogy a képek is hordozhatnak retorikai alakzatokat és igazságértéket. A képen egy amőba játékot imitáló 3x3-mas tábla kilenc mezejéből nyolc egymást váltó krokodilokat és táskákat ábrázol, egy mezőt üresen hagyva, amelybe, a játék szabályai szerint krokodil és táska ikon is kerülhetne. A poszter szövege pedig a következő egyszerü mondat: ,It's your turn. ” (Te következel).
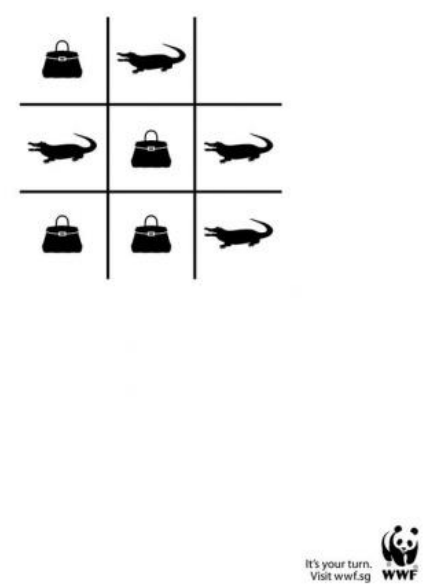

\section{4. ÁBRA. A kép forráshelye: http://theinspirationroom.com/daily/2009/wwf-its-your-turn/}

A poszter vizuális hányada segíti a közönséget, hogy a szöveg illokúciós erejét megfelelően értelmezze. A teljes konfiguráció - enthümematikus természetének köszönhetően - pedig nem csak szellemileg vonja be a nézőt, arra kérve őt, hogy a WWF reklámjában keressen kapcsolatot a krokodil és táska szimbólumai között, hanem kinetikai szempontból is kooperációra buzdítja, hiszen szó szerint meghívja őt arra a poszter, hogy valamely szimbólum kiválasztásával töltse ki az üresen hagyott blokkot. Az amőba játék formája vizuálisan azon dilemma elé állítja a fogyasztót, hogy válasszon egy újabb bőrtáska megvétele és az állatok bőrükért való lemészárolása között. A kép azáltal válik érveléssé, hogy bármelyik szimbólumot is választja a fogyasztó, azzal az előbb felsorolt két alternatíva egyikét támogatja, ezáltal nyer ez a kép is propozíciós értéket (Tseronis [2013] p. 13.) 
A fent említett példákon kívül a képek propozíciós természetének bizonyítására Blair egy másik érvet is megfogalmaz. A kanadai származású filozófus rámutat ugyanis, hogy az érvelés folyamata során az érvelő arra motivált, hogy megváltoztassa a közönség eredeti gondolatait, szándékait vagy cselekedeteit, új attitüdöket kialakítva bennük. Ezeknek az attitüdöknek, szándékoknak és viselkedéseknek azonban egyáltalán nem minden esetben van propozíciós értéke. Egy amerikai választópolgár republikánusokkal kapcsolatos preferenciái a demokratákkal szemben például nem igaz vagy hamis. Talán meggondolatlanságból szavaz rájuk, talán csak azért, mert „mindig is republikánusok voltak”, ezért evidens, hogy nekik adja voksát. Ez azonban semmiképpen nem értelmezhető az igaz-hamis dimenzió mentén. Így, hogy az érvelés során mégis okokat adunk az emberek preferenciáinak, nézeteinek, attitüdjeinek megváltoztatására az látszik, hogy - minden komponensüket figyelembe véve - még a verbális érvelések sem tekinthetők mindig propzicionálisnak. A fentiek alapján Blair azt a meglehetősen radikális kijelentést teszi, hogy nem minden érvelésnek kell, hogy legyen igazságértéke, tekintet nélkül arra, hogy verbális vagy vizuális érvelésről beszélünk. Ezért, ha egy kép nem is fejez ki propozíciókat, abból nem következik, hogy egyáltalán nem tekinthetö érvelésnek (Blair [2008] pp. 48-49.).

Blair tehát több szempontot figyelembe véve azt mondja, hogy az érveknek és állításoknak nyelvileg megmagyarázhatónak kell lennie, amely annyit jelent, hogy tudnunk kell alátámasztani vagy cáfolni öket, ez azonban nem azt jelenti, hogy eleve nyelvileg is kell kifejeznünk öket. Ez a pozíció pedig helyt ad a vizuális érvelés intézményének. The Possibility and Actuality of Visual Arguments címủ tanulmányában úgy fogalmaz, hogy lényegében a vizuális érvelés nem tér el a verbálistól, csak különböző módon fejezik ki az érveket és az általuk közvetített propozíciókat. Ezért a vizuális érvelést Blair nem tartja egy különösen izgalmas konceptuális újdonságnak, nem minősül az érvelés radikálisan eltérő szegmensének (Blair [1996] p. 38.).

\subsubsection{A nyelvi transzláció problematikája}

A képekkel kapcsolatos harmadik ellenérv arra vonatkozott, hogy a képi érvelés nem valósulhat meg nyelvi transzláció nélkül. Jelen probléma megválaszolása érdekében elöször a percepció 
tárgykörét tisztázom, majd - e fogalomhoz kapcsolódva - konkrét példa segítségével bizonyítom, hogy a vizuális elemek nyelvi fordítás híján is érvelhetnek.

\subsection{A percepciók}

Korunkban a nyelvet jelölték ki a közvetlen perceptuális tapasztalatok megjelenésének színtereként, azonban, annak ellenére, hogy a nyelv számottevően segíti gondolkodásunkat, önmagában nem képes az elmélkedés folyamatának megfelelő arénát biztosítani. Annak érdekében, hogy az emberi elme tudásra tegyen szert, az adott információk mögé kell néznie, közvetlen érzékszervi tapasztalatok segítségével. A vizuális érzékelés pszichológiai vizsgálata az elméleti filozófiából származik; egy olyan hagyományból, amelyben természetes volt, hogy az észlelésre a világgal kapcsolatos tudatosság és tudás megszerzésének eszközeként tekintettek. A percepciókkal kapcsolatos modern elméletek alapjait a 17. században fektették le, amikor Descartes és társai megfogalmazták az optika alapelveit, lehetővé téve ezzel, hogy a fények és képek fizikai tulajdonságai és a vizuális tapasztalások elkülöníthetővé váljanak. A felfedezés, hogy a szem úgy müködik a kép létrehozásában, mint egy kamera, különösen nagy hatással volt a későbbi gondolkodásra, számos vitát, újabb és újabb paradigmát létrehozva (Bruce et al [2014] pp. 77-78.).

A 19. századi domináns empirista meglátás szerint az elemi érzékelések vizsgálatával az emberi gondolkodás komplexitása feltárhatóvá válna, mivel minden összetett gondolat, amelyet korábban a tanuláson keresztül szereztünk, végső soron érzékszervi tapasztalatból származik. Ezen irányzat jeles képviselője, Helmholtz úgy véli, a percepciók tudatalatti következtetéseket vagy konklúziókat tartalmaznak, azok az érzékszervi stimulációk pedig, amelyek információkat szolgáltatnak a világról, premisszákként, vagy hipotézisekként foghatók fel. E strukturalista hozzáállás erősen ellentmondott annak a behaviorista szemléletnek, amely szerint a perceptuális érzékelés bizonyos agyterületek dinamikus müködésének eredménye. Később, a perceptuális tanulás asszociációs megközelítése az észlelés, figyelem és memória „új kognitív pszichológiájának" létrejöttét eredményezte. E szemlélet kutatói pedig számos kísérletet tettek arra, hogy tisztázzák, a stimulusok és a rájuk adott válaszok között milyen és hány féle szint jelenik meg, egyetértés azonban itt is kevés született (Bruce et al [2014] p. 79.). Az Arnheim által idézett Burner szerint a gyermek kognitív fejlődése három szakaszon megy keresztül: 
először is cselekedetei által fedezi fel a világot, majd a képalkotás segítségével, végezetül pedig a beszélt, majd írott nyelvvel. Ennek sajnálatos következménye pedig Burner szerint az, hogy a következő szint elérésével az előző valamelyest háttérbe szorul. Így, amikor a gyermek megtanul egy közvetlenül a szeme előtt lévő konstelláció mögé látni, a képesség, hogy megfelelő módon értelmezze az adott helyzetet, nem az észlelési kapacitás növekedésének köszönhetö, hanem egy új feldolgozó médium, a nyelv megjelenésének és használatának (Arnheim [1980] p. 490.). Ezért aztán a nyelvet sokáig a gondolkodás elsőszámú, nélkülözhetetlen és egyetlen elemének tekintették, pedig - Arnheim szerint - a nyelv valójában csupán kicsivel több, mint egyszerü reflektor, vagyis a körülöttünk lévő világ leképezője.

Mivel a modern szakértők azt állítják, hogy a percepciók nem mások, mint a szenzoros receptorainkba érkező ingerek mechanikus rögzülései, célszerü pár példán keresztül bemutatni, hogy az észlelés általában túlmutat a szenzoros nyersanyag puszta mechanikus rögzítésén (Arnheim [1980] p. 490.). Előtte azonban a percepciók definícióit, illetve különböző szakaszait mutatom be, a jobb megértés érdekében. Bruce, Green és Georgeson úgy írja le a percepciókat, mint a környezetünkben lévő struktúrák és események detektálását (Bruce et al [2014] p.3.), míg Liu, Volčič és Gallois olyan aktív folyamatnak nevezi, amelyben érzékszerveinket használjuk ahhoz, hogy szelektíven azonosítsuk az ingerek létezését, majd értékelésnek és értelmezésnek vetjük alá azokat (Liu et al [2015] p. 80.). Rookes és Willson pedig úgy gondolja, hogy percepcióink többé-kevésbé akkurátus képet alkotnak a körülöttünk lévő világról, mivel:

- Az ingerek mindig információgazdagok,

- Az emberi érzékszervi rendszerek hatékonyak az információgyüjtésben,

- Fogalmaink segítségével alakítjuk észlelésünket (Rookes - Wilson [2000] p. 15.).

A szakirodalom szerint a percepciók három szakasza különíthető el, ezek pedig nem mások, mint a szelekció, kategorizáció és interpretáció (Liu et al [2015] p. 81.).

1. A folyamat első fázisa a szelekció, amelyben az információ eljut érzékszerveinkhez, majd agyunkhoz. A szelekció fontos szerepet játszik abban, hogy a környezeti ingereket érthető, jelentéssel bíró tapasztalatokká alakítsuk. Az, hogy információk hadával bombáz bennünket közegünk, gyakorlatilag mindennapossá vált, az olyan ingerek száma azonban, amelyeket érthetően fel tudunk dolgozni, mégis csekélynek mondható. Ebben a 
folyamatban van segítségünkre a szelekció, amely segít kiszürni, hogy melyik stimulus lesz számunkra azonnal vagy potenciálisan hasznos. A szelektív percepció háromlépcsős folyamat, amelynek első szakasza a szelektív expozíció fázisa. Ebben a fázisban ki vagyunk téve a környezetünkből érkező ingereknek és azok hatásainak. A következő a szelektív figyelem szakasza, amelynek segítségével az információk azon részhalmazára vagyunk képesek figyelni, amelyek számunkra relevanciával bírnak, végezetül pedig a harmadik lépcsőfok, a szelektív retenció következik, amely azon információk megtartását szorgalmazza, melyekre a jövőben szükségünk lehet, és amelyek konzisztensek gondolkodásunkkal, értékeinkkel és attitüdjeinkkel.

2. A percepció második szakasza, a kategorizáció olyan mentális folyamat, amely során környezetünk elemei csoportosítjuk emberek, tárgyak és események szerint, egymáshoz való hasonló jellegük és jellemzőik alapján. A kategorizáció azért tekinthető fontosnak, mert segít az információ feldolgozójának a bizonytalanság csökkentésben, illetve az előrejelzések pontosságának növelésében. A kategóriák tehát szorgalmazzák a mások viselkedésével kapcsolatos attribúcióink kialakítását és segítenek felidézni és felismerni az adott információkat.

3. A percepciók harmadik fázisa az interpretációs szakasz, amely a jelentés azon adatokhoz való hozzárendelését jelenti, amelyeket érzékszerveinkkel a környezetünkböl nyerünk. Liu, Volčič és Gallois szerint az interpretáció ezen formája a dekódolás szinonimájaként értelmezhető. Az emberek az információkat fiziológiailag (látás, hallás, tapintás), szociológiailag (demográfia, csoporttagság) és pszichológiailag (attitüdök, hiedelmek) szerint szürik, ebben segít a percepciók interpretációs szakasza. E folyamat során ismerős kontextusokra támaszkodva értelmezzük az új ingereket és próbáljuk őket elhelyezni tudásaink, tapasztalataink alapján (Liu et al [2015] p. 83.).

Marr emellett egy moduláris modellt vezet be a vizuális érzékelés tekintetében. Meglátása szerint észlelésünk számos alfolyamatra osztható, amelyek közül mindegyik külön érzékel egy reprezentációt és átalakítja egy másikká. A látás általános feladata tehát a sorozatosan müködő modulok koordinálásában valósul meg. Az első modul az úgynevezett elsődleges vázlat (primal scetch) amely a kép terében történő fény intenzitásának változására utal. Az elsődleges vázlat továbbá 2D-s reprezentációkba rendezi a képi régiók és a határaik fény fényintenzitásának változását. A következő szint a látható objektumfelületek elrendezése - 
amelyet $2 \frac{1}{2} \mathrm{D}$ vázlatnak (21/2D scetch) nevezünk. Az objektumfelületek távolsága és iránya az észlelőtől függ. Végül ezek az információk hozzák létre az úgynevezett 3D vázlatot (3D scetch), az információk ábrázolásának 3D-s modelljét, amely meghatározza a látott objektumok formáját és mentálisan összeköti a memóriában tárolt tárgyak reprezentációival (Bruce et al [2014] p. 80.).

Bármelyik megközelítést is választjuk, látható, hogy e mentális folyamat müködését ezen a szinten nem befolyásolja a nyelvhasználat. Ahogyan arra már utaltam korábban, a nyelv természetesen segítheti a gondolati reprezentációk tisztázását, létrejöttüket azonban nem határozza meg. Ennek bizonyítékaként - Arnheimhez hasonlóan - én is Lewis E. Walkup egyik tanulmányában szereplő példáját idézem, amely a kockák kombinációjának vizualizálását vizsgálja (Walkup [1965] p. 38.). Creativity in Science through Visualization címü tanulmányában a szerző arra kéri olvasóját, hogy képzeljen el egy nagy kockát, amely 27 kisebb kockából áll, pontosan úgy, mint egy 3x3-mas Rubik kocka. Majd képzelje azt, hogy a nagy kocka teljes felszínét befestjük pirosra, ezt követően kérdezzük meg delikvensünket, hogy hány kis kockának festettük meg egy, kettő, három, vagy egyetlen oldalát sem. Miután az olvasó elárulja az általa helyesnek vélt eredményt, kérjük meg arra, hogy avasson be az általa alkalmazott mentális folyamatokba, amelyek elvezették az adott értékhez. Még egy ilyen egyszerü teszttel kapcsolatban is meglepően sokféle eredményt produkálnak a feladat résztvevői. Walkup elbeszélése szerint még azoknak az embereknek is problémát okoz e térgeometriai feladat megoldása, akik hivatásszerüen foglalkoznak a tudományokkal vagy múvészetekkel, mivel akárhogyan is próbálkoznak, képtelenek mentálisan elképzelni egy kockát és az azt felépítő kiskockákat. Ha sikerülne nekik megváltoztatni a kockával kapcsolatos vizuális felfogásaikat és egy középpontosan szimmetrikus struktúrát vizionálnának, máris közelebb kerülhetnének a megoldáshoz. Ez az új látásmód pedig a 27 kocka egyikét mutatná, amelyet a maradék 26 körülölel, mint egy kagylóhéj. E centrális pozíciójú kocka nyilvánvalóan nem kerülhet befestésre, hiszen sehogyan sem érintkezik a nagy kocka felszínével, ellentétben az összes többi kiskockával, amelyek valamilyen mértékben érintik a külső felületet. Ha pedig most megnézzük a nagy kocka hat oldalának egyikét, akkor a háromdimenziós kép kétdimenziós változatát láthatjuk, egy középponti négyzetet nyolc másik négyzet körbefonásával. E központi négyzet nyilvánvalóan csak egy oldalon festhető be, amelyböl az következik, hogy összesen 6 olyan kis négyzetünk van, amelynek egyetlen oldala válik pirossá. Ezt követően áttérhetünk a 
kocka 12 élére, ahol minden él három kockát foglal magában, amelynek középső eleme két oldalán kerül befestésre, így összesen 12 kocka két oldala lesz piros. Ezek után pedig nem marad más hátra, mint a 8 sarokelemünk vizsgálata, amelyeknek nyilvánvalóan három oldala lesz befestve, és a feladatot elvégeztük. A leghatásosabb megközelítés tehát az volt, ha magunk elé képzelünk egy átlátszó kockát, és egyszerủen megszámoljuk az azt alkotó kis kockák festékkel borított oldalait, valahogy úgy, mint amikor valaki az ujjait használja az eredmény kiszámításához. Arnheim felteszi a kérdést, hogy vajon túlmentünk-e a megadott információkon? A válaszom, egyáltalán nem. Pusztán annyi történt, hogy gondolatban túlszárnyaltunk azon a strukturálatlan halom alkotóelemen, amelyet egy kisgyermek érzékelne. A teljes kép ismeretében egy gyönyörü kompozíciót láthatunk, amelynek minden elemét az egészben elfoglalt helye definiálja. A kérdésre, hogy szükségünk volt-e a nyelvre e feladat megoldásához, a válaszunk ismét nemleges, habár a nyelv segítheti eredményeink kodifikálását. Ennek tükrében pedig azt mondhatjuk, hogy amire a feladat megfejtéséhez igazán szükségünk volt, az nem más, mint a vizuális gondolkodás, kreativitás, találékonyság és képi intelligencia (Arnheim [1980] p. 491.).

Ebben a fejezetben ez idáig a képi érvelést támogató és cáfoló elméletekről, a szavak és képek összefonódásáról, valamint a propozíciók természetéről, szerepéről nyújtottam áttekintést. Ahogyan az eddigi összefoglalásomból kiderült, véleményem szerint a képek is elhelyezhetők a retorika értelmezési keretében, a vizuális jelek képességeinek és jellemzőinek köszönhetően. A továbbiakban a képek struktúráját alkotó mikro-kontextusokat, illetve a képi érvelés szociális, társadalmi és pszichológiai funkcióit, valamint a médiában betöltött szerepét mutatom be, emellett zárásképpen kitérek majd a képi hazugságok jellemzőire és lehetőségeire is.

\subsection{A vizuális retorika mint interpretáció/processzus}

\subsubsection{A vizuális retorika és a média}

A jelen fejezetben vizsgálatom a képek struktúráinak és a képi érvelés médiában betöltött szerepének áttekintésére vállalkozik, annak szociális, társadalmi és pszichológiai funkcióit is górcső alá véve. Történetének bemutatásakor már láthattuk, hogy a tudományos diskurzusok egyik leginkább vitatott diszciplínája, a retorika hányattatott múltra tekint vissza. Nagy állomásai, végzetes elfáradásai, változatos tudományos megközelítései mind megfigyelhetők 
voltak. Az a színtér azonban, amely újjáélesztette a retorika területét és azóta is felvirágoztatja azt, nem más, mint a média. Aczél szerint a média egyszerre tekinthető kommunikációs rendszernek, szociális interfésznek, ágensnek és üzenetnek (Aczél [2012] p. 19.). Mára a retorika és a média kölcsönhatásáról elmondható, hogy a retorika maga is médium és minden médium retorikus. A retorikai érdeklődés visszatértét eredményezte többek között a médiumok multiplikálódása, a szerzőség és a befogadás konfigurációja, vagy a részvételi diskurzus létrejötte (Aczél [2012] p. 19.).

\subsubsection{Multidimenzionalitás}

James Potter a médiaüzeneteket multidimenzionális entitásokként írja le, amelyeknek interpretálása kognitív, emotív, esztétikai és morális kiterjedések mentén történik (Potter [2016] pp. 25-26.). Míg a kognitív dimenzió az üzenetek tartalmára, addig az emotív a fogyasztókból kiváltott érzelmekre, az esztétikai a kommunikátor művésziségére, a morális aspektus pedig az adott médiaüzenet erkölcsi megítélésére vonatkozik. Véleményem szerint a szöveges üzenetek mellett a képek elemzése is elvégezhető a fent említett dimenziók mentén, hiszen egy vizuális üzenet is ugyanúgy apellál tudásunkra, érzelmeinkre és erkölcseinkre a kommunikátor által kiválasztott megfelelő stílus alkalmazásával, mint a verbális üzenetek, hacsak nem még jobban. E megállapításomat a Roque által használt 1998-as amerikai „Victory” plakát példájával támasztom alá, amely - címét leszámítva - egy teljesen vizuális poszter, így nem tartalmaz semmilyen verbális elemet (Roque [2014] p. 185.). A kép egy V-jelet mutató kezet ábrázol, amely a latin eredetű victoria, győzelem kifejezésre utal. Ezt a mára egyértelmüen univerzális jelzést maga Winston Churchill is gyakorta alkalmazta a II. világháború idején, nagyban népszerüsítve azt. Észre kell azonban vennünk, hogy a jelzéshez használt további három ujj nem simul a képen látható kéz tenyerére az öt ujj egységét alkotva, ezek ugyanis hiányoznak a képről, egy megcsonkított kéz látványát nyújtva ezzel. 


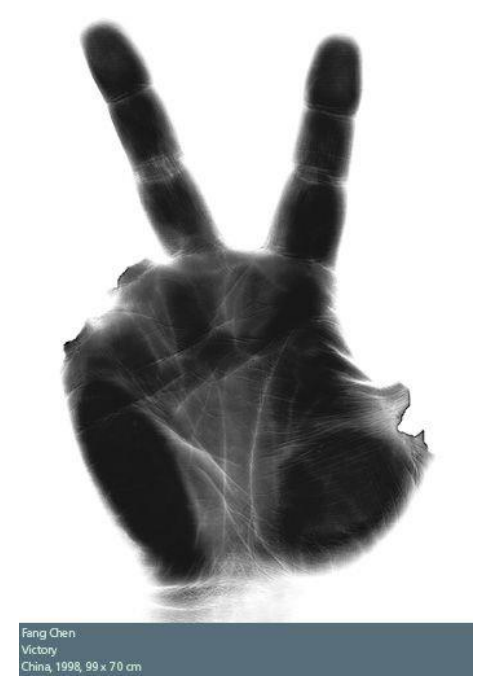

\section{5. ÁBRA. A kép forráshelye: https://hu.pinterest.com/pin/74942781270592285/}

Ugyan a kép szerzője nem kíván specifikus üzenetet közvetíteni posztere által, mégis képesek vagyunk azt a fent említett négy dimenzió mentén, szubjektív módon elemezni. A kép által közvetített kognitív dimenziót, azaz az üzenet tartalmát tekintve azt mondhatjuk, hogy egy megcsonkított kezet látunk, amelynek két ujja a győzelem jelét mutatja. A kép érzelmi kiterjedése véleményem szerint arra utal, hogy az emberek - céljaik vagy boldogságuk elérése érdekében - gyakran kénytelenek óriási áldozatokat hozni, szenvedni. Ha a kommunikátor üzenete mögött gunyoros, szarkasztikus szándékot feltételezünk, a kép, kontextustól függően kifejezhet olyan gondolatot is, hogy „Gratulálunk gyözelmedhez, pusztán x ember pusztulását kivánta meg diadalod!”. A kommunikátor stílusát, azaz a vizuális elem esztétikai dimenzióját tekintve a kép fekete fehér, röntgenfelvételre utaló jellegét is érdemes számításba vennünk, az azonban, ha a képet balesetként értelmezzük, Roque szerint nagyban megnehezíti a kép által közvetített győzelmi üzenet értelmezését. Végezetül, a képi üzenet negyedik, morális kiterjedése az ujjak által kifejezett győzelem erkölcsi megítélését jelenti, saját értelmezésem szerint azt sugallva, hogy nem egészen biztos, hogy megérte elsőségünk az áldozatot. A retorikai alakzatokat tekintve nem csak a metafora, hanem az irónia trópusa is megjelenik a poszteren. A kép négy dimenzió alapján történő értelmezése mellett hadd kapcsolódjam vissza disszertációm hipotéziséhez, amely azt mondja ki, hogy a vizuális jelek képesek igazságértéket közvetíteni, azaz propozicionálisnak nevezhetők. Ha Fang Chen Victory plakátjára tekintünk és leírjuk, amit látunk, egy lehetséges propozíció az volna, hogy „a képen látható kéz a győzelem jelét mutatja”. 
Ha a kép mélyebb jelentését keressük, a propozíció így szólna: „győztem” (Roque [2014] p.184.). Úgy vélem, ez a plakát is eklatáns példája annak, hogy a képek számos esetben közvetítenek igazságértéket, még akkor is, ha semmilyen verbális elem nem áll rendelkezésünkre értelmezésükkor.

A vizuális érvelésnek igazi vonzereje, hogy számos esetben sokkal hitelesebbnek, „,igazabbnak” tünnek képek által kifejezett érveink, mint nyelvi bizonyításaink. „,Abban, amit a saját szemünkkel látunk, nem csalatkozhatunk”, fogalmazza meg Terestyéni Tamás Kommunikációelmélet - A testbeszédtől az internetig címü munkájában. Az említett idézet is amellett látszik érvelni, hogy a képek állításokat tesznek, bizonyos dolgokat igaznak, másokat pedig hamisnak igyekeznek láttatni, mindeközben hitelt és megbízhatóságot sugározva ábrázolásuk tárgyáról. Véleményem szerint Terestyéni felvetése egyúttal azt is indikálja, hogy a képek szerkesztését tekintve a kamera és az azt irányító személy sem semleges, meghatározva, hogy mit és hogyan észleljünk (Deli [2016] p.23.).

\subsubsection{Ideológia, interpretáció, identifikáció és nyelv}

David Blakesley munkájában a vizuális retorika négyes megközelítését javasolja: a film ideológiája, interpretációs és identifikációs perspektívája, illetve nyelve alapján (Blakesley [2003] p. 4.). A film ideológiájának megközelítése a filmet, mint ideológiai funkciókat ellátó entitást vizsgálja tartalma, illetve technikai apparátusa alapján. A filmkritika esszémüfajának feladata, hogy a film komplex jelensége mögött meglássa az uralkodó ideológiákat, szándékokat, ennek eszköze pedig lehet a retorikai elemzés módszere, amelynek segítségével felfedhetö, hogy a filmek hogyan érik el hatásukat, illetve milyen érdekeket szolgálnak. A következö, interpretációs megközelítés a filmet retorikai szituációként értelmezi, a rendező, a film és a nézők bevonásával. A szerző véleménye szerint az említett három tényező felelős a jelentés létrehozásáért, a filmélményt retorikai helyzetté alakítva ezzel. A Blakesley által idézett Chatman úgy fogalmaz, hogy a film interpretációja a közönség reakcióit, a zsáner formális kidolgozását és funkcióit, illetve a jelentés szimbolikus reprezentációit is magában foglalja. Chatman azonban tartózkodik attól, hogy a film szituációs természetének artikulálása mögött a retorikát jelölje meg főszereplönek, véleménye szerint ugyanis a retorika legföbb feladata a nyelvi trópusok és formák vizuális megfelelőinek bemutatása, interpretálása. A következő, 
identifikációs megközelítés a film retorikáját egyszerre tartja az azonosulás és megosztás eszközének. A film stílusa ideológiai, pszichológiai vagy társadalmi céllal irányítja a nézők figyelmét, amely alapján Metz úgy véli, hogy az identifikáció a jelölő képzeletbeli világában történik meg, mivel a film narratívái megteremtik a lehetőséget, hogy megjelenjen az azonosulás a másodlagos valóságban. Így tudunk a film során megjelenő különböző szereplőkkel, érzésekkel, történésekkel azonosulni. A számomra leginkább releváns perspektíva, a film nyelve a filmet szemiotikailag és fenomenológiailag is nyelvtani jelrendszernek tekinti, különös figyelmet fordítva a nézők szemszögére és a percepciós folyamatokra. A már említett Metz munkássága pedig különösen nagy hatással volt a nézők perspektívájának jelrendszerére irányuló struktúrák kifejlesztésére. E szemiotikai jelrendszer képzelethez (azaz a másodlagos identifikáció birodalmához) való hozzárendelésével Metz áthelyezi a hangsúlyt a film felépítésére és befogadására, ezáltal javasolva, hogy a film nem pusztán nyelvi funkciókkal bír (pl.: saját jelrendszere és nyelvtannal analóg filmes technikái által), hanem a közönség retorikai meggyőzését és identitásának artikulálását is segíti. A nyelvtani jelrendszer pedig, Blakesley felfogása szerint, megfeleltethető az olyan filmes technikáknak, mint a kameraállás, speciális vizuális effektek, adott nézőpontok, ikonikus szimbolizmus, vizuális ismétlés, stb. (Blakesley [2003] pp. 4-8.). Báron György Testkultúra és Pszichológia Alfred Hitchcock filmjeiben címü müvében úgy ír Hitchcockról, a 20. század legnagyobb angol filmrendezőjéröl, mint aki a filmet nem ábrázolásként, hanem nyelvként fogja fel, és akinek fontosabb a valóságszerüségnél az, hogy az egyes jelek a kívánt hatást közvetítsék. A film nyelvét illetően Báron így fogalmaz Hitchcock munkásságáról: „A filmtörténetben ismerünk nála jelentősebb stílusteremtő, nyelvújító mủvészeket, ám ha valaki a filmi hatások mechanizmusát akarja tanulmányozni, ahhoz az ő életműve kimeríthetetlen forrásul szolgál. Elvégre a filmnyelv nem más, mint bizonyos hatások elérése bizonyos képekkel, beállításokkal, fényekkel, mozgással. S ehhez a világ összes rendezője közül alighanem Hitchcock értett a legjobban: filmjeit a kezdő rendezők úgy forgathatják, mint a mozgóképi nyelv páratlanul gazdag szótárát” (Báron [2004] p. 21.).

A jelen disszertáció amellett érvel, hogy a fent említett négy vizuális retorikai kategória nem csak a mozgó-, hanem az állóképek esetében is szükségszerűen érvényes, hiszen a kép grammatikai struktúráin keresztül közvetíti felénk a képalkotó ágens szándékait, bizonyos dolgokat pozitívnak, értékesnek és kívánatosnak láttatva, míg másokat elítélendőnek, negatívnak és hitványnak. A vizuális reprezentációk, akárcsak a szöveges megjelenítések, a kommunikátor 
szándéka szerint egységnyi tudásanyagot képeznek mindenből, ami komplex, kiemelve azokat a viszonyokat, amelyeket a befogadóval láttatni kívánunk. Így tehát azt mondhatjuk, hogy a kép sem objektív, hiszen keretezi a számunkra elérhető tudásokat és kultiválja a társas világgal kapcsolatos percepcióinkat, hogy bizonyos dolgokat inkább így lássunk, s ne úgy (Baran - Davis [2008] p. 296.).

\subsection{Hazudhatnak-e a képek?}

Disszertációm fókuszában a képi érvelés és a képek propozicionális természetének vizsgálata áll, amelynek létezését több ízben is igyekeztem a rendelkezésre álló szakirodalom alapján bizonyítani, példákkal illusztrálni. Ha azonban feltételezzük, hogy a képek - jelen esetben specifikusan a média képei - érvelnek, állításokat tesznek, kijelentéseket fogalmaznak meg, akkor az is eszünkbe juthat, hogy esetleg nem igazak az állítások és kijelentések, amelyeket tesznek, vagyis, hogy a képek hazudnak. Tasnádi Róbert a képeket a tudás jellegzetes vizuális formáinak tekinti (Tasnádi [2012]), de koránt sem bizonyos, hogy az általuk közvetített tudás érvényes, igaz. E fejezet zárásaként ezzel a problémával foglalkozom, főként Winfred Noth munkássága alapján. A képi fordulat korszakában a vizuális jelek elemzése és értelmezése elengedhetetlen, a képek manipulatív szándékának vizsgálata azonban jóval korábbra, 1895-re tehetö, amikor is Gustave LeBon The crowd: a study of the popular mind címü müvében a következőképpen fogalmazott a képekröl, mint a primitív emberek félrevezetésének elsőszámú médiumáról: „A tömegek csak képekben tudnak gondolkodni és pusztán általuk lehet őket befolyásolni. Csak a képek tudják őket megrémíteni vagy meggyőzni, így ezek válnak cselekedeteik elsődleges okává... Számukra a valótlan majdnem olyan fontos, mint a valós. Erős hajlamuk van arra, hogy ne tegyenek semmi különbséget” (Le Bon [2001] p. 15.). Noth kevésbé elitista, ám a fenti állítással egyező véleménye szerint korunkban a verbális érvelés visszaszorulása, hanyatlása figyelhető meg a vizuális médián keresztül, a reklámoktól a számítógépek képernyőjéig. A szerző úgy gondolja, hogy a vizualitás teljhatalma olyan kontrollálatlan érzelmi bevonódást eredményez, amelynek eredményeképpen a befogadó kritikai szemlélete teljes mértékben megszünik (Noth [1995] pp. 10-12.). De hogyan is hazudnak a képek, miben áll valótlanságuk? 
Egyértelmü, hogy a képek, különösen a fényképek gyakran olyan tárgyra utalnak, amelyek a valóságban nem léteznek, ettől függetlenül nem biztos, hogy hazugságként ítéljük meg öket. Gondoljunk csak a szürrealizmus látásmódjára, amely létrehozta a fantazmagóriák - a szó magyar szinonimái szerint: álomvilág, ábrándkép, rémlátás, lehetetlen elképzelés vagy üres képzelgés - világát (Császi [2014]), és amelyben Salvador Dalí Elfolyó óra címü munkájában az ágakról, asztalról leolvadó faliórákat láthatunk. E festmény készítőjét nem-igen nevezhetjük hazugnak, a kép azonban mégsem esik az igazság kategóriájába, legalább is a pozitivista felfogás szerint. A képek tehát közvetíthetnek tényszerü igazságokat és valótlanságokat is, a kérdés azonban, hogy képesek-e igazat vagy hamisat állítani, továbbra is megválaszolatlan. Noth szerint a képek igazság vagy hamisságtartalmának három aspektusa van: szemantikai, szintaktikai és pragmatikai (Noth [1995] pp. 10-12.). A szemantikai szempont alapján a képeknek meg kell felelnie azoknak a tényeknek, amelyeket ábrázolnak. A szintaktika perspektívája arra utal, hogy a képeknek nem pusztán egy tárgyat kell reprezentálnia, hanem közvetítenie kell e tárgyhoz kapcsolódó állításokat is, míg az utolsó, pragmatikai szempont azt mondja ki, hogy kell, hogy legyen egyfajta megtévesztési szándék a képi üzenet befogadójával szemben.

A szemantikai aspektus vizsgálatával kezdve azt mondhatjuk, hogy leginkább a fényképeket tekinthetjük a képi üzenetek prototípusának, amelyek szükségszerüen igazak, mivel kielégítik a tényekhez való legszorosabb kapcsolódás szemantikai kritériumát. Bizonyos körülmények között a képeket bírósági okirati dokumentumként is elfogadják, a szóbeli vallomás helyettesítőjeként. Találó példa lehet Noth szerint az útlevélfotó jogi státusza, amely valós személyazonosságot feltételez a jelölő és jelölt között, így, jogi szempontból az igazságot (vagy hazugságot) maga a fénykép hordozza (Noth [1995] pp. 10-12.). A képi üzenetek igazságának vagy hamisságának szintaktikai dimenziója kapcsán érdemes megvizsgálnunk a nyelv kifejezéseit. A nyelvben csakis a mondatok, és nem az azokat felépítő szavak lehetnek igazak vagy hamisak. A már említett gombrichi példamondat, „, A macska a szönyegen van” lehet igaz, vagy hamis, de a mondat komponensei - pl.: macska vagy szőnyeg - nem értelmezhetők az igazhamis dimenziók alapján. Az igazságérték csak mondatokból, vagy állításokból származhat, amelyben az alany szintaktikai kapcsolatban áll az állítmánnyal. Mivel a képekben nincsenek szavak vagy verbális kijelentések, számos kutató cáfolja azt, hogy a képek állításokat tehetnek, legyenek azok igazak vagy hamisak. Gombrich például - Art and Illusion címü munkájában úgy érvel, hogy a hazugságokhoz kijelentésekre van szükség; a kijelentéseknek pedig szintaxisra; 
ezért a képek nem tudnak állításokat tenni, így hazudni sem (Gombrich [1960] p. 56.). Ennek ellentmondva Noth Peirce jelelméletének generikus szemiotikai terminológiáját használva bevezeti a rhéma fogalmát, amely a szavak általános szemiotikai ekvivalense, illetve a dicentum jelenségét, amely szemiotikailag a propozícióknak feleltethetők meg (Peirce [1931-1935]). A kérdésre pedig, hogy a képek müködhetnek-e önálló dicentikus jelekként, tehát nem pusztán rhémákat, hanem az azokhoz köthető igaz vagy hamis propozíciókat is képesek-e közvetíteni, a válasz Noth és saját véleményem szerint is mindenképpen igen.

Ugyan Gombrich azt állítja, hogy a képeknek van logikája, de szintaxisa, ezáltal propozíciós értéke nincsen, Yoos azt mondja, hogy mind a kettő van nekik, a különbség csak abban rejlik, hogy a képi logika és szintaktika különbözik azok köznyelvi megfogalmazásától. A Venn diagramok, amelyeket képi nyelvnek tekinthetünk, például híján vannak ugyan a Gombrich által feltételként megszabott lineáris szintaxisnak, helyette azonban - térbeli alakzatot alkotva egyfajta kommunikatív szintaxist reprezentálnak, amely balról jobbra, jobbról balra, sőt, fejjel lefelé is értelmezhető (Yoos [2016]).

Végezetül, a képi igazság pragmatikai aspektusát vizsgálva azt mondhatjuk, hogy minden hazugság egy állítást vagy kijelentést feltételez, mivel minden hazugnak az a célja, hogy megtévessze a befogadót és meggyőzze őt saját kijelentésének igazságáról. Isenberg definíciója szerint a hazugság olyan állítás, amelyet a kibocsátó nem vél igaznak, mégis igazságként akarja elfogadtatni a befogadóval (Mahon [2016]). Ahogyan azt már az igazságértéknél említettem, úgy jelen esetben, a hamisságnál is fontos kiemelnem, hogy semmi sem lehet hamis, amely felszólító, óhajtó, kérdő vagy egyéb, a kijelentőtől eltérő módban van. Can pictures lie? címü tanulmányában Noth úgy fogalmaz, hogy valahányszor a jeleket az igazság érvényesítésére, kinyilatkoztatására használjuk, ugyanannyiszor alkalmazhatjuk őket a megtévesztés eszközeként is. Ha képesek állításokat tenni, akkor képesek hazudni is (Noth [1995] pp. 10-12.). Yoos pedig úgy véli, hogy a képi hazugság vizsgálatához nem pusztán az ábrázolt tartalmat, illusztrációt kell tekintetbe vennünk, hanem a kommunikáció kontextusában manifesztálódó akaratot is, hiszen, ahogyan a szavak segítségével - az irónia és humor eszközét alkalmazva - képesek vagyunk elleplezni valódi szándékainkat, úgy a képekkel is közvetíthetünk rejtett állításokat, szándékokat (Yoos [2016]). Mivel e fejezetben - számos kutatóra hivatkozva - azt az álláspontot erősítettem, 
hogy a vizuális jelek képesek állításokat tenni, úgy vélem logikus azt feltételeznünk, hogy ezek az állítások egyaránt lehetnek igazak és hamisak is.

\section{9. Összegzés}

Disszertációm jelen fejezetében a képeket és a vizuális érvelés jellemzőit, lehetőségeit mutattam be. Vitathatatlan, hogy a vizuális jelek rendkívüli hatással vannak ránk; elkeserítenek és megindítanak, empátiát vagy félelmet váltanak ki belölünk és gyakorta örömet, vidámságot okoznak. Az azonban, hogy képesek-e érvelni, igaz vagy hamis állításokat tenni a szakirodalom egyik legvitatottabb kérdése. Ennek feltérképezése érdekében disszertációm először a vizuális retorika történeti áttekintését kísérelte meg, majd annak konceptualizációja következett. Foss alapján elkülönítettem a vizuális retorika artefaktumként és vizuális adatok tudományaként történő megközelítését, illetve bemutattam Ott és Dickinson Foss-nál valamivel rendszerezőbb, érzékenyebb modelljét, amely a vizuális retorikát mint nyilvános üzenetet, mint a hétköznapi valóság megalapozóját és végül mint logikát közelíti meg. Mivel a retorika alakzatai vagy trópusai a vizuális retorika konceptuális keretében is értelmezhetők, a nyilvános üzenet perspektíván belül említést nyert mind a vizuális metafora, mind pedig a metonímia, szinekdoché és irónia.

Következő alfejezetem, a vizuális retorika problematizálása a vizuális retorika létjogosultságának fejtegetését foglalta össze. Számos kutató, mint például Perelman és Tyteca, Fleming vagy Kruiger cáfolja a nem nyelvi érvelés lehetőségét, Eemeren és Grootendorst pedig egyenesen úgy véli, hogy az érvelés elkerülhetetlenül verbális folyamat, amelynek mindenképpen szüksége van a nyelvhasználatra. Kneupper szerint a nonverbális eszközök használhatóak ugyan az érvelés során, mégsem képesek érvként funkcionálni. Ralph Johnson arra világít rá, hogy a vizuális érvelés hatalmas mértékben függ a verbális megnyilvánulásoktól és a képek kizárólag a szavakról történő fordítással válhatnak érvekké. Aspeitia ezzel szemben a képek nélkülözhetetlen szerepét hangsúlyozza az érvelési folyamat során, véleménye szerint ugyanis a vizuális jelek nem pusztán a szöveget kísérő, illusztratív funkciókkal bírnak, hanem maguk is önálló jelentést közvetítenek. Roque tanulmányában azt hangsúlyozza, hogy a képek és szavak szigorú, abszolút elválasztása lehetetlen, hiszen nagyon erős kötelék, sőt átfedés van 
köztük. Nyíri a képeket a gyakorlati tudás hordozóinak tekinti, amelyek akkor is képesek eljuttatni a kívánt üzenetet, amikor a szavak már nem elegendőek.

Elsőként a vizuális retorika mint előadásmód/produktum megközelítésének kifejtése következett, amelyben a vizuális retorika fogalmait, Perelman és Tyteca jelenlét (presence) modelljét mutattam. A jelenlét fogalma kiemelkedően fontos szerepet játszhat bizonyos nézetek elfogadásában vagy elutasításában - illetve a hozzá szorosan kapcsolódó élénkség (vividness) koncepcióját elemeztem, amelyet pszichológiai kutatások úgy definiálnak, mint érzelmileg érdekes és konkrét információk halmazát, vagy a kép gazdagságát és részletességét leíró tényezőt.

Ezután disszertációm a vizuális retorika mint érvelés/procedúra típusú szemlélet ismertetésére tért ki. A szakirodalom részletes feltérképezésével azt találtam, hogy a képeket általában három kritikával szokták illetni. Elöször is azzal, hogy homályosak, önkényesek és kétértelműek, ez a feltételezés pedig azt a nézetet erősíti, hogy a képek kevésbé precízek, mint a szavak, különösen az írott szavak. E kijelentés cáfolatára olyan kutatókkal egyetértve, mint Birdsell, Groarke, Blair és Noth magam is úgy vélem, hogy a képek lehetnek ugyan homályosak, ez a tulajdonságuk azonban nem különíti el őket a szavaktól, amelyek szintén lehetnek félreérthetőek vagy pontatlanok. Kiemeltem továbbá a kontextus fontosságát, bemutatva annak három aspektusát: a közvetlen vizuális kontextust, a közvetlen verbális kontextust, illetve a vizuális kultúrát. A második, disszertációm szempontjából különös relevanciával bíró kritika, amellyel a vizuális érvelést szokás illetni azt állítja, hogy a vizuális kommunikáció nem tartalmaz igazságértéket, így nem képes propozíciókat közvetíteni, amely azonban az érvelés alapfeltétele lenne. A propozíció fogalmi meghatározása után (olyan kutatókra támaszkodva, mint Groarke, Tindale, Copi, Cohen stb.) Anthony Blair „What's Czechoslovakia to me, anyway?" példájával illusztráltam a vizuális érvelés propozicionális természetét, lehetőségét. Ezt követően Birdsell és Groarke dohányzásellenes, illetve a WWF nemzetközi civilszervezet 2009es állatokkal való visszaélés ellen készített kampány poszterét mutattam be, részletesen kifejtve azt. Annak érdekében, hogy a harmadik ellenrévet, azaz a képek szövegre való lefordításának szükségességét is bemutassam, disszertációmban a percepciók, vizuális nyelv és vizuális gondolkodás hármasának elemzése következett. Többek között a Liu, Volčič és Gallois-féle definícióra támaszkodva áttekintést adtam a percepciókról és azok müködéséről, majd három 
szakaszát (szelekció, kategorizáció és interpretáció) ismertettem. Annak bizonyítására, hogy az észlelés legtöbbször túlmutat a szenzoros nyersanyag puszta mechanikus rögzítésén Walkup egyik tanulmányában szereplő példáját idéztem, amely a kockák kombinációjának vizualizálását vizsgálta. Rudolf Arnheimhez hasonlóan magam is azt a következtetést vontam le Walkup példájából, hogy nem volt szükségünk nyelvhasználatra a feladat megoldásához, azaz létezik vizuális gondolkodás nyelv nélkül is.

Ezt követően a retorika mint interpretáció/processzus megközelítés alapján a képek struktúráját alkotó mikro-kontextusokat, illetve a képi érvelés szociális, társadalmi és pszichológiai funkcióit, valamint a médiában betöltött szerepét mutattam be. A képi üzenetek multidimenzionális természetének bizonyítására a Roque által használt 1998-as „Victory” plakátot hívtam segítségül, amelynek interpretálását mind a négy, kognitív, emotív, esztétikai és morális kiterjedések mentén elvégeztem. Majd Blakesley alapján a vizuális retorika négyes megközelítését mutattam be, a film ideológiája, interpretációs és identifikációs perspektívája, illetve a számomra leginkább releváns film nyelve alapján, amely a filmet szemiotikailag és fenomenológiailag is nyelvtani jelrendszernek tekinti, különös figyelmet fordítva a nézők szemszögére és a percepciós folyamatokra. E négy aspektust nem pusztán a filmekre, hanem a képekre is érvényesnek tekintettem.

Végezetuil Winfred Noth tanulmányára támaszkodva a képi hazugsággal foglalkoztam szemantikai, szintaktikai és pragmatikai aspektusok alapján, ahol a szemantikai szempont azt mondja ki, hogy a képeknek meg kell felelnie azoknak az általuk ábrázolt tényeknek, a szintaktika perspektívája arra utal, hogy a képeknek nem pusztán egy tárgyat kell reprezentálnia, hanem közvetítenie kell e tárgyhoz kapcsolódó állításokat is, míg az utolsó, pragmatikai szempont azt jelöli, hogy kell, hogy legyen egyfajta megtévesztési szándék a képi üzenet befogadójával szemben. 


\section{A hírek}

\subsection{A hírek történeti elhelyezése}

„All the reporters in the world working all the hours of the day could not witness all the happenings in the world."

Walter Lippmann ([2009] p. 338.)

Amikor egy mai modern hírlapot olvasgatunk, általában a következő témájú hírekkel találkozhatunk: politikával és kormányzati tevékenységekkel kapcsolatos, gazdasági és tudományos, egészségügyi vagy éppen kulturális, egyházi témájú hírekkel. Természetesen vannak még baleseteket és bünügyeket bemutató hírek, időjárás és sport, valamint olyan besorolhatatlan bulvárhírek, amelyek a sztárok és hírességek tevékenységeit ismertetik. Érdekes megfigyelni, hogy a legelső magyar nyelvü hírlapok (Magyar Hírmondó - 1780; Hazai Tudósítások - 1806) tematikus szempontból majdnem minden fent említett egységet tartalmaztak, leszámítva a sporthíreket, amelyek - társadalmi okokból - csak a 19. század végén jelentek meg. A hírek történeti elhelyezéséhez a magyar kutatók közül elsősorban Andok Mónika írásaira támaszkodom, munkáiból a továbbiakban is többször idézek (Andok [2003] p. 71.).

Eredetüket tekintve az újságok az évente megjelenő kalendáriumokból alakultak ki, amelyek kezdetben - a 15-16. században - pusztán időjelző funkcióval bírtak, azaz a hónapokat sorolták fel, később azonban vásárjegyzékkel, eseményjegyzékkel és krónikákkal is bővültek. E krónikák érdekessége, hogy a világtörténet kezdetétöl a Biblia alapján mesélték el az eseményeket, eleinte kevésbé részletesen, majd az utolsó 4-5 év történéseit behatóbban írták le. Ezekről a krónikákról váltak le később a hírek, amelyeknek Andok szerint két különlegessége figyelhető meg. Egyrészt, a krónikás, korának eseményeit nem fragmentumként érzékeli és mutatja be, hanem egy globális folyamat részének, és ezáltal egy világmagyarázat elemének tekinti. Tehát, míg a kortárs hírek egyik legfontosabb attribútuma az aktuális jelleg, addig a régi korok híreinek legfőbb sajátossága a folyamatokban betöltött szerep volt, így helyet kaphatott benne az isteni érő és elrendelés, mint történelemformáló tényező. Ehhez kapcsolódik a

8 "Ha a világ összes riportere a nap minden órájában dolgozna, akkor sem lehetne szemtanúja a világ minden eseményének." 
krónikákból kialakuló hírek másik érdekessége, a média szocializáló funkciója, amely a hírek folyamatos történetmesélésbe illesztettsége miatt jóval dominánsabb volt, mint a mai, töredezetten észlelt hírek esetében (Andok [2003] p. 71.).

A fent említett, a ma olvasható témákkal szinte teljesen megegyező tárgykörök közül a legszorosabb cenzori ellenőrzés alatt álló politikai hírek a belpolitikai élettel kapcsolatosak, megjelennek továbbá a külföldi eseményekhez és az uralkodók döntéseihez köthető hadi hírek is. Később, a politikai élet virágzásával megjelentek a vidéki élet és a vármegyék életének történései, a 19. század második hányadában pedig már a pártokkal kapcsolatos hírek is olvashatók voltak, míg a 20. század elején, egy újfajta típusként a különböző politikai beszédek kivonatai is elérhetővé váltak. A gazdasági hírek forrásai a kereskedői, üzleti levelek voltak, amelyekből tájékozódni lehetett a szőlő terméséről, a bor, a gabona és a dohány áráról, később, a kiegyezés után azonban differenciáltabb hírek is megjelentek, amelyek már a közgazdaságtan szellemi irányzatára is támaszkodtak és magukban foglalták a csődeljárások és tőzsdék híreit is. A bünügyekkel foglalkozó hírek alapjául egyrészt a rendőrségi jelentések, másrészt az elkövetés környékéről származó szóbeli, majd levélbeli beszámolók szolgáltak, amelyek pontosságukban szinte megegyeztek a hivatalos jegyzőkönyvekkel, tartalmazták azonban a helyiek erkölcsi ítéletét, véleményét is. A bulvárhírekben a korábbi populáris irodalomtörténetei voltak felfedezhetők és - mivel minden kornak megvoltak a maga hírességei, sztárjai - e müfaji altípus is megtalálható 1780-tól a lapokban, a maihoz képest szinte változatlan formában. Számos elemző a disszertációm szempontjából leginkább releváns katasztrófahíreket is a tabloidok közé sorolja, amelyek szintén szerepelnek a 18. század sajtóhírei között, tüzvészek, áradások vagy földrengések formájában (Andok [2003] p. 71.).

\subsection{A hírek konceptualizációja}

Amikor a hírek definiálására vállalkozunk, számos eltérő meghatározással találkozunk, melyek közül a legtöbben felmerül valamilyen formában a viszony és a viszonylagosság problémája. Berkowitz megközelítése szerint például a hírek vizsgálata olyan, mintha egy hologramot próbálnánk értelmezni. Mindenki más oldalról, más szögből látja azt, a tér minden egyes pontjáról különböző aspektusait észleli ugyanannak a holografikus képnek, így egy és ugyanazon személy nem képes az egész hologram minden részletét egyszerre érzékelni (Berkowitz [1997] p. 
xi.). Carey hírmeghatározásában már radikálisabb, kétpólusú problémafelvetést látunk: a szerző szerint a hírek a közönség számára érthetővé vagy homályossá teszik a valóságot, megváltoztatnak vagy megerősítenek attitüdöket, hitelességet vagy kétséget jelképeznek a befogadók számára (Carey [2009] p. 45.). Jack Fuller definíciója pedig három kulcsszóval írja le a híreket: időszerüség, érintettség egy adott közösség számára, relevancia (Fuller [1997] p. 7.). A definíció imént említett elemei azonban nyilvánvalóan rámutatnak, hogy az adott hírszerkesztő valósághoz való viszonya alapvetően befolyásolja, hogy mely jelenségeket tekint lényegesnek, ezáltal a híreket az érvelés elemeként kell vizsgálnunk, amelyre szükségszerüen érvényesek a retorika és a meggyőzés értelmezési keretei. A Retorikai lexikon meghatározása is ezt a szemléletet erősíti: a hír a tájékoztató müfajcsoport legalapvetőbb műfaja. Hagyományos értelemben hírnek tekintjük mindazt, amiről úgy véljük, hogy értesülnünk kell; a médiában ezzel szemben a hír az, amit a média azzá tesz. Ezáltal azt tekintjük hírnek, amit valahol valaki fontosnak, érdekesnek tart (Adamik [2010] p. 500.). Összességében elmondható, hogy a hírek meghatározása teljes mértékben szétfeszíti a rendelkezésre álló definíciós kereteket, nem segít továbbá az sem, hogy a hírközlő számára az a hír, ami elhangzik a rádióban, televízióban, ami megjelenik a lapokban, míg a közönség számára az, ami érdekli (Andok [2013] p. 33.).

Berkowitz következő hármas megközelítése azonban hozzájárulhat a hírek konstrukciójának, természetének és viszonylagos aspektusainak jobb megértéséhez:

1. A keretek viszonylagossága: A hírek nem kézzelfogható, materiális tartalmak, amikre a jó újságírók rábukkannak. Nincsenek idő- és térbeli határaik, egyedül az ember által rájuk szabott korlátok.

2. A szociális viszonylagosság: A hírek eredendően nem bírnak értékekkel, amelyek néhány eseményt relevánssá, néhányat redundánssá tehetnének. Társadalmi szempontból a hírek olyan emberi konstrukciók, amelyek az újságírók informális konszenzusa alapján nyernek, vagy nem nyernek hírértéket, azonban a világban található történetek önmagukban nem képviselnek értékeket.

3. A szubjektív viszonylagosság: Végül hadd tegyünk említést az újságírói elfogultságról: az újságírók nem képesek objektívek maradni a körülöttük lévő világgal kapcsolatban, bármilyen keményen is próbálják kiküszöbölni személyes véleményük és hiedelmeik integrálását a hírek szerkesztésekor (Berkowitz [1997] p. xi.). 
Stuart Allan szintén hármas megközelítést javasol, amely egyfajta pragmatikus köntösbe bújtatja a híreket, ezáltal szorgalmazva a média és társadalom dichotómiájának feloldását:

1. A hír mint politikaalkotó egység: Azon szemléletek szerint, amelyek a kormányzati szférára fókuszálnak, a hírek, mint a demokrácia képviselői jelennek meg, a fogyasztókra pedig jogokkal rendelkező szavazópolgárokként tekintenek. Olyan sarkalatos kérdések merülnek fel a hírmédiával kapcsolatban, mint a pártatlanság és méltányosság, a cenzúra, a rágalmazás és az információ szabadsága, a magánélet védelme stb.

2. A hír mint árucikk: Gazdasági szempontból a hírek megvásárlásra és eladásra szánt árucikként foghatók fel. E megközelítés a közönség tagjaira elsősorban úgy tekint, mint aktuális (vagy potenciális) fogyasztókra, akiknek a figyelméért minden nap megküzdenek a hirdetők (vagy, a közhíradó esetében az állam számszerüsíti azt, igazolva a közpénzekből nyújtott támogatásokat). A hírmédia tulajdonosainak változó dinamikáját is górcső alá veszi ez a megközelítés (pl.: a koncentráció, konglomeráció és globalizáció fogalmak szemszögéből) különösen mivel ezek összefüggenek a profitmaximalizálással helyi, nemzeti vagy nemzetközi szinten.

3. A hír mint a közvélemény formálója: Allan utolsó megközelítése a híreket a közszféra birodalmán belüli „racionális-kritikai vita” határmezsgyéjére helyezi, ahol a legfőbb figyelem a hírmédia diszkurzív tér kialakításában betöltött meghatározó szerepére hárul, azaz a társadalmi kérdésekről zajló nyilvános tanácskozás fontosságára. A hírek népszerü attitüdöket formáló hatását tovább erősíti az, hogy a jelen szemlélet a közönséget a nyilvános párbeszéd résztvevőinek tekinti, hangsúlyozva a közvélemény fontosságát a hatalmi viszonyok felett (Allan [2010] p. 4.).

Schudson a híreket a demokrácia szükséges, de nem elégséges feltételeként jelöli meg, melyek segítik az adott képviseleti kormányzat létrejöttét és fenntartását. Schudson a hírek demokráciaalkotó szerepének azalábbi hat normatív funkcióját különíti el, nyilvánvaló azonban, hogy a valóságban ezek az alapelvek a kormányzat érdekeitől függően torzulhatnak. Ezáltal e folyamatban szintén megmutatkozik a hír mint érvelő egység meggyőző, véleményformáló ereje. 
1. Információ: A hírek teljes körü és korrekt tájékoztatást nyújtanak az állampolgároknak, hogy azok megalapozott politikai döntéseket hozhassanak.

2. Vizsgálat: A hírek folyamatos felügyelet alatt tartják az olyan koncentrált hatalmi forrásokat, mint a kormányhatalom.

3. Elemzés: A hírek koherens értelmezési keretet szolgáltatnak, hogy segítsen az állampolgároknak megérteni a körülöttük zajló komplex eseményeket.

4. Társadalmi empátia: A hírek eljuttatják hozzánk társadalmunk, vagy a világ más polgárainak történetét, hogy ezáltal tájékozódhassunk a kevésbé szerencsések helyzetéről és jobban megbecsülhessük sajátunkat.

5. Publikus fórum: A modern hírmédia a polgárok közötti párbeszéd fórumát is biztosítja, ezzel bemutatva a változatos társadalmi csoportok különböző perspektíváit.

6. Mozgósítás: A hírek bizonyos politikai programok és perspektívák szószólójaként is funkcionálnak, és képes e programok támogatása érdekében mozgósítani az embereket (Schudson [2008] p. 9.).

A már említett Császi Lajos olvasatában egy másfajta szemlélettel találkozhatunk a híreket illetően, a szerző ugyanis a médiahírek struktúráját a filmes történetekével állítja párhuzamba. Szerinte ,a médiahíreket a populáris kultúra egyik olyan alfajának tekintjük, amelyek a „,Szociális melodrámák” közé tartoznak. Hibrid müfajok, amelyek formalizált keretüket azoktól a populáris mítoszoktól kapják, amelyeken keresztül az eseményeket történetekké változtatják át, ám az így megteremtett sztereotip drámai kereteket tárgyilagos, valósághủ részletekkel igyekeznek kitölteni” (Császi, Katasztrófák média-reprezentációja).

A hírek egy másik aspektusára hívja fel a figyelmet Silverstone, aki úgy gondolja, hogy a hírek függőséget okoznak, különösen, amikor a világ rendezetlen, bizonytalan. Véleménye szerint a hírek a fenyegetettség, kockázat és veszély közvetítésének kulcsfontosságú intézményei, amelyek fogyasztása elengedhetetlenül fontos ahhoz, hogy feltérképezzük az ontológiai biztonságunk létrehozásához és fenntartásához szükséges kapacitásainkat (Silverstone [1994] p. 17.).

A fent említett hírelméletek és megközelítések alapján összességében tehát azt mondhatjuk, hogy a hírek eseményekkel, helyzetekkel vagy ideákkal kapcsolatos, faktuális 
információk azonnali és lényegi összegzése (beleértve a véleményeket és interpretációkat is) (Stepp [2013] p. 84.), úgy prezentálva, hogy egy bizonyos közönséget érdekeljen, valamint segítse tagjait a környezetükben történő elboldogulásban, illetve segítse a demokrácia kialakítását és fenntartását (Barkóczi - Deli [2016]).

\subsubsection{A hírek múfajbesorolása}

A továbbiakban a hírek klasszikus müfajbesorolását ismertetem, előtte azonban szükségszerü kitérnem arra, hogy mit is értünk müfaj alatt, hogyan is zajlik a különböző médiaszövegek és médiatartalmak elemzése. Jostein Gripsrud négy nagy területet különít el, amelyek szemszögéböl vizsgálhatók a müfajok (Andok [2013] pp. 36-37.). Ezek a szemiotika, amely a jeleket, a hermeneutika, amely az értelmezést, befogadást, a retorika, amely a szituációt és nyelvhasználatot, és végül a narratológia, amely az elbeszélés formáit elemzi.

1. A szemiotika megközelítése szerint a müfaj olyan kód, amely meghatározza, milyen típusú jeleket és hogyan kombinálunk a szövegek egy bizonyos osztályán belül.

2. A hermeneutika ezzel szemben úgy tekint a müfajra, mint az elvárási horizont egy részére, amelynek értelmezéséhez támaszkodnunk kell előzetes ismereteinkre, tapasztalatainkra. Ez azt jelenti, hogy nem „naiv” módon ülünk le egy bizonyos hírmüsor, talk show vagy bünügyi film elé, hanem elözetes tudásainkat alapul véve elvárásokat fogalmazunk meg az adott médiatartalommal kapcsolatosan. Nem meglepő tehát Gripsrud szerint minden müfaj mögött egyfajta sajátos világnézet áll, amely a társadalmi lét különböző aspektusaira fókuszál.

3. A retorikai szemlélet a müfajt pragmatikai jelenségnek tekinti, amely Aczél szerint semmiképpen sem formális egység, hanem a szándék és a hatás közötti kapcsolat megteremtője, amely a társas viszonyokat cselekvő módon alakítja (Aczél [2009] p. 82.).

4. A narratológia területe zárja a sort, amely a müfajt szerkezeti formaként írja le, figyelembe véve a formához tartozó funkciót is (Andok [2013] pp. 36-37.).

Denis McQuail A tömegkommunikáció elmélete címü munkájában úgy ír a müfaj kifejezésről, mint egy bizonyos kulturális termék megkülönböztetésére használt elméleti kategória, amely 
leggyakrabban fajtát vagy típust jelöl. Míg a filmelméletben, amelyből a kifejezés származik, vitatott értelemmel bír - egyszerre utalva az alkotó szerzőség és a müfajba sorolás megjelölésére - a tömegmédia területén a müfaj fogalmi meghatározása nem kétséges, mivel a szerzőség kérdése többnyire nem merül fel (McQuail [2003] p. 288.). A McQuail által támogatott müfajtipológia bemutatásához a szerző Bergert idézi, aki szerint minden televíziós tartalom besorolható az alábbi ábrán látható négy alaptípus egyikébe, az objektivitás és az érzelmi telítettség mértékétől függően.

\begin{tabular}{|c|c|c|c|}
\cline { 2 - 4 } \multicolumn{1}{c|}{} & \multicolumn{3}{c|}{ Objektivitás } \\
\cline { 2 - 4 } \multicolumn{1}{c|}{} & & Nagymértékü & Kismértékü \\
\hline \multirow{3}{*}{$\begin{array}{c}\text { Érzelmi } \\
\text { telítettség }\end{array}$} & Erös & Vetélkedő & Dráma \\
\cline { 2 - 4 } & & & \\
\cline { 2 - 4 } & Gyenge & Aktualitás & Rábeszélés \\
\hline
\end{tabular}

\section{TÁBLA. A televiziós müfajok struktúráját bemutató tipológia (saját szerkesztésü tábla)}

A nagymértékủ objektivitással és erős érzelmi telítettséggel rendelkező vetélkedókategóriába valódi játékosok versenyéről szóló műsorok tartoznak, pl.: kvízműsorok, sportvetélkedők, jellemzőjük pedig, hogy egyidejüleg valósak és érzelmileg bevonóak. Az ideális esetben objektív és érzelemmentes aktualitás tárgykörébe tartozik az összes hír-, dokumentum- és ténymüsor. A magas érzelmi telítettségü, objektivitásban szükölködődráma lefedi az összes fikciós elbeszélést és a müfajok széles körét, míg az utolsó, mindkét dimenzióban alacsony értékü rábeszélés kategória a kibocsátó befolyásolási szándékát tükrözi, így ide sorolhatjuk a reklám és propaganda bizonyos formáit. E séma jó kiindulási alapot ad a televíziós müfajok struktúráját illetően, megnehezíti azonban a helyzetet, hogy napjainkban olyan kevert zsánerek születnek, mint az „info- és edutainment”, vagy a „dokudráma”, amelyek besorolása gyakran nehézségekbe ütközik (McQuail [2003] p. 291.). A tömegmédia müfajait illetően azonban McQuail megfogalmazott öt általános érvényű alapigazságot, amelyek kapcsolhatók az előzőleg bemutatott Gripsrud-féle elemzési lehetőségekhez, bár ő nem tudományterületenként halad: 
- A müfajokat a médiatartalom elóállítói és fogyasztói azonos módon határozzák meg

- A müfajok azonosítása funkció, forma és tartalom szerint történik

- A műfajok megőrzik textuális formájukat és segítik azok fejlesztését

- A müfajok segítenek a szövegek előállításában és értelmezésében

- A müfajokat sajátos nyelv, logika és formátumok jellemzik (McQuail [2003] p. 291.)

A müfaj diszciplináris hátterének áttekintése után áttérek a hírek arisztotelészi zsánerbesorolásának ismertetésére. Mivel a média maga is egy retorikus közeg, annak elemei, pl.: a hírek is szükségszerúen argumentatív értéket nyernek, egyfajta müfaj besorolást kapnak. „A müfaj szó egyszerüen „rendet” jelent. A művészeti alkotások esetében a műfaj egy típus, osztály, vagy prezentációs kategória, jellegzetes és könnyen azonosítható jellemzőkkel” Silverblatt [2007] p. 3.). Könyvében, a Rétorikában Arisztotelész a retorikai beszédek három típusát különíti el: a jogi beszédet, a tanácskozó beszédet és a bemutató beszédet (Arisztotelész [1982] 1358b).

1. A jogi beszédfaj (genus iudicale) a döntéshozatalt szorgalmazó perbeszédek alapjául szolgál, témája az igazság vagy igazságtalanság, müfajai a vád- és védőbeszédek. Ideje a múlt, érzelmi világa a szigor vagy a megbocsátás indulata.

2. A tanácskozó beszédfaj (genus deliberativum) müködése azonban jövő idejü, témái az előny és a hátrány, müfajai a politikai beszédek, a választási kampányok beszédei, a reklámok vagy az erkölcsi intelmek. Érzelmei a félelem és a remény.

3. A legutolsó arisztotelészi zsáner a bemutató beszéd (genus demonstrativum), amelynek ideje a jelen, funkciója a dicséret vagy elmarasztalás. Témakörei a szépség és a rútság bemutató beszédekben, alkalmi beszédekben, dicséretekben és ismertetőkben. Indulatai az öröm és gyülölet.

Kenneth Burke szerint ez az utolsó arisztotelészi müfaj olyan különböző területeket tartalmaz, mint a propaganda, hirdetések, irodalmi müvek, retorikai stratégiák és eszközök: eszközök, amelyek meghatározzák az emberek egymáshoz és a világhoz való kapcsolatát (Burke [1969]). Ezen elmélet alapján úgy vélem, hogy a hírek besorolhatók a genus demonstrativum, azaz a bemutató beszéd müfajába, amely elsősorban arra törekszik, hogy egy bizonyos világnézetet kialakítson, az információ megszerzése és átadása helyett. A híreken keresztül a feladó egy 
nyelvi és képi világot hoz létre, és arra hívja meg az embereket, hogy ők is hasonlóképpen lássák a világot. A hír tehát „nem közöl, hanem értelmez, azonosít: világképet formál, és igazol”(Aczél [2008]) ezáltal pedig nem az információ, hanem az érvelés alapegységének tekinthető.

\subsection{A hírek és a meggyőzés}

A hírgyártás folyamatát vizsgáló társadalomtudósok általában a következő kifejezéseket szokták használni a témában, nem kis felháborodást keltve ezzel az újságírók körében: „hírcsinálás”, „hírgenerálás”, „,valóságkonstruálás”, ,az a hír, amit az újságírók előállítanak” stb. Még azok az újságírók is offenzívnak találják e fordulatokat, akik kritikusan állnak kollégáik és intézményeik napi gyakorlataihoz. Mentségükre azt szokták felhozni, hogy az alkalmanként előforduló torzítások, pontatlanságok és szenzációhajhászás ellenére egy felelős újságíró sohasem állít valótlant, mindig csak hiteles adatokra, tényekre támaszkodik. A társadalomtudományok kutatói természetesen nem azt állítják, hogy a médiahírek szerkesztői hazudnak, hanem azt, hogy létrehoznak; teremtenek és alkotnak (Schudson [1989]). Ideális esetben a hírszerkesztők olyan tartalmakat hoznak létre, amelyek számunkra érdekesek, relevánsak, fontosak, és amelyek segítenek nekünk társadalmi kérdésekben helyes döntést hozni onnan, hogy melyik filmet érdemes megnézni egészen odáig, hogy melyik politikai jelöltre szavazzunk. Manapság a hírmüsorok, és a hírekkel foglalkozó online vagy nyomtatott lapok széles körben elterjedtek a médiában. Teljes médiahálózattal rendelkezünk, amely eljuttatja hozzánk a híreket, ezért azt gondolhatnánk, hogy rengeteg lehetőségünk van informálódni a világ eseményeiről. Számos kutatás azonban azt bizonyítja, hogy annak ellenére sem tudunk sokat, hogy a különböző médiumok híreinek kereszttüzében éljük életünket. Timothy Borchers meglátása szerint a hír nem más, mint egy termék, amelyet a médiaszervezetek stratégiai marketing és keretezés segítségével eljuttatnak a közönséghez. Ezáltal a hír egy olyan konstrukcióvá válik, amely a valóság egy változatát írja le, az újságírói normáknak és konvencióknak, valamint a politikai érdekeknek megfelelően (Borchers [2012] pp. 118-119.).

Communication as Culture címü munkájában Carey megkülönbözteti a kommunikáció transzmissziós és rituális megközelítését, amely elkülönítés a hírek esetében is mindenképpen releváns (Carey [2009]). A kultúránkban leginkább elterjedt transzmissziós szemléletet a „küldés” „fogadás” „közlés” vagy „mások informálása” kifejezésekkel írhatjuk le, amely 
metaforikus értelemben arra utal, hogy a 19. században az áruk és emberek mozgását lényegében azonos folyamatnak tekintették az információ áramlásával, hiszen mind a két tényezőt a „kommunikáció” kifejezéssel illették. E megközelítés középpontjában a jelek vagy üzenetek nagy távolságban történő közvetítése áll, amelynek célja az informálás és ellenőrzés. A kommunikáció rituális szemléletének kisebb jelentőséget tulajdonítunk, pedig sokkal jelentősebb történeti hagyományokkal rendelkezik. Archaikus természete ellenére azonban semmiképpen nem tekinthető elavultnak vagy korszerütlennek, sőt, a hozzá köthető „részvétel” „közösség” „megosztás” és a „közös tudás birtoklása” kifejezések miatt úgy vélem, a rituális megközelítés jelen korunkban mindennél relevánsabb a hírmeggyőzés szempontjából. E szókapcsolatok egyúttal rávilágítanak a „commonness”, „communion”, „community”, és „communication” kifejezések közös gyökereire és identitására is. A rituális megközelítés nem az üzenetek térbeli terjedésére utal, sokkal inkább a társadalmi struktúrák fenntartására és rendszerezésére, vagy a közös hit és értékek képviseletére. Ha a híreket a transzmissziós modell alapján vizsgáljuk, információkat és tudást közvetítő eszközként tekinthetünk rájuk, amelyek - gyakran a szórakoztatás céljából - továbbítják üzeneteiket egyre nagyobb távolságokban. A rituális szemlélet azonban másfajta problémákra fókuszál a híreket illetően. Ez utóbbi megközelítés ugyanis az újságolvasást kevésbé tekinti információk továbbításának és fogadásának, sokkal inkább a társadalmi folyamatokban való részvételre és egy olyan helyzetre helyezi a hangsúlyt, amelyben nem az új tudás, hanem egy bizonyos világnézet ábrázolása és megerősítése válik fontossá. Így a befogadó fő feladata nem az információszerzés, hanem a médiahír által motivált drámai szerepvállalás, melynek segítségével az események aktív részesévé válhat. Carey szerint tehát a hír dráma, amely nem ad leírást a világról, hanem a „drámai erők és akciók arénáját ábrázolja" (Carey [2009] p. 17.).

Azzal az állítással kapcsolatosan tehát, hogy az újságírás és a hírmédia általában mindent megtesz a tömeg objektív tájékoztatása érdekében, jobb, ha óvatosak maradunk. Mire egy hírlap eléri olvasóit, egy sor szelekciós folyamaton megy keresztuil, onnantól kezdve, hogy milyen elemeket nyomtassanak, és milyen pozícióban nyomtassák őket, mennyi helyet foglalhat el egyegy cikk, milyen vizuális komponensekkel egészíthető ki, mekkora hangsúlyt fektessenek rá stb. (ezek a funkcionális kérdések természetesen ugyanúgy relevánsak a televíziós, rádiós és az online médiahírek esetében is). Lippmann szerint tehát nincs objektív mérce, minden az újságírók döntéseinek és a hírlap érdekeinek függvénye (Lippmann [2009] p. 354.). Ugyancsak 
Lippmanntól származik az igazság és a hírek közötti releváns különbségtétel, a szerző ugyanis úgy véli, a hírekkel szemben az igazság nem spontán jön. A hírek funkciója az, hogy megjelöljenek egy eseményt, míg az igazság funkciója, hogy napvilágra hozza a rejtett tényeket, összefüggéseket keressen közöttük és képet fessen a valóságról, amely szerint az emberek eljárhatnak. Amit általában kapunk tehát, az nem igazság, hanem tények sorozata, amelyet behatárol a különböző riporterek értelmezési kerete, a rágalmazástól való félelem, így a hírek egyértelmüen felszínes, sztereotípiákkal, standardizáltsággal és ítéletekkel terhelt egységek, amelyek figyelmen kívül hagyják az apró finomságokat (Lippmann [2009] p. xviii.).

Schudson Tuchman szavait idézi, aki a következő kiváló megállapítást teszi a hírekröl: „Azt állítani, hogy a hogy egy hírjelentés se több, se kevesebb, mint történet, nem lealacsonyító vagy fikcióval vádoló kijelentés. Inkább arra figyelmeztet bennünket, hogy a hírek - mint minden nyilvános dokumentum - olyan konstruált valóságnak tekinthetők, amelyek saját belső érvényességgel rendelkeznek" (Tuchman [1976] p. 97.) ${ }^{9}$.Az újságírás tehát, mint bármely más történetmesélő (storytelling) tevékenység, egyfajta fikció, amely saját konvenciói és értelmezési elvei alapján müködik, saját szociológiai, ideológiai és irodalmi korlátai között. A hír tehát egy konstruált világképet teremt bennünk, pedig látszólag tárgyilagosabb, mint a tudósítás, semlegesebb, mint a tárca, objektívebb és elfogulatlanabb, mint a vezércikk. Éppen ezáltal válhat a meggyőzés és manipuláció alapkövévé, a világkép legészrevehetetlenebb alakítójává (Aczél [2008]).

Carey, Lipmann és Tuchman meglátásával egybehangzóan Aczél Petra „A manipuláció manipulációja: a médiahír" címü írásában az alábbi felvetést fogalmazza meg a különböző a hírek, mint reprezentációk kontextualizálásáról: „Minden reprezentáció, megjelenítés manipulatív. Mert a történéseknek, eseményeknek egy más jelrendszerben, időviszonyban, jelenlétben kell újraéledniük. (...) Ez az átalakítás, ez a formálás manipulál. Azért fordulunk jellemzően ugyanahhoz a hírorgánumhoz, mert ott azonosulási lehetőséget, összecsengést érzünk azzal, ahogyan mi tudjuk, mi ismerjük a világot; ez pedig nyilvánvaló bizonyítéka annak, hogy a hír nem objektív" (Aczél [2008]).

\footnotetext{
9 ,To say that a news report is a story, no more, but no less, is not to demean the news, not to accuse it of being fictitious. Rather, it alerts us that news, like all public documents, is a constructed reality possessing its own internal validity"
} 
De milyen módszerekkel igyekeznek a médiumok világképünket formálni? Hogyan történik ez a meggyőzési vagy esetenként manipulációs folyamat? A hírmeggyőzés módszereinek elkülönítéséhez Larson a következő fogalmakat javasolja:

- Mellőzés: A hírek bemutatásakor gyakran előfordul, hogy bizonyos események minimális hangsúlyt, időt vagy említést, az újságok esetében pedig előnytelen pozíciót kapnak a híradáskor. A globális felmelegedés veszélyeit pl. Al Gore „An Inconvenient Truth" címü kisfilmje elött a média figyelmen kívül hagyta, nem tartotta elég relevánsnak, szenzáció-dúsnak a témát.

- A szponzor előnyben részesítése: mivel minden hírmüsorban megjelenő szolgáltatásnak, terméknek vagy intézménynek van legalább egy (vagy több) úgynevezett szponzora - ez lehet akár az állam is - a hírek riporterei és a szerkesztői igyekeznek enyhíteni bármilyen negatív információt a szponzorral kapcsolatosan.

- A pszeudoesemény: a „pszeudo” görög szó eredeti jelentése hamis vagy félrevezető. A pszeudovalóság kifejezés Boorstintól származik, aki úgy véli, virtuális, avagy szintetikus valóságban élünk, amely nem spontán, hanem elöre megtervezett, folyamatosan reprodukált, az igazi valósághoz való viszonya pedig homályos (Boorstin [1992] pp. 11-33.). Bár hatalmas híranyaggal rendelkeznek a hírszerkesztők napról napra, mégsem tekinthető mindegyik érdekesnek vagy szórakoztatónak, azért az újságírók és hírszerkesztők feladata, hogy drámaivá, vagy bizarrá tegyék az eseményt, nagyobb nézettségre/olvasottságra számítva ezzel. Kapcsolódva a hírek pszeudoesemény alapú felfogásához Baudrillard úgy véli, a kommunikáció és az információ elveszítette referenciális természetét, pusztán a jelentés létrehozása és cirkulációja alapján értékelhető e két fogalom (Baudrillard [2014] p. 32.).

- Elöítéletek verbális és nonverbális jelek alapján: Egy tehetséges kérdező egészen más színben tudja feltüntetni interjúalanyát valódi énjéhez képest. A politikusok gyakran panaszkodnak, hogy a híripar megtévesztő reprezentációi miatt felkészületlennek, inkompetensnek, vagy csak idegesnek és kényszeredettnek tünnek interjúik során. A hírek vizuális ábrázolása napjaink egyik legfontosabb és 
legkérdésesebb területe, amelynek disszertációm külön fejezetet szentel a későbbiekben (Larson [2010] pp. 359-361.).

A fentiek alapján nyilvánvalóvá válik, hogy hírfogyasztók a hírek nyújtotta világ-darabokban próbálnak eligazodni, ez azonban kifejezetten problémás, hiszen már nem azt ismerték meg, ami történt, hanem, ami nem történt, vagy csak lehet, hogy történni fog. Aczél ezt a hírek valóságtól való végzetes elszakadásának nevezi, amely önállóságot teremtett a müfaj számára: létrehozta a fajsúlyos és fajsúlytalan hírt, a bulvárhírt; a hírt, ami történéseket rejt el, vagy ami eseményeket arcátlanul tagad (Aczél [2008]). Ahogy láthattuk, médiahírek létrehozóinak munkáját ugyan rendkívül sok formális megkötés kíséri, pl.: szabályok, eljárások, vagy hagyományok, amelyek meghatározzák az „objektivitás” jelentését, azt az állítást azonban, hogy az újságírók és hírszerkesztők egyszerúen és sikeresen képesek tükrözni a valóságot, a jelen tanulmány - számos kutatóval egyetértve - cáfolja (Manoff - Schudson [1986] p. 6.).

A hírek meggyőző természete azok felépítésében is egyértelmüen kimutatható. Egy közel egy évszázados iránymutatás szerint az újságíróknak az 5W \& $1 \mathrm{H}$ modell szerint szükséges eljárnia, amelyben az $5 \mathrm{~W}$ a What? Who? Where? When? Why?, míg a H a How? kérdőszót jelzi. $\mathrm{Az}$ említett séma a mai napig része az újságíró képzések katekizmusának, hiszen mind a szerkesztők, mind a közönség tagjai elvárják, hogy a legfontosabb kérdések megválaszolásra kerüljenek. Azonban e kérdések látszólagos egyszerüsége és logikussága mögött egy teljes interpretációs keretet rejlik, amelyből még a legjobb és legobjektívabb újságírók is hasznot húzhatnak. Nem mindegy természetesen, hogy az adott tudósító kihez fordul kérdéseivel és azokat milyen formában teszi fel. Ki számít magas hírértékủ valakinek? Milyen tények vagy események minősülnek méltónak arra, hogy a „mi” kérdésre válaszoljanak? Még a ránézésre legegyszerübb „mikor” és „hol” kérdések is problémásak, torzítóak lehetnek (Manoff Schudson [1986] p. 3.). E kérdések pedig nyilvánvalóan implikálják, hogy a hír koránt sem elfogulatlan. De milyen híreket is dolgoz fel a sajtó? Számtalan félvállról vett választ tudunk javasolni: amihez kedve van; ami segíti az eladást; bármit, amit éjfélig fel tudnak dolgozni; amit mindig is feldolgozott. Van ennél pár méltóbb válasz is természetesen: a híreket; a tényeket; azt, ami fontos. Bizonyos mértékben minden válasz magában foglal egyfajta filozófiát a hírek természetével kapcsolatban, azonban úgy tünik, mégsem vagyunk képesek egyenes feleletet adni. Nem létezik általánosan elfogadott norma, ahogyan nincsen filozófiai Legfelsőbb Bíróság 
sem, amely választ adhatna kérdéseinkre. Ha elfogadjuk Wittgenstein nézetét, amely szerint egy szó jelentése mindig a használatától függ és attól a nyelvi játéktól, amelyben szerepel, rá kell döbbennünk, hogy azok a nyelvi játékok, amelyben a „hírek” és a „tények” szavak szerepelnek, szintén nem tartalmaznak szigorú meghatározásokat e kifejezésekről. Ahogyan a hírgyártás maga sem egy olyan jogilag elismert szakma, mint a pszichiátria vagy az orvostudomány, amelyek kifejezéseinek meghatározására hivatalos szervek nyertek felhatalmazást. Annak ellenére azonban, hogy a hírgyártói fogalmaknak nincsen általánosan elfogadott normarendszere, a hírgyártás folyamatának lépései és a hírértéket növelő faktorok elkülönítése mégis lehetséges (Manoff - Schudson [1986] pp. 38-39.). E folyamat lépcsőinek elkülönítésekor szintén érdemes odafigyelnünk arra, hogy a hírszerkesztők milyen nagymértékben preferálják a jól dramatizálható, könnyen sematizálható és szerkeszthető metavalósággal (a valóságról szóló valósággal) gerjesztett (ál)eseményeket, híréhségünk kielégítése érdekében (Aczél [2008]).

\subsection{A hírgyártás folyamata}

A hírgyártást illetően hagyományosan négy lépést tudunk elkülöníteni: a hírek gyüjtését, szelektálását, csomagolását és prezentálását. Aczél szerint ez a folyamat tulajdonképpen megegyezik a klasszikus retorika beszédalkotási folyamatával (a feltalálással, elrendezéssel, kifejezéssel és előadással) (Aczél [2012] p. 95.). Így a hírgyártás különböző fázisai alapvetően megegyeznek a szövegalkotás állomásaival. A hírek gyüjtése és szelektálása szükségszerüen az eredeti koncepció elszegényedéséhez vezet, kiemelve annak egyes részeit és elhagyva más elemeit, ezáltal azonban új intertextuális viszonyok jönnek létre és új koncepciók születnek.

A következőkben hadd említsek néhány olyan tényezőt Luhmann alapján, amelyek fontos szerepet játszanak a hírek kiválasztásában:

- Meglepetés: Az adott információnak újdonságnak kell lennie és szakítania kell a meglévő elvárásokkal, de ahhoz, hogy észlelni tudjuk újszerüségét, ismerős kontextusokra van szükségünk, pl.: földrengések, vállalatok bedőlése, titkos viszonyok stb.

- Konfliktusok: A médiában megjelenő konfliktusok mindig nagy népszerüségnek örvendenek, mivel a jövőbeli bizonytalanság teret ad az izgalomnak, feszültségnek és az esetleges találgatásoknak. 
- Mennyiségek: A mennyiségek különösen hatékonyan ragadják meg figyelmünket. A mennyiségek meglehetősen heurisztikusak, mivel a számok magas igazságértéket és relevanciát sugallnak.

- Helyi vonatkozások: Az emberek többnyire annyira magabiztosak azzal kapcsolatban, hogy mi történik szomszédságukban, hogy minden járulékos információ különösen magas értéket képvisel, pl.: egy kutya megharapta a helyi postást.

- Normaszegések: A normaszegések tipikusan magas hírértékü témák. Jelenthetik a jogszabályok megsértését, azonban még jelentősebbek az erkölcsi szabályszegések és a századforduló óta igen relevánssá váló politikai korrektség megsértése. Mondanom sem kell, hogy a hírérték emelkedik, ha mindezeket a normaszegéseket prominens emberek követik el (Luhmann [2000] pp. 28-31.).

A fenti faktorokat Aczél a következőkkel egészíti ki. Magas a hírértéke mindannak, ami:

- Rekord-ízü: sokkal nagyobb teljesítménynek tünik, ha egy ember a fülével húz el egy kamiont, mintha önként, munka mellett betegeket ápol egy kórházban.

- Folytatható: egy katasztrófa újabb és újabb részletekkel nyújt elegendő muníciót a média számára akár több hónapra is.

- Könnyen leegyszerüsíthető: jóra, rosszra, igazságra és hazugságra, ezzel lehetővé téve a gyors azonosítás aktusát, pl.: a politikai híreket általában ilyen kategóriákban értelmezzük (Aczél [2008]).

Az imént említett tényezők (meglepetések, helyi érdekek, rekordok, mennyiségek stb.) semmit sem mondanak a jövőről. Még a mennyiségek sem tudnak semmi biztosat mondani a jövőbeni lehetőségekről, ezért azt mondhatjuk, hogy a hírek jövőbeni bizonytalanságokat generálnak és tartanak fenn, ellentétben minden folyamatossággal kapcsolatos bizonyítékkal, amiket mindennapi észlelésünk vált ki. Csomagolás alatt a hírek vizuális és verbális kódok segítségével történő elrendezését és keretezését értem. Ez óhatatlanul is különböző érték-asszociációk kialakítására biztatja a befogadót (Aczél [2012] pp. 95-96.). Végül, de nem utolsó sorban a hírek prezentálását ismertetem, a hírek bemutatásának különböző módjai, a kommunikátor, a körülmények, az időtényező és a beszédhelyzet hozzárendelésével. 
A hírek prezentálását illetően elengedhetetlen bemutatnom egy fontos tényezőt, a stílust. A hírek általában közömbös vagy választékos stílusúak lehetnek, a különbözö minősítések (melléknevek vagy határozószók) felettébb ritka alkalmazásával (Andok [2003] p. 70.). Az egyik legerösebb stiláris követelmény ahhoz, hogy egy eseményt a hírek múfajába sorolhassunk, a nézőpont jelöletlensége. Az aktuális beszélő nem jelölheti magát sem nyelvtanilag, sem egyéb módokon: ha az alany feltüntetett, akkor a szöveg automatikusan kizáródik a hírek müfajából és áttevődik a tudósításba. Érdekes, hogy ez a jelenség mennyit változott az elmúlt 200 évben. A már említett, 1780-as években megjelenő Magyar Hírmondó a híreit az ország különböző vidékeiről érkező olvasói levelek alapján állította össze, és, ha az olvasó valóban a két szemével látott egy eseményt, azt mindig kiemelték a közleményben, hogy növeljék a potenciális hír hitelességét. Ma ennek éppen az ellenkezője figyelhető meg: a híreket csak akkor tekinthetjük objektívnek, ha az valóban mentes az alany grammatikai jelölésétől, máskülönben tudósításról beszélünk (Andok [2003] p. 69.).

Természetesen a hírek objektivitása az alany nyelvi jelölésétöl függetlenül is problémás. Ahogyan azt már említettem, a hírek gyüjtése és szelektálása egyfajta szürőn keresztül történik; a gyüjtés és a válogatás kettős gesztusa alakítja ki a stílust, amely bizonyos értelemben a teljesség megrablása, az elszegényedés funkciója. A stílusban benne rejlik a manipuláció lehetősége is, amely a hír esetében nem múvészi, tehát nem az esztétikai élmény kialakítója, hanem bizonyos érzelmi hatások kiváltója, amely a látásmód és a világról való tudás átalakulását eredményezi (Aczél [2008]). Így a manapság nagyra értékelt objektivitás, semlegesség, vagy tárgyilagosság egyenlő a felelősségvállalás és az ember elvetésével. Hiszen az ember semmiképpen sem értékmentes, elköteleződései, értékei teszik emberivé. Éppen ezért tudnunk kell, hogy a nyelvileg, képileg objektív, semleges, tárgyilagos stílusúnak tủnő hírek is ugyanúgy egy bizonyos értékrend mentén jönnek létre, e jellegükből adódóan pedig még inkább manipulatívak (Aczél [2008]).

Az utolsó kérdés, amire ebben a fejezetben kitérek, hogy hogyan válnak az „események” „hírekké”, azaz minek kell ahhoz teljesülnie, hogy egy eseményt hírként aposztrofáljunk. Ahhoz, hogy e kérdés megválaszolásra kerülhessen, Galtung és Rugea hírek kommunikációjának láncát mutatja be, amely a szelektálás és torzítás fogalmainak kiemelésével juttat el bennünket a világ híreitől azok személyes feldolgozásáig. 
Figure 1. The chain of news communication

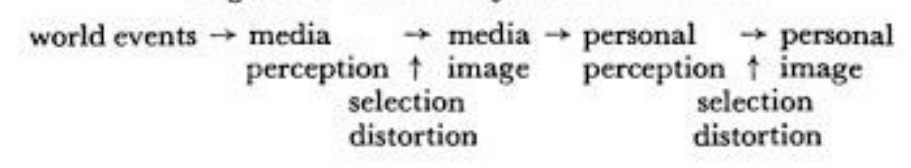

6. ÁBRA. A kép forráshelye:

http://journals.sagepub.com/doi/pdf/10.1177/002234336500200104

A médiaipar szelekciós és torzító folyamatai döntik el, hogy melyek azok az információk, amelyek - érdekeiktől függően - a közönség elé tárhatók (narratable) és melyek azok, amelyek nem (un/nonnaratable). Az utóbbi kategóriába olyan információk sorolhatók, amelyek vagy jogi akadályokba ütköznek (pl.: társadalmi, szerzői, általános vagy formális), vagy ellentmondanak az elbeszélő hatáskörének, érdekeinek, esetleg nem üti meg az elbeszélhetőség küszöbértékét, mert nem elég szokatlan, vagy problémás (Prince [1988] p. 1.). A fent említett kommunikációs hírmodellen kívül Galtung és Rugekét olyan dimenziót is bemutat, amelyek révén a hírérték jelentéstartalmát lehetséges meghatározni. A szerzőpáros úgy véli, hogy bizonyos kulturális tényezők jelentősen befolyásolhatják az események hírekké való alakulását, így elsősorban az „elit emberek és elit nemzetek”, valamint a „negatív események” fontosságát hangsúlyozza a hírérték tekintetében. A szerzők négy faktort különítenek el az elitekkel és negativitással kapcsolatosan:

- Minél inkább kapcsolódik az esemény az elit nemzetekhez, annál nagyobb esélye van arra, hogy hírré váljon.

- Minél inkább kapcsolódik az esemény az elit emberekhez, annál nagyobb esélye van arra, hogy hírré váljon.

- Minél személyesebbé tehető az esemény - a különböző egyének cselekedetei miatt annál nagyobb esélye van arra, hogy hírré váljon.

- Következményeit tekintve minél negatívabb az esemény, annál nagyobb esélye van arra, hogy hírré váljon (Galtung - Ruge [1965] p. 65.). 
Miért az elitek?

Ahogyan a legtöbb országban elérhető népszerü magazinokban is láthatjuk, az eliteket gyakran az átlagemberek képviselőiként mutatják be. Egy történet arról, hogy a király hogyan ünnepelte a születésnapját pl. nem tér el sokban attól, ahogyan bármelyikünk ünnepelné, de a mindennapi emberek közül nagyon nehéz lenne kiválasztani, hogy kit érjen a megtiszteltetés azzal kapcsolatosan, hogy élményeit elmesélhesse (Galtung - Ruge [1965] p. 68.). Egyértelmü továbbá az is, hogy az elit emberek és elit nemzetek tetteinek jóval súlyosabb következményei vannak, mint másokénak. Nem kiemelt fontosságuk emeli a hírek értékét, hanem inkább a tény, hogy az általános azonosulás tárgyaként tekintünk rájuk, amely megadja számukra a médiában történő önreprezentáció lehetőségét. Így tehát elmondható, hogy az elitközpontú hírek kommunikációs rendszerében az átlagos embereknek nem adatik meg a lehetőség, hogy önmagukat direkt módon képviseljék, pusztán a többi, elit személyen keresztül van esélyük véleményük és értékeik megtestesítésére (Langer [2003] p. 141.).

Miért a negatív hírek?

„There is so little to be happy about in the news" - tartja a mondás, de mi lehet ennek az alapigazságnak, valamint a negatív és cinikus hírek címlapokon való túlsúlyának hajtómotorja? E jelenség magyarázatára a médiatudósok gyakran a piaci igényekre hivatkoznak: az egészen az 1940-es évekre visszanyúló kutatások, valamint az eladással kapcsolatos mutatók is azt támasztják alá, hogy az emberek a negatív híreket abszolút mértékben preferálják a pozitívokhoz képest. A kultúrától függetlenül megfigyelhető jelenség az egyén alapvető biztonság szükségletéből fakad, amely az egyik elsődleges, a média segítségével bizonyos mértékig kontrollálható, fiziológiai igény (Angelusz [2003] pp. 3-24.). A közönség negativitáshoz való vitathatatlan vonzódását Joseph E. Uscinski az evolúciós pszichológia hagyományaival magyarázza, mivel e tudományág szerint a közönség a híreket a környezetben található potenciális fenyegetések feltérképezése miatt fogyasztja, így amikor a nézők olyan hírekkel találják magukat szemben, amelyek félelmet vagy dühöt indukálnak, jobban odafigyelnek rájuk (Uscinski [2014]). Ez a reakció többnyire automatikus, a közönség nincsen tudatában annak, hogy megkülönböztetett figyelmet szentel egyes híreknek, míg másoknak nem (Barkóczi - Deli [2006]). Galtung és Ruge szerint a negativitással kapcsolatos preferenciáinkat a következő tényezők indokolják: 
- A negatív hírek könnyebben lépnek be a hírcsatornákra, mert jobban megfelelnek a gyakoriságára vonatkozó kritériumoknak. A pozitív és a negatív pólusok közti aszimmetria mindig is megfigyelhető volt, hiszen a negatív ügyek általában sokkal könnyebbek és hirtelenebbek, mint a pozitívak. Gondoljunk csak arra, hogy mennyi időt vesz igénybe, hogy felneveljünk és iskoláztassunk egy személyt, és hogy meghaljon egy balesetben; hogy mennyi idő kell egy ház felépítéséhez, és hogy leégjen egy tüzvészben; vagy, hogy megépítsünk egy repülőgépet, és hogy később lezuhanjon.

- A negatív események megítélése mindig konszenzust teremt, míg a pozitívak értékelésében lehetnek különbségek (McGregor [2003]). Pl.: Egy földrengés, amely számtalan áldozatot szed, mindenki számára negatív eseményként jelenik meg, míg egy új kormányintézkedés mást fog jelenteni a szimpatizánsoknak, mint a kormányellenes embereknek. A negatív hírek az emberek számos látens vagy manifeszt igényét elégítik ki.

- A negatív hírek általában váratlanabbak, mint a pozitívak, hiszen egyfelől ritkábbak, másfelöl kevésbé előre jelezhetők. A nyugati kultúrákat tekintve a pozitív változások, azaz a fejlődés olyasvalami, amelyet normális, sőt, triviális dolognak tekintünk, ezért gyakran alábecsüljük értékét, hiszen nem képvisel számunkra semmi újat, semmi meglepőt (Deli [2015] pp. 182-183).

\section{A katasztrófahírek}

\subsection{A katasztrófahírek konceptualizációja}

Ahogyan azt a hírek szelektálási folyamata kapcsán már kifejtettem, bizonyos faktorok (pl.: meglepetés, konfliktus, normaszegések stb.) meghatározó szerepet játszanak abban, hogy az események hírekké váljanak. Zavar- és félelemkeltő természetük miatt a katasztrófák is magas hírértékkel rendelkezö események, amelyeket nem pusztán váratlan bekövetkezésük, hanem a közösséget fenyegető jellegük is érdekessé tesz. A katasztrófák széleskörü társadalmi hatása a régebbi korok emberének szerencsétlenségekhez füződő mélyen vallásos szemléletéből fakad, amely szerint a katasztrófák nem pusztán szerencsétlenségeknek, hanem univerzális érvényességü jeleknek, isteni üzeneteknek tekinthetők. A csapásokban vagy a közösség múltbéli 
cselekedetei feletti ítéletet, vagy a jövőbeli sorsukkal kapcsolatos figyelmeztetést látták, végrehajtójuknak pedig a Gonoszt tartották. Mára a Gonosz fogalma szekularizálódott, de - a látens erkölcsi funkcióhoz hasonlóan - nem veszett el teljesen, ahogyan a bünösök és bünbakok keresése, a múltbéli hibák felsorakoztatása és a hősök bemutatása is megtalálható a mai, szerencsétlenségekről szóló híradásokban (Császi [2002] p. 172.). A kortárs meghatározások közül a Webster-féle nagyszótár a következőképpen definiálja a katasztrófákat: bármely történés, amely kárt vagy sérülést okoz; súlyos és hirtelen balszerencse; csapás. A katasztrófák súlyos és hirtelen szerencsétlenséget jelölnek, amelyek emberi életek, vagyon stb. elvesztéséhez vezetnek. A csapás magában foglalja az egyén vagy teljes közösség mély szorongását vagy bánatát (Quarantelli [1998] p. 52.). Dynes szerint a katasztrófák a közösség külső vagy belső határainak károsodását jelentik. Olyan alkalmak ezek, amelyek a normák sérülése miatt megszakítják a mindennapi élet megszokott menetét és arra sarkallják a közösség tagjait, hogy rendkívüli erőfeszítéseket tegyenek a társadalom normatív rendjének megóvása érekében, egyfajta kollektív szolidaritást kialakítva ezzel (Dynes [1994]). Fritz definíciója szerint a katasztrófák olyan időben és térben koncentrált események, amelyek következtében a társadalom, vagy annak egy alegysége fizikai és társadalmi károkat szenved, amely a társadalom, vagy annak alegységeinek összes, vagy néhány funkciójának károsodásához vezet (Lindell [2011] p. 1.).

Típusait tekintve megkülönböztethetünk természeti katasztrófákat, pl.: földrengések, árvizek, szélviharok, járványok, illetve ember által okozott technikai jellegü ipari baleseteket, pl.: repülőgép-katasztrófa, majd a hatvanas évektől kezdve az olyan politikai krízisek is a kutatás tárgyaivá váltak, mint a terrorista akciók vagy politikai személyek ellen elkövetett merényletek. Ez utóbbiak azért kerülhettek az ember által okozott katasztrófák elemzési körébe, mert ezekben az esetekben - a politikai rend megrendülése miatt - a társadalomban a természeti és technikai katasztrófákhoz hasonló zavarok alakulnak ki. (Császi [2002] p. 174.). Ezt kiegészítve Carr úgy véli, a katasztrófákkal kapcsolatos koncepciók változhatnak azok sebessége, komplexitása és az okozott károk, de legföképpen a kollektív társadalmi reakció alapján, így tehát nem minden vihar, földrengés vagy áradás tekinthető katasztrófának. Amíg a hajó képes előbukkanni a hullámok alól, amíg a város képes ellenállni a földrengés okozta pusztításnak, és amíg a gátak képesek megtartani a medréből kilépő folyó hömpölygő víztömegét, addig nem beszélhetünk katasztrófáról. Onnantól kezdve válik egy esemény katasztrófává, hogy a társadalom kulturális védelme összeomlik. A halottak, sebesültek és a többi kár mind csak következményei a 
csapásnak, de nem tekinthetők magának a katasztrófának. Az pedig, hogy egy közösség hogyan reagál a szerencsétlenségre, függ annak kultúrájától, morális hátterétől, vezetőségétől is (Carr [1932] pp. 207-218.). Carr konklúziója arra enged következtetni, hogy a katasztrófák minden esetben emberi tevékenység eredményeként jönnek létre, nem természeti, vagy természetfeletti erők hatására. A katasztrófák a kulturális védelem összeesésének következményei, ezért alapvetően ember alkotta fogalomként kell őket kezelni, ez pedig deduktíve annyit jelent, hogy az emberiség maga felelős tetteiért és mulasztásaiért (Quarantelli [1998] p. 19.). Más társadalomtudósok, köztük Gilbert egy új paradigmát említ a katasztrófákat illetően, amely elutasítja a külső hatásokat és az ellenük való védekezést, mint a katasztrófáért felelős tényezőket és a rájuk adott válaszreakciót. Véleménye szerint ugyanis a katasztrófák eredendően a szociális kapcsolatok megrendüléséből és a társadalmi kiszolgáltatottságból erednek. Kreps a katasztrófákat társadalmi katalizátornak nevezi, a következö radikális állítást téve: „Disasters both reveal elemental processes of the social order and are explained by them". Quarantelli ágens-specifikus megközelítésnek nevezi a katasztrófák ilyen jellegü értelmezését, Horlick-Jones pedig egyenesen úgy fogalmaz, hogy a modern katasztrófák az közintézmények általi árulás arénáiként jelennek meg (Quarantelli [1998] p. 73.). E kijelentések mind bizonyítékai a katasztrófák problematikus természetének a társadalomtudományi megközelítés alapján, azonban az említett kutatók feltevései időszerủek és indokoltak a 21. század katasztrófáit tekintve is.

A továbbiakban a katasztrófák különböző fázisainak elkülönítését mutatom be, amely szintén a már említett Carr nevéhez köthető, aki - kronológiai szempontok alapján - az alábbi sorrendet állapította meg:

1. Az első az úgynevezett elözetes periódus (preliminary period), amely során a szerencsétlenséget okozó tényezők hozzákezdenek a folyamat előkészítéséhez, elindításához. Az előzetes intervallum hosszúsága változó lehet. Míg az 1917 dec. 6-án, Halifax városában bekövetkezett katasztrófában a robbanóanyagokkal megrakott „Mont Blanc” elnevezésü francia teherszállító hajó és a rakomány nélküli, „Imo” nevezetü norvég hajó összeütközése elötti előzetes periódus kb. huszonhárom perc volt, addig Andrew Kehoe, a bathi általános iskola megkeseredett választott kincstárnoka hónapokig szőtte ördögi tervét, csaknem egy tonna dinamitot rejtegetve az iskola pincéjében. 
2. A második fázis a katasztrófa tényleges kezdetét jelöli, ezért Carr ezt a zavar és fejetlenség (dislocation and disorganisation phase) szakaszának nevezi. Meghatározó tényezői ennek a ciklusnak a szerencsétlenség összetettsége és erőssége. Néhány katasztrófa olyan mértékủ pusztítást végzett, hogy teljes közösségeket söpört el a föld színéről, pl.: Pompeii pusztulása a Vezúv Kr. előtt 79-es kitörésének következtében, vagy az amerikai őslakos Mandán törzs 19. századi pusztulása a megjelenő himlőnek köszönhetően.

3. Szerencsére, az ehhez hasonló abszolút katasztrófák kivételesnek számítanak, a legtöbb szerencsétlenséget követően a közösség egy része - ugyan jelentősen megcsonkítva és megrázva, mint a Halifax katasztrófa esetében - talpon marad és küzd fennmaradásáért. Így a zavar és fejetlenség ciklusa gyakran egy harmadik, az úgynevezett átrendezés és újraszervezés (readjustment and reorganisation) fázisába lép át. A közösség kulturális összeomlását és a közvetlen életveszély kialakulását általában egyfajta spontán, szervezetlen segítségnyújtás követi - pl.: a sebesültek azonnali mentése, a halottak kiszabadítása, egybegyüjtése - ezt követően azonban fokozatosan kapcsolódnak be az intézményesített szervek, pl.: tüzoltók, rendörök, katonák, a Vöröskereszt dolgozói stb., akik együtt, szervezetten lépnek fel.

4. A közösségi szolgáltatások katasztrófahelyzet miatt kialakult szervezetlensége azonban megnehezítheti a különböző intézmények azonnali fellépését. A Halifax partjainál bekövetkezett robbanás és a valamelyest használható vészhelyzeti tervek elkészítése között tizennyolc óra telt el, míg az Egyesült Államok történetének legsúlyosabb természeti katasztrófája, az 1900-as Galveston hurrikán rombolása után a mentések kb. tíz-tizenkét órával később kezdődtek csak meg. Ezt a periódust Carr a zavar okozta késedelemnek (confusion-delay) nevezi (Carr [1932] pp. 211-213.).

Bármely katasztrófa esetében három szintet különböztethetünk meg a csapást követő helyreállást illetően: a.) Az individuális újraszerveződés szintje, b.) Az interaktív újraszerveződés szintje, c.) A kulturális újraszerveződés szintje. Az első, individuális szinten az egyénnek alkalmazkodnia kell megváltozott környezetéhez. Meg kell határoznia a változást, annak mértékét és időtartamát, és hozzá kell igazítania életét. A különböző egyének sok esetben eltérően reagálnak a módosult körülményekre, a hallucinációktól kezdve a hisztérián át számos visszacsatolási típus figyelhető meg. Az egyén azonban nem egyedül vesz részt a katasztrófahelyzet kezelésében. Környezete 
figyelembevétele különbözö interaktív folyamatokat ösztönöz, pl.: kölcsönös segítségnyújtás, tapasztalatok kicserélése stb. Normál körülmények között természetesen megvannak a társadalom azon csoportjai, amelyekkel önszántunkból kapcsolatot teremtünk, és akikkel bizonyos helyzetekben bizonyos szociális rituálék szerint alakítjuk cselekedeteinket és beszédünket. A katasztrófa azonban megzavarja a normál kapcsolatok és normál szituációk rendjét, és arra sarkall bennünket, hogy idegen helyzetekben, idegen emberekkel lépjünk kapcsolatba. Gyakran azonban nem elegendő az egyén szintjén, illetve társadalmi kölcsönhatásokon keresztül kezelni a változásokat. Mivel a katasztrófa lényege a kulturális összeomlás, a kollektíva ezen a szinten is szükségszerüen átalakulásokon megy keresztül. A különböző katasztrófákat kísérő tipikus kulturális változások pl.: új közegészségügyi program és új bizottságok fejlesztése, a közösségi munka kialakítása, iskolafejlesztési programok korszerüsítése, a súlyosan érintett területek újjáépítése stb. (Carr [1932] pp. 213-214.).

Ahogyan azt Carr is implikálja, katasztrófahelyzetben a társadalom kulturális védelme összeomlik, így feltételezhető, hogy a különböző kultúrák eltérő módokon reagálnak vészhelyzetben. Alexander úgy véli, hogy a kultúrák olyan dinamikus jelenségek, amelyek bizonyos faktorok hatására jelentős mértékben megváltozhatnak. Így a katasztrófakutatók gyakran írnak „katasztrófa-kultúrákról”, vagy „katasztrófa-szubkultúrákról”, amelynek tagjaiból az ismételt fenyegetettség különös reakciót vált ki. Olyan reakciót, amelyet egyéb tekintetben nem lehetne kulturálisan meghatározni. Így tehát azt mondhatjuk, hogy a katasztrófák létrehozzák saját kultúrájukat, amelyek túllépnek a meglévő kulturális határokon. A katasztrófakultúrák pozitív formái mindennél többre tartják a polgári védelmet és a veszély enyhítését, míg a negatív típusú katasztrófa-kultúrák mítoszokat és téves feltételezéseket gyártanak; a legtöbb kultúrában azonban a két viselkedésminta kombináltan jelenik meg. A normák, értékek, hiedelmek, ismeretek és a technológia mind más-más szubkulturális formát öltenek. A nyugati társadalmakban például - amelyek percepcióit föként az elektronikus média szabja meg - a televíziós hírszolgáltatások a katasztrófákat szórakoztató bulvármüsorokká alakítják, személyesen bevonva a nézőket a tragédia eseményeibe (Alexander [2000] p. 62.). 


\subsection{A katasztrófahírek médiareprezentációja}

Médiareprezentációjukat tekintve Császi a katasztrófák kapcsán egyfajta hierarchiát említ, a szerző szerint ugyanis minél váratlanabb, hosszabb ideig tartó és minél nagyobb területet érintő csapásról van szó, annál nagyobb és tartósabb hatást képes gyakorolni a sajtóra. A fentiek miatt nevezik a médiakritikai zsargonban a katasztrófahíreket obstruktív híreknek, hiszen fizikai és morális fontosságuk miatt megkülönböztetett pozíciót tölthetnek be a médiában, míg a közösség életét közvetlenül nem érintő, úgynevezett nem-obstruktív hírek közlése esetlegessé, a szerkesztőség preferenciáinak függvényévé válhat (Császi, Katasztrófák média-reprezentációja). Kutatások igazolják, hogy az elmúlt huszonöt év katasztrófahíreit tekintve jelentősen megnőtt a katasztrófák aránya a hírekben az azt megelőző huszonöt év tudósításaihoz képest. A vizsgálatokból az is kiderült, hogy nem a szerencsétlenségek száma szaporodott meg az elmúlt évtizedekben, hanem a média mutatott fokozott érdeklődést a témában (Császi [2002] p. 172.). Ez a jelenség Fisher szerint az úgynevezett puha hírek elterjedésének köszönhető, amely szemben a kemény hírekkel, amelyek definíció szerint az incidens technikai részleteire koncentrálnak, pl.: időjárási viszonyok, utasok száma a repülőn, a szállított vegyi anyagok összetétele, a pilóta többéves tapasztalata stb. - föként az emberi érdeklődésnek megfelelően mutatja be a történteket, pl.: interjúalanyokon keresztül bemutatott információk, túlélök, áldozatok történetei stb. (Császi [2002] p. 172.). Ezek a változások nyilvánvalóan implikálják, hogy a média egyre nagyobb szerepet játszik a katasztrófák potenciális szekuláris jelentéseinek szimbolikus konstrukciójában (Császi [2002] p. 172.). Alátámasztja ezt Jeremy Iggers Good News, Bad News címủ munkája is, amelyben a szerző úgy fogalmaz, hogy a hírmédia legalább három fontos szerepet tölt be közössége életének alakításában, túlmutatva a puszta információátadáson: közös valóságot konstruál, létrehozza a nyilvánosságot, valamint elősegíti az erkölcsi értékek és a közösségi élet kialakulását. A hírmédia központi szerepet játszik abban, hogy a komplex, modern társadalmakban élő emberek fejében kialakítson egyfajta képet. Ez a kép részleteiben természetesen eltér a különbözö fejekben, mégis ez a megosztott információ adja közös valóságunk, közös kultúránk alapját (Iggers [1999] p. 116.). Annak ellenére tehát, hogy a média információs teljesítménye igen nagy, kimagasló szerepet játszik a kollektív identitás kialakításában és a közösség integrációjában, különösen az olyan, nagy tömegeket érintő, veszélyes helyzetekben, mint a katasztrófák bekövetkezése. 
Felmerülhet azonban a kérdés, hogy vajon a különböző médiumok azonos képet alakítanak-e ki az emberek fejében, vagy eltérő hatékonysággal működnek. Mitől függ, hogy az emberek hogyan észlelik az adott katasztrófát és milyen jelentőséget tulajdonítanak neki? Császi a kaliforniai földrengéseket vizsgáló Turner kutatását idézi, aki a katasztrófahírekkel kapcsolatos felmérései alapján azt találta, hogy a szerencsétlenség idején a hivatalos brossurák és felvilágosító anyagok hatékonysága kifejezetten alacsony volt a vizsgált lakosság körében. Nem meglepő módon a leggyakoribb forrásként a tévét jelölték meg, ezt a napisajtó követte, majd a rádió, végül a magazinok és filmek zárták a sort (Császi [2002] p. 181.). A televízió kifejezetten alkalmas médium arra, hogy a katasztrófa azonnaliságát az emberek otthonába vigye. Az áldozatokat, pusztítást és erőszakot bemutató képek a befogadó számára valóságossá teszik az amúgy távoli eseményeket. De, ahogyan arra a korábbiakban már utaltam, a kameramunka nem mindig objektív. Megfigyelhető ugyanis az a tendencia, hogy a televízió mindig a legrosszabb, legdramatikusabb elemekre koncentrál, amely elhitetheti a nézővel, hogy az egész katasztrófa sújtotta terület ugyanolyan állapotban van. Pl.: A mérsékelt erejü földrengések látványos pusztítást végeznek ugyan, de gyakran csak egy maroknyi épületet érintenek. Ezek túlreprezentáltsága a médiában elhitetheti a nézőkkel, hogy az egész város alatt megrendült a föld, hasonló károkat okozva a többi épületen is (Alexander [2000] p. 62.). Mindazonáltal semmi sem motiválja jobban a közösségi összefogást, mint a televízió. Amikor szívszorító, drámai jelenetek jelennek meg a televízióban gyakran jelentős nyilvános reakciót figyelhetünk meg a szolidaritást, adományokat, és önkéntességet illetően. A katasztrófák televíziós közvetítése és a nyilvános fellépés erőssége és hossza közötti korreláció mértékével kapcsolatos megfigyelések alátámasztották, hogy - a nyugati kultúrákban - e két tényező körülbelül megegyezik, tehát addig tart a közösségi segítségnyújtás, ameddig a média foglalkozik az eseménnyel (kivéve, ha belföldi, vagy szomszédos államokat sújtó katasztrófákról van szó, ilyenkor a nyilvános segítségnyújtás akár hónapokig is tarthat) (Alexander [2000] p. 62.).

Turner kutatásában szerepet kaptak a filmek is, mint a katasztrófahelyzetekkel kapcsolatos információforrások. Susan Sontag The Imagination of Disaster címủ munkájában úgy fogalmaz, hogy egy tipikus sci-fi film olyan kiszámítható struktúrával rendelkezik, mint a westernfilmek, klasszikus kocsmai verekedéseikkel, szőke tanárnőikkel és pisztoly párbajaikkal az elhagyott föutcán. Míg Sontag szerint a sci-fi filmek és híradások történetmeséléseiben a westernfilmek kiszámítható fordulatait találjuk meg, fontos kiemelnünk, hogy ez nem csak az 
említett, vadnyugati zsáner sajátossága, hiszen ezek a történetmesélési fordulatok legalább olyan régiek, mint maga az ember. Ezek adják a mesék, a mítoszok (főként az eredetmítoszok) struktúráit is, és ezért olyan sikeresek a hollywoodi filmek. Ezeket a formulákat kérik számon a forgatókönyvön, a rendezésen, és a történetvezetésen is, hiszen ez kultúrákat átívelően mindenkinek a sajátja (McIver [2017] p. 6.). E jelenség felismerése egyetemes tehát a vizuális történetmesélésben és a tévémüfajokban, beleértve természetesen a katasztrófahíreket is, amelyekben szintén egyértelmüen visszaköszön.

Sontag alapján a science fiction filmek forgatókönyve öt egységre bontható, amely a hírek struktúrájának szempontjából is releváns:

1. Az elsőben a legnagyobb gyanútlanság közepette hirtelen megtörténik a szerencsétlenség, amely lehet természeti katasztrófa, vagy valamilyen természetfeletti szörnyeteg megjelenése is. Ezt általában egyetlen ember sejti meg, aki többnyire egy terepkutatáson lévő fiatal, facér tudós. Eleinte sem szomszédjai, sem kollégái nem hisznek neki.

2. A második szakaszban a hős szemtanúkat gyüjt maga köré és segítségükkel értesíti a helyi rendfenntartó erőket a szükségállapotról, a rend őrei azonban tehetetlennek bizonyulnak. Ebben a fázisban tudjuk meg azt is, hogy a veszély továbbra is fennáll, azonban mostanra már nem csak a közeli területeket, hanem az egész Földet is fenyegeti.

3. A harmadik a kollektív mozgósítás fázisa, azonban itt még közel sem találták meg a megoldást a problémák orvoslására, így az általános kétségbeesés és rettegés erősíti a fennálló feszültséget. Ugyanebben a fázisban, az ország fóvárosában a tudósok és katonai erők konferenciákat tartanak, ahol a film főhőse előadást tart diagramok, térképek, táblák és egyéb vizuális eszközök segítségével, az addigi potenciális megoldások azonban kivitelezhetetlennek bizonyulnak.

4. A negyedik szakaszban már megkísérlik a probléma eliminálását, azonban továbbra is kudarcot vallanak a helyi erők, az érintett lakosság evakuálásával pedig ismét - a kezdeti szakaszhoz hasonló - pánik tör ki, mindenki fejvesztve menekül. Olyan kötelező elemek jelennek meg ebben a részben, mint a fejvesztve menekülö, egymást taposó tömeg és az öket makulátlan fehér kesztyüjében irányító rendőr.

5. A lezáró szakaszban a történet hőse olyan megoldást talál, amely azelőtt senkinek nem jutott eszébe, megállítja a szerencsétlenséget és (a film származási helyétől függően) a 
karakterek meghitt egymásra találása figyelhető meg. A katarzis azonban nem tart örökké, mindenki sejti, hogy a probléma megoldása csak ideiglenes, a szerencsétlenség bármikor bekövetkezhet újra (Sontag [1965] pp. 42-43.).

Császi szerint a katasztrófafilmek fentebb említett, rögzített formuláit követik a katasztrófákról szóló hírek is, amelyek egységesen bemutatják az áldozatokat, károkat, a mentési munkálatokat, az esetleges felelösöket és hősöket (Császi [2002] pp. 181-182.). Ezen a vonalon továbbmenve Quarantelli a médiában megjelenő túlzóan tragikus képeket és a tisztviselők szívszaggató monológjait bemutató, saját intézményüket promotáló médiumok tevékenységét „,disaster pornography"-nak, azaz katasztrófa pornográfiának nevezi (Quarantelli [1998] p. 83.). De vajon mikor tekinthetö a média nemkívánatos kórságnak és mikor hasznos szövetségesnek? Katasztrófahelyzetben a média szerepe kritikus a tájékoztatást és figyelmeztetést illetően. Kapcsolatot teremt a nyilvánosság és a hivatalos erők között, segíti a károsultakat és a mentőakciókat, ezáltal tagadhatatlanul rendkívül értékes funkciót tölt be, mégis vannak bizonyos korlátai. Ahhoz, hogy hatékonyan tudjuk használni a média nyújtotta lehetőségeket, fontos, hogy megismerjük annak müködését és észrevegyük potenciális torzításait (Dynes et al [2007] p. 414.).

A média lehengerlőnek találja a válsághelyzeteket és katasztrófákat, különösen a televízió esetében, amely drámai vizuális elemeivel jóval nagyobb hatást képes kelteni, mint az egyszerü, faktuális kijelentések. A vizuális elemek segítségével ma is elöttünk van, ahogyan a repülőgép belecsapódik a World Trade Center ikertornyaiba, ahogyan a Katrina hurrikán képei is elevenen élnek emlékezetünkben. De már a televízió elött is különösen nagy hírértékkel rendelkező témák voltak a katasztrófák a média számára, amióta csak létezett újságírás. Amikor megtörténik a tragédia, a média tájékozódni kezd, megpróbál minden információt megszerezni róla, sajtóstábokat delegál, háttértörténetet kreál, és végül jelenti az eseményeket. Gyakran ahogyan az az ottawai viharok idején is történt - a különbözö médiaorgánumok teljes müsoridejüket az eset bemutatásának szentelik, és minden munkatársukat mozgósítják a szükséges információk beszerzésének érdekében. Amikor a coloradoi Columbine High School két tizenéves tanulója 1999-ben megölte 13 diáktársát és megsebesített másik 21-et, majd önmagával is végzett, a KCNC TV, Denverben, minden munkatársának segítségét igénybe vette a 13 órás nonstop tudósításhoz: „, Well over 150 newsroom regulars and extras pitched in to 
make the extensive coverage possible. Off-duty employees came...without being summoned and took up posts..." (Dynes et al [2007] p. 414.). A média gyakran alkalmaz technikai erőforrásokat is ahhoz, hogy minél szélesebb ismereteket tudjon bemutatni. A St. Helen vulkán 1980-as kitörésekor az NBC helikoptert küldött a kráterhez, a fedélzetén egy geológussal, aki később szakmai szempontok alapján kommentálta az eseményeket (Dynes et al [2007] p. 414.). Ma pedig, a közösségi média és a részvételi kultúra korában - ahol a közönség aktívan vesz részt a különböző médiatartalmak generálásában és szerkesztésében - a hivatalos hírszolgáltatók gyakran támaszkodnak az utca emberének megfigyeléseire, az általa készített képi és videó anyagokra is.

\subsection{A vizualitás szerepe a hírekben}

„Photographs have the kind of authority over imagination today, which the printed word had yesterday, and the spoken word before that. They seem utterly real." 10

Walter Lippmann ([2009] p. 92.)

Ahogyan az a vizualitás konceptualizációjánál már előkerült, számos kutató véli úgy, hogy a 20. század fókuszában megkérdőjelezhetetlenül a vizualitás áll. Az említett Mitchell, Gombrich, Arnheim és sokan mások mind hozzájárultak a vizualitás pszichológiai-alapú klasszikus megalapozásához és ezáltal visszavonhatatlan térnyeréséhez. Nem hiába vált a vizuális kommunikáció, vizuális észlelés, vizuális retorika, vizuális tudatosság vagy a vizuális gondolkodás 20. század kulcsszavaivá. Ez természetesen rányomta bélyegét a tömegtájékoztatás müködésére is, amit mára egy kifejezetten kép-domináns médiának tekinthetünk, szemben a korábbi szóközpontú megközelítéssel (Newton [2013]). Történetét tekintve a képrögzítés a fotográfiával kezdődött, ami nagyban átalakította a festészetet is, hiszen a festők célja a minél valósághübb ábrázolás volt, a fényképezőgép pedig mindezt gyorsabban, pontosabban és olcsóbban végezte, így a festészet absztrakt irányba tolódott. Joseph Nicéphore és Louis Jacques Mandé Daguerre, a fényírás francia feltalálói pedig egyszersmind megváltoztatták a müvészetet és a médiát a dagerrotípia eljárásmódjának segítségével. Az újságírásban a fotográfiák a 19. század második felében nyertek népszerüséget, kiszorítva ezzel az újságok korábbi, rajzolt

\footnotetext{
${ }^{10}$ Mára a fényképeknek nagy hatalma van a képzelet felett. Olyan hatalom ez, ami a nyomtatásé volt tegnap, és a szóé volt azelött: teljességgel valódinak tünnek. (Saját fordítás)
} 
illusztrációit a cikkekből, szerzőiket pedig professziójukból. Nagy-Britanniában 1861-re már 2000 vándor fotográfust jegyeztek, átalakítva (és nem megszüntetve) ezzel a korábbi kánonokat, müveltségeszményt és a médiáról alkotott addigi felfogást [Sipos [2016] pp. 3-4.). Mára, a képi fordulat korszakában a nyomtatott és online újságírás alapjának tekinthetők a képek, és - ismét ellentmondva a vizuális érvelés propozíciós természetét támadó ellenérveknek - koránt sem díszítő funkciójuk miatt alkalmazzák őket. A cikkben megjelenő kép retorikus, hiszen nem csak kiegészít és egyértelműsít, hanem állít, meggyőz, szimbolikus jellegének köszönhetően pedig retorizál és dramatizál.

Mindezek ellenére elmondható, hogy a képek viszonylag nehezen inkorporálhatók az újságírással kapcsolatos jelenlegi kutatásokba, hiszen az újságírást elsősorban a hírek és vélemények szavak által vezérelt közlésének tekintjük. Ugyan a képek különböző módokon, de szorosan kapcsolódnak hozzá - pl.: alátámasztanak, kiegészítenek, cáfolnak vagy megerősítenek - mégis a szavak maradnak az újságírás mesterségének mérvadó kulcselemei. Ez pedig azt jelenti, hogy amíg az újságírásra úgy tekintünk, mint a szisztematikus érvelések, kötött szerkezetü eljárások, illetve standardizált kódok és viselkedések összességére, amelynek elsődleges funkciója a racionális nyilvános válasz elősegítése, addig egy olyan eszköz alkalmazása, amely eltér az újságírással szemben alkotott elvárásoktól, mindenképpen problematikus (Zelizer [2010] p. 3.). Alátámasztva e nézetet, Andén-Papadopoulos úgy fogalmaz, hogy a képeket ugyan a világ eseményeit közvetítő, hamisítatlan ablaknak és ezáltal az újságírás objektivitásának garanciájának tekinthetjük, a tisztán vizuális médiumokat sokan mégis egyszerűen az érzelmek birodalmának, és ezáltal a racionalista Felvilágosodásban gyökerező újságírói hírek intézményének legfőbb ellenségének tartják (Andén-Papadopoulos [2008] p. 3.). A kutatók között természetesen szép számban találunk olyat (pl.: John Fiske, S. Elizabeth Bird, James Carey, Kevin Barnhurst, vagy John Nerone) aki külön kezelte a híreket az információk, bizonyítékok, tények, és az értelem koncepcióitól. A fent említett szerzők úgy vélik, hogy az újságírás reprezentációs formái - a tabloidok, vagy a populáris és életmód újságírás - a szórakoztatás, közösségépítés és a jelentés generálás eszközei (Zelizer [2010] p. 3.). Postman pedig egyenesen azt állítja, hogy az újságírás inkoherens és triviális tartalmakat termel, mivel a média pusztán egy hangon szólal meg: a szórakoztatás és dramatizálás hangján (Postman [1985] p. 84.). És mégis, az a jelenleg is fennálló, alapértelmezett megközelítés, amely szerint az újságírás a racionálisan érvelő információátadás tevékenysége, hasznos kiindulópont lehet a 
képek szavaktól eltérő szerepéről való gondolkodásban, különösen az olyan bizonytalan események idején, amikor a nyilvános információ iránti igény kritikusnak mondható. Kutatók szerint a képek müködését két dimenzió befolyásolja, az egyiket denotációnak, a másikat konnotációnak nevezzük. A denotáció megjelölés arra utal, hogy a kép azt mutatja, ahogyan a dolgok a valóságban léteznek, ezért általában az „indexikusság”, „referencialitás” és „valószerüség” kifejezésekkel hozhatók kapcsolatba. A konnotáció ezzel szemben arra utal, hogy a képek többet nyújtanak, mint amit az elkapott pillanat ábrázol, ezért a „szimbolizmus”, „általánosíthatóság” és „egyetemesség” kifejezései köthetők hozzá. A legtöbb újságíró még mindig a kép denotációs erejét privilegizálja, így annak érdekében, hogy növeljék tartalmaik megbízhatóságát, a fényképek nyújtotta realizmust kihasználva nagyobb számú és ismertségü képet jelenítenek meg. A konnotációs érték azonban ugyanilyen fontossággal bír. Stuart Hall például úgy találta, hogy a képeket (különösen a katasztrófaképeket) gyakran szimbolikus és asszociatív módon használják azáltal, hogy azok nem az újságcikk központi témáját ábrázolják, hanem az azokból eltávolított, vagy periferikus jelenetekre utalnak, így -a fogyasztót nagymértékben bevonva - különböző értelmezésekre, találgatásokra adnak lehetőséget (Hall [1973] pp. 11-12.). Ez utóbbi, konnotációs dimenzióból kiindulva elmondható, hogy amikor egy katasztrófa egyetlen fényképbe van belesürítve, a kamera sokkal többet kínál annál a látványnál, mint amit valóban ábrázol. Azok a képek, amelyek összetettek, inkább sematikusak, mintsem részletesek, konvencionálisak és egyszerüsítettek, különösen jól múködnek ebben a tekintetben.

\subsubsection{Az apokaliptikus vizuális ábrázolás}

Az apokalipszis - azaz a hétköznapi értelemben (hibásan) vett világvége - és a katasztrófa koncepciói és ábrázolásai számos egyezést mutatnak, hiszen a katasztrófák egyszerre retorikusak és apokaliptikusak is. A 2010-es ajkai vörösiszap-katasztrófáról szóló hírek gyakran „vörös apokalipszisként" aposztrofálták az esetet, de számos forrás a közel-keleti háborúkat, sőt, egy nagyobb erejű ónosesőt is apokaliptikus állapotként említ, hiszen - a katasztrófához hasonlóan ez is egyfajta (végső) szükségállapotot, veszélyhelyzetet, hirtelen bekövetkező, megrázó eseményt jelöl.

A Jelenések könyvének első fejezete középpontjában a ,the apokalypsis of Jesus Christ”, azaz Jézus Krisztus igazságának megjelenése áll. Ez volt az első olyan írás, amely az 
apokalipszis szót használja. A legtöbb ember számára e kifejezés a világ végével kapcsolatos kataklizmatikus, katasztrofális képeket jelöl, pedig a szó etimológiáját tekintve semmilyen köze nincsen a világ pusztulásához (Himmelfarb [2010] p. 1.). Az apokalipszis (apokalüpszisz) ógörög eredetü kifejezés, melynek jelentése feltárás, kinyilvánítás. Tudományos használatában keresztény, illetve zsidó alkotásokra vonatkozik, amelyek valamely mennybéli vagy jövőbéli eseménnyel kapcsolatos kinyilatkoztatást, leleplezést közölnek. Ezen események szimbólumait, történeteit és képeit „apokaliptikus irodalomnak” is szokás nevezni. A végső dolgok tanához való kapcsolódását nem a szó jelentése, hanem a Jelenések könyvénektartalma ihlette. Hubbes László Revolution of the Eye: A Spectactular Rhetoric of the Apocalyptic címü munkájában úgy fogalmaz, hogy az apokalipszis maga a képi fordulat megtestesítője, a „szem forradalma”, ősi, anti-ikonikus kontextusainak köszönhetően. A képzelet projekciójára támaszkodva az apokalipszis meg- és újratermeli látványos reprezentációit, amelyek erős kifejezőképességüket valós és rejtélyes képekből, valamint szörnyü és kívánatos látomásokból nyerik. A hagyományos, keresztény és zsidó apokalipszisek szimbolikus és allegorikus ikonográfiát használnak, az evilági és transzcendens valóságok narratív reprezentációihoz, de ugyanúgy bemutatnak élénk leírásokat a világ végéről és az újjászületett új világokról is (Hubbes [2017] p. 159.). Az apokalipszisek ábrázolásakor azonban a szöveg alapú reprezentációk jelentéktelennek, sok esetben elenyészőnek tekinthetők a vizuális müvészetek képi ábrázolásaival szemben. Ez pedig - jelen tanulmány értelmezése szerint -nyilvánvaló bizonyítéka annak, hogy az apokalipszis eredeti kódja vizuális, hiszen semmi más nem adhatja vissza élénkebben a félelem, a szenvedés és a rettegés pillanatát, mint a képi ábrázolás. Az apokalipszis képei - a mítikus és implicite biblikus képekkel szemben - nem az egyetemes káosz-kozmosz dichotómiát ábrázolják, legalább is nem a tradicionális értelemben. Vizuális elemei egy különleges világnézetet, értékelméletet jelenítenek meg, ahol az isteni erők ikonográfiája majdnem olyan ijesztően mutatkozik meg, mint a Gonosz komorsága. Nem a teremtés mint kozmosz áll az ősi káosszal szemben, hanem éppen ellenkezőleg: az eredendő büntől megromlott teremtés mint fenyegető káosz áll az elveszett, de remélt és megígért kozmosszal szemben (Hubbes [2017] p. 161.). Csak úgy, mint a katasztrófa vizuális ábrázolásaiban: a természeti csapások által megcsonkított, tönkretett környezet, vagy a terrortámadások során lemészárolt emberek tucatjainak rendezetlen őskáoszából igyekszünk a megnyugvás, helyreállás kozmosza felé haladni. 


\subsubsection{A katasztrófaképek}

Az újságírás képei kulcsfontosságú szerepet játszanak a katasztrófahelyzetek, és az azok elleni küzdelem interpretálásában, hiszen egyszerre mutatják be a történteket és többek között az áldozat, az emberiség, a hősök, a hazafiság és a segítségnyújtás tágabb kontextusban értelmezett fogalmait (Zelizer [2004] p. 115.). Zelizer ezt a , vizualitás hangjával” magyarázza (the voice of the visual), ahol a hang koncepciója arra utal, hogy a kép a környezet elképzelt, érzelmi és kontingens jegyei felé orientálódik, lehetővé téve ezzel a szélesebb kontextusokkal, eseményekkel, emberekkel, gyakorlatokkal, és más képekkel való kapcsolatteremtést. A kép hangja a denotációs és a konnotációs erőre egyaránt támaszkodik, egyszerre összekötve azokat és túlmutatva rajtuk (Zelizer [2010] p. 13.).

Müködésüket tekintve a katasztrófaképek kevésbé értelmezhetők a világ megértéséhez szükséges biztos és egyértelmü jelek sorának keretében: inkább analogikusnak tekintik őket mivel folyamatosak és többé/kevésbé terminusokban értelmezendök, mint digitálisnak - amelyek diszkrétek és a vagy/vagy terminussal írhatók le. Mivel a világ affektív és ösztönös nézőpontját kínálják, Zelizer szerint általában indexikusak - mert figyelmünket az eseményre irányítják; materiálisak - tehát kézzel foghatóak; ikonikusan és szintaktikailag nem meghatározhatók mivel homályosan, porózus formában reprezentálják az eseményt. Legfontosabb jellemzőjük pedig, amely megkülönbözteti őket a többi, más eseményt leíró képtől az, hogy a megértés töredékét kínálják csupán, ezáltal az esemény hátterében meghúzódó indokokkal, célokkal, elkövetőkkel, felelősökkel stb. kapcsolatos találgatásra, spekulációra ösztönzik befogadóikat amellett, hogy maguk a képek kristálytiszta propozíciót közvetítenek (pl.: halottak, vagy túlélök képének bemutatása) (Zelizer [2010] p. 6.).

De hogyan is írható le a katasztrófaképek müködése, miben rejlik erejük? A fotográfia 19. századi megjelenése lehetővé tette a befogadók számára, hogy olyan eseményeknek legyenek tanúi, amikhez korábban nem volt hozzáférésük. Ennek eredményeképpen, a háború és az azzal járó horror mindenki számára elérhető volt: mindazok a civilek, akik a háború közvetlen észlelésétől távol tudtak maradni, a képek segítségével ott lehettek a fronton, tanúi lehettek a csatamezőkön történő vérontásnak és mészárlásnak a fotográfus kamerájának lencséjén keresztuil. Ez a jelenség pedig morális, kulturális és tudományos kérdéseket is felvet, amely 
folyamatos vitákat generál a halálhírekröl készült kutatások területén. Ezek a viták pedig nem választhatók el a közszférában megjelenő általános diszkusszióktól a katasztrófákat, és általuk a halál témakörét illetően. Számos kutató úgy véli, az emberi szenvedés és a halál grafikai megjelenítései egyre inkább láthatóvá válnak a hírekben, mások azonban úgy vélik, hogy rengeteg halállal vagy haldoklással kapcsolatos kép sohasem kerül be a hírekbe, az etikai korlátozások, a közízlés és a társadalmi érzékenység miatt - legalább is a legtöbb nyugati országban a hírszervezetek explicit szabályokat támasztanak a halállal kapcsolatos képek közzétételével szemben (Hanusch [2010] pp. 55-59.). Fraser úgy fogalmaz, hogy a média vezetői egyre hátborzongatóbb és részletgazdagabb képekkel szeretnék illusztrálni a halált, ugyanakkor szürik is a tartalmakat, hogy azok elfogadhatók legyenek a nyilvánosság számára (Fraser [1992] p. 24.).

A fotók, amint azt Barthes (1977) és számos szemiotikus állítja, mindig egy adott kontextusban léteznek, és - konnotatív jellegüknek köszönhetően - számos társadalmi jelentés társítható hozzájuk. Gyakran, különösen a háborúk és terrorcselekmények idején ezek a jelentések politikai hátterüek, ennek eredményeképpen a haláleseteket nagy érzékenységgel kezelik. (Az újmédia korszakában természetesen a hírgyártásba belépnek az amatőrök is, professzionális technikai eszközeikkel (Dahlgren [2009] p. 152.), gondoljunk csak a 2015-ös párizsi terrortámadásra, ahol számos mobileszközzel készített videofelvétel került ki a bataclani mészárlásról, a konvergens kultúra e jelenségének vizsgálata azonban a jelen szakdolgozat kereteibe nem fér bele.) A háborúk történetét tekintve az Amerikai Polgárháború (1861-1865) volt az első, amelynek eseményeit folyamatosan végigkísérték fotók segítségével, ezek azonban csak a legritkább esetekben érték el a nyilvánosságot, legtöbbször ugyanis galériákban vagy képeskönyvekben tették közzé öket. Amikor az I. világháború tombolt (1914-1918), az amerikai kormány szigorú cenzúrát alkalmazott, így gyakorlatilag nem jelentek meg fotók az amerikai emberáldozatokról a médiában. A spanyol polgárháborút (1936-39) azonban a katasztrófafotográfia korának nevezhetjük, mivel ez volt első olyan háború, amely során nagymértékben é szabadon fényképezték az eseményeket a közönség egyesítése és a modern háborús fotózás megalapítása érdekében. Ezt követően, a II. világháborúban (1939-1945) az újságok és magazinok még több képet hoztak le a háború okozta krízishelyzetről, haldoklókról és halottakról, amelyek közül az első a Life magazinban jelent meg 1943 szeptemberében. A képen három katona holtteste látható Új-Guinea partjainál, a képet kísérő szöveg pedig a következő 
volt: „Miért is kell nyilvánosságra hozni ezt a képet egyáltalán? Három amerikai katona fekszik egy ismeretlen tengerparton. Azért, hogy bántsuk vele az embereket? Azért, hogy morbidak legyünk? Nem, nem ez az oka. Szimplán az, hogy a szó sohasem lesz elegendő” (Hanusch [2010] p. 65., a szerző saját fordítása). Barbie Zelizer a náci megszállás vizuális reprezentációit tekintve a következő állítást teszi: A nácizmus alatt készített felvételek könyörtelenül írják le a horrort szigorú, naturalisztikus ábrázolásaikkal; a holttestek furcsa szögben fordulnak egymás felé, a kemencék tele vannak hamuval, a koponyák savasodva hevernek a földön, a német civilek pedig lesújtva állnak a vérontás felett. A fotográfusok megérkeztével a híreket ellepték a tábor horrorának rémisztő pillanatfelvételei (Zelizer [1998] p. 89.). A Vietnámi Háború kitörésének idejére (1955-1975) a katasztrófafotósok már hozzá voltak szokva azokhoz az extrém vizuális tartalmakhoz, amikről a felvételek szóltak. Ez volt továbbá az első olyan háború, amelynek híradásában a nyomtatott sajtótermékeit a televízió is kiegészítette, a háború borzalmait behozva ezzel az amerikai és európai nappalikba (Hanusch [2010] p. 67.).

Az elmúlt néhány évtizedben a természeti és ember okozta katasztrófák hírei is jobban megragadták a publikum figyelmét, mint bármelyik másik téma. Tekintettel a katasztrófák eredményeire (pl.: halál, sérülések, pusztítás, terrortámadások, a Katrina hurrikán, az Indiaióceáni szökőár, Kelet-Japánban történt Földrengés vagy a tornádók véget nem érő sora) nem meglepő, hogy az emberek a tömegtájékoztatáshoz fordulnak információszerzés céljából (Houston et al [2012] p. 607.). A háborúkkal szemben azonban a természeti katasztrófák és a terrorcselekmények vizuális reprezentációja nehézkes. Vicki Goldberg úgy fogalmaz, hogy a katasztrófa nem várakozik a fotográfusokra, hogy az megérkezzenek és elkészítsék felvételét, ezért nagyon ritkán adatik meg számukra a lehetőség, hogy bármit elkapjanak a katasztrófa utóhatásain kívül (Goldberg [1991] p. 194.). Vizuális reprezentációjuk azonban elengedhetetlen, hiszen mára a vizuális és grafikus tartalmak nem hozzáadott elemeknek, hanem a történetmesélés és érvelés elsőszámú hordozóinak tekintendők (Haddow - Haddow [2014] p. 47.). A terrorizmus és természeti, vagy ember által okozott katasztrófák fenyegető képeinek óriási hatása van a nyilvánosságra. Amikor például nő a terrorizmust vagy katasztrófákat bemutató képek száma a hírmédiában, úgy nő a publikum félelme és a vezetőséggel kapcsolatos elfogadása, bizalma is. Számos kutató specifikusan azt vizsgálja, hogy a terrorizmust bemutató vizuális elemek milyen hatással vannak a kormány vezetőivel kapcsolatos attitüdökre, és a legtöbben úgy vélik, a két faktor egyenesen arányos: minél több a kép, annál mélyebb a politikusok iránti bizalom és 
elfogultság. Egy másik kutatás azt mutatta be, hogy amikor a közönség fájdalommal, aggodalommal és megdöbbenéssel reagált a szeptember 11-i terrorakcióra, sokkal több képet tudott felidézni a hírekben bemutatott vizuális tartalmak közül. Ez pedig újabb bizonyíték a képek meggyőzőerejével kapcsolatosan (Reynolds [2009] p. 86.). A képekről tehát általánosan elmondható, hogy segítik az események felidézését, az emberek sokkal inkább emlékeznek a vizuális elemekre, mint a nem vizuálisakra - visszautalva Aczél memória meghatározására, amelyben azt a klasszikus retorika egyik legfontosabb elemeként, sőt, sarokköveként említi (Aczél [2012] p. 40.). Zelizerrel egyetértve Reynolds úgy véli, az újságok és a televízió terrorizmussal kapcsolatos hírei nem pusztán a kép denotatív jelentését juttatják el a nézőkhöz egy vizuális elemmel: az Irakban harcoló amerikai katona holtteste a patriotizmust, a terrorizmus elleni harcot és a gyászoló család fájdalmát is magában foglalja (Reynolds [2009] p. 86.). A terrorizmus képeinek nem csupán az érzésekre van azonban hatása, a képi érvelés eszközével ugyanis befolyásolhatják politikai döntéshozatalunkat, konatív attitüdjeinket egyaránt. A szakirodalom szerint a Bushkormány gyakran visszautalt szeptember 11-e képeire, amelyek magukban hordozzák az iraki háború legitimációjához szükséges érveket (Gadarian [2013] pp. 67-85.).

\section{Az esettanulmány}

\subsection{Az esettanulmány története}

1870-ben Christopher Columbus Langdell amerikai jogászt, egyetemi tanárt és az oktatás módszertanának megújítóját a Harvard Law School dékánjává választották. Mielőtt azonban átvette volna az Intézet irányítását, a jogászhallgatók oktatásának elsődleges módszere az úgynevezett Dwight módszer volt, amely a jog mindenkori státuszának fejből való memorizálását és társaik előtt való prezentálását jelentette. Langdell azonban úgy vélte, a hallgatók oktatásának van ennél jobb módja is, így olyan metódus kifejlesztésébe kezdett, amely személyes tanulási tapasztalatain alapult. Joghallgatóként Langdell minden jogi precedenst elolvasott és megtanult, amely a különböző kurzusokon elhangzott. Ezek az irányadó mintaesetek általában magukban foglalták az ügy részleteit, adatait, a bírói ítéletet, valamint a törvény alkalmazását az adott esetre. Később, ahelyett, hogy a diákok megtanulják és visszamondják ezeket a faktuális adatokat, Langdell úgy vélte, hogy - a jog alapvető 
fogalmainak ismerete mellett - az is üdvözlendő lenne, ha a hallgatók ezeket a koncepciókat értelmezni és alkalmazni is tudnák. Éppen ezért összeállított egy számos jogesetet bemutató, gyakorlati kurzust, amely során a hallgatók a kurzust megelőzően elolvasták és elemezték az adott eseteket, majd az órán Langdell kérdéseket tett fel az üggyel kapcsolatosan, közösen megbeszélve a jogeset problémáit, tanulságait. E metódus végül a „szókratészi módszer” néven vált ismertté (Wrench [2012] p. viii.).

1908-ban megalapították a Harvard Business School-t is, amelynek akkori dékánja, Edwin F. Gay a Harvard Law School módszeréhez hasonló oktatási eljárást kívánt bevezetni, amelyet a probléma módszernek nevezett. Sajnos a probléma módszer nem volt képes tovább fejlődni, így a kar továbbra is gyakrabban alkalmazta a frontális oktatás, mint a problémák megvitatásának eszközét. 1919-ben azonban új dékánt választottak a Harvard Business School élére: Wallace P. Donham, volt ügyvéd, a Harvard jogi karán végzett és sokáig ugyanitt tanított vállalati pénzügyeket. A szókratészi módszer volt diákjaként Donham ismerte a jogi képzésben elterjed eset alapú megközelítés előnyeit, azonban a vállalati világ alapvető különbségeket mutatott a jogban használt módszerekkel szemben - az üzleti életben előforduló esetek ugyanis nem voltak olyan módon, olyan rendszerben és olyan logikussággal, írásos formában összefoglalva, mint a jogi precedensek. Hogy ezt a rést betöltse, Donham létrehozta a Bureaufor Business Research elnevezésủ intézményt, és arra sarkallta karát, hogy - az új intézménnyel együttműködve - készítsenek esettanulmányokat a különböző üzleti ügyekről, üzleti vezetőkről, egyfajta tudományos kutatásként. Ezek a korai esetek a professzorok és üzletemberek közötti interakciók átiratai voltak, amelyek az adott üzleti döntést vagy döntések sorozatát írták le. Ez a képzési gyakorlat végül a „Case Method”, azaz az esettanulmány módszere néven terjedt el, és hamar az oktatás elsődleges módszerévé vált a legnagyobb egyetemeken (Wrench [2012] p. viii.).

\subsection{Az esettanulmány módszere a társadalomtudományokban}

Mára, az esettanulmány módszerét - a jogi és gazdasági területeken kívül - a társadalomtudományokban is előszeretettel alkalmazzák, mivel kiválóan alkalmas olyan komplex területek feltérképezésére és megértésére, mint az oktatás, a kommunikáció, a szociológia vagy a társadalmi közösséget érintő problémák, pl.: szegénység, munkanélküliség, 
drogfüggőség, illiteráció, vagy bizonyos egyszeri esetek, pl.: a Highland Towers összeomlása Kuala Lumpurban az 1990-es években, a 2004-es achehi tsunami hatásai, esetleg a dolgozat középpontjában álló Katrina hurrikán következményei (Zainal [2007] pp. 1-2.). Annak oka, hogy a társadalomtudományokban is jelentős népszerüségre tett szert az esettanulmány módszere az, hogy a kutatók egyre inkább felismerték a kvantitatív módszerek korlátozó hatásait a holisztikus, mélyreható társadalmi vagy viselkedéses kutatásokat illetően. Az esettanulmány metódusán keresztül ugyanis - a statisztikai adatokon túlmenve - megismerhetők a viselkedéses kondíciók a cselekvő szemszögéből is. Mivel a jelen módszer egyszerre tartalmaz kvalitatív és kvantitatív adatokat, könnyedén képes rámutatni egy jelenség folyamatára és kimenetelére, a vizsgált esetek teljes körü megfigyelése, rekonstrukciója és elemzése révén (Zainal [2007] p. 1).

Az esettanulmány módszere lehetővé teszi a kutató számára, hogy egy különleges kontextus adatait nagy alapossággal vizsgáljon meg. A megfigyelés tárgya általában egy kortárs jelenség, esemény vagy kondíció a valós életböl, amelynek vagy egy kisebb földrajzi területét, vagy korlátozott számú személyét vizsgálja (Zainal [2007] p.2.). Ennek megfelelöen Yin a következőképpen definiálja az esettanulmányt, társadalomtudományi megközelítés alapján: Az esettanulmány egy empirikus vizsgálat, amely jelenkori eseményeket vizsgál azok való életbéli kontextusában úgy, hogy a határ a jelenség és kontextus között nem egészen evidens, így számos forrás, szemszög és perspektíva alapján alkot elméletet (Yin [1984] p. 23.).

Fidel szerint akkor érdemes az esettanulmány módszerét alkalmazni, amikor:

- Az eset számos tényezőt és kapcsolatot tartalmaz

- Nincs alapszabály arra vonatkozóan, hogy mely tényezők és kapcsolatok fontosak

- Amikor a tényezők és kapcsolatok direkt módon megfigyelhetők, vizsgálhatók (Fidel [1984] p. 273.)

Az esettanulmány egyfelől a vizsgált esemény átfogó megértésére törekszik, másfelől azonban általánosabb elméleti állításokat dolgozhat ki a megfigyelt jelenségek szabályszerüségeiről (Fidel [1984] p. 274.). Éppen ezért Becker úgy határozza meg az esettanulmány módszerét, mint egy egyedi eset elemzését, amely alapján feltételezhetö, hogy egy teljes jelenség ismerete egyetlen adott eset intenzív feltárásával megszerezhető (Becker [1970] p. 75.). Az esettanulmányok nem szigorúan tervezettek, így, amikor egy kutató előre meghatározott struktúra nélkül kezd hozzá 
elemzéséhez arra számít, hogy a kutatás menete a vizsgálódás során a talált eredmények szerint változhat. Az esettanulmány flexibilitása tekinthető e módszer legfontosabb jellemzőjének (Becker [1970] p. 76.).

\subsection{Az esetek típusai}

Összességében az eseteknek három alapvető jellemzője van: 1. szignifikancia, 2. megfelelő mennyiségű információ, 3. következtetések, konklúziók hiánya. Egyrészt tehát az eset mindig egy fontos üggyel, vagy fontos ügyek sorozatával foglalkozik, amely valamely (jogi, szervezeti, politikai, társadalmi, etc.) szempontból mai, modern világunkban releváns lehet. Másrészt az esetnek elegendő mennyiségü adatot kell ahhoz szolgáltatni, hogy az olvasó fel tudja vázolni a lehetséges eredményeket. Valamennyi adatot természetesen minden esetben találhatunk, ezek azonban nem mindig relevánsak, amely súlyos problémákat okozhat az értelmezésben. Végezetül az esetek nem fogalmazzák meg egyértelmủen, hogy mi lett volna a legmegfelelőbb döntés egy adott helyzetben. Ezért elmondható, hogy az esettanulmány módszerének szempontjából az eredmények másodlagosak a folyamatokhoz képest.

Végezetül az esetek két típusának bemutatása következik: az úgynevezett valós esetek (profile cases) és fiktív esetek (fictional cases).

A valós esetek valós társadalmi, politikai, jogi vagy esetleg szervezeti jelenségeket írnak le és valós emberek döntéseit mutatják be. Ezek az esetek általában nagyobb terjedelmüek, hiszen megfelelő mennyiségű adatot kell szolgáltatniuk az eseményekkel kapcsolatosan. Pl.: ha a British Petroleum kommunikációját vizsgáljuk a Deepwater Horizon olajfúró torony 2010-es, louisianai katasztrófáját illetően, akkor először pár oldalban a mélytengeri fúrás mechanizmusát érdemes bemutatni; majd a katasztrófát eredményező baleset részleteit és a British Petroleum válaszát szükséges részletezni, végezetül az egyéb kommunikációs lehetőségek kiaknázásának kell következni. Ezek az esetek a Harvard Business School 1920-as évekbeli módszerének megtestesítői (Wrench [2012] p. x.).

A fiktív esetek kisebb terjedelmü összefoglalók - főként gazdasági és jogi területen elterjedtek - és szintén valós szervezeti problémákat írnak le, de fikcionalizáltak, annak érdekében, hogy az eset tömörebb, érthetőbb legyen. Az esetírás e módját a Harvard Business 
Review támogatta, amely minden számában bemutatott egy rövid esetet arra kérve a szakértőket, hogy mérlegeljék, méltassák az ügyet (Wrench [2012] p. x.).

\subsection{Az esettanulmány módszerének előnyei}

Azon kívül, hogy az esettanulmány egy rendkívül rugalmas és könnyedén értelmező kutatási tapasztalat, számos további elönye létezik. Először is, e kutatásmódszertan esetében az adatok vizsgálata legtöbbször azok használatának kontextusában történik, azaz abban a helyzetben, amelyben cselekvés/történés végbe megy. Az esettanulmány fókuszában állhat pl. egy olyan folyamat, amely során egy személy egy autentikus szöveget értelmez. Az olvasó stratégiáinak feltérképezése érdekében a kutatónak az alanyt saját környezetében kell vizsgálnia (pl.: tantermi olvasásról vagy szórakozásból történő olvasásról van szó). Ez ellentmond pl. a kísérlet módszerének, amely szándékosan elkülöníti az adott jelenséget kontextusától, és korlátozott számú változóra fókuszál (Zainal [2007] p. 4.).

Másrészt belső, instrumentális és kollektív variációit tekintve elmondható, hogy az esettanulmány módszere az adatok kvantitatív és kvalitatív típusú elemzésére is alkalmas. Egyéni esetek longitudinális vizsgálatai során pl. újságcikkek írásait, fotóit, vagy fócímeit is vizsgálhatják, amelyek a viselkedések leíró jellegü elemzését adják, míg vannak olyan esettanulmányok, amelyek az egyének numerikus és kategorikus válaszai alapján vizsgálódnak (Zainal [2007] p. 4.).

Harmadrészt az esetek kvalitatív típusú, részletes és alapos vizsgálata nem pusztán az adatok valós környezetében történő megfigyelésére alkalmas, hanem a való élet eseményeinek, jelenségeinek komplex természetét is képes feltárni, amelyre egy kísérleti vagy kérdőíves módszerrel nem lenne lehetőség. A szövegolvasás tanulmányozása során pl. nem csupán az olvasó által használt stratégiákat tárhatjuk fel, hanem azok okait, illetve a stratégiák más

stratégiákkal való kapcsolatát is, hiszen az olvasás egy meglehetősen komplex kognitív folyamat, amely nem vizsgálható más észlelési stratégiáktól függetlenül (Zainal [2007] pp. 4-5.).

A felsoroltakon kívül további Wrench öt alpontban fogalmazza meg az említett módszer hasznosságát: 
1. Valóságalapot ad közvetett tapasztalatoknak: az esettanulmányok segítségével mások döntéseit, helyzetét tehetjük elemzésünk tárgyává.

2. Konkrét problémákra fókuszál: míg számos más módszernek nincsen referenciakerete, az esettanulmány valós eseményeken alapuló történeteket mutat be (hacsaknem magukat a konkrét eseményeket).

3. Fejleszti a döntéshozatallal kapcsolatos készségeket: a vizsgálati módszerek később alkalmazhatók valós döntéshozatali szituációkban.

4. Szélesíti a perspektívákat: kérdések, állítások, feltevések segítségével a legegyszerübb folyamatokat is rendkívüli részletességgel képes elemezni.

5. Különböző nézőpontokat kínál: ahány elemzés, annyi féle megoldás jöhet létre, amely szorgalmazza az adott eset teljes körü kivizsgálását, értelmezését (Wrench [2012] pp. Xxi.).

\subsection{Az esettanulmány módszerének hátrányai}

Vitathatatlan előnyeinek ellenére az esettanulmány módszerét számos kritikával is illették. Először is azzal, hogy nem kellően rigorózus, nincs mögötte szigorú szabályrendszer vagy értelmezési struktúra, ezáltal elfogult álláspontokat találhatunk, amelyek befolyásolják az eredmények és konklúziók irányát, minőségét (Zainal [2007] p. 5.).

Másrészt az esettanulmányról számos kutató úgy véli, hogy e módszer kevés alapot ad a tudományos általánosításra, hiszen a legtöbb ilyen jellegü kutatás kevés, vagy egyetlen személy/esemény viselkedését, jellemzőit vizsgálja (Zainal [2007] p. 5.).

Harmadrészt az esettanulmányokat gyakran túl terjengősnek, vontatottnak találják, amelyeket nehéz követni, a dokumentáció rendkívüli hosszúsága miatt. Különös tekintettel az etnográfiai vagy longitudinális természetű kutatásoknál, ahol, a vizsgálat hossza miatt az adatok menedzselése és szisztematikus elrendezése nehézkessé válhat (Zainal [2007] p. 5.).

\subsection{Integrált komplex módszertani keret: esettanulmány és tartalomelemzés}

A tartalomelemzés képek, szövegek és szimbolikus elemek szisztematikus elemzését jelenti, amely nem feltétlenül a szerző vagy felhasználó szemszögéből történik. Bár a tartalomelemzés 
kifejezés 1941-ig nem jelent meg angol nyelven, a szöveg szisztematikus elemzése az egyház 17. századi inkvizíciós törekvései óta fellelhető. A nyomtatás megjelenése után ugyanis az egyház aggódni kezdett a nem vallásos jellegű nyomtatott anyagok terjedését illetően, így fokozottan figyelmet fordított az újságok tartalmára, különösen erkölcsi kérdések kapcsán (Krippendorff [2004] p. 3.). A tartalomelemzés legfontosabb megkülönböztető jegye más kvalitatív vagy interpretatív elemzésekhez képest, hogy igyekszik a tudományos módszer alapvető normáinak megfelelni azáltal, hogy illeszkedik a társadalomkutatás pozitivista paradigmájához, amely a következö kritériumokat fogalmazza meg (Neuendorf [2002] p. 10.).

\section{- Objektivitás - interszubjektivitás:}

A tudományos kutatások egyik legfőbb célja, hogy olya leírást vagy magyarázatot adjanak egy bizonyos jelenséggel kapcsolatosan, amely kiküszöböli a kutató torzításait. Az objektivitás tehát minden esetben kívánatos kritérium. Berger és Luckman The social construction of reality címü munkájában arra hívja fel a figyelmet, hogy valódi objektivitás nem létezik, hiszen a „tudás” vagy a „tények” minden esetben társadalmilag konstruáltak és elfogadottak, így, e szemlélet szerint az emberi megismerés elkerülhetetlenül szubjektív, mégis törekednünk kell a vizsgálatok során a következetességre (Berger - Luckmann [1966]). Ez abban is megmutatkozik, hogy a kutatók általában nem az „ez igaz?”, hanem az „egyetértünk abban, hogy ez igaz?” kérdést teszik fel. A tudományban ezt a jelenséget interszubjektivitásnak nevezik, utalva ezzel a tartalomelemzés eredendően emberi mivoltára (Neuendorf [2002] p. 11.).

- A priori tervezés:

Bár az a priori (vagyis a „tény elötti”) tervezés valójában része az objektivitás-interszubjektivitás követelményének való megfelelésnek, fontossága miatt külön pontban kap hangsúlyt. A tartalomelemzéses beszámoló gyakran olyan vizsgálatot mutat be, amelynek változóit csak az üzenetek/jelenségek megfigyelése után adják meg. Ez a teljességgel induktív megközelítés sérti a tudományos törekvések irányait. A kódolási szabályokat és a változókkal kapcsolatos minden döntést a megfigyelések kezdete előtt kell meghatározni. Humán kódolás esetén a kódkönyv és a kódolási forma ideális esetben előzetesen jön létre. Ez tehát a tartalomelemzés hátrányaként fogható fel, mindazonáltal a kreativitás és az innováció felfedezhető a jelen módszerben is. Az ilyen jellegü elemzés tartalmát tehát előbb fel kell deríteni, mielőtt a végleges kódolási rendszert 
kőbe vésnénk, így e procedúrát egyszerre tekinthetjük az induktív és a deduktív módszer kombinációjának (Neuendorf [2002] pp. 11-12.).

- Megbízhatóság:

A megbízhatóságot úgy határozzuk meg, mint a mérési eljárás mértékét, amely ugyanazokat az eredményeket eredményezi ismételt kísérletek esetében. Amikor a tartalomelemzésben humán kódolókat alkalmazunk, intercoder azaz kódolók közötti megbízhatóságról kell beszélnünk, amely a két vagy több kódoló közötti egyetértés szintjére utal. A tartalomelemzésben kiemelt szerepe van a megbízhatóságnak; elfogadható megbízhatósági szint hiányában a tartalomelemzési vizsgálatok értelmetlenné válnak (Neuendorf [2002] p. 12.).

- Érvényesség:

Az érvényesség kifejezés arra utal, hogy az empirikus vizsgálat mennyire tükrözi a kódolók egyetértési szintjét a fogalom valós jelentésével kapcsolatosan. Az érvényesség általában a következő kérdéssel foglalkozik: „Valóban azt mérjük, amit mérni akarunk?” Bár a tartalomelemzésben a kutató a főnök, végső döntést hozva arról, hogy milyen mérendő és mérhető fogalmakat vizsgál, számos iránymutatás áll rendelkezésre az érvényesség javítása érdekében (Neuendorf [2002] p. 12.).

- Általánosíthatóság:

A megállapítások általánosíthatósága arra utal, hogy az eredmények milyen mértékben alkalmazhatók más esetekre. Az általánosítás általában egy nagyobb csoportra/populációra vonatkozik, amelyből a mintavétel történt. Miután 300 városi lakos eredményeit összesítik, a kutatók nyilván abban bíznak, hogy eredményeik a város minden lakosának esetében általánosan érvényesek lesznek (Neuendorf [2002] p. 12.).

\section{- Megismételhetőség:}

Egy tanulmány megismételhetősége védelmet jelent a megállapítások túláltalánosíthatóságával szemben. A replikáció magában foglalja egy tanulmány megismétlését különböző esetekben vagy más összefüggésben, ellenőrizve, hogy hasonló eredményeket találtak-e minden egyes 
alkalommal. A kutatási jelentéseknek minden esetben elegendő információt kell adniuk a kutatás módszerét és protokollját illetően, hogy mások szabadon megismételhessék azt (Neuendorf [2002] pp. 12-13.). A tartalomelemzések gyakran hátránnyal rendelkeznek a megismételhetőség tekintetében. Egyes tartalmak történelmi relevanciája megakadályozza az ismételt mintavételt, mint pl. Hogenraad és McKenzie Európai Unió megalakulásához vezető politikai beszédelemzése (Hogenraad - McKenzie [1999] pp. 97-116.).

\section{- Hipotézisvizsgálat:}

E tudományos módszer deduktívnak tekinthető, vagyis az elméletböl egy vagy több hipotézis (feltételezett állítás a változók közötti kapcsolatról) állítható fel. Minden hipotézis deduktíve tesztelhető: a kutatók minden változóra méréseket végeznek, és a köztük lévő kapcsolatokat statisztikailag megvizsgálják annak érdekében, hogy lássák, a feltételezett állítás beigazolódott-e vagy sem. Amennyiben a hipotézis alátámasztásra kerül, az további támogatást nyújt annak az elméletnek, amelyből származik. Amennyiben nem kerül alátámasztásra, az elmélet bizonyos mértékig megkérdőjelezhetővé válik. Ha a meglévő elmélet nem elég erős ahhoz, hogy hipotézist lehessen felállítani azzal kapcsolatosan, általában egy vagy több kutatási kérdés felállítása következik. Egy kutatási kérdés a változók közötti lehetséges kapcsolatokról informálódik. A deduktív tudományos modellben a hipotéziseket és kutatási kérdéseket az adatgyüjtést megelőzően állítják fel (Neuendorf [2002] p. 13.).

Az esettanulmány kapcsán felsorolt kritikák, és a tartalomelemzés fent bemutatott formuláinak ellenére jelen disszertáció az esettanulmány módszerét tartja elsődleges vizsgálati módszerének az elemzés tárgyát képező két katasztrófa bemutatására, mivel - rugalmas természetének köszönhetően - egyedül ez a módszer képes a választott, komplex vizuális eseményeket átfogóan, kontextusuktól függetlenül és függően új nézőpontokat, perspektívákat kínálva értelmezni; azok kvalitatív és kvantitatív adatait is értékelni; és a produktum (mint eredmény, mint logika), a procedúra (mint dialektika, mint eljárás), és a processzus (mint retorika, mint folyamat) hármasában vizsgálni.

Felvethető ugyan, hogy jelen tanulmány adott esetekből ragad ki képeket és azok elemzésén keresztül mutatja be a vizuális retorika mint önálló diszciplína és a produktum-, procedúra-, és processzus-orientált vizsgálati módszer érvényességét, vizsgálatomra azonban 
mégis esetelemzésként tekintek. A két katasztrófa képei gyakorlatilag eseteket kondenzálnak, sürítenek. Egy eset összetettsége is ebben mutatkozik meg. Ahogyan azt tartalomelemzés kapcsán említettem, egyes tartalmak történelmi, politikai, társadalmi relevanciája megakadályozhatja az eredmények általánosíthatóságát. Az esettanulmány módszere pont ezt a torzítást hivatott kiküszöbölni, segítségével ugyanis nem csak a képek tartalma, hanem azok kontextusa is ugyanúgy a fókuszba kerülhet. Elemzésem ezáltal egyfajta hibrid módszerrel közelít, amelynek egyik bemenete a tartalomelemzés - képek kódolásán keresztül - a másik, fö bemenete pedig az eset, amelyben vizsgálatom a képek kontextusát, szándékát, hatását, megjelenített toposzát és perspektíváit is képes tekintetbe venni. Mivel az eset- és a tartalomelemzésnek is alapvető eleme a megbízhatóság, amely a két vagy több kódoló közötti egyetértés szintjére utal, vizsgálatomat én is társkódolóval végeztem el. A kódolásban Németh Gabriella, a Budapesti Corvinus Egyetem Társadalmi Kommunikáció Doktori Iskolájának doktorjelöltje volt segítségemre.

\subsection{Az elemzés módszere}

Disszertációm két esemény - a Katrina hurrikán mint természeti katasztrófa, illetve a Bataclan színházelleni terrortámadás mint ember által okozott katasztrófa - médiában megjelenő vizuális anyagainak vizsgálatára vállalkozik, összesen 150 kép elemzésével. Forrásukat tekintve olyan platformokról gyüjtöttem képeket, mint a CNN, a US News, a The New York Times, a The Huffington Post, a Daily Mail vagy a Nyugat, az Origó és a Blikk online oldalai. A képeket véletlenszerủ mintavételen alapuló adatgyüjtés (random sampling) módszerével választottam ki. Az elemzés célja megvizsgálni, hogy mennyiben hasonlít és mennyiben tér el egy természeti és egy ember által okozott katasztrófa vizuális reprezentációja, feltételezve, hogy a két eset vizsgálata során számos különbségre mutat majd rá értekezésem. A választott két esemény 75-75 képének produktum, procedúra és processzus alapú elemzéséhez az alábbi kódrendszert választottam:

1. A kép produktum típusú megközelítését tekintve olyan aspektusokat vizsgáltam, mint: előtér, nem, kor, feketék/fehérek, pozitúra/proxemika, öltözet, háttér, mise en scène, azaz a kép fókuszának, keretbe helyezésének vizsgálata. A 8 kód közül a pozitúra/proxemika kódot végül az összesítés során elvetettem, mivel a fényképeken szereplö alakok, épületek stb. rengeteg különböző féle pozícióban jelentek meg 
egymás mellett, így ez nem volt alkalmas arra, hogy összehasonlítás alapját képezze. Ez tehát a kép eredmény típusú megközelítése, amely - kontextusából kiragadva pusztán azokat az elemeket vizsgálja, amelyek jelen vannak, felépítik a vizuális elemet.

2. A kép mint procedúra, azaz eljárás megközelítésében az alábbi aspektusok vizsgálatára tértem ki: a kamera nézőpontja (alulról, felülről, szemből vagy hátulról mutatja be), az alakok mozdulata, mimikája, a kamera proxemikája (közeli vagy távoli kép), speciális effektek (éles vagy homályos elemek a képen), és az időfaktor. A fent említett öt kód a megközelítés a kép készítöjének megközelítésének elemzési szempontrendszere. Ahogyan ö látja és láttatja a történteket. Ez az aspektus tehát már kontextusában vizsgálja a képet, nézőpontja pedig mindenképpen értéktelített, akaratvezérelt.

3. A kép mint processzus, azaz folyamat megközelítést tekintve három kódot határoztam meg: a kép szándékát, hatását, harmadik aspektusként pedig a kép által bemutatott toposzt, vagy megtestesített cselekményelemet (pl.: szenvedés, agresszió, veszteség, halál stb.).

A két katasztrófa ilyen típusú, produktum - procedúra - processzus hármasára épülő esetelemzése lehetővé teszi a vizuális elem holisztikus értelmezését, leírva a képen jelenlévő elemeket, az eljárást, amelyben létrejött, végezetül pedig a szándékot, a hatást, amit kiváltani kíván, érvényesítve ezzel a logika, dialektika és retorika triádját és bizonyítva, hogy a vizuális retorika mind a három aspektus kielégítésére tökéletesen alkalmas. 


\section{A Katrina hurrikán}

More than once, a society has been seen to give way before the wind which is let loose upon mankind; history is full of the shipwrecks of nations and empires; manners, customs, laws, religions - and some fine day that unknown force, the hurricane, passes by and bears them all

away.

Victor Hugo, Les Misérables ([2009] p. 163.)

A Katrina hurrikánt az Amerikai Egyesült Államok egyik legpusztítóbb és leghalálosabb természeti katasztrófájaként tartják számon, amely 2005. augusztus 29-én érte el az Államok déli partvidékét 203 km/h-ás szélsebességgel, és példátlan pusztítást okozva söpört végig Mississippi, Alabama és Luisiana államok felett (National Geographic [2008. 12. 19.]). A Saffir-Simpsonskála alapján eleinte 1-es kategóriájú hurrikánként tombolt Dél-Floridában, majd, miután elérte az 5. fokozatot a Mexikói-öböl központja felett, 3. kategóriájú hurrikánná gyengült az öböl északi részének megközelítése során (Tiba [2011] p. 21.).

Ugyan az előkészületek folyamán számos intézkedéssel (pl.: gátak emelése, evakuációra való felszólítás, konferenciaközpontok, sportcsarnokok, pl.: Superdome felkészítése az emberek fogadására stb.) igyekeztek minimalizálni a veszteségeket és emberáldozatokat, a New Orleans-t védő gátak közül három hamar átszakadt, és a város 80 \%-a víz alá került (National Geographic [2008. 12. 19.]), az elszegényedett területek lakosai pedig - gépjármü híján - nem tudták elhagyni a térséget, így sokan saját otthonukban várták a Katrina hurrikánt (Magyar nemzet [2015. 08. 29.]). Az elöntött városokban 4,5 méter magasan állt a víz, amelynek következtében megszünt az áram- és vízellátás, járványveszély fenyegetett - újra felütötte a fejét a kolera és a tífusz is - a halálos áldozatok száma pedig kb. 1800-ra tehetó (a Daily News 1839-re becsülte az elhunytak számát, míg az AccuWeather 1800, az Insurance Journal több mint 1800, a The New Orleans Times - Picayune pedig 1833 áldozatról írt) (Magyar Nemzet [2015. 08. 29.]). A Tropical Cyclone Report - amely a The New Orleans Times-hoz hasonlóan szintén 1833 halálos áldozatról számol be - megoszlásukat tekintve a következö adatokat közölte: a halottak közül 1577 Louisiana, 238 Mississippi, 14 Florida, 2 Georgia, és 2 Alabama államban esett a hurrikán áldozatául (Knabb et al [2005] p. 11.). A halál oka 40\%-ban fulladás, 25\%-ban sérülés vagy trauma, 11\%-ban pedig szívelégtelenség (The Data Center [2016. 08. 26.]). Az áldozatok közel 
fele 74 éves kor feletti volt (The Data Center [2016. 08. 26.]). A Superdome stadionban és a konferenciaközpontban elszállásolt kb. 50.000 ember éjjelente rájuk törő bandákról, fosztogatásokról, éhezésről, nemi erőszakról és gyilkosságokról számolt be, amely miatt a Katrina hurrikánhoz direkt vagy indirekt módon köthető halálos áldozatok száma még bizonytalanabbá vált (Magyar Nemzet [2005. 09. 04.]).

A katasztrófa gazdasági vetületét tekintve kb. 108 milliárd dolláros kárról számoltak be a hírek, amely az egyik legköltségesebb hurrikánná teszi a Katrinát, háromszor akkora teljes monetáris kárral, mint az Ike Hurrikán (2008) és négyszer akkorával, mint az Andrew hurrikán (Knabb et al [2005] pp. 12-13.). A Mexikói-öbölben 21 olajkitermelő állomás süllyedt el a tengerben, és további 20 olajfúrótorony rongálódott meg. Ennek megfelelően az amerikai energetikai miniszter arról számolt be, hogy összesen 60 millió hordó kőolajat és feldolgozott olajterméket szabadít fel stratégiai tartalékából a nemzetközi energetikai ügynökség egy súlyos energiaválság megelőzése céljából (Magyar Nemzet [2005. 09. 04.]).

Politikai aspektusát tekintve a Katrina hurrikán következtében kialakult krízishelyzet silány kezeléséért, a segítségnyújtásban mutatott késedelemért és a rendfenntartás hiányáért sokan a szövetségi kormányt tették felelőssé. George Bush, akkori amerikai elnök csak négy nappal a katasztrófa után indult a hurrikán és árvíz sújtotta területekre. A New Orleans-tól nem messze található Biloxi utcáit járva Bush maga is elégedetlenségét fejezte ki a késlekedés miatt. Később úgy nyilatkozott, hogy: bár sok ember (orvosok, katonák, mentőalakulatok stb.) keményen dolgozik, egyelöre kudarcot vallottak a katasztrófa sújtotta New Orleans megsegítésére tett kísérletek (Magyar Nemzet [2005. 09. 04.]). A szenátus kormányzati ügyek bizottságának republikánus és demokrata párti vezetője kötelességüknek nevezte feltárni a felkészületlenség okait valamint azt, hogy miért maradhattak el a vihar hatását mérséklő intézkedések. Válaszul Jesse Jackson, az ismert emberi jogi aktivista New Orleansban arra tett utalást, hogy a késlekedésben szerepet játszott, hogy az érintettek többsége szegény, fekete bőrü (Magyar Nemzet [2005. 09. 04.]). Egy 2005. szeptember 6-7-e között végzett, különböző kulturális és etnikai csoportok Katrina hurrikánnal kapcsolatos percepcióit vizsgáló kutatás szerint $70 \%$ afroamerikai volt dühös és elégedetlen a kormány tevékenységét illetően, míg a fehér lakosságnak csak 46\%-a nyilatkozott így. Ugyanebben a tanulmányban az afroamerikai lakosság 66\%-a érezte úgy, hogy a kormányzat reakciója gyorsabb lett volna, ha az áldozatok 
fehérek lettek volna, míg a fehérbőrủ megkérdezettek csak 17\%-a nyilatkozott így (Martin Nakamaya [2010] p. 54). Szakértők szerint a hurrikánt követően is előfordultak olyan politikai döntések, amelyek ellehetetlenítették a fekete lakosság helyzetét. A New York Times Magazine egyik cikkében úgy fogalmaz, hogy afroamerikaiakat többször is hátrányosan különböztették meg a kártalanítási összeg megállapítása során, amely miatt több ezer családnak nem volt lehetősége az újrakezdésre (The New York Times Magazine [2015. 08. 18.]). Ezzel egybehangzóan Lilly Workneh, a Huffington Post Black Voices rovatának vezető szerkesztője azt nyilatkozta, hogy New Orleans történetének médiareprezentációja olyan volt, mintha két külön város történetét mesélné el. Véleménye szerint volt egy fehér és egy fekete narratíva, ahol még a szóhasználat is megdöbbentően különbözött: ugyanolyan környezetben, szituációban a fehér áldozatok a médiában rendre élelmet „találtak”, míg a feketék élelmet „fosztogattak” maguknak (Huffington Post [2015. 08. 27.]).

\subsection{A Katrina hurrikán 3P alapú esetelemzése}

\section{Produktum:}

Előtér: A Katrina hurrikánt ábrázoló 75 fotóból 42 előterében jelentek meg alakok, ebből 18 képen egyedüli emberábrázolásról van szó (néhány jellemző képet kiemelve: F7, F8, F26, F33, F39, F43, F48, F59, F64, F74 stb.), amely arra enged következtetni, hogy a fénykép készítője az egyedüli megküzdés, magárahagyatottság érzését igyekezett erősíteni a befogadóban. Négy kép esetében a fókuszként tekinthető alakok nem a fénykép elöterében, hanem a hátterében voltak láthatók (ezek az F12, F19, F22, F57). George Bush, akkori amerikai elnök 3 fotón volt jelen (F25, F51, F74), utóbbin a televízió képernyőjén keresztül. Ahol nem emberek voltak a középpontban, ott vagy természeti képeket találunk (F10, F34, F36, F42, F46, F47); vagy Istenhez köthető ábrázolásokat, pl.: feszületek (F13, F14) Krisztus kép (F54); vagy épületeket, házakat, otthonokat látunk (F2, F3, F6, F24, F29, F38, F44, F63, F70); esetleg roncsokat és szemetet (F22, F49, F50, F53, F67). Egy fotó ábrázolta magát a hurrikánt (F41), több pedig Amerika szimbólumait (Davis Jefferson volt elnök szobrát (F68) és az amerikai zászlót (F75), ez utóbbi azonban gyakran nem egyedül, hanem emberek kezében jelent meg (F62, F66)), egy esetben pedig fényképalbum volt a kép fókuszában (F73). 
Nem: 9 fényképen jelent meg csak női alak (F1, F5, F19, F21, F39, F40, F45, F48, F74) 25-ön csak férfi (néhány jellemző képet kiemelve: F7, F11, F25, F26, F27, F43, F59, F64, F71 stb.) és 12 olyan fotót találtam, amelynek az előterében, vagy hátterében vegyesen voltak jelen férfiak és nök (jellemző képek: F9, F12, F17, F20, F24, F51, F50, F62 stb.).

Kor: A legtöbb fotón (33 db, néhány jellemző elemet kiemelve: F4, F7, F8, F11, F17, F25, F28, F32, F48, F59, F66 stb.) középkorú és fiatal emberek láthatók, 4-en kisbaba (F4, F17, F40, F65), 6-on pedig idős ember (F1, F9, F15, F20, F27, F74) is szerepel, pár képen vegyes korosztályok találhatók (néhány jellemző kép: F12, F22, F45, F52).

Fekete/Fehér: A fényképek közül 18 fehér börủ embert/embereket mutat be (jellemző képek: F1, F7, F9, F18, F26, F37, F52, F66 stb.), 20-on feketék láthatók (pl.: F5, F16, F19, F24, F45, F59, F62 stb.), 7 db vegyes képet találtam (F4, F12, F22, F28, F40, F65, F69) és egy olyat, amely latino férfit ábrázol (F33).

Kutyák: 5 fotón jelenik meg kutya (F5, F14, F32, F57, F72), van, amelyiken több is.

Öltözet: Öltözetüket tekintve leggyakrabban hétköznapi viselet volt jellemző (27 db fotó, pl.: F1, F5, F16, F18, F19, F20, F21, F22, F39, F43, F52, F74 stb.), több kép félmeztelenembereket ábrázolt (11 fotó), de a katonai (F4, F9, F11, F15, F37, F66), rendőri (F16, F57, F65, F69, F71), mentős (F40), tüzoltó (F58) és elegáns (George Bush, F25) viselet is megjelent, helyenként átfedésekkel.

Háttér: Ahogyan azt már az előtér elemzésekor említettem, a háttérben gyakran szerepeltek alakok. 14 olyan fotót találtam, amelynek vagy csak a hátterében, vagy a hátterében is szerepelnek alakok: F1, F8, F12, F15, F16, F17, F19, F22, F40, F43, F52, F57, F65, F69. Elöntött házakat is gyakran találhatunk a háttérben, összesen 18 esetben: F6, F7, F9, F10, F19, F23, F24, F26, F27, F34, F37, F43, F44, F45, F49, F60, F61, F72. Elöntött utakat 10 esetben ábrázolnak (F5, F16, F28, F30, F39, F42, F46, F47, F59, F67). Két esetben láthatók feszületek és sírok a háttérben (F13, F14), mind a két esetben bárányfelhők és napsütés kíséretében. Említésre méltó még a helikopter háttérábrázolása, ez 5 fényképen figyelhető meg: F1, F11, F20, F47, F64. Két fotón láthatunk halottakat a háttérben (F5, F61), a halottat ábrázoló fotókat azonban külön alfejezetben elemzem. A többi fénykép hátterén többnyire vihar, kosz, roncsok, szobabelsők, 
leszakadt vezetékek találhatók, illetve előfordulnak olyan képek is, amelyeknek nincsen háttere, az előtér kitölti a teljes fotót, vagy nem releváns a háttér (11 fotó esetében, pl.: F31, F34, F39, F48 stb.).

Mise en scène: A keretbe helyezést tekintve a legtöbb esetben (38 fotó; néhány jellemző elemet kiemelve: F3, F4, F11, F14, F18, F 26, F38, F47, F55, F62, F66, F71, F75 stb.) a fókusz a kép közepén volt, 13 esetben (F2, F7, F20, F27, F29, F30, F33, F37, F52, F58, F61, F69, F72) a baloldalán, 11 esetben (F1, F5, F16, F19, F25, F40, F43, F44, F49, F57, F74) a jobboldalán, 6 fotón $(\mathrm{F} 24, \mathrm{~F} 32, \mathrm{~F} 35, \mathrm{~F} 50, \mathrm{~F} 53, \mathrm{~F} 64)$ az alsó részén, 3 fotón (F10, F42, F54) a felső részén és végezetuil, 4 fotó esetében (F34, F45, F48, F63) az egész kép hangsúlyos volt.

Halottábrázolás: A 75 fotóból 6 db-on jelent meg a halál motívuma, ezek közül 2-n pusztán implicit módon: az egyik fotón (F35) egy temető előterében fehér zászlókkal emlékeznek meg a hurrikán áldozatairól, itt a zöld fübe nevekkel ellátott apró zászlók láthatók csupán; a másik fotón (F55) csak egy saját kezüleg készített, gyermek méretü sír látszik, lepedővel fedve és téglákkal rögzítve, fejfája pedig egy fakereszt. A lepedőn fekete festékkel a következő szöveg látszik: „Here lies Vera - God help us”. A maradék négy fotón a halottat explicit módon mutatják. Két fotón (F5, F61) a halott a távolban, hason fekve lebeg a víz színén; egy másikon (F32) szintén hason fekve mutatják, de itt nem vízen, hanem sárban hever. Az utolsó kép (F31) egy takaróval és fém lappal eltakart halottat mutat be, neki csak a lábszárai látszódnak.

\section{Procedúra:}

A kamera nézőpontja: Érdekes volt megfigyelni, hogy a szemből és a felülről készített fényképek aránya nagyjából kiegyenlített volt. 35 fotó készült szemből (néhány jellemző elemet kiemelve: F1, F4, F15, F22, F28, F33, F46, F54, F57, F69, F72 stb.), és 31 fotó készült felülről (pl.: F5, F7, F10, F19, F24, F31, F39, F44, F50, F61, F73 stb.). A felülről készített fotók jellemzően az elöntött területeket, a víz hatalmát és az ember küzdelmét mutatják be a vízzel szemben. Az alsó kameraállásból készült fényképek száma sem elhanyagolható, 8 db ilyen kép készült (F13, F14, F27, F29, F64, F65, F68, F75). Mind a két feszületet ábrázoló fotó alulról készült, hasonlóképpen egy villámcsapás, egy vizet hozó helikopter és Jefferson Davis volt 
amerikai elnök szobra is alulról került lefotózásra, ezzel mutatva az ö nagyságukat, mindenható, pusztító vagy éppen segítő természetüket.

Mozdulatok: A mozdulatok kód 25 kép esetében nem volt értelmezhetö. A maradék imágóból 25-ön valamely aktív mozgás volt megfigyelhető. Az F4-es fotón például katonák mentenek egy csecsemőt, míg az F9-esen két katona egy idős asszonyt ment ki elöntött házából. További példák aktív, küzdelemmel teli, mozgalmas fényképekre: F11, F14, F22, F39, F59 stb. 19 képen egyfajta passzió figyelhető meg: az F7-es fotón a fiatalember teljesen elárasztott nappalija kanapéján ül, feltett lábbal, karjával a fejét támasztva. Hasonlóképpen az F18-as képen is több, középkorú férfi és nő várja egy helyben állva a segítséget. A passzív, mozdulatlan képekre példa még: F8, F20, F25, F33, F56 stb. 3fotón gyengédségböl, gondoskodásból fakadó mozdulatok láthatók: F1, F17, F57. Szintén 3 fotón agresszióból eredő, erőszakos mozgás figyelhető meg: F16, F42, F69.

Mimika: A mimika kód 40 kép esetében nem volt értelmezhető. 15 fotón a komolyság, kilátástalanság jellemezte az emberek arckifejezését (néhány jellemző elemet kiemelve: F8, F9, F17, F33, F68 stb.). 5 fotó szenvedésről, elgyötörtségről, fájdalomról árulkodik: F11, F21, F48, F56, F63. Aggodalom, rémület 3 fotón látható: F1, F4, F72. 4 fényképen mutatnak az arcok elszántságot: F14, F15, F28, F43. Érdekes módon, bizonyos fotókon ( 6 db) optimizmus, sőt, mosoly, nevetés látható az emberek arcán: F18, F19, F23, F57, F64, F73.

A kamera proxemikája: A kamera proxemikája kód arra utalt, hogy közeli, vagy távoli képről van-e szó az adott fotó esetében. Távolról készült fényképből volt több, összesen $40 \mathrm{db}$, ezek közül néhányat kiemelve: F10, F12, F13, F18, F22, F34, F42, F47, F60, F67 stb. Közeli képböl 35 db készült, ezek közül példaként említeném az: F1, F2, F21, F25, F35, F48, F64 stb. képeket.

Effektek: Mivel valós események fényképeit elemeztem, speciális effektekkel, filterekkel, képi szerkesztettséggel nem találkoztam, így az effektek kód kapcsán azt vizsgáltam, hogy a fénykép készítője élesen vagy homályosan láttatja-e a kép előterét, illetve hátterét, kijelölve ezzel a kép fókuszát, lényegi elemét. A fényképek nagy többségében (57 fotó) az egész kép éles volt, nem volt semmilyen effekt, homályosság észlelhető. Ezekre példa: F4, F5, F12, F20, F27, F32, F49, F55, F62, F74 stb. 14 esetben találtam olyan fotót, ahol az elötér volt éles, a háttér homályos. 
Néhány jellemző elem: F16, F21, F46, F52, F57, F64 stb. 3 esetben volt a háttér éles és az előtér homályos: F2, F19 és F25. Egyetlen esetben volt az egész kép homályos (F9).

Időfaktor: A fotók elemzésekor észrevehető volt, hogy minden képen megjelenik valahogy az idő jelensége. E kód szerint 4 kategóriát hoztam létre, ezek: a lassú, passzív idő, amelyben kevés mozgás, főként a segítségre való várakozás figyelhető meg; az aktív, gyors, cselekvő képek, amelyeken főként a mentés, helyreállítás, vihar elől való menekülés látható; a kontraszt, ahol a múlt és jelen közti különbség kerül a fókuszba; és végezetül az elmúlás képei, amelyeken az örök nyugodalom, vagy egy otthon, egy élet összeomlása látható. Érdekes módon lassú időt ábrázoló fotóból találtam a legtöbbet, 35 db-ot (ezekre példa: F7, F9, F16, F22, F28, F39, F53, F72 stb.). Aktív mozgást, cselekvést ábrázoló fotóból 22 db volt (pl.: F11, F15, F36, F47, F51, F62, F66, F71 stb.). Kontrasztot ábrázoló fotóból 11-et találtam, ezekre jó példa: F3, F5, F8, F13, F21, F68, F75. A legkevesebbet az elmúlást ábrázoló fotókból találtam, összesen 7 db-ot. Ezek: F1, F31, F32, f35, F38, F55, F61.

\section{Processzus:}

A kép szándéka: A képek szándékának elemzésekor 9 kódot különítettem el, ezek: a hurrikán okozta pusztítás ( 24 db, pl.: F3, F6, F8, F22, F29, F38, F49 stb.); az életben maradásért való küzdelem (22 db, pl.: F11, F12, F24, F28, F45 stb.); az újjáépülés vagy reménység (7db, pl.: F13, F14, F19, F47 stb.); az elborzasztás (6 db, pl.: F2, F5, F31, F32, F50 stb.); a túlélők fájdalmának bemutatása ( 6 db, pl.: F21, F33, F40, F48 stb.); a bünözés és rendőri beavatkozás ( 2 db, pl.: F16, F69); a fehér túlélők jobb helyzete (F18) és végezetül a kormány tevékenységével kapcsolatos elégedetlenség bemutatásának szándéka (F74).

A kép hatása: A kiváltani kívánt hatást tekintve szintén 9 kódot különböztettem meg. A leggyakoribb a megindítás érzelmének kiváltása volt, 31 esetben találtam ilyen hatású fotót (néhány jellemző elem: F1, F4, F8, F21, F33, F48, F62 stb.); 11 db ijesztő hatású képet találtam (pl.: a vihar érkezése, a mindent elöntő víz - F29, F31, F41, F46 stb.); 9 db megdöbbentő fénykép volt a mintámban (F10, F12, F26, F37 stb.); meglepő módon 6 olyan fotót is találtam, amely a reményteljességet, bizakodást erősíti a befogadóban (pl.: F6, F13, F14, F65 stb.); 5db sokkoló, esetenként undorító elem volt (pl.: F2, F5, F7, F61, F71); 4 fotó a felháborítás céljából 
jött létre (pl.: a fehér lakosság mentése vidáman, vizespalackokkal telik - F16, F18, F20, F69); szintén 4 fotó a nyugalom, megnyugvás érzését keltette (pl.: F25, F47, F51, F57); 2 gúnyos, ironikus képet találtam (F70, F74), és végezetül két olyan fotót, ami a vagány, amerikai macsót mutatja be (F23, F27).

Toposzok: A fényképek által megjelenített toposzokat tekintve 11 kategóriát alkottam. A leggyakoribb toposz (18 képpel) a veszteség volt. Ezekre példa: F3, F10, F22, F33, F38 stb. A második legnépszerübb kategória a szenvedés volt, 14 elemmel, pl.: F1, F9, F20, F26, F39, F40 stb. A következő a reménység toposza volt, 12 elemmel, pl.: F6, F14, F19, F44, F51 stb. Ezután a rémület toposza következett, 7 elemmel (pl.: F4, F29, F50 stb.), majd a halál, 6 elemmel (pl.: F5, F31, F32, F66 stb.) és a küzdelem 5-tel (pl.: F28, F43, F45 stb.). Az agresszió (pl.: F2), a nyugalom (pl.: F18) és a hősiesség (pl.: F15) kategóriák mindegyikébe három fotó tartozott, a sort pedig a pusztítás (pl.: F36) és irónia (pl.: F74) zárta 2-2 elemmel.

\section{A Bataclan színház elleni terrortámadás}

2015. november 13-án este, robbanószerekkel és géppisztolyokkal felfegyverkezett dzsihadista terroristák előre megtervezett támadássorozatot követtek el Párizs különbözö pontjain. 21 óra 16 perckor három helyen robbantás és hat helyen lövöldözés történt, a számos báron és éttermen kívül többek között a kb. 81.000 féröhelyes Stade de France stadionnál (20 minutes [2015. 11. 14.]), a legtöbb halálos áldozatot azonban a Bataclan színház elleni merénylet követelte, amelynek koncerttermében több, mint 1500 fö hallgatta az Eagles of Death Metal amerikai zenekar koncertjét (Origo [2016. 11. 13.]). 21 óra 40 perckor három fegyveres érkezett a Bataclan elé, akik közül ketten a föbejárat felé indultak. Itt fejbelötték a biztonsági őröket, majd a koncertterembe belépve tüzet nyitottak a szórakozó tömegre. A mészárlás 10 perce zajlott, amikor egy biztonsági őr megnyitotta a vészkijáratot a menekülni próbáló emberek számára, ott azonban a harmadik terrorista fogadta öket, aki szintén tüzet nyitott rájuk, majd csatlakozott a bent lévő másik két merénylőhöz. Számos túlélő több, mint három órán keresztül bujkált a földön fekvő holttestek között.20 perccel a támadás kezdete után két, kézifegyverrel ellátott rendőr érkezett a helyszínre a színházban túszul ejtettek segítségére, a kommandósok azonban 
csak éjfél után rohamozták meg az épületet, ahol a két terroristát alig két percen belül hatástalanították: az egyiket lelőtték, a másik felrobbantotta magát.

Utólag a túlélők arról számoltak be, hogy a terroristák hosszas beszédet is tartottak a túszul ejtetteknek, amelyben elmondták, hogy az Iszlám Állam nevében és Francois Hollande elnök miatt történik mindez, akinek kormánya részt vesz az ellenük szerveződött, 2014 augusztusa óta élesben müködő nyugati koalícióban (Origo [2018. 01. 02.]). A merénylök a túszokhoz francia, egymás között arab nyelven beszéltek (Origo [2016. 11. 13.]).

A Bataclanban összesen 89-en haltak meg, 99-en pedig súlyosan megsebesültek (Origo [2016. 11. 13.]).A támadást vélhetően Ahmed és Mohammed Almuhamed, Görögországon keresztül érkező szíriai migráns, illetve a 29 éves francia állampolgár, Omar Ismaël Mostefai követte el (Dailymail [2015. 11. 15.]).

\subsection{A Bataclan színház elleni terrortámadás 3P alapú esetelemzése}

\section{Produktum:}

Előtér: A Bataclan elleni terrortámadást ábrázoló 75 fotóból 62 előterében jelentek meg alakok, ebböl csupán 8 képen látható egyedüli emberábrázolás (néhány jellemző képet kiemelve: F18, F21, F37, F41, F62 stb.), amely - a Katrina hurrikán ábrázolásával szemben - arra enged következtetni, hogy a fényképek készítői nem annyira az egyedüli megküzdés, magárahagyatottság érzését igyekezett erősíteni a befogadóban, mint inkább a kollektív veszteség és fájdalom érzetét. Négy kép esetében a fókuszként tekinthető alakok nem a fénykép előterében, hanem a hátterében voltak láthatóak (ezek az F20, F31, F61, F69). A legtöbb képen több alak, helyenként egész tömeg látható. François Hollande akkori francia elnök 2 fotón látható (F40, F74). Ahol nem emberek voltak a középpontban, ott vagy virágcsokrokat és gyertyákat ábrázoló fényképek (p1.: F20, F31, F66, F72), vagy véres lábnyomokat és cipök (F7, F44), vagy a terrorcselekménnyel kapcsolatos világszintü összefogás szimbólumai, pl.: francia színekbe öltözött a Tower Bridge (F25), a Sydney Operaház (F26) és a riói Megváltó Krisztus Szobra (F27) látható. Egy képen utcafront található az előtérben (F29), egy másikon golyó ütötte lyukat láthatunk, végezetül két olyan fényképet találtam, amelyek elöterében Pray for Paris és egy másik, békéért imádkozó felirat található. 
Nem: 9 fénykép elő-vagy hátterében jelent meg csak női alak (F20, F5, F19, F21, F39, F40, F45, F48, F74) 35-ön csak férfiak (néhány jellemzö képet kiemelve: F1, F13, F33, F54, F71 stb.) és 21 olyan fotót találtam, amelynek az előterében, vagy hátterében vegyesen voltak jelen férfiak és nők (néhány jellemző képet kiemelve: F8, F13, F23, F38, F59, F70 stb.).

Kor: A legtöbb fotón (37 db, néhány jellemzö képet kiemelve: F4, F97, F21, F28, F37, F59, F70 stb.) fiatal emberek láthatók, 15-ön középkorúak (F20, F40, F65, F74 stb.), 6-on pedig vegyes korosztályok láthatók (néhány jellemző képet kiemelve: F23, F30, F50, F5269). Kisbaba és idős ember nem látható rajtuk.

Nem fehér/Fehér: A Bataclan elleni terrorcselekmény képeit illetően nem a fekete/fehér, hanem a nem fehér/fehér kódot alkalmaztam, itt ugyan is nem annyira feketék, mint inkább az arab, török, vagy egyéb kultúrához tartozó egyének jelentek meg inkább. Mégis, a fényképek közül 58 fehér bőrü embert/embereket mutatott be (néhány jellemzö képet kiemelve: F1, F9, F18, F37, F52, F68 stb.), 2-n nem fehér emberek láthatók (F24, F50 stb.), illetve 3 db vegyes képet találtam (F14, F17, F70).

Öltözet: Öltözetüket tekintve leggyakrabban hétköznapi viselet volt látható (41 db fotó; néhány jellemzö elemet kiemelve: F4, F8, F23, F24, F32, F41, F50, F55 stb.), azonban - mivel a fotók többsége a túlélők mentését mutatja be - számos átfedést tapasztaltam a hétköznapi, rendőri és mentős öltözetet illetően. Rendőri öltözet 20 fotón (F9, F15, F17, F29, F30, F43, F54 stb.), mentős pedig 16-on tünt fel (F1, F3, F6, F16, F29, F36). Több kép félmeztelen embereket ábrázolt (4 db, pl.: F3, F14, F38, F49), de alufólia dzsekis (4 db, F39, F50, F51, F60), vizsgálati egyenruhás (F53, F65), és 2 elegáns viseletet bemutató fotót találtam, mind a kettő Hollande elnököt ábrázolta (F40, F74).

Háttér: Ahogyan azt már az előtér elemzésekor említettem, bizonyos esetekben nem az előtérben, hanem a háttérben jelentek meg alakok (36 kép, pl.: F20, F31, F35, F41, F61, F69 stb.). 21 esetben házakat, utcákat mutattak be a képek (pl.: F2, F4, F15, F65 stb.). 13 esetben láthatunk fényeket a háttérben (pl.: F9, F11, F17, F30, F34, F48 stb.), 7 fotón ikonikus épületeket (pl.: Notre Dame székesegyház, a Bataclan színház, épülete, a 66. La Carillon bár stb., pl.: F43, F57, F62, F66), 2 esetben pedig az égboltot, hegyeket láthatjuk (F25, F27). 
Mise en scène: A keretbe helyezést tekintve a legtöbb esetben (66 fotó; néhány jellemző elemet kiemelve: F3, F4, F11, F14, F26, F38, F47, F56, F62, F68, F71, F75 stb.) a fókusz a kép közepén volt, 5 esetben (F20, F30, F31, F55, F59) a baloldalán, 3 esetben (F18, F58, F62) a jobboldalán, 1 fotó (F23) esetében pedig az egész kép hangsúlyos volt. A kép alsó, felső részeit nem hangsúlyozta egyetlen fotó sem.

Halottábrázolás: A 75 fotóból 11 db-on jelent meg a halál motívuma, ezek közül 4-en implicit módon: az egyik fotó (F44) pl. egy elhagyott pár cipőt, mögötte véres pulóvert mutat be; az F72 és F73 kódú fotón a kép fókuszában vér van, körülötte apró gyertyák, virágcsokrokkal. A többi képen azonban kifejezetten explicit, minden részletet bemutató halálábrázolást láthatunk. Az F8as képen pl. a Bataclan színház belső koncertterme tárul elénk, a padlóján több tucat halottal, körülöttük minden csupa vér.

\section{Procedúra:}

A kamera nézőpontja: A kiválasztott képek közül a szemből készült fotókból találtam a legtöbbet, összesen 48 db-ot (pl.: F3, F12, F21, F30, F44, F53, F67 stb.). 11 fotó készült felülről (néhány jellemző elemet kiemelve: F1, F7, F23, F28, F71, F74, F75 stb.), és 10 fotó készült alulról, (p1.: F15, F19, F24, F43, F54, F58 stb.), ezek általában a rendöröket, mentősöket, vagy pl. a riói Megváltó Krisztus szobrát mutatják be, ezzel utalva az ő nagyságukra, hősiességükre, segítő erejükre. A felülről készített fotók jellemzően a halottakat, egymáson fekvő áldozatokat mutatják be, de a Párizs terein egybegyült nagy létszámú, gyászoló tömegeket is felülröl fotózták. Hátsó és oldalsó kameraállásból 3-3 fotó készült, ezekre pl. F42, F45, F55 és F46, F56, F57.

Mozdulatok: A mozdulatok kód 9 kép esetében nem volt értelmezhető. A maradék fényképből 28-on aktív, küzdelemmel teli, mozgalmas akciókat láthatunk: a mentősök rohanva harcolnak a sebesültek életeért, a túlélök telefonon hívják szeretteiket, barátaikat, a rendőrök szintén mobilon intézkednek, szervezik a mentést (pl.: F1, F3, F6, F14, F35, F46, F49, F71 stb.). 16 kép a túlélők és szeretteik gyászát írja le, a legtöbb képen gyertyagyújtást, kitörő sírást és virágcsokrok földre helyezését láthatjuk (p1.: F12, F19, F31, F41, F56, F63, F74, stb.). 15 fotón mozdulatlan alakok láthatók: alakok, akik tanácstalanul állnak, akik egy helyben imádkoznak, akik a 
sérültjeik/halottaik mellett hitetlenkedve, a távolba nézve várnak (pl.: F5, F8, F17, F23, F40, F55, F69 stb.). 4 fotón ölelkező embereket láthatunk (F11, F30, F32, F39), 3 fotón pedig agresszióból eredő, erőszakos mozgás figyelhető meg: F15, F37, F70.

Mimika: A mimika kód 30 kép esetében nem volt értelmezhető. 19 fotón a komolyság, kilátástalanság jellemezte az emberek arckifejezését (néhány jellemző elemet kiemelve: F14, F17, F33, F38 stb.). 16 fotó szenvedésröl, elgyötörtségröl, fájdalomról árulkodik: F3, F10, F13, F20, F39 F56, F67 stb. Aggodalom, rémület 9 fotón látható: F4, F16, F40 stb. Az emberek arcán elszántságot és lelkierőt egyetlen fotó sem mutatott be, illetve reményteljességet is csak egyetlen képen láthatunk (F24).

A kamera proxemikája: Ahogyan azt a Katrina hurrikán elemzésekor említettem, a kamera proxemikája kód arra utalt, hogy közeli, vagy távoli képről van-e szó az adott fotó esetében. Távolról készült fényképböl volt több, összesen 56 db, ezek közül néhányat kiemelve: F2, F10, F12, F13, F18, F22, F34, F42, F47, F63, F71 stb. Közeli képböl 19 db készült, ezek közül példaként említeném az: F7, F24, F44, F25, F33, F56, F74 stb. képeket.

Effektek: A Bataclan színház elleni merényletről készült fényképekröl általánosan elmondható, hogy homályosak, rossz minőségüek, hiszen jelentős részüket az utca embere készítette mobiltelefonjával. Éppen ezért meglehetösen kiegyenlített lett az éles és homályos képek aránya, (éles: 22 db - ezekre pl.: F3, F14, F35, F64, F74, stb., homályos: 21 db - ezekre pl.: F1, F2, F23, F38, F41, F47, F60, stb. 28 esetben találtam olyan fotót, ahol az előtér volt éles, a háttér homályos. Néhány jellemző elem: F6, F21, F46, F55, F59, F67 stb. 4 esetben volt a háttér éles és az előtér homályos: F20, F31, F49 és F68.

Időfaktor: A Katrina hurrikán elemzésekor létrehozott 4 kategória itt is érvényes volt. Hasonlóképpen az előző elemzéshez, itt is lassú időt ábrázoló fotóból találtam a legtöbbet, 37 dbot (ezekre példa: F4, F11, F17, F25, F30, F54, F62, F69 stb.). Aktív mozgást, cselekvést ábrázoló fotóból 25 db volt (pl.: F10, F15, F33, F45, F65, F71 stb.). Az elmúlást ábrázoló fotókból összesen 12-t találtam. Ezek: F1, F2, F8, f35, F57, F66, F75 stb. Kontrasztot ábrázoló fotóból csupán egyet találtam: F58. 


\section{Processzus:}

A kép szándéka: A Katrina hurrikánról készült fotók szándékának elemzésekor 9 kódot különítettem el. Ezek közül a „fehér túlélők jobb helyzete” jelen elemzés esetében nem értelmezhető, illetve érdekes módon, a Katrina 7 reménységgel kapcsolatos fotójával szemben itt egyetlen egy kép sem utalt optimizmusra, reményre. A pusztítás kódhoz 5 képet rendeltem (pl.: F53, F57, F58 stb.); az életben maradásért való küzdelemhez 13 fotót, pl.: F3, F14, F28, F48, F51 stb.); az elborzasztáshoz 11 képet, pl.: F2, F4, F8, F44, F74 stb.); a túlélök fájdalmának bemutatásához 27 fotót, pl.: F9, F12, F21, F39, F52, F67 stb.); a bünözés és rendöri beavatkozáshoz 11 képet, pl.: F15, F29, F43, F70); és végezetül a kormány tevékenységével kapcsolatos elégedetlenség bemutatásának szándékához 2 fényképet találtam: F40, F74. Jelen elemzéskor plusz egy kategória is megjelent, ez pedig a nemzeti és nemzetközi összetartás kategóriája, 6 fényképpel, pl.: F22, F23, F24, F26 stb.

A kép hatása: A kiváltani kívánt hatást tekintve a Katrina hurrikán esetelemzésekor 9 kódot különböztettem meg, jelen vizsgálatban azonban 5 kódot elimináltam, ezekre példát nem találtam. Ilyen volt a meglehetősen téma specifikus „amerikai macsó” kategória, illetve a gúny, a megdöbbentés, illetve a remény és a nyugalom/megnyugvás kategóriája. A legtöbb kép megindító hatást keltett, 34 ilyen fotót találtam, pl.: F11, F19, F24, F31, F46, F56, F74 stb.; utána az ijesztő kategória következett 22 képpel, pl.: F37, F53, F54, F60, F75 stb. Sokkoló/undorító fotóból 18 db-ot találtam, pl.: F3, F5, F28, F38, F49, F72 stb., végezetül felháborító hatású képbőll 1-re találtam példát: F68.

Toposzok: A fényképek által megjelenített toposzokat tekintve a Katrina hurrikán elemzésekor 11 kategóriát alkottam. Jelen vizsgálatban ennél kevesebb, 9 kategóriát különítettem el. A leggyakoribb toposz (20 képpel) a szenvedés volt. Ezekre példa: F3, F10, F12, F35, F46, F64 stb. A második legnépszerübb kategória a veszteség volt, 12 elemmel, pl.: F11, F19, F44, F58, F66, F74 stb. A következő a halál toposza volt, 11 elemmel, pl.: F1, F4, F8, F48, F72 stb. Ezután az összetartás toposza következett, 10 elemmel (pl.: F22, F25, F39 stb.), majd a küzdelem, 9 elemmel (pl.: F14, F33, F38, F65 stb.), valamint a tétlenség és agresszió 4-4 elemmel (pl.: F17, F29 és F15, F70 stb.). A rémület toposza 3 fényképen jelent meg (pl.: F40, F51, F54), a 
hősiesség kategóriába pedig pusztán 2 képet soroltam: F9, F45. A reménység, pusztítás és irónia toposza nem jelent meg a bataclani terrortámadás képein.

\section{Konklúziók}

Azon hipotézisem, amely szerint a természeti katasztrófának minősülő Katrina hurrikán és az ember által okozott katasztrófának tekintendő Bataclan Színház ellen elkövetett terrorakció vizuális megjelenítése számos eltérést mutat, vizsgálatom alapján beigazolódott. A produktum, azaz eredményközpontú megközelítést illetően elmondható, hogy a bataclani merénylet esetében 20 fotóval több ábrázolt embereket az előterében, míg a Katrina hurrikán fotóin gyakran természeti képeket, roncsokat, elöntött otthonokat láthatunk. Észrevehetö, hogy a Katrina hurrikánról készült képek föként középkorú, fekete férfiakat mutatnak be, míg a bataclani lövöldözés kapcsán zömében fiatalokat és csak fehér embereket mutatnak, amely különösen érdekes egy ennyire multikulturális, etnikailag sokszínủ fơvárosban. (A 75 fotóból összesen kettőn jelent meg nem fehér ember.) Ez pedig arra utalhat, hogy a terrorcselekményt a sajtó az európai, fehér ember elleni vérengzésként láttatta, feltételezhető azonban, hogy az áldozatok között nem csak fehér börü, helybéli franciák voltak. Öltözéküket tekintve mind a két esetben hétköznapi ruházatból láthatunk a legtöbbet, azonban megfigyelhető, hogy a bataclani merénylet képein jóval több (összesen 38) alkalommal találtunk rendöri, mentős vagy katonai öltözéket, szemben a Katrina hurrikán képeivel, ahol csak 13 esetben láthatunk hivatalos személyeket mentés, segítségnyújtás közben, ezáltal a Bataclanról készült képek sokkal nagyobb állami bevonódást és összefogást mutatnak be, szemben a Katrina képeivel, ahol gyakran fordulnak elő emberek, apró csónakban ülve, magukra hagyva a végtelen vízen. A képek hátterét tekintve a Katrina hurrikánról készült fotókon 14 esetben láthatók további alakok, mentés, míg a bataclani lövöldözés képein 36 esetben találunk alakokat. Míg az előbbiben inkább a vihar okozta természeti károk kerülnek a háttérbe, együttesen mutatva azt az emberek küzdelmével és szenvedésével, addig az utóbbi az emberi sokaság félelmét, rettegését, sőt, egyfajta tömeges káoszt mutat be. A kép keretbe helyezését (mise en scène) tekintve a vihar ábrázolásakor 38 esetben, a mészárlást illetően 66 alkalommal került a hangsúly a kép közepére, sokkal fókuszáltabb, direktebb és esetlegesen erőszakosabb ábrázolást generálva ezzel. Halottábrázolását tekintve a Katrina hurrikán képein 75 fotóból mindössze 6 db-on jelent meg a halál motívuma. Ezek közül 2-n pusztán implicit módon: az egyik fotón (F35) egy temető 
előterében apró fehér zászlókkal emlékeznek meg a hurrikán áldozatairól, míg a másik fotón (F55) csak egy saját kezüleg készített, gyermek méretü sírt láthatunk, lepedővel fedve és téglákkal rögzítve. A mészárlást tekintve 75 fotóból 11 db-on jelent meg a halál motívuma, amelyből 4 implicit módon utalt rá, pl.: az F72 és F73 kódú fotón a kép középpontjában vértócsa látszik, körülötte apró gyertyák, virágcsokrokkal. A többi, 7 db képen azonban kifejezetten explicit, minden részletet bemutatóhalálábrázolást láthatunk, különösen jó példa erre a Bataclan koncerttermét ábrázoló fotó, ahol több tucat holttestet láthatunk, vérbe fagyva (F8).

A procedúra, vagy eljárásalapú megközelítésben elöször a kamera nézőpontját vizsgáltam. Míg a Katrina hurrikánról készült sajtófotók zöme szemböl és felülről készült, szinte teljesen kiegyenlített arányban (35, illetve $31 \mathrm{db}$ ), addig a bataclani mészárlás képei közül 48 készült szemből, míg felülről készült fotóból csak 11-et találtam, ismét kiemelve ezzel az ember által okozott katasztrófa fókuszáltabb, direktebb ábrázolási módját. Mind a két katasztrófa esetében találhatók alulról készült fotók is, ezek többnyire a rendőrök, mentő szolgálatok, vagy szimbolikus alakok (pl.: Jefferson Davis volt amerikai elnök szobra vagy a riói Megváltó Krisztus szobra) nagyságát, mindenható erejét mutatják be. Az alakok mozdulatait tekintve a vihar fotóit illetően 25 képen valamely aktív mozgást figyelhetünk meg, 19-en passzív, lemondó, reménytelen alakokat látunk, míg 3 fotó gyengéd, 3 pedig agresszív mozdulatokat mutat be. E kód 25 kép esetében értelmezhetetlen volt. A lövöldözés képeit illetően pusztán 9 fotó esetében nem volt értelmezhető a mozgás kódja. Eltérések mutatkoznak továbbá az aktív mozgást (pl.: mentés, menekülés, gyász kifejezése koszorúzással, gyertyagyújtással) illetően is, jelen vizsgálatban ugyanis 44 aktív cselekvést, és csak 15 passzív, tétlen mozgást ábrázoló képet találtam. A többi képen agresszió, rendőri rajtaütés látható. Az alakok mimikáját tekintve mind a két esetben a komorság, kilátástalanság arckifejezése volt a leggyakoribb, közvetlenül utána pedig a szenvedés és rémület kategóriája következett. Különbség volt azonban, hogy a Katrina hurrikán ábrázolása esetében két olyan kategóriát is elkülönítettem, ami a bataclani lövöldözés kapcsán egyáltalán nem mutatkozott meg, ezek pedig az elszánt (4 fotóval), és a mosolygó, optimista arckifejezések (6 fotóval) csoportjai. Az emberi gonoszságból származó vérontás képein tehát nincsen jele a reményteljességnek, egyfelől az események elkerülhetősége, másfelől pedig az akció hirtelensége miatt. Fontos tényező továbbá az is, hogy egy természeti katasztrófa esetében nincsenek közvetlen felelösök, így a beletörödés, elfogadás könnyebben alakul ki, mint 
egy terrortámadást illetően. A következő a kamera proxemikája kód volt, amely arra utalt, hogy közeli, vagy távoli képről van-e szó az adott fotó esetén. A Katrina hurrikán ábrázolásakor szinte ugyanannyi távoli kép készült, mint közeli (40-35 arányban távoliból volt több), míg a lövöldözés esetében ugyanez az arány valamivel nagyobb volt, (56-19 arányban távoli fotóból volt több), mivel ezek a fotók könnyedén tudták ábrázolni a vihar/támadás teljes kontextusát, minden történését és veszteségeit. Az effektek kód kapcsán - mivel valós események fényképeit elemeztem - speciális effektekkel, filterekkel, képi szerkesztettséggel nem találkoztam, így tehát azt vizsgáltam, hogy a fénykép készítője élesen vagy homályosan láttatja-e a kép előterét vagy hátterét, meghatározva ezzel a kép fókuszát. A Katrina hurrikán képeiről általánosan elmondható, hogy jó minőségüek és professzionálisak, leggyakrabban pedig előterük és hátterük is éles (57 kép). Ezzel szemben a bataclani mészárlás képein jól látszik, hogy jelentős részüket az utca embere készítette mobiltelefonjával, mivel homályos, rossz minőségü képből csaknem ugyanannyi készült, mint élesböl (21-22 arányban élesből volt több). Mind a két katasztrófa esetében tipikus effekt volt az éles előtér, homályos háttér beállítás, amely láttatja ugyan az eseményeket, mégis nyilvánvalóan kijelöli a kép hangsúlyos elemét. Mind a két katasztrófa elemzésekor észrevehető volt, hogy minden képen megjelenik valahogy az idő jelensége, méghozzá meglehetősen hasonló módon. A Katrina és a Bataclan esetében is a lassú, passzív időt bemutató fényképből volt a legtöbb (az előbbiben a segítségre való várakozás, utóbbiban pedig a felismerés, megtörtség ábrázolásában), majd az aktív, mentést vagy menekülést bemutató képek következtek. Az elmúlás képeiből a lövöldözés esetében csaknem kétszer annyi volt látható.

Végezetül a processzus, vagy folyamat irányú megközelítésben három kódot különítettem el, ezek pedig: a kép szándéka, a kép hatása, valamint a kép által megjelenített toposz. A képek szándékát tekintve számos kategóriát elkülönítettem, ezek közül a Katrina hurrikán sajtófotóinak esetében a leggyakoribbak a hurrikán okozta pusztítás, az életben maradásért való küzdelem, illetve a reménység bemutatásának szándéka volt. Ez utóbbi - ahogyan arra már korábban utaltam - semmilyen formában nem jelent meg a bataclani merénylet kapcsán. Itt ugyanis a túlélők és szeretteik fájdalma, az életben maradásért való közdelem, illetve az elborzasztás, sokkolás szándéka volt felfedezhető. Hatásukat tekintve számos hasonlóságot véltem felfedezni. Ugyan a kódok többsége (pl.: amerikai macsó, reményteljesség, irónia/gunyorosság, vagy a megnyugvás kategóriája) egyáltalán nem jelent meg a bataclani terrortámadás képein, 
leggyakoribb hatásaik azonban viszonylag egybecsengőek. Mind a két katasztrófa esetében a megindító hatású képekből volt a legtöbb. Ezután az ijesztő kategória következett, végezetül a Katrina hurrikán esetében a megdöbbentő, a Bataclan esetében az undorító/sokkoló hatású fényképekből volt a legtöbb. Elemzésem végéhez érve, a toposzokat illetően a vihar tükrében a veszteség, szenvedés, illetve a reménység volt a három legnépszerübb kategória, míg a merényletet illetően a szenvedés, a veszteség, valamint a halál toposzai. Említésre méltó azonban - mivel csak egy képpel marad el a halál toposzától - az összetartozás toposza 10 elemmel, amely a hurrikán esetében egyáltalán nem jelenik meg.

Összességében elmondható tehát, hogy a természeti és ember által okozott katasztrófák médiareprezentációját tekintve megfigyelhetők bizonyos általános jellemzők, mégis, alapvető eltérések mutatkoznak az ábrázolás céljait, eszközeit, a kiváltott érzelmeket és hatást, valamint a képviselt toposzokat illetően. A média egészen máshogy mutatja be azt, amikor az anyatermészet írja felül az emberi élet és a mindennapok megszokott menetét, és azt, amikor az ember, a megtestesült Gonosz fordul önmaga ellen. A hurrikán prezentálásában a vihar által okozott pusztításon, az emberi, természeti és materiális veszteségek megindító bemutatásán és a folyamatos küzdelmen kívül megjelentek a szebb jövővel kapcsolatos reményteljesség, újjászületés és megváltás toposzai is, míg a terrortámadás esetében a kaotikus körülmények okozta rettegés, szenvedés és halál megjelenítése dominált, gyakran sokkoló, megrendítő elemekkel. A két eset vizsgálatán keresztuil továbbá nyilvánvalóvá vált az is, hogy a 3P (produktum, procedúra, processzus) vizuális retorikai elemzési módszer alkalmas bármely adott esetet egészében, holisztikusan vizsgálni, nem pusztán a képek elrendezési logikáját, hanem létrejöttük eljárásmódját és az általuk kiváltott hatást is tekintetbe véve.

\section{0. Összefoglalás}

A képek és a képjelentés csupán a 20. századra vált kiemelkedően fontos szemponttá mind a retorika-, mind pedig a filozófiatudomány számára. Nyíri Kristóf ennek okát egyértelműen a kommunikációtechnológia fejlődésében látja. Az 1400-as évek előtt Európa nem ismerte a képsokszorosítás technikáját, s csak a fotográfia feltalálásával vált lehetségessé a valóság pontos képi megjelenítése, addig ugyanis a filozófia és a retorika szavakkal, szavakról szólt (Nyíri [2011] p.5.). Ma - a képi fordulat létrejöttének korszakában - azonban számos válasz született a 
képfilozófia és képi retorika alapproblémáira. Jelen értekezés is egyfajta válaszként, magyarázatként jött létre, a vizuális retorikát övező dichotómiával kapcsolatosan. Tanulmányom annak bizonyítékaként íródott, hogy a képek nem csupán másodlagos, kiegészítésre szoruló és váró entitások, hanem az érvelés önálló, alapvető egységei. Meglátásom szerint a vizuális elemek ugyanúgy képesek érvelni, közölni, bírálni, igaz állításokat tenni vagy - ahogy a saigoni kivégzés megjelenítésében is láttuk - hamis valóságot mutatni, és valakinek a sorsát egy életre megpecsételni. Ennek alátámasztásaként disszertációm öt hipotézist állított fel és válaszolt meg, illetve egy új, átfogó elméleti keretet dolgozott ki a képek elemzésének módszereként. Jelen tanulmány egy természeti, és egy ember által okozott katasztrófa - a Katrina hurrikán és a Bataclan Színház elleni merénylet - sajtófotóinak vizsgálatát mutatta be, a megalkotott elemzési módszer azonban bármilyen kép esetében alkalmazható.

Első feltevésem arra irányult, hogy a vizuális retorika önálló diszciplináris terület. E feltevés egyfelöl a vizuális retorika történetéből indult ki, amely azt mutatja, hogy a vizuális retorika a „létezik ilyen” és nem a „létezik” kategóriáját jeleníti meg; másfelől a vizuális retorika megtévesztő elnevezésének problematikáját vette alapul, amely szubdiszciplináris, alárendelt pozícióba kényszeríti a nyelvi kóddal és szabályrendszerrel rendelkező verbális retorika mellett. Pedig - ahogyan azt disszertációmban is kifejtem - a retorika nem pusztán nyelvi szimbólumok összessége, ennek eredményeképpen a retorikai folyamatok dimenziói sem csak a diskurzusokban lelhetők fel. Ott vannak minden olyan térben orientált, nem lineáris, több dimenziós emberi tapasztalatban, amelyek diszkurzív szimbólumokon keresztül nem, a vizualitáson keresztül azonban könnyedén értelmezhetők.

Második állításom a vizuális retorikai érvelés diszciplináris létezésére vonatkozott; tehát arra, hogy diszciplinárisan legitim-e a vizuális retorika mint logikai-kommunikatív folyamat meghatározás, vagy csupán interszekcióként, metszetként fogható fel? Nyíri nyomán a képiség és a látás új világában, a vizuális retorika újjászületéséről beszélünk, míg Aczél a retorikus nyelvet az imagisztikus kifejezéssel azonosítja. A vizuális retorikai érvelés bizonyításaként értekezésemben Foss produktum/artefaktum, illetve processzus/vizuális adatok tudománya típusú retorikai megközelítését mutattam be, amelyben az előbbi egy kontextualitástól független, eredményközpontú megközelítést kínál, melynek fókuszában egy termék, műalkotás, tárgy, egyszóval artefaktum áll; míg az utóbbi a vizuális imágók, adatok elemzésérének folyamatára 
vonatkozik, egyfajta értelmező megközelítést javasolva. A Foss-féle, kétdimenziós paradigmán kívül Ott és Dickinson érzékenyebb és rendszerezőbb hármas szemléletét is bemutattam, amely a vizuális retorikát nyilvános üzenetként, a hétköznapi valóság megalapozójaként, illetve logikaként írja le, átfogó képet adva ezzel a vizuális retorikai érvelést illetően. Ezt követően ismertettem a vizuális retorikai érveléssel kapcsolatos legfontosabb ellenérveket, amelyek szerint a vizuális kommunikáció egyfelől túlságosan önkényes és kétértelmü, másfelől nem tartalmaz igazságértéket/propozíciót, ezáltal nem képes érvelésként ellátni feladatát. Három kép elemzésén keresztül mutattam be, hogy a vizuális retorikai érvelés diszciplinárisan lehetséges, a képek által tett állítások pedig tisztán érthetőek, valamint értelmezhetőek az igaz/hamis dimenziókban.

Harmadik állításom arra vonatkozott, hogy a vizuális retorika kielégíti az érvelés mind három (produktum - procedúra - processzus típusú) minőségét. Értekezésem elején elsőként az argumentáció mint produktum típusú megközelítést fejtettem ki, amely - formális logikai kötődésének köszönhetően - felettébb szabad felfogást kínál: nem foglalkozik azzal, hogy az érvelést ki hozza létre, kinek és milyen célból, pusztán eredményként tekinti az érvelést. A vizuális retorika mint előadásmód/produktum megközelítésben olyan alapfogalmakat tisztáztam, mint a „presence” és „vividness” koncepciói, amelyek szintén eredményként tekintenek a vizuális retorikai érvelésre. Az argumentáció procedúraként való megközelítése arra utal, hogy az argumentációt dinamikák, eljárások, szabályos minták és műveletek müködtetik. Ilyenkor egy bizonyos képi elemet egy másik elem viszonylatában értelmezünk, ezért - az előző szemlélettel ellentétben - nem a mi, hanem a hogyan kérdés kerül a középpontba. Vizuális retorikai értelmezését tekintve a procedurális megközelítés kapcsán a fent említett problematizálásra és a vizuális retorikával kapcsolatos ellenérvekre tértem ki, ezek ugyanis eljárásként tekintenek a retorikai folyamatokra, az önkényesség kérdésére, a propozíciók megalkotására és a képi igazság vagy hazugság létrejöttére. Végezetül, az argumentáció processzusként/interpretációként való megközelítése egyfajta pragmatikus, hatás és szándékalapú felfogást hozott létre, melynek vizuális retorikai vetületét a média tükrében értelmeztem. Olyan fogalmak kifejtésére került sor, mint a médiaüzenetek multidimenzionalitása, az ideológia, interpretáció, identifikáció és nyelv, illetve a képi hazugság kérdése a vizualitásban.

Negyedik hipotézisem arra vonatkozott, hogy a vizuális retorikai érvelés nyelvi transzláció nélkül is lehetséges, amely állítás szorgalmazza egy új paradigma létrejöttét a vizuális 
retorika, azon belül az érvelés területével kapcsolatosan. Jelen hipotézis megválaszolásának érdekében elöször a percepciók fogalomkörét fejtettem ki, amelynek segítségével közelebb kerülhettem az elemi érzékelések és az emberi gondolkodás komplexitásának megértéséhez. Ezt követően Lewis E. Walkup egyik tanulmányában szereplő példáját idéztem, amelyben egy Rubik kockának megfelelő, 3×3-mas, 27 apró kockából álló egységgel kapcsolatos matematikai problémát említ. Walkup példája kiválóan bizonyítja, hogy számos feladat megfejtéséhez nincs szükségünk sem nyelvi fordításra, sem másra, mint a vizuális gondolkodás, kreativitás, találékonyság és képi intelligencia eszközeire.

Végezetül, utolsó hipotézisem a természeti és ember által okozott katasztrófák híreinek vizuális reprezentációjára vonatkozott. Feltételeztem, hogy a két, különböző típusú katasztrófa eltéréseket mutat majd mind a produktum, mind pedig a procedúra és processzus megközelítését tekintve. A kiválasztott 75-75 sajtófotó elemzésekor a három aspektuson belül számos kódot különítettem el. A produktum, azaz eredmény/logikaalapú megközelítésben az előtér, nem, kor, feketék/fehérek, pozitúra/proxemika, öltözet, háttér, valamint a mise en scène kódokat; a procedúra, vagyis eljárás/dialektikaalapú szemlélet alapján a kamera nézőpontja, mozdulatok, mimika, a kamera proxemikája, effektek és időfaktor kódokat; végezetül a processzus, tehát folyamat/retorikaalapú megközelítésben a kép szándékát, hatását, illetve az általa megjelenített toposzok kódját határoztam meg. Vizsgálatom alapján kiderült, hogy az anyatermészeti és emberi gonoszság által okozott katasztrófa vizuális reprezentációja számos eltérést mutat. Míg az előbbi a pusztítás, küzdelem és reménység/megváltás hármasát, addig az utóbbi a rettegés, szenvedés és halál motívumait jeleníti meg.

A fentiek alapján elmondható tehát, hogy a vizuális retorika képes mindarra, amire verbális párja, sőt, számos esetben felülmúlja azt. A képek a racionális és absztrakt gondolkodás alappilléreinek és az információ elsődleges hordozóinak tekintendők, amelyek úgy tudatnak, közölnek és informálnak, és amelyek úgy érvelnek és bizonyítanak, hogy bármely tárgy jelenlévőbbé, élénkebbé válik, mint az írott, vagy kimondott szó által. Jelen disszertáció is annak bizonyítéka, hogy a szavak dominanciájának évszázadai után, a képi fordulat és a képek hatalmának korszaka megkérdőjelezhetetlenül és visszavonhatatlanul elérkezett. 


\section{Bibliográfia}

Aczél, Petra; Logikusan dialektikus, retorikusan logikus: az érvelés „átmeneti” értelmezései. In: A. Jászó Anna - Aczél Petra (szerk.); [2006]: A prózaritmus és a szónoki beszéd. Budapest: Trezor Kiadó. (pp. 79-89). ISBN:0349000918442

Aczél, Petra; [2008]: A manipuláció manipulációja: a médiahír. Képmás. http://aczelpetra.hu/A\%20manipul\%C3\%A1ci\%C3\%B3\%20manipul\%C3\%A1ci\%C3\%B 3ja.pdf

Aczél, Petra; [2009]: Új Retorika. Közélet, Kommunikáció, Kampány. Kalligram: Pozsony. ISBN: 9788081010538

Aczél, Petra; [2012]: Médiaretorika. Magyar Mercurius: Budapest. ISBN: 978-963-9872-15-8

Aczél, Petra; Szóerő. A Retorika Kutatás Új Irányairól. http://www.communicatio.hu/mktt/dokumentumok/konferenciak/2005/poszterek/aczelpet ra.htm

Aczél, Petra - Adamik, Tamás; [2010]: Enthüméma. In: Adamik, Tamás és A. Jászó, Anna (szerk.) [2010]: Retorikai lexikon. Kalligram: Pozsony.

Adamik, Tamás - A. Jászó, Anna - Aczél, Petra; [2005]: Retorika. Osiris Kiadó: Budapest. ISBN: 9789633894668

Adamik, Tamás; [2002]: A példa és az enthüméma Arisztotelész szerint. In: A. Jászó Anna - L. Aczél Petra (szerk.): A klasszikus retorikai bizonyítás. Trezor Kiadó: Budapest. (pp. 15-27).

Adamik, Tamás (főszerk.); [2010]: Retorikai lexikon. Kalligram: Pozsony. ISBN: 978-80-8101344-7 
Aiello, M. - Pratt-Hartmann, Ian - Van Benthem, Johan (szerk.); [2007]: Handbook of Spatial Logics. Springer Science: Dordrecht. ISBN 978-1-4020-5586-7

Allan, Stuart (szerk.); [2010]: News Culture. Third edition. Open University Press, McGraw-Hill Education: Glasgow. ISBN-13: 978-0335235650; ISBN-10: 0335235654

Alexander, David [2000]: Confronting Catastrophie. New Perspectives on Natural Disasters. Oxford University Press: USA. ISBN-10: 1580532683; ISBN-13: 978-0195216967

Al-Musawi, Muhsin J.; Arabic rhetoric. In: Thomas O. Sloane; (szerk.); [2006]: Encyclopedia of Rhetoric. (C) Oxford University Press: Oxford. Encyclopedia of Rhetoric: (e-reference edition). 16 February 2007. DOI: 10.1093/acref/9780195125955.001.0001; ISBN13: 9780195125955ISBN10

Andén-Papadopoulos, Kari; [2008]: The Abu Ghraib torture photographs: News frames, visual culture, and the power of images. Journalism: Volume: 9 issue: 1. SAGE Publications. (pp. 5-30). DOI: 10.1177/1464884907084337

Anderson, Alan Ross - Belnap, Noel D.; [1992]: Entailment: The Logic of Relevance and Necessity. Volume II. Prinston University Press: Princeton, N. J. (pp. 142-267). ISBN-13: 978-0691071923; ISBN-10: 0691071926

Andsager, Julie L. - White, H. Allen; [2007]: Self Versus Others: Media, Messages, and the Third-Person Effect. Lawrence Erlbaum Associates: Mahwah, New Jersey, London. ISBN13:978-1-135-59893-8

Andok, Mónika; [2003]: A hír mint szövegtípus. Iskolakultúra. (pp. 68-76). http://epa.oszk.hu/00000/00011/00076/pdf/iskolakultura_EPA00011_2003_11_068076.pdf 
Andok, Mónika; [2013]: A hírek története. L’Harmattan Kiadó: Budapest. ISBN: 9789632366258

Angelusz, Róbert; [2003]: Amíg Hírekként Megjelennek... Az Eseményektől a Hírekig. Jel-Kép. 3. Szám. (pp. 3-24).

Aristotle; [1952]: Rhetoric. Translated by W. Rhys Roberts. Encyclopaedia Britannica: UK. (1354a)

Aristotle; [2015]: Prior Analytics. Aeterna Press: UK. ISBN-13: 978-0872200647

Arisztotelész; [1961]: Organon. Szerkesztette: Szalai Sándor; Fordította: Rónafalvi Ödön Szabó Miklós. Akadémia Kiadó: Budapest.

Arisztotelész; [1982]: Rétorika. Fordította: Adamik Tamás. Gondolat: Budapest. (1354al5) \& (1358b) \& (1404b) \& (1378a) \& (1355b). ISBN: 963-281-201-8; ISBN-10: 0872200647

Arnheim, Rudolf; [1954]: Art and Visual Perception: A Psychology of the Creative Eye. University of California Press: Berkeley, Los Angeles and London. ISBN-10: 0520243838; ISBN-13: 978-0520243835

Arnheim, Rudolf; [1980]: A Plea for Visual Thinking. Critical Inquiry, Vol. 6, No. 3. The University of Chicago Press. (pp. 489-497).

Aspeitia, Axel A. B.; [2011]: Words and Images in Argumentation. Springer Science+Business Media B.V. DOI: 10.1007/s.10503-011-9259-y http://www.filosoficas.unam.mx/ abarcelo/PDF/words_and_images.pdf

Bacon, Francis; [1994]: The Advancement of Learning. Second edition. Dodo Press: New York. ISBN-10: 1466348046; ISBN-13: 978-1466348042 
Barilli, Renato; [1989]: Rhetoric. University of Minnesota Press: Minneapolis. ISBN: 978-08166-1729-6

Baran, Stanley - Davis, Dennis; [2008]: Mass Communication Theory: Foundations, Ferment, and Future. Cengage Learning: Boston, MA: Wadsworth. ISBN-13: 978-0-495-89887-0; ISBN-10: 0-495-89887-2

Barkóczi, Janka - Deli, Eszter; [2016]: Egy Hazai Katasztrófahír és a Negatív Hírek Közlésének Stratégiája. A negative hírközlés stratégiája: A vörösiszap-katasztrófa hírelemzése az első napitv-beszámolók alapján. Jel-Kép: 3. Szám.

http://communicatio.hu/jelkep/2016/3/JelKep_2016_3_Barkoczi_Janka__Deli_Eszter.pdf

Báron, György; [2004]: Szédülés: Testkultúra és Pszichológia Alfred Hitchcock filmjeiben. Mesteri Pályamunka. Színház- és Filmmüvészeti Egyetem. DLA Képzés. http://www.filmacademy.hu/uploads/dokumentumtar/barongydolgozat.pdf

Barthes, Roland; [1977]: Image, Music, Text. Fontana Press: London. ISBN: 0006861350

Barthes, Roland; [1997]: A régi retorika. Fordította: Szigeti Csaba. In: Az irodalom elméletei. III. Szerkesztette: Thomka Beáta. Jelenkor: Pécs. (pp. 69-175).

Baudrillard, Jean; [2014]: Screened out. Vers: London, New York. ISBN 1-85984-660-2; ISBN 1-85984-385-9 (pbk)

Becker, H. S.; [1970]: Sociological Work: Method and Substance. Aldine: Chicago, IL.

Benveniste, Émile; [1974]: Problèmes de linguistique générale II.Gallimard: Paris. ISBN: 2070204200 
Berger, Peter L. - Luckmann, Thomas; [1966]: The Social Construction of Reality: A Treatise in the Sociology of Knowledge. Anchor Books: New York. ISBN 0-385058985; 9780385058988

Berkowitz, Daniel A.; [1997]: Social Meanings of News: A Text-Rreader. SAGE Publications, Inc.: USA. ISBN-13: 978-0761900764; ISBN-10: 0761900764

Bermúdez, José Luis; [2003]: Thinking Without Words. Oxford University Press: Oxford.

Birdsell, David S. - Groarke, Leo; [1996]: Toward a Theory of Visual Argument: Argumentation and Advocacy. The Journal of the American Forensic Association. Volume 33, Issue 1.

Bitzer, Lloyd F.; [1959]: Aristotle's enthymeme revisited. Quaterly Journal of Speech 45. (pp. 399-408.)

Bitzer, Lloyd F.; [1968]: The Rhetorical Situation. Philosophy and Rhetoric. Vol. 1. (pp. 1-14).

Blair, J. Anthony - Johnson, Ralph; [1987]: Argumentation as Dialectical. Argumentation. (pp. 41-56). DOI: $10.1007 / \mathrm{BF} 00127118$

Blair, Anthony J. - Johnson, Ralph H.; [1994]: Logical Self-Defense. McGraw-Hill Inc.: USA. ISBN 10: 0070326665; ISBN 13: 9780070326668

Blair, Anthony J.; [1996]: The Possibility and Actuality of Visual Arguments, Argumentation and Advocacy, 38.o. http://www-bcf.usc.edu/ stables/blair.pdf

Blair, Anthony J.; The Rhetoric of Visual Arguments. In: Hill, Charles A. - Helmers, Marguerite; [2008]: Defining Visual Rhetorics. Lawrence Erlbaum Associates: Mahwah, New Jersey \& London. ISBN: 1-4106-0997-9

Blair, Anthony J.; [2012]: Groundwork in the Theory of Argumentation. Selected Papers of J. Anthony Blair. Springer Science: London \& New York. ISBN 978-94-007-2363-4 
Blakesley, David (szerk.); [2003]: The Terministic Screen: Rhetorical Perspectives on Film. Southern Illinois University Press: Carbondale, IL. ISBN-13: 978-0809328291; ISBN-10: 0809328291

Bonds, M. E.; [1991]: Wordless Rhetoric: Musical Form and the Metaphor of the Oration. Harvard University Press: USA. ISBN: 0674956028, 9780674956025

Boorstin, Daniel Joseph; [1992]: The image: A Guide to Pseudo-Events in America. Vintage Books, pp. 11-33. ISBN-10: 0679741801; ISBN-13: 978-0679741800

Borchers, Timothy; [2012]: Persuasion in the Media Age. Third Edition. Waveland Press: Long Grove, Illinois. ISBN-13: 978-1577668268; ISBN-10: 157766826X

Borg, Barbara E.; Rhetoric and art in third-century ad Rome. In: Elsner, Jaś - Meyer, Michel; [2014]: Art and Rhetoric in Roman Culture. Cambridge University Press: UK. ISBN-13: 978-1107000711; ISBN-10: 1107000718

Brinton, Alan; [1981]: Situation in the Theory of Rhetoric. Philosophy and Rhetoric Vol. 14. No. 4. (pp. 234-248).

Brinton, Alan; [1988a]: Appeal to Angry Emotions. Informal Logic. Volume 10. Number 2. X.2. (pp. 77-87).

Bruce, Vicki - Georgeson, Mark A. - Green, Patrick R.; [2014]: Visual Perception: Physiology, Psychology and Ecology. Fourth edition. Psychology Press: USA and Canada. ISBN: 978-1-84169-238-8 (pbk)

Burgin, Victor; [1996]: In/different Spaces: Place and Memory in Visual Culture. University of California Press: Berkeley and Los Angeles. ISBN: 9780520202993 
Burke, Kenneth; [1969]: A Rhetoric of Motives. University of California Press: Berkeley and Los Angeles. ISBN: 0-520-01546-0

Campbell, George; [1963]: The Philosophy of Rhetoric: Landmarks in Rhetoric and Public Address. Southern Illinois University Press: USA.

Campelo, Adriana - Aitken, Robert - Gnoth, Juergen; [2010]: Visual Rhetoric and Ethics in Marketing of Destinations. Journal of Travel Research. SAGE Publications. DOI: $10.1177 / 0047287510362777$

https://www.researchgate.net/profile/Juergen_Gnoth/publication/249701271_Visual_Rhe toric_and_Ethics_in_Marketing_of_Destinations/links/5553ef2408ae6943a86f4001.pdf

Carey, James W.; [2009]: Communication as Culture: Essays on Media and Society. Routledge: New York \& London. ISBN 0-203-92891-1

Carr, Lowell J.; [1932]: Disasters and the Sequence-Pattern Concept of Social Change.American Journal of Sociology. Volume 38. (pp. 207-218.)

Casaregola, Vincent - Farrar, Julie; [2010]: Twentieth-century rhetoric IN Enos, Teresa (szerk.); [2010]: Encyclopedia of Rhetoric and Composition. Communication from Ancient Times to the Information Age. Routledge: New York; London. ISBN 0- 203-85488-8

Cavender, Nancy M. -Kahane, Howard; [2010]/[2006]: Logic and Contemporary Rhetoric: The Use of Reason in Everyday Life. Eleventh Edition. Wadsworth Cengage Learning: USA. ISBN-10: 1-305-965602-8; ISBN-13: 978-1-305-95602-5

Chandler, Daniel; [2007]: Semiotics. The Basics. Routledge: London and New York. ISBN-10: 0415363756; ISBN-13: 978-0415363754

Charlton, Michael; [2008]: Visual Rhetoric: Definitions, Debates, and Disciplinarity. ProQuest: Norman, Oklahoma. 
Conley, Thomas M. [1984]: The Enthymeme in Perspective. Quaterly Journal of Speech 70. (pp. 168-187.)

Connor, Ulla; [1996]: Contrastive Rhetoric: Cross-Cultural Aspects of Second Language Writing. Cambridge University Press: United Kingdom.

Copi, Irving M. - Cohen, Carl - McMahon, Kenneth; [2014]: Introduction to Logic. Fourteenth Edition. Pearson Education Limited: England. ISBN 10: 1-292-02482-8; ISBN 13: 978-1292-02482-0

Corbett, Edward P. J.; [1965]: Classical Rhetoric for the Modern Student. Oxford University Press: New York.

Cornoldi, C. - De Beni, R. - Giusberti, F. - Marruci, F. - Massironi, M. - Mazzoni, G.; The Study of Vividness of Images. In: Logie, Robert H. -Denis, Michel; [1991]: Mental Images in Human Cognition. Elsevier: North Holland. ISBN: 978-0-444-88894-5

CTI Reviews; [2016]: History and Theory of Rhetoric. Fourth Edition. Study Guide. Cram101 Textbook Reviews.

Császi, Lajos; [2002]: A Média Rítusai: A kommunikáció neodurkheimi elmélete. Osiris Kiadó: Budapest.

Császi, Lajos; [2014]: Másságok és azonosságok a médiában az aura elvesztése után - Walter Benjamin aktualitása. Médiakutató. http://www.mediakutato.hu/cikk/2014_01_tavasz/05_massag_azonossag_media.pdf?\#sea $\mathrm{rch}=\mathrm{sz} \% \mathrm{C} 3 \% \mathrm{BCrrealizmus}$

Császi, Lajos; Katasztrófák média-reprezentációja. http://www.c3.hu/ jelkep/JK993/csaszi/csaszi.htm 
Dahlgren, P.; [2009]: The Troubling Evolution of Journalism. In: Zelizer, Barbie (szerk.): The Changing Faces of Journalism. Tabloidization, Technology and Truthiness. Routledge: New York. ISBN-10: 0415778255; ISBN-13: 978-0415778251

De Certeau, Michel; [1988]: The Practice of Everyday Life. University of California Press: Berkeley, CA. ISBN 0-520-23699-8

Deli, Eszter; Media Argumentation: A Novel Approach to Television Rhetoric and the Power of the News. In: Benedek, András -Nyíri, Kristóf (szerk.); [2015]: Beyond Words; Pictures, Parables, Paradoxes. Peter Lang Edition: Frankfurt. ISBN: 97836316638513631663854 365305883 X 9783653058833

Deli, Eszter; Új ecset, új vászon - A modern képkorszak lehetőségei és kihívásai. In: Benedek, András - Nyíri, Kristóf (szerk.); [2016]: Képi Tanulás mühelye Füzetek. Visual Learning Lab Papers: Volume 1. Budapest.

Deli, Eszter - Németh, Gabriella; [2017]: Can pictures argue? The mutual examination of visual propositions and tropes within images. SMART Project. Varna: International Management Institute.

Dynes, Russell R.; [1994]: Disasters, Collective Behavior, and Social Organization. University of Delaware Press: Newark, DE. ISBN-10: 0874134986; ISBN-13: 978-0874134988

Dynes, Russell R. - Rodríguez, H. - Quarantelli, Enrico L. (szerk.); [2007]: Handbook of Disaster Research. Springer Science+Business Media: USA. ISBN: 978-0-387-73952-6

Eemeren, Frans H. van - Grootendorst, Rob; [2004]: A Systematic Theory of Argumentation, The Pragma-dialectical Approach. Cambridge University Press: Cambridge. ISBN: 0$521-83075-3$ 
Eisner, Will; [1985]: Comics and Sequential Art. Expanded Edition. Poorhouse Press: USA.

Enos, Teresa (szerk.); [2010]: Encyclopedia of Rhetoric and Composition. Communication from Ancient Times to the Information Age. Routledge: New York; London. ISBN 0- 203$85488-8$

Faden, Ruth R. - Beauchamp, Tom L.; [1986]: A History and Theory of Informed Consent. Oxford University Press: New York, Oxford. ISBN: 0-19-503686-7

Ferreira-Buckley, Linda; Nineteenth-century Rhetoric. In: Enos, Teresa (szerk.); [2010]: Encyclopedia of Rhetoric and Composition. Communication from Ancient Times to the Information Age. Routledge: New York; London. ISBN 0-203-85488-8

Fidel, Raya; [1984]: The Case Study Method: A Case Study. LISR 6. (pp. 273-288).

Finocchiaro, Maurice A.; The Dialectical Approach to Interpretation and Evaluation. In: Eemeren, Frans H. van et al (szerk.); [1995]: Perspectives and Approaches: Proceedings of the Third International Conference of Argumentation. Volume 1. 183-95. Sic Sat: Holland, Amsterdam.

Fisher, Walter R.; Judging the Quality of Audiences and Narrative Rationality. In: Golden, James L. - Pilotta, Joseph J. (szerk.); [1986]: Practical Reasoning in Human Affaires: Studies in Honor of Chaim Perelman. Reidel Publishing: Holland. ISBN-13: 978-94-0108578-6; DOI: 10.1007/978-94-009-4674-3

Fleming, David; [2005]: Can pictures be arguments? Communication \& Mass Media Complete. Argumentation \& Advocacy. Summer96, Volume 33, Issue 1.

Forgács, Gábor; [2015]: Az érvelés mint lehetséges tudomány. Élet és Tudomány, LXX. Évfolyam. 35. Szám. 
Foss, Sonja K. - Foss, Karen A. - Trapp, Robert; [1985]: Contemporary Perspectives on Rhetoric. Waveland Press: Illinois.

Foss, Sonja K.; Theory of Visual Rhetoric. In: Smith, Ken - Moriarty, Sandra - Barbatsis, Gretchen - Kenney, Keith (szerk.); [2005]: Handbook of Visual Communication: Theory, Methods, and Media. Lawrence Erlbaum Associates Inc.: Mahwah, New Yersey. ISBN13: 978-0805841794; ISBN-10: 0805841792

Foss, Sonja K.; Framing the Study of Visual Rhetoric: Toward a Transformation of Rhetorical Theory Images. In: Hill, Charles A. - Helmers, Marguerite; [2008]: Defining Visual Rhetorics. Lawrence Erlbaum Associates: Mahwah, New Jersey \& London. ISBN: 14106-0997-9

Fraser, Derek; [1992]: Media re-define reality of death. Media Development. Volume 39. Issue 4.

Freeley, Austin J. - Steinberg, David L.; [2009]: Argumentation and Debate: Critical Thinking for Reasoned Decision Making. Twelfth Edition. Cengage Learning: USA. ISBN-13: 978-0-495-09590-3; ISBN-10: 0-495-09590-7

Fuller, Jack; [1997]: News Values: Ideas for an Information Age. University of Chicago Press: Chicago. ISBN: 0226268802, 9780226268804

Gadarian, Shana Kushner; Beyond the Water's Edge: Threat, Partisanship, and the Media. In: Sinclair, Samuel Justin - Antonius, Daniel (szerk.); [2013]: The Political Psychology of Terrorism Fears. Oxford University Press: New York. (pp. 67-85). ISBN: 0199925933; 9780199925933

Galtung, J. -Ruge, M. H.; [1965]: The Structure of Foreign News. Journal of Peace Research. Sage Publications. http://journals.sagepub.com/doi/pdf/10.1177/002234336500200104 
Gáspári, László; [1991]: Retorika. Egységes jegyzet/Kézirat. Nemzeti Tankönyvkiadó: Budapest.

Goel, Vinod - Gold, CA Brian - Kapur, Shitij - Houlel, Sylvain; [1997]: The seats of reason? An imaging study of deductive and inductive reasoning. Cognitive Neuroscience and Neuropsychology, NeuroReport. Volume 8, Issue 5.(pp. 1305-1310). http://www.yorku.ca/vgoel/reprints/goel.neuroreport.97.pdf

Goldberg, Vicki; [1991]: The Power of Photography. Abbeville Press: New York.

Gombrich, E. H.; [1960]: Art and Illusion: A Study in the Psychology of Pictorial Representation. Phaidon Press: London.

Gombrich, E. H.; A Látható Kép. In: Horányi, Özséb (szerk.); [2003]: Kommunikáció I-II. General Press: Budapest. (pp. 92-107). ISBN:9789639459052

Govier, Trudy; [2014]/[2010]: A Practical Study of Argument. Enhanced Seventh Edition. Cengage Learning: USA, Wadsworth. ISBN: 128541523X, 9781285415239

Groarke, Leo; [1996]: Logic, Art and Argument. Informal Logic Volume 18. Numbers 2\&3. Philosophy Publications: University of Windsor Scholarship at UWindsor. (pp. 105129). http://scholar.uwindsor.ca/cgi/viewcontent.cgi?article=1023\&context=philosophypub

Groarke, Leo - Tindale, Christopher W.; [2004]: Good Reasoning Matters! A Constructive Approach to Critical Thinking. Third Edition. Oxford University Press: New York.

Grootendorst, Rob; Some Fallacies about Fallacies. In: Eemeren, Frans H. van - Grootendorst, Rob - Blair, Anthony J. - Willard, Charles A. (szerk.); [1987]: Argumentation: Across the Lines of Disciplines, Studies of Argumentation in Pragmatics and Discourse Analysis. Foris Publications: USA. ISBN: 90-6765-256-3 
Gross, Alan G. - Dearin, Ray D.; [2003]: Chaim Perelman. SUNY Press: USA. ISBN 0791455599,9780791455593

Haddow, George D. - Haddow, Kim S.; [2014]: Disaster Communications in a Changing Media World. Second Edition. Butterworth-Heinemann: USA. ISBN: 9780124078680

Hajek, Alan;[1992]: Trick-arguing: The Times Literary Supplement. September 4.

Hall, Stuart; The Determinations of News Photographs. In: Young, Jock - Cohen, Stanley; [1973]: The Manufacture of News. Sage Publications: London. ISBN: 0803903251, 9780803903258

Hanusch, Folker; [2010]: Representing Death in the News Journalism: Media and Mortality. Palgrave Macmillan: USA. ISBN: 978-0-230-23046-0; DOI: 10.1057/9780230289765

Hill, Charles A. - Helmers, M.; Introduction. In: Hill, Charles A. - Helmers, Marguerite; [2008]: Defining Visual Rhetorics. Lawrence Erlbaum Associates: Mahwah, New Jersey \& London. ISBN: 1-4106-0997-9

Hill, Charles A.; The Psychology of Rhetorical Images. In: Hill, Charles A. - Helmers, Marguerite; [2008]: Defining Visual Rhetorics. Lawrence Erlbaum Associates: Mahwah, New Jersey \& London. ISBN: 1-4106-0997-9

Himmelfarb, Martha; [2010]: The Apocalypse: A Brief History. John Wiley \& Sons Ltd.: Singapore. ISBN: 1405113464,9781405113465

Hogenraad, Robert - McKenzie, Dean P.; [1999]: Replicating Text: The Cumulation of Knowledge in Social Science. Quality and Quantity. Volume 33. (pp. 97-116). DOI: https://doi.org/10.1023/A:1026421730175 
Hoopes, James; [1991]: Peirce on Signs: Writings on Semiotic by Charles Sanders Peirce. UNC Press Books: USA. ISBN: 0807843423, 9780807843420

Horner, Winifred B.; Eighteenth century rhetoric. In: Enos, Teresa (szerk.); [2010]: Encyclopedia of Rhetoric and Composition. Communication from Ancient Times to the Information Age. Routledge: New York; London. ISBN 0-203-85488-8

Houston, J. Brian - Pfefferbaum, Betty - Rosenholtz, Cathy Ellen; [2012]: Disaster News: Framing and Frame Changingin Coverage of Major U.S. Natural Disasters, 2000-2010. Journalism \& Mass Communication Quarterly, SAGE Publication. (pp. 606-623).

Hubbes, László A.; Revolution of the Eye. Teh Spectacular Rhetoric of the Apocalyptic. In: Benedek, András - Veszelszki, Ágnes (szerk.); [2017]: Virtual Reality - Real Visuality. Virtual, Visual, Veridical. Peter Lang Edition: Frankfurt. ISBN: 631731048. DOI: $10.3726 / \mathrm{b} 11592$

Hugo, Victor; [2006]: Les Misérables. Objective Systems Pty. Ltd. ISBN: 142504932X, 9781425049324

Iggers, Jeremy; [1999]: Good News, Bad News: Journalism Ethics and the Public Interest. Westview Press: USA. ISBN-10: 0813329523; ISBN-13: 978-0813329529

Ivor, Yorke; [2013]: Television News. Focal Press: Burlington.

Jasinski, James; [2001]: Sourcebook on Rhetoric: Key Concepts in Contemporary Rhetorical Studies. Sage Publications: London and New Delhi. ISBN: 9780761905042

Johnson, Ralph H.; Why "Visual Arguments" aren't Arguments. Department of Philosophy. University of Windsor. http://web2.uwindsor.ca/courses/philosophy/johnsoa/visargtext.htm 
Jørgensen, Charlotte; [2007]: Interpreting Perelman's Universal Audience: Gross vs. Crosswhite. OSSA Conference Archive. 80.

Jünger, Ernst; [2015]: Die Schere. Sämtliche Werke. Band 16.

Kant, Immanuel; [2004]: Lectures on Logic. Cambridge University Press: UK. ISBN: 9780521546911

Kennedy, George A.; Classical rhetoric. In: Sloane, Thomas O. (szerk.); [2006]: Encyclopedia of Rhetoric. (C) Oxford University Press: Oxford. (e- reference edition). DOI: 10.1093/acref/9780195125955.001.0001; ISBN13: 9780195125955ISBN10

King, Jeffrey C. - Soames, Scott - Speaks, Jeff; [2014]: New Thinking about Propositions. Oxford University Press: UK. ISBN-10: 0199693765; ISBN-13: 978-0199693764

Kjeldsen, Jens E.; [2015]: The Study of Visual and Multimodal Argumentation. Springer Science+Business Media Dordrecht. Argumentation. Volume29. (pp. 115-132). DOI: 10-1007/s10503-015-9348-4

Knabb, Richard D. - Rhome, Jamie R. - Brown, Daniel P.; [2005]: Tropical Cyclone Report: Hurricane Katrina 23 - 30 August 2005. National Hurricane Center.

Kosslyn, Stephen M. - Pomerantz, James R.; [1977]: Imagery, Propositions, and the Form of Internal Representations. The Johns Hopkins University. DOI: 10.1016/00100285(77)90004-4

Krippendorff, Klaus; [2004]: Content Analysis: An Introduction to Its Methodology. SAGE Publication: USA. ISBN: 0-7619-1544-3

Kutrovátz, Gábor; In: Danka, István - Zemplén, Gábor (szerk.); [2018]: Érvelés, Tárgyalás, Meggyőzés, kézirat, kiadás alatt. 
L. Aczél, Petra; [2002]: A Szó Ereje, Érvek a Retorikai Bizonyításban. In: A Régi Új Retorika. A Klasszikus Retorikai Bizonyítás. Trezor Kiadó: Budapest.

L. Aczél Petra [2003]: Erős szavak. A bizonyítás mint a szöveg tulajdonsága. Világosság. (pp. 171-178). http://www.vilagossag.hu/pdf/20040419120505.pdf

Lakoff, George - Johnson, Mark; [1980]: Metaphors We Live By. University of Chicago Press: Chicago. ISBN: 9780226468013

Langer, John; Tabloid Television and News Culture: Access and Representation. In: Cottle, S. (szerk.); [2003]: News, Public Relations and Power. SAGE Publications: London. ISBN13: 978-0761974963; ISBN-10: 0761974962

Lanham, R. A.; [1991]: A Handlist of Rhetorical Terms. University of California Press: Berkeley and Los Angeles. ISBN: 0520076680, 9780520076686

Larson, Charles U.; [2010]: Persuasion: Reception and Responsibility. Twelfth Edition. Cengage Learning: USA, Wadsworth. ISBN-13: 978-0-495-56750-9; ISBN-10: 0-495-56750-7

Le Bon, Gustave; [2001]: The Crowd - A Study of the Popular Mind. Dover Publications, Inc.: USA. ISBN: 9780486419565, 0-486-41956-8

Lindell, Michael K.; [2011]: Disaster Studies. Texas A\&M University. SAGE Publications: USA. DOI: $10.1177 / 205684601111$ http://www.sagepub.net/isa/resources/pdf/disaster\%20studies.pdf

Lippmann, Walter; [2009]: Public Opinion. Transaction Publishers: USA, New Brunswick. ISBN: 1-56000-999-3 
Liu, Shuang - Volčič, Zala - Gallois, Cindy; [2015]: Introducing Intercultural Communication: Global Cultures and Contexts. SAGE Publications: California. ISBN-13: 9781848600362; ISBN-10: 1848600364

Lózsi, Tamás; [2017]: A reklám mint érvelés. Doktori értekezés.

Luhmann, Niklas; [2000]: The Reality of the Mass Media. Polity Press: Cambridge. ISBN 0$8047-4077-1$

Lyyra, Pessi; [2005]: Review of José Luis Bermúdez: Thinking without Words. Oxford University Press Oxford. ISBN 0195159691

Mahon, James Edwin; [2016]: The Definition of Lying and Deception. The Stanford Encyclopedia of Philosophy. https://plato.stanford.edu/entries/lying-definition/\#Bib

Manoff, Robert Karl - Schudson, Michael (szerk.); [1986]: Reading the News: A Pantheon Guide to Popular Culture. Pantheon Books: New York. ISBN-10: 039474649X; ISBN13: 978-0394746494

Margitay, Tihamér; [2007]: Az Érvelés Mestersége. Typotex Kiadó: Budapest. ISBN: 978-9639664-37-1

Margitházi, Beja; Látványos érvek, lehengerlő képek. A vizuális retorika pozicionálása. In: Raátz Judit - Tóthfalussy Zsófia (szerk.); [2010]: A retorika és határtudományai. Trezor Kiadó: Budapest. ISBN: 9789638144362

Martin, Judith N. - Nakamaya, Thomas K.; [2010]: Intercultural Communication in Contexts. Fifth Edition. The McGraw-Hill Companies, Inc.: New York. ISBN: 978-0-07-338512-9

McGregor J.; [2003]: Restating News Values: Contemporary Criteria for Selecting the News. Massey University. 
http://mmc.twitbookclub.org/MMC911/Readings/Week\%2003/Judy\%20McGregor\%20\%20Final\%20Paper.PDF.pdf

McIver, Gillian; [2017]: Art History for Filmmakers: The Art of Visual Storytelling. Bloomsbury Publishing: New York, London. ISBN: 1474246206

McQuail, Denis; [2003]: A Tömegkommunikáció Elmélete. Osiris Kiadó: Budapest. ISBN: 9789633895641

McQuarrie, Edward F. - Phillips, Barbara J.; [2004]: Beyond visual metaphor: A new typology of visual rhetoric in advertising. Marketing Theory. SAGE Publications: Volume 4 (1/2). (pp. 113-136.) DOI: 10.1177/1470593104044089

McQuarrie, Edward F. - Philips, Barbara J.; [2008]: Go figure! New directions in advertising rhetoric. M.E. Sharpe: New York. ISBN-13: 978-0765618016; ISBN-10: 076561801X

Meyer, M.; The Rhetoric of Roman Painting within the History of Culture: A Global Interpretation. In: Elsner, J. - Meyer, M.; [2014]: Art and Rhetoric in Roman Culture. Cambridge University Press: UK. ISBN-13: 978-1107000711; ISBN-10: 1107000718

Minto, William; [2008]: Logic, Inductive and Deductive. Read Books. ISBN: 140868487X, 9781408684870

Mitchell, W. J. T.; [1994]: Picture theory: Essays on Verbal and Visual Representation. University of Chicago Press: Chicago. ISBN: 9780226532325

Mitchell, W. J. T.; [2008]: Showing seeing: a critique of visual culture. Journal of Visual Culture. SAGE Publications: Volume 1 (2). (pp. 165-181). http://citeseerx.ist.psu.edu/viewdoc/download?doi=10.1.1.116.1089\&rep=rep1\&type=pdf 
Moss, Ann; Commonplaces and commonplace books. In: Sloane, Thomas O. (szerk.); [2006]: Encyclopedia of Rhetoric. (C) Oxford University Press: Oxford. (e- reference edition). DOI: 10.1093/acref/9780195125955.001.0001; ISBN13: 9780195125955 ISBN10

Murphy, James J. - Katula, Richard A. - Hoppmann, Michael; [2013]: A Synoptic History of Classical Rhetoric. Fourth Edition. Routledge: New York and London. ISBN-10: 0415532418; ISBN-13: 978-0415532419

Neuendorf, Kimberly A.; [2002]: The Content Analysis Guidebook. Sage Publications: USA. ISBN: 978-0-7619-1977-3

Newton, Julianne; [2013]: The Burden of Visual Truth: The Role of Photojournalism in Mediating Reality. Routledge: New York.

Noth, Winfred; [1995]: SRB Insights: Can Pictures Lie? 6(2) The Semiotic Review of Books: Volume 6(2). (pp. 10-12).

Nyíri, Kristóf; [2000]: A gondolkodás képelmélete. http://www.mek.iif.hu/porta/szint/tarsad/filoz/kepelm/html/index.htm

Nyíri, Kristóf; [2003]: From Texts to Pictures: The New Unity of Science. https://www.academia.edu/4494104/From_Texts_to_Pictures_The_New_Unity_of_Scien ce_2003_

Nyíri, Kristóf; [2011]: Kép és Idő. Magyar Mercurius: Budapest. ISBN: 978-963-9872-13-4

Nyíri, Kristóf; Elfelejtett képelméletek. In: Benedek, András - Nyíri, Kristóf (szerk.); [2016]: Képi Tanulás mühelye Füzetek. Visual Learning Lab Papers: Volume 3. Budapest. 
Nyíri, Kristóf; Pictorial Truth. In: Benedek, András - Veszelszki, Ágnes (szerk.); [2017]: Virtual Reality - Real Visuality. Virtual, Visual, Veridical. Peter Lang Edition: Frankfurt. ISBN: 978-3-631-73104-8

O'Keefe, Daniel J.; The Concepts of Argument and Arguing. In: Cox, J. Robert - Willard, Charles A. (szerk.); [1982]: Advances in Argumentation Theory and Research. Southern Illinois University Press: USA.(pp. 3-23). ISBN-10: 0809310503; ISBN-13: 9780809310500

Olson, Lester C. [2007]: Intellectual and Conceptual Resources for Visual Rhetoric: A Reexamination of Scholarship Since 1950. The Review of Communication. Routledge. DOI: $10.1080 / 15358590701211035$

Ott, Brian L. - Dickinson, Greg; [2009]: Visual Rhetoric and/as Critical Pedagogy. In: Lunsford, Andrea A. - Wilson, Kirt H. - Eberly, Rosa A. (szerk.); [2009]: The SAGE Handbook of Rhetorical Studies. SAGE Publications: USA. ISBN: 1412909503, 9781412909501

Palló, Gábor; [2005]: Enciklopédizmus, diszciplínák, interdiszciplínák, projektek. Világosság. (pp. 19-30).

Patton, John H.; [1979]: Permanence and Change in Rhetorical Theory. Central States Journal. Volume 30. Number 2.

Peirce, Charles S.; In: Hartshorne, Charles - Weiss, Paul - Burks, Arthur W.; [1931-1935]: The Collected Papers of Charles Sanders Peirce. Harvard University Press: Cambridge, MA. https://colorysemiotica.files.wordpress.com/2014/08/peirce-collectedpapers.pdf

Perelman, Chaïm; [1963]: The Idea of Justice and the Problem of Argument. Routledge \& Kegan Paul Limited Broadway House: London. ISBN-10: 0710036108; ISBN-13: 9780710036100 
Perelman, Chaïm - Tyteca, L. Olbrechts; [1971]: The New Rhetoric: A Treatise on Argumentation. Notre Dame University Press: Notre Dame, London. ISBN-10: 0268004463; ISBN-13: 978-0268004460

Perelman, Chaïm; [1979]: The New Rhetoric and the Humanities: Essays on Rhetoric and its Applications. D. Reidel Publishing Company: Holland, USA, England. ISBN: 978-90277-1018-5

Perelman, Chaïm; [1982]: The Realm of Rhetoric. University of Notre Dame Press: Notre Dame and London. ISBN: 978-0-268-01604-3

Perelman, Chaïm; [2018]: A Retorika Birodalma. Retorika és Érvelés. Tinta Könvykiadó: Budapest. Ford.: Major Hajnalka. ISBN: 978-963-409-091-5

Perloff, Richard M.; [2010]: The Dynamics of Persuasion Communication and Attitudes in the 21st Century. Fourth Edition. Routledge: New York. ISBN-10: 0415805686; ISBN-13: 978-0415805681

Petty, Richard E. - Cacioppo, John P.; [1986]: Communication and Persuasion - Central and Peripheral Routes to Attitude Change. Springer-Verlag New York Inc.: New York. DOI: 10.1007/978-1-4612-4964-1; ISBN: 978-1-4612-9378-1

Phillips, Barbara J. - McQuarrie, Edward F.; [2004]: Beyond Visual Metaphor: A New Typology of Visual Rhetoric in Advertising.Marketing Theory 4(1/2). SAGE Publications. (pp. 113-136). DOI: 10.1177/1470593104044089

Pietarinen, Ahti-Veikko; [2006]: Signs of Logic - Peircean Themes on the Philosophy of Language, Games and Communication. Springer: Dordrecht. DOI: 10.1007/1-4020-37295; ISBN: 978-90-481-6944-3 
Pólos László - Rúzsa Imre; [1987]: A Logika Elemei. Tankönyvkiadó: Budapest. ISBN: 963-1801519

Postman, Neil; [1985]: Amusing Ourselves to Death: Public Discourse in the Age of Show Business. Viking: New York.

Potter, W. James; [2016]: Media Literacy. Eights Edition. SAGE Publications: USA. ISBN-10: 1483379329; ISBN-13: 978-1483379326

Pratkanis, Anthony; - Aronson, Elliot; [1992]: A Rábeszélőgép - Élni és Visszaélni a Meggyőzés Mindennapos Mesterségével. W. H. Freeman and Company: New YorkOxford. ISBN: 9789637853036

Prince, Gerald; [1988]: The Disnarrated. Penn State University Press. Volume 22. Number 1. (pp. 1-8).

Quarantelli, E. (szerk.); [1998]: What is a Disaster? Perspectives on the Question. Routledge: London. ISBN-10: 0415178991; ISBN-13: 978-0415178990

Quintilianus, Marcus F.; [2008]: Szónoklattan. Szerkesztő: Adamik Tamás. Kalligram: Pozsony. (Institution oratoria)

Richards, Daniel; [2009]: Visual Argument Reconsidered: 'Objective' Theory and a Classical Rhetorical Approach. TigerPrints. https://tigerprints.clemson.edu/cgi/viewcontent.cgi?article=1569\&context=all_theses

Rivkin, Julie - Ryan, Michael (szerk.); [2004]: Literary Theory: An Anthalogy. Blackwell Publishing Ltd.: UK. ISBN: 978-1-405-10695-5

Reynolds, Amy; [2009]: Terrorism and the Press: An Uneasy Relationship. Peter Lang Publishing Inc.: USA. ISBN: 0820495166, 9780820495163 
Rookes, Paul - Willson, Jane; [2000]: Perception: Theory, Development and Organisation. Psychology Press: London and Philadelphia. ISBN: 0415190940, 9780415190947

Roque, Georges; Political Rhetoric. In: Edda Weigand (szerk.); [2008]: Dialogue and Rhetoric. John Benjamins Publishing Company: Amsterdam/Philadelphia. ISBN: 9789027210197

Roque, Georges; [2009]: What is Visual in Visual Argumentation? OSSA Conference Archive. http://scholar.uwindsor.ca/cgi/viewcontent.cgi?article=1222\&context=ossaarchive

Roque, Georges; [2014]: Should Visual Arguments be Propositional in Order to be Arguments? Springer Science+Business Media Dordrecht. DOI: 10.1007/s10503-014-9341-3

Ryle, Gilbert; [2015]: Dilemmas: The Tarner Lectures 1953. Cambridge University Press: UK. ISBN-10: 1107113628; ISBN-13: 978-1107113626

Saussure, Louis de - Schulz, Peter; [2005]: Manipulation and Ideologies in the Twentieth Century: Discourse, Language, Mind. John Benjamins Publishing: Amsterdam/Philadelphia. ISBN: 9789027227072

Schudson, Michael; [1989]: The sociology of news production. Media Culture Society. SAGE Publications. Volume 11. Issue: 3. (pp. 263-282). http://mcs.sagepub.com/content/11/3/263

Schudson, Michael; [2008]: News and Democratic Society: Past, Present, and Future. The Hedgehog Review. (pp. 7-21). http://www.iasc-culture.org/eNews/2009_10/Schudson_LO.pdf

Scott, Linda M.; [1994]: Images in Advertising: The Need for a Theory of Visual Rhetoric. Journal of Consumer Research. Volume 21. Number 2. Oxford University Press. (pp. 252-273). http://www.jstor.org/stable/2489819?seq=1\#page_scan_tab_contents 
Searle, John R.; A képi reprezentáció. In: Horányi Özséb (szerk.); [2003]: A sokarcú kép: Válogatott tanulmányok a képek logikájáról. Typotex: Budapest. ISBN: 9639326763

Síklaki, István; [1994]: A Meggyőzés Pszichológiája. MTA Pszichológiai Intézete: Budapest. ISBN: 9638471115

Silverblatt, A.; [2007]: Genre Studies in Mass Media: A Handbook. M.E. Sharp Inc.: New York. ISBN-10: 076561670X; ISBN-13: 978-0765616708

Silverstone, R.; [1994]: Television and Everyday Life. Routledge: London, New York. ISBN: 0415016479,9780415016476

Singh, Arun Kumar; [2015]: Social Psychology. PHI Learning Private Ltd.: Delhi. ISBN-10: 812035057X; ISBN-13: 978-8120350571

Sipos Júlia; Képi reprezentáció és hitelesség a 21. századi médiatartalom elöállításában. In: Benedek, András - Nyíri, Kristóf (szerk.); [2016]: Képi Tanulás mühelye Füzetek. Visual Learning Lab Papers: Volume 1. Budapest.

Sloane, Thomas O. - Gregg, R. B. - Nilson, T. R. - Rein, I. J. - Simons, H. W. - Stelzner, H. G. - Zacharias, D. W.; [1971]: Report of the Committee on the Advancement and Refinement of Rhetorical Criticism. In: Bitzer, I. F. - Black, E. (szerk.); The Prospect of Rhetoric: Report of the National Developmental Project, sponsored by Speech Communication Association. Prentice-Hall: Englewood Cliffs, NJ. (pp. 220-227).

Sloane, Thomas O. (szerk.); [2006]: Encyclopedia of Rhetoric.@Oxford University Press: Oxford. (e-reference edition).

DOI: $\quad 10.1093 /$ acref/9780195125955.001.0001; ISBN13: 9780195125955ISBN10

Sontag, Susan; [1965]: The Imagination of Disaster. Commentary/October 65. (pp. 42-48). 
https://americanfuturesiup.files.wordpress.com/2013/01/sontag-the-imagination-ofdisaster.pdf

Sontag, Susan; [1973]: On Photography. Farrar, Straus \& Giroux: New York. ISBN 0-79532699-8

Spence, Charles -Deroy Ophelia; Crossmodal Mental Imagery. In: Lacey, Simon -Lawson, Rebecca; [2013]: Multisensory Imagery. Springer Science \& Business Media: USA. ISBN: 9781461458784

Stepp, Carl Sessions; [2013]: Editing for Today's Newsroom: New Perspectives for a Changing Profession. Routledge: New York. ISBN: 1317785088, 9781317785088

Sulzer, Johann Georg; General Theory of the Fine Arts. In: Baker, N. K. - Christensen, T. (szerk.); [1995]: Aesthetics and the Art of Musical Composition in the German Enlightment, Selected Writings of Johann Georg Sulzer and Heinrich Christoph Koch. Cambridge University Press: USA. ISBN: 0521360358, 9780521360357

Szabó, Zoltán - Szörényi, László; [1997]: Kis magyar retorika. Bevezetés az irodalmi retorikába. Helikon Kiadó: Budapest. ISBN: 9632084608

Szathmári, István (szerk.); [2003]: A Retorikai-stilisztikai Alakzatok Világa. Tinta Könyvkiadó: Budapest. ISBN: 9639372463

Szent, Ágoston; [2012]: A Keresztény Tanításról. Kairosz Kiadó: Budapest. Ford.: Böröczki Tamás.

Tasnádi, Róbert; [2012]: Miről szólnak a képek? Sajtófotó, képjelentés, kontextus a média- és kommunikációkutatás nézőpontjából. Médiakutató. http://www.mediakutato.hu/cikk/2012_04_tel/08_mirol_szolnak_a_kepek/?q=k\%C3\%A9 pek\#k\%C3\%A9pek 
Tátrai, Szilárd; [2004]: A kontextus fogalmáról. Magyar Nyelvőr. 128. évf. 4. sz. (pp. 479-494.)

Tiba, Cintia; [2011]: A Katrina hurrikán. Eötvös Loránd Tudományegyetem. Földrajz- és Földtudományi Intézet. Meteorológiai Tanszék. Szakdolgozat. Budapest.

Tindale, Cristopher W.; [1999]: Acts of Arguing - A Rhetorical Model of Argument. State University of New York Press: USA. ISBN: 0-7914-4387-6

Tindale, Cristopher W.; [2004]: Rhetorical Argumentation: Principles of Theory and Practice. SAGE Publications: USA.

Tóth, Tamás; [2004/1]: Lehetséges-e „jó” retorika? Világosság. (pp. 11-20). http://www.vilagossag.hu/pdf/20040510102958.pdf

Toulmin, Stephen E.; [1958]: The Uses of Argument. First Edition. Cambridge University Press: U.K. ISBN-10: 0521066441; ISBN-13: 978-0521066440

Toulmin, Stephen E. - Rieke, Richard - Janik, Allan; [1984]: An introduction to reasoning. Second Edition. Macmillan Publishing Company: USA. ISBN: 0024211605, 9780024211606

Tseronis, Assimakis; [2013]: Argumentative functions of visuals: Beyond claiming and justifying. Virtues of argumentation: proceedings of the 10th International Conference of the Ontario Society for the Study of Argumentation (OSSA). http://dare.uva.nl/document/2/147415

Tuchman, Gaye; [1976]: Telling Stories, Journal of Communication. DOI: 10.1111/j.14602466.1976.tb01942.x

Uscinski, Joseph E.; [2014]: The People's News: Media, Politics, and the Demands of Capitalism. New York University Press: New York. DOI: 10.1002/polq.12328 
Vico, Giambattista; [1982]: Principles of a New Science Concerning the Common Nature of Nations. (The Third New Science). In: Pompa, Leon; (szerk.\& ford.); [2002]: Vico: Selected Writings. Cambridge University Press: Cambridge. (pp. 159-267). ISBN-10: 0521387264; ISBN-13: 978-0521387262

Vitéz, Ferenc; [2012]: Hazudik-e a sajtófotó? Médiakutató. http://www.mediakutato.hu/cikk/2012_02_nyar/01_hazudik_e_a_sajtofoto

Wacha, Imre; [1994]: A retorika kompetenciái. In: A régi új retorika. Szemimpex Kiadó: Budapest.(pp. 53-88).

Walkup, Lewis E.; [1965]: Creativity in Science through Visualisation. Battelle Memorial Institute. Columbus Laboratories. Southern Universities Press: Columbia, Ohio. Volume: 21. Issue: 1. (pp. 35-41).

Walters, Shannon; [2014]: Rhetorical Touch: Disability, Identification, Haptics. University of South Carolina Press: Columbia, South Carolina. ISBN: 978-1-61117-383-3; ISBN: 978$1-61117-384-0$

Walton, Douglas; [1989]: Informal Logic: A Handbook for Critical Argumentation. Cambridge University Press: Cambridge. ISBN-10: 0521370329; ISBN-13: 978-0521370325

Walton, Douglas; [1995]: A Pragmatic Theory of Fallacy. University of Alabama Press: Tuscaloosa. ISBN: 35487-0380

Walton, Douglas; [2007]: Media Argumentation: Dialectic, Persuasion and Rhetoric. Cambridge University Press: New York. ISBN: 9780511619311

Walton, Douglas; [2008]: The three bases for the enthymeme: A dialogical theory, Journal of Applied Logic. Volume 6. Issue 3. (pp. 361-379). 
http://www.sciencedirect.com/science/article/pii/S1570868307000481

Welch, Kathleen E.; Delivery. In: Sloane, Thomas O. (szerk.); [2006]: Encyclopedia of Rhetoric. (C) Oxford University Press: Oxford. (e-reference edition). DOI: 10.1093/acref/9780195125955.001.0001; ISBN13: 9780195125955ISBN10

Wenzel, Joseph W.; Perspective on Argument. In: Benoit, William L. - Hample, Dale - Benoit, Pamela J. (szerk.); [1992]: Readings in Argumentation. New York. (pp. 121-143).

Wilhelm, Oliver - Engle, Randall W.; [2004]: Handbook of Understanding and Measuring Intelligence. First Edition. SAGE Publications: Thousand Oaks, California. ISBN-10: 0761928871; ISBN-13: 978-0761928874

Wrench, Jason S. (szerk.); [2012]: Casing Organizational Communication. USA: Kendall Hunt Publishing Company. p.viii. ISBN: 978-0-7575-9684-1

Wright, Elizabethada A.; [2005]: Rhetorical Spaces in Memorial Places: The Cemetery as a Rhetorical Memory Place/Space. Rhetoric Society Quarterly. Volume 35. Number 4. Taylor \& Francis Ltd. (pp. 51-81).

Yin, Robert K.; [1984]: Case Study Research: Design and Methods.Sage Publications: Beverly Hills.

Yoos, George E.; [2016]: How Pictures Lie. Rhetoric Society Quarterly. Volume 24. Number 1/2. (pp. 107-119). http://www.jstor.org/stable/pdf/3885962.pdf

Zainal, Zaidah; [2007]: Case study as a research method. Jurnal Kemanusiaan. Volume 9.

Zarefsky, David; [2014]: Rhetorical Perspectives on Argumentation - Selected Essays by David Zarefsky. Springer International Publishing: Switzerland. DOI: 10.1007/978-3-31905485-8; ISBN: 978-3-319-05484-1 
Zelizer, Barbie; [1998]: Remembering to Forget: Holocaust Memory Through the Camera's Eye. University of Chicago Press: Chicago, IL. ISBN: 0-226-97972-5

Zelizer, Barbie; When War is Reduced to a Photograph. In: Allan, Stuart - Zelizer, Barbie (szerk.); [2004]: Reporting War - Journalism in Wartime. Routledge: USA. ISBN-10: 0415339987; ISBN-13: 978-0415339988

Zelizer, Barbie; [2010]: About to Die - How News Images Move the Public. Oxford University Press: New York. ISBN: 0199779988; 9780199779987

\section{Online bibliográfia}

http://journals.sagepub.com/doi/pdf/10.1177/002234336500200104

http://mp.natlib.govt.nz/detail/?id=16137\&l=en

http://theinspirationroom.com/daily/2009/wwf-its-your-turn/

http://www.ng.hu/Termeszet/2008/12/Katrina_a_pusztito_hurrikan

https://courses.helsinki.fi/sites/default/files/course-

material/4482592/22.3_MT2004\%20Phillips.pdf

https://hu.pinterest.com/pin/74942781270592285/

https://ladonnapigra.wordpress.com/2013/01/24/birdsell-and-the-everlasting-visual-argument/

https://mno.hu/kulfold/felgyorsitjak-a-mentest-new-orleansban-561663

https://mno.hu/kulfold/tiz-eve-pusztitott-a-katrina-hurrikan-1301932

https://www.datacenterresearch.org/data-resources/katrina/facts-for-impact/

https://www.huffingtonpost.com/entry/hurricane-katrina-media-new-

orleans_us 55dc999fe4b0a40aa3ac448d 
https://www.nytimes.com/2015/08/23/magazine/why-new-orleans-black-residents-are-stillunder-water-after-katrina.html? r=1

http://www.20min.ch/ro/sports/football/story/Soudain--1-une-des-bombes-explose-en-plein$\underline{\text { match-27994743 }}$

http://www.dailymail.co.uk/news/article-3319244/Video-reveals-horrific-moment-terroristsopened-fire-crowd-music-fans-Bataclan-killing-89-people-shows-musician-hiding-drumsescape.html

http://www.origo.hu/nagyvilag/20161110-igy-tortent-a-parizsi-terrortamadas-evfordulo.html http://www.origo.hu/nagyvilag/20151116-megoldast-hozhat-sziriaban-a-parizsi-tragedia.html http://content.time.com/time/magazine/article/0,9171,988783,00.html http://maimanohaz.blog.hu/2013/11/03/eddie_adams_leghiresebb_fotojanak tortenete http://www.newseum.org/2015/05/12/pulitzer-prize-photography-saigon-execution/ https://www.audubon.org/birds-of-america/booby-gannet

\section{A témában megjelent publikációk}

Deli, Eszter; [2017]: Can Images be Arguments?: The Possibility of Visual Argumentation in the WWF Nature Conservancy Campaigns. In: Benedek András, Veszelszki Ágnes (szerk.) Virtual Reality - Real Visuality: Virtual, Visual, Veridical. 198 p. Frankfurt am Main; New York; Berlin; Bern; Bruxelles; New York; Oxford; Wien: Peter Lang GmbH, Internationaler Verlag der Wissenschaften, 2017. pp. 41-50. (Series Visual Learning; 7.) (ISBN:978-3-631-73104-8)

Deli, Eszter - Németh, Gabriella; [2017]: Using the Arts to Achieve Social Impact: Can pictures argue? The mutual examination of visual propositions and tropes within images. Varna: International Management Institute, p. 15. 
Barkóczi, Janka - Deli, Eszter; [2016]: Egy hazai katasztrófahír és a negatív hírek közlésének stratégiája: a negatív hírközlés stratégiája: a vörösiszap-katasztrófa hírelemzése az első napi tv-beszámolók alapján. JEL-KÉP: Kommunikáció, Közvélemény, Média 5:(3) pp. 1-9.

Sipos, Júlia - Deli, Eszter; [2016]: Képi reprezentáció és hitelesség a 21. századi médiatartalom előállításában. Új ecset, új vászon: A moder képkorszak lehetőségei és kihívásai. Budapest: BME GTK Müszaki pedagógia Tanszék, p. 30. (Képi Tanulás Mühelye Füzetek. Visual learning Lab papers; 1.sz. (2016/1.).) (ISBN:9789633132326)

Deli, Eszter; [2015]: A médiaérvelés új megközelítése és a hírek hatalma. In: Doktoranduszok Országos Szövetsége Tavaszi szél: absztraktkötet 2015. p. 485. Konferencia helye, ideje: Eger, Magyarország, 2015.04.10-2015.04.12. Budapest: Publio Kiadó, p. 126. (ISBN:978963-397-702-6)

Deli, Eszter; [2015]: Media Argumentation: A novel approach to Television Rhetoric and the Power of the News. In: András Benedek, Kristóf Nyíri (szerk.) Beyond Words: Pictures, Parables, Paradoxes. p. 260. Frankfurt: Peter Lang Verlag, 2015. p. 177. (Visual Learning; 5.) (ISBN:978-3-631-66385-1)

Deli, Eszter; [2014]: The Hungarian Argumentation Culture in the Light of Modern Societies ONLINE JOURNAL OF COMMUNICATION AND MEDIA TECHNOLOGIES 4:(2) pp. 109-125.

Deli, Eszter - Németh, Gabriella; [2018]: Money does not talk. The image of money talks. In: Society \& Economy. Kiadatás alatt. 


\section{Függelék}

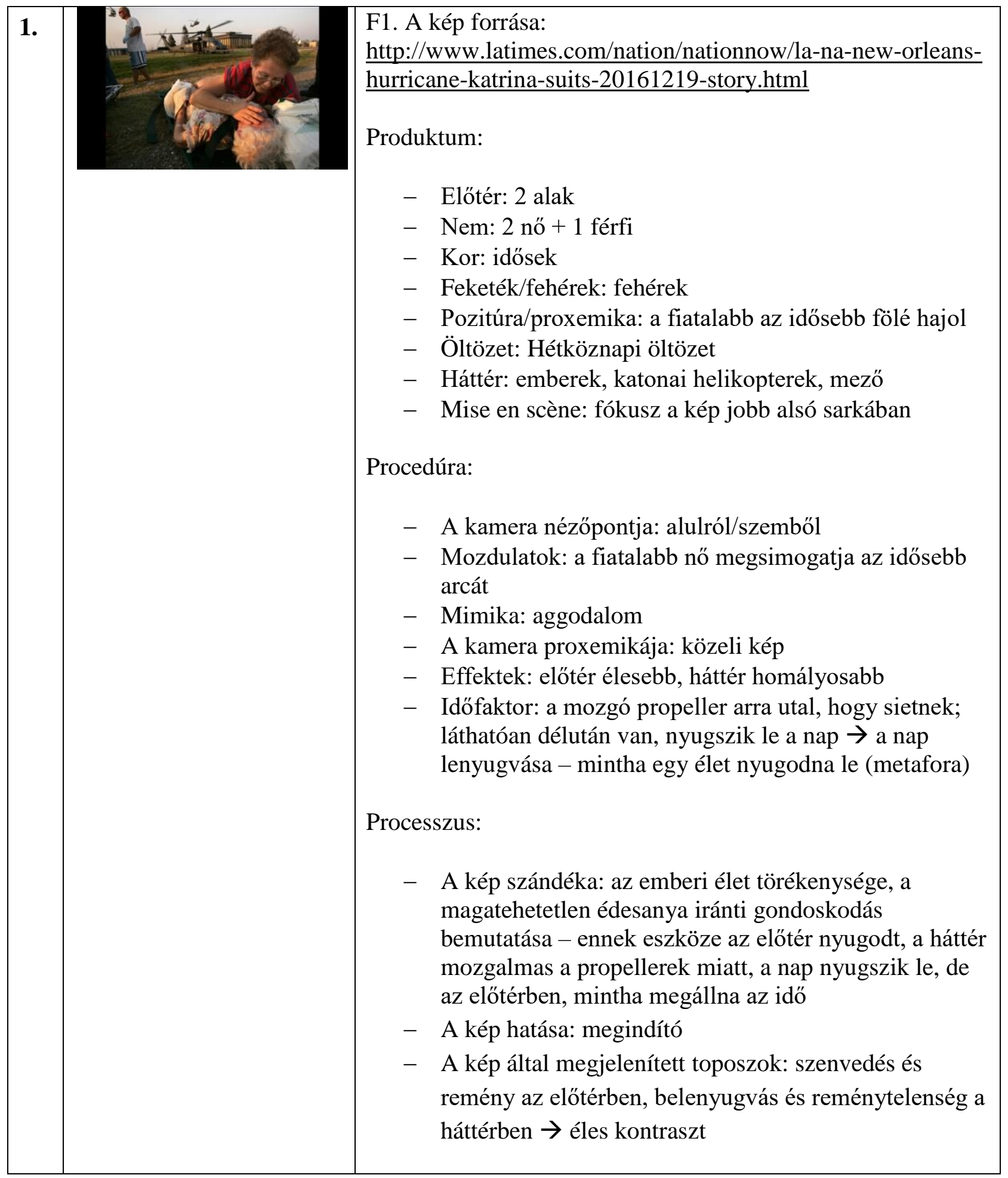




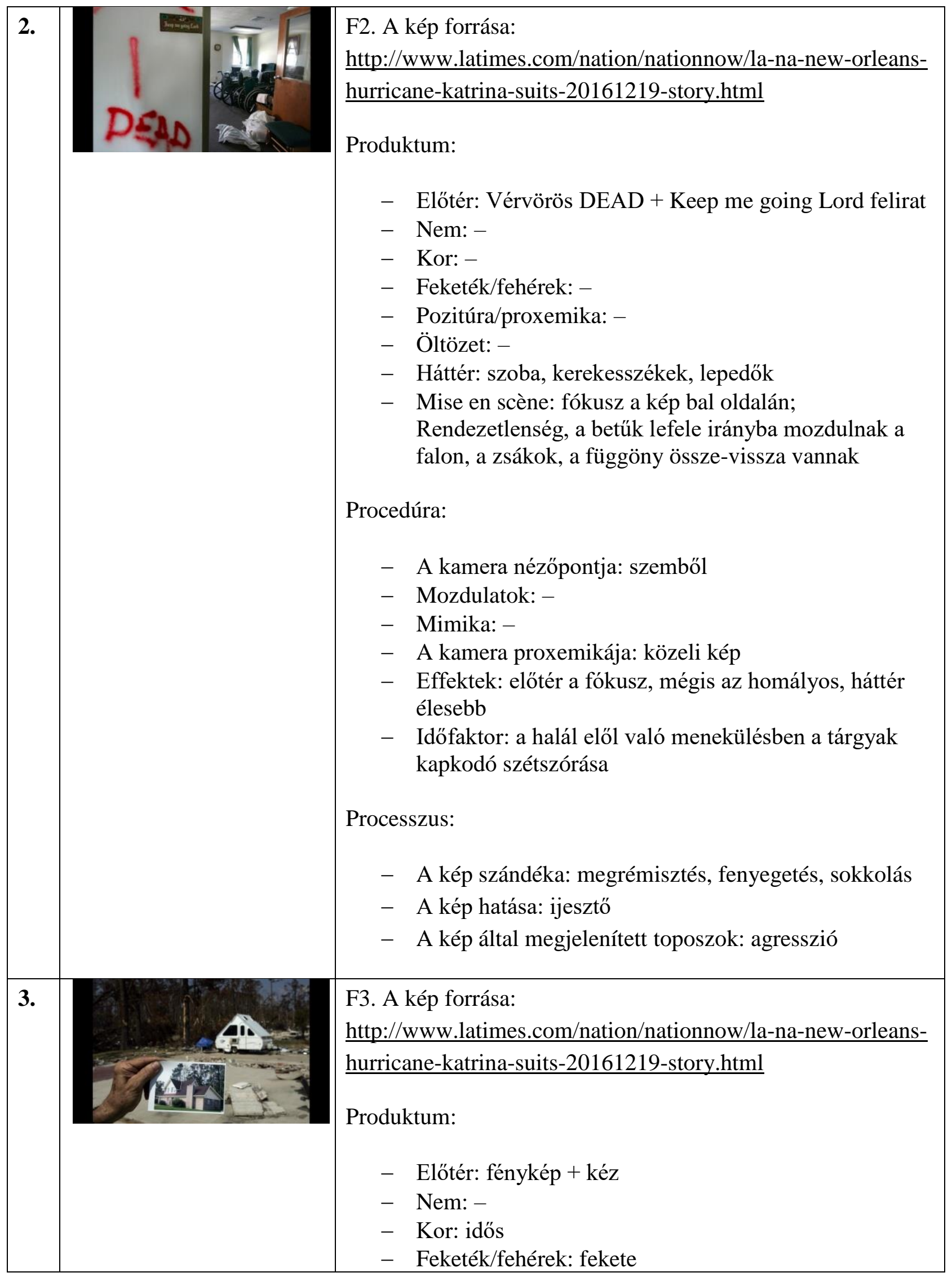




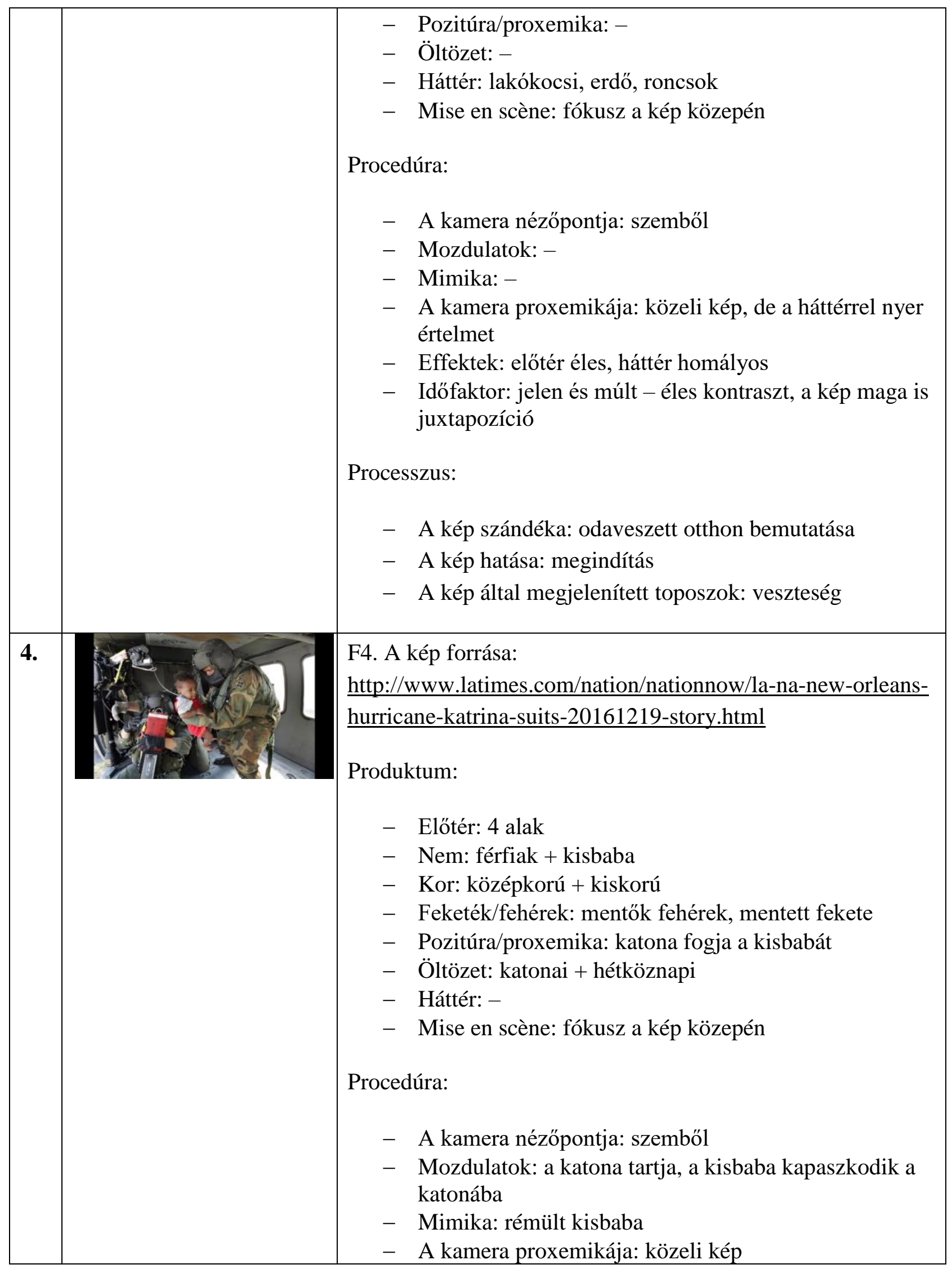




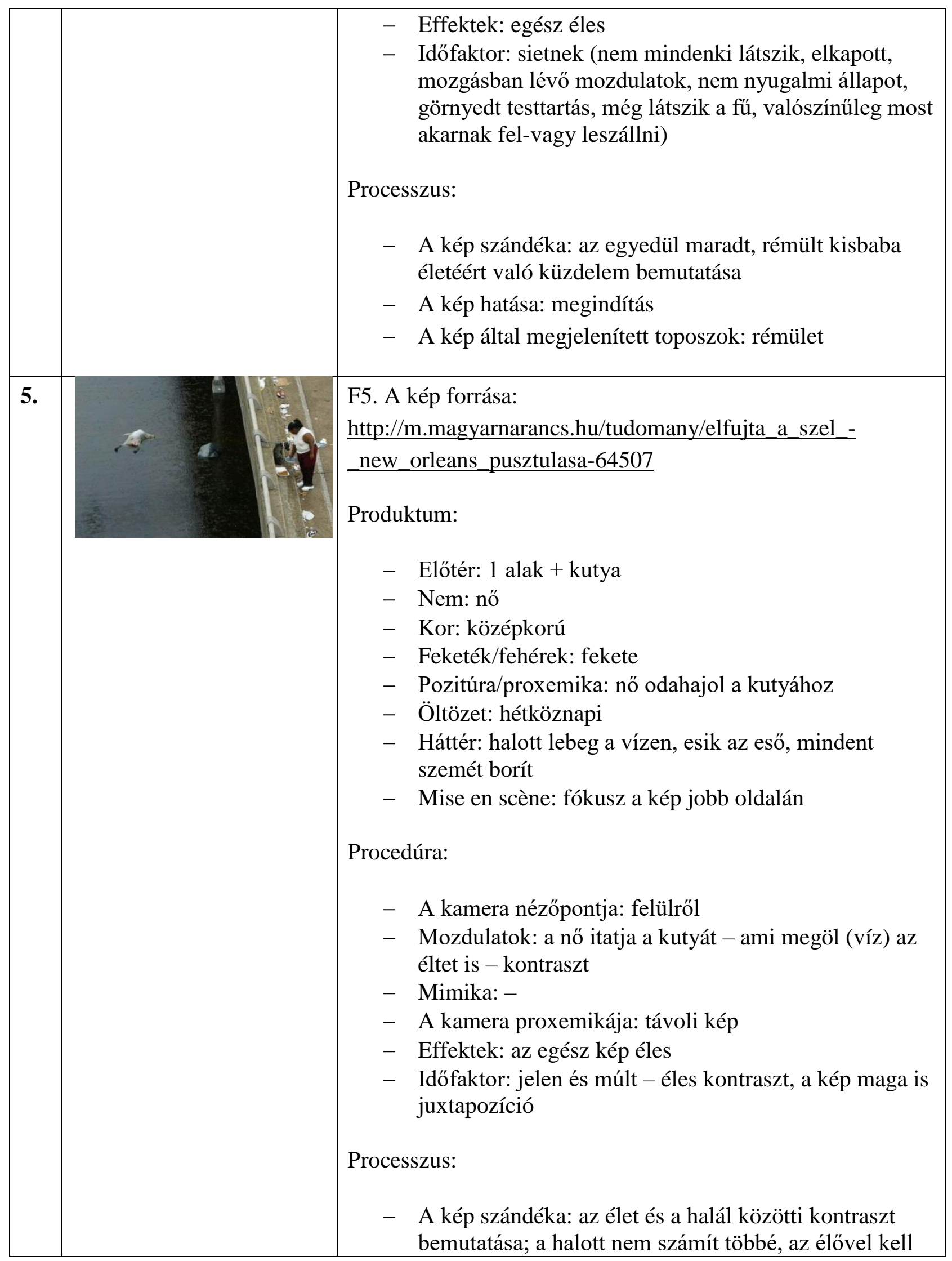




\begin{tabular}{|c|c|c|}
\hline & & $\begin{array}{ll} & \text { foglalkozni } \\
\text { - } & \text { A kép hatása: sokkolás } \\
\text { - } & \text { A kép által megjelenített toposzok: halál }\end{array}$ \\
\hline 6. & 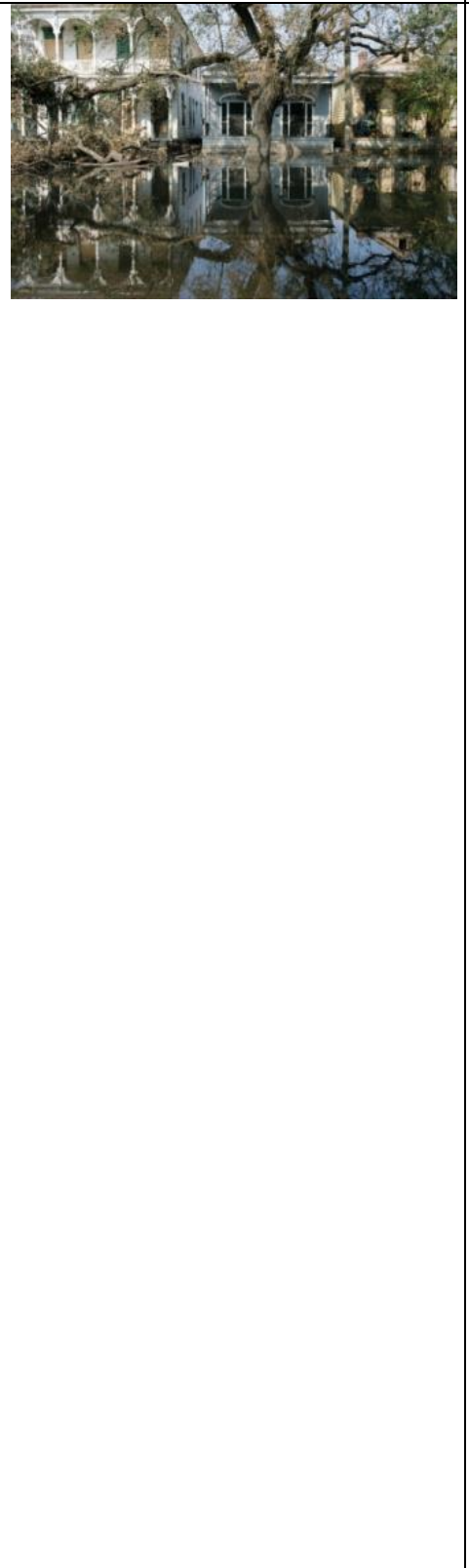 & 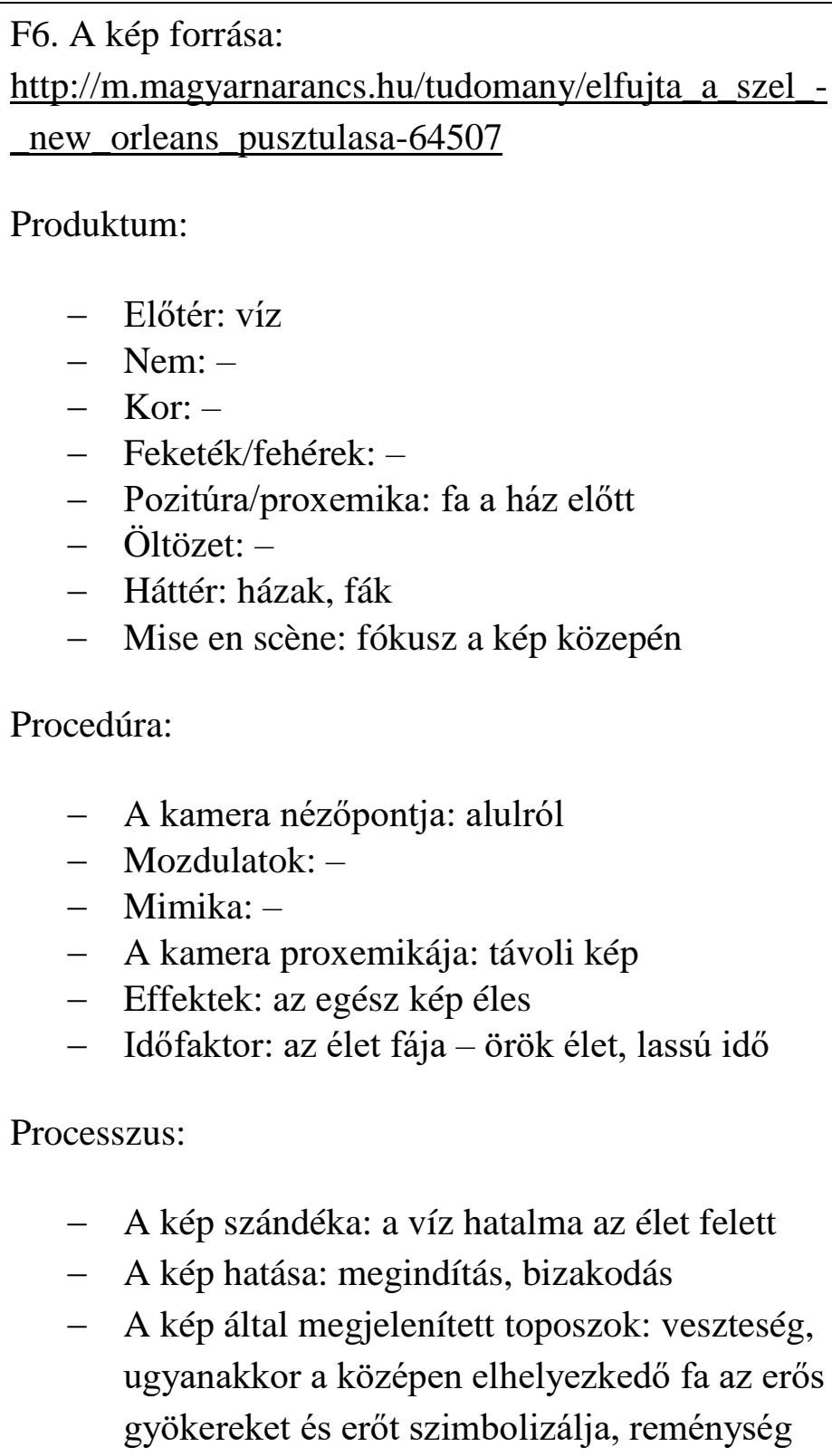 \\
\hline 7. & $0 L^{2}=2$ & $\begin{array}{l}\text { F7. A kép forrása: } \\
\text { http://m.magyarnarancs.hu/tudomany/elfujta_a_szel__- } \\
\text { new_orleans_pusztulasa-64507 } \\
\text { Produktum: } \\
\quad \text { _ Előtér: } 1 \text { alak + víz }\end{array}$ \\
\hline
\end{tabular}




\begin{tabular}{|c|c|}
\hline & $\begin{array}{l}\text { - Nem: férfi } \\
\text { - Kor: fiatal } \\
\text { - Feketék/fehérek: fehér } \\
\text { - Pozitúra/proxemika: - } \\
\text { - Öltözet: félmeztelen } \\
\text { - Háttér: bútor + víz } \\
\text { - } \text { Mise en scène: fókusz a kép bal oldalán } \\
\text { Procedúra: } \\
\text { - A kamera nézöpontja: felülröl } \\
\text { - Mozdulatok: keresztbetett láb, fejet támasztó kar } \\
\text { - Mimika: közömbösség } \\
\text { - A kamera proxemikája: közeli kép } \\
\text { - Effektek: az egész kép éles } \\
\text { - Idöfaktor: áll az idö } \\
\text { Processzus: } \\
\text { - A kép szándéka: a víz hatalma az élet felett } \\
\text { - A kép hatása: megdöbbentés, sokkolás } \\
\text { - A kép által megjelenített toposzok: nyugalom }\end{array}$ \\
\hline 8. & $\begin{array}{l}\text { F8. A kép forrása: } \\
\text { http://www.latimes.com/nation/nationnow/la-na-new-orleans- } \\
\text { hurricane-katrina-suits-20161219-story.html } \\
\text { Produktum: } \\
\text { - Elötér: } 1 \text { alak } \\
\text { - Nem: férfi } \\
\text { - } \text { Kor: fiatal } \\
\text { - } \text { Feketék/fehérek: fekete } \\
\text { - Pozitúra/proxemika: a többi alak körbeveszi a fekvő } \\
\text { - alakot } \\
\text { - } \text { Öltözet: félmeztelér: sok alak, feketék } \\
\text { - Mise en scène: fókusz a kép alsó, középső részén } \\
\text { Procedúra: } \\
\text { - A kamera nézőpontja: felülröl } \\
\text { - Mozdulatok: megtört, öntudatlan fekvés, végtagok } \\
\quad \text { szorosan a testhez húzva }\end{array}$ \\
\hline
\end{tabular}




\begin{tabular}{|c|c|c|}
\hline & & $\begin{array}{l}\text { - Mimika: kifejezéstelen arc } \\
\text { - } \text { A kamera proxemikája: távoli kép } \\
\text { - } \text { Effektek: az egész kép éles } \\
\text { - } \text { Időfaktor: zajlik a mentés, szállítják az embereket, } \\
\text { mégis, mintha állna az idő - éles kontraszt } \\
\text { Processzus: } \\
\text { - A kép szándéka: a víz hatalma az élet felett } \\
\text { - A kép hatása: megdöbbentés, sokkolás } \\
\text { - } \\
\text { A kép által megjelenített toposzok: szenvedés, } \\
\text { ugyanakkor remény is - már a katonai repülőn vannak, } \\
\text { a jelenlévők be vannak szíjazva, elindultak már, vagy } \\
\text { most indulnak egy szárazabb, biztonságosabb helyre }\end{array}$ \\
\hline 9. & 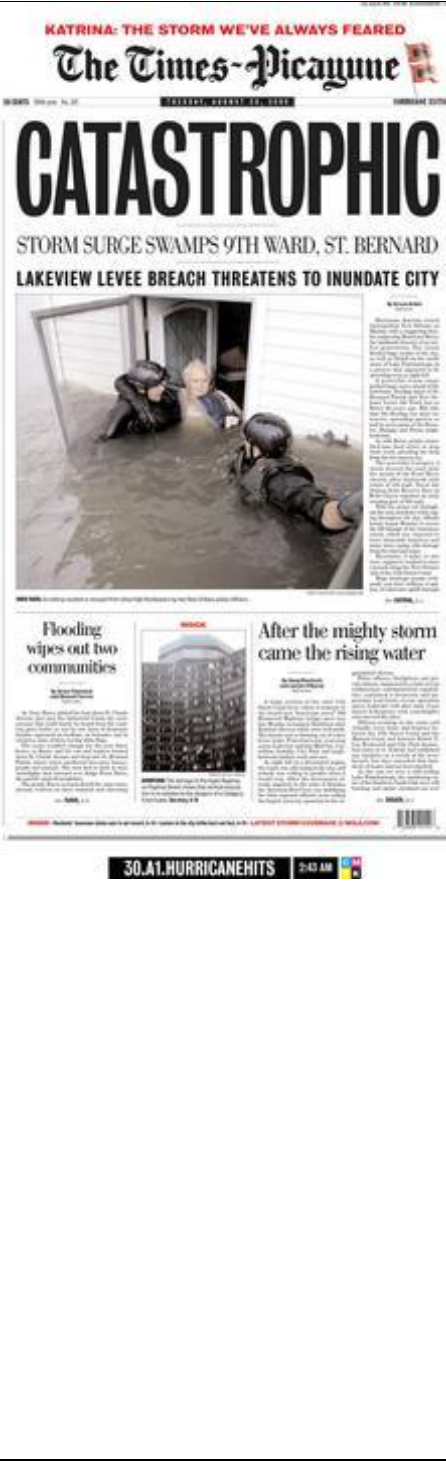 & $\begin{array}{l}\text { F9. A kép forrása: https://en.wikipedia.org/wiki/The_Times- } \\
\text { Picayune\#/media/File:Times-Picayune_Katrina_083008.jpg } \\
\text { Produktum: } \\
\text { - Elötér: } 3 \text { alak + víz } \\
\text { - Nem: } 2 \text { férfi + 1 nő } \\
\text { - Kor: fiatalok + idős } \\
\text { - Feketék/fehérek: fehér } \\
\text { - Pozitúra/proxemika: két szorosan egymás melletti és } \\
\text { - } \text { Öltözet: katonai + hétköznapi } \\
\text { - Háttér: ház + ajtó } \\
\text { - Mise en scène: fókusz a kép közepén } \\
\text { Procedúra: } \\
\text { - A kamera nézőpontja: felülről } \\
\text { - Mozdulatok: az idős nő az egyik katonába } \\
\text { - } \text { kapaszkodik } \\
\text { - Aimika: komorság } \\
\text { - Effektek: - } \\
\text { - Időfaktor: lassú, óvatos mentés } \\
\text { Processzus: } \\
\text { - A kép szándéka: a mentőalakulat erőfeszítéseinek, } \\
\text { áldozatkészségének és a tehetetlen idős nő mentésének }\end{array}$ \\
\hline
\end{tabular}




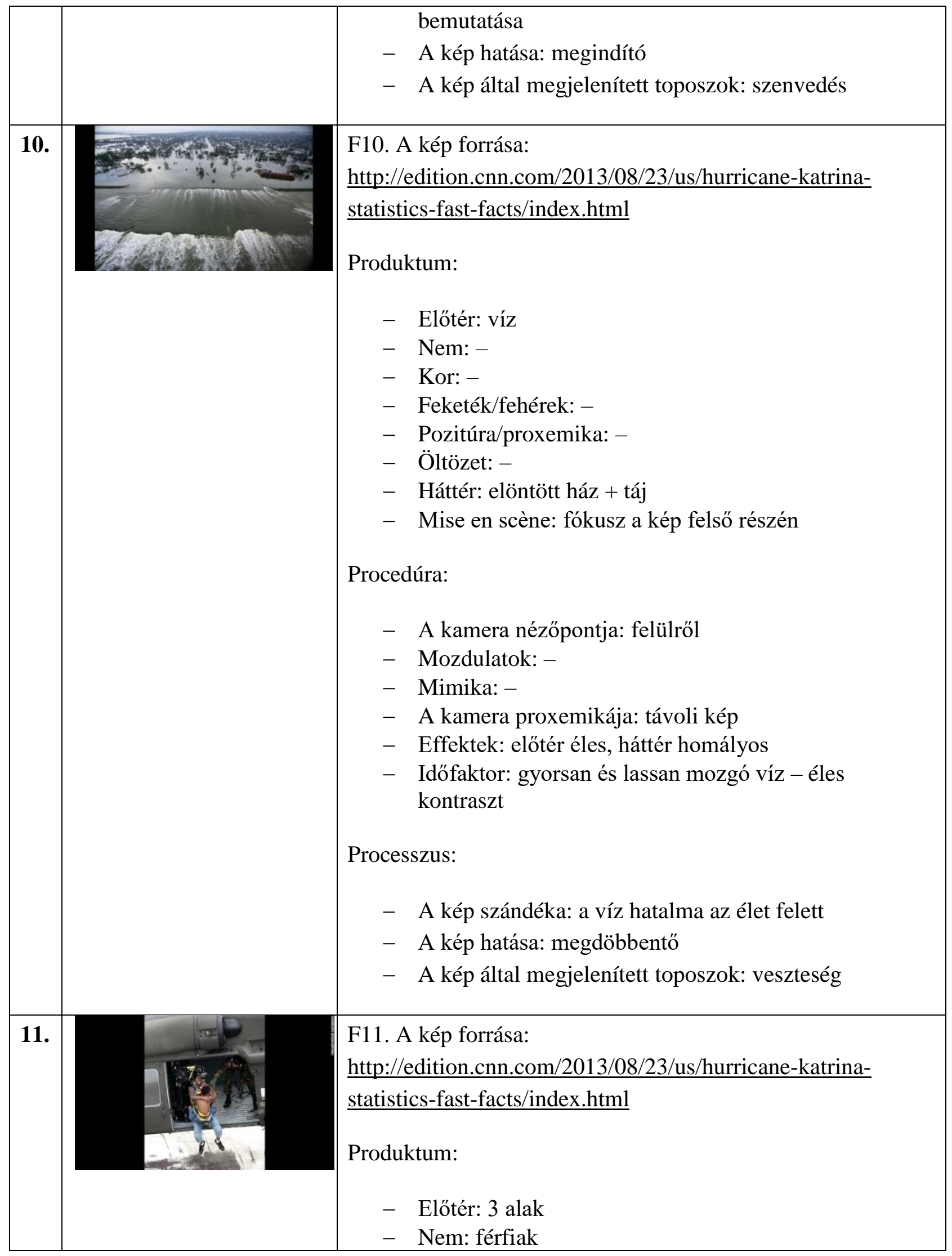




\begin{tabular}{|c|c|c|}
\hline & & 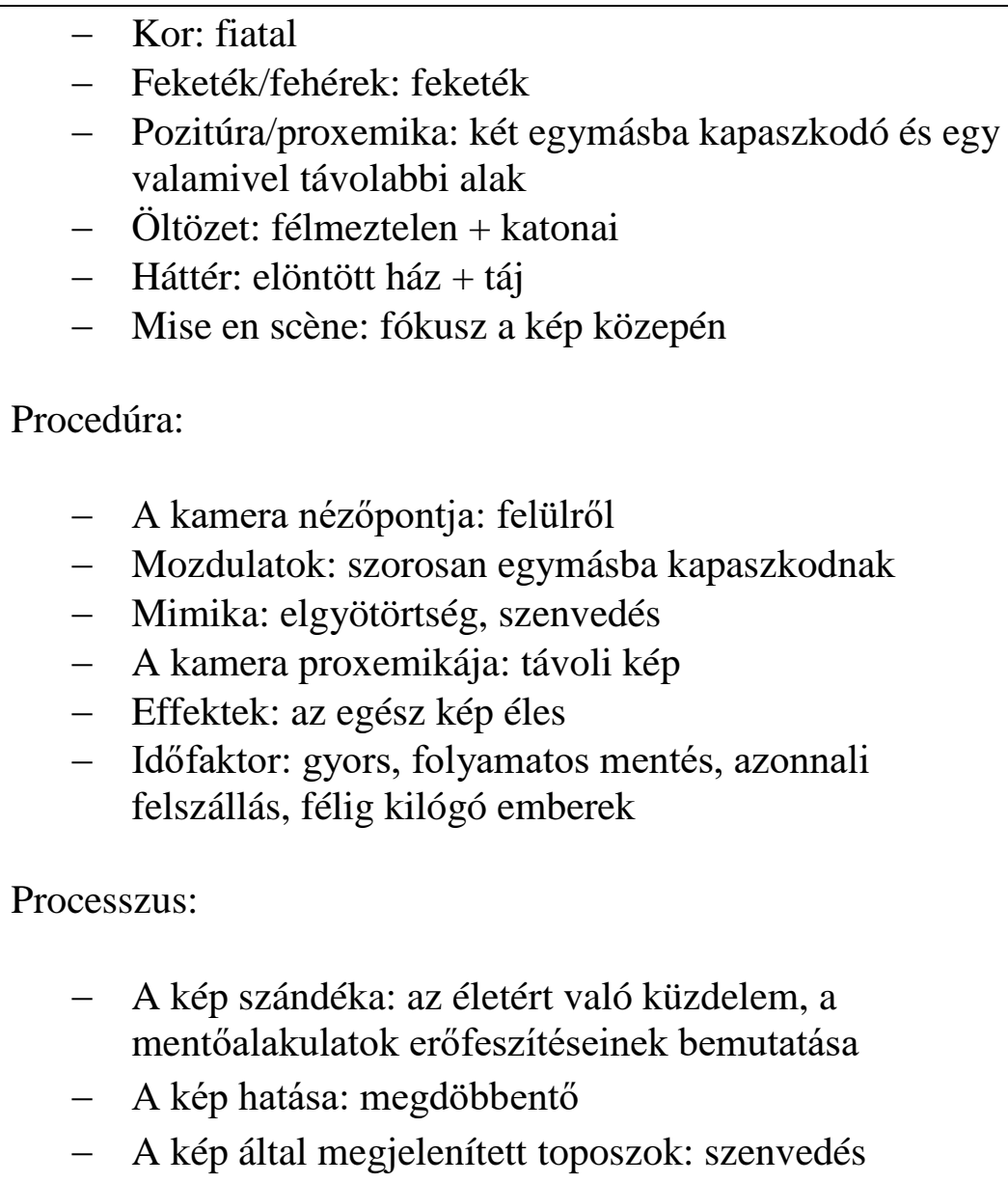 \\
\hline 12. & 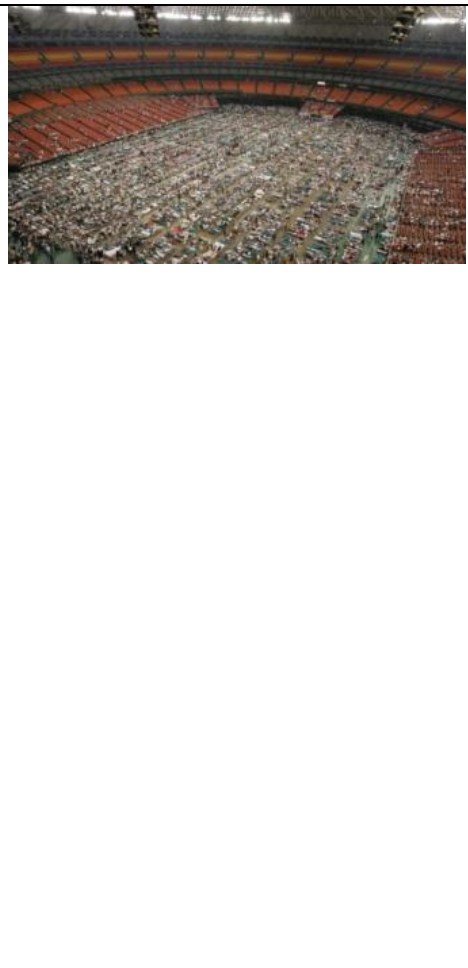 & $\begin{array}{l}\text { F12. A kép forrása: } \\
\text { http://edition.cnn.com/2013/08/23/us/hurricane-katrina- } \\
\text { statistics-fast-facts/index.html } \\
\text { Produktum: } \\
\text { - Előtér: - } \\
\text { - Nem: - } \\
\text { - Kor: - } \\
\text { - Feketék/fehérek: - } \\
\text { - Pozitúra/proxemika: tömörülés, szoros egymás } \\
\text { - } \text { Ölltëttiség } \\
\text { - Háttér: rengeteg ember } \\
\text { - Mise en scène: fókusz a kép közepén } \\
\text { Procedúra: } \\
\text { - A kamera nézőpontja: felülröl }\end{array}$ \\
\hline
\end{tabular}




\begin{tabular}{|c|c|c|}
\hline & & $\begin{array}{l}\text { - Mozdulatok: - } \\
\text { - Mimika: - } \\
\text { - A kamera proxemikája: távoli kép } \\
\text { - Effektek: az egész kép éles } \\
\text { - } \text { Időfaktor: áll az idő, reménytelen, nyomorult helyzet } \\
\text { Processzus: } \\
\text { - A kép szándéka: a túlélésért az embertelen } \\
\text { - } \text { körülmények elviselésének bemutatása } \\
\text { - A kép hatása: megdöbbentő }\end{array}$ \\
\hline 13. & 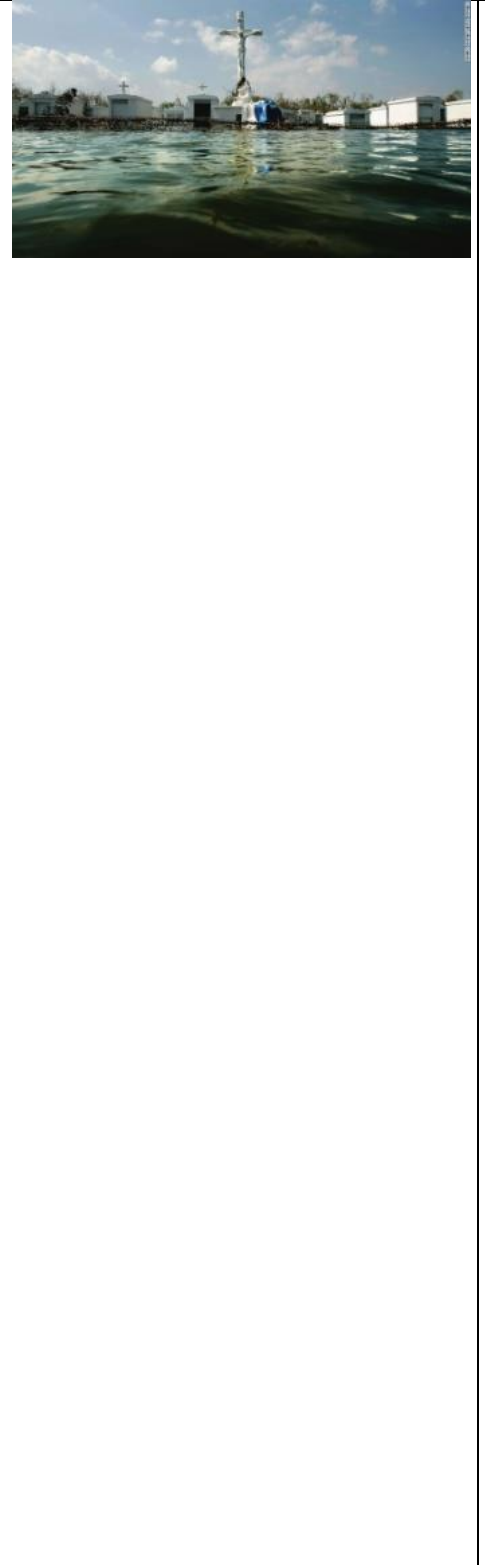 & 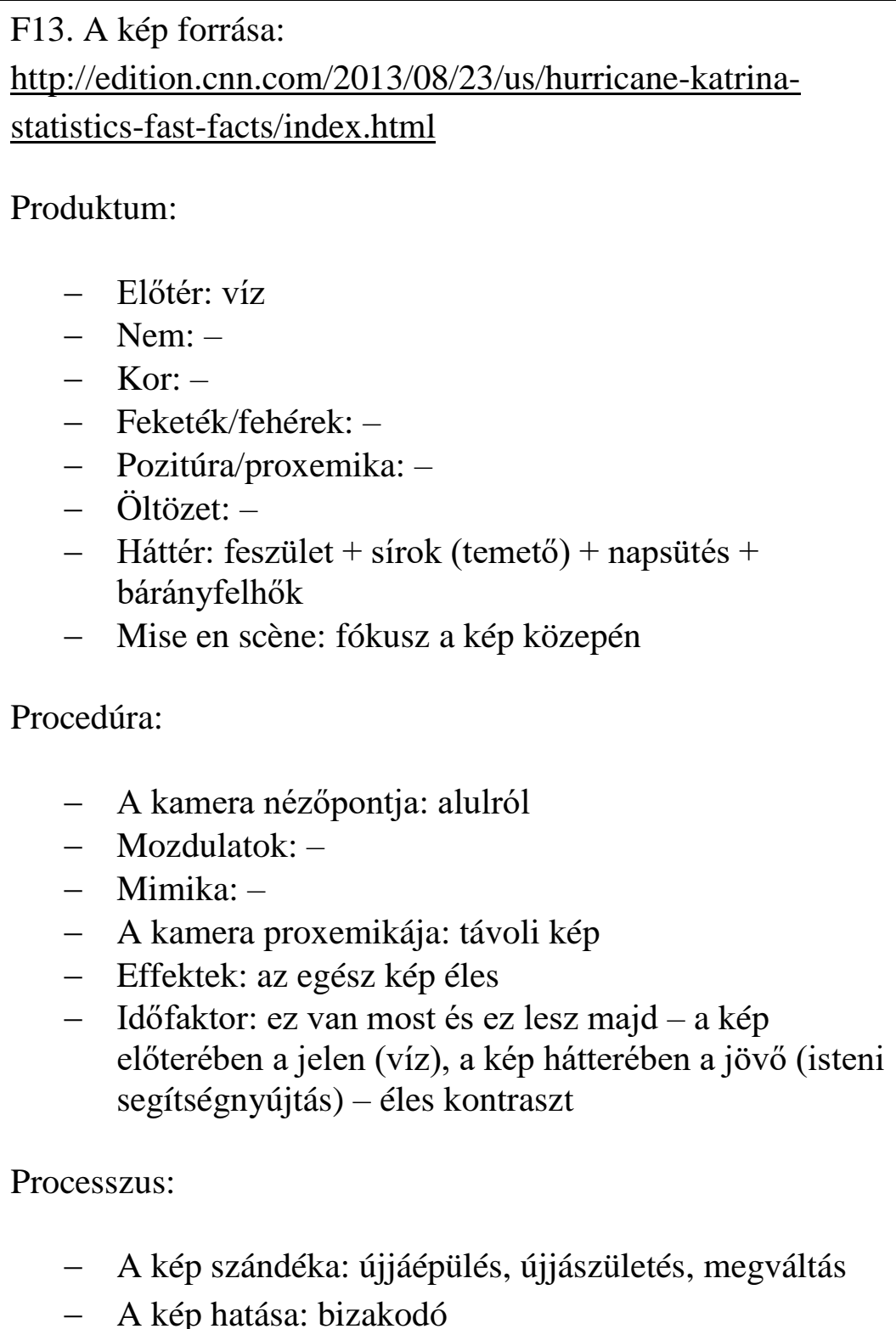 \\
\hline
\end{tabular}




\begin{tabular}{|c|c|}
\hline & - A kép által megjelenített toposzok: remény \\
\hline 14. & $\begin{array}{l}\text { F14. A kép forrása: https://thebark.com/content/photographs- } \\
\text { carol-guzy-pulitzer-prize-winner } \\
\text { Produktum: } \\
\text { - Elötér: kutya } \\
\text { - Nem: - } \\
\text { - Kor: - } \\
\text { - Feketék/fehérek: - } \\
\text { - Pozitúra/proxemika: - } \\
\text { - Öltözet: - } \\
\text { - Háttér: feszület + víz + farönkök + napsütés + } \\
\text { - } \text { bárányfelhők } \\
\text { Procedúra: en scène: fókusz a kép közepén } \\
\text { - A kamera nézőpontja: alulról } \\
\text { - Mozdulatok: a kutya kiutat keres a víztömegböl } \\
\text { - Mimika: figyelő tekintet } \\
\text { - A kamera proxemikája: közeli kép } \\
\text { - Effektek: az egész kép éles } \\
\text { - Időfaktor: a kutya a jövő, a biztonság felé halad } \\
\text { Processzus: } \\
\text { - A kép szándéka: újjáépülés, újjászületés, megváltás } \\
\text { - A kép hatása: bizakodó } \\
\text { - A kép által megjelenített toposzok: remény }\end{array}$ \\
\hline 15 & $\begin{array}{l}\text { F15. A kép forrása: } \\
\text { http://edition.cnn.com/2013/08/23/us/hurricane-katrina- } \\
\text { statistics-fast-facts/index.html } \\
\text { Produktum: } \\
\text { - Előtér: } 2 \text { alak } \\
\text { - Nem: férfi + nő } \\
\text { - Kor: idős + középkorú } \\
\text { - Feketék/fehérek: feketék } \\
\text { - Pozitúra/proxemika: idős nő a katona karjaiban }\end{array}$ \\
\hline
\end{tabular}




\begin{tabular}{|c|c|c|}
\hline & & $\begin{array}{l}\text { - Öltözet: katonai + otthonka } \\
\text { - Háttér: civilek, katonák } \\
\text { - Mise en scène: fókusz a kép közepén } \\
\text { Procedúra: } \\
\text { - A kamera nézőpontja: szemből } \\
\text { - Mozdulatok: a katona magabiztosan tartja a karjában } \\
\text { - } \text { az idős nőt } \\
\text { - } \text { A kamika: elszántság } \\
\text { - Effektek: elötér éles, háttér homályos } \\
\text { - Időfaktor: sietség } \\
\text { Processzus: } \\
\text { - A kép szándéka: a mentőalakulatok erőfeszítéseinek, } \\
\text { áldozatkészségének bemutatása } \\
\text { - A kép hatása: megindító } \\
\text { - A kép által megjelenített toposzok: hősiesség }\end{array}$ \\
\hline 16 & Sentosta & 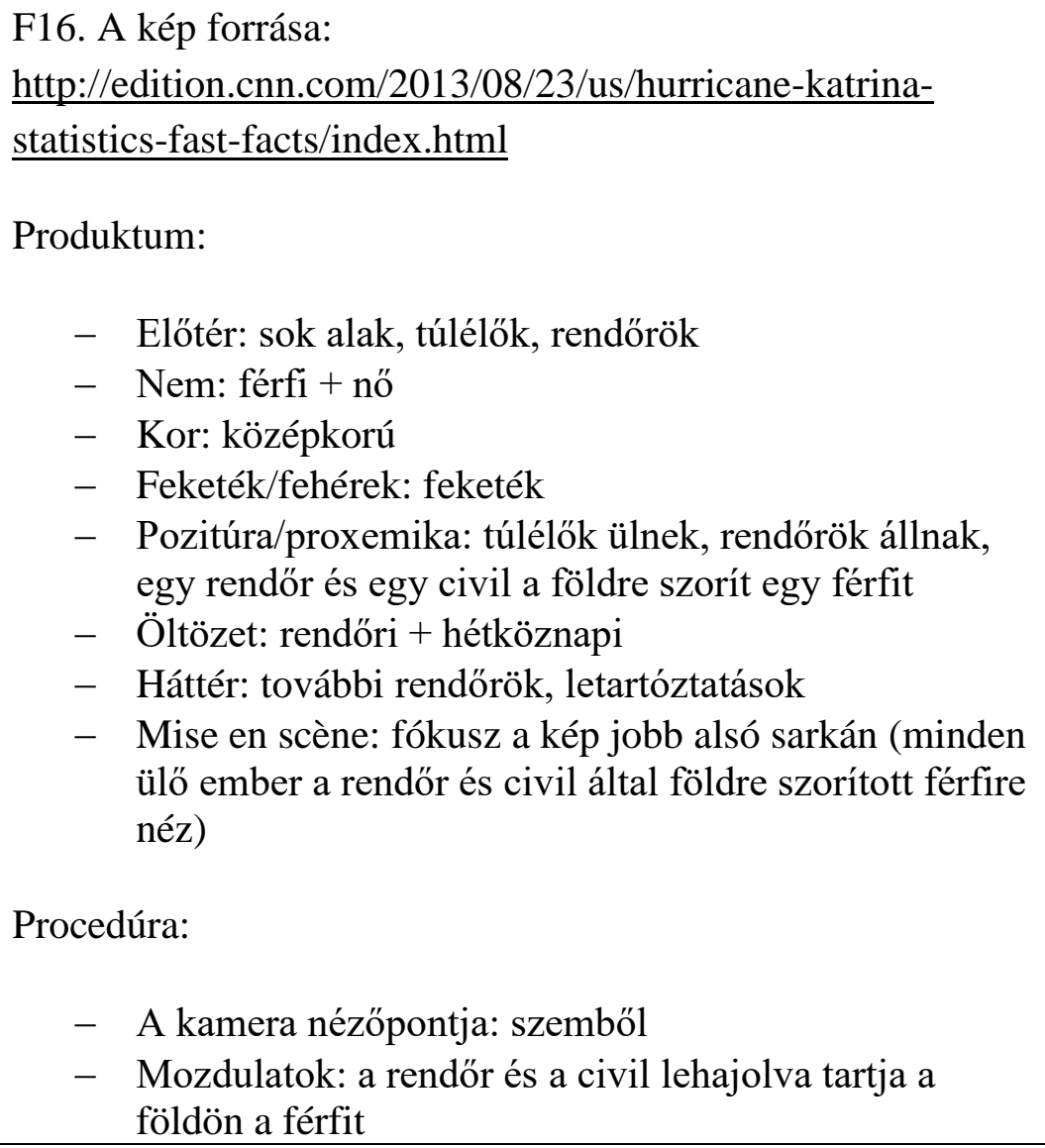 \\
\hline
\end{tabular}




\begin{tabular}{|c|c|}
\hline & $\begin{array}{l}\text { - Mimika: - } \\
\text { - } \text { A kamera proxemikája: távoli kép } \\
\text { - Effektek: előtér éles, háttér elsötétül } \\
\text { - } \text { Időfaktor: áll az idő } \\
\text { Processzus: } \\
\text { - A kép szándéka: az amúgy is nehéz helyzetben } \\
\quad \text { elöforduló bünözés és a rendezettség és rendezetlenség } \\
\text { közötti éles kontraszt bemutatása } \\
\text { - } \\
\text { A kép hatása: felháborító (a mentőalakulatoknak a } \\
\text { - mentésen felül még a bünözést is kontrollálni kell) } \\
\text { - A kép által megjelenített toposzok: agresszió }\end{array}$ \\
\hline 17. & 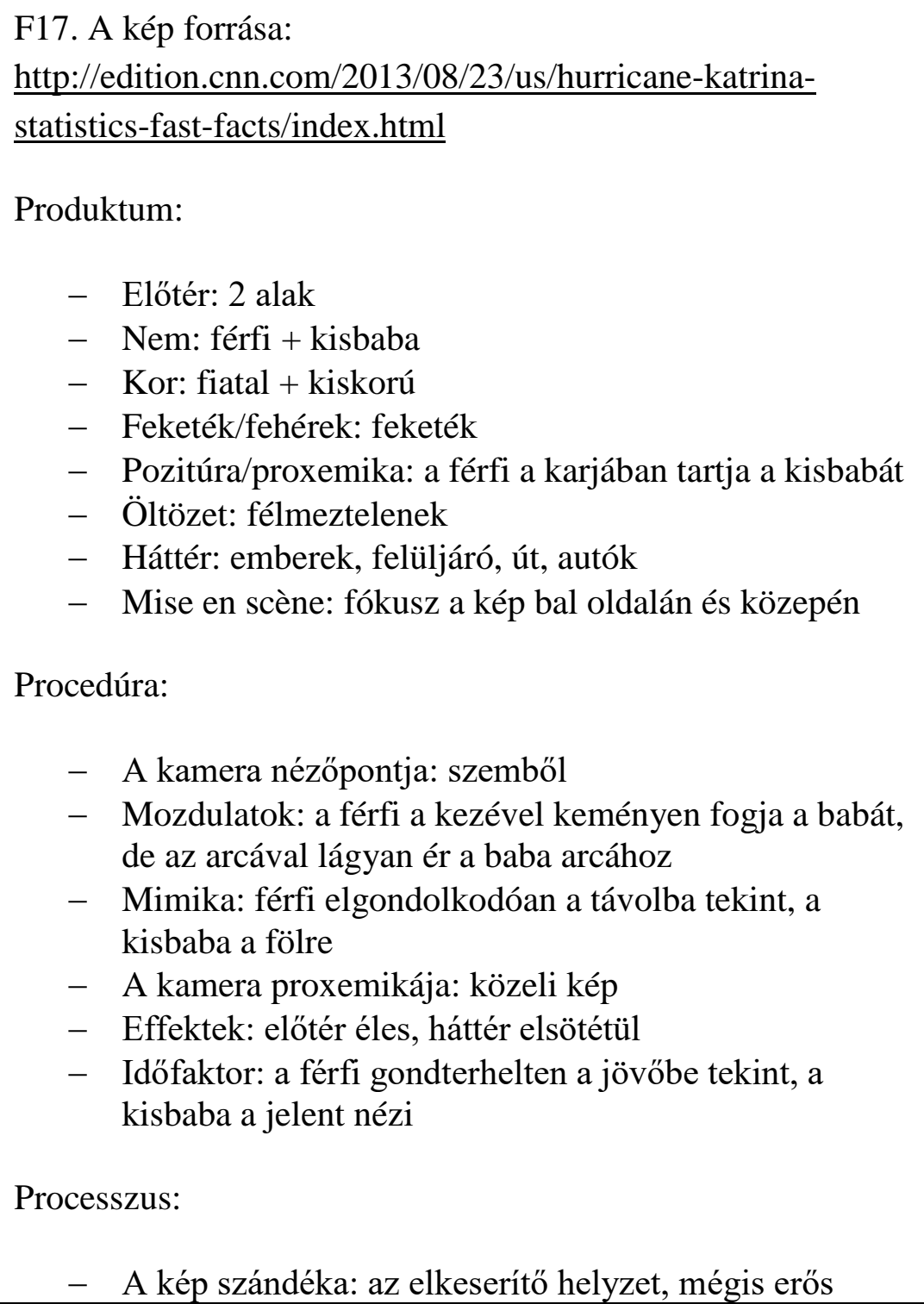 \\
\hline
\end{tabular}




\begin{tabular}{|c|c|c|}
\hline & & $\begin{array}{l}\text { összetartás bemutatása } \\
\text { _ A kép hatása: megható } \\
\text { _ } \quad \text { A kép által megjelenített toposzok: veszteség és } \\
\text { remény }\end{array}$ \\
\hline 18. & 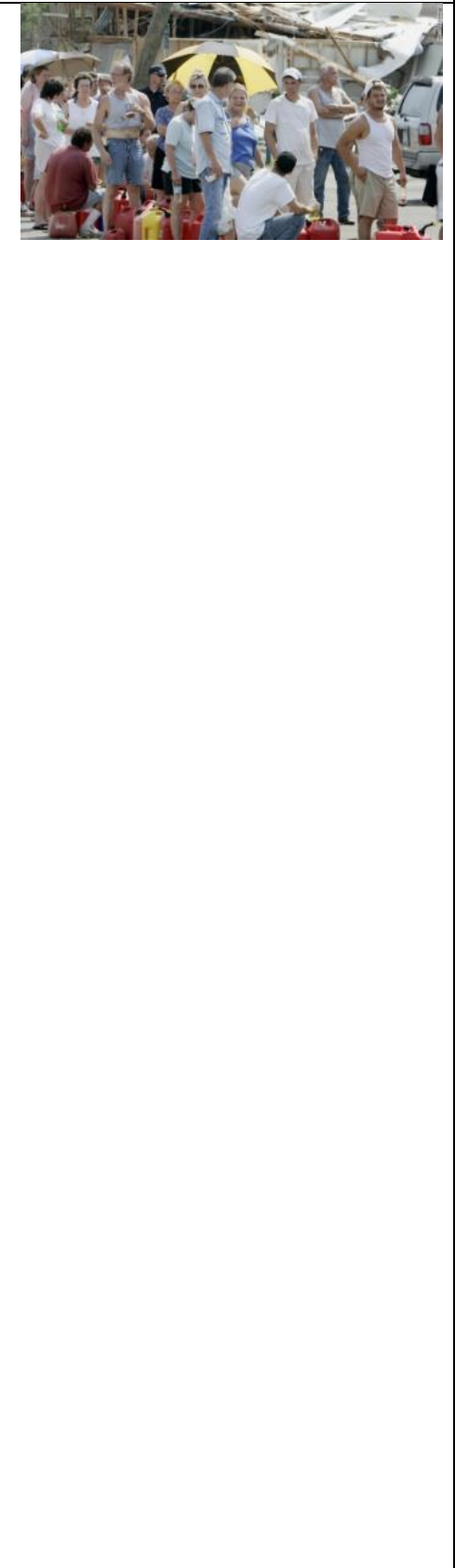 & 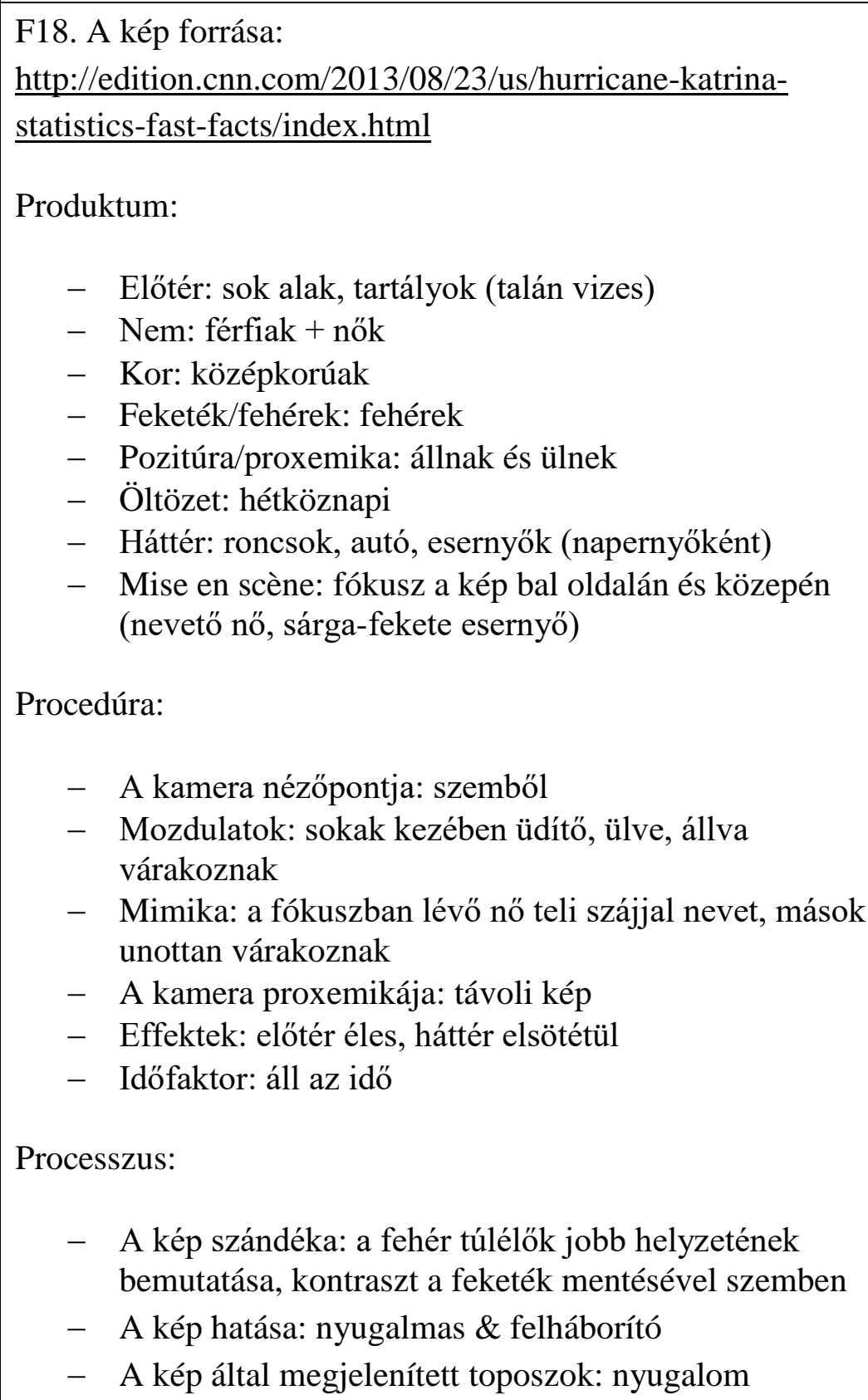 \\
\hline 19. & & $\begin{array}{l}\text { F19. A kép forrása: } \\
\text { http://edition.cnn.com/2013/08/23/us/hurricane-katrina- } \\
\underline{\text { statistics-fast-facts/index.html }}\end{array}$ \\
\hline
\end{tabular}




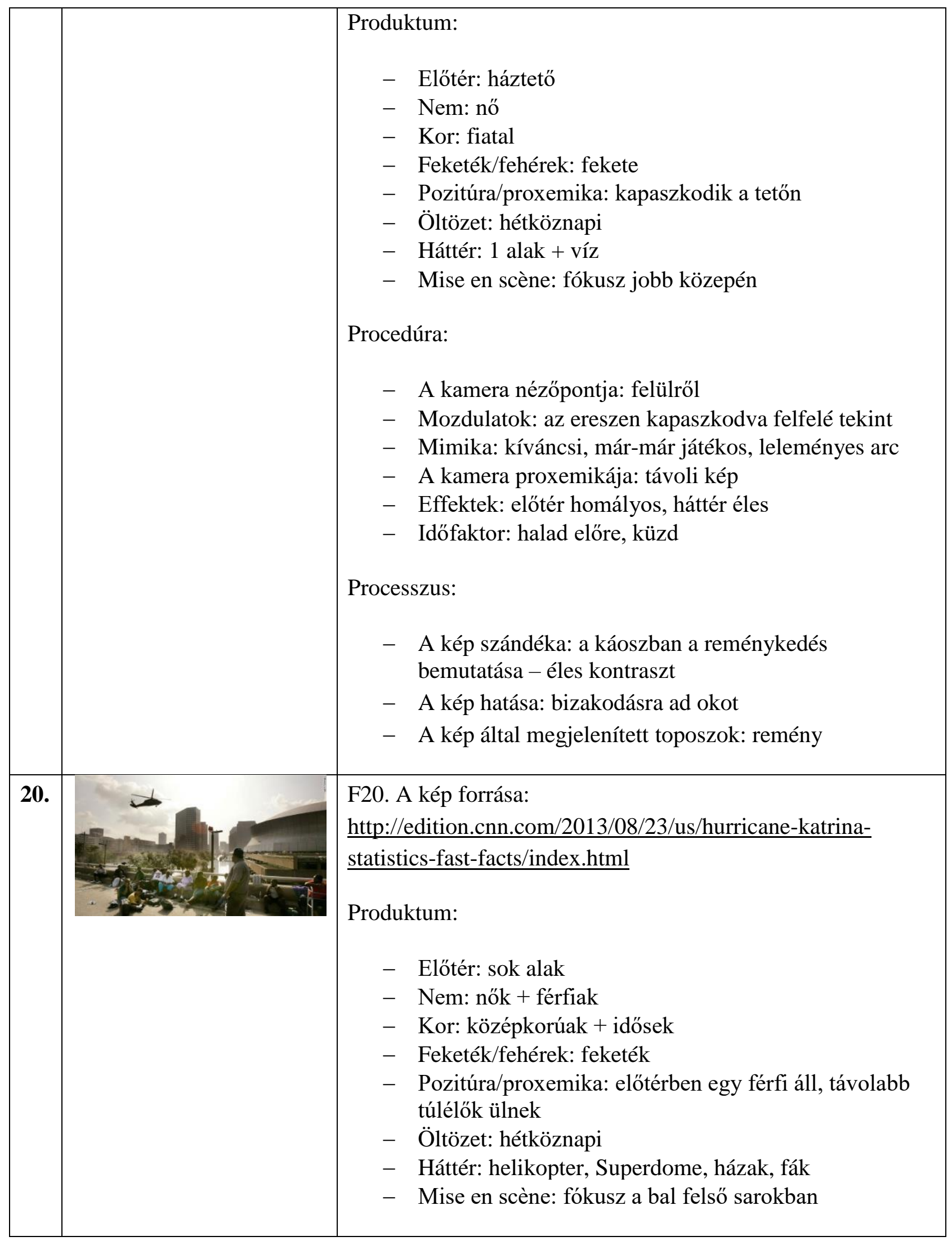




\begin{tabular}{|c|c|c|}
\hline & & 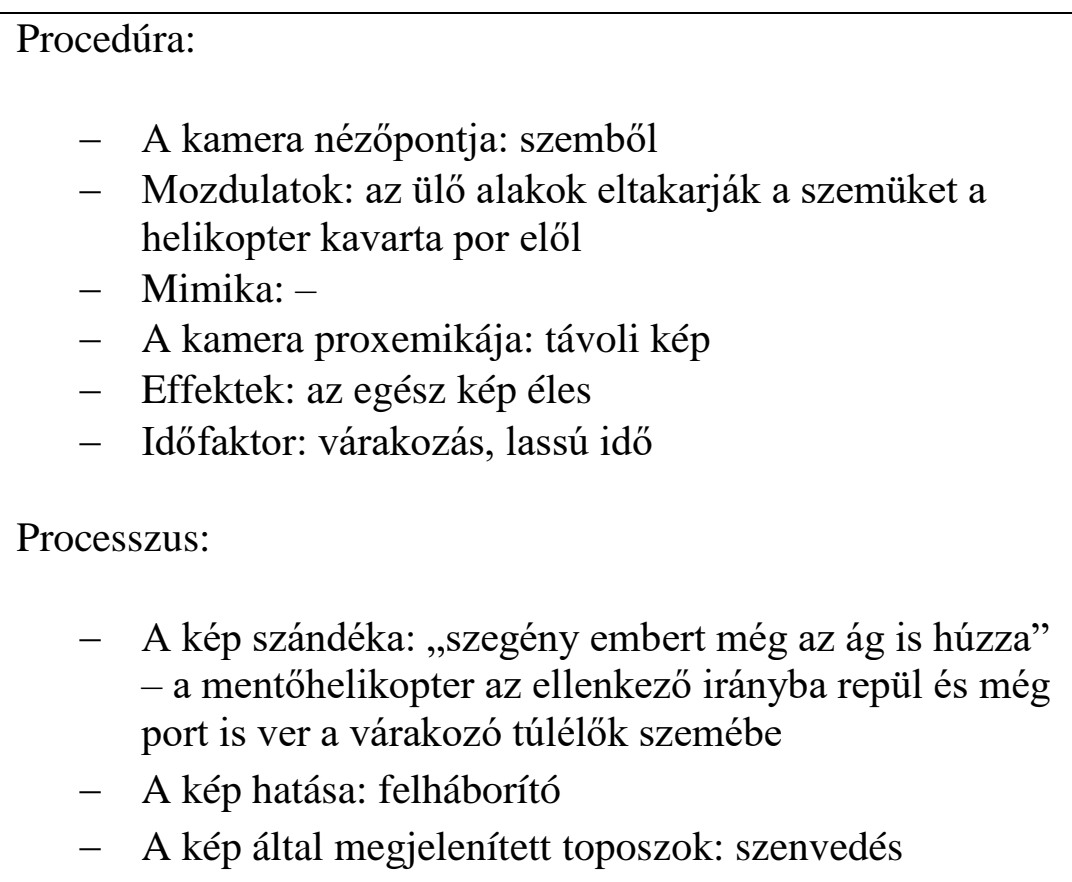 \\
\hline 21. & Q $3 x$ & $\begin{array}{l}\text { F20. A kép forrása: } \\
\text { http://edition.cnn.com/2013/08/23/us/hurricane-katrina- } \\
\text { statistics-fast-facts/index.html } \\
\text { Produktum: } \\
\text { - Elötér: } 1 \text { alak } \\
\text { - } \text { Nem: nő } \\
\text { - } \text { Kor: középkorú } \\
\text { - Feketék/fehérek: fehér } \\
\text { - Pozitúra/proxemika: elötérben egy nö áll } \\
\text { - Öltözet: hétköznapi } \\
\text { - Háttér: roncsok, fák, szemét } \\
\text { - Mise en scène: fókusz a kép közepén } \\
\text { Procedúra: } \\
\text { - A kamera nézőpontja: szemböl } \\
\text { - Mozdulatok: a nő a szája elé kapja a kezét, a kezében } \\
\quad \text { kulcsokat, zseblámpát tart, napszemüveget tart } \\
\text { - Mimika: fojtogatja a sírás } \\
\text { - A kamera proxemikája: közeli kép } \\
\text { - Effektek: az előtér éles, a háttér homályos } \\
\text { - Időfaktor: kontraszt a múlt és jelen között }\end{array}$ \\
\hline
\end{tabular}




\begin{tabular}{|c|c|c|}
\hline & & $\begin{array}{l}\text { Processzus: } \\
\text { - A kép szándéka: a károk és a szenvedés bemutatása } \\
\text { - A kép hatása: megindító } \\
\text { - A kép által megjelenített toposzok: szenvedés }\end{array}$ \\
\hline 22. & 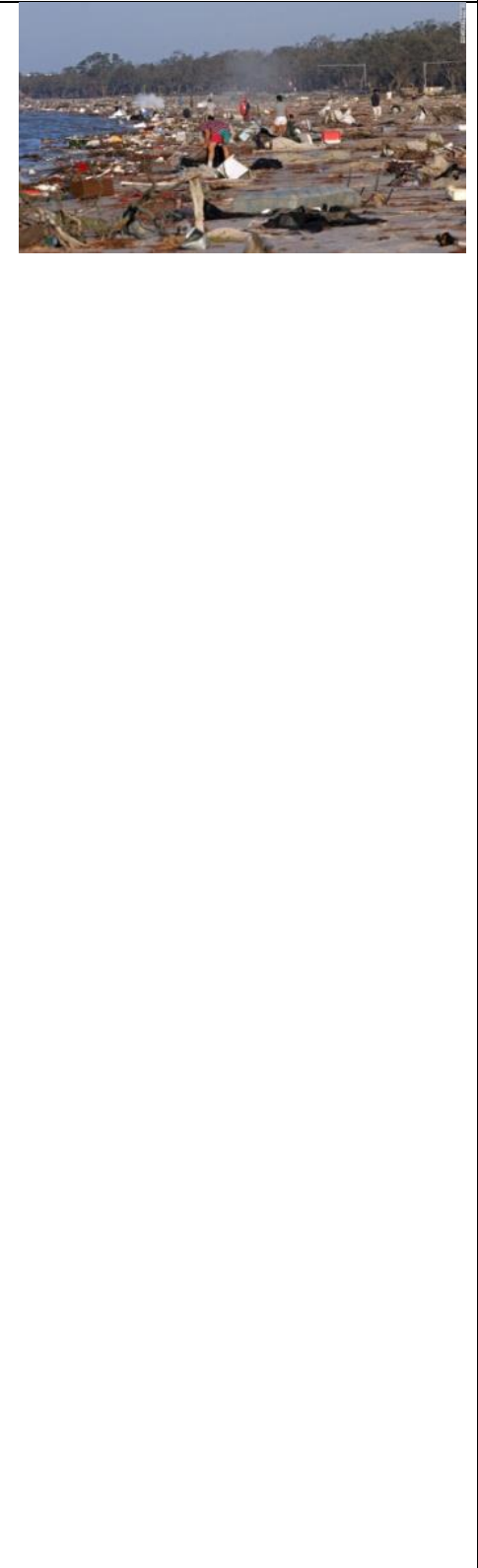 & $\begin{array}{l}\text { F22. A kép forrása: } \\
\text { http://edition.cnn.com/2013/08/23/us/hurricane-katrina- } \\
\text { statistics-fast-facts/index.html } \\
\text { Produktum: } \\
\text { - Elötér: tengerpart, romok, roncsok, szemét mindenhol } \\
\text { - Nem: férfiak + nök } \\
\text { - } \text { Kor: több korosztály } \\
\text { - Feketék/fehérek: fehérek + feketék } \\
\text { - Pozitúra/proxemika: egymástól távolabb, elszórtan } \\
\text { - } \text { Önnak az alakokzet: hétköznapi } \\
\text { - Háttér: férfi - női alakok, roncsok, fák } \\
\text { - Mise en scène: fókusz a kép közepén } \\
\text { Procedúra: } \\
\text { - A kamera nézőpontja: szemböl } \\
\text { - Mozdulatok: az emberek hajlongva mentik, ami } \\
\text { - menthető } \\
\text { - Mimika: - } \\
\text { - Effekektek: az egész kép éles } \\
\text { - Időfaktor: - } \\
\text { Processzus: } \\
\text { - A kép szándéka: a károk bemutatása } \\
\text { - A kép hatása: megindító, elkeserítő } \\
\text { - A kép által megjelenített toposzok: veszteség }\end{array}$ \\
\hline 23. & 3 & $\begin{array}{l}\text { F23. A kép forrása: } \\
\text { http://edition.cnn.com/2013/08/23/us/hurricane-katrina- } \\
\text { statistics-fast-facts/index.html }\end{array}$ \\
\hline
\end{tabular}




\begin{tabular}{|c|c|}
\hline & 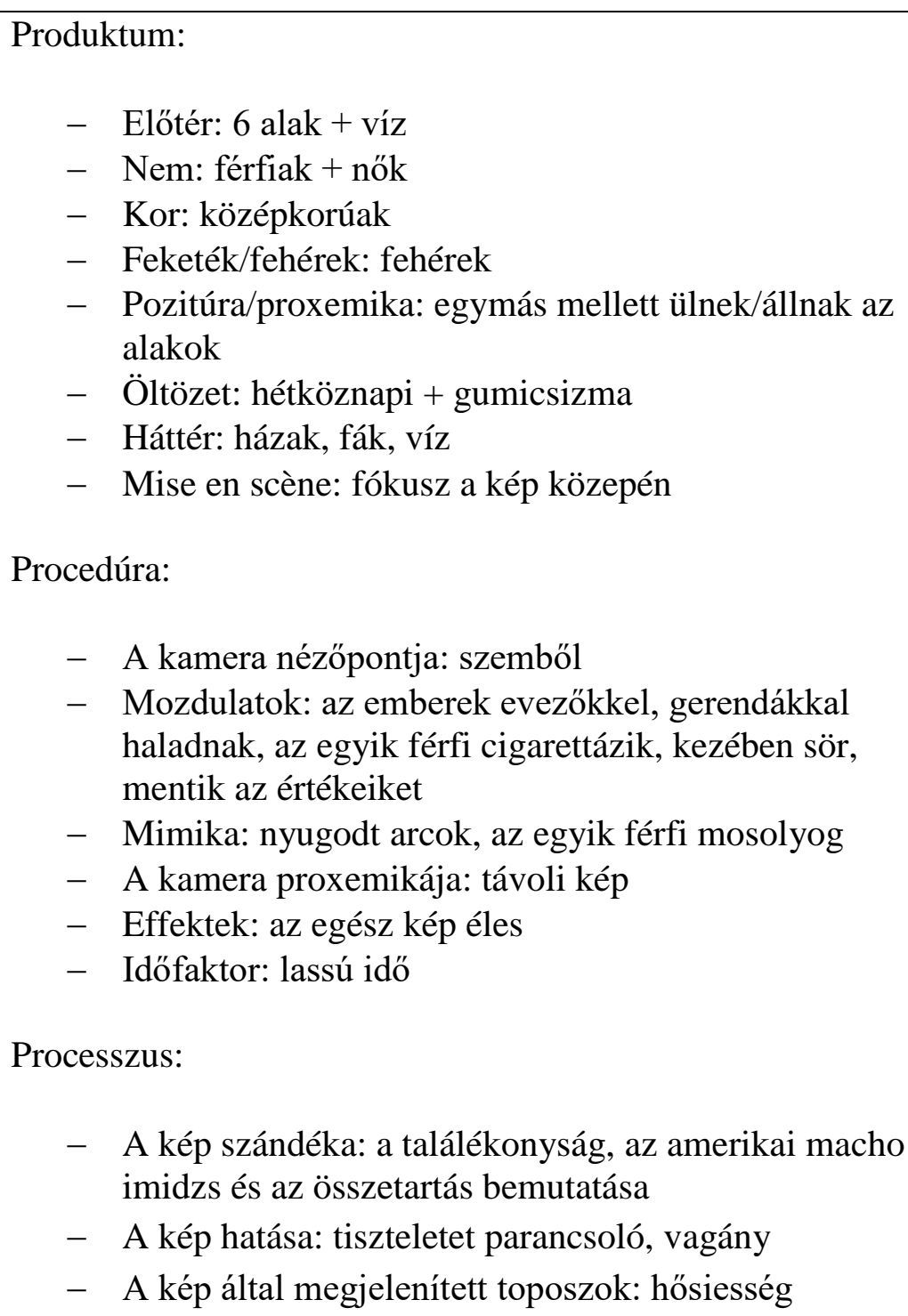 \\
\hline 24. & 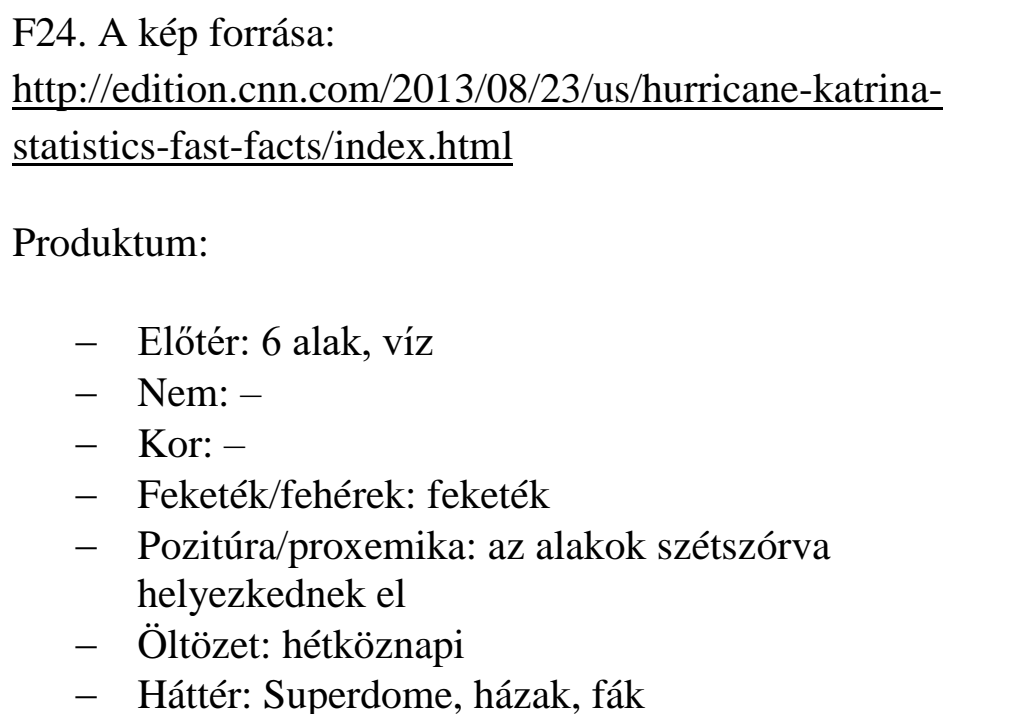 \\
\hline
\end{tabular}




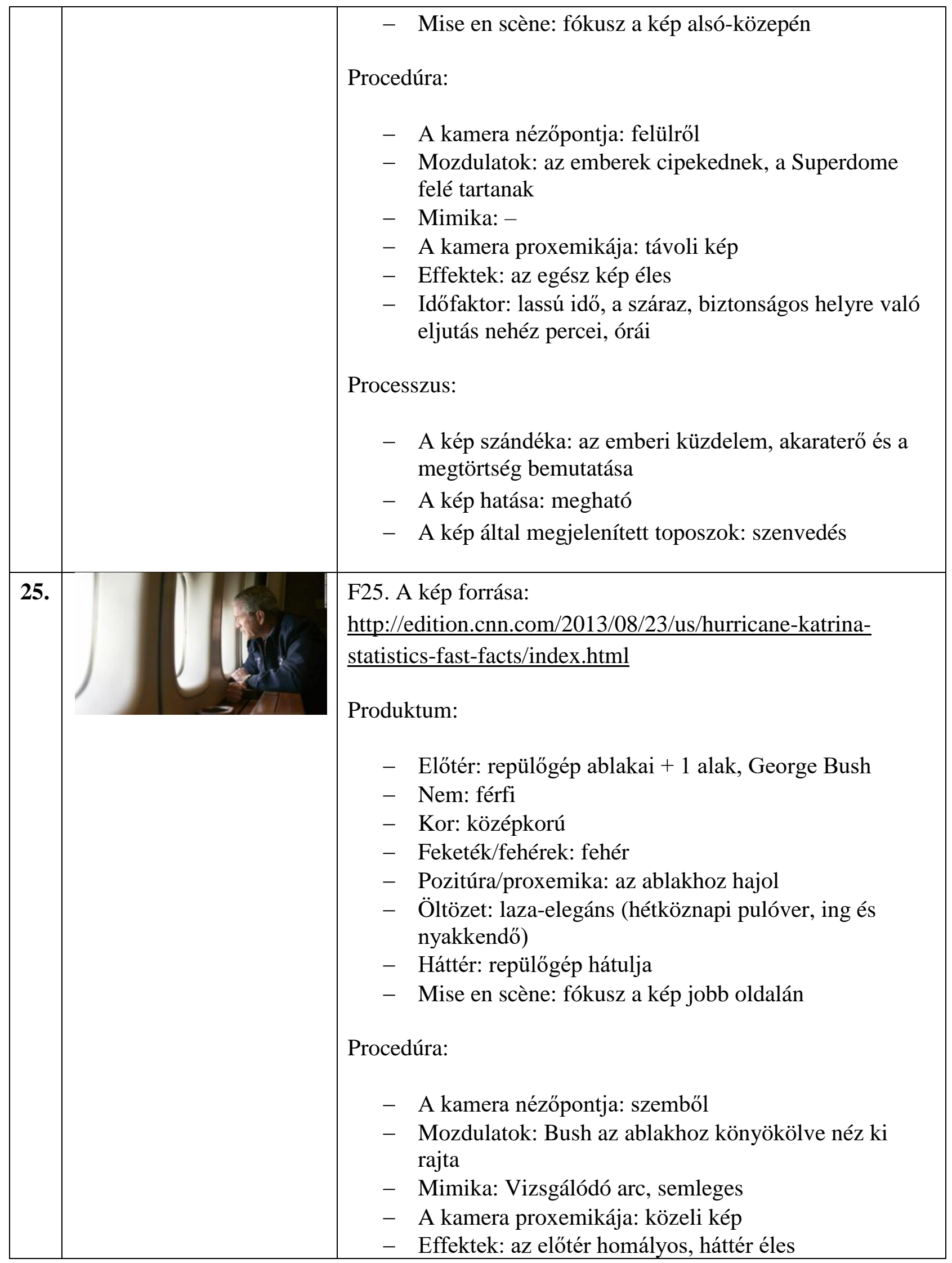




\begin{tabular}{|c|c|}
\hline & $\begin{array}{l}\text { - Időfaktor: lassú idő } \\
\text { Processzus: } \\
\text { - A kép szándéka: George Bush érkeztének bemutatása, } \\
\text { és annak biztosítása, hogy a kormány törődik az } \\
\text { emberekkel } \\
\text { - A kép hatása: nyugodt, a megbízható vezető hatását } \\
\text { - kelti }\end{array}$ \\
\hline 26. & 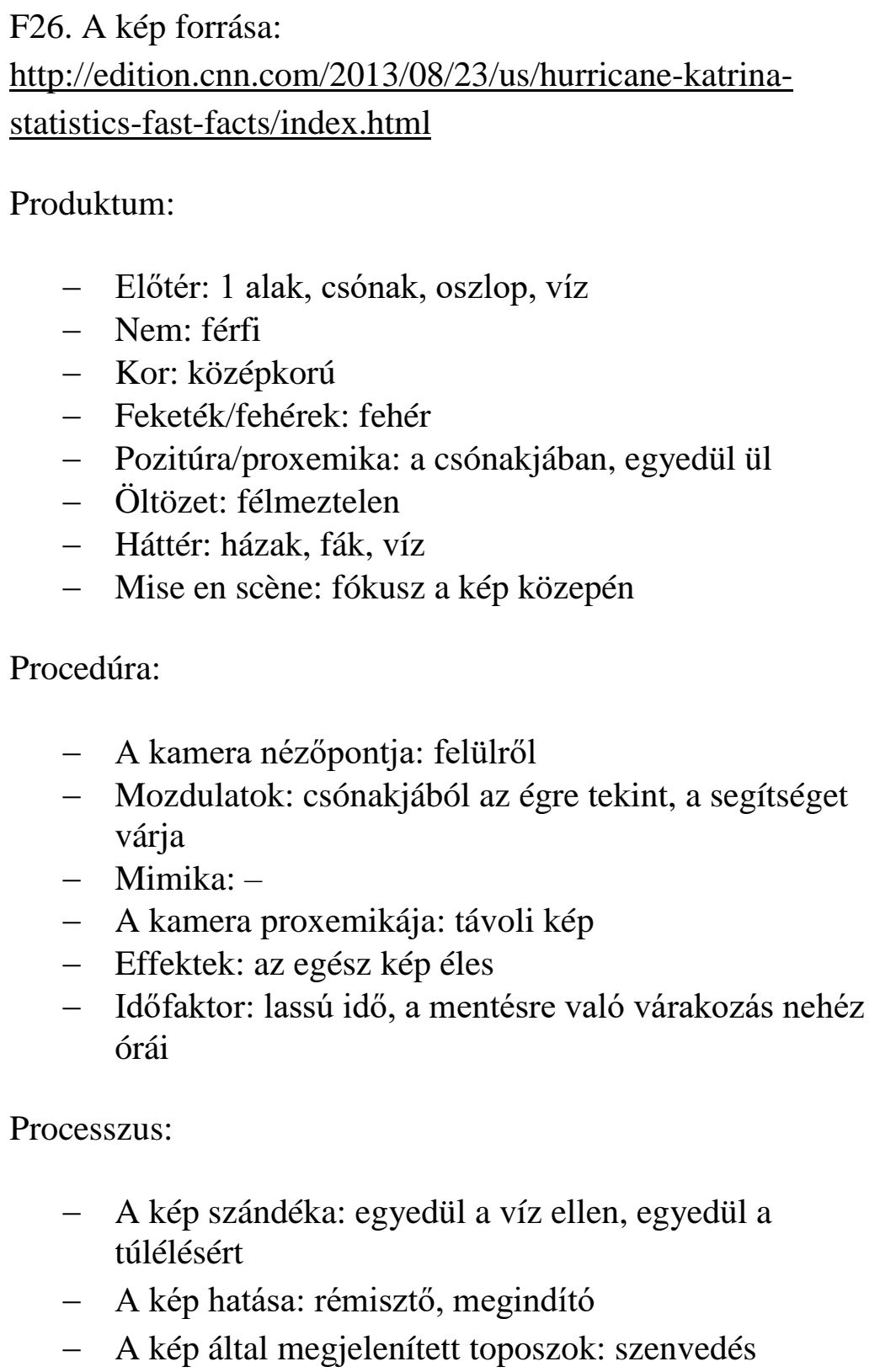 \\
\hline
\end{tabular}




\begin{tabular}{|c|c|c|}
\hline 27. & & $\begin{array}{l}\text { F27. A kép forrása: } \\
\text { http://edition.cnn.com/2013/08/23/us/hurricane-katrina- } \\
\text { statistics-fast-facts/index.html } \\
\text { Produktum: } \\
\text { - Elötér: } 1 \text { alak, víz } \\
\text { - Nem: férfi } \\
\text { - Kor: idős } \\
\text { - Feketék/fehérek: fehér } \\
\text { - Pozitúra/proxemika: az utca közepén áll } \\
\text { - Öltözet: hétköznapi + cowboy kalap } \\
\text { - Háttér: házak, fák, tüz, víz } \\
\text { - Mise en scène: fókusz a kép bal oldalán } \\
\text { Procedúra: } \\
\text { - A kamera nézőpontja: alulról mutatja } \\
\text { - Mozdulatok: a testtartása az igazi amerikai machoé, } \\
\text { - kezében sör, szájában cigarettát tart } \\
\text { - Mimika: macho, nemtörödöm, bátor } \\
\text { - } \text { A kamera proxemikája: távoli kép } \\
\text { - Időfaktor: lassú idő } \\
\text { Processzus: } \\
\text { - A kép szándéka: a félelmet nem ismerö, vakmerö férfi } \\
\text { - }\end{array}$ \\
\hline 28. & III & $\begin{array}{l}\text { F28. A kép forrása: } \\
\text { http://edition.cnn.com/2013/08/23/us/hurricane-katrina- } \\
\text { statistics-fast-facts/index.html } \\
\text { Produktum: } \\
\text { - Elötér: } 2 \text { alak, víz } \\
\text { - Nem: férfiak } \\
\text { - Kor: középkorúak } \\
\text { - Feketék/fehérek: fehér + fekete } \\
\text { - Pozitúra/proxemika: egymáshoz közel ülnek egy } \\
\quad \text { csónakban }\end{array}$ \\
\hline
\end{tabular}




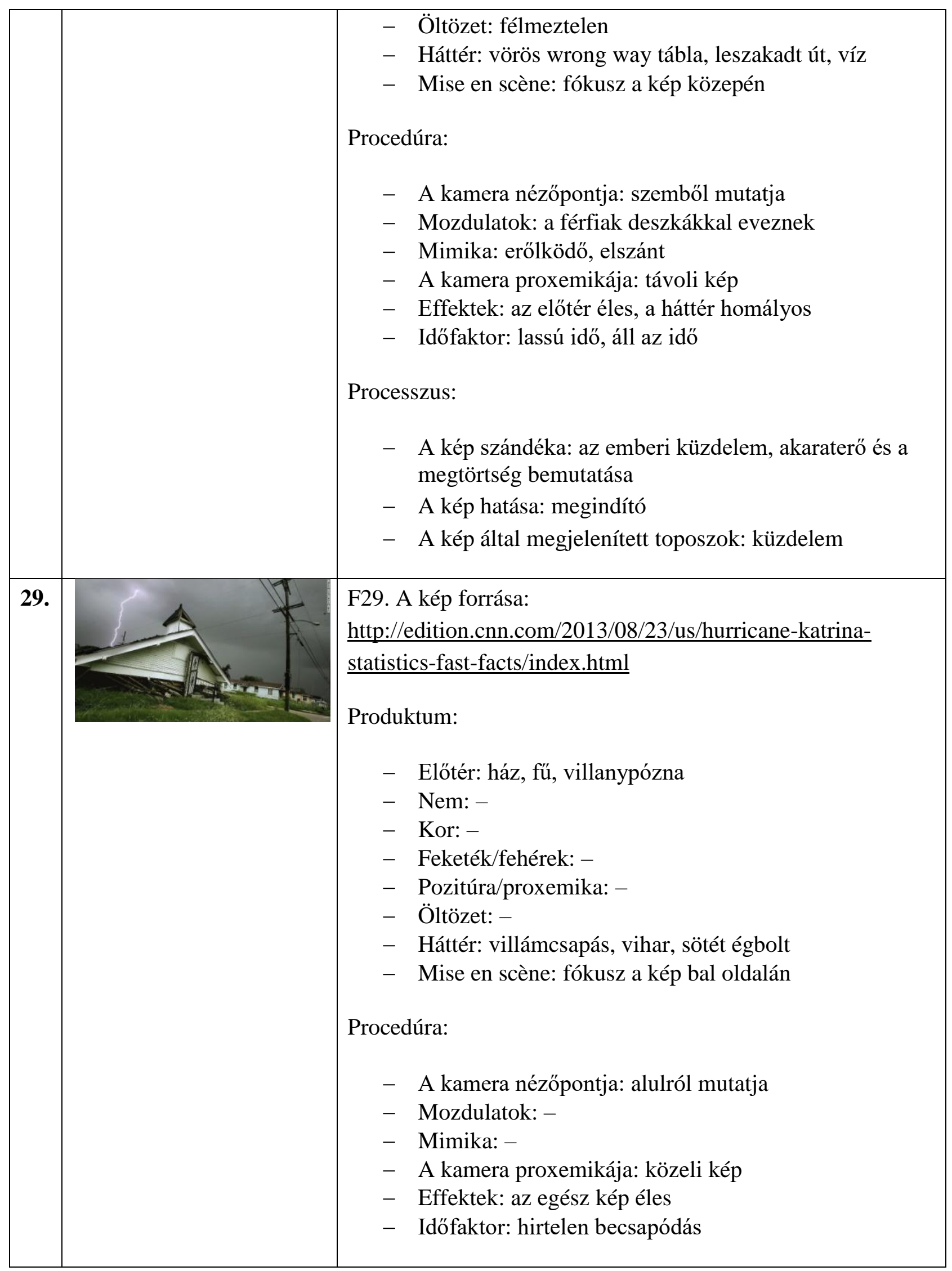




\begin{tabular}{|c|c|c|}
\hline & & 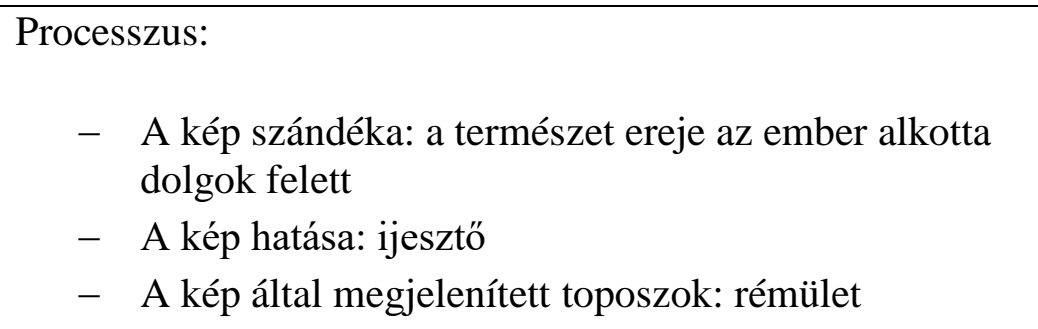 \\
\hline 30. & 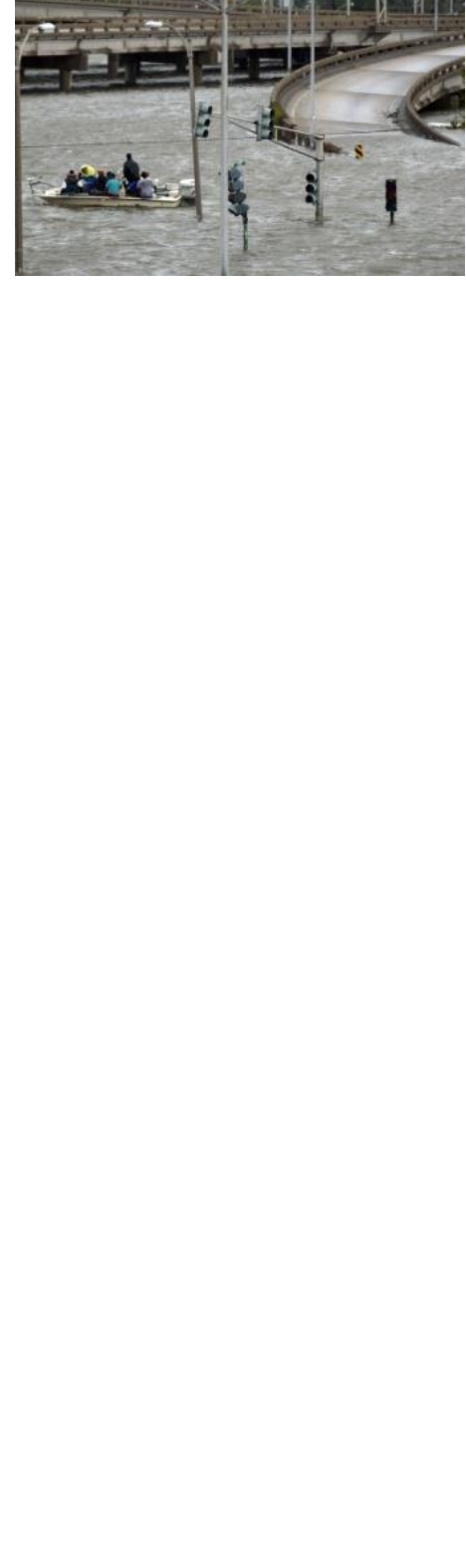 & 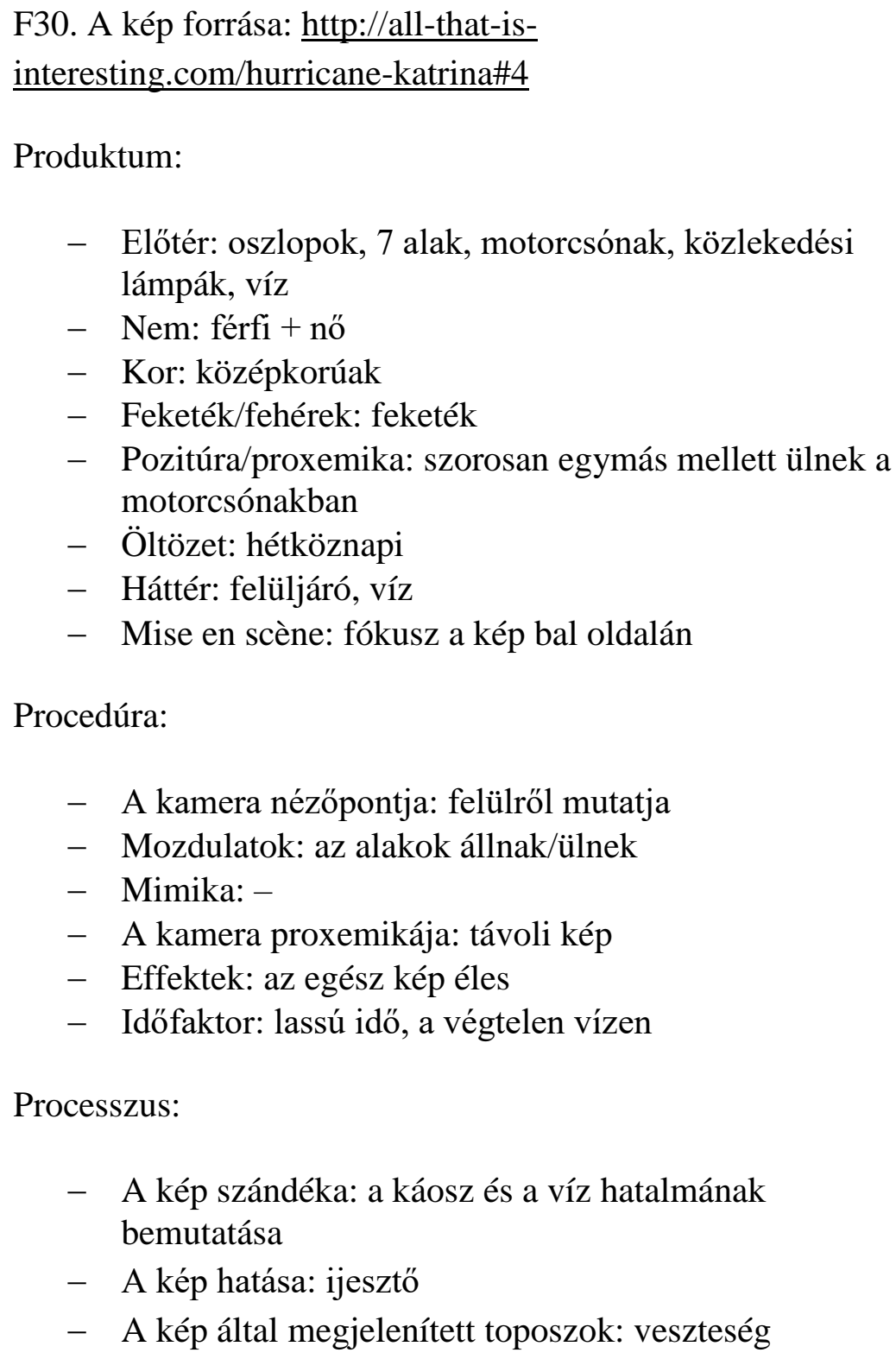 \\
\hline
\end{tabular}




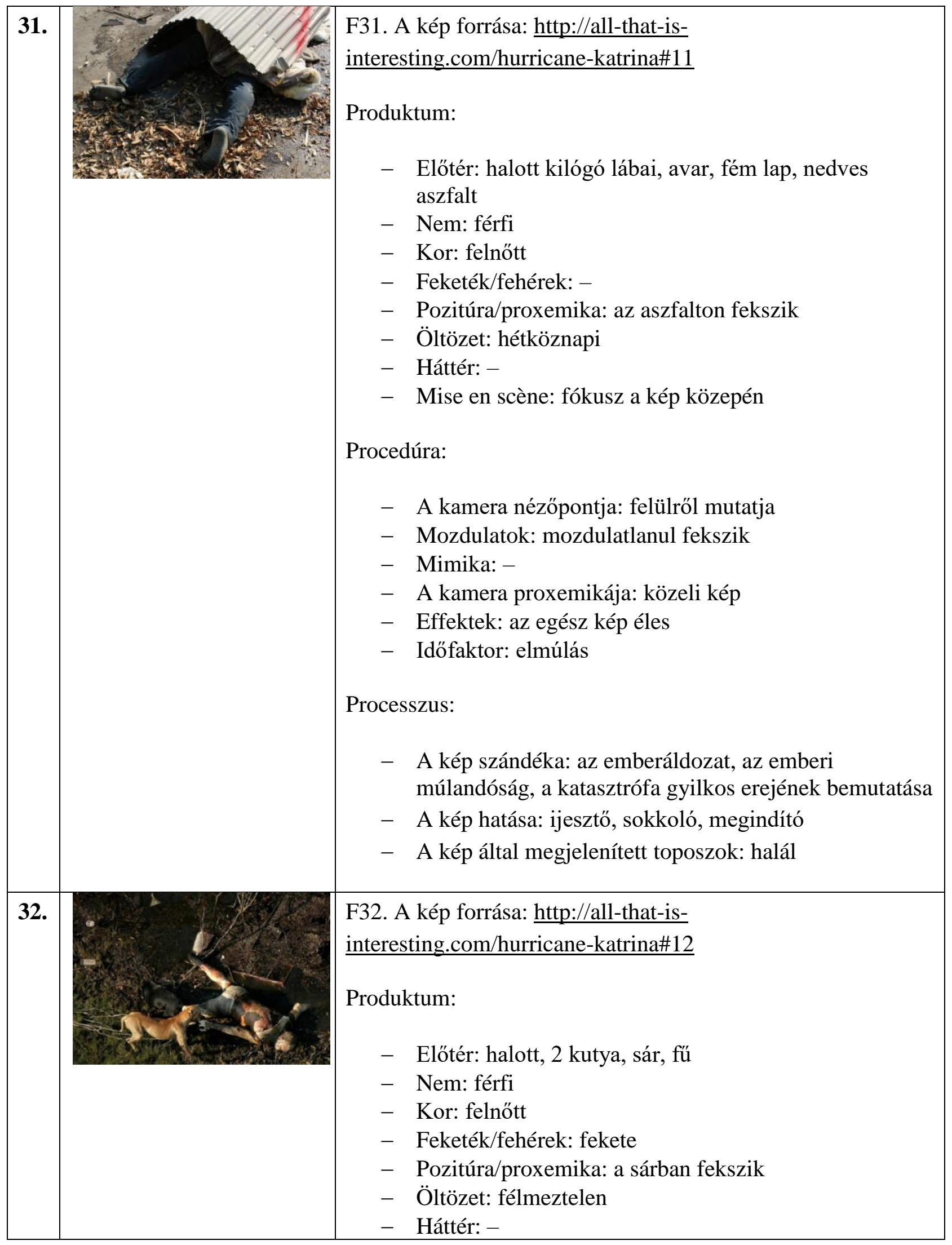




\begin{tabular}{|c|c|c|}
\hline & & 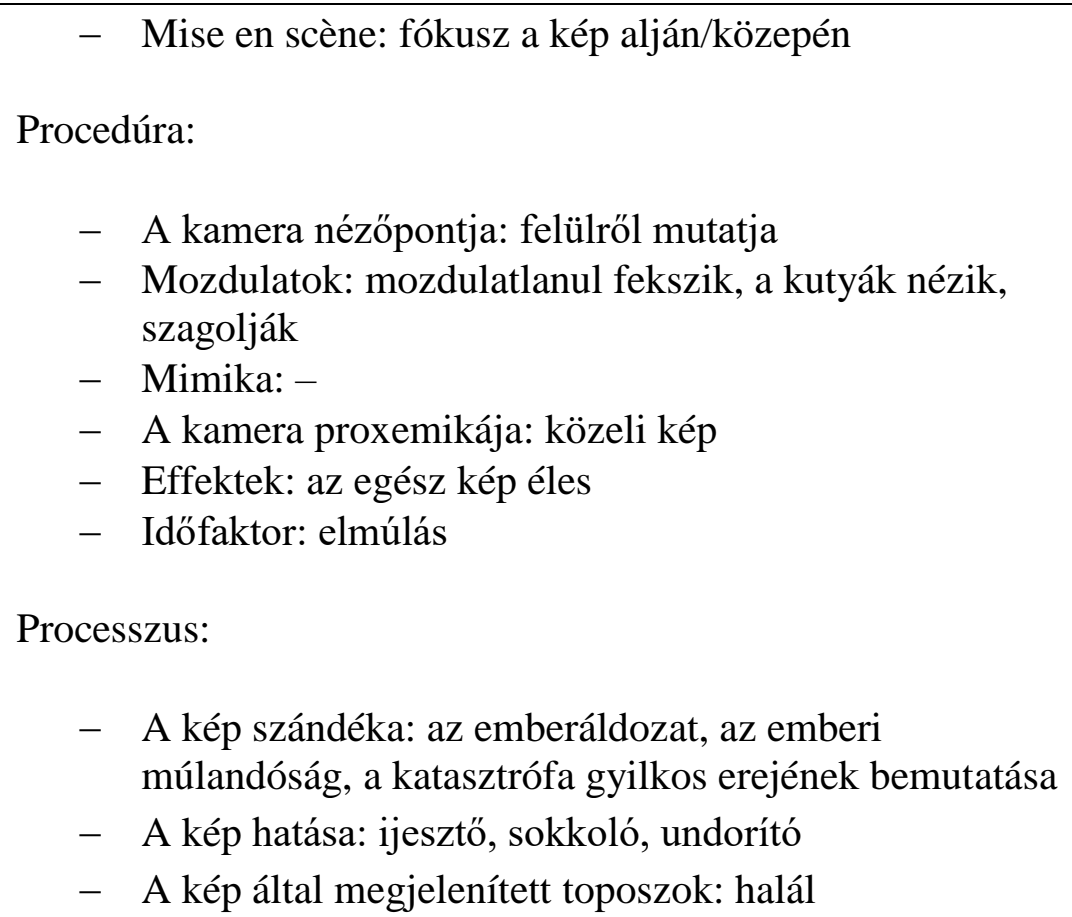 \\
\hline 33. & 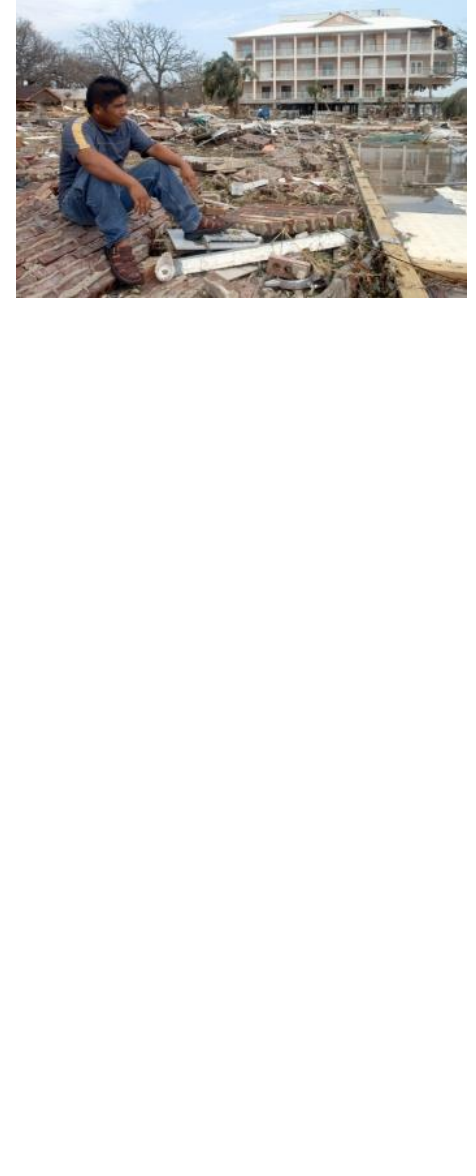 & $\begin{array}{l}\text { F33. A kép forrása: http://www.origo.hu/nagyvilag/20150828- } \\
\text { katrina-new-orleans-hurrikan-ujjaepites-ray-nagin- } \\
\underline{\text { evfordulo.html }} \\
\text { Produktum: } \\
\text { - Előtér: } 1 \text { alak, roncsok } \\
\text { - } \text { Nem: férfi } \\
\text { - } \text { Kor: középkorú } \\
\text { - Feketék/fehérek: latino } \\
\text { - Pozitúra/proxemika: a romok tetején ül } \\
\text { - Öltözet: hétköznapi } \\
\text { - Háttér: roncsok, megrongálódott ház, fák } \\
\text { - Mise en scène: fókusz a kép bal oldalán } \\
\text { Procedúra: } \\
\text { - A kamera nézőpontja: szemből mutatja } \\
\text { - Mozdulatok: a férfi magába roskadva ül } \\
\text { - Mimika: kilátástalanság } \\
\text { - A kamera proxemikája: közeli kép } \\
\text { - Effektek: az egész kép éles } \\
\text { - Időfaktor: áll az idő }\end{array}$ \\
\hline
\end{tabular}




\begin{tabular}{|c|c|c|}
\hline & & $\begin{array}{l}\text { Processzus: } \\
\begin{array}{l}\text { - A kép szándéka: az elkeseredettség bemutatása } \\
\text { - A kép hatása: megindító } \\
\text { - A kép által megjelenített toposzok: veszteség }\end{array}\end{array}$ \\
\hline 34. & (1) & 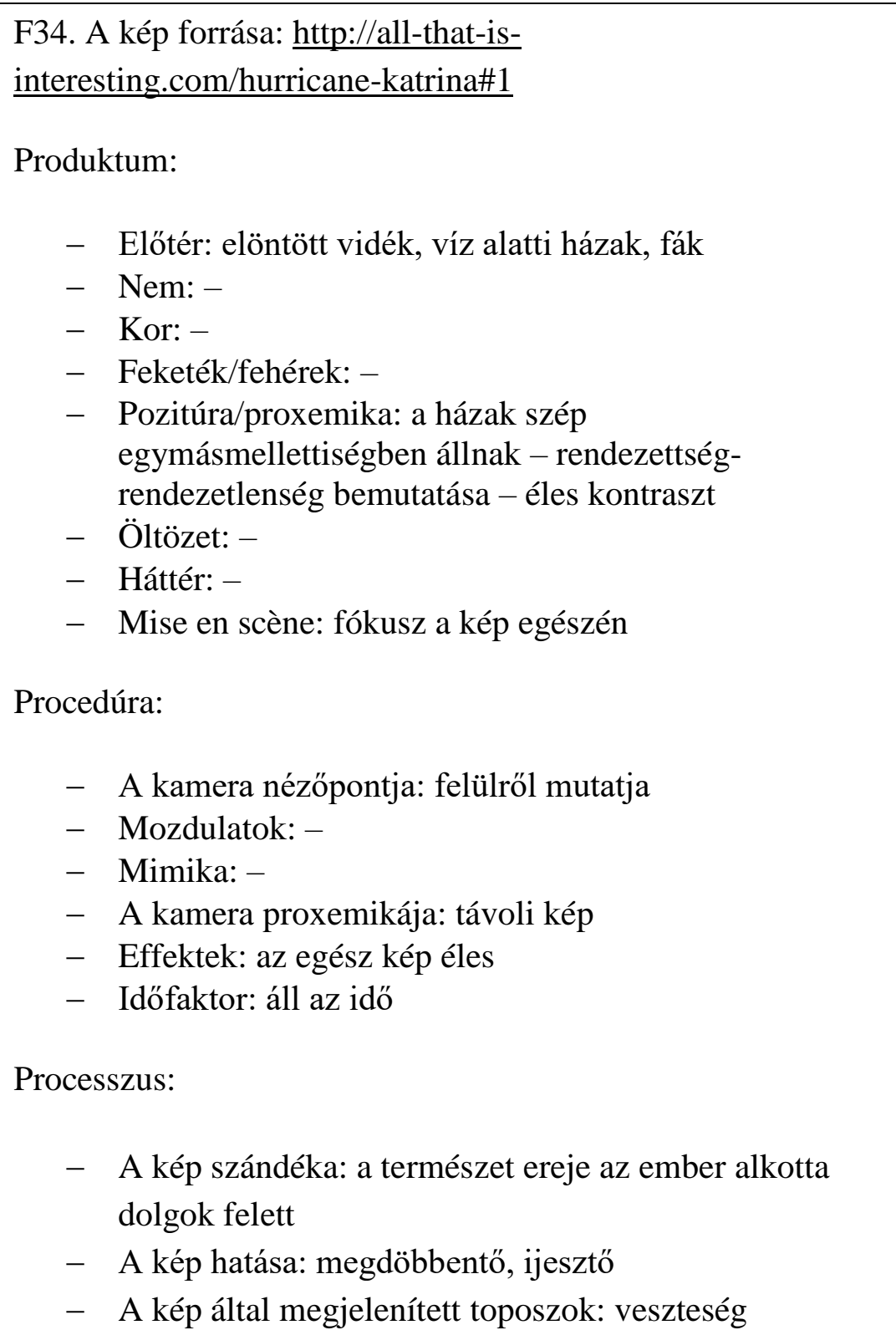 \\
\hline 35 & & $\begin{array}{l}\text { F35. A kép forrása: http://www.origo.hu/nagyvilag/20150828- } \\
\text { katrina-new-orleans-hurrikan-ujjaepites-ray-nagin- } \\
\text { evfordulo.html }\end{array}$ \\
\hline
\end{tabular}




\begin{tabular}{|c|c|}
\hline & 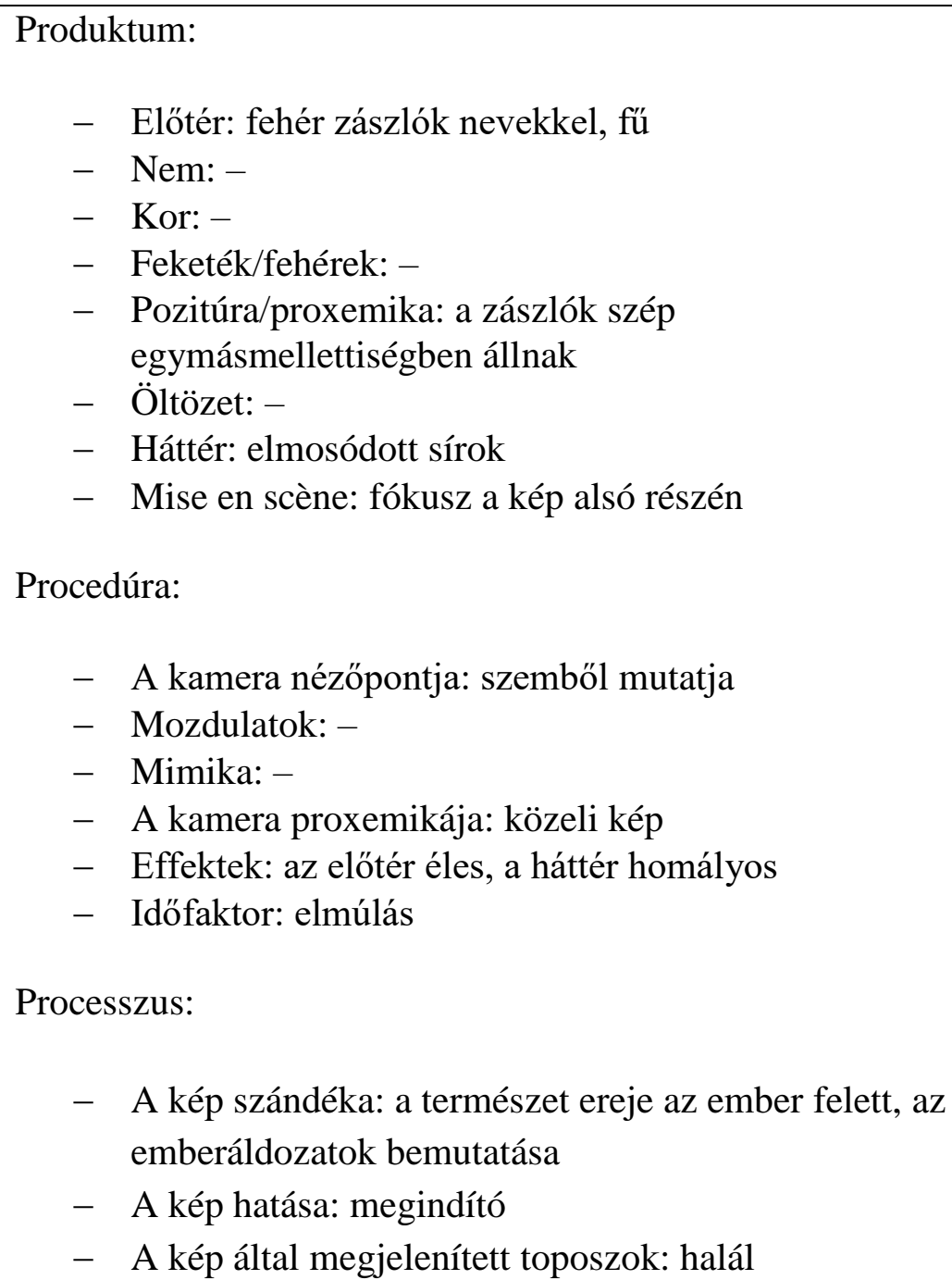 \\
\hline 36. & $\begin{array}{l}\text { F36. A kép forrása: http://all-that-is- } \\
\text { interesting.com/hurricane-katrina\#4 } \\
\text { Produktum: } \\
\text { - Elötér: aszfalt, kavicsos út, bokrok } \\
\text { - Nem: - } \\
\text { - Kor: - } \\
\text { - Feketék/fehérek: - } \\
\text { - Pozitúra/proxemika: az út végén vár a vihar } \\
\text { - Öltözet: - } \\
\text { - Háttér: viharfelhők, sötét éj, szivárvány alakú fények } \\
\text { - Mise en scène: fókusz a kép közepén } \\
\text { Procedúra: }\end{array}$ \\
\hline
\end{tabular}




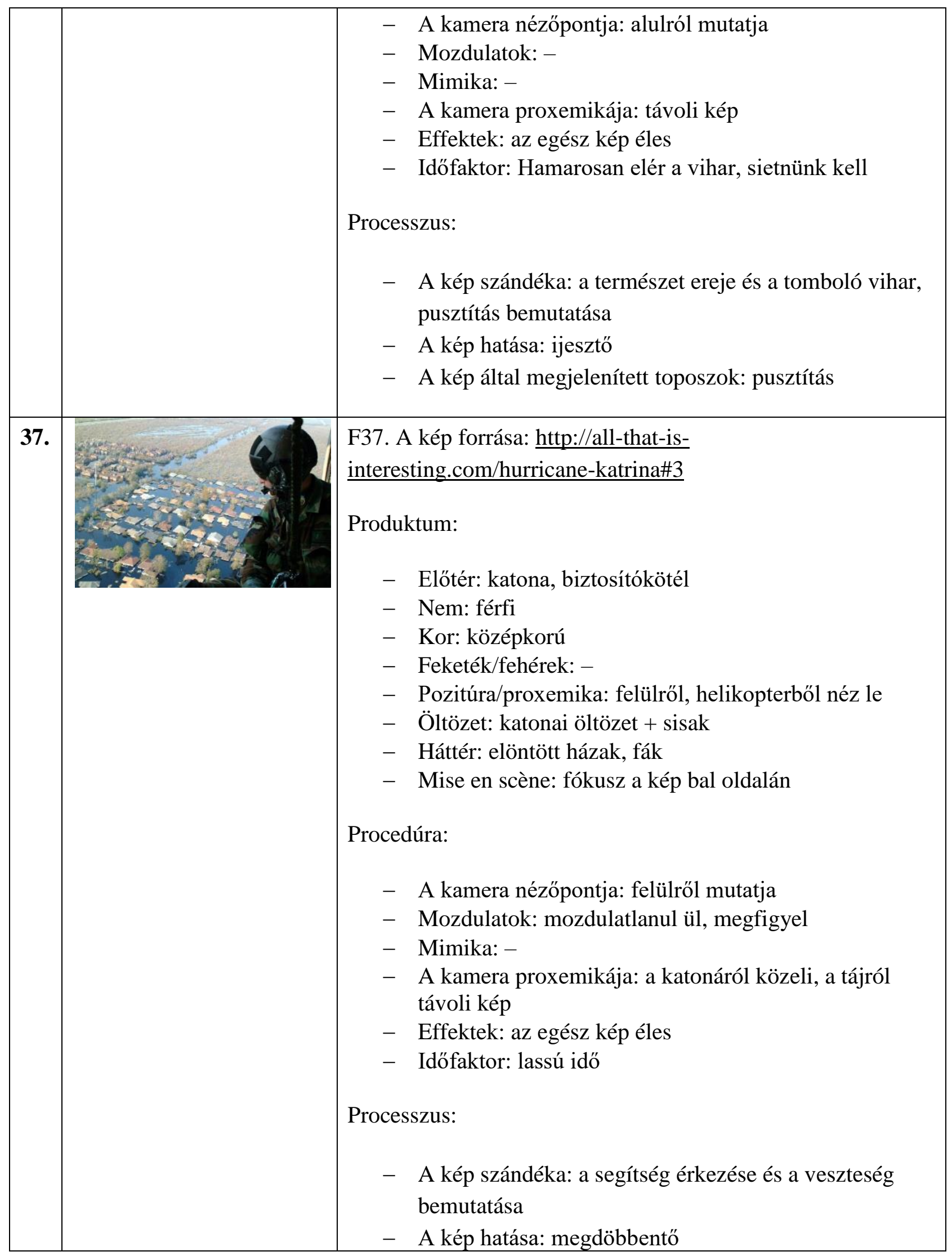




\begin{tabular}{|c|c|c|}
\hline & & - A kép által megjelenített toposzok: veszteség \\
\hline 38. & & 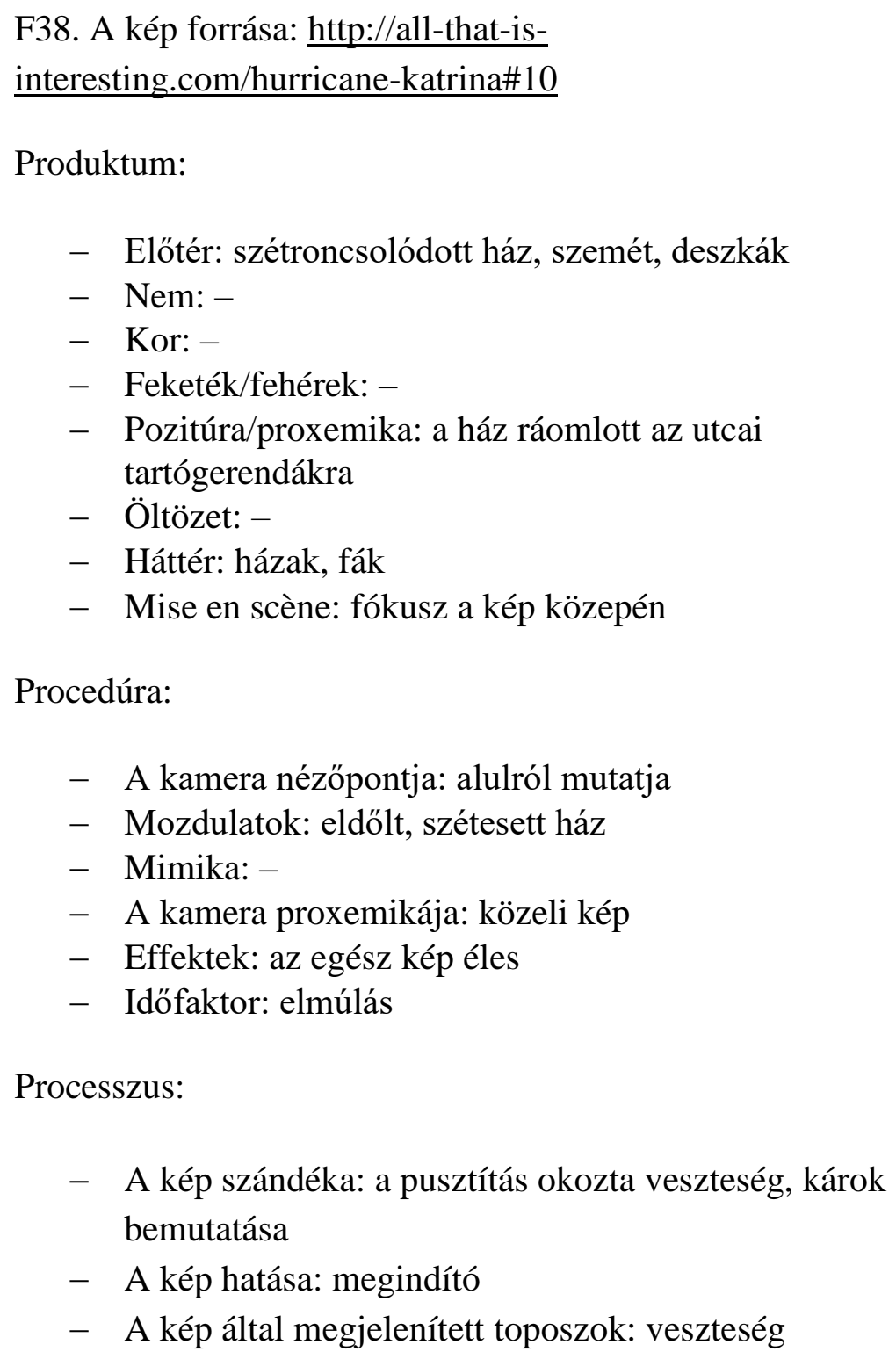 \\
\hline 39. & & $\begin{array}{l}\text { F39. A kép forrása: } \underline{\text { http://all-that-is- }} \\
\text { interesting.com/hurricane-katrina\#6 } \\
\text { Produktum: } \\
\text { - Előtér: } 1 \text { alak, táska, vizesüvegek, olaj, víz } \\
\text { - Nem: nő } \\
\text { - Kor: középkorú } \\
\text { - Feketék/fehérek: fekete } \\
\text { - Pozitúra/proxemika: a vízben félig elmerülve megy }\end{array}$ \\
\hline
\end{tabular}




\begin{tabular}{|c|c|c|}
\hline & & $\begin{array}{l}\text { - Öltözet: hétköznapi } \\
\text { - Háttér: - } \\
\text { - Mise en scène: fókusz a kép közepén } \\
\text { Procedúra: } \\
\text { - } \text { A kamera nézőpontja: felülről mutatja } \\
\text { - Mozdulatok: az értékeit előre tolva próbál haladni a nő } \\
\text { - Mimika: - } \\
\text { - } \text { A kamera proxemikája: távoli kép } \\
\text { - Effektek: az egész kép éles } \\
\text { - } \text { Időfaktor: lassú idő } \\
\text { Processzus: } \\
\text { - A kép szándéka: a túlélők helyzetének és } \\
\text { - } \text { szenvedésének bemutatása } \\
\text { - A kép hatása: megindító, sokkoló } \\
\text { A kép által megjelenített toposzok: szenvedés }\end{array}$ \\
\hline 40. & whets: & 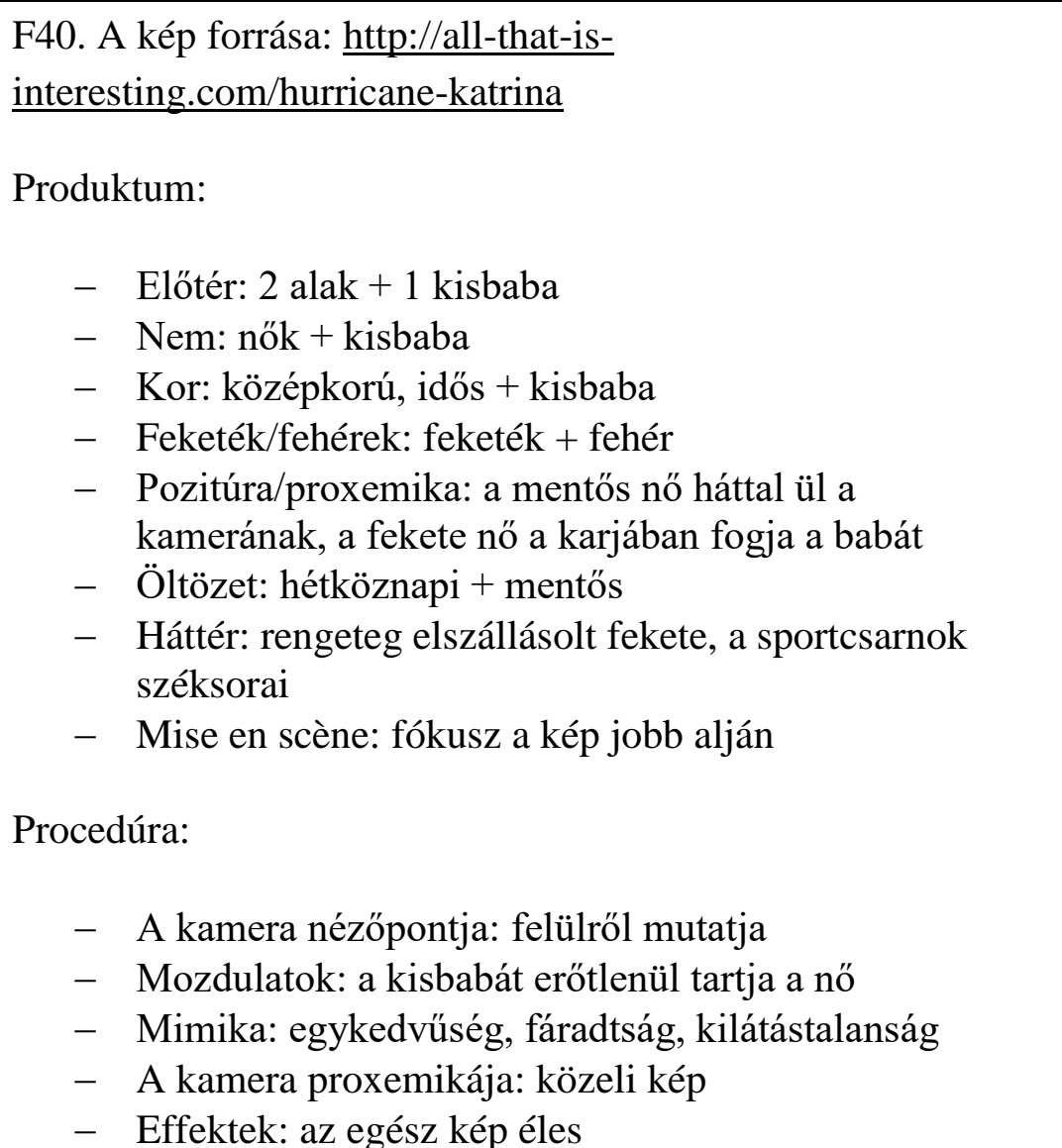 \\
\hline
\end{tabular}




\begin{tabular}{|c|c|c|}
\hline & & $\begin{array}{l}\text { - Időfaktor: lassú, várakozással teli órák, napok, hetek } \\
\text { Processzus: } \\
\text { - A kép szándéka: a túlélök embertelen körülményeinek } \\
\text { bemutatása } \\
\text { - A kép hatása: megindító } \\
\text { - }\end{array}$ \\
\hline 41. & 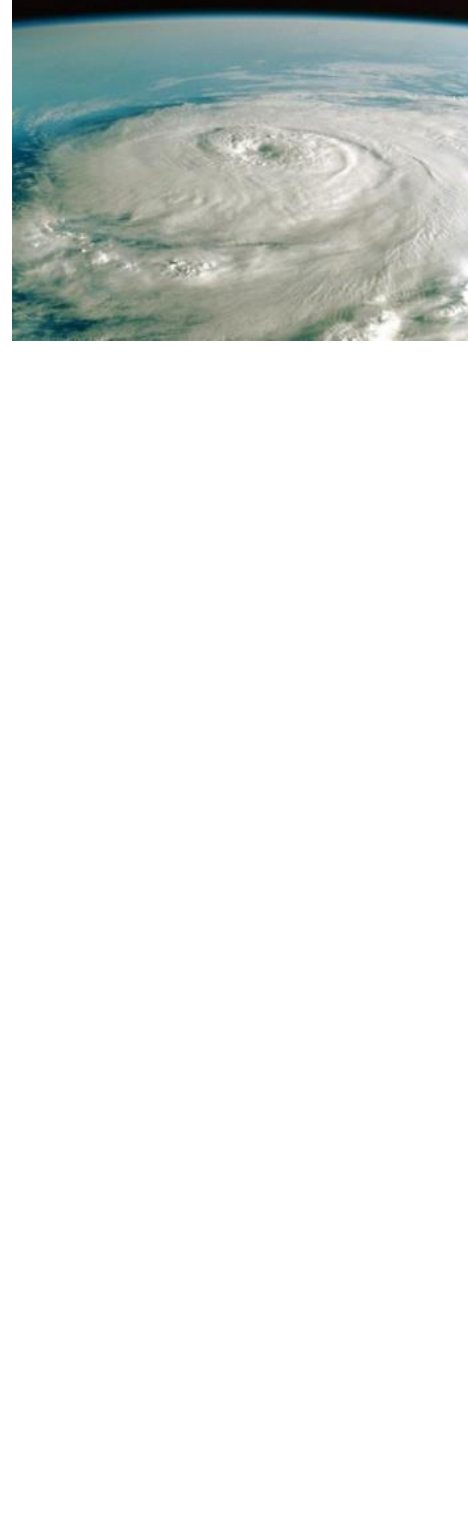 & 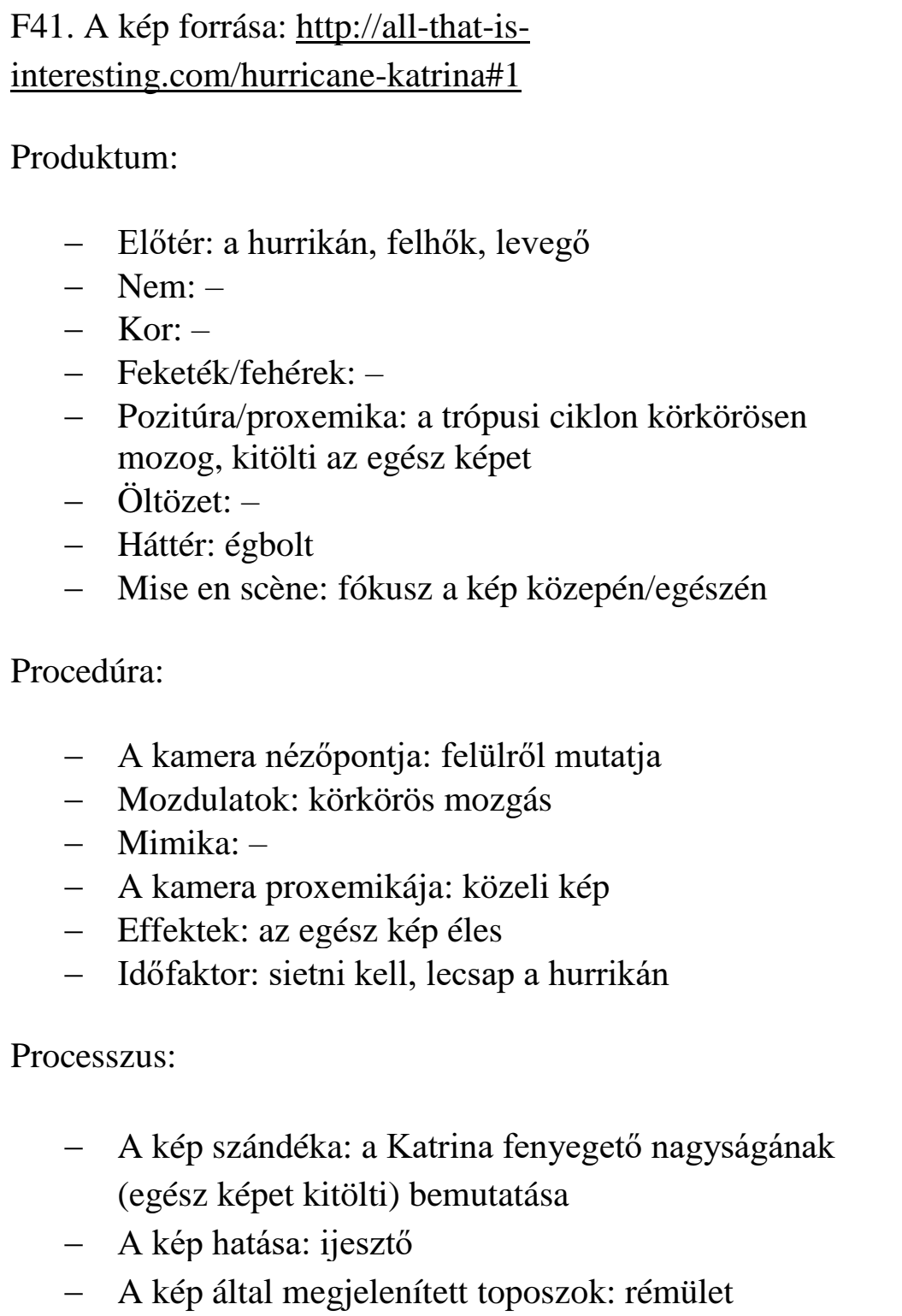 \\
\hline
\end{tabular}




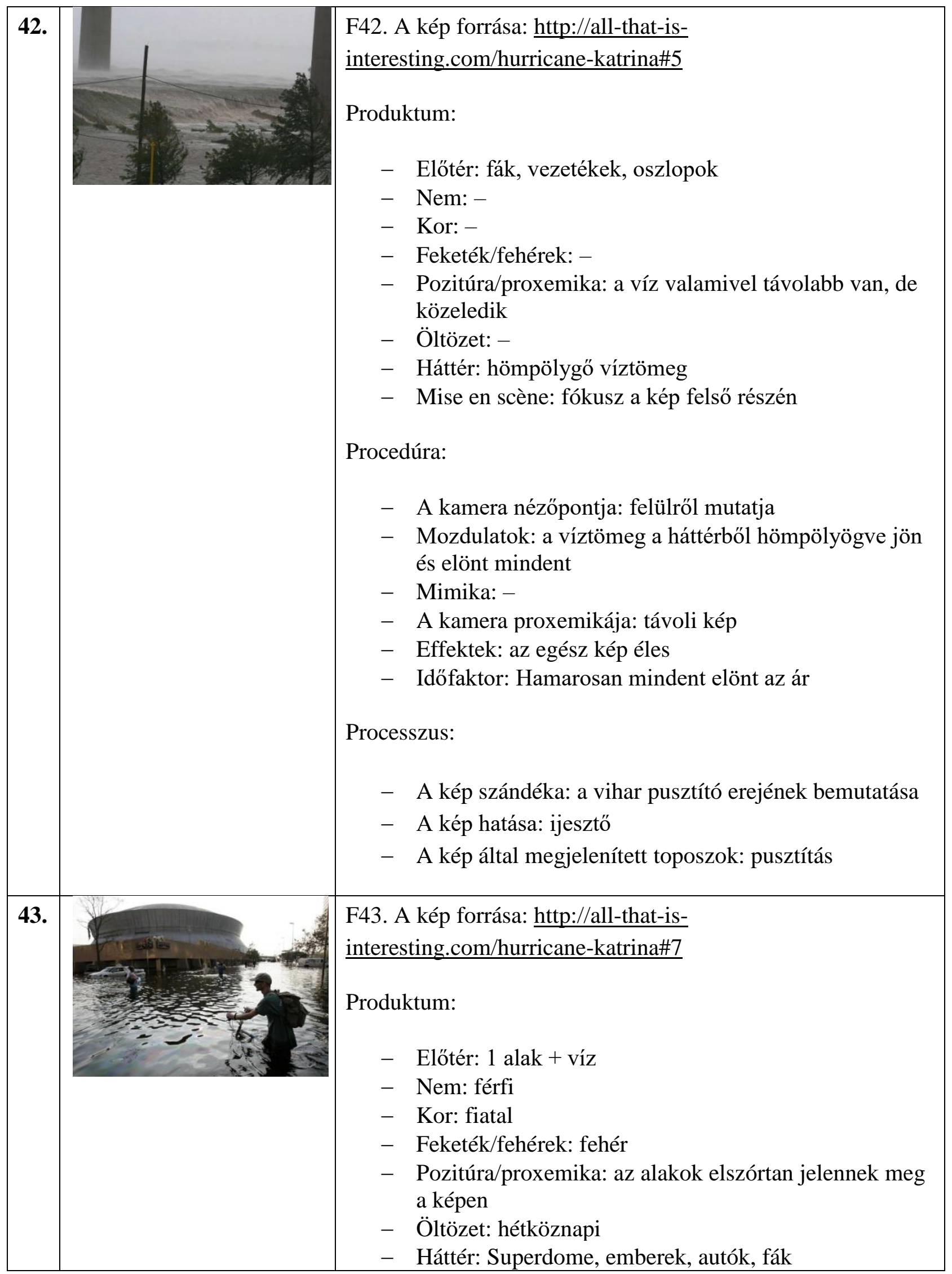




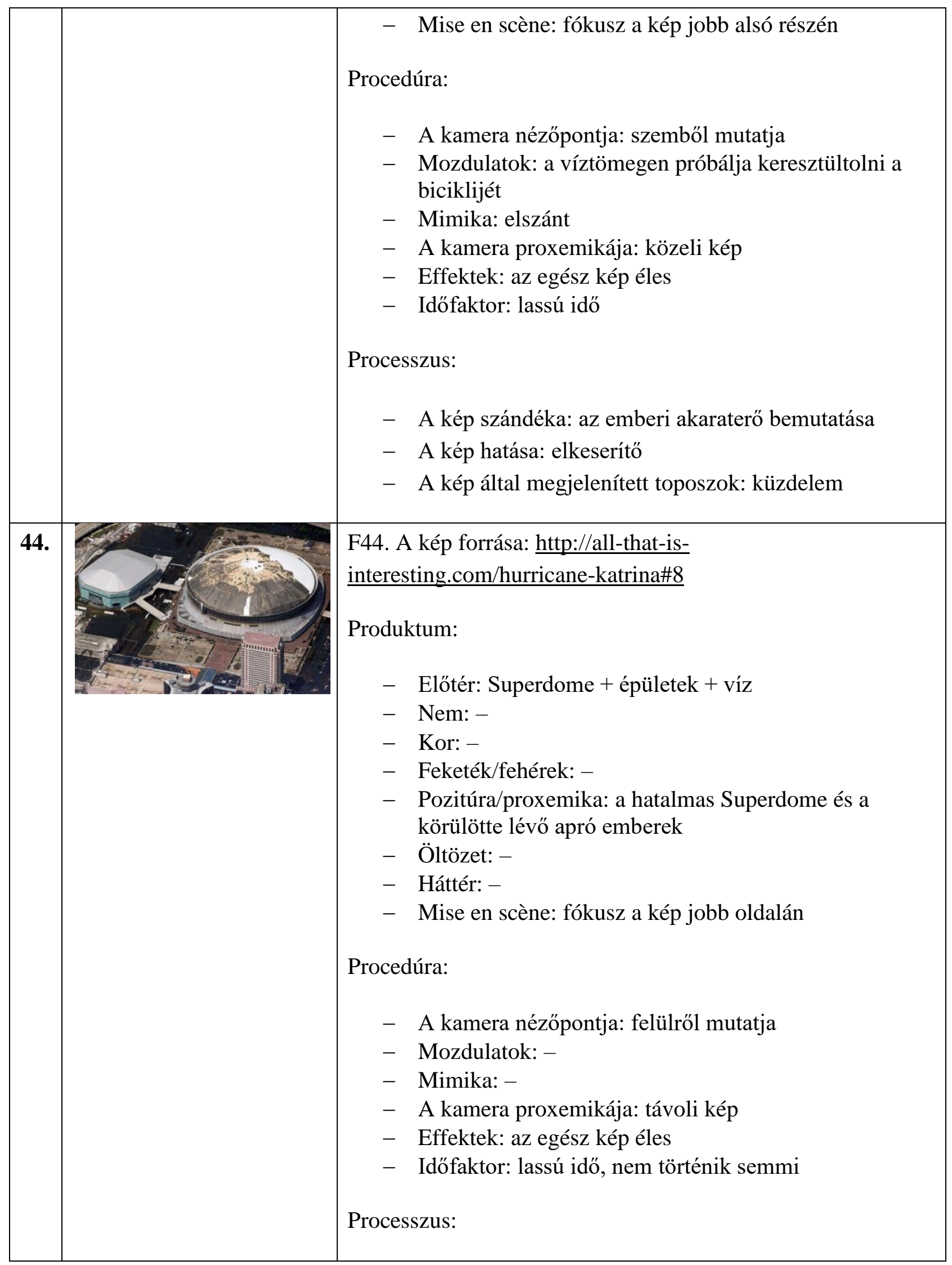




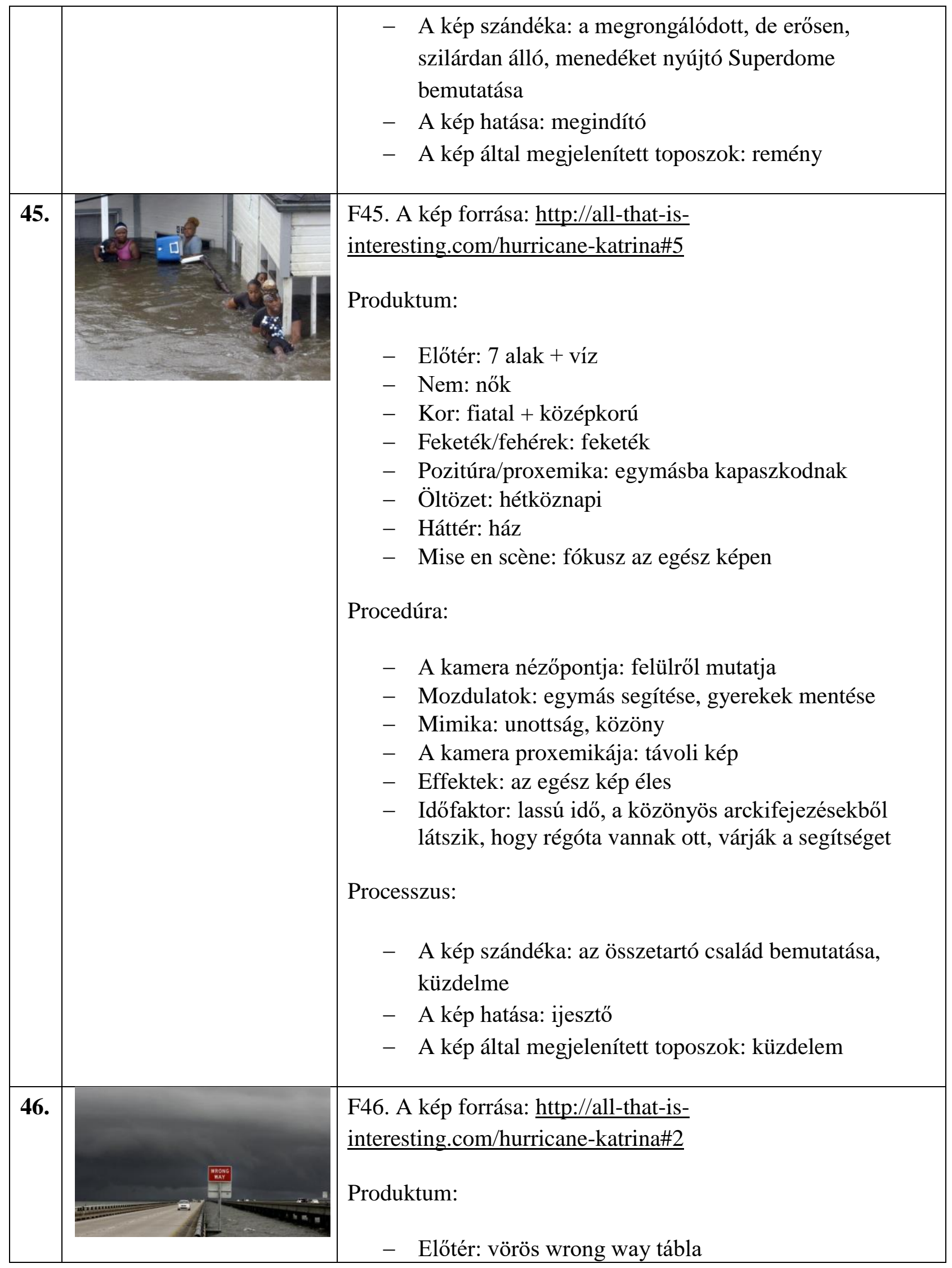




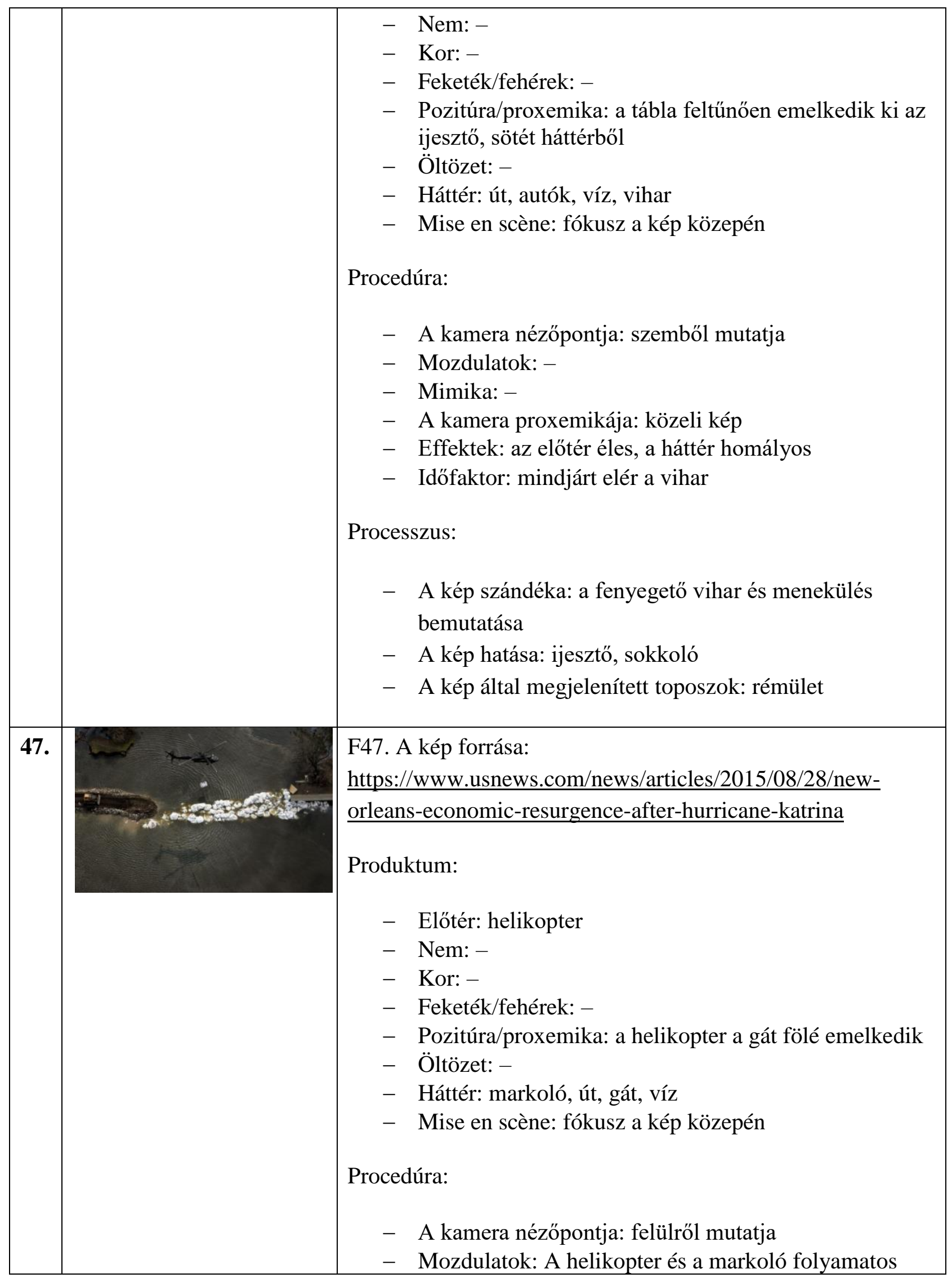




\begin{tabular}{|c|c|}
\hline & $\begin{array}{l}\text { mozgásban van, végzi a helyreállításokat } \\
\text { - } \text { Mimika: - } \\
\text { - } \text { A kamera proxemikája: távoli kép } \\
\text { - } \text { Effektek: az egész kép éles } \\
\text { - } \text { Időfaktor: sietség, aktív építkezés } \\
\text { Processzus: } \\
\text { - A kép szándéka: a mentések és helyreállítások } \\
\text { - } \text { } \text { A kemutatás hatása: megnyugtató } \\
\text { - } \text { A kép által megjelenített toposzok: remény }\end{array}$ \\
\hline 48. & $\begin{array}{l}\text { F48. A kép forrása: } \\
\text { https://www.usnews.com/news/articles/2015/08/28/new- } \\
\text { orleans-economic-resurgence-after-hurricane-katrina } \\
\text { Produktum: } \\
\text { - Előtér: } 1 \text { alak } \\
\text { - Nem: nő } \\
\text { - Kor: fiatal } \\
\text { - Feketék/fehérek: fekete } \\
\text { - Pozitúra/proxemika: nagyon közel a kamerához } \\
\text { - Öltözet: - } \\
\text { - Háttér: - } \\
\text { - Mise en scène: fókusz az egész képen } \\
\text { Procedúra: } \\
\text { - A kamera nézőpontja: szemből mutatja } \\
\text { - Mozdulatok: - } \\
\text { - Mimika: fájdalom, szenvedés, veszteség } \\
\text { - A kamera proxemikája: nagyközeli kép } \\
\text { - Effektek: az egész kép éles } \\
\text { - Időfaktor: lassú, fájdalmas időszak } \\
\text { Processzus: }\end{array}$ \\
\hline
\end{tabular}




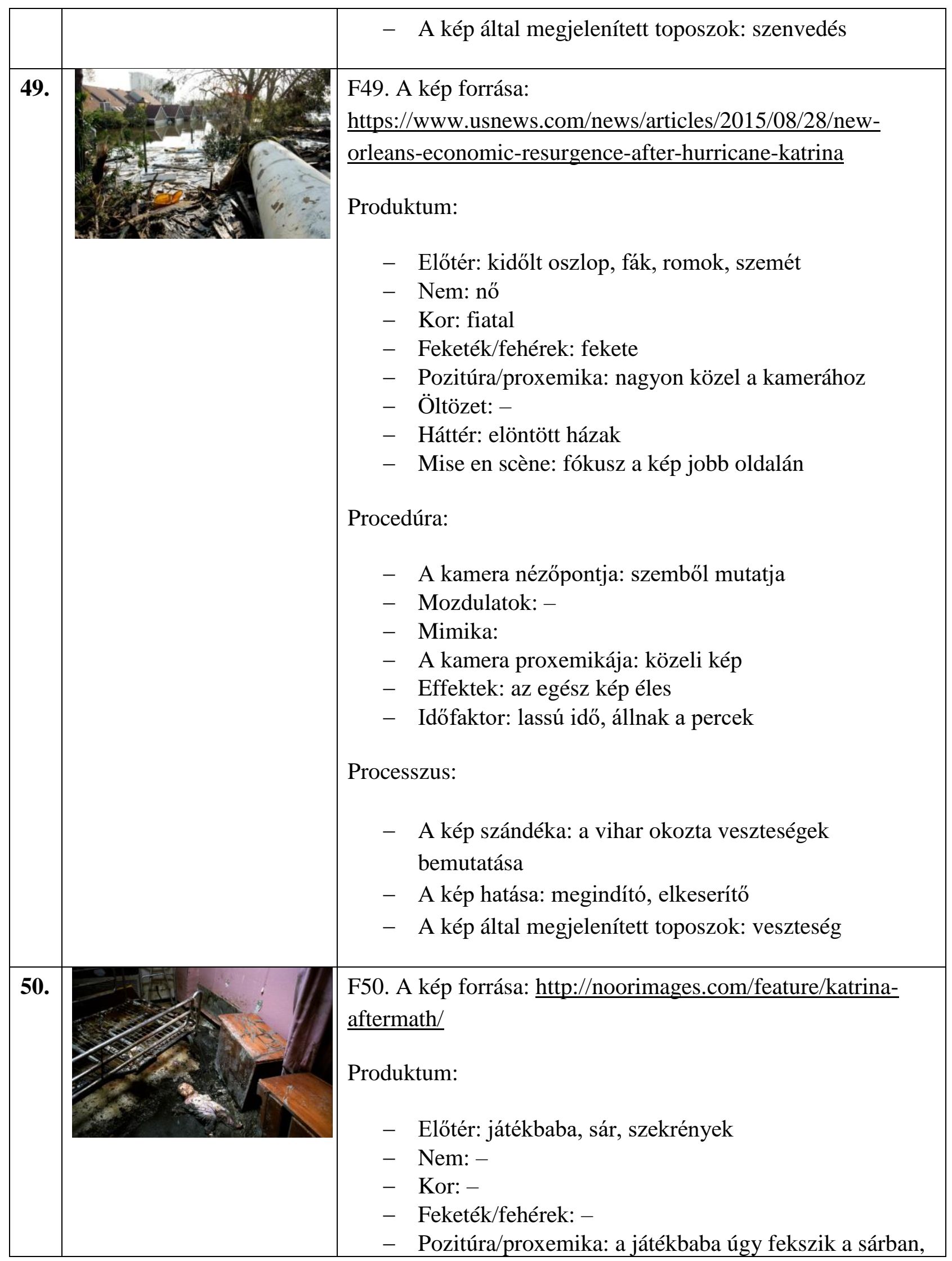




\begin{tabular}{|c|c|c|}
\hline & & $\begin{array}{l}\text { mint egy halott csecsemő } \\
\text { - Öltözet: rugdalózó } \\
\text { - } \text { Háttér: ágykeret, összecsukott szék, kosz } \\
\text { - } \text { Mise en scène: fókusz a kép alján } \\
\text { Procedúra: } \\
\text { - A kamera nézőpontja: felülről mutatja } \\
\text { - Mozdulatok: szétálló végtagok } \\
\text { - Mimika: kifejezéstelen arc } \\
\text { - A kamera proxemikája: közeli kép } \\
\text { - } \text { Effektek: az egész kép éles } \\
\text { - Időfaktor: áll az idő } \\
\text { Processzus: } \\
\text { - A kép szándéka: a játékbaba halott csecsemő } \\
\\
\text { - benyomását kelti } \\
\text { - A kép hatása: ijesztő, sokkoló } \\
\text { A kép által megjelenített toposzok: rémület }\end{array}$ \\
\hline 51. & 12 & $\begin{array}{l}\text { F51. A kép forrása: } \\
\text { https://www.usnews.com/news/articles/2015/08/28/new- } \\
\text { orleans-economic-resurgence-after-hurricane-katrina } \\
\text { Produktum: } \\
\text { - Előtér: } 9 \text { alak, autó } \\
\text { - Nem: férfiak + nők } \\
\text { - Kor: középkorú } \\
\text { - Feketék/fehérek: fehérek + } 1 \text { fekete } \\
\text { - Pozitúra/proxemika: szorosan állnak az autó tetején } \\
\text { - Öltözet: hétköznapi } \\
\text { - Háttér: romok, leszakadt vezetékek, házak } \\
\text { - Mise en scène: fókusz a kép közepén } \\
\text { Procedúra: } \\
\text { - A kamera nézőpontja: szemből mutatja } \\
\text { - Mozdulatok: lehajolnak a leszakadt vezetékek elöl, az } \\
\text { - } \text { Mgyik alak int } \\
\text { - A kamera proxemikája: távoli kép } \\
\text { - Effektek: az egész kép éles }\end{array}$ \\
\hline
\end{tabular}




\begin{tabular}{|c|c|}
\hline & $\begin{array}{l}\text { — Időfaktor: sietség } \\
\text { Processzus: } \\
\text { - A kép szándéka: a kormány segítő szándékának } \\
\text { bemutatása } \\
\text { - A kép hatása: remény a segítségre } \\
\text { - A kép által megjelenített toposzok: remény }\end{array}$ \\
\hline 52. & 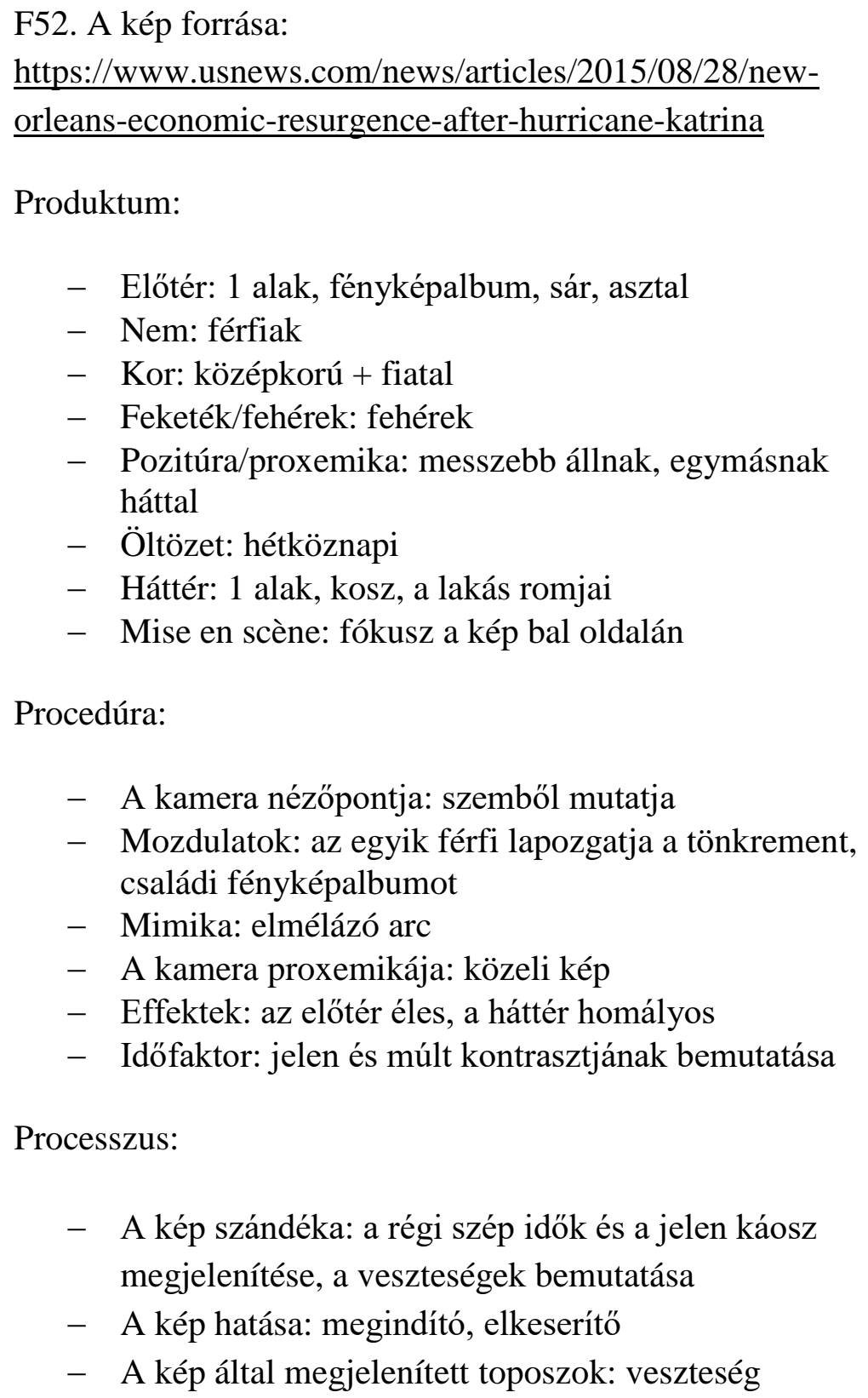 \\
\hline
\end{tabular}




\begin{tabular}{|c|c|c|}
\hline 53. & $E$ & 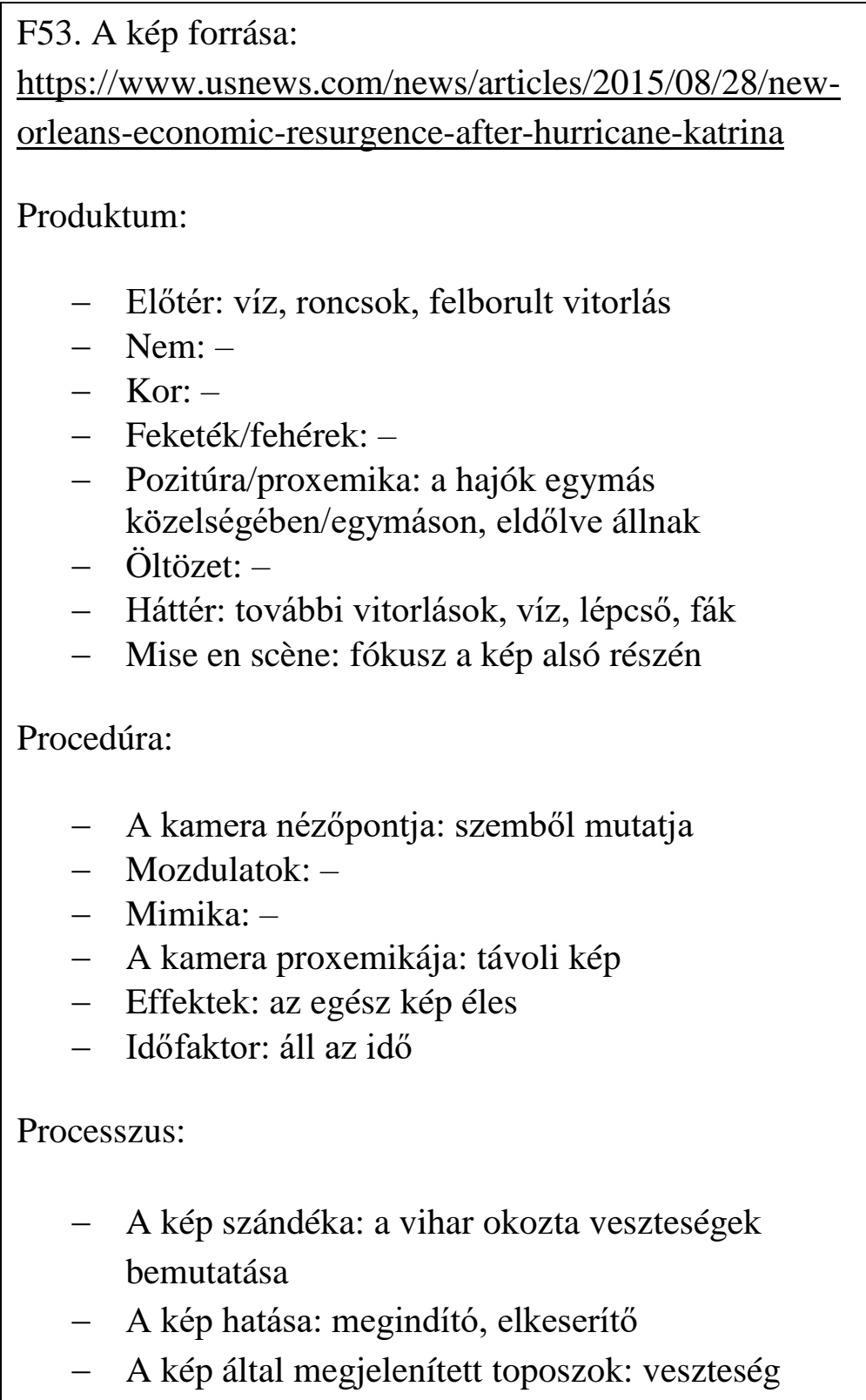 \\
\hline 54. & $\frac{1}{3} \mathrm{y} \frac{3}{5}$ & $\begin{array}{l}\text { F54. A kép forrása: http://noorimages.com/feature/katrina- } \\
\text { aftermath/ } \\
\text { Produktum: } \\
\text { - Elötér: parafatáblán Krisztus kép, feszületek, } \\
\text { fényképek } \\
\text { - Nem: - } \\
\text { - } \text { Kor: - } \\
\text { - Feketék/fehérek: - } \\
\text { - Pozitúra/proxemika: a képek, keresztek egymás }\end{array}$ \\
\hline
\end{tabular}




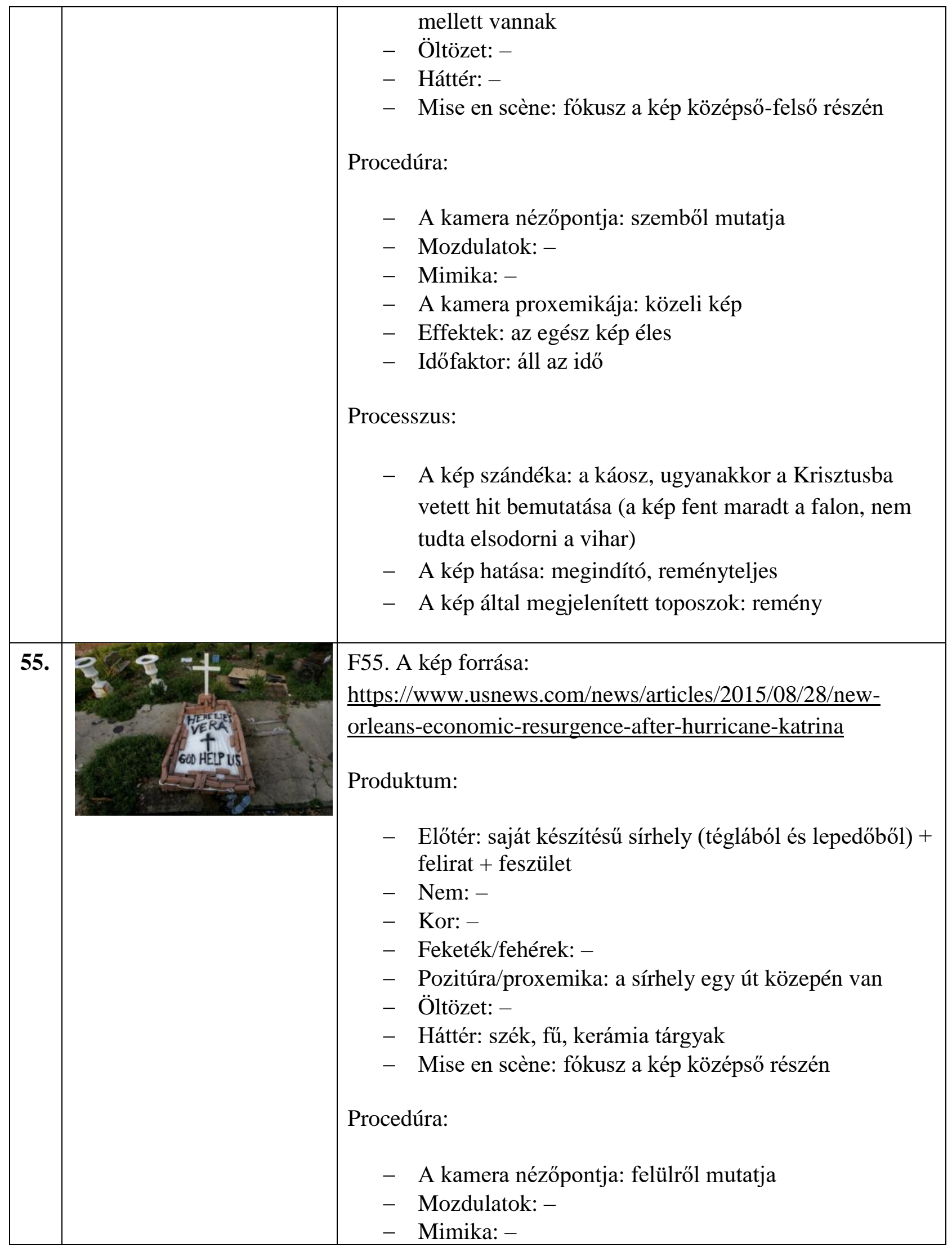




\begin{tabular}{|c|c|}
\hline & $\begin{array}{l}\text { - A kamera proxemikája: közeli kép } \\
\text { - Effektek: az egész kép éles } \\
\text { - } \text { Időfaktor: az elmúlás bemutatása } \\
\text { Processzus: } \\
\text { - A kép szándéka: a fájdalom, a szenvedés, a halál } \\
\quad \text { bemutatása } \\
\text { - A kép hatása: megindító } \\
\text { - A kép által megjelenített toposzok: halál }\end{array}$ \\
\hline 56. & $\begin{array}{l}\text { F56. A kép forrása: } \\
\text { http://www.latimes.com/nation/nationnow/la-na-new-orleans- } \\
\text { hurricane-katrina-suits-20161219-story.html } \\
\text { Produktum: } \\
\text { - Elötér: } 1 \text { alak, játék mackó, gerendák } \\
\text { - Nem: fiú } \\
\text { - Kor: kisgyerek } \\
\text { - Feketék/fehérek: fehér } \\
\text { - Pozitúra/proxemika: egy fa deszka tetején ül } \\
\text { - Öltözet: félmeztelen } \\
\text { - Háttér: roncsok, deszkák, ajtókeret } \\
\text { - Mise en scène: fókusz a kép középső részén } \\
\text { Procedúra: } \\
\text { - A kamera nézőpontja: szemből mutatja } \\
\text { - Mozdulatok: a kisfiú a fejét fogja } \\
\text { - Mimika: elkeseredettség } \\
\text { - A kamera proxemikája: közeli kép } \\
\text { - Effektek: az egész kép éles } \\
\text { - Időfaktor: a jelen elkeserítỏ állapota, a múlt } \\
\text { visszasírása } \\
\text { Processzus: } \\
\text { - A kép szándéka: a gyermeki fájdalom, kétségbeesés, } \\
\text { - } \text { bemutatása } \\
\text { - A kép hatása: megindító } \\
\text { A kép által megjelenített toposzok: szenvedés }\end{array}$ \\
\hline
\end{tabular}




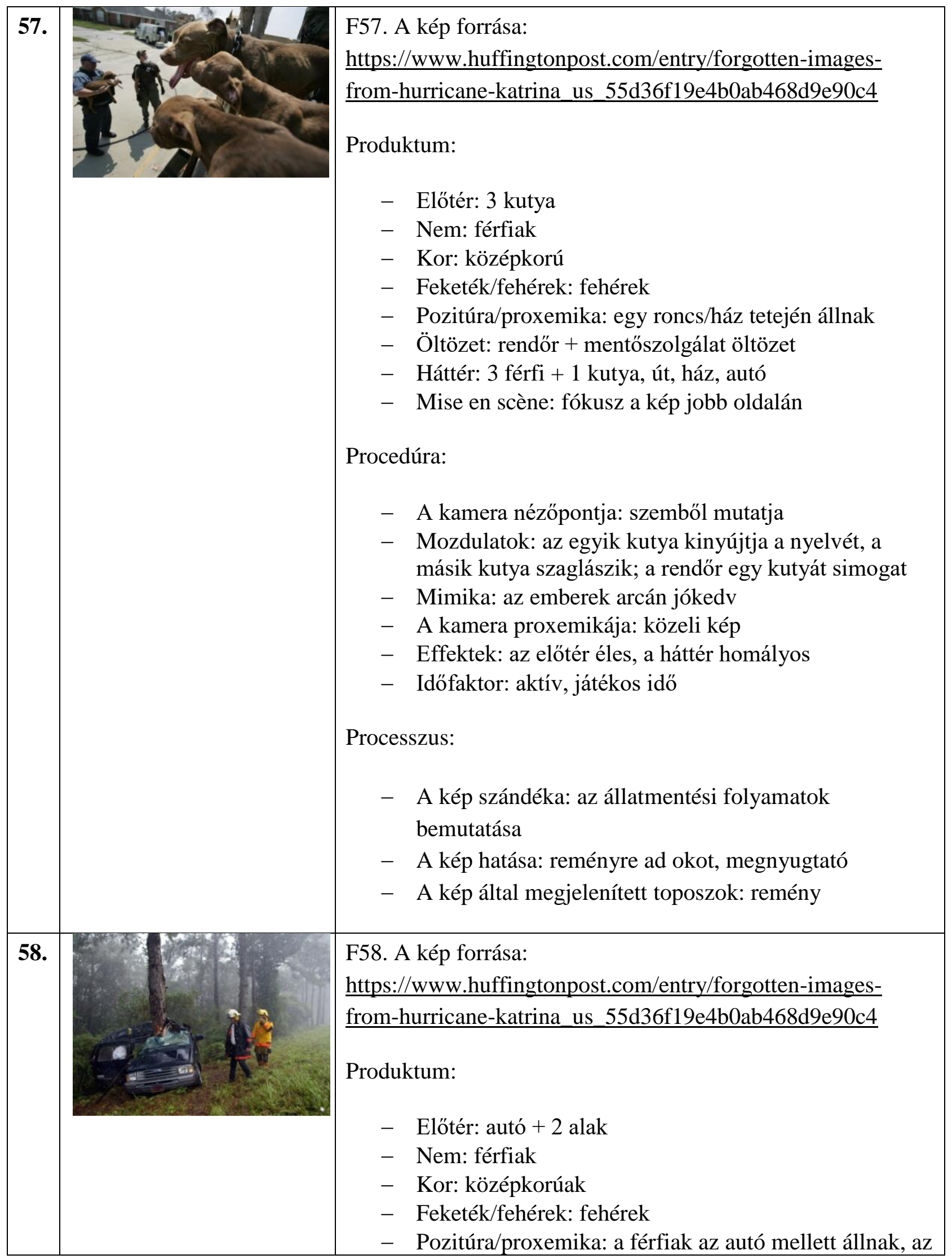




\begin{tabular}{|c|c|}
\hline & 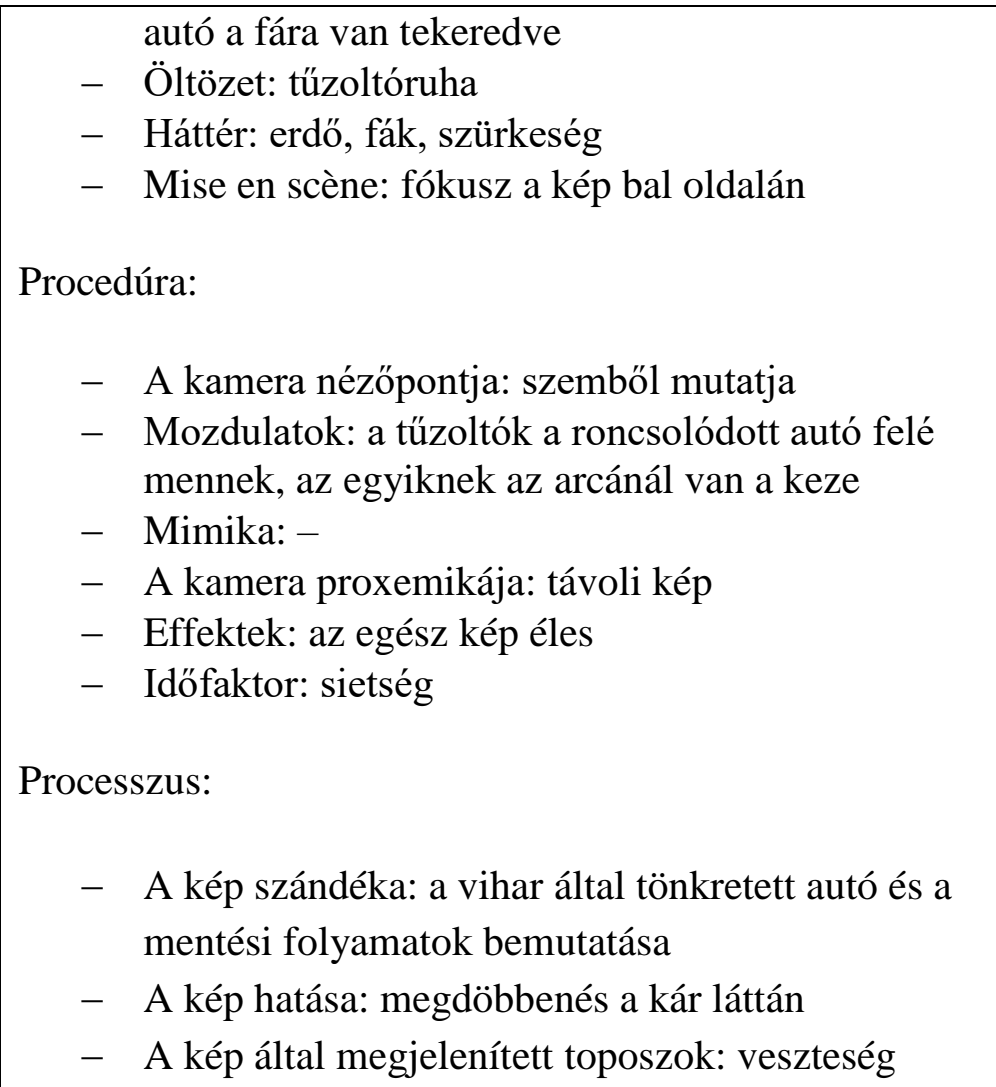 \\
\hline 59 & 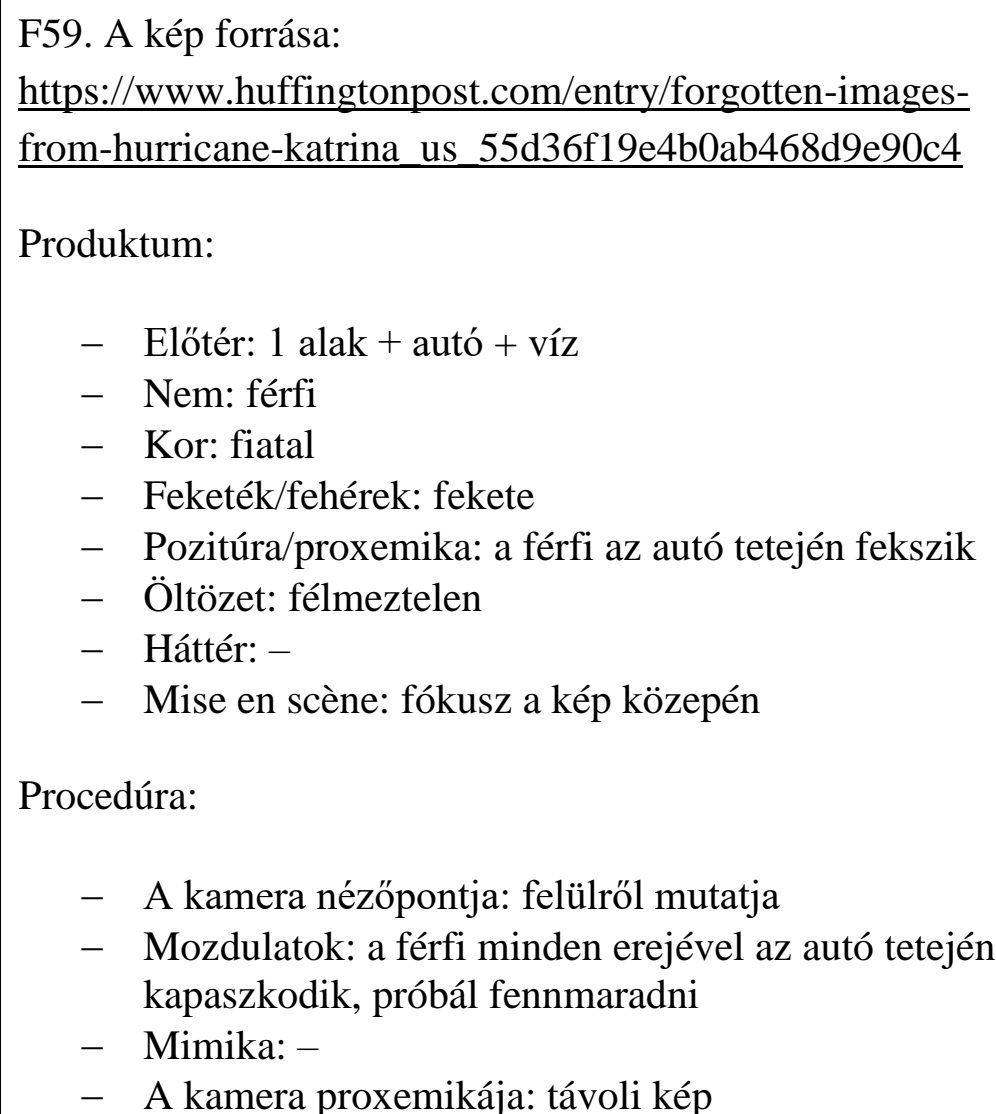 \\
\hline
\end{tabular}




\begin{tabular}{|c|c|}
\hline & $\begin{array}{l}\text { - } \text { Effektek: az egész kép éles } \\
\text { - } \text { Időfaktor: sietség } \\
\text { Processzus: } \\
\text { - } \\
\quad \text { A kép szándéka: az árral szembeni küzdelem } \\
\text { - } \\
\text { A kép hatása: ijesztő, sokkoló } \\
\text { - }\end{array}$ \\
\hline 60. & 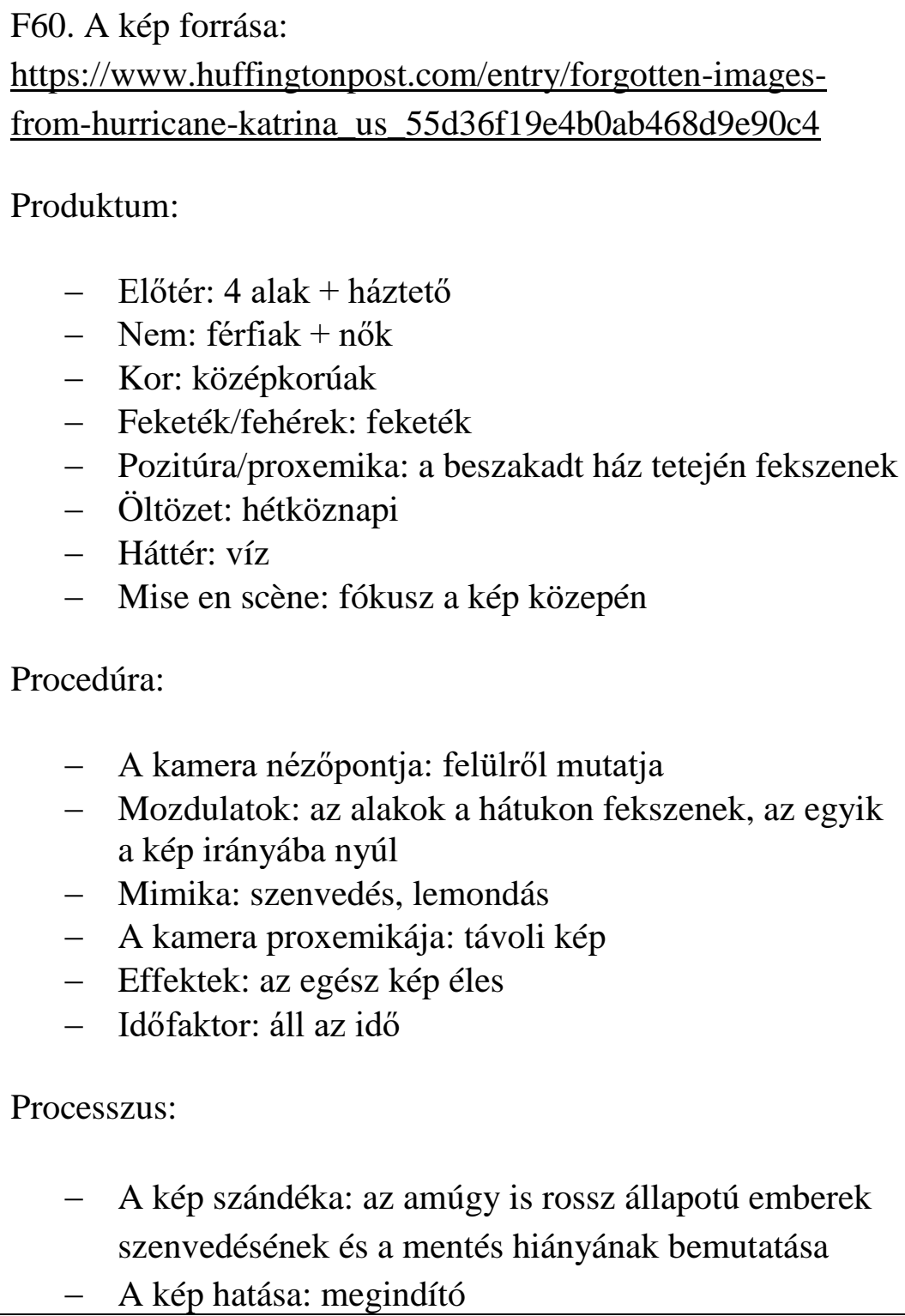 \\
\hline
\end{tabular}




\begin{tabular}{|c|c|}
\hline & - A kép által megjelenített toposzok: szenvedés \\
\hline 61. & 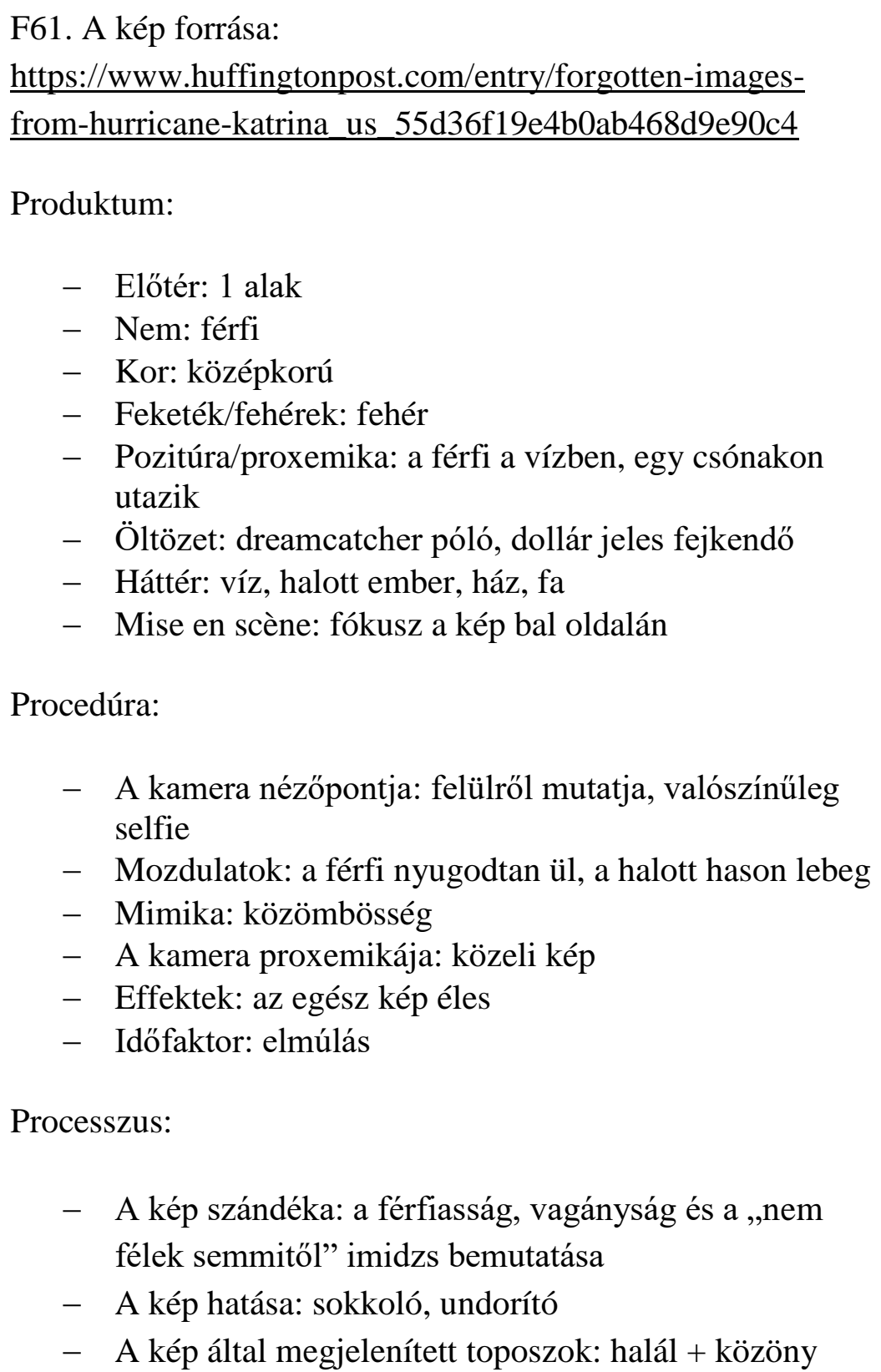 \\
\hline
\end{tabular}




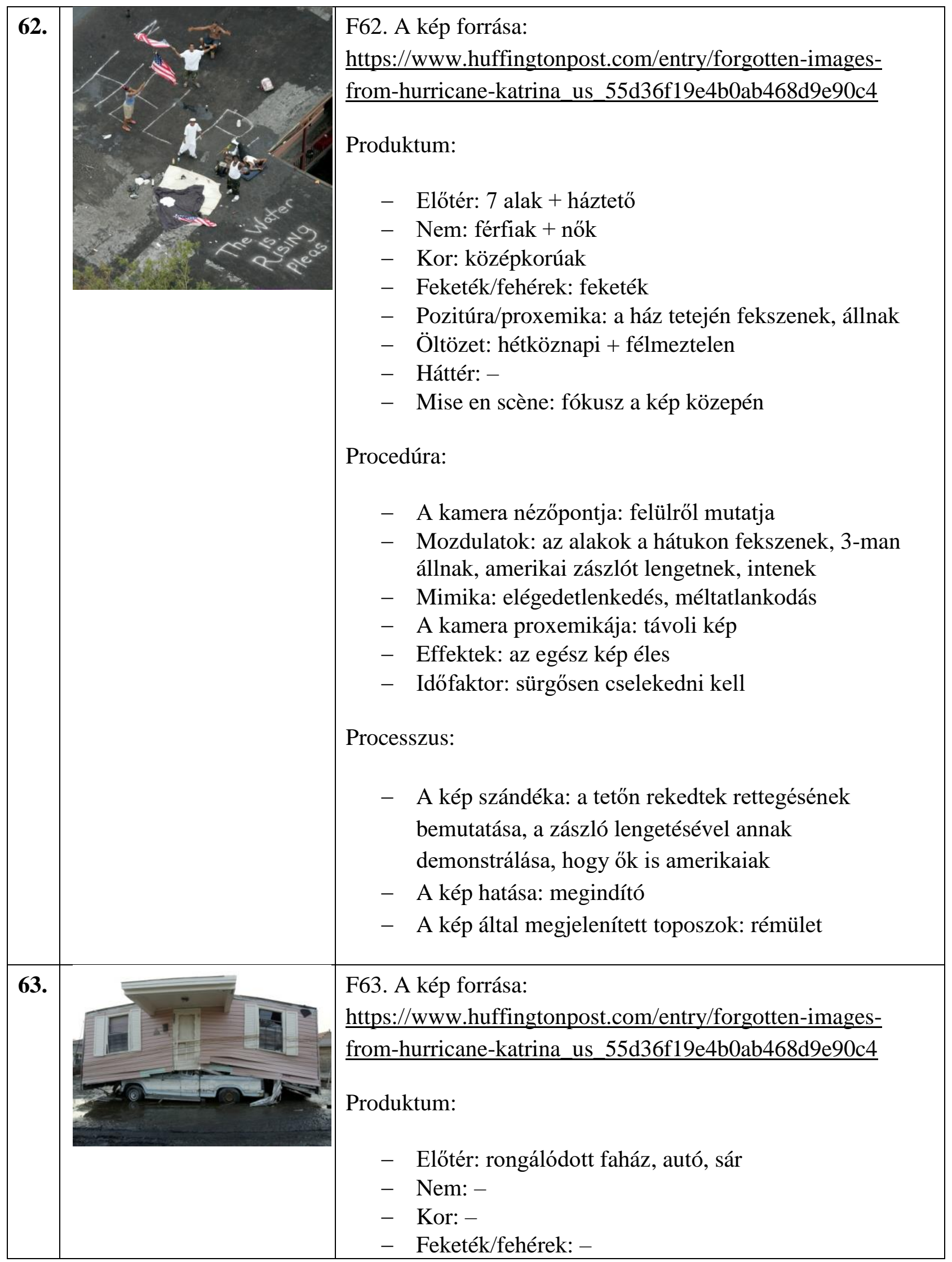




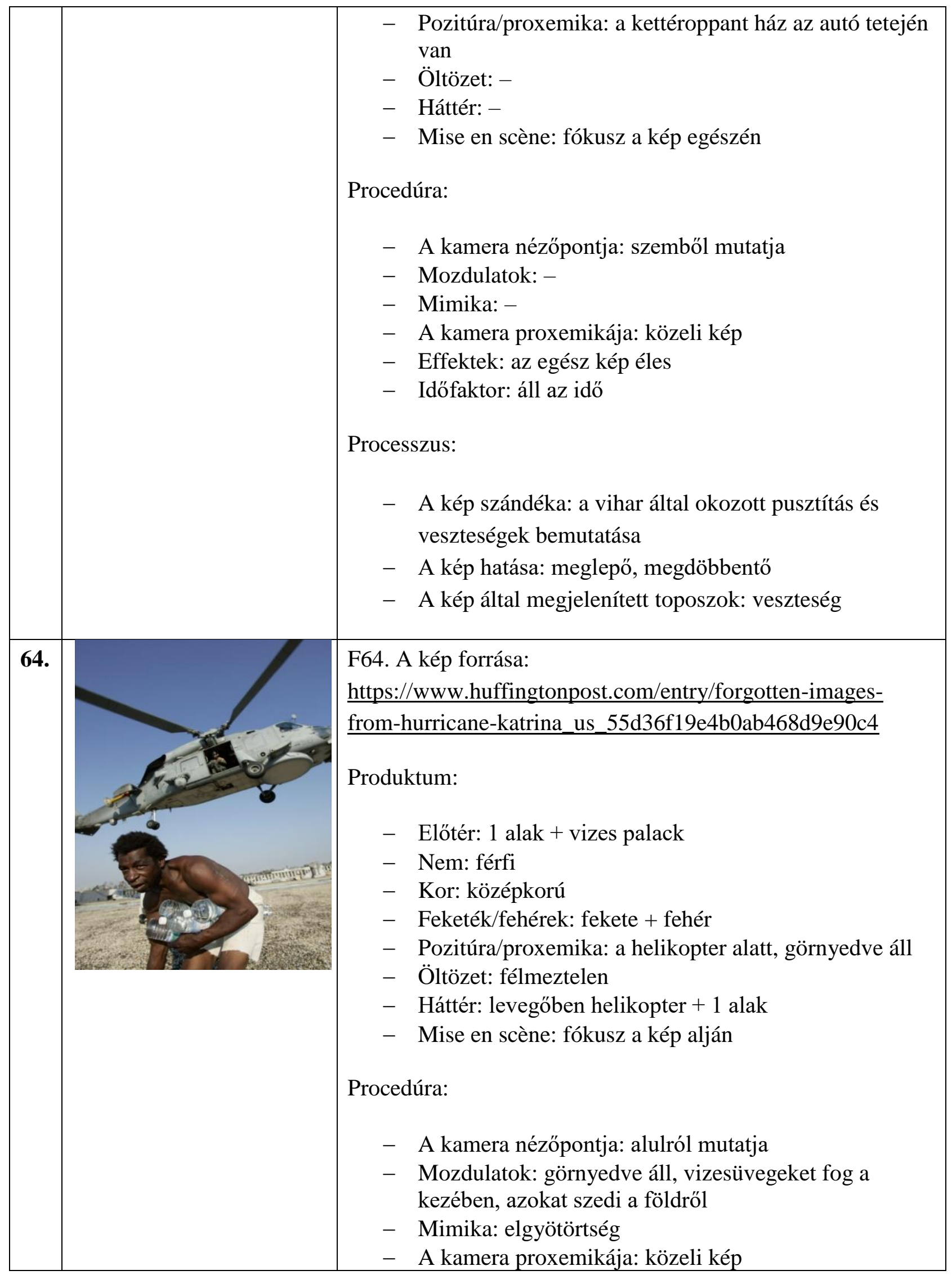




\begin{tabular}{|c|c|c|}
\hline & & $\begin{array}{l}\text { - Effektek: az előtér éles, a háttér homályos } \\
\text { - } \text { Időfaktor: hirtelen kell cselekedni, most van itt a } \\
\text { lehetőség, hogy vízhez jusson } \\
\text { Processzus: } \\
\text { - A kép szándéka: az emberek túlélésért megtett } \\
\quad \text { törekvései, kínjai } \\
\text { - A kép hatása: megindító } \\
\text { - } \text { A kép által megjelenített toposzok: küzdelem }\end{array}$ \\
\hline 65. & & 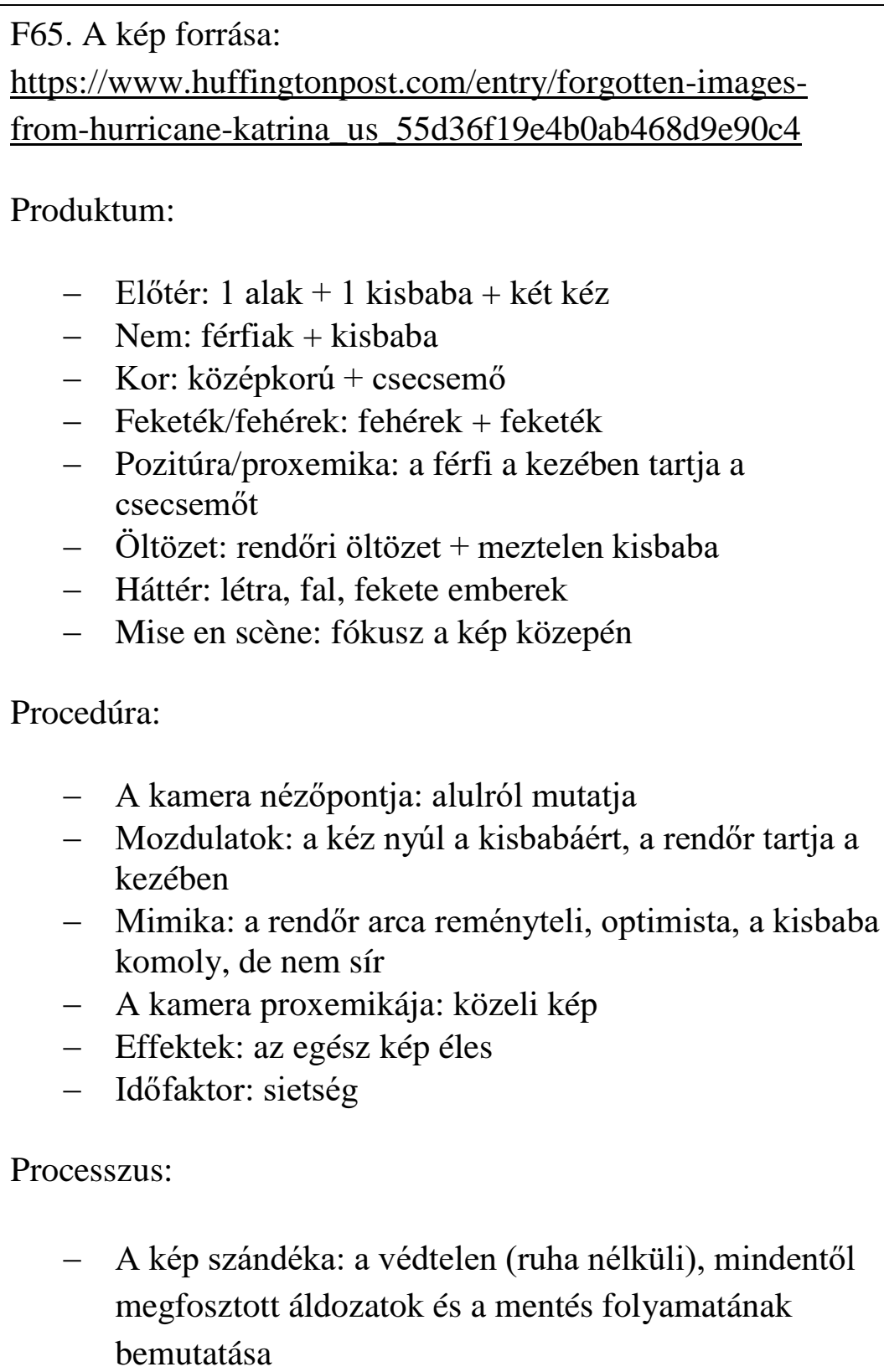 \\
\hline
\end{tabular}




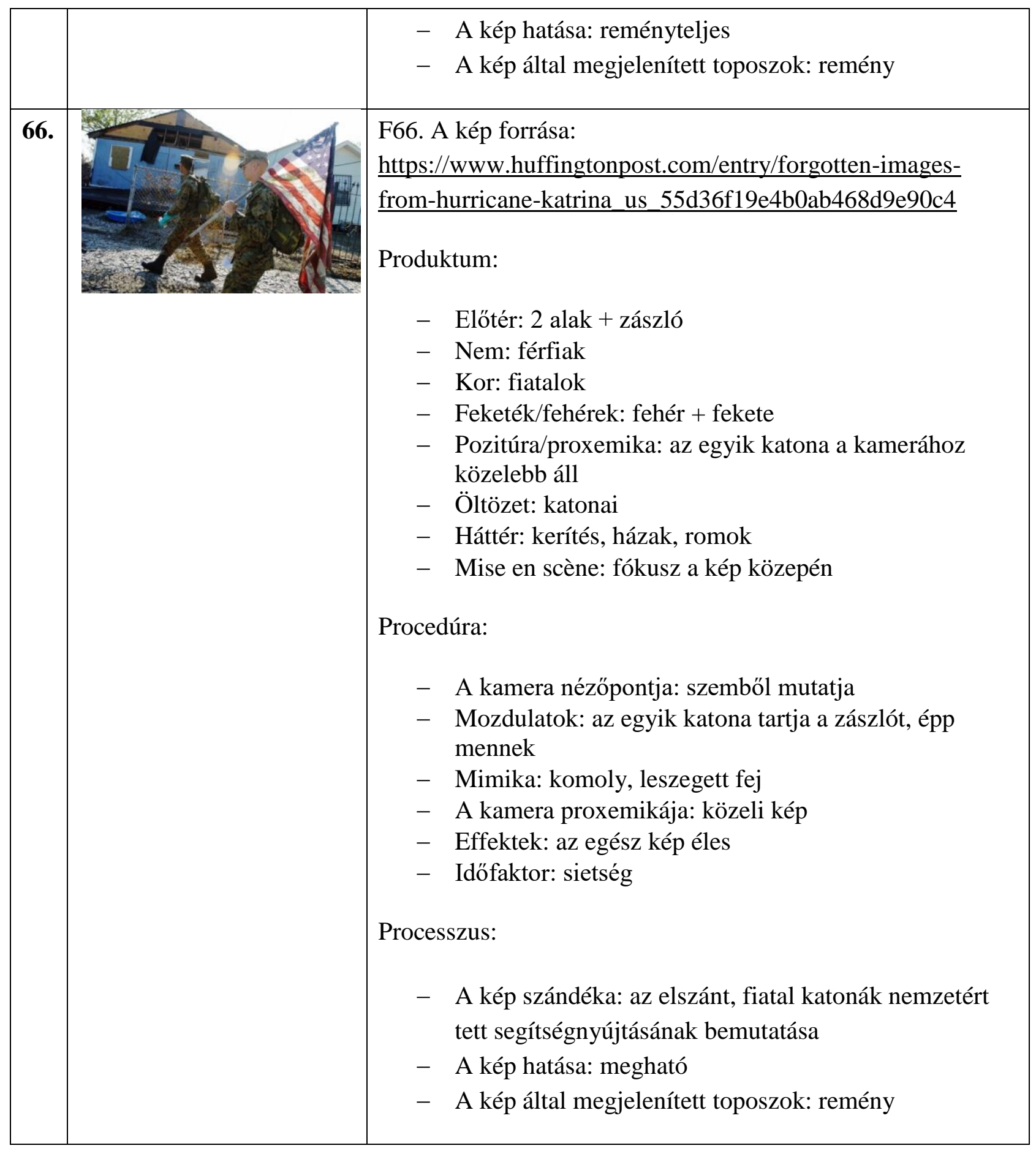




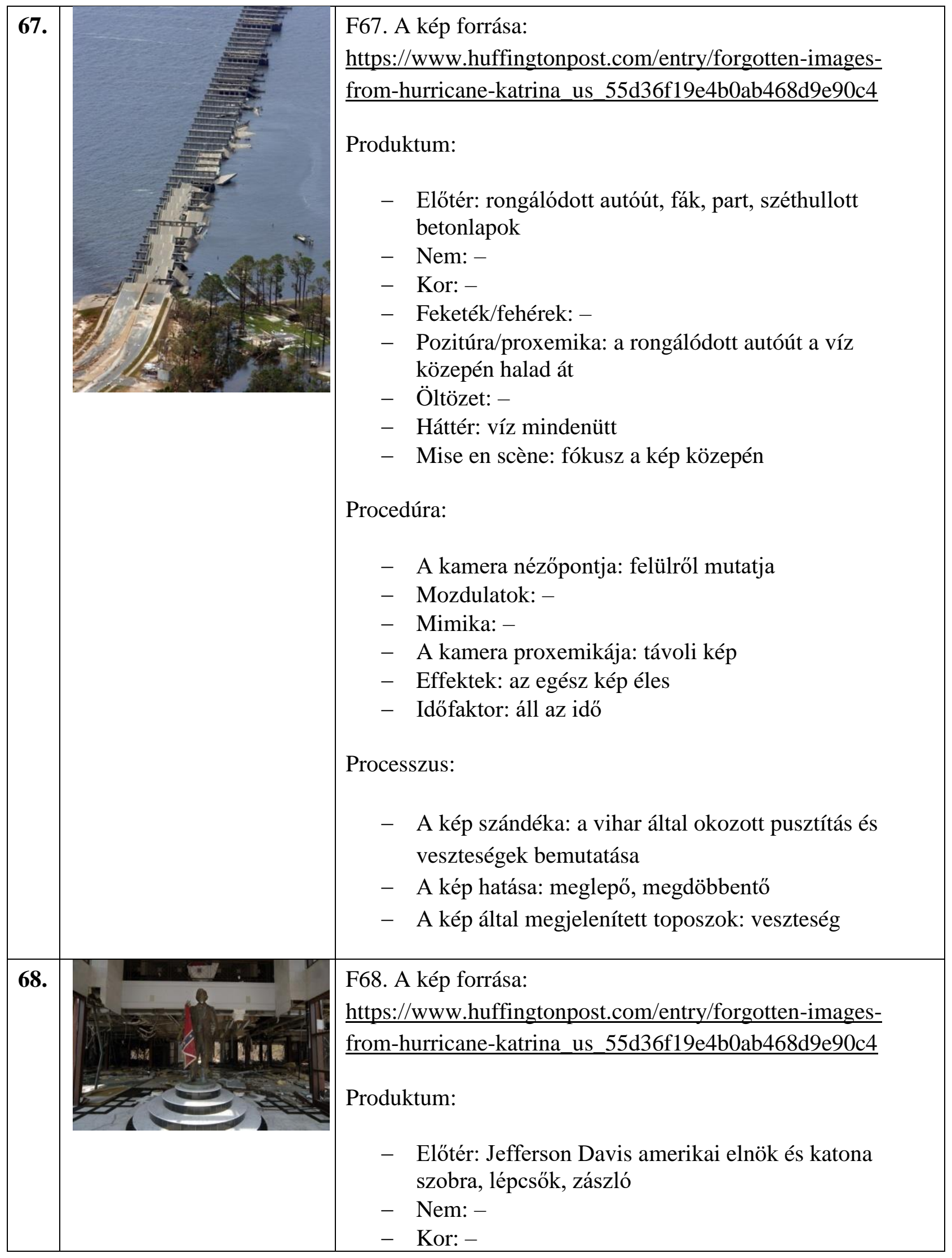




\begin{tabular}{|c|c|c|}
\hline & & 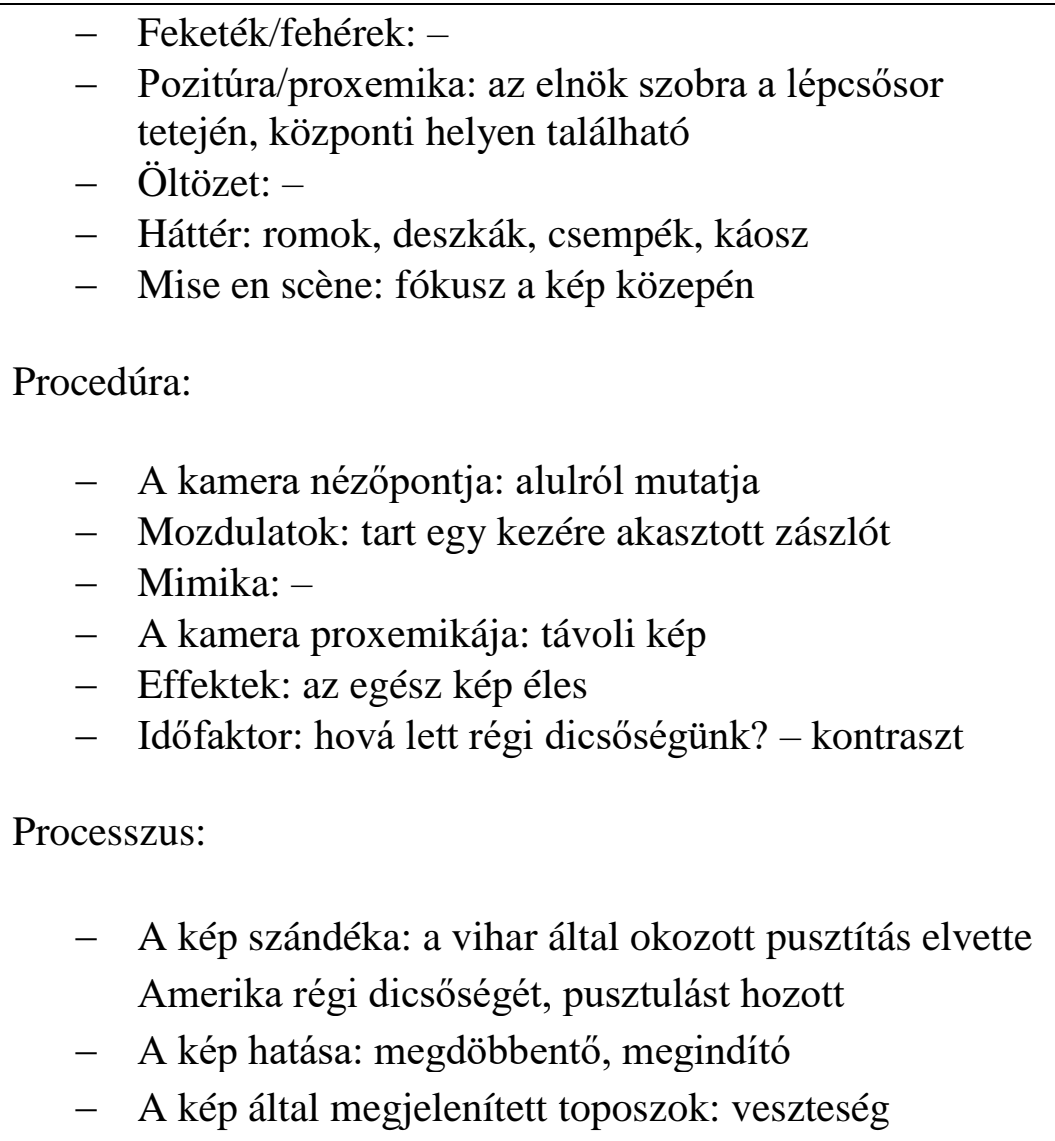 \\
\hline 69 & & 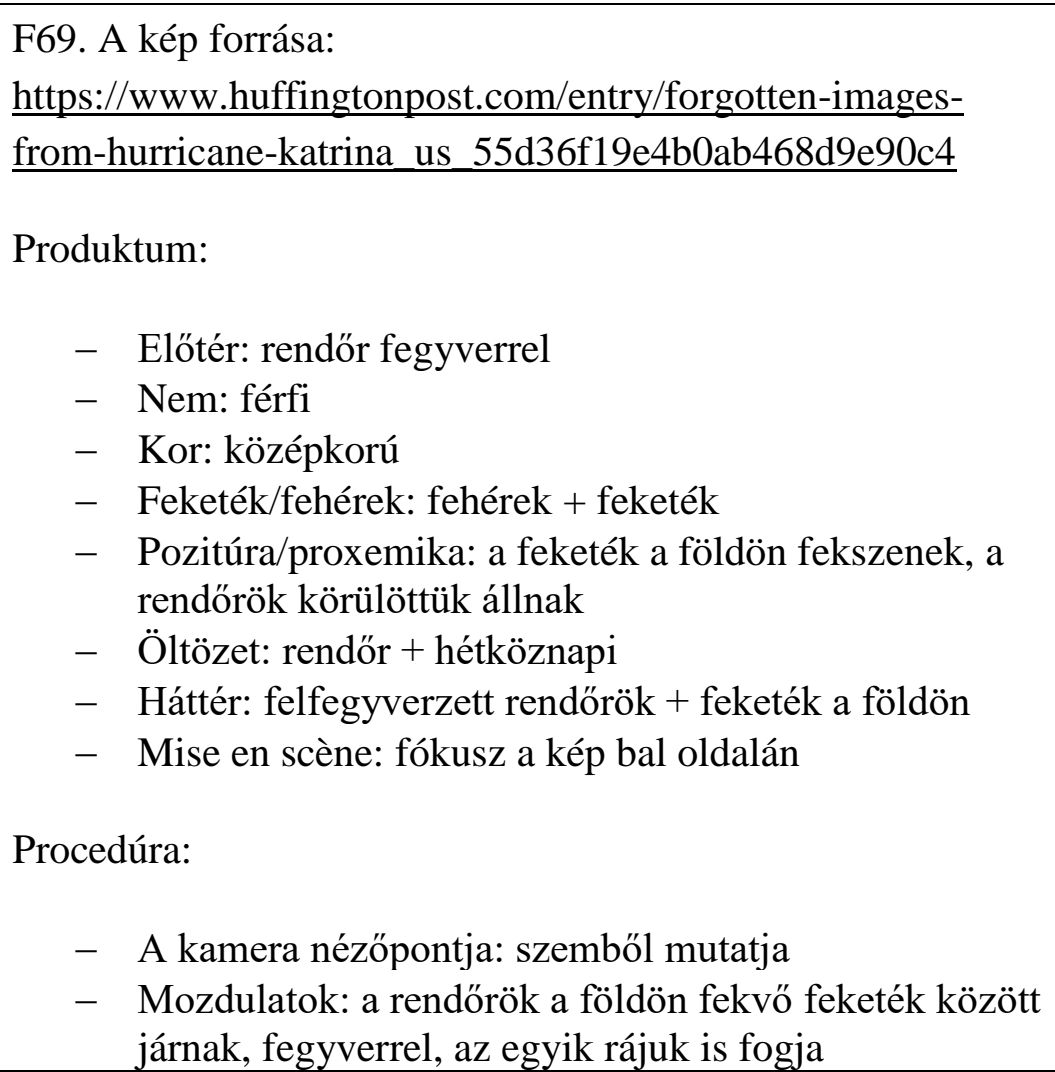 \\
\hline
\end{tabular}




\begin{tabular}{|c|c|c|}
\hline & & 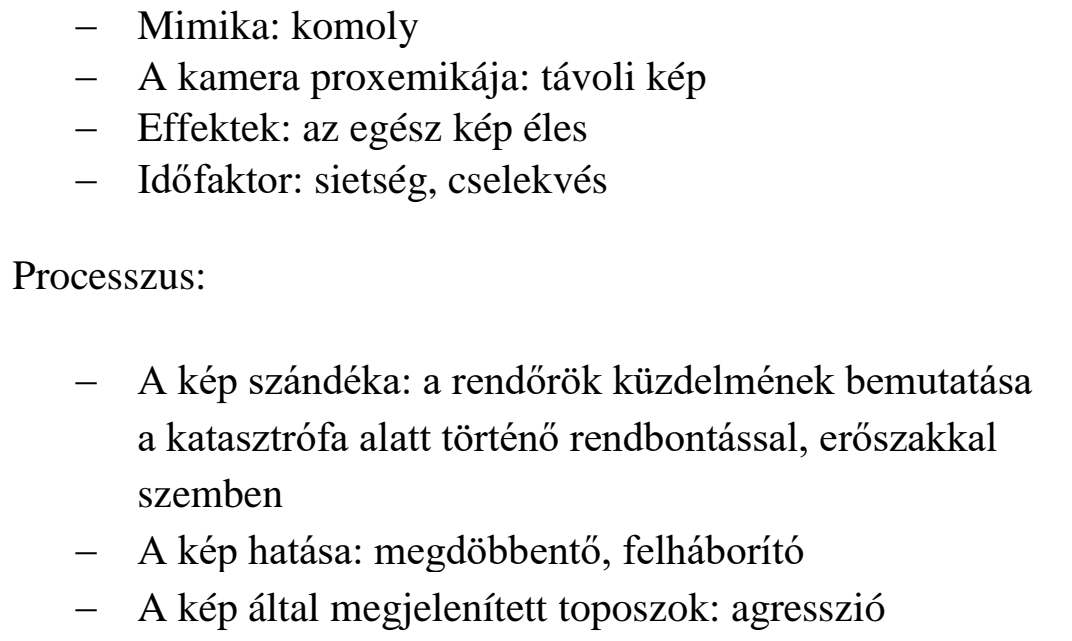 \\
\hline 70. & $\int_{-12}^{3}$ & 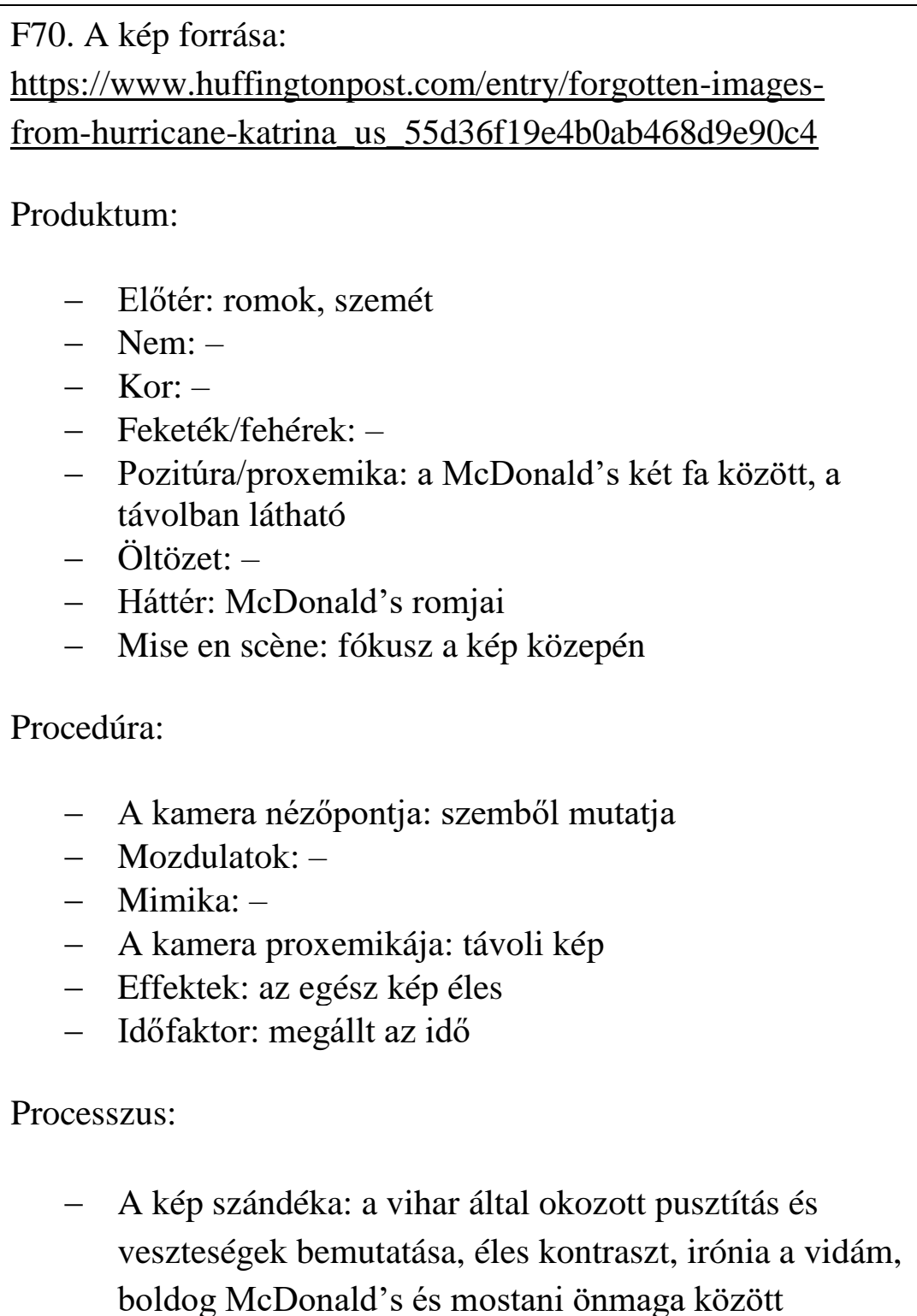 \\
\hline
\end{tabular}




\begin{tabular}{|c|c|c|}
\hline & & $\begin{array}{l}\text { - A kép hatása: megdöbbentő } \\
\text { - A kép által megjelenített toposzok: veszteség, irónia }\end{array}$ \\
\hline 71. & & 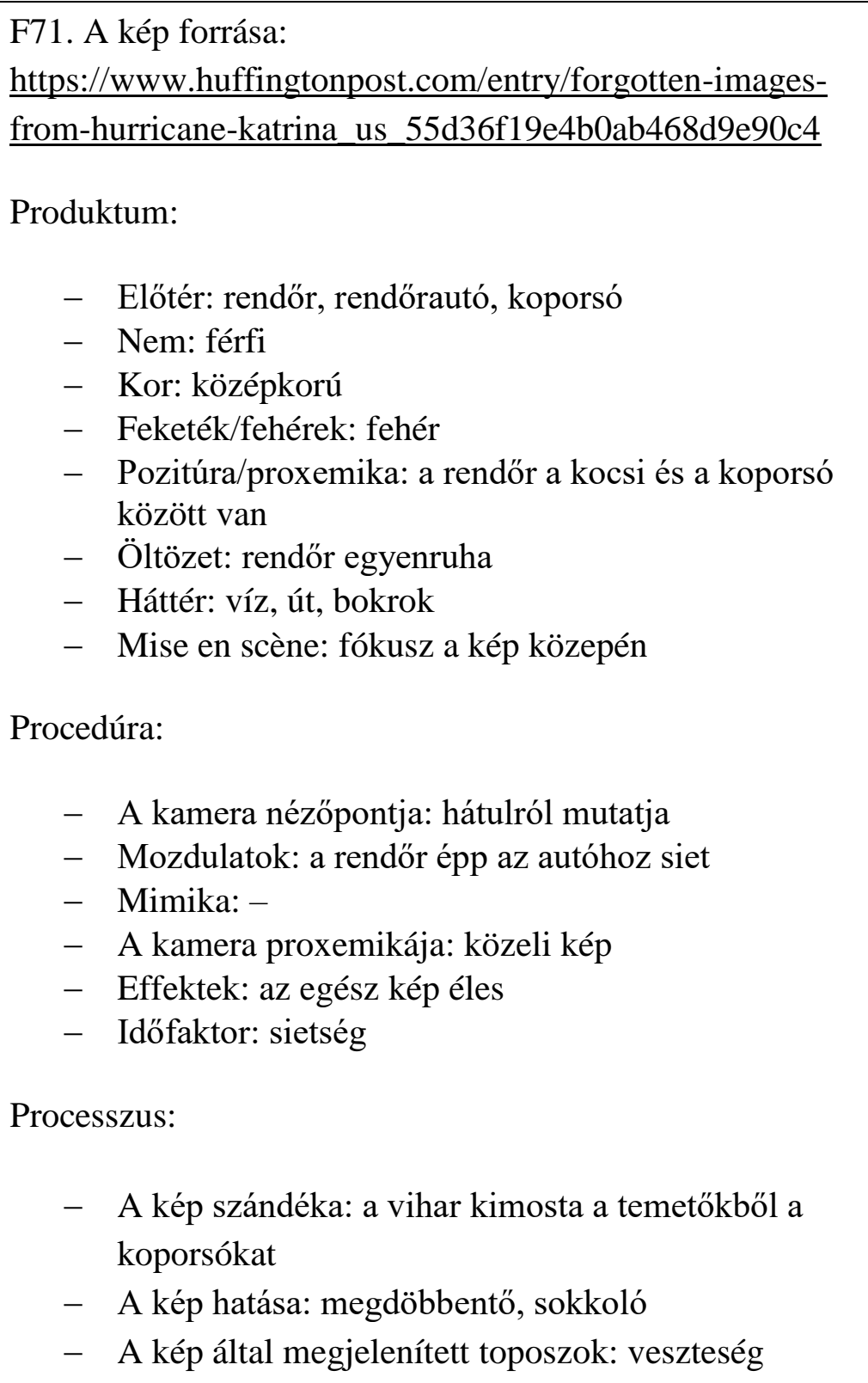 \\
\hline 72 & $\int_{1-1}$ & $\begin{array}{l}\text { F72. A kép forrása: } \\
\text { https://www.huffingtonpost.com/entry/forgotten-images- } \\
\text { from-hurricane-katrina_us_55d36f19e4b0ab468d9e90c4 } \\
\text { Produktum: } \\
\begin{array}{l}\text { - Elötér: kutya, háztető } \\
\text { - Nem: - }\end{array}\end{array}$ \\
\hline
\end{tabular}




\begin{tabular}{|c|c|}
\hline & 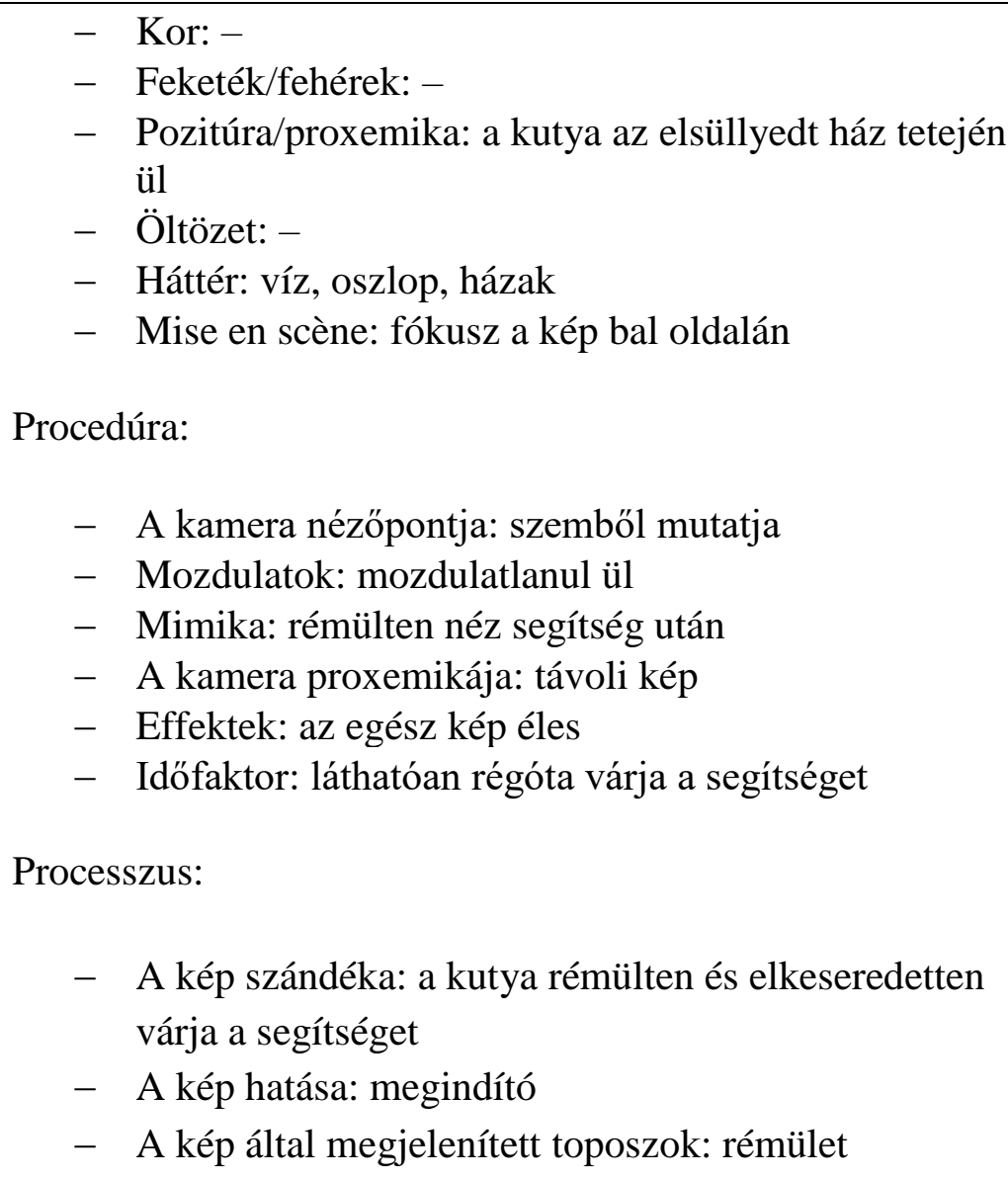 \\
\hline 73. & 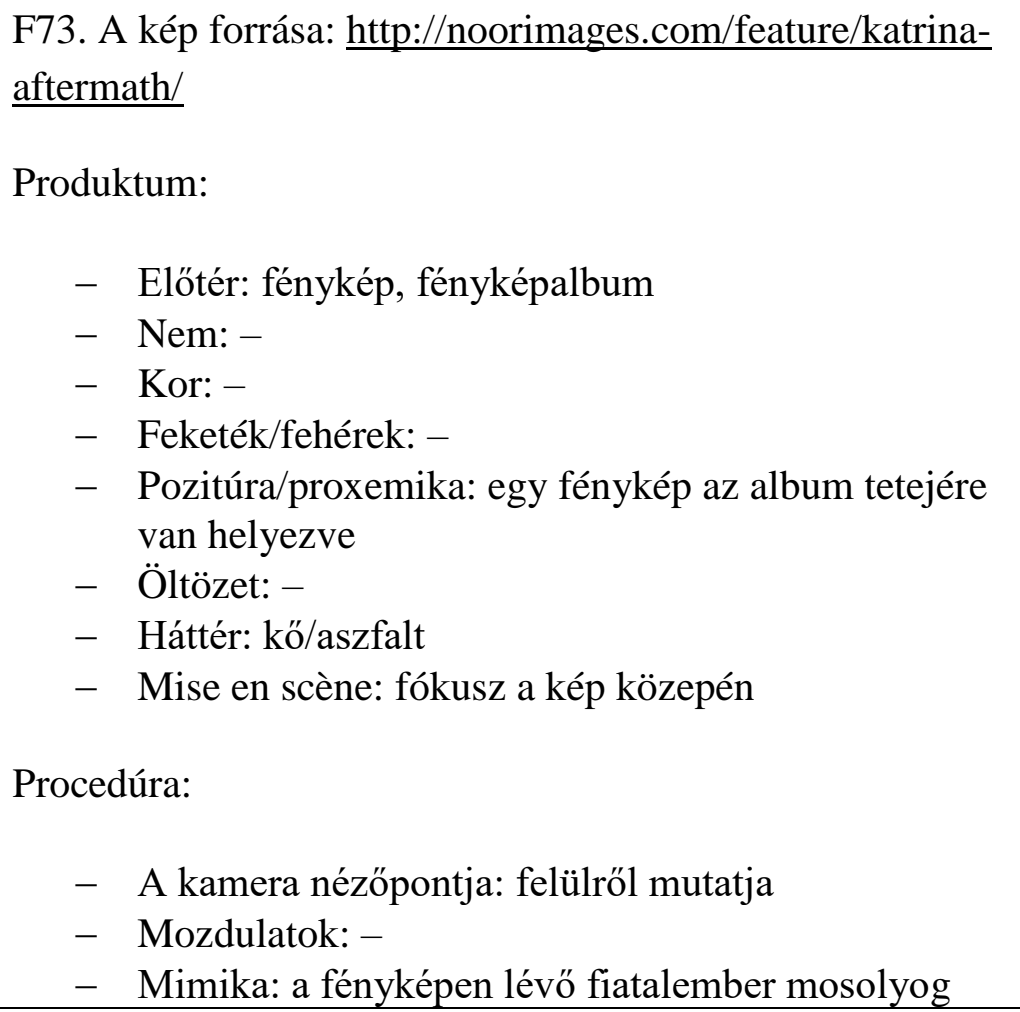 \\
\hline
\end{tabular}




\begin{tabular}{|c|c|}
\hline & $\begin{array}{l}\text { - A kamera proxemikája: távoli kép } \\
\text { - Effektek: az egész kép éles } \\
\text { - Időfaktor: megállt az idő } \\
\text { Processzus: } \\
\text { - A kép szándéka: a fényképalbum a felmenő } \\
\text { generációkat mutatja be, a fiatalember képe is } \\
\text { hozzájuk került - valószínüleg együtt vannak már a } \\
\text { - túlvilágon } \\
\text { - A kép hatása: megindító }\end{array}$ \\
\hline 74. & $\begin{array}{l}\text { F74. A kép forrása: } \\
\text { http://www.latimes.com/nation/nationnow/la-na-new-orleans- } \\
\text { hurricane-katrina-suits-20161219-story.html } \\
\text { Produktum: } \\
\text { - Elötér: } 1 \text { alak, televízió, George Bush, szőnyeg, } \\
\text { - telefon, fotel } \\
\text { - Nem: nő } \\
\text { - } \text { Kor: idős } \\
\text { - } \text { Peketék/fehérek: fekete } \\
\text { - elfordulvára/proxemika: a televízió mellett ül, attól } \\
\text { - Öltözet: hétköznapi } \\
\text { - Mise en scène: fókusz a kép jobb oldalán } \\
\text { Procedúra: } \\
\text { - A kamera nézőpontja: felülröl mutatja } \\
\text { - Mozdulatok: a nő fogja a fejét } \\
\text { - Mimika: undor, elégedetlenség, méltatlankodás } \\
\text { - A kamera proxemikája: távoli kép } \\
\text { - Effektek: az egész kép éles } \\
\text { - Időfaktor: áll az idő } \\
\text { Processzus: } \\
\text { - A kép szándéka: a nő elégedetlen a kormány } \\
\text { segítségnyújtásával }\end{array}$ \\
\hline
\end{tabular}




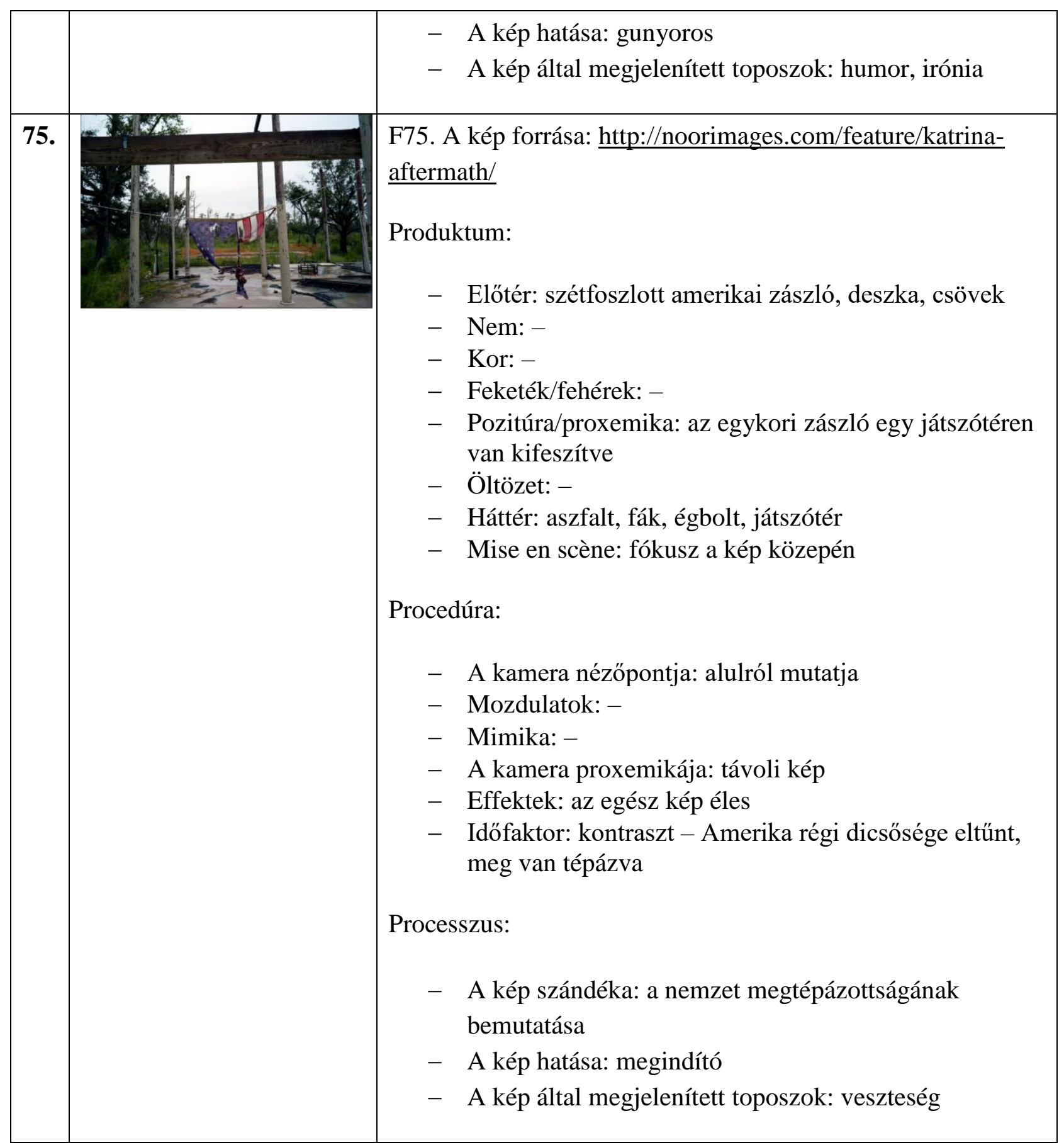




\begin{tabular}{|c|c|c|}
\hline 1. & is 237 & 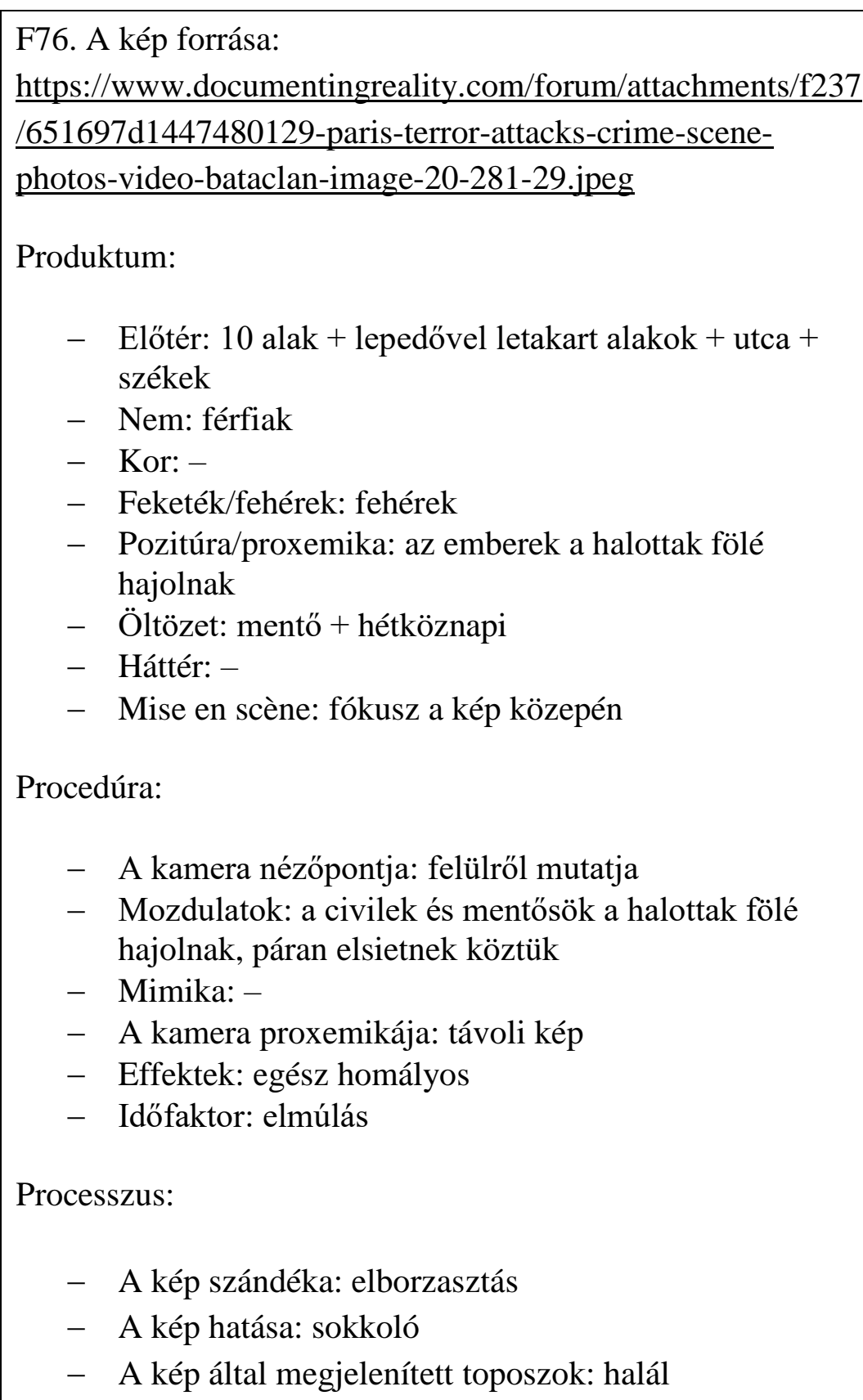 \\
\hline 2. & $4=$ & $\begin{array}{l}\text { F77. A kép forrása: } \\
\text { https://www.documentingreality.com/forum/attachments/f237 } \\
\text { /651699d1447480129-paris-terror-attacks-crime-scene- } \\
\text { photos-video-bataclan-image2.jpg } \\
\text { Produktum: } \\
\quad \text { - Előtér: } 2 \text { alak + halottak + székek } \\
\quad \text { - Nem: férfiak }\end{array}$ \\
\hline
\end{tabular}




\begin{tabular}{|c|c|}
\hline & $\begin{array}{l}\text { - Kor: - } \\
\text { - Feketék/fehérek: fehérek } \\
\text { - Pozitúra/proxemika: a két rendőr egymásnak háttal áll } \\
\text { - Öltözet: rendőr egyenruha } \\
\text { - Háttér: autók, ház } \\
\text { - Mise en scène: fókusz a kép közepén } \\
\text { Procedúra: } \\
\text { - A kamera nézőpontja: szemből mutatja } \\
\text { - Mozdulatok: a rendőrök intézkednek, telefonálnak } \\
\text { - Mimika: - } \\
\text { - A kamera proxemikája: távoli kép } \\
\text { - Effektek: egész homályos } \\
\text { - Időfaktor: elmúlás } \\
\text { Processzus: } \\
\text { - A kép szándéka: elborzasztás } \\
\text { - A kép hatása: sokkoló } \\
\text { - A kép által megjelenített toposzok: halál }\end{array}$ \\
\hline 3. & 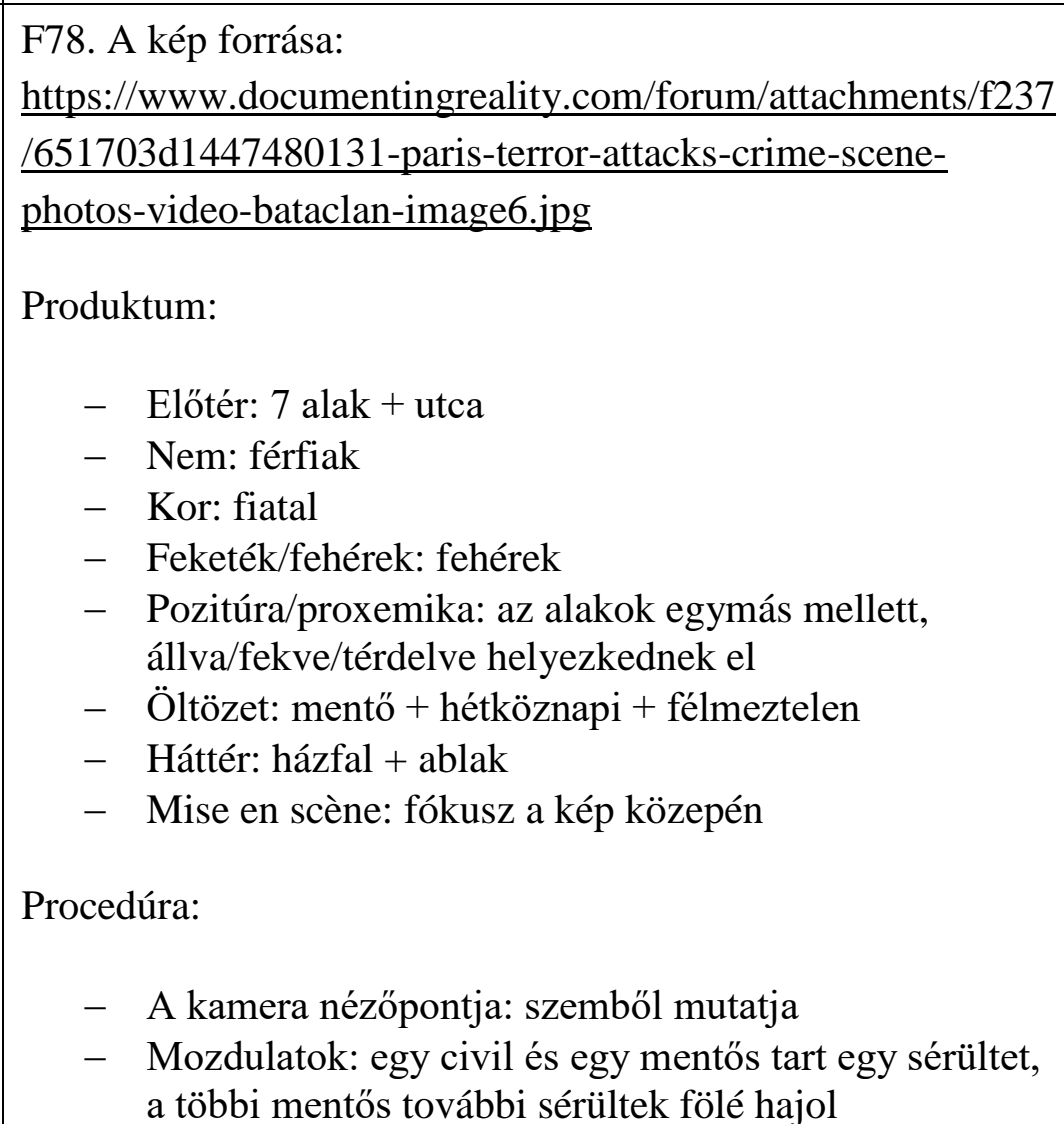 \\
\hline
\end{tabular}




\begin{tabular}{|c|c|}
\hline & $\begin{array}{l}\text { - Mimika: erőlködés, fájdalom } \\
\text { - A kamera proxemikája: távoli kép } \\
\text { - Effektek: az egész kép éles } \\
\text { - Időfaktor: aktív, gyors } \\
\text { Processzus: } \\
\text { - A kép szándéka: életben maradás } \\
\text { - A kép hatása: sokkoló } \\
\text { - A kép által megjelenített toposzok: szenvedés }\end{array}$ \\
\hline 4. & 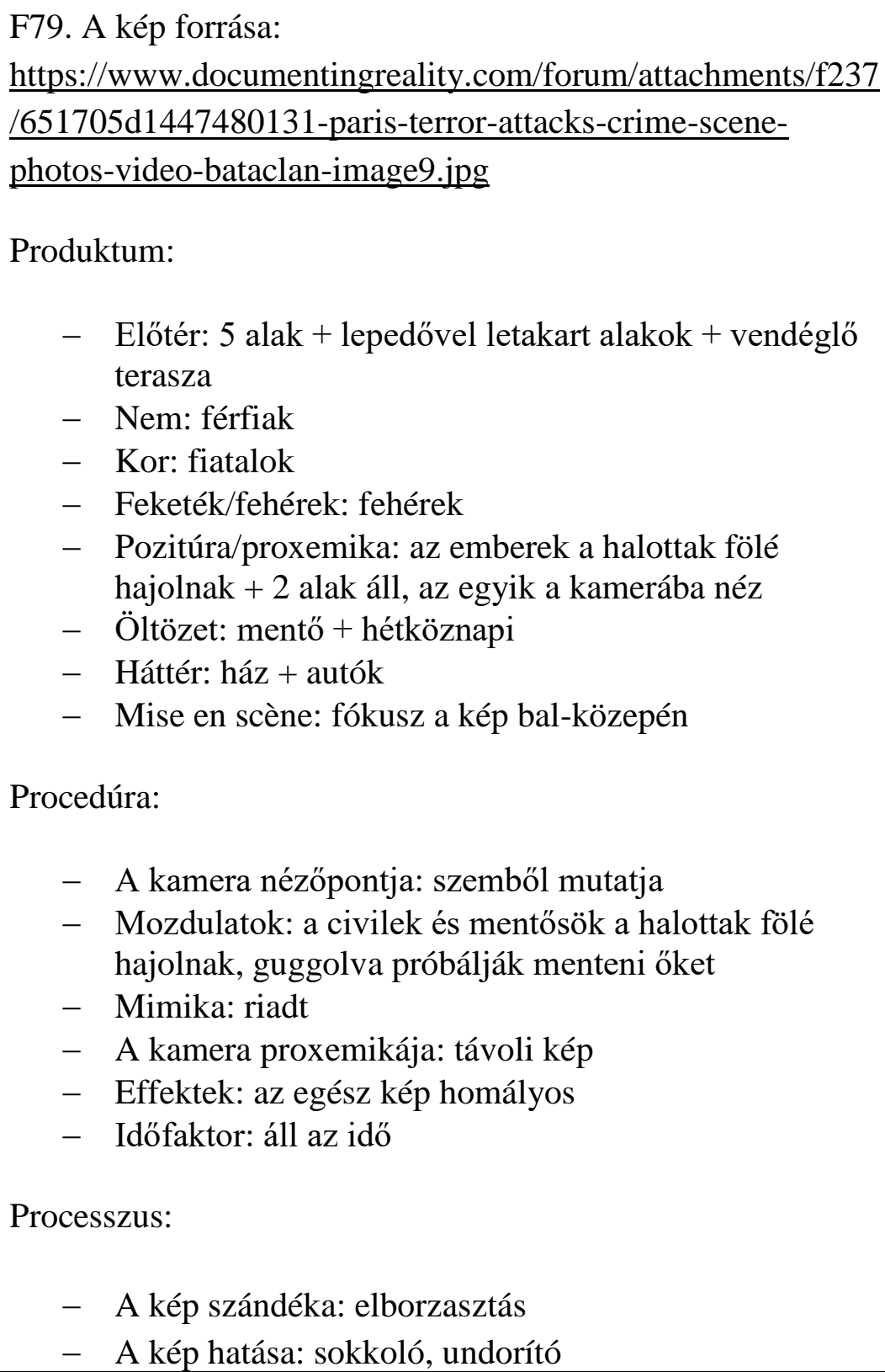 \\
\hline
\end{tabular}




\begin{tabular}{|c|c|c|}
\hline & & - A kép által megjelenített toposzok: halál \\
\hline 5. & 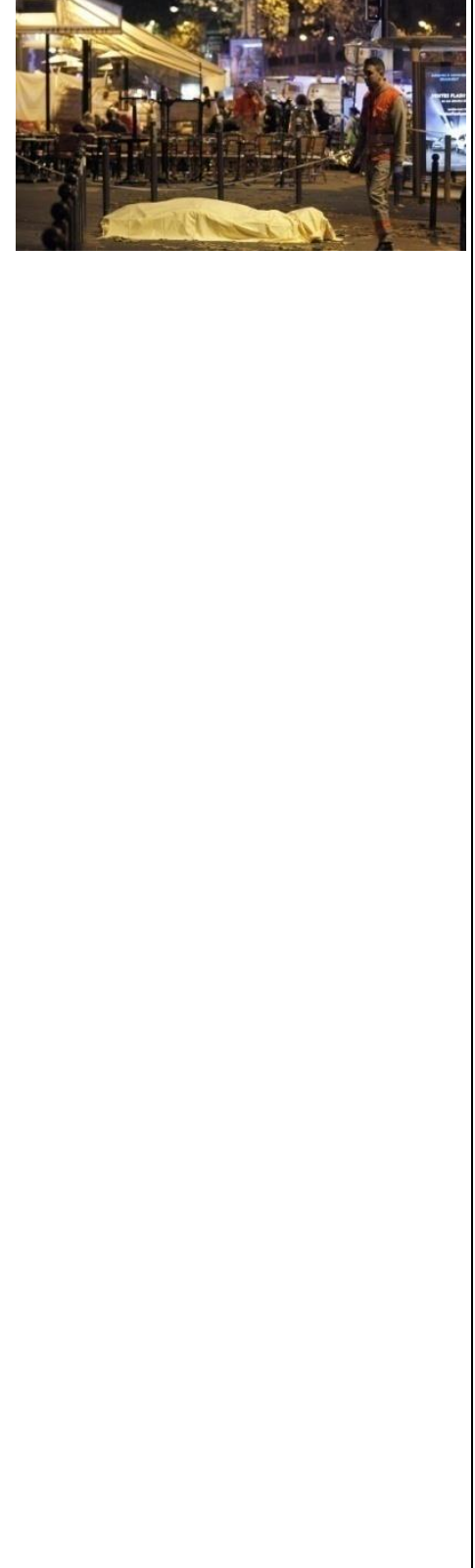 & $\begin{array}{l}\text { F80. A kép forrása: } \\
\text { https://www.documentingreality.com/forum/attachments/f237 } \\
\text { /651771d1447504169-paris-terror-attacks-crime-scene- } \\
\text { photos-video-bataclan-55.jpg } \\
\text { Produktum: } \\
\text { - Elötér: } 1 \text { alak + lepedővel letakart alak } \\
\text { - Nem: férfi } \\
\text { - Kor: fiatal } \\
\text { - Feketék/fehérek: fehérek } \\
\text { - Pozitúra/proxemika: a mentős a halott mellett áll } \\
\text { - Öltözet: mentős } \\
\text { - Háttér: ház + mentősök + alakok + székek } \\
\text { - Mise en scène: fókusz a kép közepén } \\
\text { Procedúra: } \\
\text { - A kamera nézőpontja: szemből mutatja } \\
\text { - Mozdulatok: a mentős görnyedten, a távolba nézve áll } \\
\text { - a halott mellett } \\
\text { - Mimika: - } \\
\text { - E kamera proxemikája: távoli kép } \\
\text { - Időfaktor: elmúlás } \\
\text { Processzus: } \\
\text { - A kép szándéka: elborzasztás } \\
\text { - A kép hatása: sokkoló, megindító } \\
\text { - A kép által megjelenített toposzok: halál }\end{array}$ \\
\hline
\end{tabular}




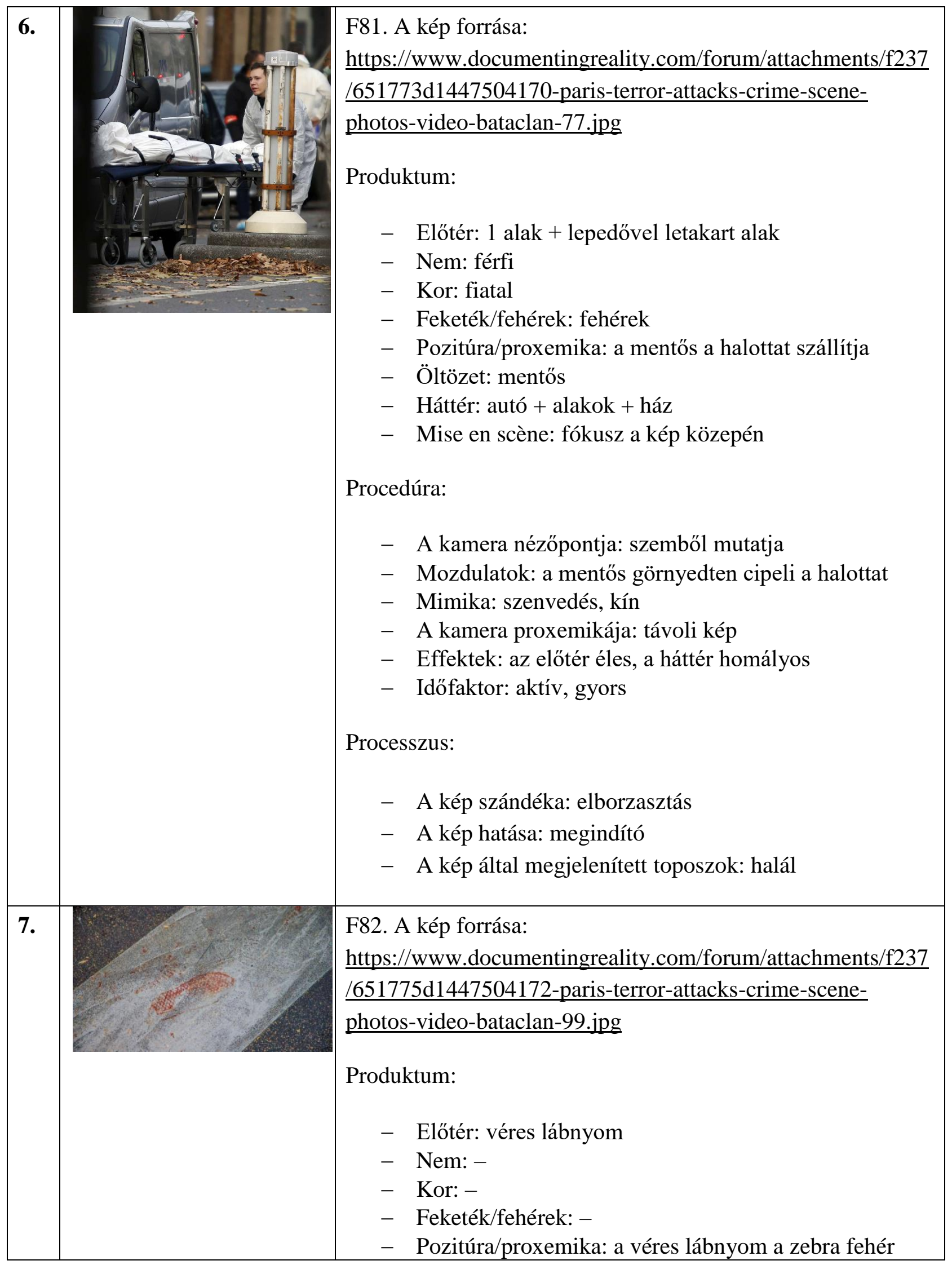




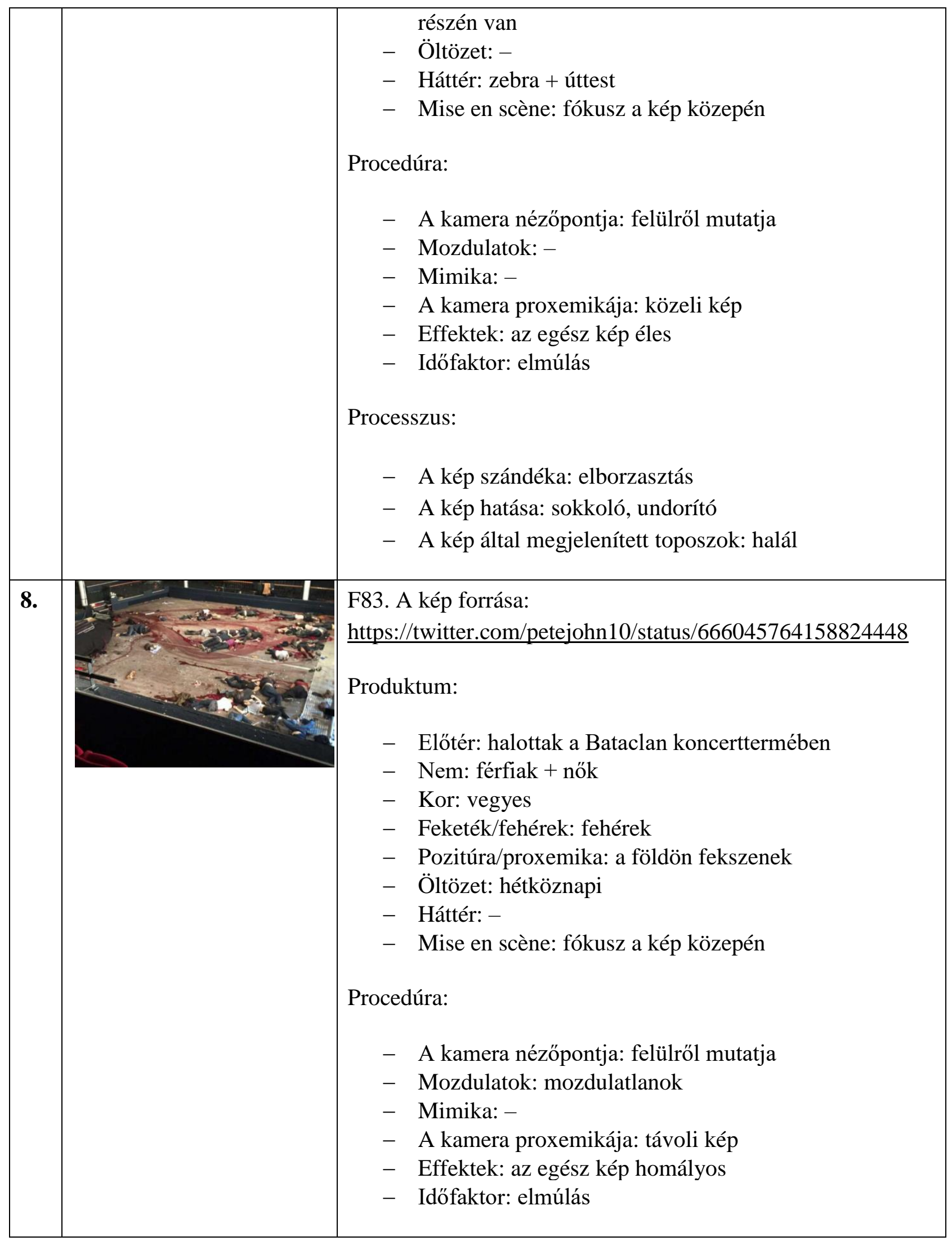




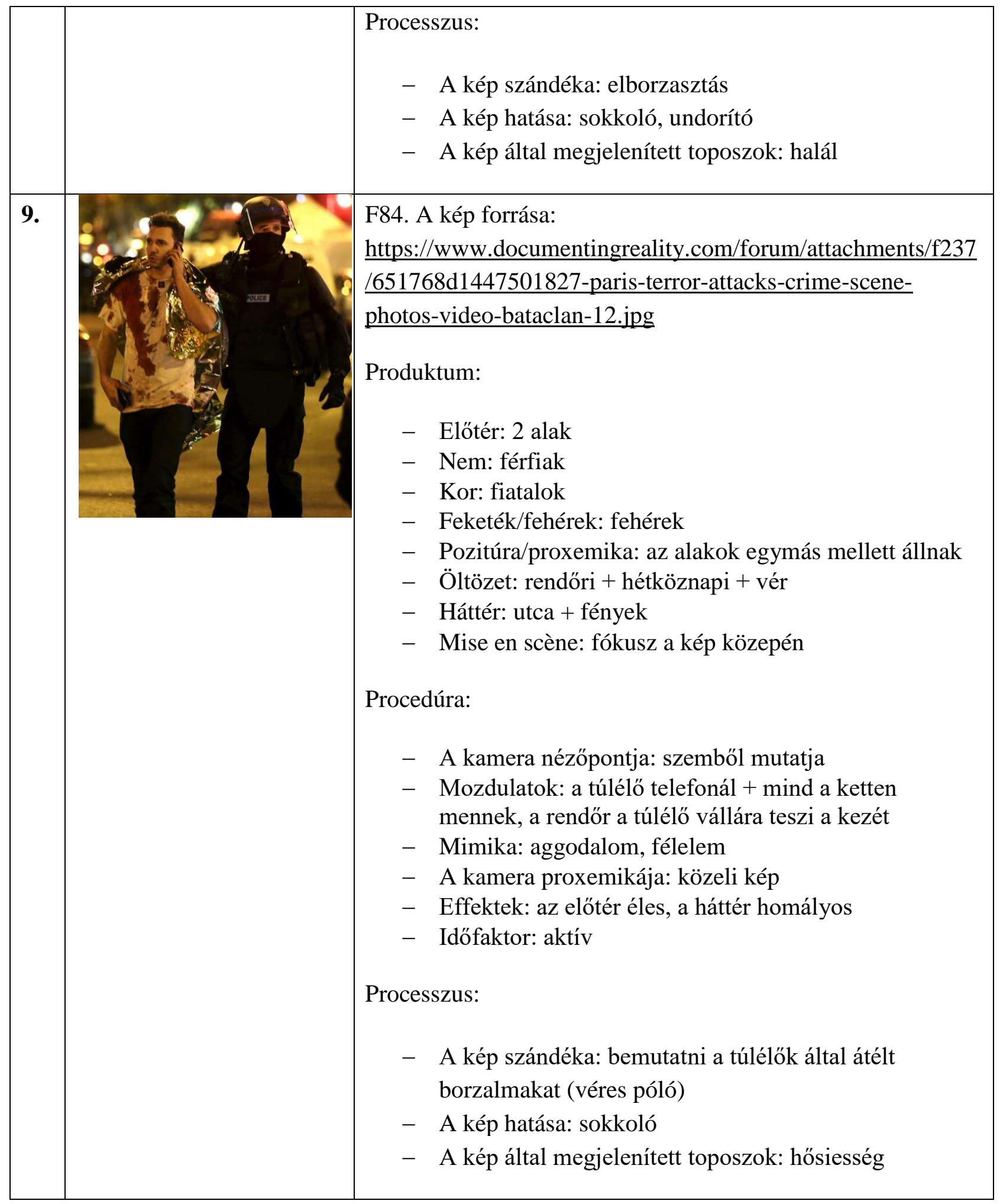




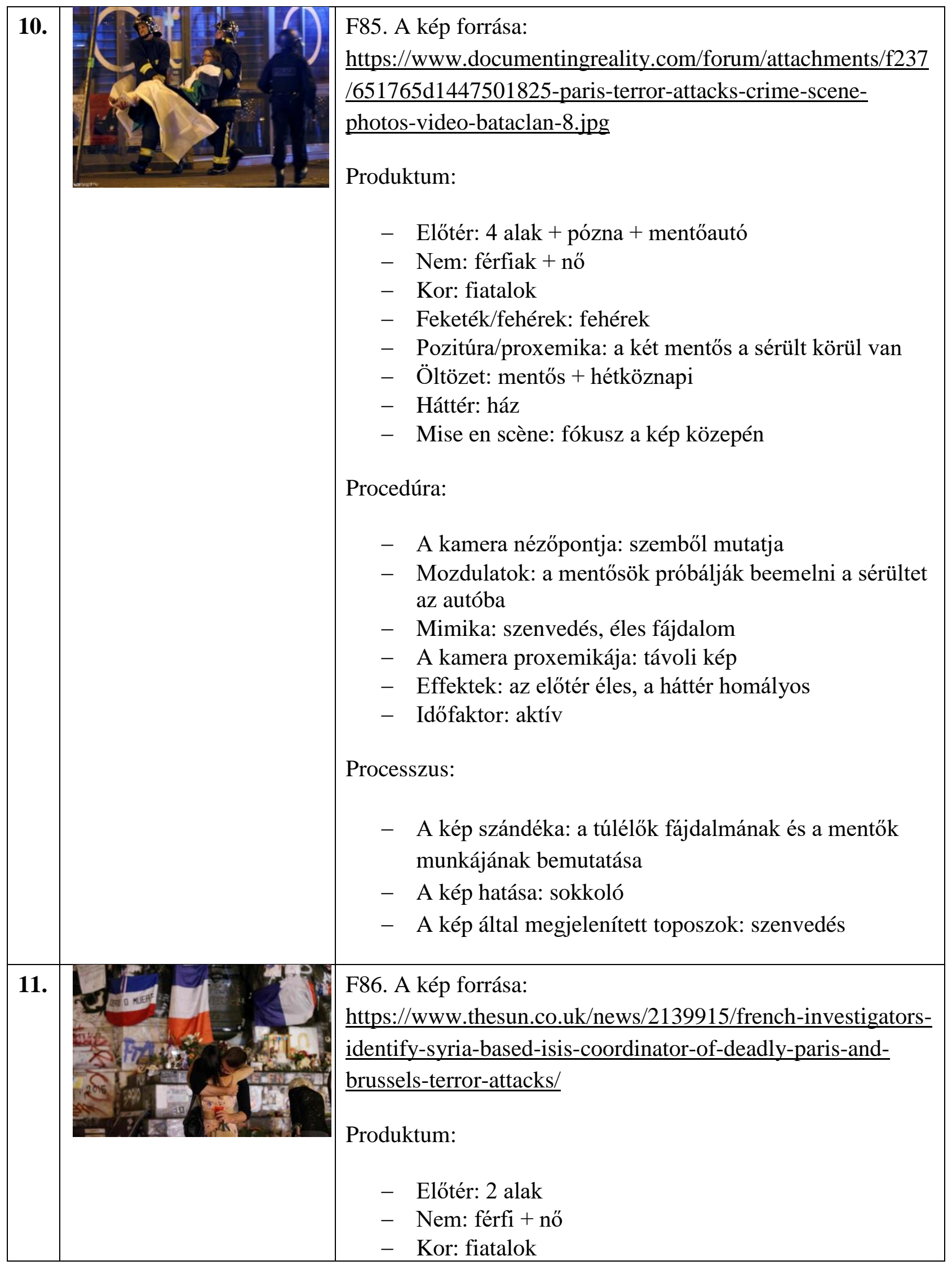




\begin{tabular}{|c|c|}
\hline & 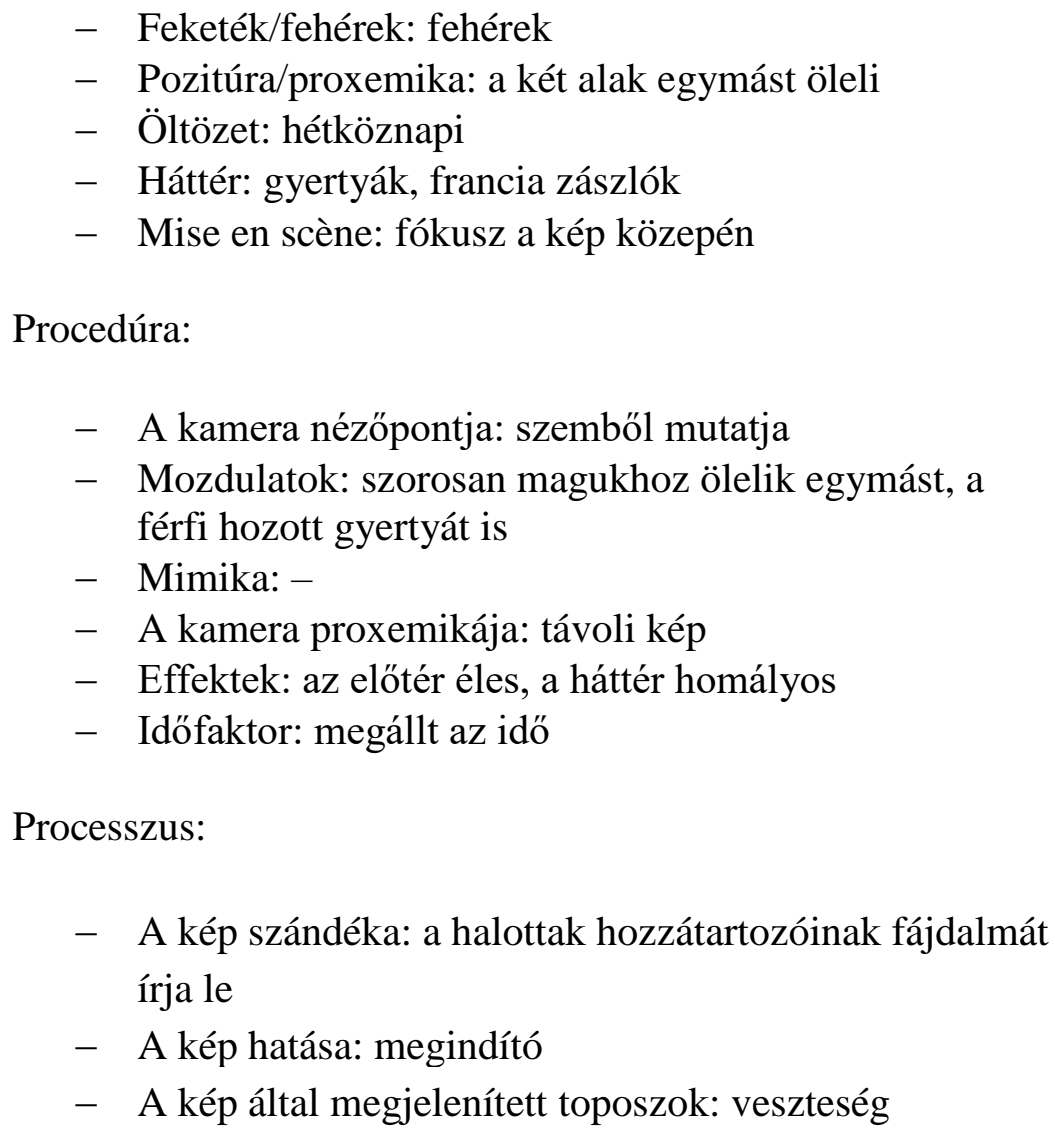 \\
\hline 12. & $\begin{array}{l}\text { F87. A kép forrása: } \text { http://www.dailymail.co.uk/news/article- } \\
\text { 3318972/100-minutes-stunned-world-moment-bomber-blew- } \\
\text { horrific-slaughter-concert-hall-account-carnage-Paris- } \\
\text { massacre-unfolded.html } \\
\text { Produktum: } \\
\text { - Előtér: } 2 \text { alak + sérült } \\
\text { - Nem: férfi + nö } \\
\text { - } \text { Kor: fiatalok } \\
\text { - } \text { Feketék/fehérek: fehérek } \\
\text { - Pozitúra/proxemika: a két alak a sérült mellett térdel } \\
\text { - Öltözet: hétköznapi } \\
\text { - Háttér: alakok + utca } \\
\text { - Mise en scène: fókusz a kép közepén } \\
\text { Procedúra: } \\
\text { - A kamera nézőpontja: szemböl mutatja } \\
\text { - Mozdulatok: a nő a szemét törli, sír, a férfi igyekszik }\end{array}$ \\
\hline
\end{tabular}




\begin{tabular}{|c|c|c|}
\hline & & $\begin{array}{l}\text { menteni a sérültet } \\
\text { - } \text { Mimika: szenvedés, fájdalom, koncentráció } \\
\text { - } \text { A kamera proxemikája: távoli kép } \\
\text { - } \text { Effektek: az elötér éles, a háttér homályos } \\
\text { - } \\
\text { Időfaktor: passzív } \\
\text { Processzus: } \\
\text { - } \\
\text { A kép szándéka: a sérültek hozzátartozóinak fájdalmát } \\
\text { - } \\
\text { - } \\
\text { A kép hatása: megindító } \\
\text { A kép által megjelenített toposzok: szenvedés }\end{array}$ \\
\hline 13. & 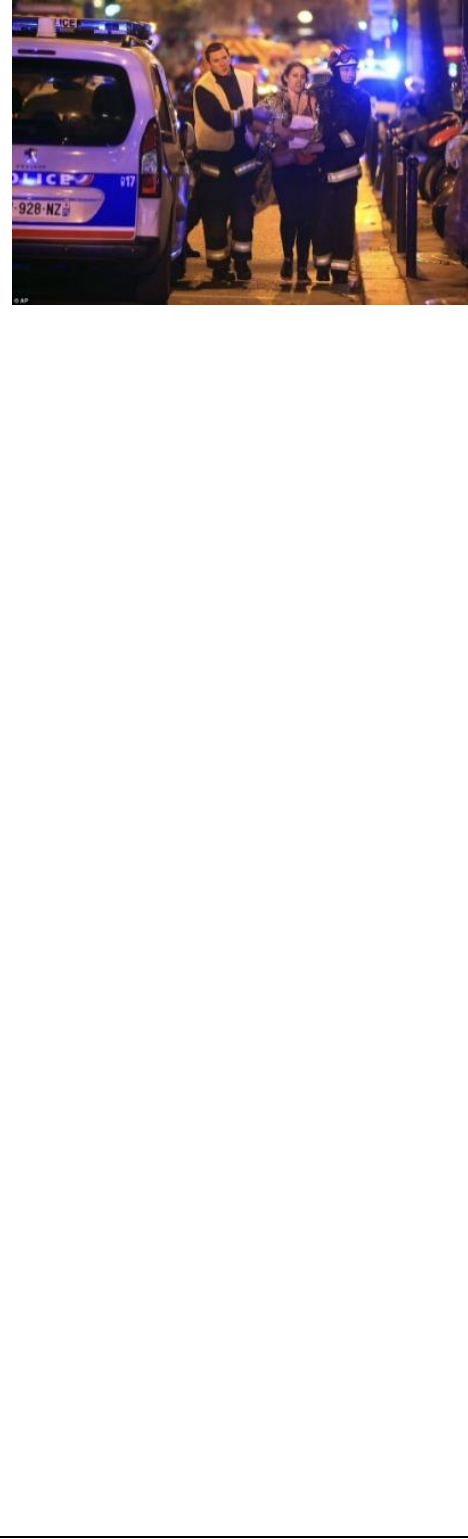 & 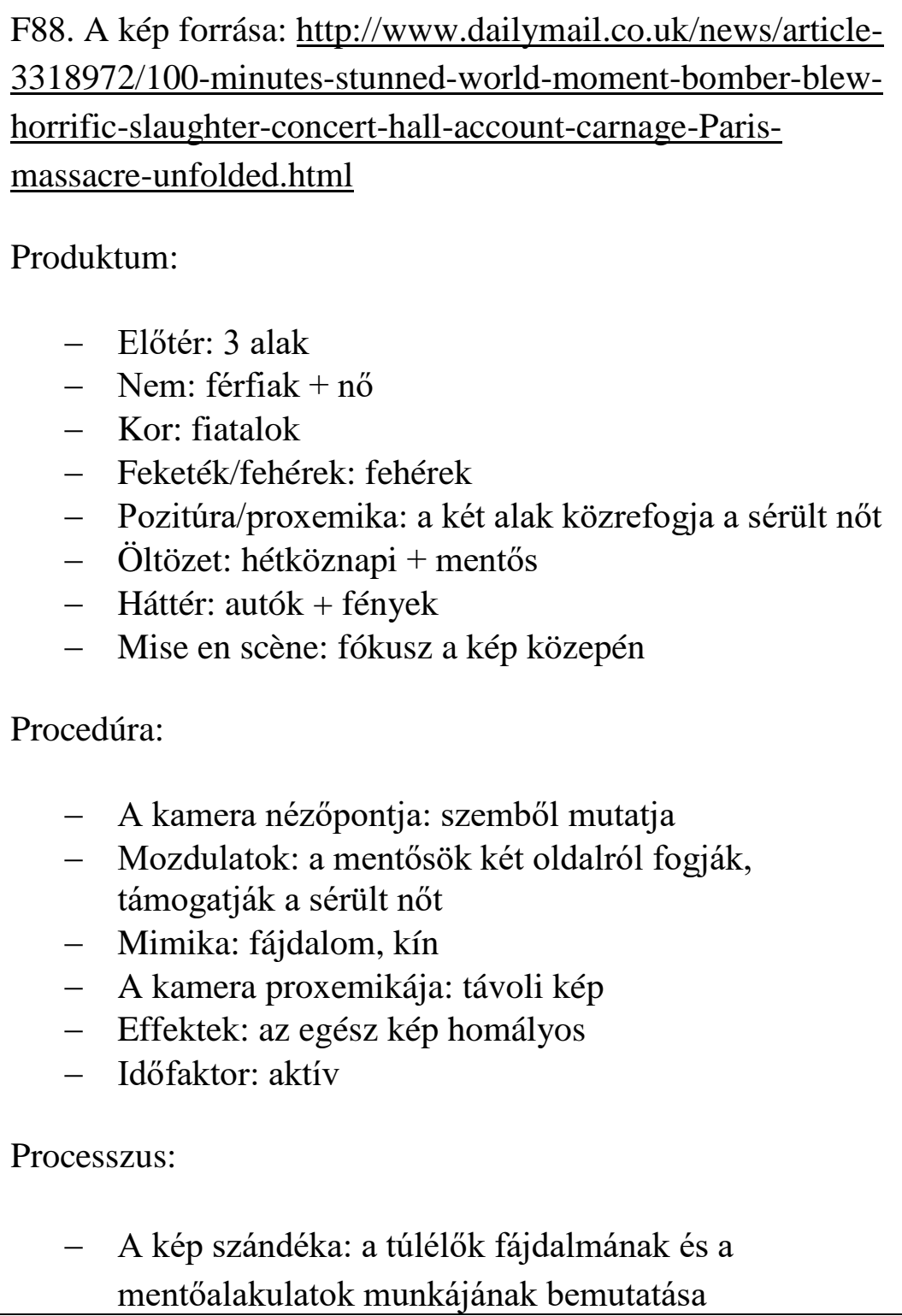 \\
\hline
\end{tabular}




\begin{tabular}{|c|c|c|}
\hline & & $\begin{array}{l}\text { - A kép hatása: megindító } \\
\text { - A kép által megjelenített toposzok: szenvedés }\end{array}$ \\
\hline 14. & 18 & 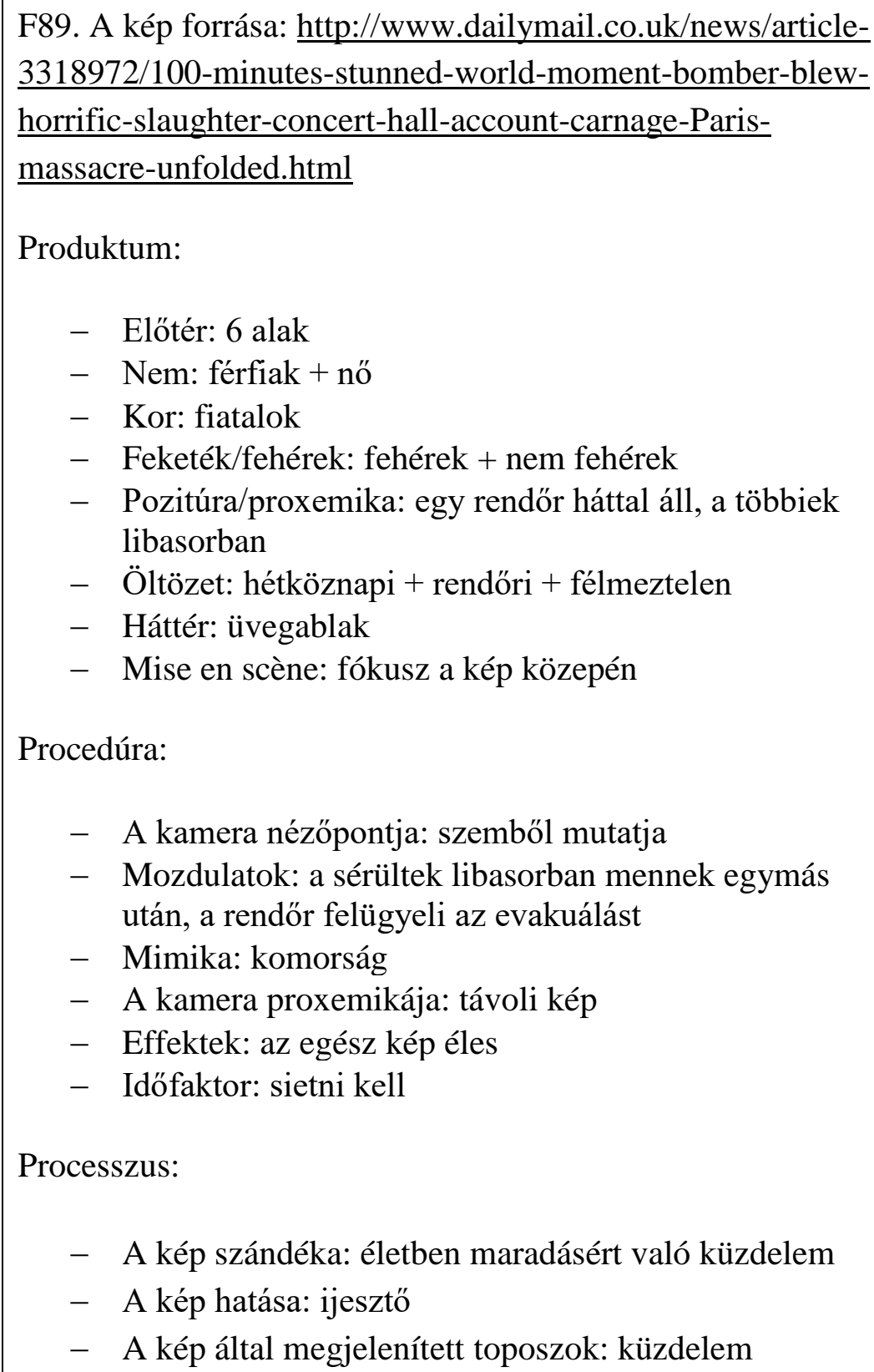 \\
\hline 15 & $=$ & $\begin{array}{l}\text { F90. A kép forrása: http://www.dailymail.co.uk/news/article- } \\
\text { 3318972/100-minutes-stunned-world-moment-bomber-blew- } \\
\text { horrific-slaughter-concert-hall-account-carnage-Paris- } \\
\text { massacre-unfolded.html } \\
\text { Produktum: }\end{array}$ \\
\hline
\end{tabular}




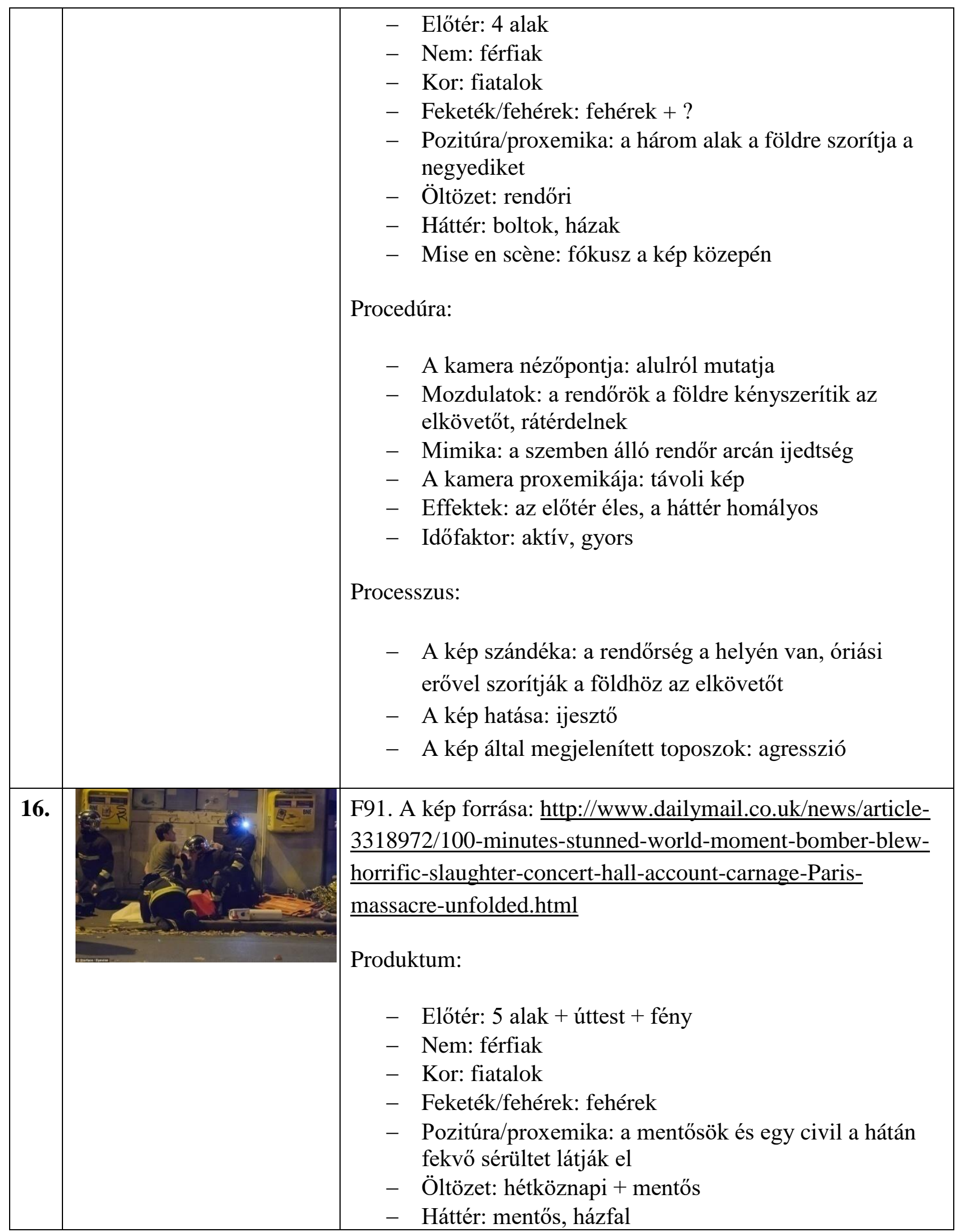




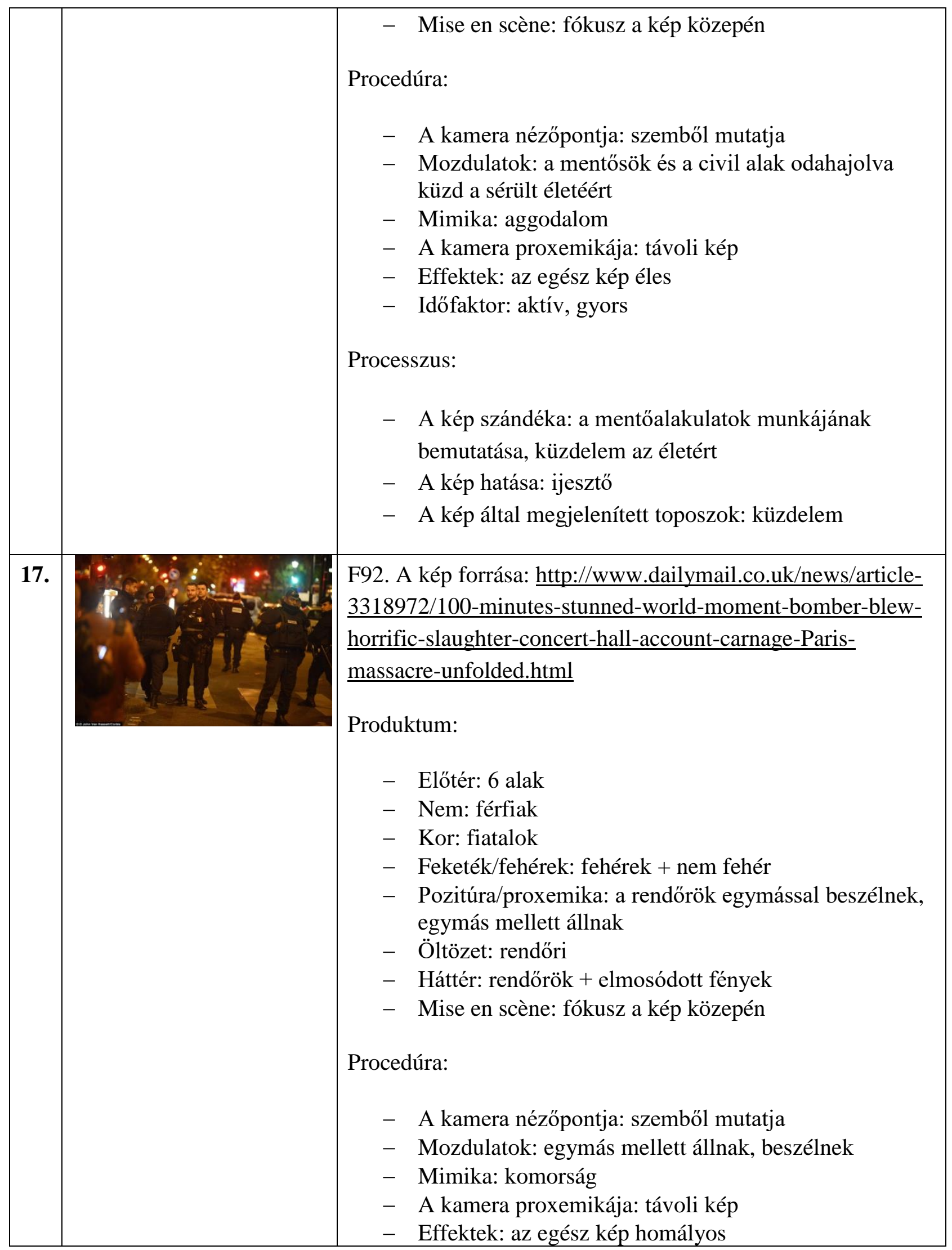




\begin{tabular}{|c|c|c|}
\hline & & 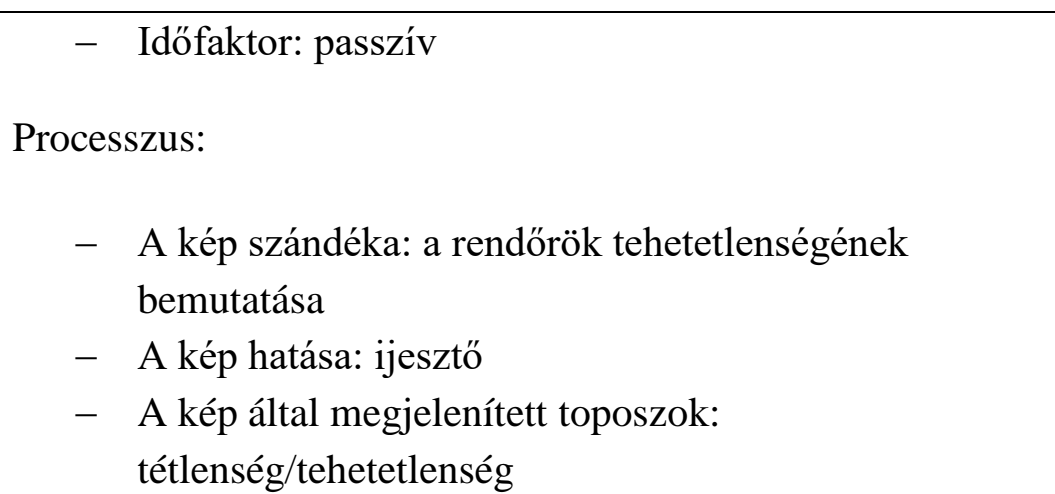 \\
\hline 18. & 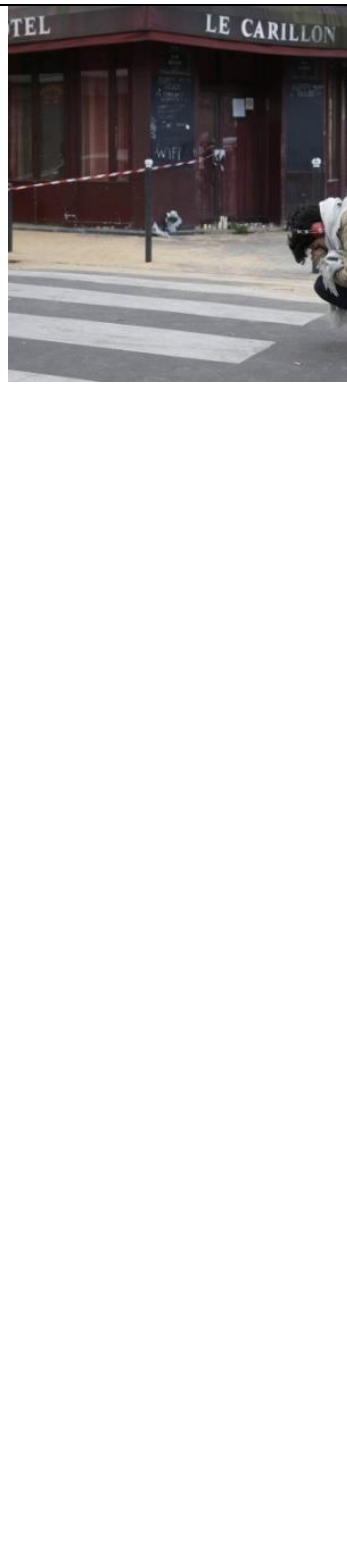 & 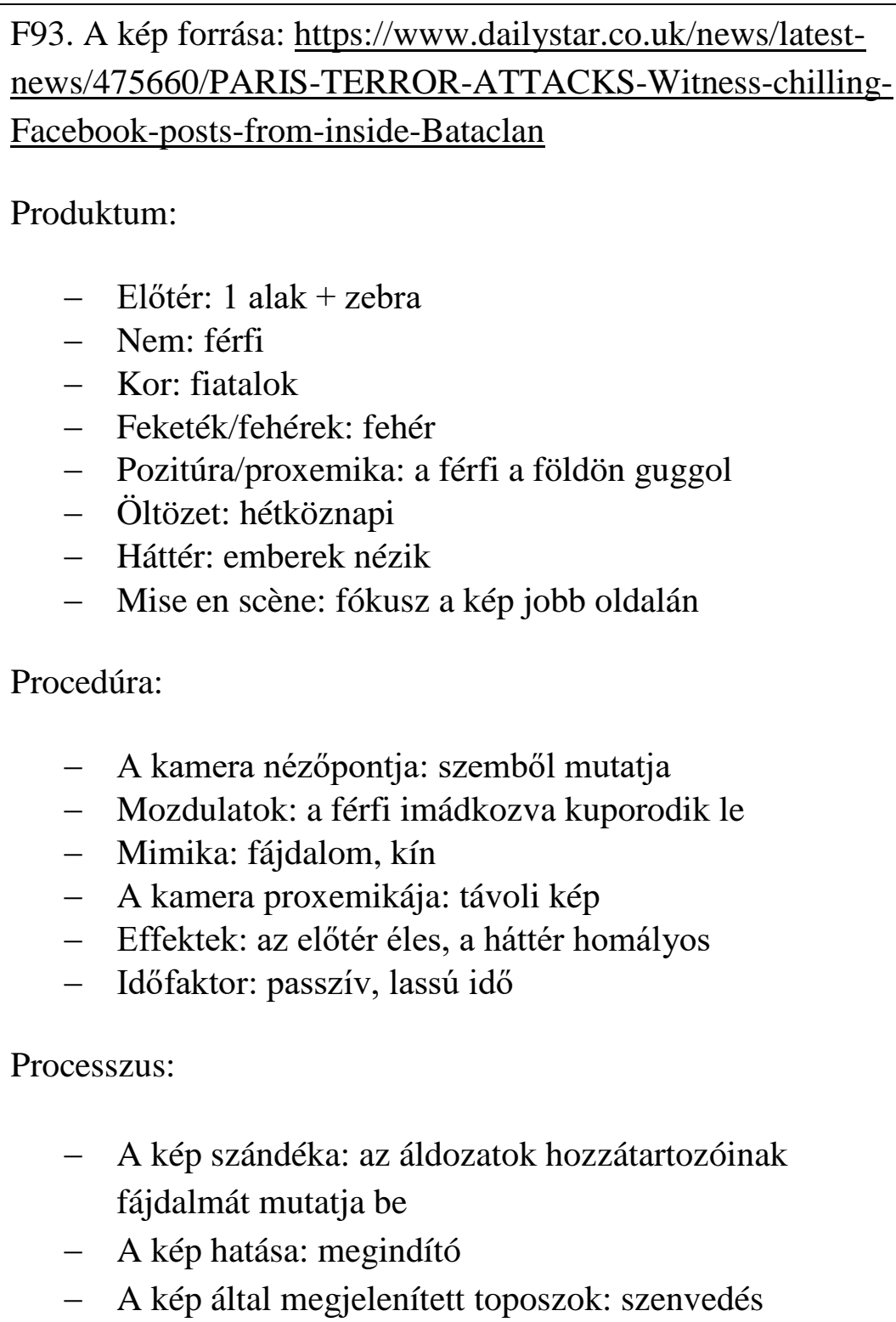 \\
\hline
\end{tabular}




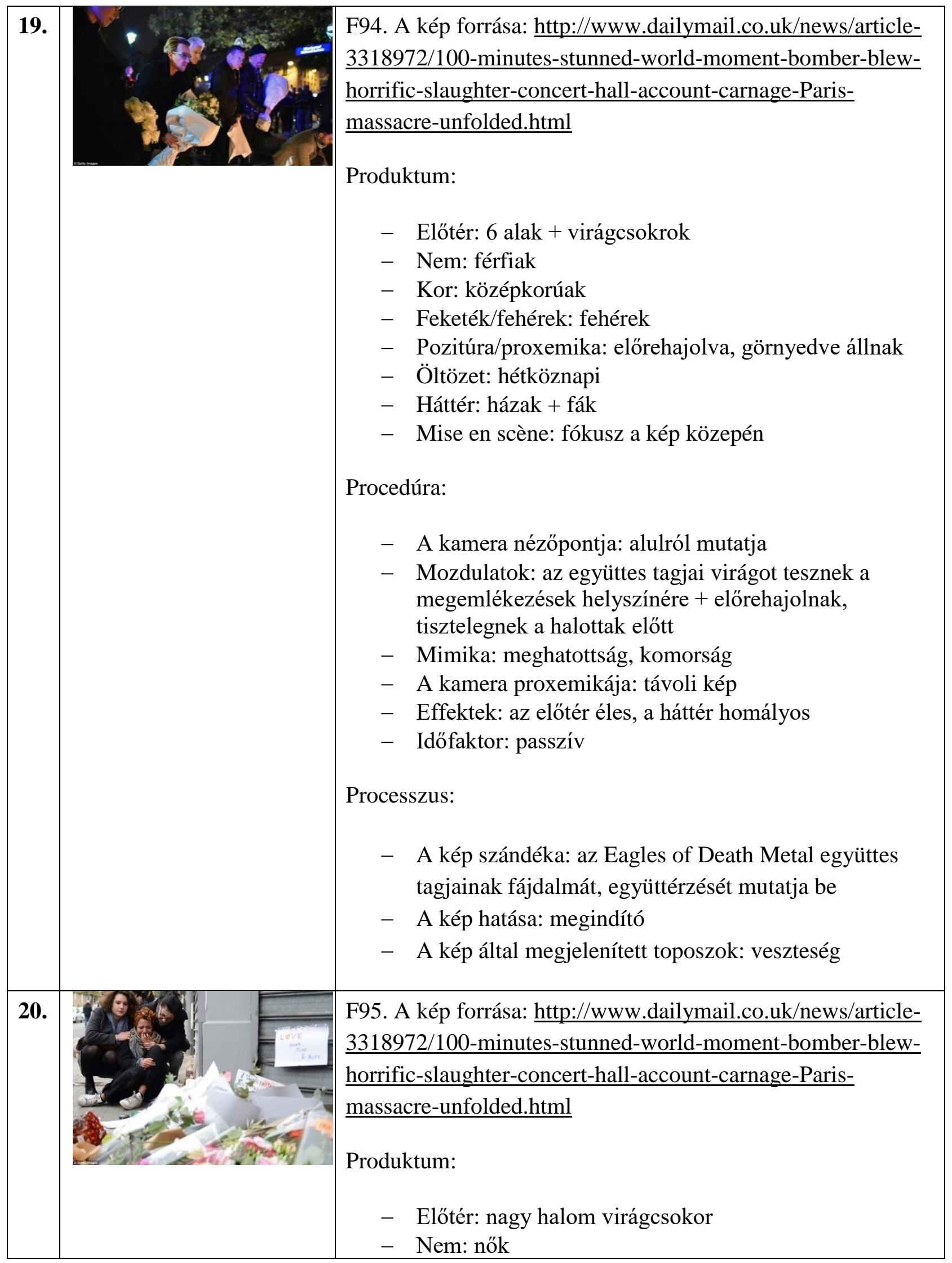




\begin{tabular}{|c|c|}
\hline & 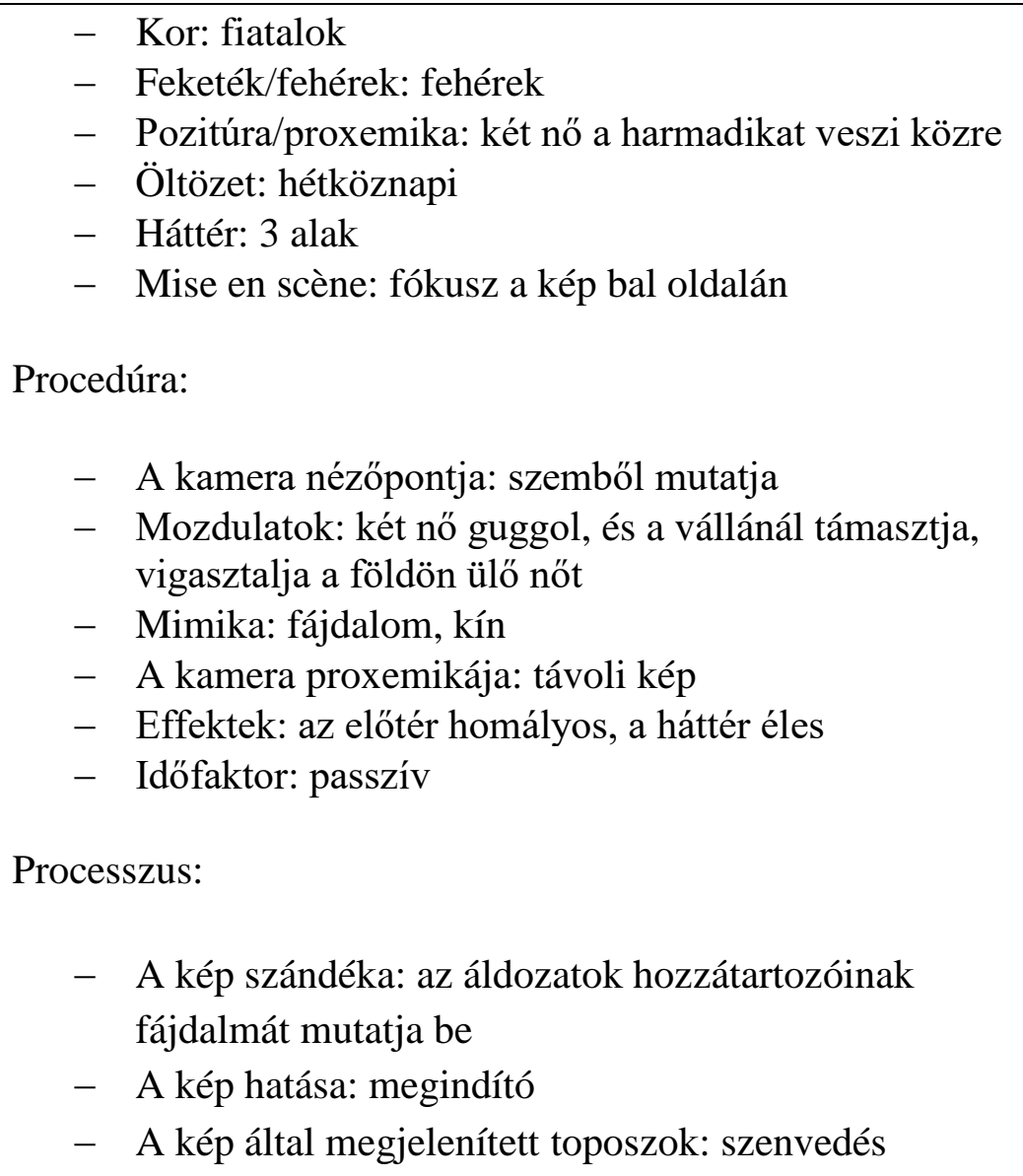 \\
\hline 21. & $\begin{array}{l}\text { F96. A kép forrása: http://www.dailymail.co.uk/news/article- } \\
\text { 3318972/100-minutes-stunned-world-moment-bomber-blew- } \\
\text { horrific-slaughter-concert-hall-account-carnage-Paris- } \\
\text { massacre-unfolded.html } \\
\text { Produktum: } \\
\text { - Előtér: } 1 \text { alak + gyertyák + levél + rózsák } \\
\text { - Nem: férfi } \\
\text { - Kor: fiatal } \\
\text { - Feketék/fehérek: fehér } \\
\text { - Pozitúra/proxemika: egy levél fölé hajol } \\
\text { - Öltözet: hétköznapi + francia zászló } \\
\text { - Háttér: } 2 \text { alak, férfi és nő } \\
\text { - Mise en scène: fókusz a kép közepén } \\
\text { Procedúra: }\end{array}$ \\
\hline
\end{tabular}




\begin{tabular}{|c|c|}
\hline & $\begin{array}{l}\text { - Mozdulatok: a férfi a levél fölé hajol, olvassa } \\
\text { - Mimika: koncentráció } \\
\text { - A kamera proxemikája: közeli kép } \\
\text { - Effektek: az előtér éles, a háttér homályos } \\
\text { - } \text { Időfaktor: passzív, áll az idő } \\
\text { Processzus: } \\
\text { - A kép szándéka: az áldozatok hozzátartozóinak } \\
\text { - fájdalmát mutatja be } \\
\text { - A kép hatása: megindító } \\
\text { - A kép által megjelenített toposzok: veszteség }\end{array}$ \\
\hline 22. & $\begin{array}{l}\text { F97. A kép forrása: http://www.dailymail.co.uk/news/article- } \\
\text { 3318972/100-minutes-stunned-world-moment-bomber-blew- } \\
\text { horrific-slaughter-concert-hall-account-carnage-Paris- } \\
\text { massacre-unfolded.html } \\
\text { Produktum: } \\
\text { - Elötér: alakok + francia zászlók + fények } \\
\text { - Nem: férfiak + nők } \\
\text { - Kor: fiatalok } \\
\text { - Feketék/fehérek: fehérek } \\
\text { - Pozitúra/proxemika: egy tömbben állnak } \\
\text { - Öltözet: hétköznapi } \\
\text { - Háttér: Nemzeti Galéria } \\
\text { - Mise en scène: fókusz a kép közepén } \\
\text { Procedúra: } \\
\text { - A kamera nézőpontja: alulról mutatja } \\
\text { - Mozdulatok: az emberek mobiltelefonjaikat az égbe } \\
\text { - tartják } \\
\text { - Mimika: komorság } \\
\text { - A kamera proxemikája: távoli kép } \\
\text { - Effektek: az egész kép homályos } \\
\text { Processzus: } \\
\text { - A kép szándéka: a franciák közös gyászának } \\
\text { bemutatása }\end{array}$ \\
\hline
\end{tabular}




\begin{tabular}{|c|c|c|}
\hline & & $\begin{array}{l}\text { - A kép hatása: megindító } \\
\text { - A kép által megjelenített toposzok: összetartás }\end{array}$ \\
\hline 23. & 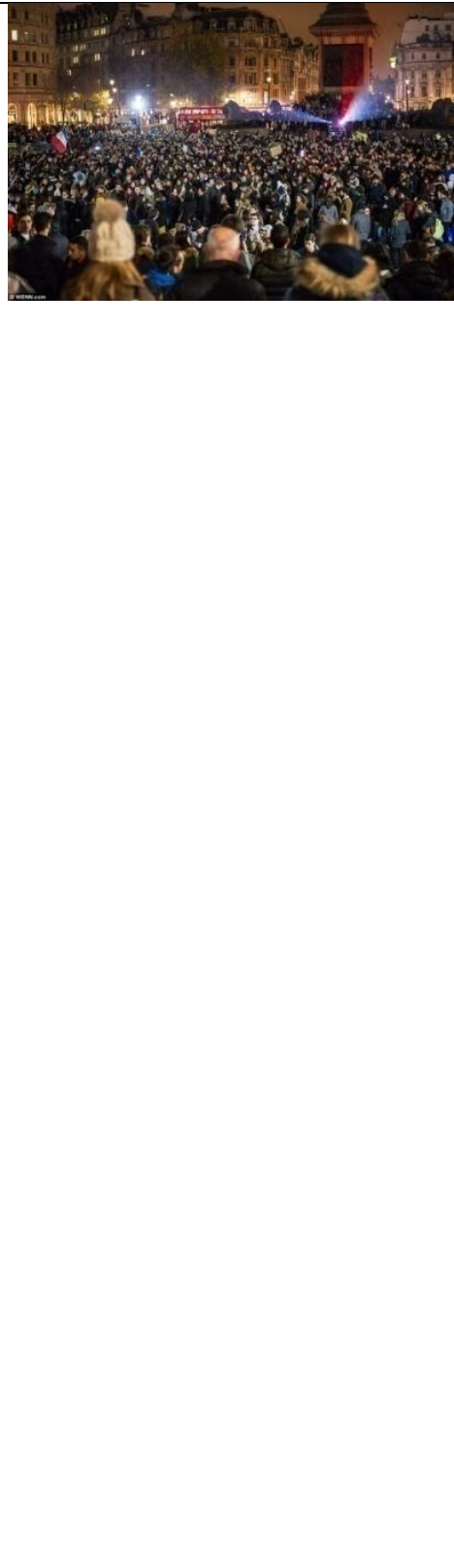 & $\begin{array}{l}\text { F98. A kép forrása: http://www.dailymail.co.uk/news/article- } \\
\text { 3318972/100-minutes-stunned-world-moment-bomber-blew- } \\
\text { horrific-slaughter-concert-hall-account-carnage-Paris- } \\
\text { massacre-unfolded.html } \\
\text { Produktum: } \\
\text { - Előtér: alakok háttal + francia zászlók + fények } \\
\text { - Nem: férfiak + nők } \\
\text { - Kor: minden korosztály } \\
\text { - Feketék/fehérek: fehérek } \\
\text { - Pozitúra/proxemika: egy tömbben állnak } \\
\text { - Öltözet: hétköznapi } \\
\text { - Háttér: házak + fények } \\
\text { - Mise en scène: fókusz az egész képen } \\
\text { Procedúra: } \\
\text { - A kamera nézőpontja: felülről mutatja } \\
\text { - Mozdulatok: az emberek egy helyben állnak } \\
\text { - Mimika: - } \\
\text { - A kamera proxemikája: távoli kép } \\
\text { - Effektek: az egész kép homályos } \\
\text { - Időfaktor: passzív, áll az idő } \\
\text { Processzus: }\end{array}$ \\
\hline 24. & & $\begin{array}{l}\text { F99. A kép forrása: http://www.dailymail.co.uk/news/article- } \\
\text { 3318972/100-minutes-stunned-world-moment-bomber-blew- } \\
\text { horrific-slaughter-concert-hall-account-carnage-Paris- } \\
\underline{\text { massacre-unfolded.html }} \\
\text { Produktum: } \\
\quad \text { - Előtér: } 4 \text { alak+ francia szív }\end{array}$ \\
\hline
\end{tabular}




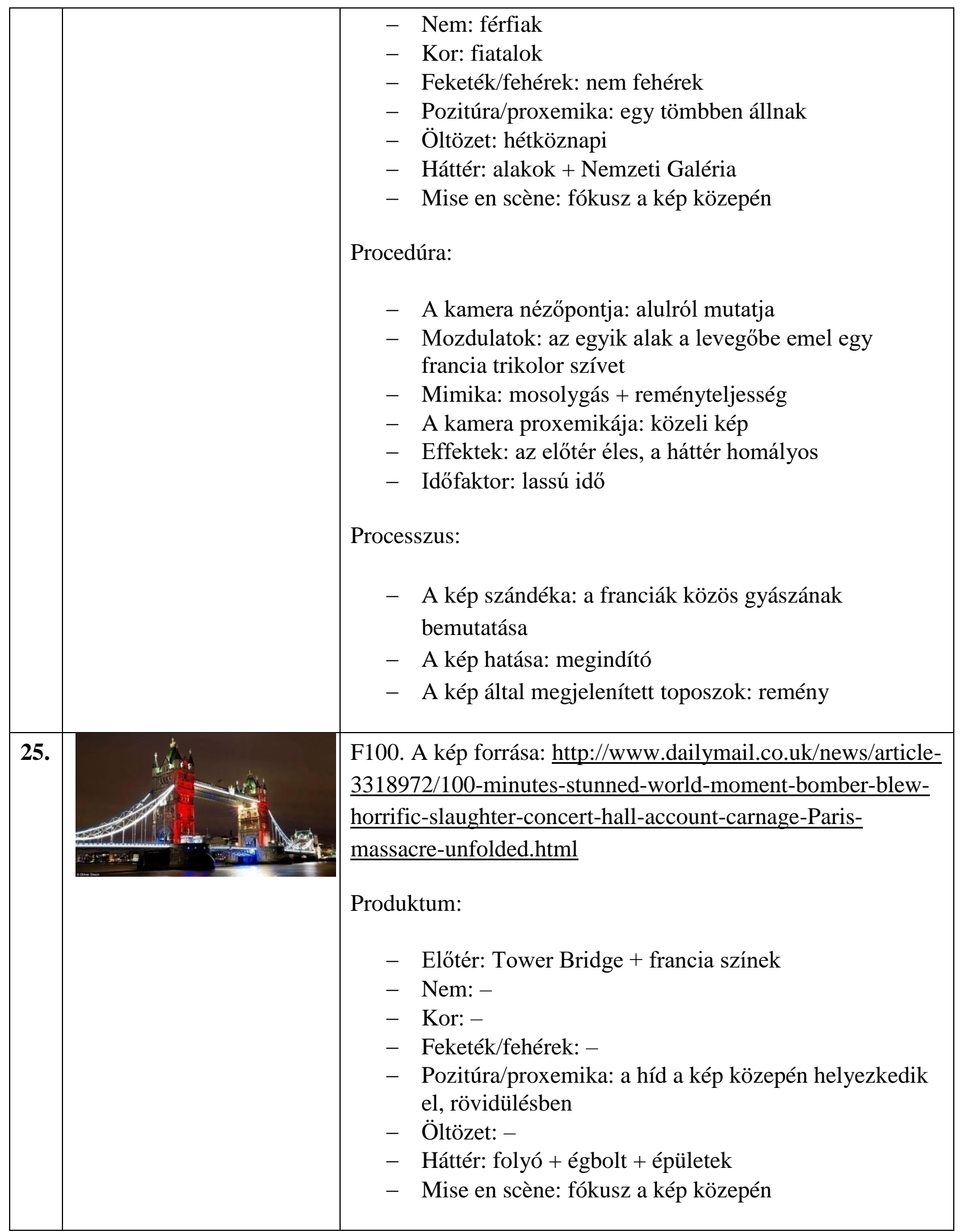




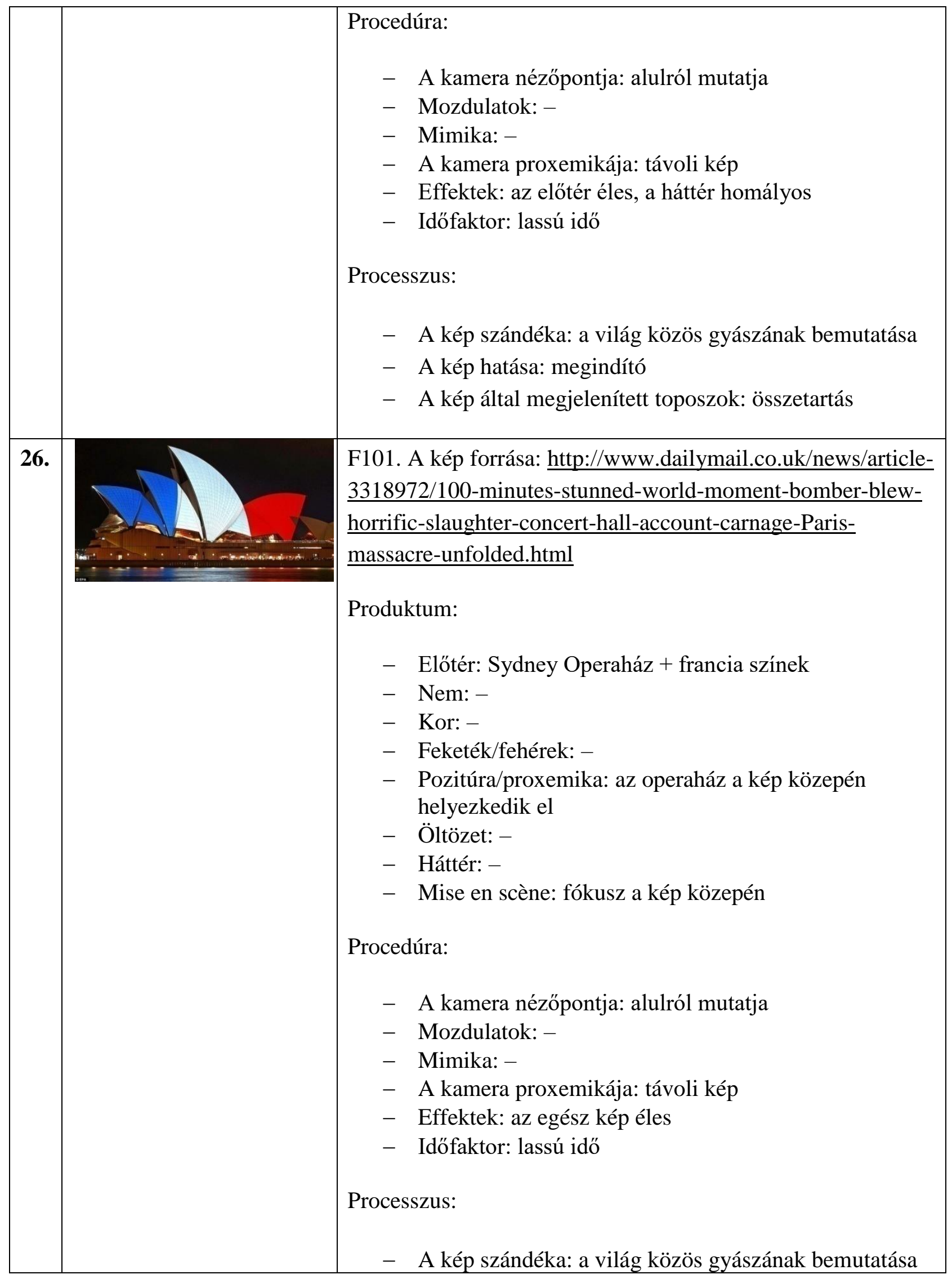




\begin{tabular}{|c|c|}
\hline & $\begin{array}{l}\text { - A kép hatása: megindító } \\
\text { - A kép által megjelenített toposzok: összetartás }\end{array}$ \\
\hline 27. & $\begin{array}{l}\text { F102. A kép forrása: http://www.dailymail.co.uk/news/article- } \\
\text { 3318972/100-minutes-stunned-world-moment-bomber-blew- } \\
\text { horrific-slaughter-concert-hall-account-carnage-Paris- } \\
\text { massacre-unfolded.html } \\
\text { Produktum: } \\
\text { - Előtér: rioi Krisztus szobor + alakok előtte } \\
\text { - Nem: - } \\
\text { - Kor: - } \\
\text { - Feketék/fehérek: - } \\
\text { - Pozitúra/proxemika: a szobor a kép közepén } \\
\text { - } \text { Öltözet: - } \\
\text { - Háttér: sötét égbolt + felhők + hegyek } \\
\text { - Mise en scène: fókusz a kép közepén } \\
\text { Procedúra: } \\
\text { - A kamera nézőpontja: alulról mutatja } \\
\text { - Mozdulatok: - } \\
\text { - Mimika: - } \\
\text { - A kamera proxemikája: távoli kép } \\
\text { - Effektek: az egész kép éles } \\
\text { - Időfaktor: lassú idő } \\
\text { - A kép szándéka: a világ közös gyászának bemutatása } \\
\text { - A kép által megjelenített toposzok: összetartás } \\
\text { - }\end{array}$ \\
\hline 28. & $\begin{array}{l}\text { F103. A kép forrása: } \\
\text { https://www.marketwatch.com/story/paris-attacked- } \\
\text { slideshow-2015-11-14 } \\
\text { Produktum: } \\
\quad \text { - Előtér: } 2 \text { alak + lepedővel félig letakart alak } \\
\quad \text { - Nem: férfiak }\end{array}$ \\
\hline
\end{tabular}




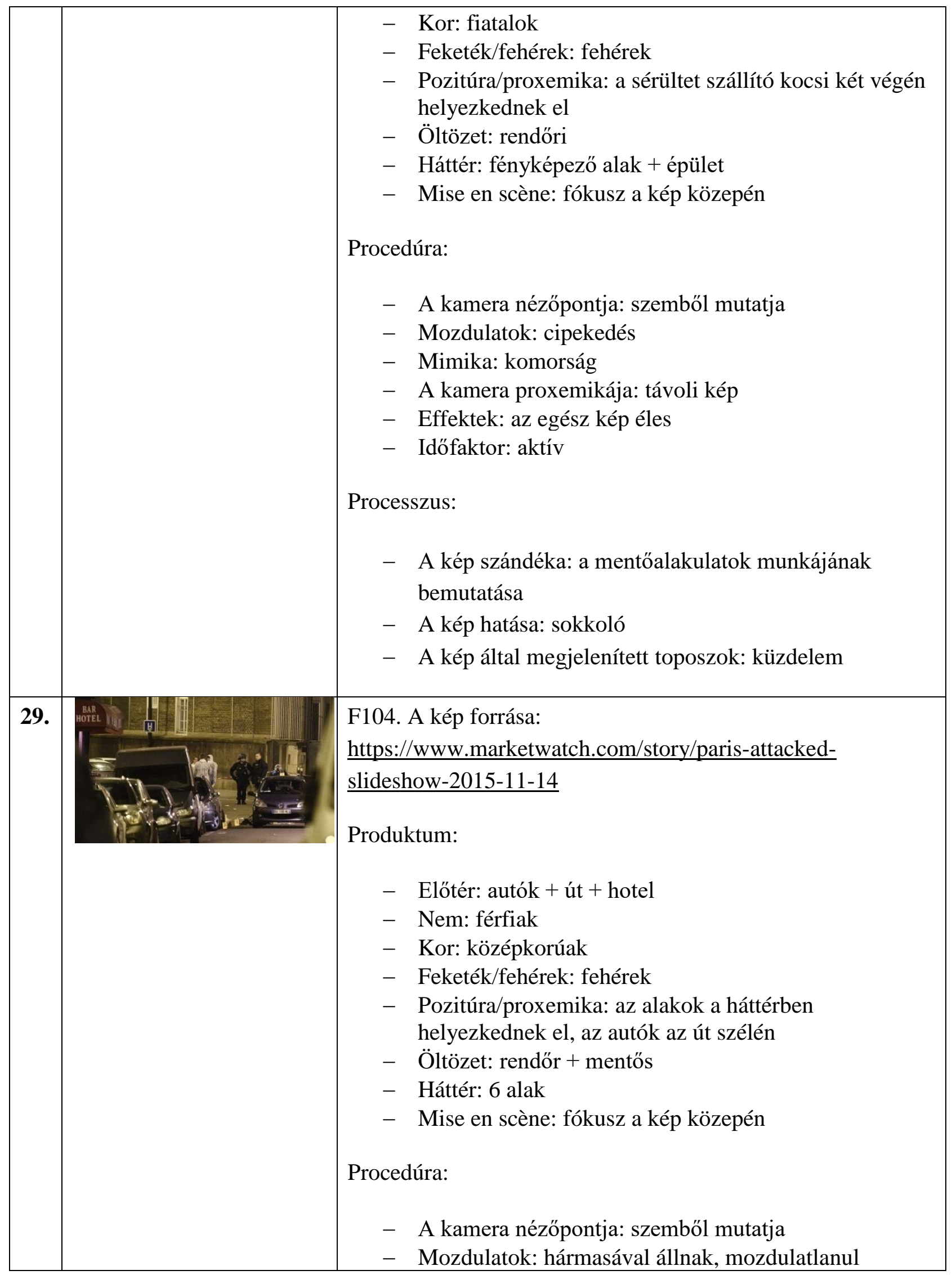




\begin{tabular}{|c|c|}
\hline & $\begin{array}{l}\text { - Mimika: - } \\
\text { - A kamera proxemikája: távoli kép } \\
\text { - Effektek: az egész kép homályos } \\
\text { - } \text { Időfaktor: lassú idő } \\
\text { Processzus: } \\
\text { - A kép szándéka: a rendőrök tehetetlenségének } \\
\text { - } \text { bemutatása } \\
\text { - A kép hatása: tárgyilagos } \\
\text { A kép által megjelenített toposzok: tétlenség }\end{array}$ \\
\hline 30. & $\begin{array}{l}\text { F105. A kép forrása: } \\
\text { https://www.marketwatch.com/story/paris-attacked- } \\
\text { slideshow-2015-11-14 } \\
\text { Produktum: } \\
\text { - Elötér: } 4 \text { alak } \\
\text { - Nem: férfiak + nők } \\
\text { - } \text { Kor: mindenféle korosztály } \\
\text { - Feketék/fehérek: fehérek } \\
\text { - Pozitúra/proxemika: } 3 \text { alak egymást öleli + } 1 \text { mellettük } \\
\text { áll } \\
\text { - Öltözet: rendör + hétköznapi } \\
\text { - Háttér: fények + utca } \\
\text { - Mise en scène: fókusz a bal oldalán } \\
\text { Procedúra: } \\
\text { - A kamera nézőpontja: szemböl mutatja } \\
\text { - Mozdulatok: } 3 \text { alak ölelkezik } \\
\text { - Mimika: megkönnyebbülés, szenvedés }+ \text { komorság } \\
\text { - A kamera proxemikája: közeli kép } \\
\text { - Effektek: az elötér éles, a háttér homályos } \\
\text { - Időfaktor: lassú idő } \\
\text { Processzus: } \\
\text { - A kép szándéka: a megmenekülés és egymásra találás } \\
\text { - } \text { okozta megkönnyebbülés bemutatása } \\
\text { A kép hatása: megindító }\end{array}$ \\
\hline
\end{tabular}




\begin{tabular}{|c|c|c|}
\hline & & - A kép által megjelenített toposzok: összetartás \\
\hline 31. & 8 & $\begin{array}{l}\text { F106. A kép forrása: } \\
\text { http://www.nyugat.hu/tartalom/cikk/terrortamadas_parizs_fra } \\
\text { nciaorszag_hollande_elnok } \\
\text { Produktum: } \\
\text { - Előtér: virágcsokrok } \\
\text { - Nem: nők } \\
\text { - Kor: középkorúak } \\
\text { - Feketék/fehérek: fehérek } \\
\text { - Pozitúra/proxemika: a két nő a virágcsokrok fölé } \\
\text { - guggol } \\
\text { - Hältözet: hétköznapi } \\
\text { - Mise en scène: fókusz a kép bal oldalán } \\
\text { Procedúra: } \\
\text { - A kamera nézőpontja: szemből mutatja } \\
\text { - Mozdulatok: a fiatalabbik lány a szája elé kapja a } \\
\text { Processzus: } \\
\text { - Mimika: szenvedés, fájdalom } \\
\text { - A kamera proxemikája: távoli kép } \\
\text { - Effektek: az előtér homályos, a háttér éles } \\
\text { - Időfaktor: lassú idő } \\
\text { - A kép szándéka: az áldozatok hozzátartozóinak } \\
\text { - A kép által megjelenített toposzok: szenvedés } \\
\text { - }\end{array}$ \\
\hline 32 & & $\begin{array}{l}\text { F107. A kép forrása: } \\
\text { http://www.nyugat.hu/tartalom/cikk/terrortamadas_parizs_fra } \\
\text { nciaorszag_hollande_elnok } \\
\text { Produktum: } \\
\quad \text { - Elötér: } 2 \text { alak } \\
\text { - Nem: férfi + nő }\end{array}$ \\
\hline
\end{tabular}




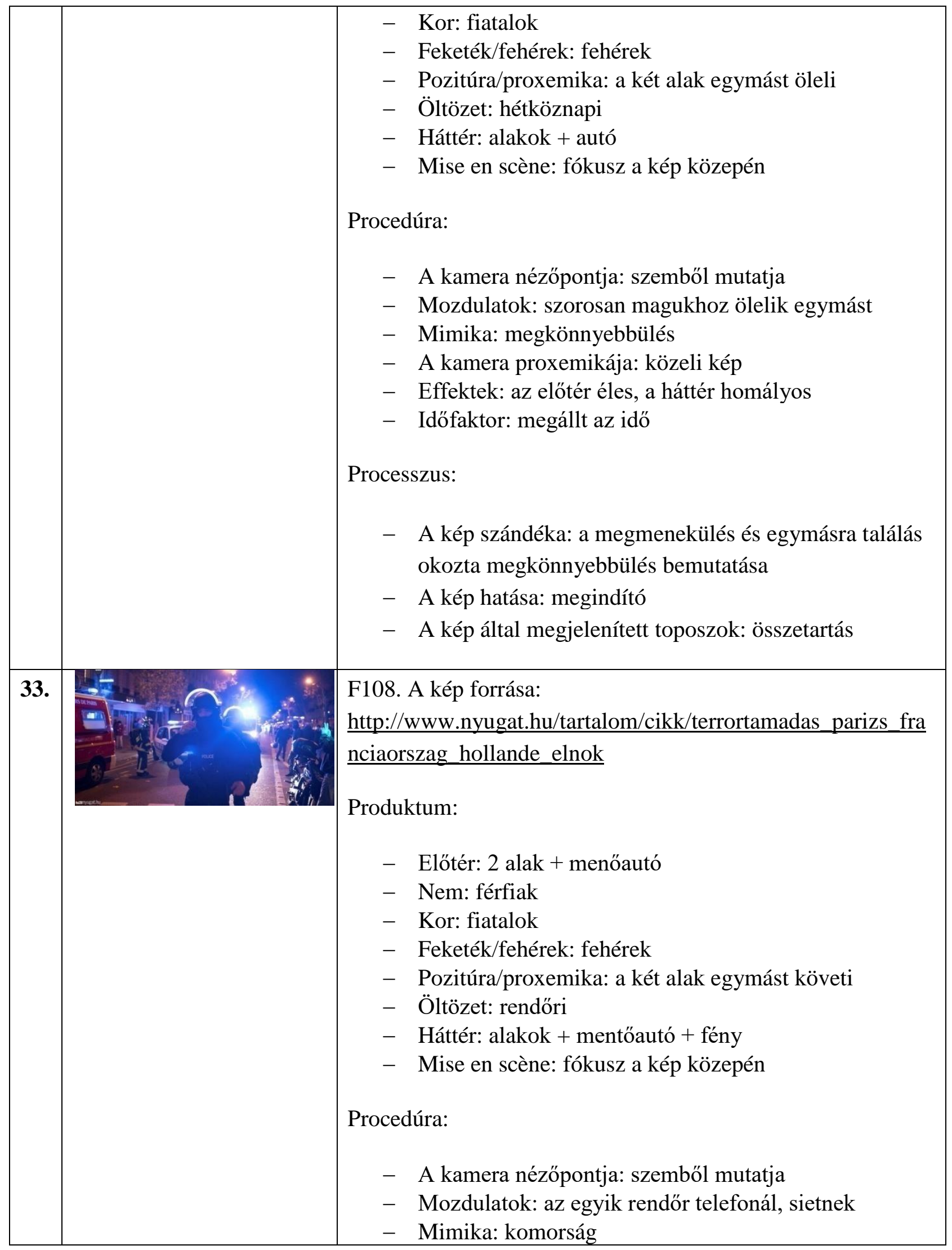




\begin{tabular}{|c|c|c|}
\hline & & $\begin{array}{l}\text { - A kamera proxemikája: közeli kép } \\
\text { - Effektek: az elötér éles, a háttér homályos } \\
\text { - } \text { Időfaktor: aktív } \\
\text { Processzus: } \\
\text { - A kép szándéka: a rendőrség munkájának, } \\
\quad \text { intézkedésének bemutatása } \\
\text { - A kép hatása: ijesztő } \\
\text { - A kép által megjelenített toposzok: küzdelem }\end{array}$ \\
\hline 34. & 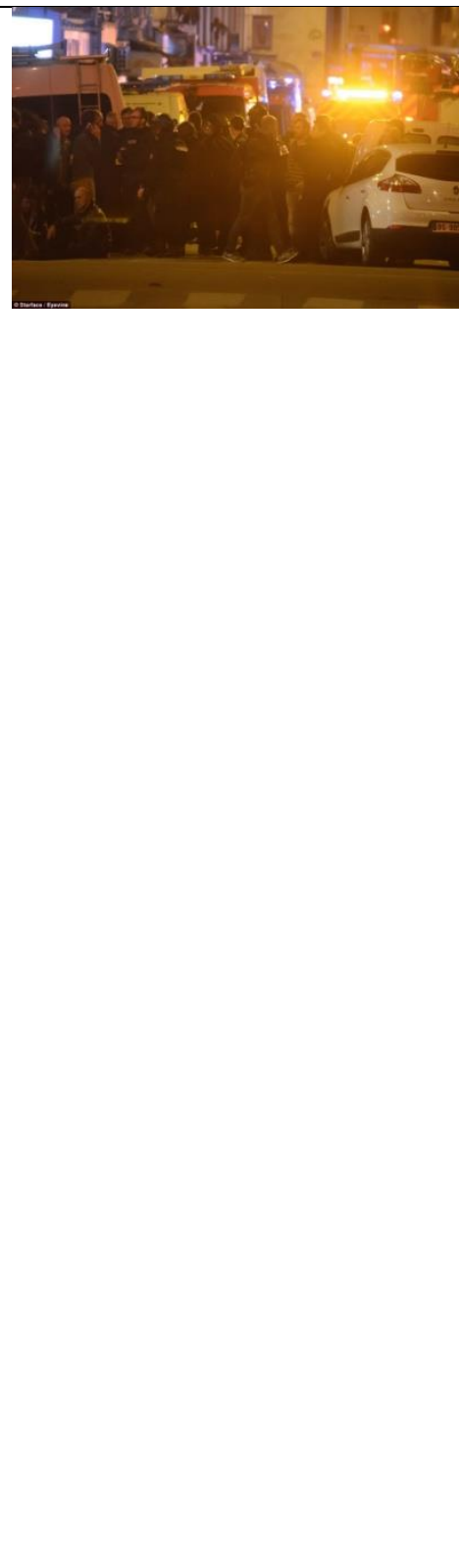 & 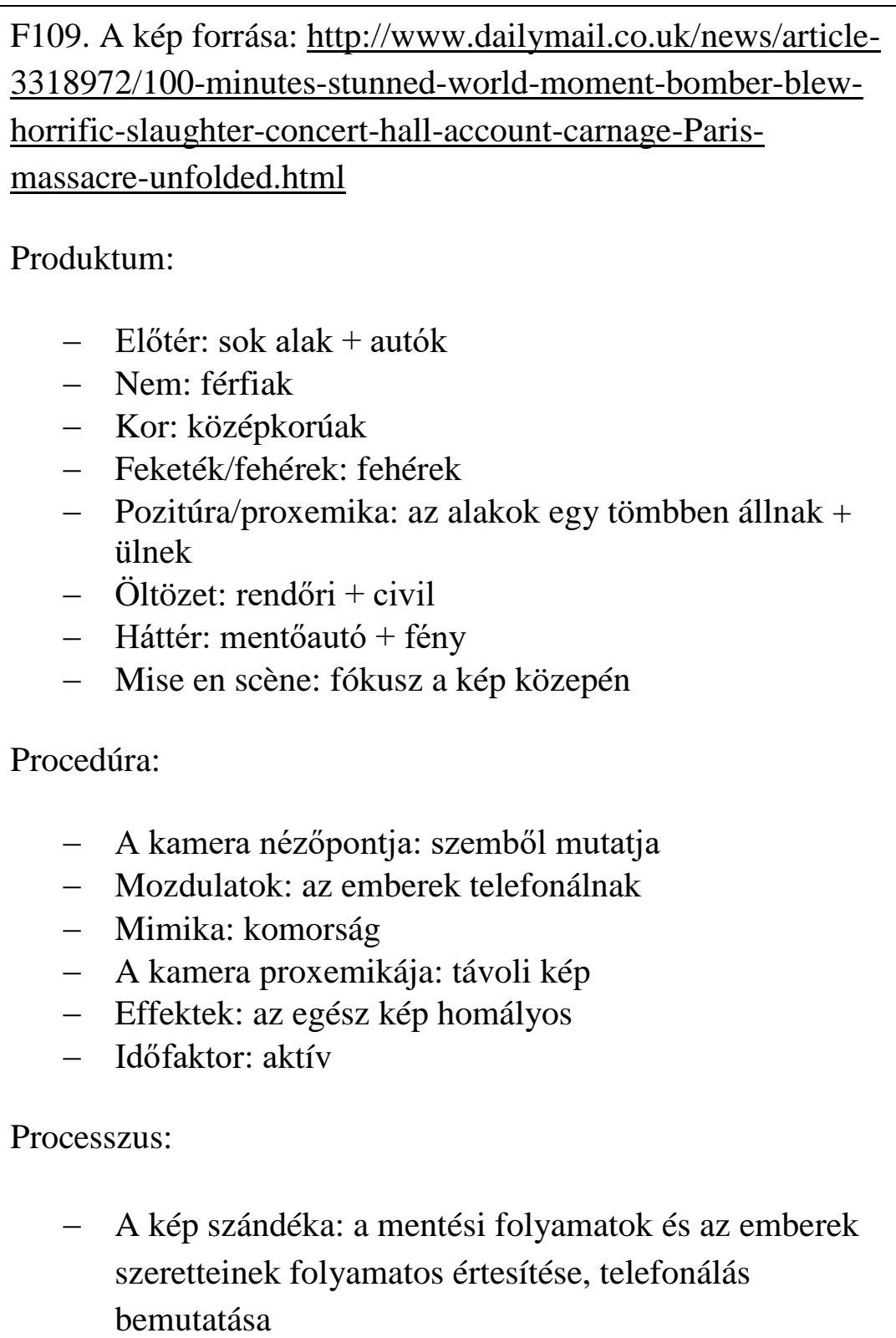 \\
\hline
\end{tabular}




\begin{tabular}{|c|c|}
\hline & $\begin{array}{l}\text { - A kép hatása: ijesztő } \\
\text { - A kép által megjelenített toposzok: küzdelem }\end{array}$ \\
\hline 35. & 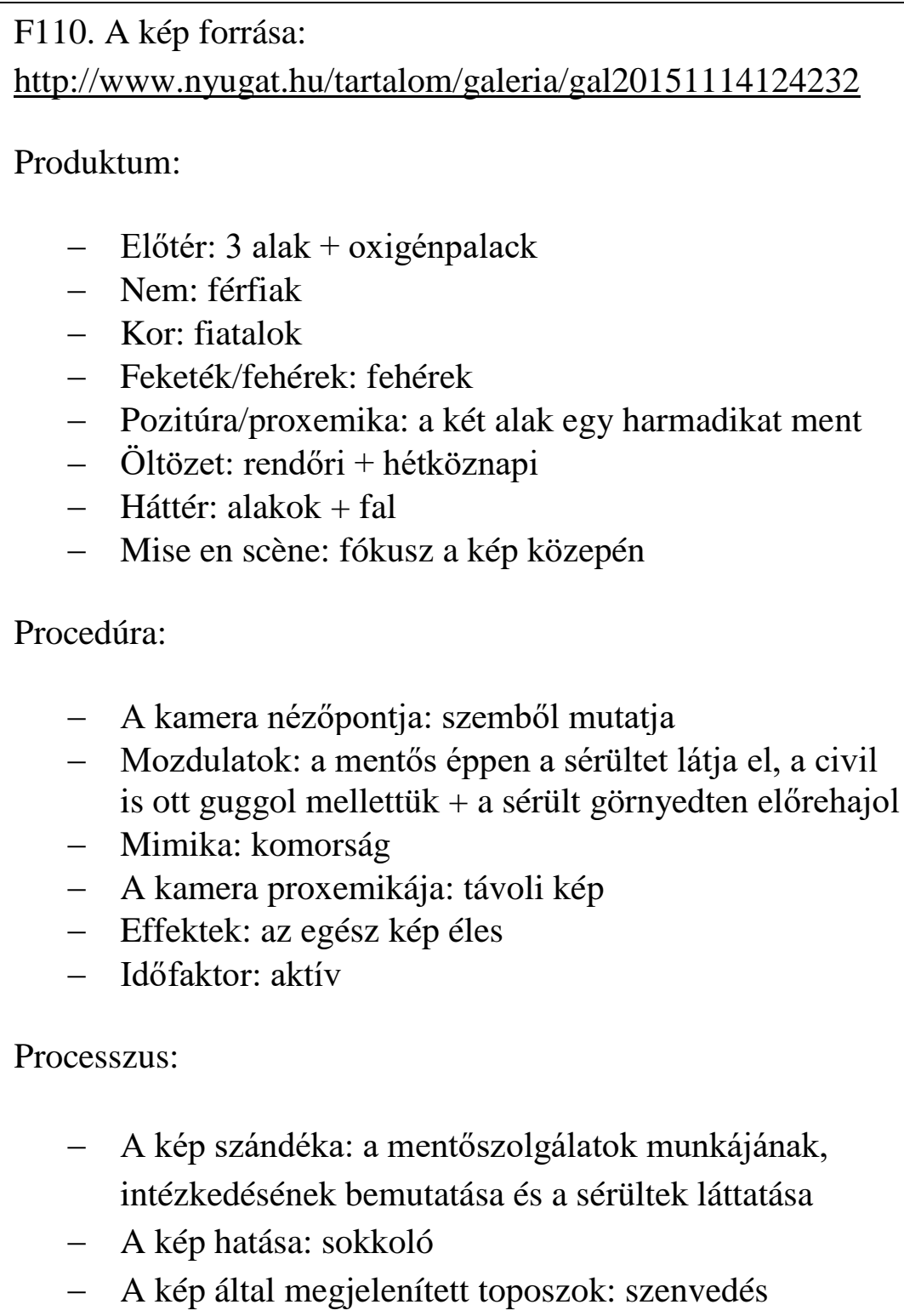 \\
\hline 36. & $\begin{array}{l}\text { F111. A kép forrása: } \\
\text { http://www.nyugat.hu/tartalom/galeria/gal20151114124232 } \\
\text { Produktum: } \\
\text { - Előtér: } 6 \text { alak + hordágy } \\
\text { - Nem: férfiak } \\
\text { - Kor: - } \\
\text { - Feketék/fehérek: fehérek }\end{array}$ \\
\hline
\end{tabular}




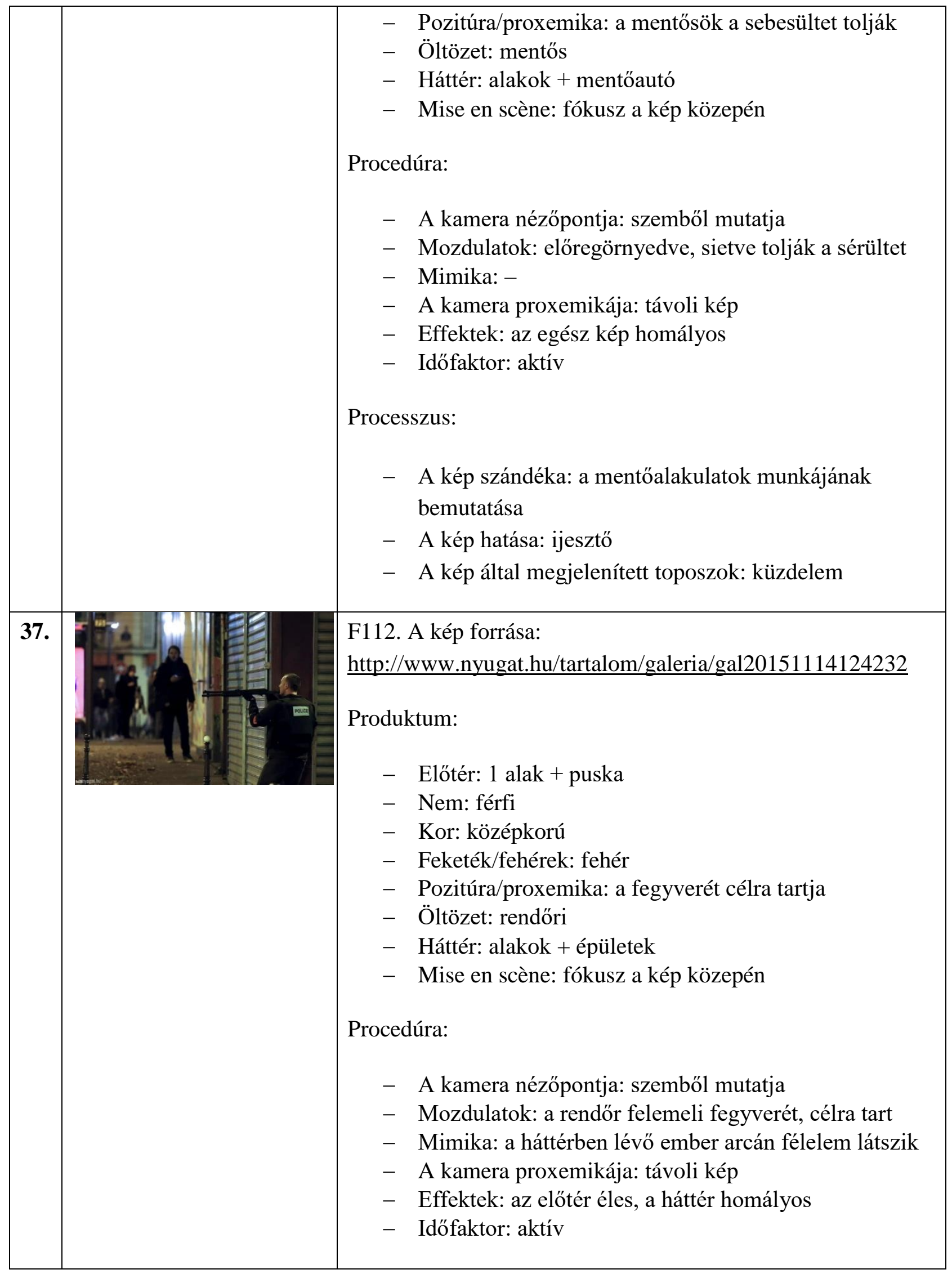




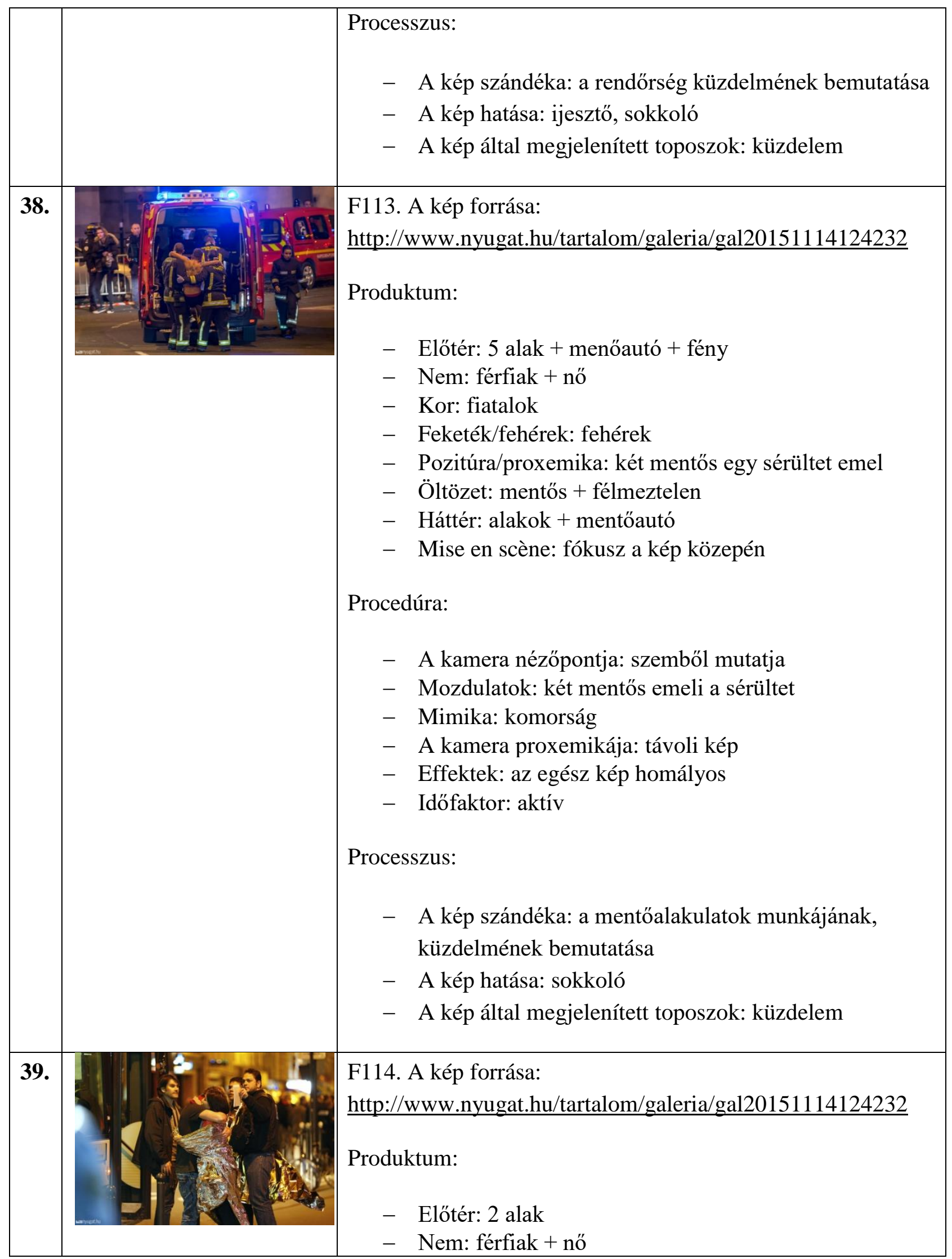




\begin{tabular}{|c|c|}
\hline & 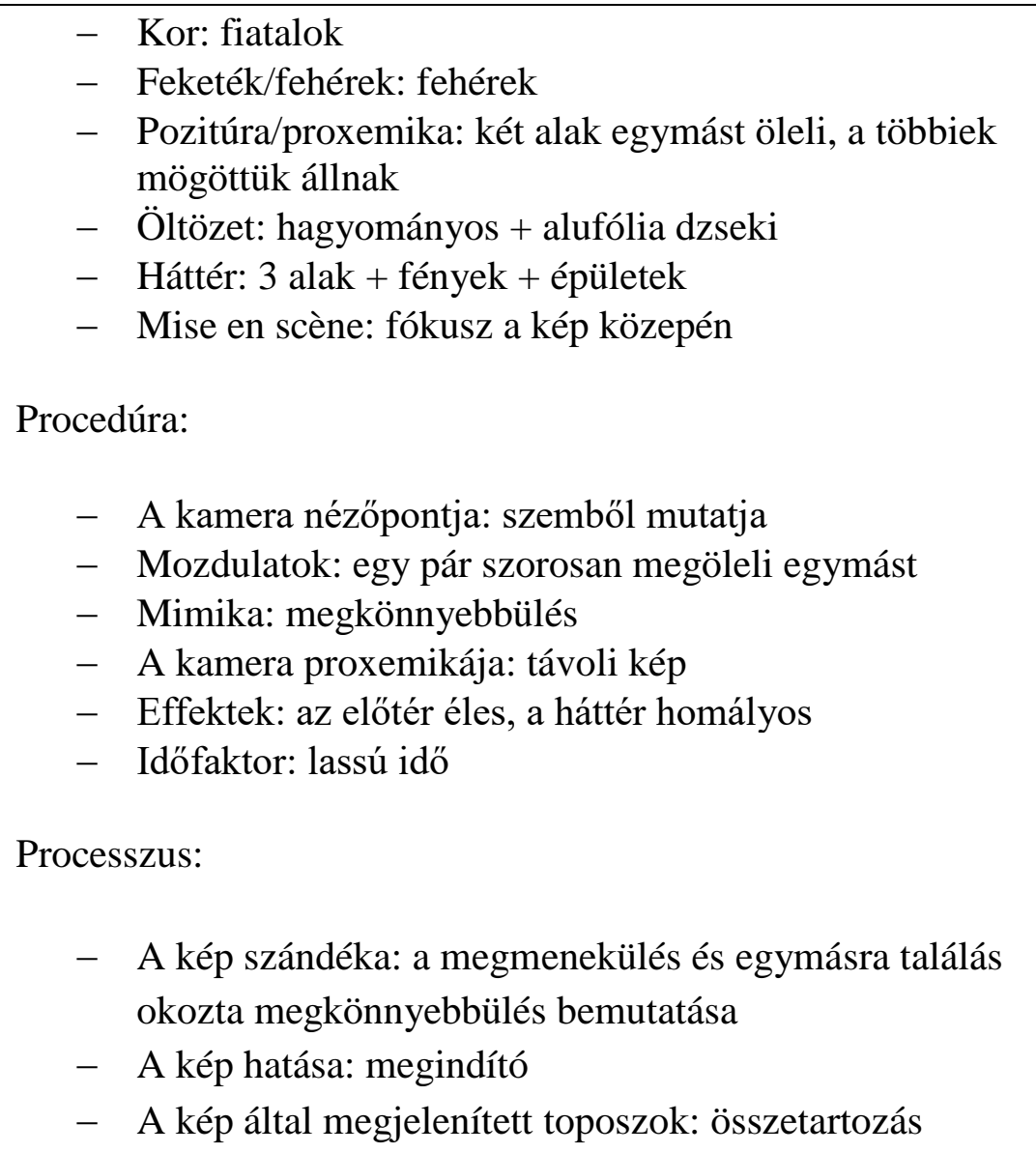 \\
\hline 40 . & 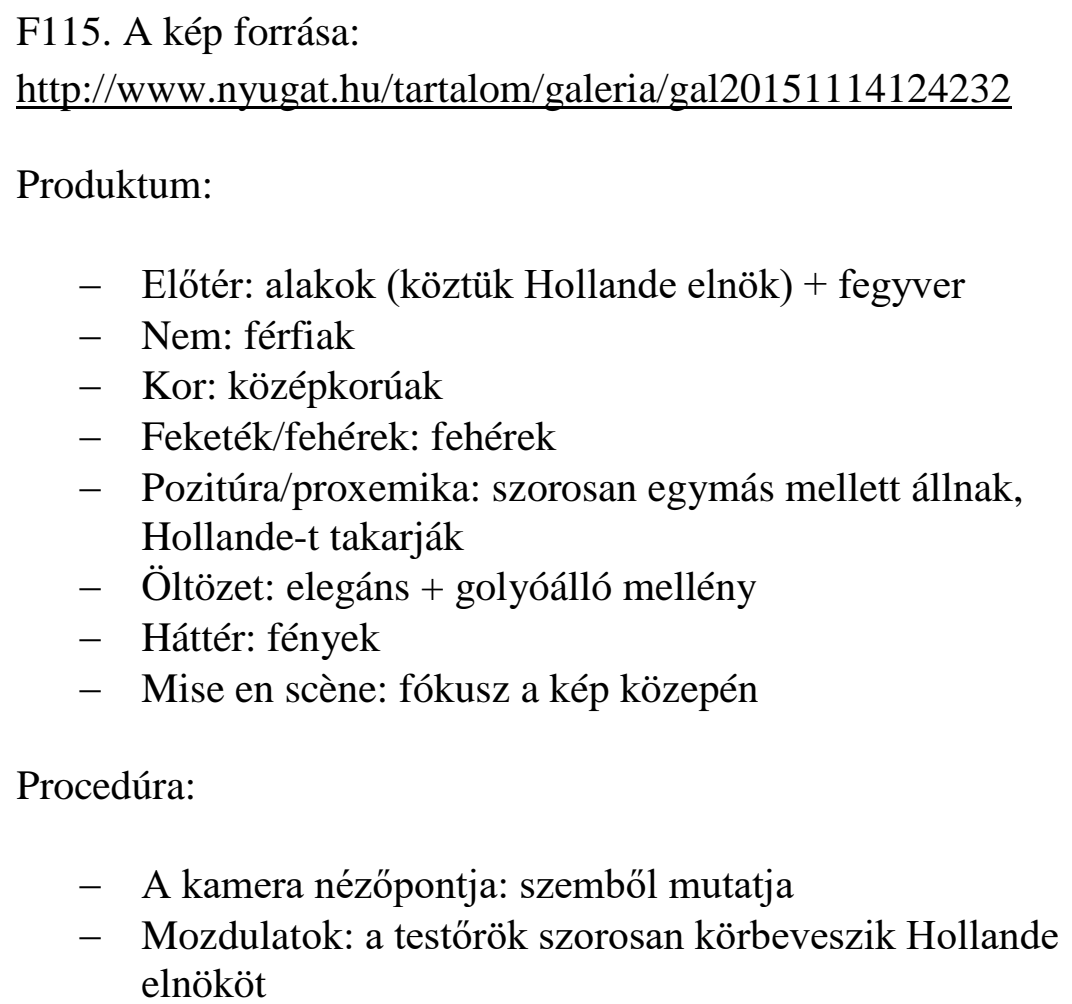 \\
\hline
\end{tabular}




\begin{tabular}{|c|c|}
\hline & $\begin{array}{l}\text { - Mimika: félelem } \\
\text { - A kamera proxemikája: közeli kép } \\
\text { - Effektek: az előtér éles, a háttér homályos } \\
\text { - } \text { Időfaktor: lassú idő } \\
\text { Processzus: } \\
\text { - A kép szándéka: Hollande elnök testőrök közötti } \\
\text { - megbúvásának bemutatása } \\
\text { - A kép hatása: ijesztő } \\
\text { - A kép által megjelenített toposzok: rémület }\end{array}$ \\
\hline 41. & 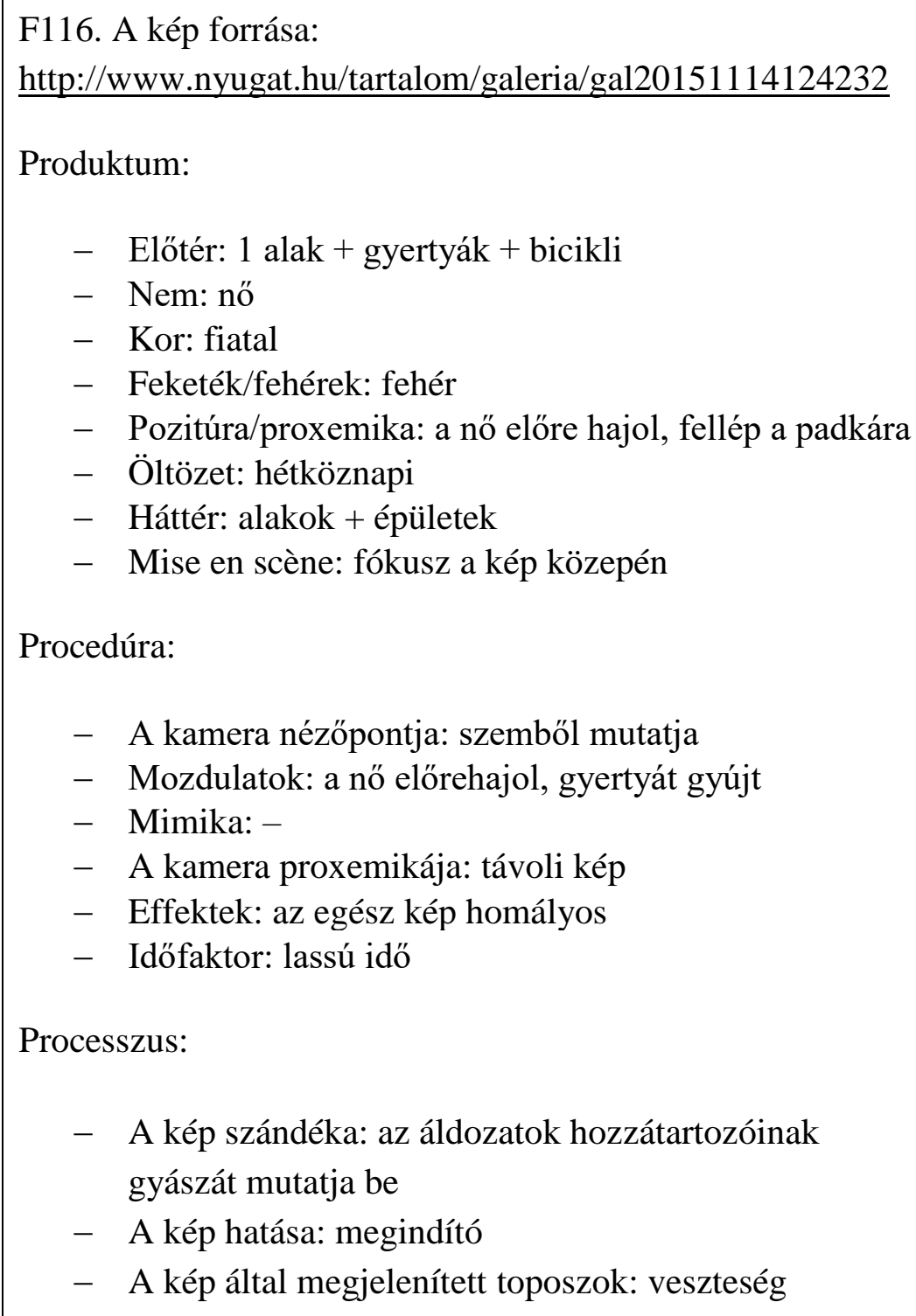 \\
\hline
\end{tabular}




\begin{tabular}{|c|c|c|}
\hline 42. & 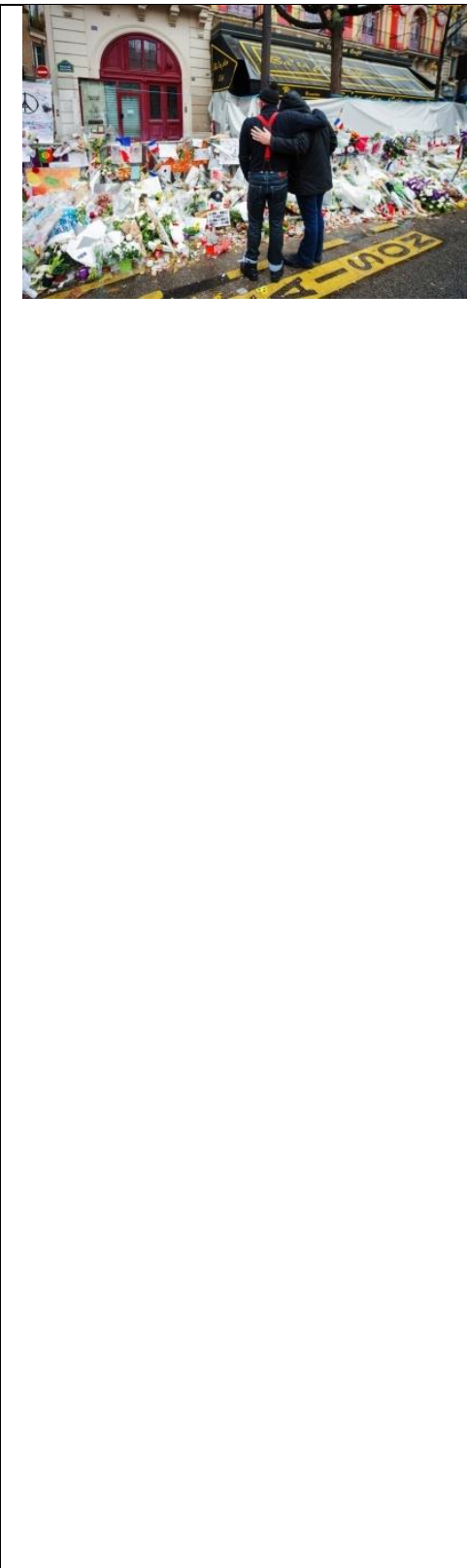 & $\begin{array}{l}\text { F117. A kép forrása: } \\
\text { https://www.billboard.com/articles/news/7573556/revisiting- } \\
\text { the-bataclan-paris-neighborhood-a-year-after-the-terrorist- } \\
\text { attacks-sting } \\
\text { Produktum: } \\
\text { - Elötér: } 2 \text { alak (Eagles of Death Metal tagjai) } \\
\text { - Nem: férfiak } \\
\text { - Kor: középkorúak } \\
\text { - Feketék/fehérek: fehér } \\
\text { - Pozitúra/proxemika: a bandatagok átkarolják egymást } \\
\text { - Öltözet: hétköznapi } \\
\text { - Háttér: virágcsokor halmok + épületek } \\
\text { - Mise en scène: fókusz a kép közepén } \\
\text { Procedúra: } \\
\text { - A kamera nézőpontja: hátulról mutatja } \\
\text { - Mozdulatok: a férfiak egymást támogatják } \\
\text { - Mimika: - } \\
\text { - A kamera proxemikája: távoli kép } \\
\text { - Effektek: az egész kép éles } \\
\text { - Időfaktor: lassú idö } \\
\text { Processzus: } \\
\text { - A kép szándéka: az együttes tagjainak együttérzését, } \\
\text { - }\end{array}$ \\
\hline 43. & Lathis & $\begin{array}{l}\text { F118. A kép forrása: } \\
\text { http://edition.cnn.com/2016/11/13/europe/paris-bataclan- } \\
\underline{\text { sting/index.html }} \\
\text { Produktum: } \\
\text { - Előtér: } 4 \text { alak } \\
\text { - Nem: férfiak } \\
\text { - Kor: fiatalok } \\
\text { - Feketék/fehérek: fehér } \\
\text { - Pozitúra/proxemika: elszórtan állnak }\end{array}$ \\
\hline
\end{tabular}




\begin{tabular}{|c|c|c|}
\hline & & 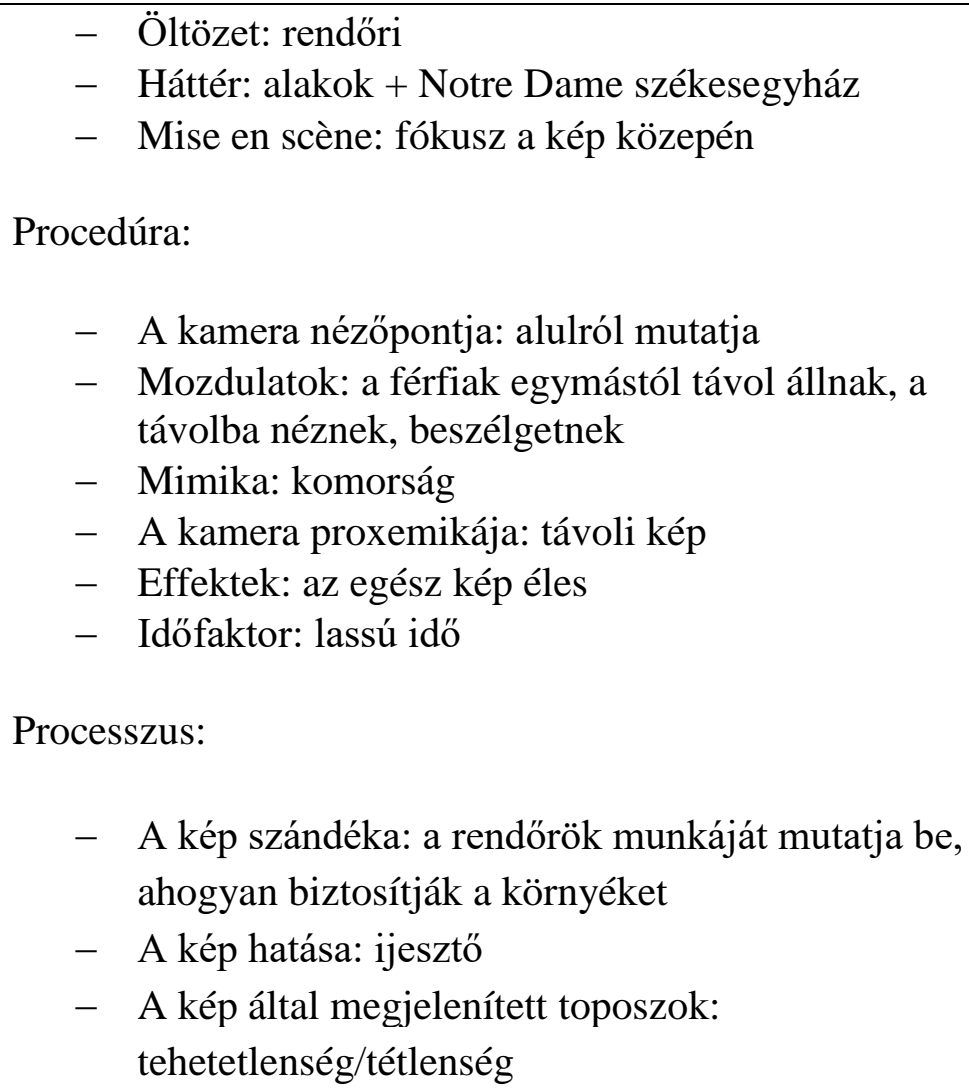 \\
\hline 44. & $=\frac{-2}{2}$ & $\begin{array}{l}\text { F119. A kép forrása: } \\
\text { http://edition.cnn.com/2016/11/13/europe/paris-bataclan- } \\
\text { sting/index.html } \\
\text { Produktum: } \\
\text { - Elötér: } 1 \text { pár cipö + padka + avar } \\
\text { - Nem: - } \\
\text { - Kor: - } \\
\text { - Feketék/fehérek: - } \\
\text { - Pozitúra/proxemika: elszórtan helyezkednek el } \\
\text { - Öltözet: - } \\
\text { - Háttér: véres felső } \\
\text { - Mise en scène: fókusz a kép közepén } \\
\text { Procedúra: } \\
\text { - A kamera nézőpontja: szemből mutatja } \\
\text { - Mozdulatok: - } \\
\text { - Mimika: - } \\
\text { - A kamera proxemikája: közeli kép }\end{array}$ \\
\hline
\end{tabular}




\begin{tabular}{|c|c|c|}
\hline & & $\begin{array}{l}\text { - Effektek: az előtér éles, a háttér homályos } \\
\text { - } \text { Időfaktor: avar + véres felső: az elmúlás szimbólumai } \\
\text { Processzus: } \\
\text { - A kép szándéka: az áldozatok és a halál szimbolikus } \\
\quad \text { reprezentációja } \\
\text { - A kép hatása: sokkoló } \\
\text { - }\end{array}$ \\
\hline 45. & +5 & 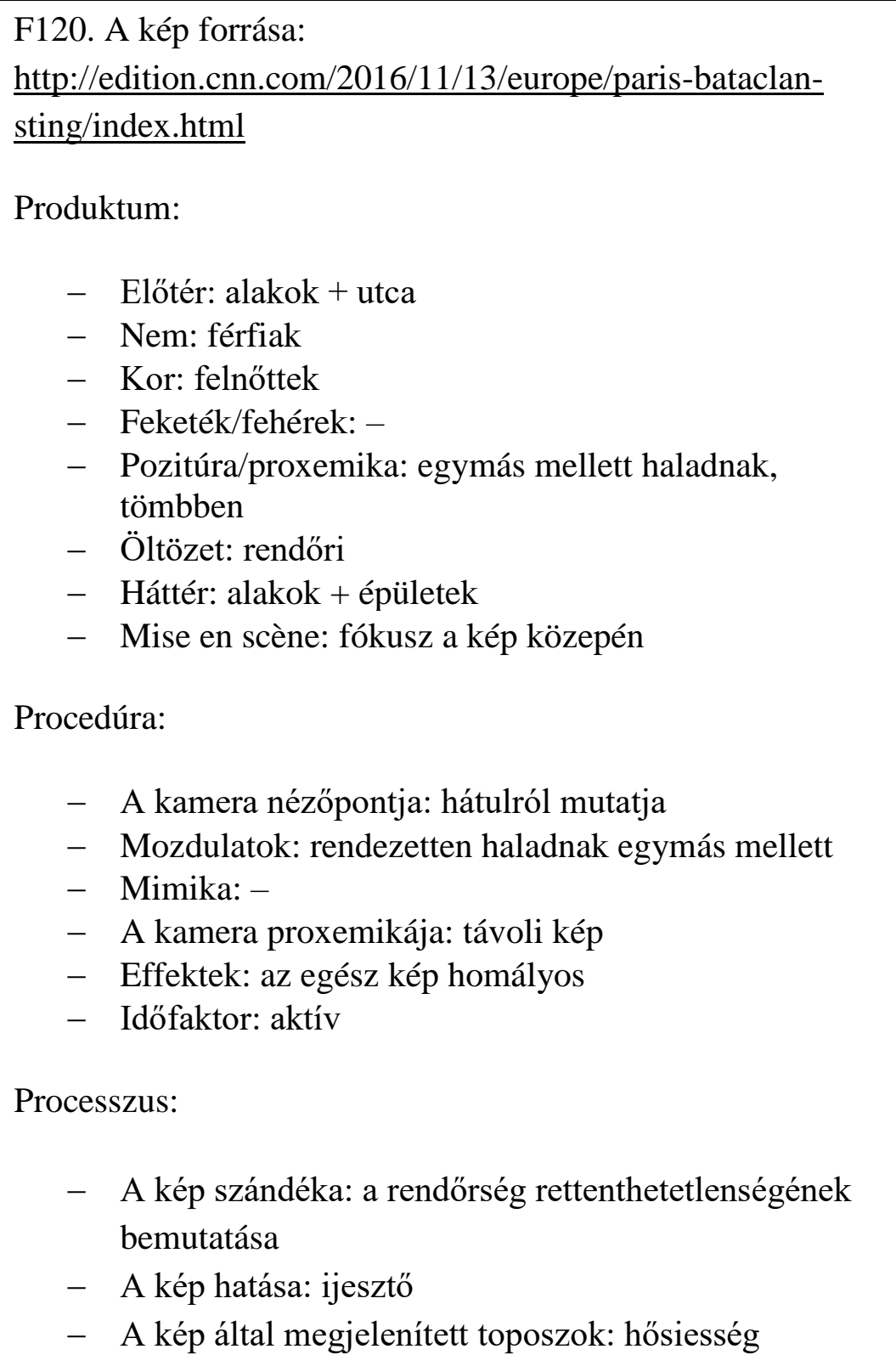 \\
\hline
\end{tabular}




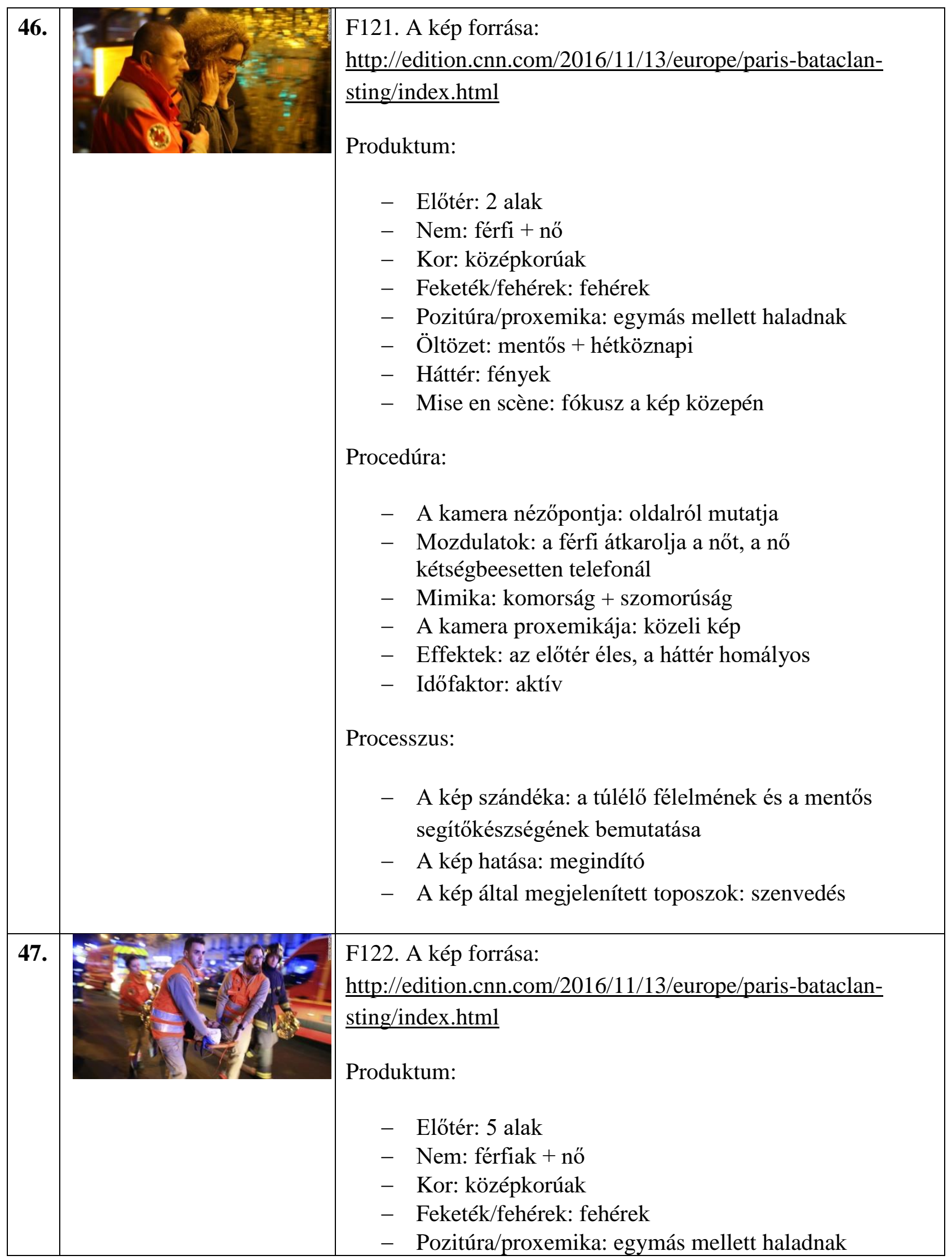




\begin{tabular}{|c|c|}
\hline & $\begin{array}{l}\text { - Öltözet: mentős + tüzoltó + hétköznapi } \\
\text { - Háttér: mentőautó + fények } \\
\text { - Mise en scène: fókusz a kép közepén } \\
\text { Procedúra: } \\
\text { - A kamera nézőpontja: szemből mutatja } \\
\text { - Mozdulatok: a mentősök rohannak a hordágyon fekvő } \\
\text { - } \text { sérülttel } \\
\text { - Aimika: aggodalom, rémület } \\
\text { - Effektek: az elötér is homályos, mert rohannak } \\
\text { - Időfaktor: sietni kell } \\
\text { Processzus: } \\
\text { - A kép szándéka: a mentők segítségnyújtásának és a } \\
\text { - } \text { sérültek megmentésének bemutatása } \\
\text { - A kép hatása: ijesztő }\end{array}$ \\
\hline 48 & $\begin{array}{l}\text { F123. A kép forrása: } \\
\text { http://edition.cnn.com/2016/11/13/europe/paris-bataclan- } \\
\text { sting/index.html } \\
\text { Produktum: } \\
\text { - Elötér: } 3 \text { alak + lepedővel letakart halott } \\
\text { - Nem: férfiak } \\
\text { - } \text { Kor: felnőttek } \\
\text { - Feketék/fehérek: - } \\
\text { - Pozitúra/proxemika: a mentősök a halott fölé } \\
\text { - } \text { görnyednek } \\
\text { - Hättér: fények + épület } \\
\text { - Mise en scène: fókusz a kép közepén } \\
\text { Procedúra: } \\
\text { - A kamera nézőpontja: szemböl mutatja } \\
\text { - Mozdulatok: a mentösök a halott felett } \\
\text { - guggolnak/görnyednek } \\
\text { - Mimika: - }\end{array}$ \\
\hline
\end{tabular}




\begin{tabular}{|c|c|}
\hline & $\begin{array}{l}\text { - Effektek: az előtér éles, a háttér homályos } \\
\text { - Időfaktor: elmúlás } \\
\text { Processzus: } \\
\text { - A kép szándéka: a mészárlás okozta veszteség és } \\
\text { emberáldozatok bemutatása } \\
\text { - A kép hatása: sokkoló } \\
\text { - A kép által megjelenített toposzok: halál }\end{array}$ \\
\hline 49. & 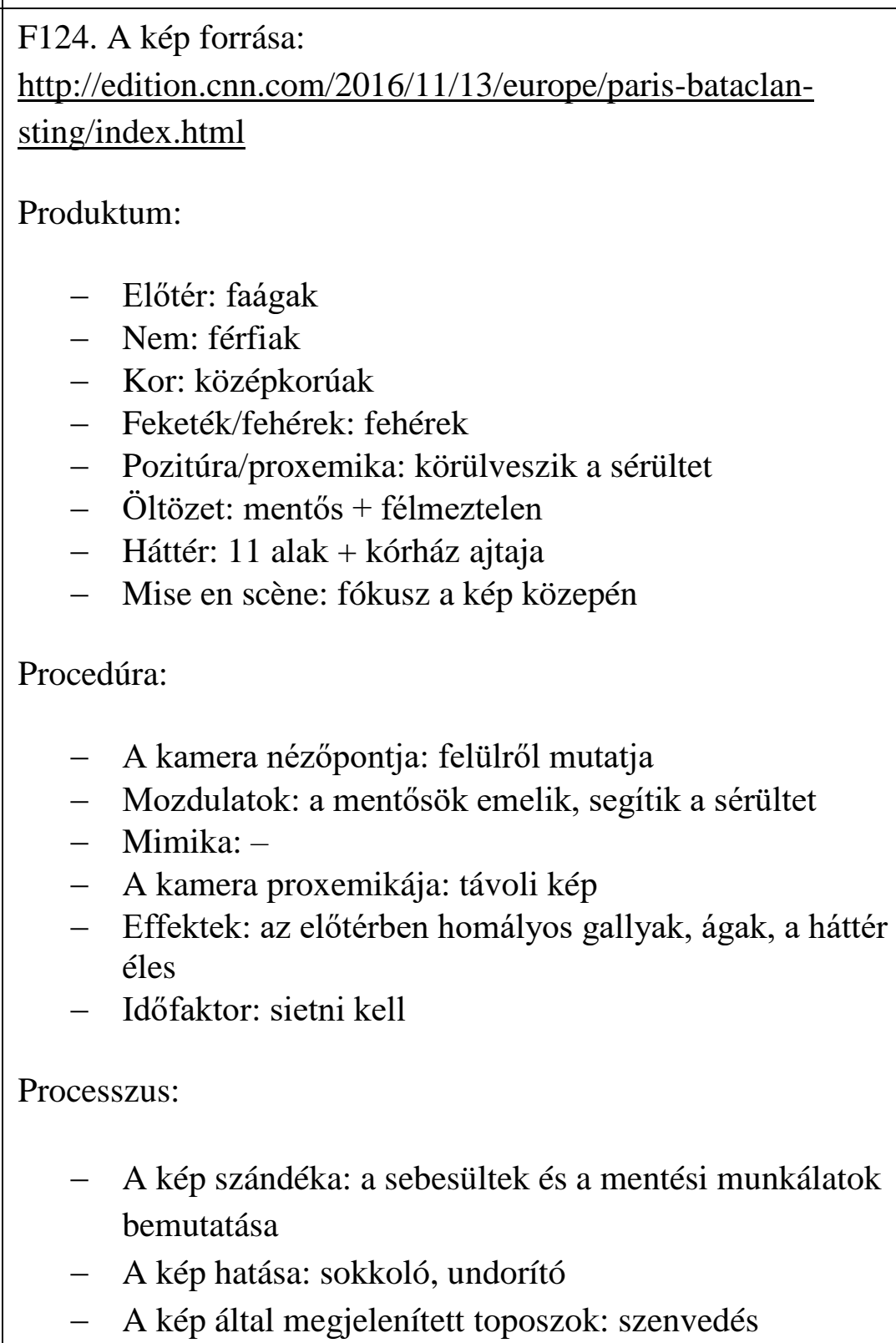 \\
\hline
\end{tabular}




\begin{tabular}{|c|c|c|}
\hline 50. & 3 & 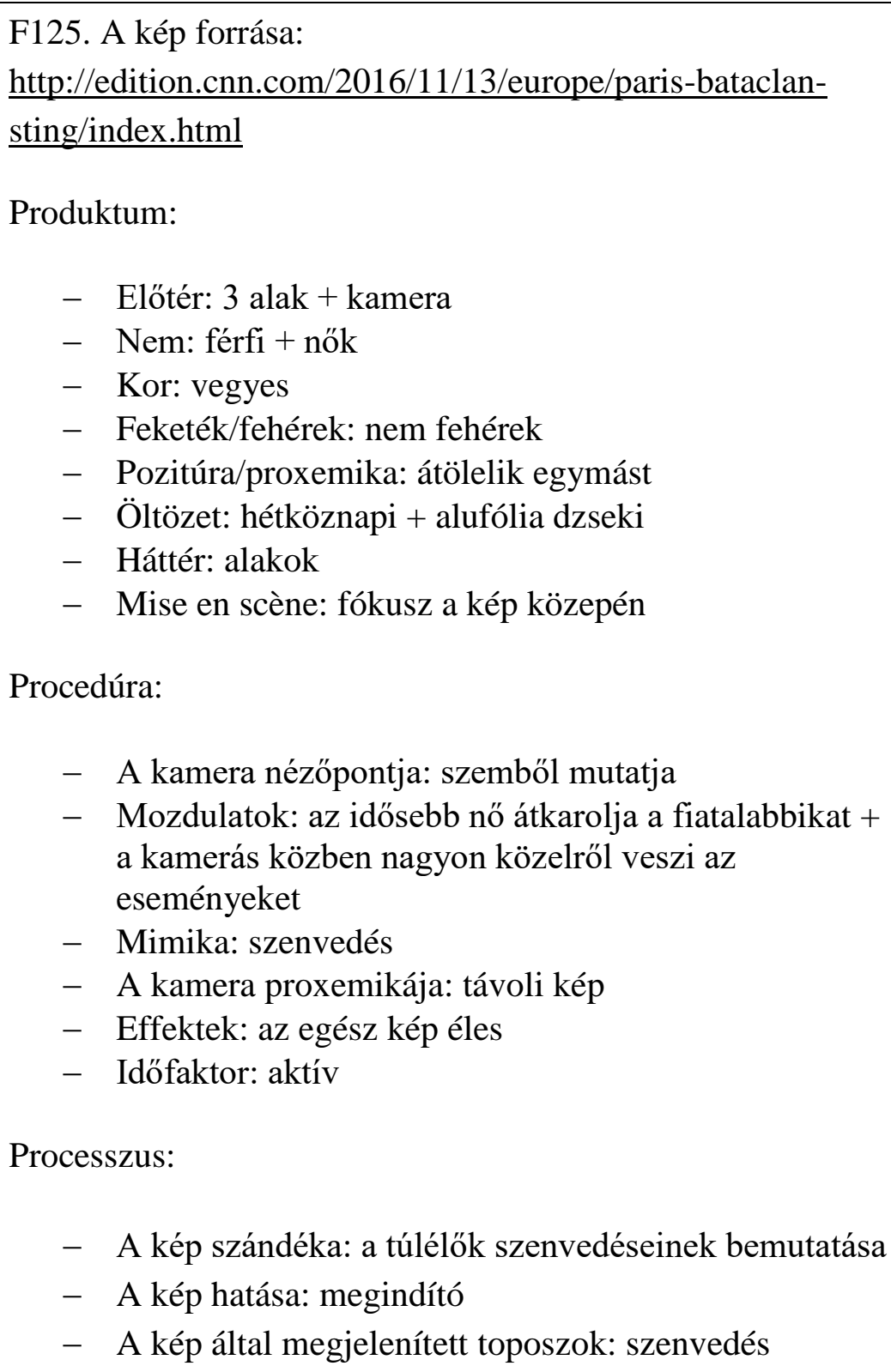 \\
\hline 51. & i: & $\begin{array}{l}\text { F126. A kép forrása: } \\
\text { http://edition.cnn.com/2016/11/13/europe/paris-bataclan- } \\
\text { sting/index.html } \\
\text { Produktum: } \\
\begin{array}{l}\text { - Elötér: } 2 \text { alak + autók } \\
\text { - Nem: férfiak } \\
\text { - Kor: középkorúak } \\
\text { - Feketék/fehérek: fehérek } \\
\text { - Pozitúra/proxemika: a mentős odaguggol a sérülthöz }\end{array}\end{array}$ \\
\hline
\end{tabular}




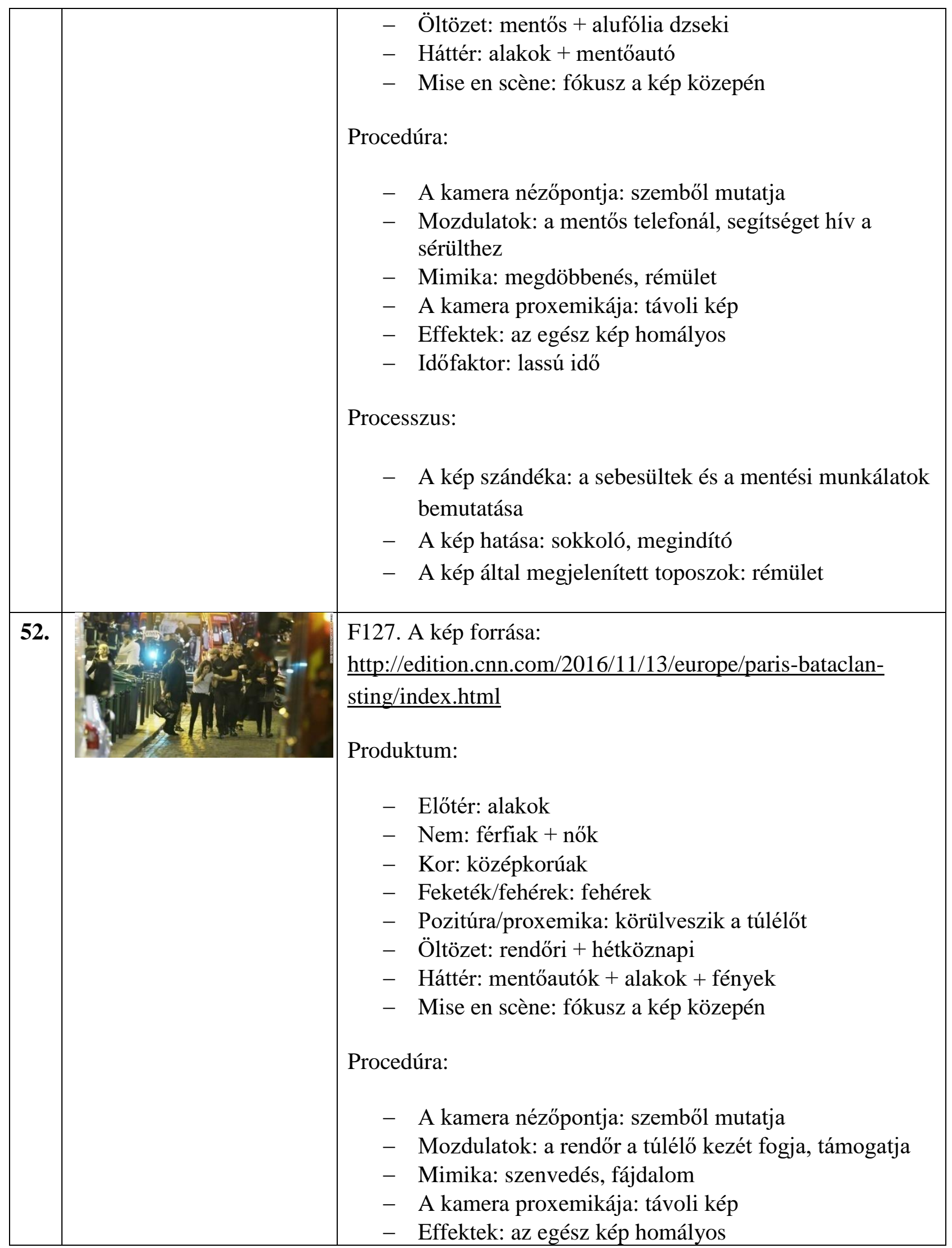




\begin{tabular}{|c|c|c|}
\hline & & $\begin{array}{l}\text { - Időfaktor: aktív } \\
\text { Processzus: } \\
\text { - A kép szándéka: a túlélők fájdalmának bemutatása } \\
\text { - A kép hatása: megindító } \\
\text { - A kép által megjelenített toposzok: szenvedés }\end{array}$ \\
\hline 53. & 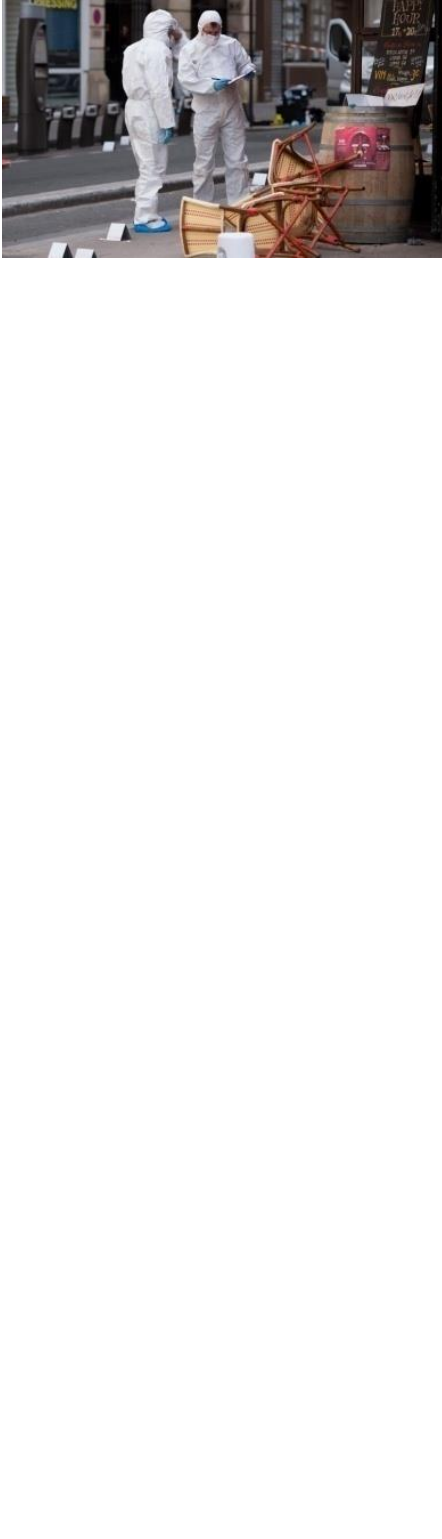 & 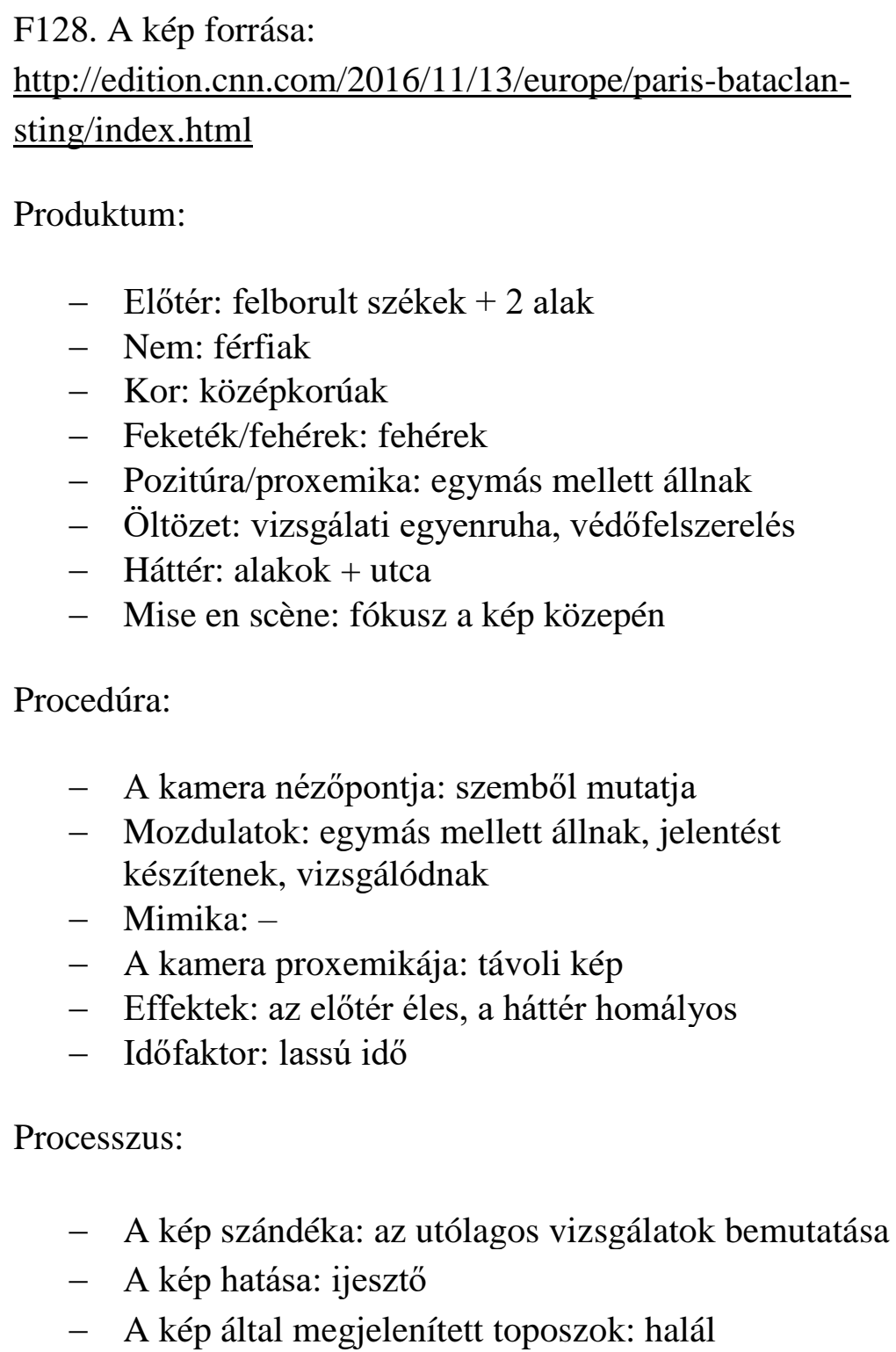 \\
\hline
\end{tabular}




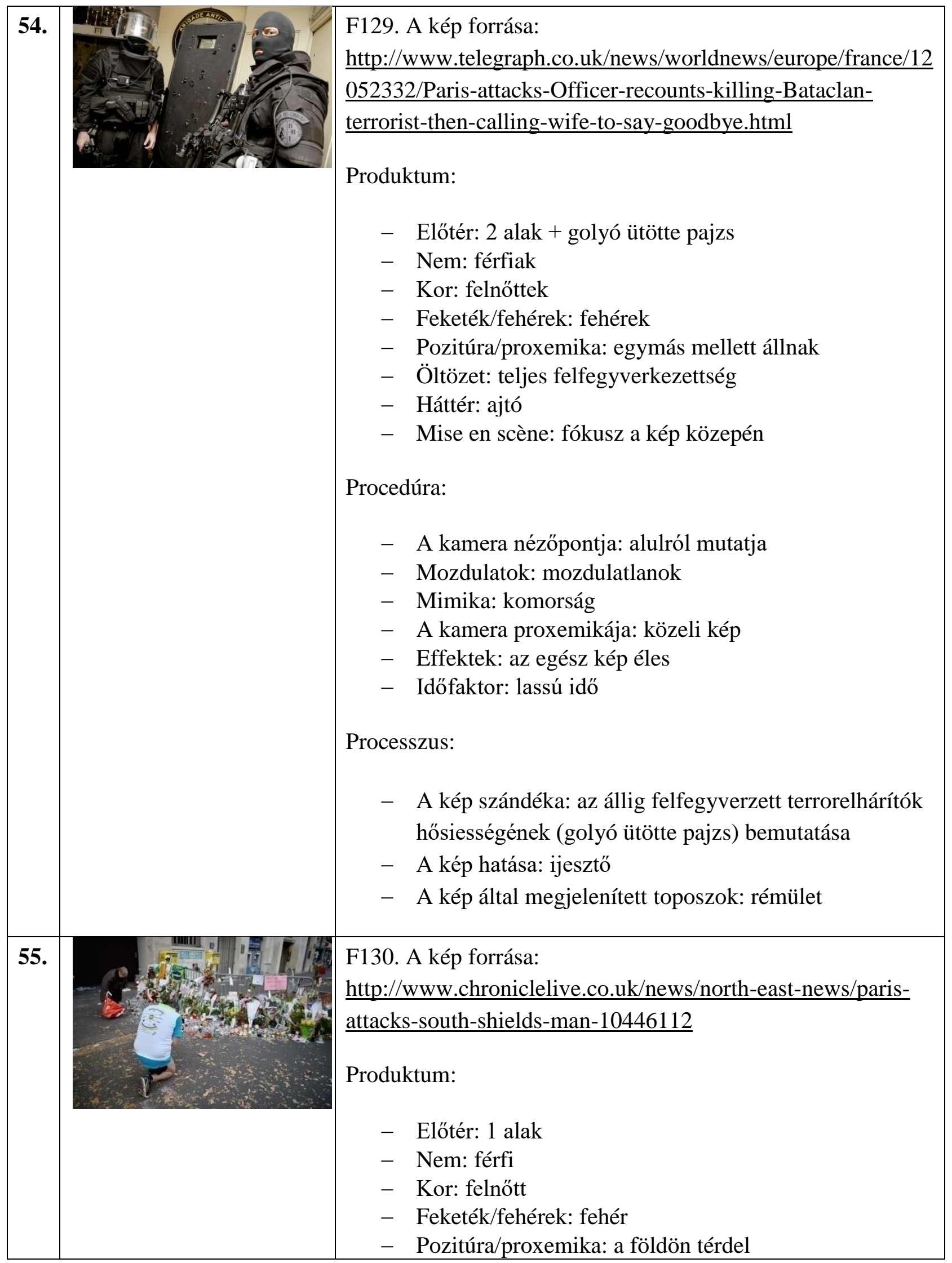




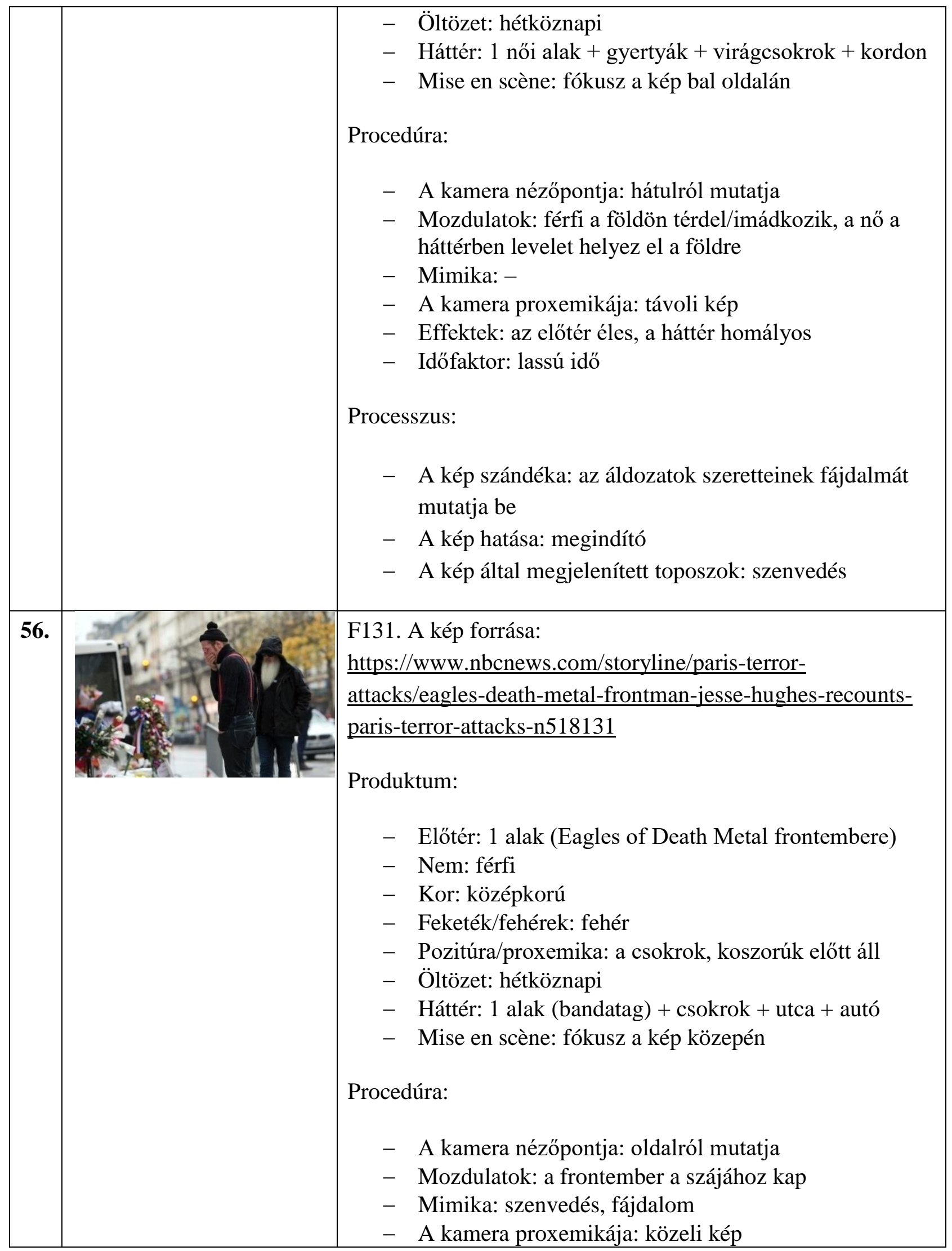




\begin{tabular}{|c|c|}
\hline & $\begin{array}{l}\text { - Effektek: az előtér éles, a háttér homályos } \\
\text { - Időfaktor: lassú idő } \\
\text { Processzus: } \\
\text { - A kép szándéka: az együttes tagjainak fájdalmát, } \\
\text { gyászát mutatja be } \\
\text { - A kép hatása: megindító } \\
\text { - A kép által megjelenített toposzok: szenvedés }\end{array}$ \\
\hline 57. & $\begin{array}{l}\text { F132. A kép forrása: http://www.complex.com/pop- } \\
\text { culture/2017/12/french-film-postponed-paris-terror-attacks } \\
\text { Produktum: } \\
\text { - } \\
\text { Elötér: Bataclan bejárata + kordonok + virágcsokrok + } \\
\text { gyertyák } \\
\text { - } \text { Nem: - } \\
\text { - } \text { Kor: - } \\
\text { - } \text { Feketék/fehérek: - } \\
\text { - } \text { Pozitúra/proxemika: a kordon mögé helyezték el a } \\
\text { - csokrokat, gyertyákat } \\
\text { - Öltözet: - } \\
\text { - } \text { Háttér: Bataclan színház } \\
\text { Procedúra: } \\
\text { - } \text { A kamen scène: fókusz a kép közepén } \\
\text { - } \text { Mozdulatok: - } \\
\text { - Mimika: - } \\
\text { - } \text { A kamera proxemikája: távoli kép } \\
\text { - Effektek: az egész kép éles } \\
\text { - } \text { Időfaktor: elmúlás } \\
\text { Processzus: }\end{array}$ \\
\hline
\end{tabular}




\begin{tabular}{|c|c|c|}
\hline 58. & 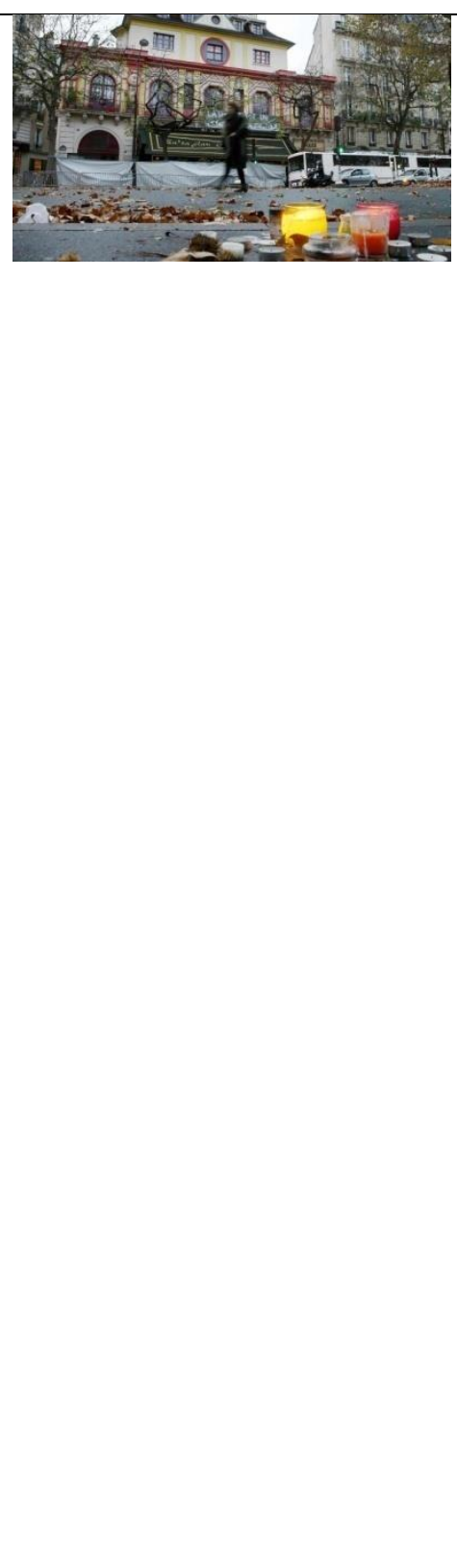 & $\begin{array}{l}\text { F133. A kép forrása: } \\
\text { http://www.news.com.au/world/europe/bataclan-terrorist- } \\
\text { attack-included-gruesome-torture-of-victims/news- } \\
\text { story/c0cc809c303487541b985ef0e57992dd } \\
\text { Produktum: } \\
\text { - Előtér: gyertyák, mécsesek } \\
\text { - Nem: nő } \\
\text { - Kor: - } \\
\text { - Feketék/fehérek: fehér } \\
\text { - Pozitúra/proxemika: a gyertyák a földön vannak } \\
\text { - Öltözet: - } \\
\text { - Háttér: } 1 \text { alak + Bataclan épülete + kordonok } \\
\text { - Mise en scène: fókusz a kép jobb alsó oldalán } \\
\text { Procedúra: } \\
\text { - A kamera nézőpontja: alulról mutatja } \\
\text { - Mozdulatok: a háttérben lévő alak elsiet } \\
\text { - Mimika: - } \\
\text { - A kamera proxemikája: távoli kép } \\
\text { - Effektek: a kép elötere éles, háttere homályos } \\
\text { - Időfaktor: rohan az élet, de a gyász megmarad } \\
\text { Processzus: } \\
\text { - A kép szándéka: a bataclani lövöldözés áldozatainak } \\
\text { - }\end{array}$ \\
\hline
\end{tabular}




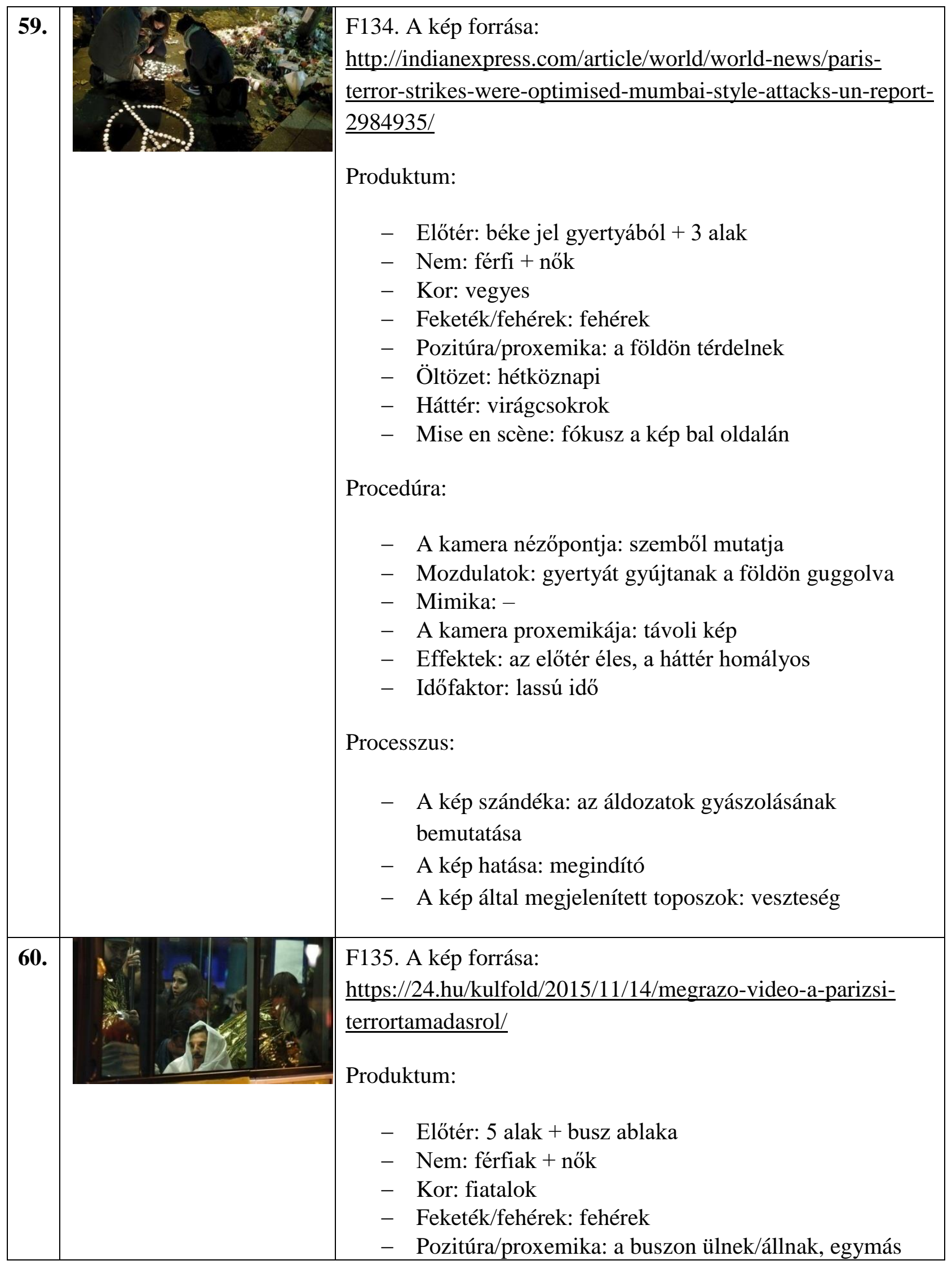




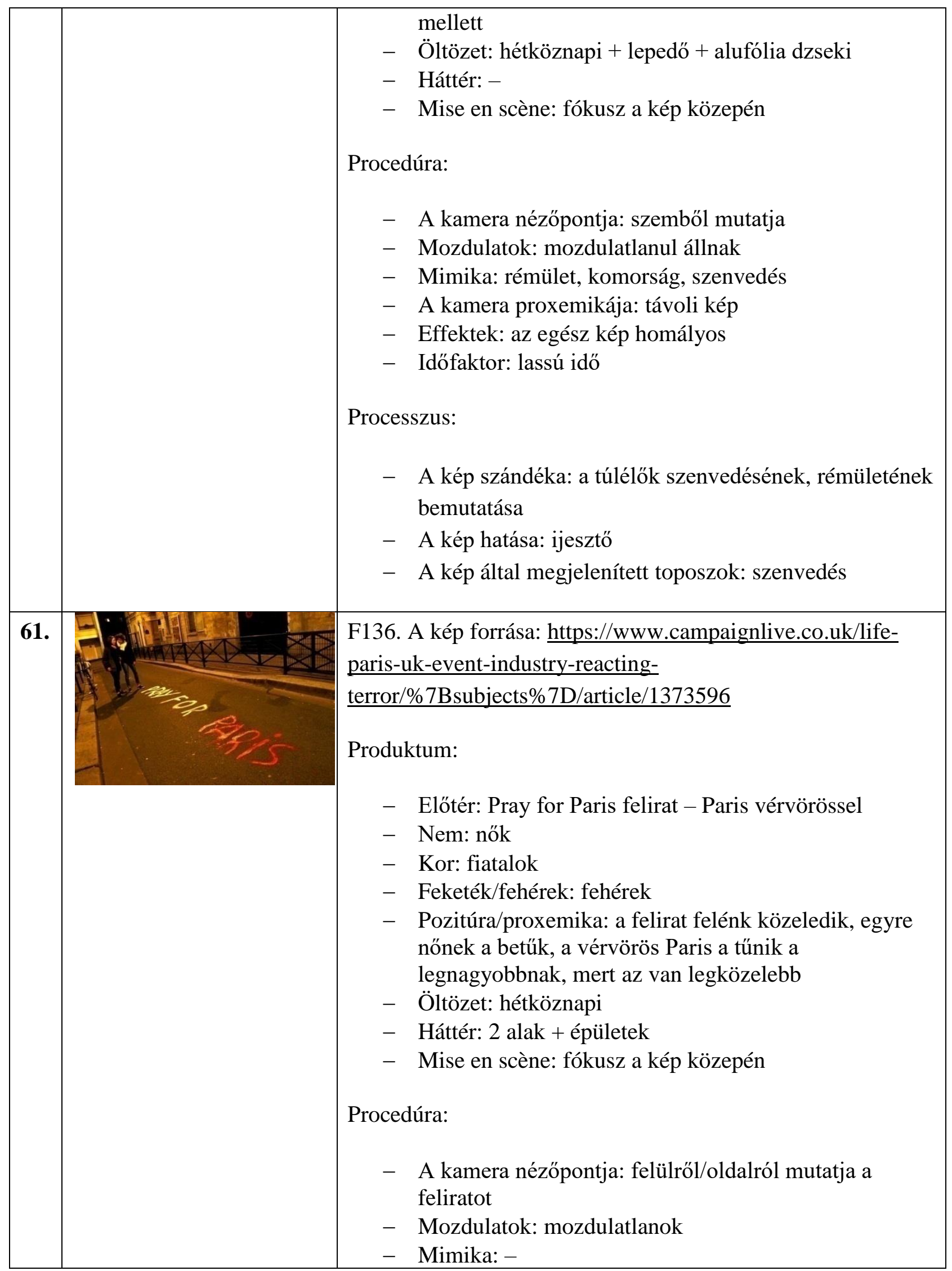




\begin{tabular}{|c|c|c|}
\hline & & $\begin{array}{l}\text { - A kamera proxemikája: távoli kép } \\
\text { - Effektek: az előtér éles, a háttér homályos } \\
\text { - Időfaktor: lassú idő } \\
\text { Processzus: } \\
\text { - A kép szándéka: a vérvörös Paris felirattal a mészárlás } \\
\text { - kegyetlenégét hívják elő } \\
\text { - A kép hatása: ijesztő } \\
\text { Által megjelenített toposzok: agresszió }\end{array}$ \\
\hline 62 & 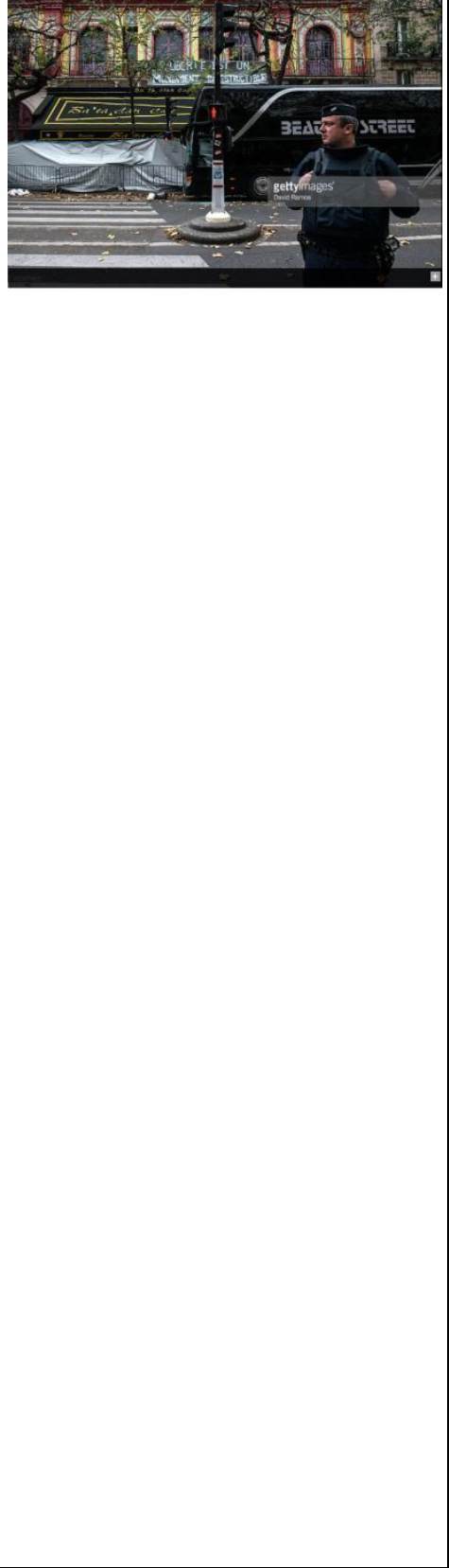 & $\begin{array}{l}\text { F137. A kép forrása: } \\
\text { http://www.gettyimages.com/event/paris-on-high-alert-as-the- } \\
\text { french-capital-recovers-from-the-terrorist-attacks- } \\
\underline{591963325 \# f r e n c h-p o l i c e-o f f i c e r-s t a n d s-g u a r d-i n-f r o n t-o f-~} \\
\text { the-main-entrance-of-picture-id497371612 } \\
\text { Produktum: } \\
\text { - Előtér: } 1 \text { alak } \\
\text { - Nem: férfi } \\
\text { - Kor: fiatal } \\
\text { - Feketék/fehérek: fehér } \\
\text { - Pozitúra/proxemika: a Bataclan színház előtt áll } \\
\text { - Öltözet: rendőri } \\
\text { - Háttér: Bataclan színház } \\
\text { - Mise en scène: fókusz a kép jobb oldalán } \\
\text { Procedúra: } \\
\text { - A kamera nézőpontja: szemből mutatja } \\
\text { - Mozdulatok: a mellényébe kapaszkodik } \\
\text { - Mimika: aggódó } \\
\text { - A kamera proxemikája: közeli kép } \\
\text { - Effektek: az egész kép éles } \\
\text { - Időfaktor: lassú idő } \\
\text { Processzus: }\end{array}$ \\
\hline
\end{tabular}




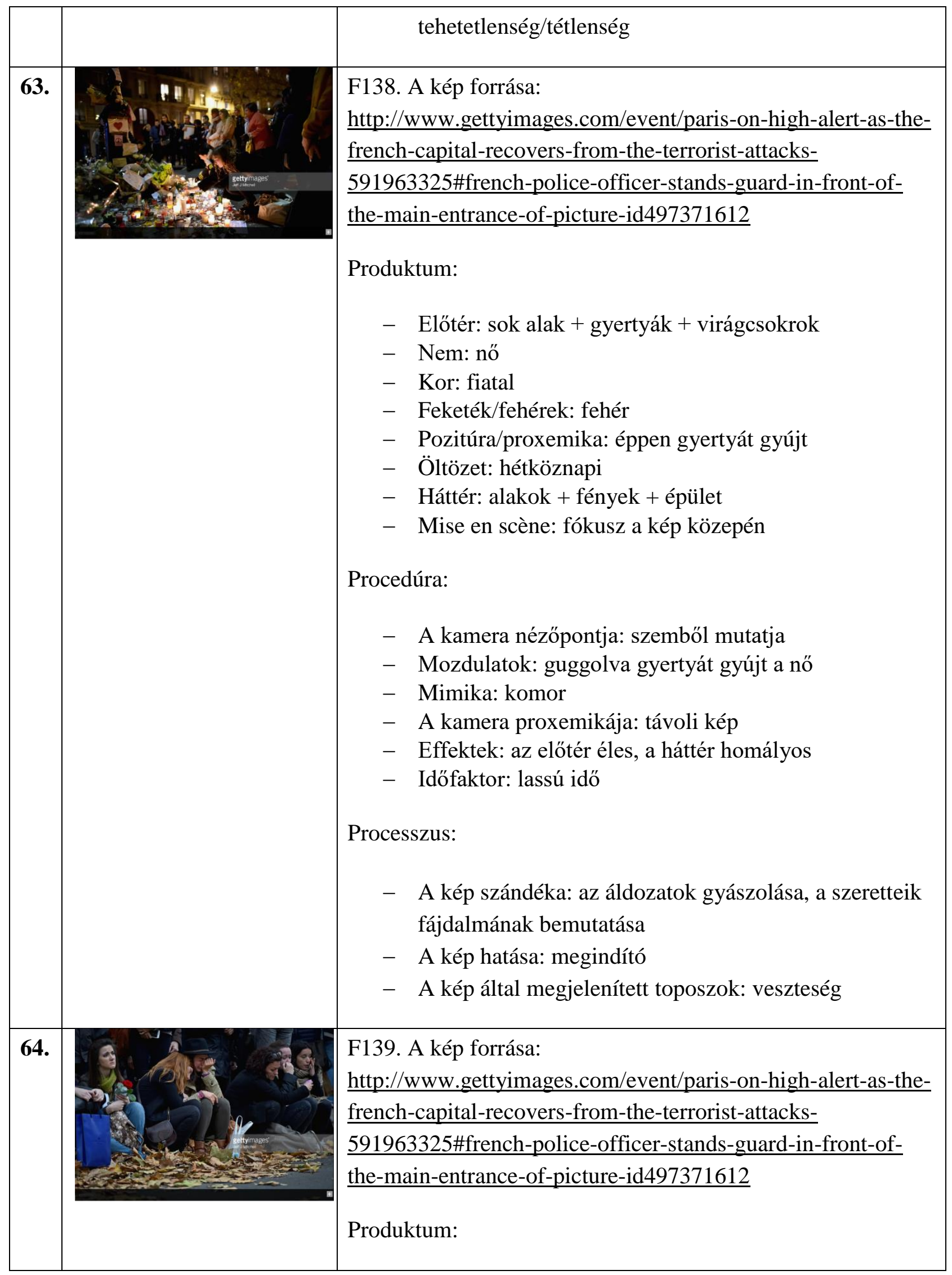




\begin{tabular}{|c|c|c|}
\hline & & 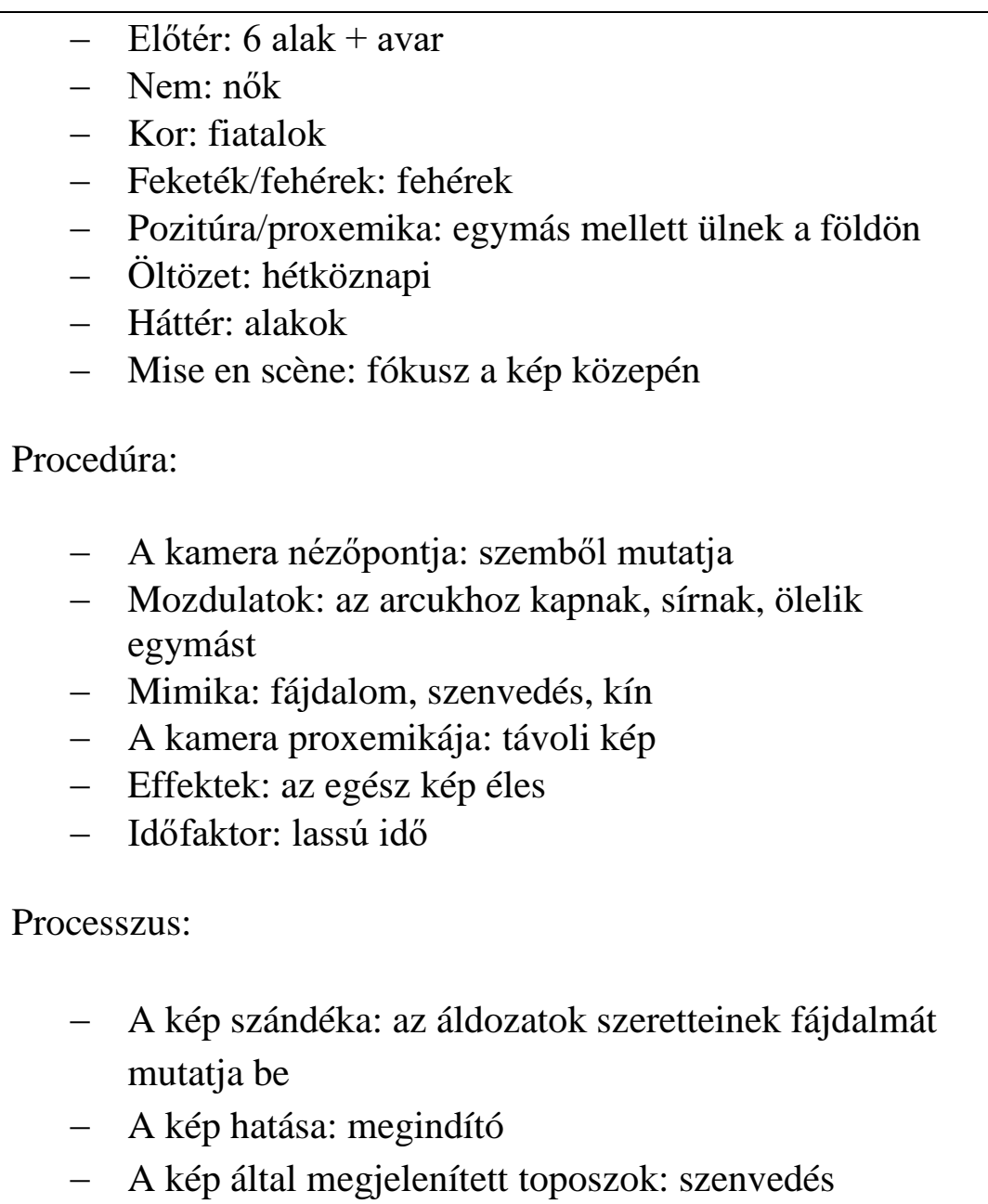 \\
\hline 65 & a-2 lilis & 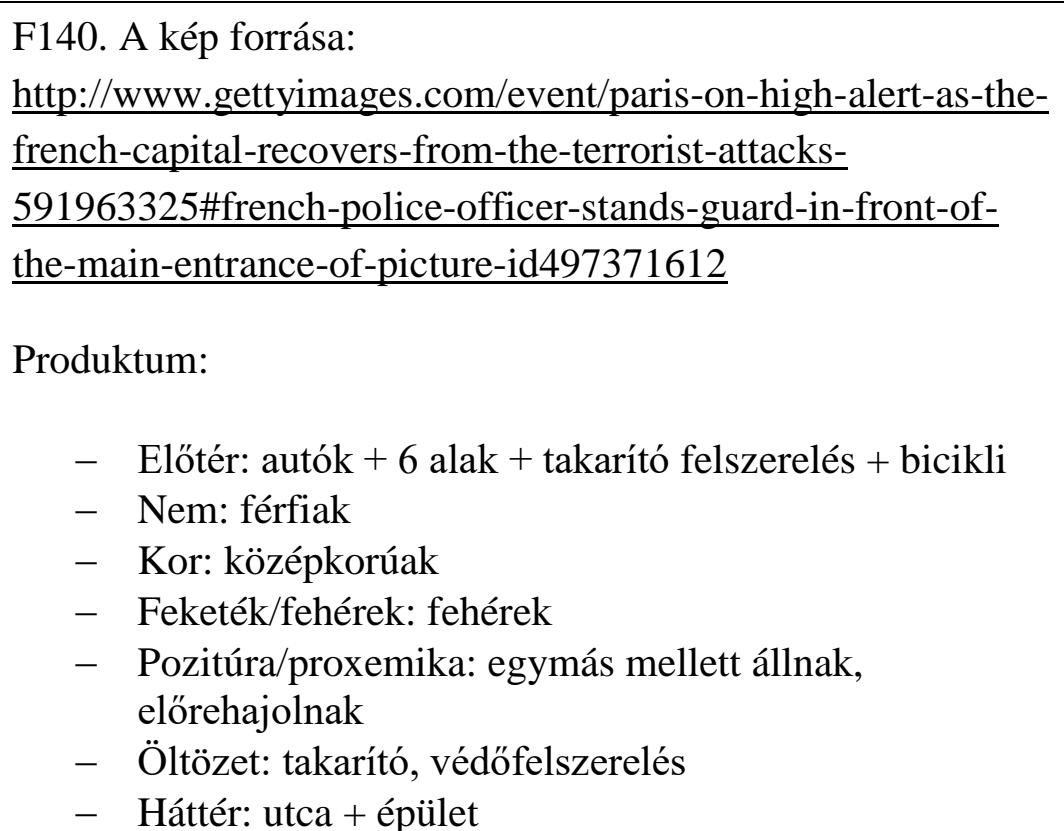 \\
\hline
\end{tabular}




\begin{tabular}{|c|c|c|}
\hline & & $\begin{array}{l}\text { - Mise en scène: fókusz a kép közepén } \\
\text { Procedúra: } \\
\text { - A kamera nézőpontja: szemből mutatja } \\
\text { - Mozdulatok: a földet (vért) mossák, fertőtlenítik } \\
\text { - Mimika: - } \\
\text { - A kamera proxemikája: távoli kép } \\
\text { - Effektek: az egész kép éles } \\
\text { - Időfaktor: aktív } \\
\text { Processzus: } \\
\text { - A kép szándéka: az utómunkálatok bemutatása } \\
\text { - A kép hatása: ijesztő, undorító } \\
\text { - A kép által megjelenített toposzok: küzdelem }\end{array}$ \\
\hline 60 & 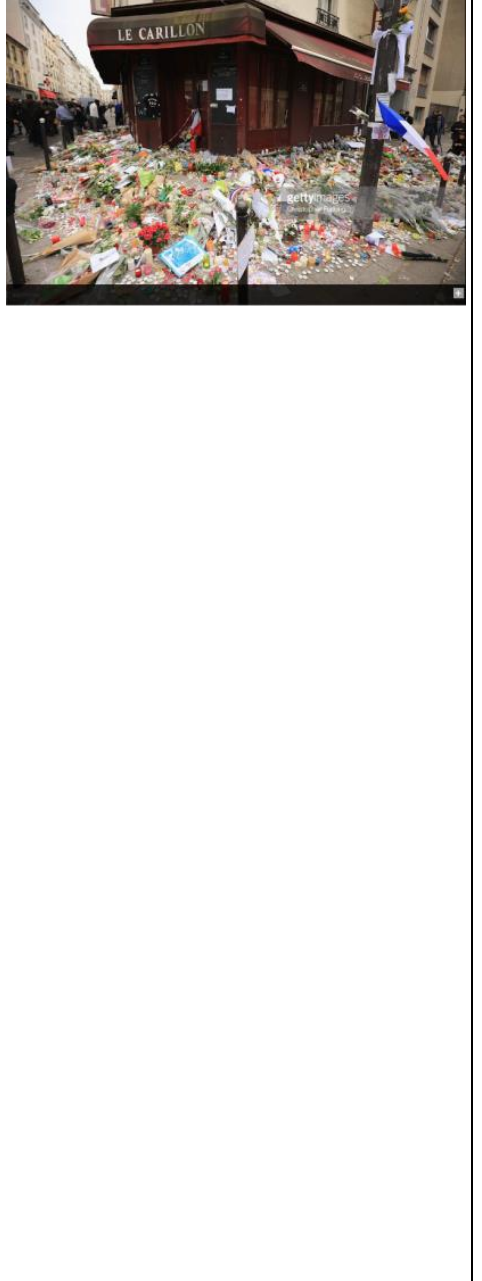 & $\begin{array}{l}\text { F141. A kép forrása: } \\
\text { http://www.gettyimages.com/event/paris-on-high-alert-as-the- } \\
\text { french-capital-recovers-from-the-terrorist-attacks- } \\
\underline{\text { 591963325\#french-police-officer-stands-guard-in-front-of- }} \\
\underline{\text { the-main-entrance-of-picture-id497371612 }} \\
\text { Produktum: } \\
\text { - Elötér: gyertyák + zászlók + virágcsokrok } \\
\text { - Nem: - } \\
\text { - Kor: - } \\
\text { - Feketék/fehérek: - } \\
\text { - Pozitúra/proxemika: a gyertyák, csokrok a földön } \\
\text { - hevernek } \\
\text { - Öltözet: - Háttér: La Carillon bár + alakok + épületek } \\
\text { - Mise en scène: fókusz a kép közepén } \\
\text { Procedúra: }\end{array}$ \\
\hline
\end{tabular}




\begin{tabular}{|c|c|c|}
\hline & & $\begin{array}{l}\text { - Időfaktor: elmúlás } \\
\text { Processzus: } \\
\text { - A kép szándéka: az áldozatok bemutatása } \\
\text { - A kép hatása: megindító } \\
\text { - A kép által megjelenített toposzok: veszteség }\end{array}$ \\
\hline 67. & $\cos x$ & 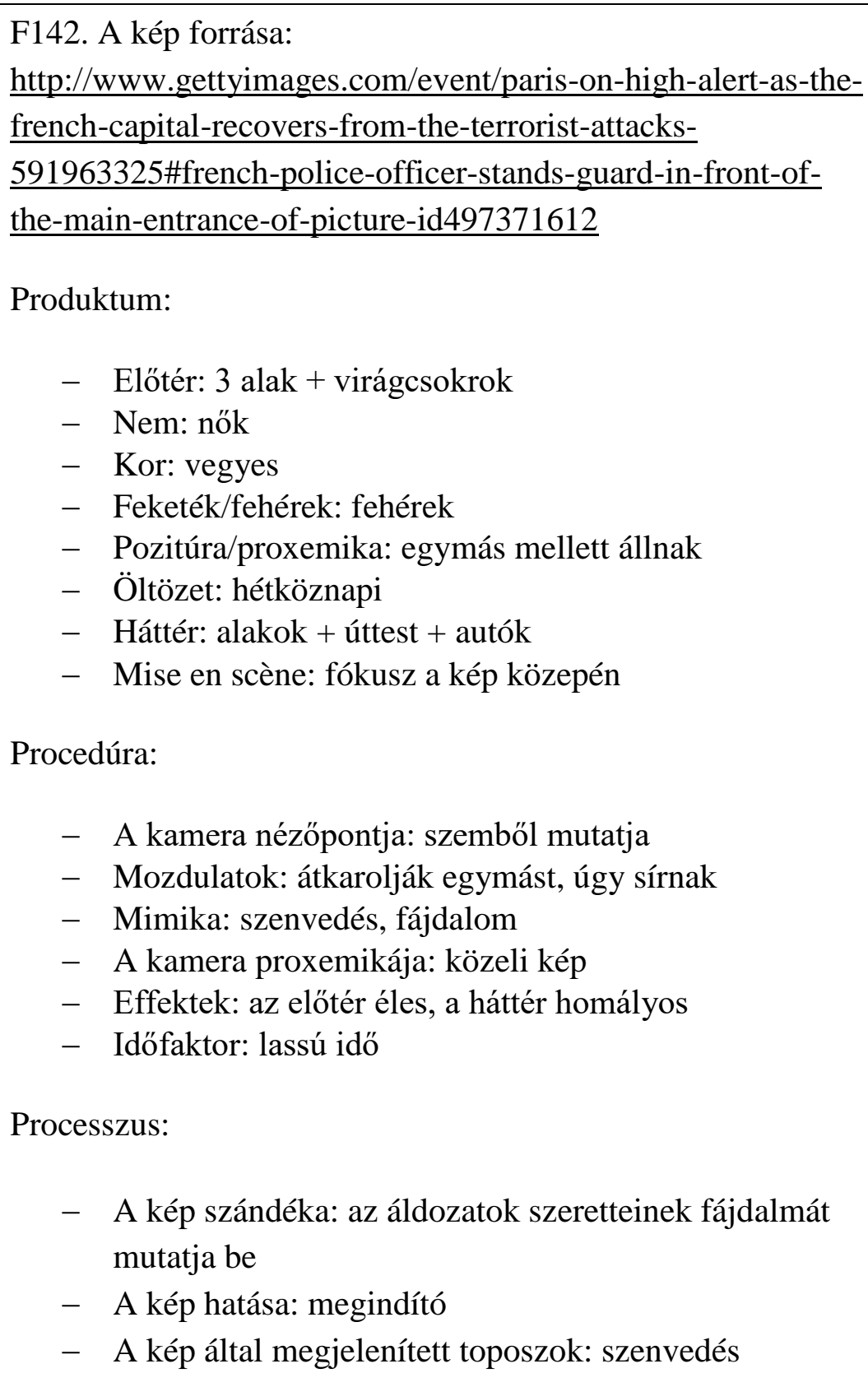 \\
\hline
\end{tabular}




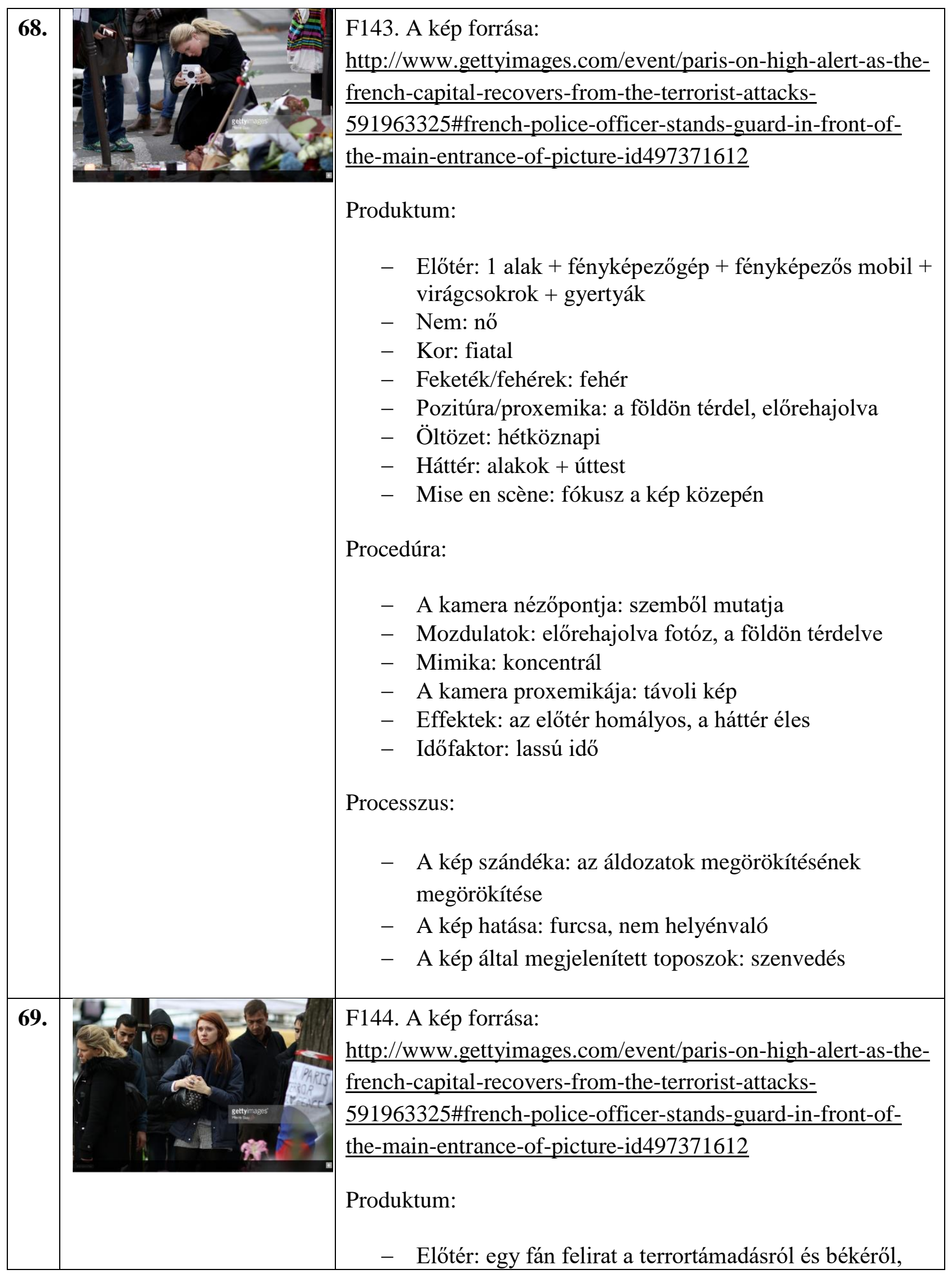




\begin{tabular}{|c|c|}
\hline & 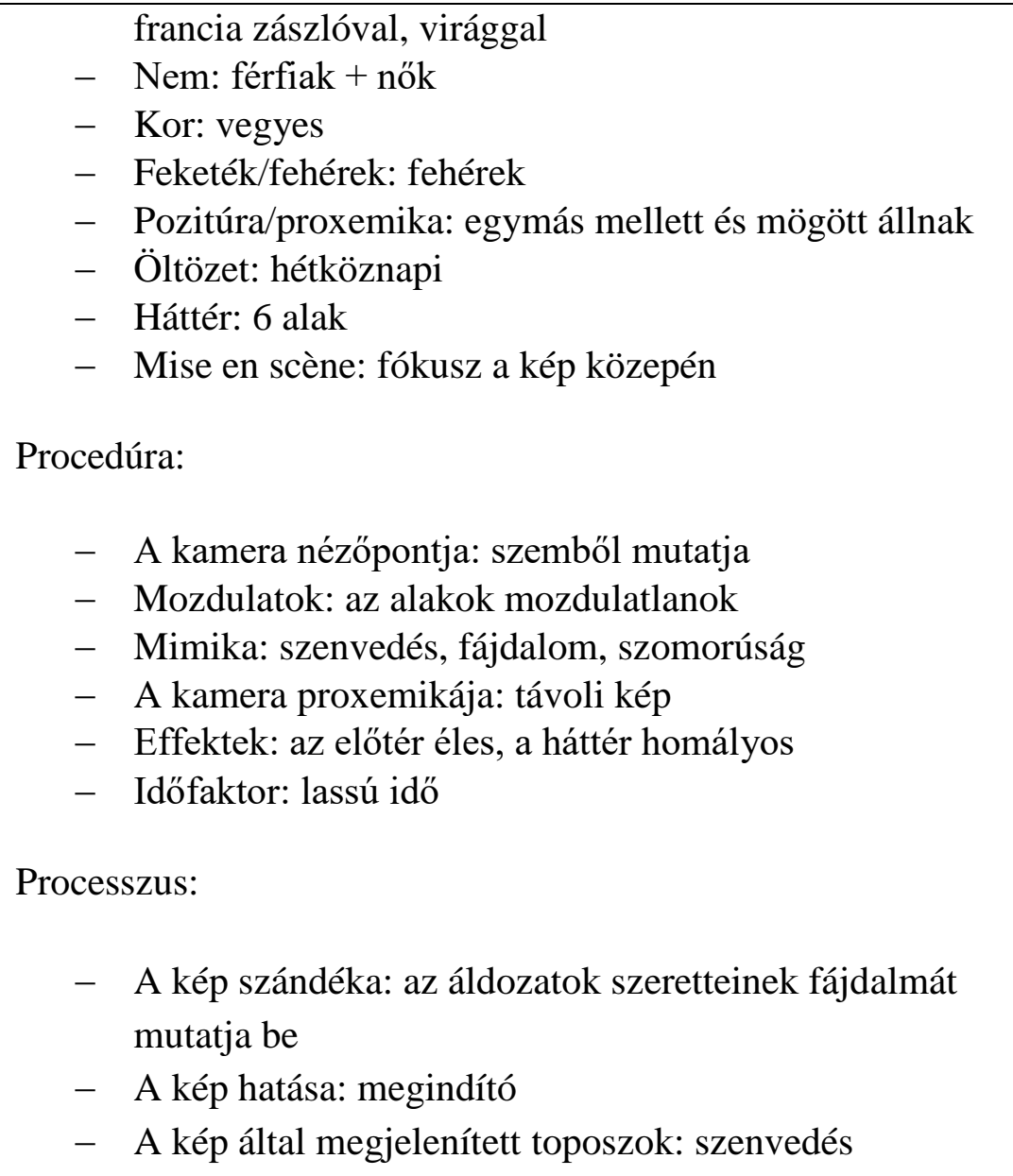 \\
\hline 70. & 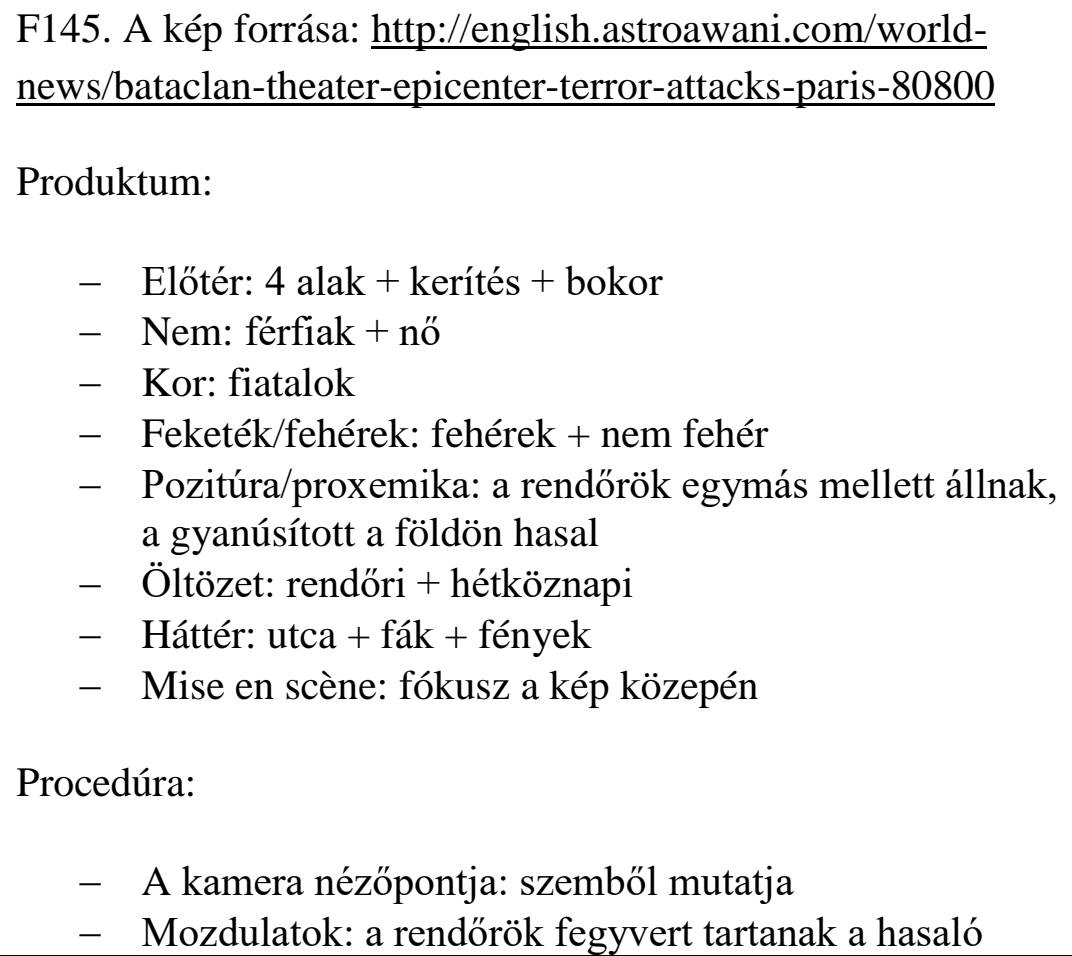 \\
\hline
\end{tabular}




\begin{tabular}{|c|c|}
\hline & \begin{tabular}{|l} 
gyanúsítottra \\
- Mimika: elszántság, komolyság \\
- A kamera proxemikája: távoli kép \\
- Effektek: az egész kép homályos \\
- Időfaktor: aktív \\
Processzus: \\
- A kép szándéka: a rendőrség bátorságának, \\
- rettenthetetlenségének bemutatása \\
- A kép hatása: ijesztő
\end{tabular} \\
\hline 71. & $\begin{array}{l}\text { F146. A kép forrása: http://english.astroawani.com/world- } \\
\text { news/bataclan-theater-epicenter-terror-attacks-paris-80800 } \\
\text { Produktum: } \\
\text { - Elötér: rendőri alakulat + autók + úttest } \\
\text { - Nem: férfiak } \\
\text { - Kor: felnőttek } \\
\text { - Feketék/fehérek: - } \\
\text { - Pozitúra/proxemika: a rendörök egymás mögött } \\
\text { - } \text { Öltäzet: rendőri } \\
\text { - Háttér: házak + fények } \\
\text { - Mise en scène: fókusz a kép közepén } \\
\text { Procedúra: } \\
\text { - A kamera nézőpontja: felülröl mutatja } \\
\text { - Mozdulatok: a rendörök elszántan menetelnek } \\
\text { - Mimika: - } \\
\text { - A kamera proxemikája: távoli kép } \\
\text { - Effektek: az egész kép homályos } \\
\text { - Idöfaktor: aktív } \\
\text { Processzus: }\end{array}$ \\
\hline
\end{tabular}




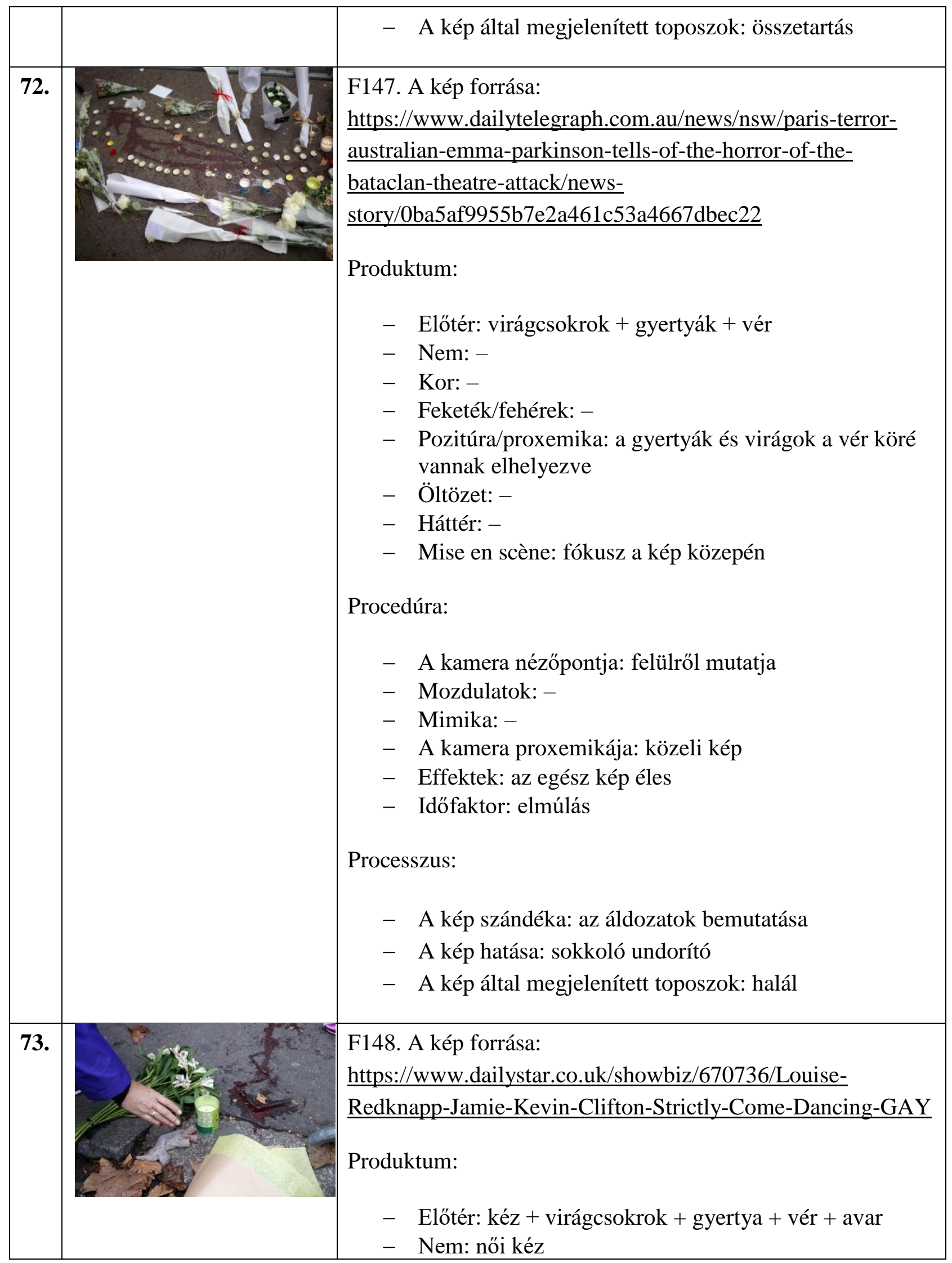




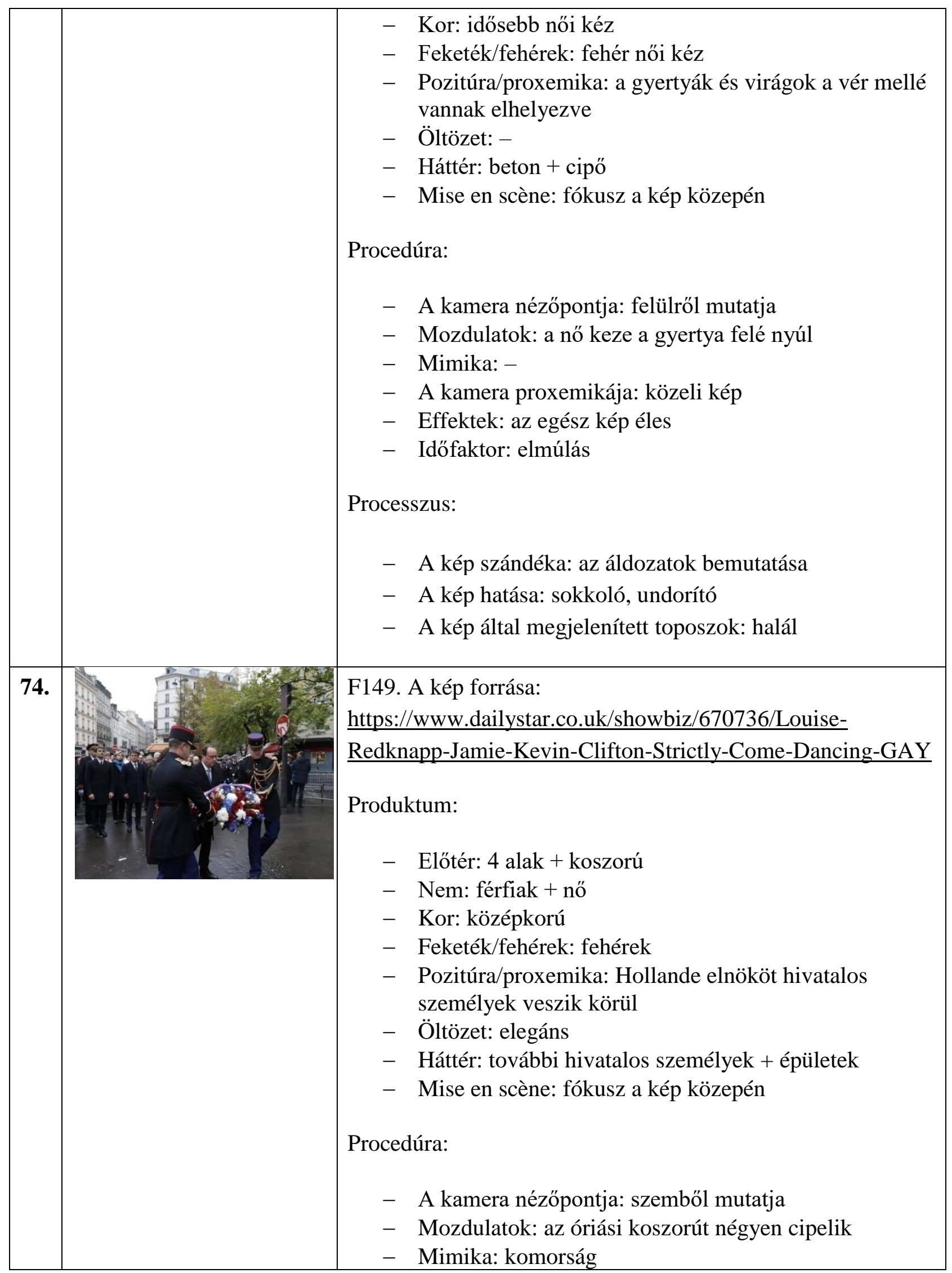




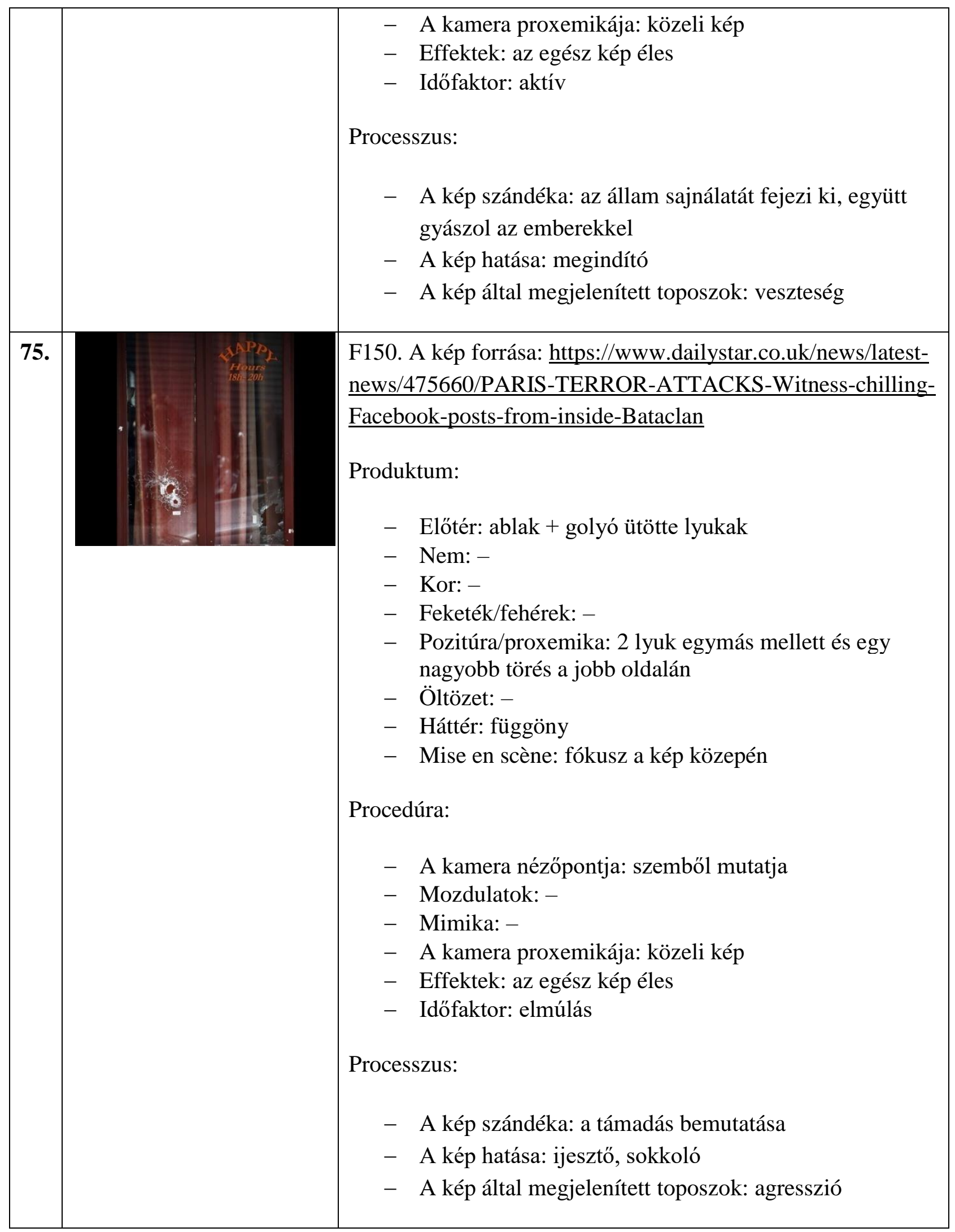

